\title{
Design Demonstrations for Category B Tank Systems Piping at Oak Ridge National Laboratory, Oak Ridge, Tennessee
}

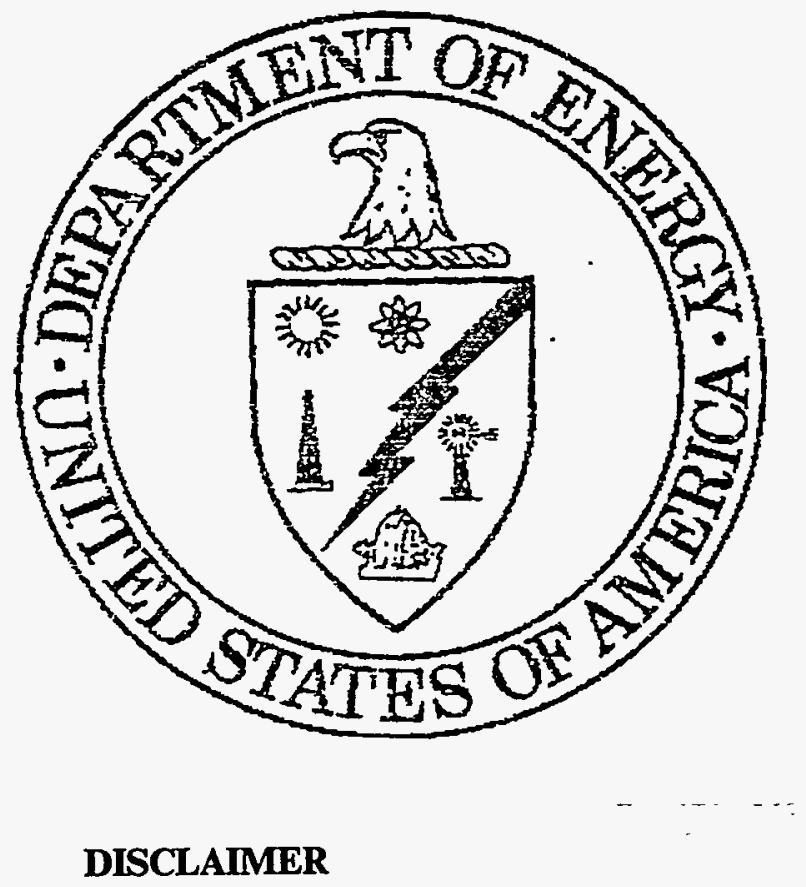

This report was prepared as an account of work sponsored by an agency of the United States Government. Neither the United States Government nor any agency thereof, nor any of their employees, makes any warranty, express or implied, or assumes any legal liability or responsibility for the accuracy, completeness, or usefulness of any information, apparatus, product, or process disclosed, or represents that its use would not infringe privately owned rights. Reference herein to any specific commercial product, process, or service by trade name, trademark, manufacturer, or otherwise does not necessarily constitute or imply its endorsement, recommendation, or favoring by the United States Government or any agency thereof. The views and opinions of authors expressed herein do not necessarily state or reflect those of the United States Government or any agency thereof.
RPRPIVED
MAR 301995
OSTI




\begin{tabular}{l} 
Foster Wheeler Environmental Corporation \\
and \\
Parsons Engineering Science, Inc. \\
$\begin{array}{l}\text { contributed to the preparation of this document } \\
\text { and should not be considered eligible contractors } \\
\text { for its review. }\end{array}$ \\
\hline
\end{tabular}




\section{DISCLAIMER}

Portions of this document may be illegible in electronic image products. Images are produced from the best available original document. 
DOE/OR/03-1195\&D2

ORNL/ER-193\&D2

Environmental Restoration and Waste Management Programs

\section{Design Demonstrations for Category B Tank Systems Piping at Oak Ridge National Laboratory, Oak Ridge, Tennessee}

Date Issued-December 1994

Prepared by

Foster Wheeler Environmental Corporation

and

Parsons Engineering Science, Inc.

Oak Ridge, Tennessee

under DOE contract DE-AC05-91OR21928

Prepared for

U.S. Department of Energy

Office of Environmental Restoration and Waste Management

under budget and reporting codes EX 20 and EW 20

OAK RIDGE NATIONAL LABORATORY

Oak Ridge, Tennessee 37831-6285

managed by

MARTIN MARIETTA ENERGY SYSTEMS, INC.

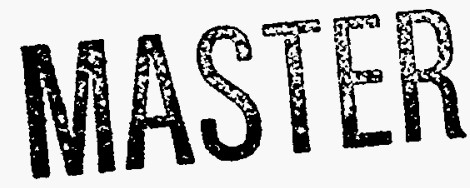

for the

U.S. DEPARTMENT OF ENERGY

under contract DE-AC05-84OR21400 


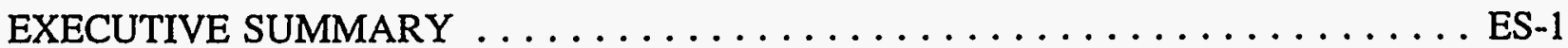

$1.0 \quad$ INTRODUCTION $\ldots \ldots \ldots \ldots \ldots \ldots \ldots \ldots \ldots \ldots \ldots \ldots \ldots \ldots \ldots \ldots . .1$

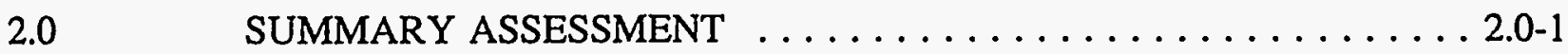

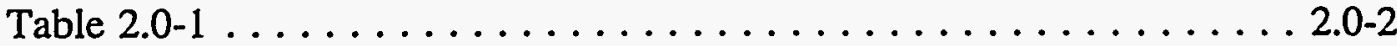

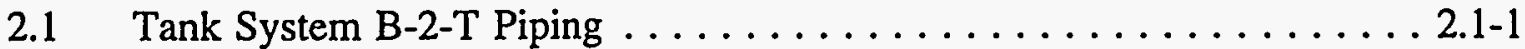

2.1.1 Tank System Summary $\ldots \ldots \ldots \ldots \ldots \ldots \ldots \ldots \ldots \ldots \ldots \ldots \ldots \ldots .11$

2.1.2 Standards for Pipe Assessment of Tank Systems . . . . . . . 2.1-1

2.1.3 Standards for Containment/Release Detection . . . . . . . . 2.1-3

2.1.4 Supplemental Information $\ldots \ldots \ldots \ldots \ldots \ldots \ldots \ldots \ldots .12 .12$

2.1.5 References ........................ 2.1-13

Figures 2.1-1 through 2.1-3

2.2 Tank System B-3-T Piping $\ldots \ldots \ldots \ldots \ldots \ldots \ldots \ldots \ldots \ldots \ldots \ldots \ldots \ldots \ldots .2 .1$

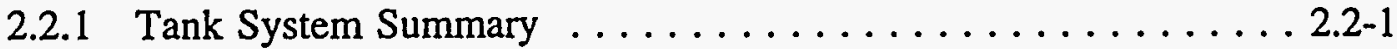

2.2.2 Standards for Pipe Assessment of Tank Systems . . . . . . . 2.2-1

2.2.3 Standards for Containment/Release Detection . . . . . . . . 2.2-3

2.2.4 Supplemental Information $\ldots \ldots \ldots \ldots \ldots \ldots \ldots \ldots \ldots .2 .2-7$

2.2 .5 References . . . . . . . . . . . . . . . . . 2.2-8

Figures $2.2-1$ through $2.2-3$

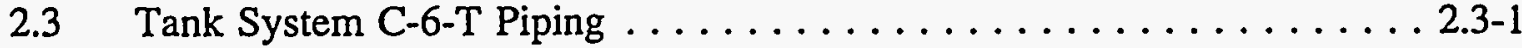

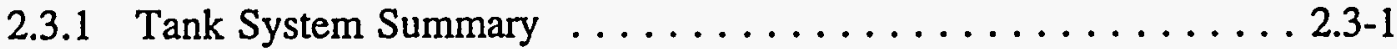

2.3.2 Standards for Pipe Assessment of Tank Systems . . . . . . . . 2.3-1

2.3.3 Standards for Containment/Release Detection . . . . . . . 2.3-3

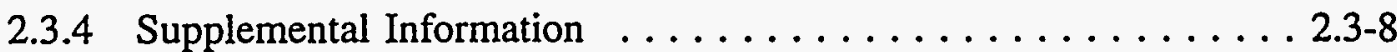

2.3.5 References ......................... 2.3-10

Figures 2.3-1 through 2.3-3

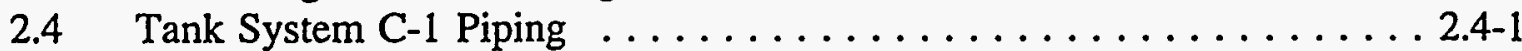

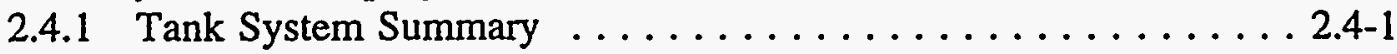

2.4.2 Standards for Pipe Assessment of Tank Systems ... . . . . . . 2.4-1

2.4.3 Standards for Containment/Release Detection . . . . . . . . 2.4-3

2.4.4 Supplemental Information $\ldots \ldots \ldots \ldots \ldots \ldots \ldots \ldots \ldots \ldots \ldots .4 .4 .5$

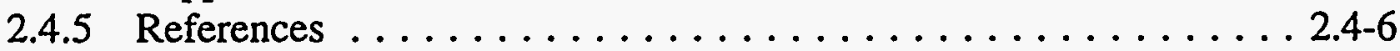

Figures 2.4-1 through 2.4-4 
Design Demonstrations - Category B Tank Systems (Piping)

2.5 Tank System C-2 Piping $\ldots \ldots \ldots \ldots \ldots \ldots \ldots \ldots \ldots \ldots \ldots \ldots \ldots \ldots \ldots \ldots .5 .1$

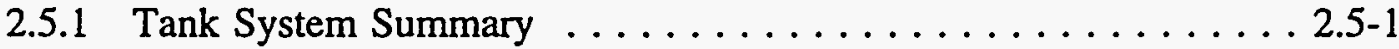

2.5.2 Standards for Pipe Assessment of Tank Systems . . . . . . . . 2.5-1

2.5.3 Standards for Containment/Release Detection . . . . . . . 2.5-3

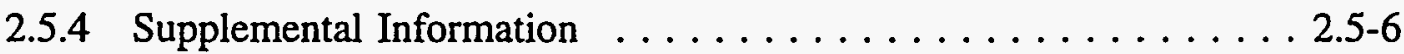

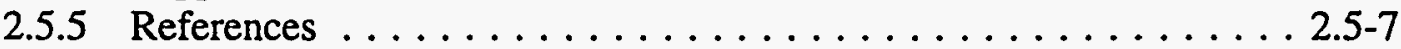

Figures 2.5-1 through 2.5-4

2.6 Tank System F-111 Piping $\ldots \ldots \ldots \ldots \ldots \ldots \ldots \ldots \ldots \ldots .6 .6 .1$

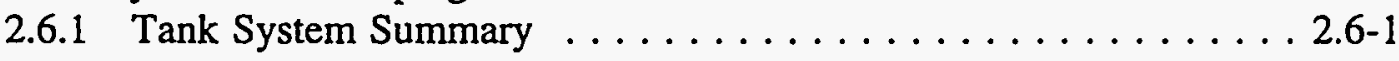

2.6.2 Standards for Pipe Assessment of Tank Systems . . . . . . . 2.6-1

2.6.3 Standards for Containment/Release Detection . . . . . . . . 2.6-3

2.6.4 Supplemental Information $\ldots \ldots \ldots \ldots \ldots \ldots \ldots \ldots .6 \ldots .6 .5$

2.6.5 References . . . . . . . . . . . . . . . . . . . . . 2.6-7

Figures 2.6-1 through 2.6-3

2.7 Tank System F-126 Piping $\ldots \ldots \ldots \ldots \ldots \ldots \ldots \ldots \ldots \ldots \ldots \ldots \ldots \ldots \ldots \ldots \ldots .7 .1$

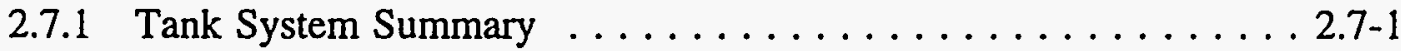

2.7.2 Standards for Pipe Assessment of Tank Systems . . . . . . . . 2.7-1

2.7.3 Standards for Containment/Release Detection . . . . . . . . 2.7-3

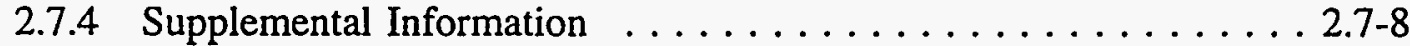

2.7 .5 References . . . . . . . . . . . . . . . . . . . 2.7-9

Figures 2.7-1 through 2.7-3

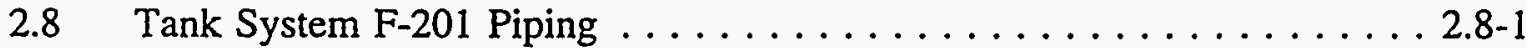

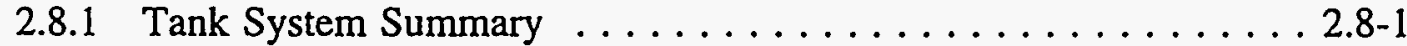

2.8.2 Standards for Pipe Assessment of Tank Systems . . . . . . . 2.8-1

2.8.3 Standards for Containment/Release Detection . . . . . . . . 2.8-2

2.8.4 Supplemental Information $\ldots \ldots \ldots \ldots \ldots \ldots \ldots \ldots \ldots .8 .4$

2.8 .5 References . . . . . . . . . . . . . . . . . . . 2.8-6

Figures 2.8-1 through 2.8-3

2.9 Tank System F-501 Piping $\ldots \ldots \ldots \ldots \ldots \ldots \ldots \ldots \ldots \ldots \ldots \ldots \ldots \ldots \ldots \ldots .9 \ldots \ldots$

2.9 .1 Tank System Summary $\ldots \ldots \ldots \ldots \ldots \ldots \ldots \ldots \ldots \ldots \ldots . . .1$

2.9.2 Standards for Pipe Assessment of Tank Systems . . . . . . . . 2.9-1

2.9.3 Standards for Containment/Release Detection . . . . . . . 2.9-2

2.9.4 Supplemental Information $\ldots \ldots \ldots \ldots \ldots \ldots \ldots \ldots .2 .9 .6$

2.9.5 References . . . . . . . . . . . . . . . . . . . . . 2.9-7

Figures 2.9-1 through 2.9-3

2.10 Tank System L-11 Piping $\ldots \ldots \ldots \ldots \ldots \ldots \ldots \ldots \ldots \ldots \ldots \ldots \ldots .10 \ldots \ldots$

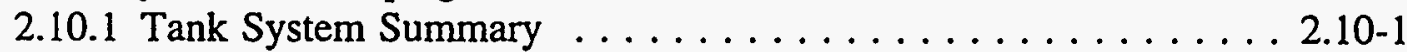

2.10.2 Standards for Pipe Assessment of Tank Systems . . . . . . . 2.10-1

2.10.3 Standards for Containment/Release Detection . . . . . . . . 2.10-3

2.10.4 Supplemental Information $\ldots \ldots \ldots \ldots \ldots \ldots \ldots \ldots .2 .10-5$

2.10 .5 References . . . . . . . . . . . . . . . . . 20-7

Figures 2.10-1 through 2.10-3 
2.11 Tank System N-71 Piping $\ldots \ldots \ldots \ldots \ldots \ldots \ldots \ldots \ldots \ldots \ldots \ldots \ldots \ldots \ldots .11-1$

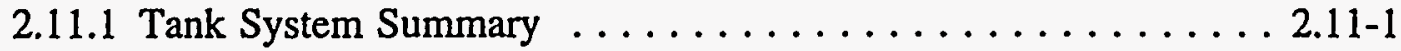

2.11.2 Standards for Pipe Assessment of Tank Systems . . . . . . . 2.11-1

2.11.3 Standards for Containment/Release Detection . . . . . . . 2.11-2

2.11.4 Supplemental Information $\ldots \ldots \ldots \ldots \ldots \ldots \ldots \ldots .2 .11-4$

2.11 .5 References . . . . . . . . . . . . . .

Figures 2.11-1 through 2.11-3

2.12 Tank System P-3 Piping . . . . . . . . . . . . . . . . . . . .

2.12.1 Tank System Summary $\ldots \ldots \ldots \ldots \ldots \ldots \ldots \ldots . . \ldots \ldots \ldots . .12-1$

2.12.2 Standards for Pipe Assessment of Tank Systems . . . . . . . 2.12-1

2.12.3 Standards for Containment/Release Detection . . . . . . . . 2.12-3

2.12.4 Supplemental Information $\ldots \ldots \ldots \ldots \ldots \ldots \ldots \ldots \ldots . .12-6$

2.12.5 References . . . . . . . . . . . . . . . . . . . 2.12-8

Figures 2.12-1 through 2.12-3

2.13 Tank System P-4 Piping . . . . . . . . . . . . . . . . . 2-1

2.13.1 Tank System Summary $\ldots \ldots \ldots \ldots \ldots \ldots \ldots . . \ldots \ldots . . .13-1$

2.13.2 Standards for Pipe Assessment of the Tank System . . . . . . 2.13-1

2.13.3 Standards for Containment/Release Detection ........... 2.13-2

2.13.4 Supplemental Information $\ldots \ldots \ldots \ldots \ldots \ldots \ldots \ldots .2 .13-3$

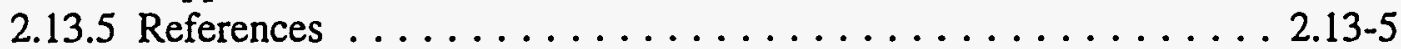

Figures 2.13-1 through 2.13-3

2.14 Tank System T-13 Piping $\ldots \ldots \ldots \ldots \ldots \ldots \ldots \ldots \ldots \ldots \ldots \ldots \ldots \ldots .14-1$

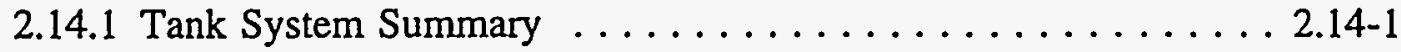

2.14.2 Standards for Pipe Assessment of Tank Systems . . . . . . . 2.14-1

2.14.3 Standards for Containment/Release Detection . . . . . . . . 2.14-3

2.14.4 Supplemental Information $\ldots \ldots \ldots \ldots \ldots \ldots \ldots \ldots \ldots . . .14-6$

2.14.5 References ........................ 2.14-7

Figures 2.14-1 through 2.14-2

2.15 Tank System WC-20 Piping $\ldots \ldots \ldots \ldots \ldots \ldots \ldots \ldots \ldots \ldots \ldots \ldots \ldots \ldots \ldots .15-1$

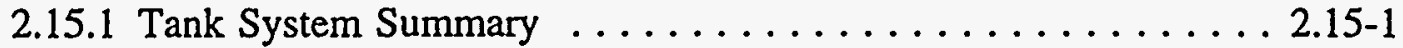

2.15.2 Standards for Pipe Assessment of Tank Systems . . . . . . . . 2.15-1

2.15.3 Standards for Containment/Release Detection . . . . . . . 2.15-4

2.15.4 Supplemental Information $\ldots \ldots \ldots \ldots \ldots \ldots \ldots \ldots \ldots .2 .15-8$

2.15 .5 References . . . . . . . . . . . . . . . . . . 2.15-9

Figures 2.15-1 through 2.15-4

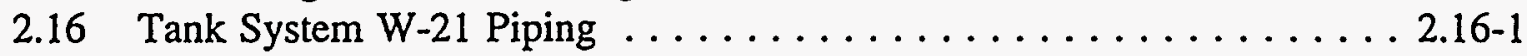

2.16.1 Tank System Summary . . . . . . . . . . . . . . . 2.16-1

2.16.2 Standards for Pipe Assessment of Tank Systems . . . . . . . 2.16-1

2.16.3 Standards for Containment/Release Detection . . . . . . . 2.16-3

2.16.4 Supplemental Information $\ldots \ldots \ldots \ldots \ldots \ldots \ldots \ldots . .16-6$

2.16 .5 References ......................... 2.16-8

Figures 2.16-1 through 2.16-4 
Design Demonstrations - Category B Tank Systems (Piping)

2.17 Tank System $W-22$ Piping $\ldots \ldots \ldots \ldots \ldots \ldots \ldots \ldots \ldots \ldots \ldots \ldots .17-1$

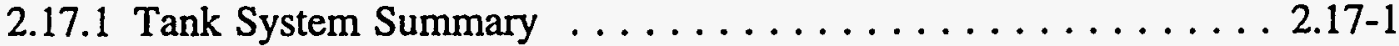

2.17.2 Standards for Pipe Assessment of Tank Systems . . . . . . . . 2.17-1

2.17.3 Standards for Containment/Release Detection . . . . . . . . 2.17-4

2.17.4 Supplemental Information $\ldots \ldots \ldots \ldots \ldots \ldots \ldots \ldots \ldots .17 .10$

2.17.5 References ........................ 2.17-11 Figures 2.17-1 through 2.17-4

2.18 Tank System W-23 Piping $\ldots \ldots \ldots \ldots \ldots \ldots \ldots \ldots \ldots \ldots \ldots \ldots \ldots \ldots \ldots .18-1$

2.18.1 Tank System Summary $\ldots \ldots \ldots \ldots \ldots \ldots \ldots \ldots \ldots . . .18-1$

2.18.2 Standards for Pipe Assessment of Tank Systems . . . . . . . . 2.18-1

2.18.3 Standards for Containment/Release Detection . . . . . . . . 2.18-4

2.18.4 Supplemental Information $\ldots \ldots \ldots \ldots \ldots \ldots \ldots \ldots .2 .18-9$

2.18 .5 References . . . . . . . . . . . . . . . . 2.18-11

Figures 2.18-1 through 2.18-4

2.19 Tank System W-24 Piping . . . . . . . . . . . . . . . 2.19-1

2.19.1 Tank System Summary . . . . . . . . . . . . . . 2.19-1

2.19.2 Standards for Pipe Assessment of Tank Systems . . . . . . . 2.19-1

2.19.3 Standards for Containment/Release Detection . . . . . . . . 2.19-3

2.19.4 Supplemental Information $\ldots \ldots \ldots \ldots \ldots \ldots \ldots \ldots \ldots . .19 .5$

2.19 .5 References . . . . . . . . . . . . . . . . . . .

Figures 2.19-1 through 2.19-4

2.20 Tank System W-25 Piping $\ldots \ldots \ldots \ldots \ldots \ldots \ldots \ldots \ldots \ldots .2 .20$. $\ldots \ldots \ldots$

2.20 .1 Tank System Summary $\ldots \ldots \ldots \ldots \ldots \ldots \ldots \ldots .2 .20 \ldots \ldots$

2.20.2 Standards for Pipe Assessment of Tank Systems . . . . . . 2.20-1

2.20.3 Standards for Containment/Release Detection . . . . . . . . 2.20-3

2.20 .4 Supplemental Information $\ldots \ldots \ldots \ldots \ldots \ldots \ldots \ldots .2 .20-5$

2.20 .5 References . . . . . . . . . . . . . . . . . 2.20-6

Figures 2.20-1 through 2.20-4

2.21 Tank System W-26 Piping $\ldots \ldots \ldots \ldots \ldots \ldots \ldots \ldots \ldots \ldots \ldots \ldots \ldots \ldots \ldots .2 .21-1$

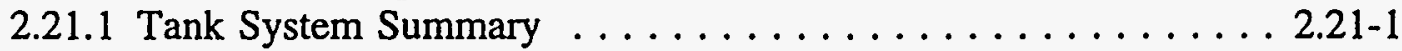

2.21.2 Standards for Pipe Assessment of Tank Systems . . . . . . . 2.21-1

2.21.3 Standards for Containment/Release Detection . . . . . . . . 2.21-3

2.21.4 Supplemental Information $\ldots \ldots \ldots \ldots \ldots \ldots \ldots \ldots .2 .21-5$

2.21 .5 References . . . . . . . . . . . . . . . . 2.21-6

Figures 2.21-1 through 2.21-4

2.22 Tank System W-27 Piping $\ldots \ldots \ldots \ldots \ldots \ldots \ldots \ldots \ldots \ldots \ldots \ldots \ldots . . .22-1$

2.22 .1 Tank System Summary $\ldots \ldots \ldots \ldots \ldots \ldots \ldots . . . \ldots .22-1$

2.22.2 Standards for Pipe Assessment of Tank Systems . . . . . . 2.22-1

2.22.3 Standards for Containment/Release Detection . . . . . . . . 2.22-3

2.22.4 Supplemental Information . . . . . . . . . . . . . 2.22-5

2.22 .5 References . . . . . . . . . . . . . . . . . . 2.22-6

Figures 2.22-1 through 2.22-4 
2.23 Tank System W-28 Piping $\ldots \ldots \ldots \ldots \ldots \ldots \ldots \ldots \ldots \ldots \ldots \ldots \ldots \ldots \ldots .23-1$

2.23 .1 Tank System Summary $\ldots \ldots \ldots \ldots \ldots \ldots \ldots \ldots . . \ldots \ldots \ldots . .23-1$

2.23.2 Standards for Pipe Assessment of Tank Systems . . . . . . . 2.23-1

2.23.3 Standards for Containment/Release Detection . . . . . . . . 2.23-3

2.23.4 Supplemental Information $\ldots \ldots \ldots \ldots \ldots \ldots \ldots \ldots \ldots \ldots \ldots \ldots \ldots .23-5$

2.23 .5 References . . . . . . . . 23-6

Figures 2.23-1 through 2.23-4

2.24 Tank System W-29 Piping $\ldots \ldots \ldots \ldots \ldots \ldots \ldots \ldots \ldots \ldots \ldots \ldots .2 .24-1$

2.24.1 Tank System Summary $\ldots \ldots \ldots \ldots \ldots \ldots \ldots . . \ldots \ldots .2 .24-1$

2.24.2 Standards for Pipe Assessment of Tank Systems . . . . . . . . 2.24-1

2.24.3 Standards for Containment/Release Detection . . . . . . . . 2.24-3

2.24.4 Supplemental Information $\ldots \ldots \ldots \ldots \ldots \ldots \ldots \ldots \ldots \ldots \ldots \ldots \ldots .2 .24-5$

2.24 .5 References . . . . . . . . . . . . . . . . . 2.24-6

Figures $2.24-1$ through $2.24-4$

2.25 Tank System $W-30$ Piping $\ldots \ldots \ldots \ldots \ldots \ldots \ldots \ldots \ldots \ldots \ldots \ldots \ldots \ldots \ldots \ldots . .25-1$

2.25.1 Tank System Summary $\ldots \ldots \ldots \ldots \ldots \ldots \ldots \ldots .2 .25-1$

2.25.2 Standards for Pipe Assessment of Tank Systems . . . . . . . . 2.25-1

2.25.3 Standards for Containment/Release Detection . . . . . . . . 2.25-3

2.25.4 Supplemental Information $\ldots \ldots \ldots \ldots \ldots \ldots \ldots \ldots .2 .25-5$

2.25 .5 References . . . . . . . . . . . . . . . . . 2.25-6

Figures 2.25-1 through 2.25-4

2.26 Tank System W-31 Piping $\ldots \ldots \ldots \ldots \ldots \ldots \ldots \ldots \ldots \ldots \ldots \ldots \ldots .2 .26-1$

2.26 .1 Tank System Summary $\ldots \ldots \ldots \ldots \ldots \ldots \ldots \ldots . . .2 .26-1$

2.26.2 Standards for Pipe Assessment of Tank Systems . . . . . . 2.26-1

2.26.3 Standards for Containment/Release Detection . . . . . . . . 2.26-3

2.26.4 Supplemental Information $\ldots \ldots \ldots \ldots \ldots \ldots \ldots \ldots \ldots . .2 .26-5$

2.26 .5 References ........................ 2.26-6

Figures 2.26-1 through 2.26-4

2.27 Transfer Lines Piping System $\ldots \ldots \ldots \ldots \ldots \ldots \ldots \ldots \ldots \ldots \ldots \ldots \ldots \ldots \ldots \ldots .27-1$

2.27.1 Pipe System Summary . . . . . . . . . . . . . . . . 2.27-1

2.27.2 Standards for Pipe Assessment of Tank Systems . . . . . . 2.27-1

2.27.3 Standards for Containment/Release Detection . . . . . . . 2.27-5

2.27.4 Supplemental Information $\ldots \ldots \ldots \ldots \ldots \ldots \ldots \ldots . \ldots \ldots .2 .27-11$

2.27.5 References ......................... 2.27-13

Figures 2.27-1 through 2.27-5

2.28 Tank System S-223 Piping $\ldots \ldots \ldots \ldots \ldots \ldots \ldots \ldots \ldots \ldots \ldots \ldots \ldots \ldots \ldots \ldots \ldots \ldots \ldots \ldots \ldots \ldots .28-1$

2.28.1 Tank System Summary . . . . . . . . . . . . . . . 2.28-1

2.28.2 Standards for Pipe Assessment of Tank Systems . . . . . . . 2.28-1

2.28.3 Standards for Containment/Release Detection . . . . . . . . 2.28-3

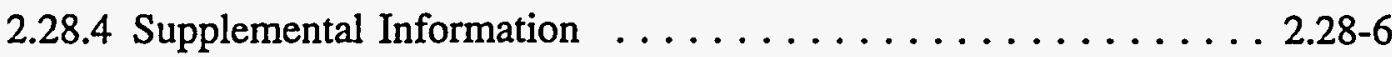

2.28 .5 References . . . . . . . . . . . . . . . . . . 2.28-8

Figures 2.28-1 through 2.28-3 
2.29 Tank System S-324 Piping $\ldots \ldots \ldots \ldots \ldots \ldots \ldots \ldots \ldots \ldots \ldots \ldots \ldots \ldots \ldots .29 .1$

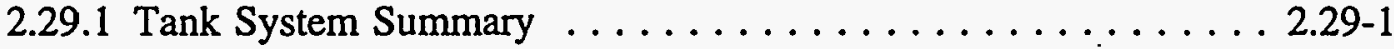

2.29.2 Standards for Pipe Assessment of Tank Systems . . . . . . . . 2.29-1

2.29.3 Standards for Containment/Release Detection . . . . . . . 2.29-2

2.29.4 Supplemental Information . . . . . . . . . . . . . 2.29-6

2.29 .5 References . . . . . . . . . . . . . . . . . . . . 2.29-7

Figures 2.29-1 through 2.29-3

2.30 Tank System S-523 Piping . . . . . . . . . . . . . . . 2.30-1

2.30 .1 Tank System Summary $\ldots \ldots \ldots \ldots \ldots \ldots \ldots \ldots .2 .30-1$

2.30.2 Standards for Pipe Assessment of Tank Systems . . . . . . 2.30-1

2.30.3 Standards for Containment and Release Detection . . . . . . 2.30-2

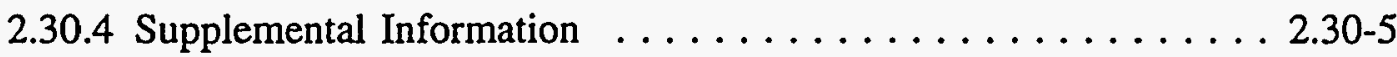

2.30 .5 References . . . . . . . . . . . . . . . . . . . .

Figures 2.30-1 through 2.30-3 


\section{ACRONYMS}

$\begin{array}{ll}\text { AEC } & \text { Atomic Energy Commission } \\ \text { ASHRAE } & \text { American Society of Heating, Refrigeration, and Air Conditioning Engineers } \\ \text { AMCA } & \text { Air Moving and Conditioning Association } \\ \text { ASME } & \text { American Society of Mechanical Engineers } \\ \text { CMP } & \text { helically corrugated metal pipe } \\ \text { DOE } & \text { Department of Energy } \\ \text { ERDA } & \text { Energy Research and Development Administration } \\ \text { FFA } & \text { Federal Facility Agreement } \\ \text { ICPL } & \text { Interconnecting Pipe Line } \\ \text { LLLW } & \text { liquid low-level waste } \\ \text { MVCT } & \text { Melton Valley Collection and Transfer } \\ \text { MVCTS } & \text { Melton Valley Collection and Transfer System } \\ \text { NFPA } & \text { National Fire Protection Association } \\ \text { NHF } & \text { New Hydrofracture Facility } \\ \text { ORNL } & \text { Oak Ridge National Laboratory } \\ \text { psig } & \text { pounds per square inch, gauge } \\ \text { PWD } & \text { Process Waste Drain } \\ \text { PWTP } & \text { Process Waste Treatment Plant } \\ \text { REDC } & \text { Radiochemical Engineering Development Center } \\ \text { R/h } & \text { rem per hour } \\ \text { RHD } & \text { Radioactive Hot Drain } \\ \text { RHD-HOG } & \text { Radioactive Hot Drain-Hot Offgas } \\ \text { RHDR } & \text { Radioactive Hot Drain Recoverable } \\ \text { RPP } & \text { Radioactive Processing Plant } \\ \text { SS } & \text { stainless steel } \\ \text { SMACNA } & \text { Sheet Metal and Air Conditioning Contractors National Association } \\ \text { UCC-ND } & \text { Union Carbide Corporation Nuclear Division } \\ & \end{array}$




\section{EXECUTIVE SUMMARY}

Demonstration of the design of the piping systems described in this report is stipulated by the Federal Facility Agreement (FFA) between the U.S. Environmental Protection Agency (EPA)Region IV, the Tennessee Department of Environment and Conservation (TDEC), and the U.S. Department of Energy (DOE). This report provides a design demonstration of the secondary containment and ancillary equipment of 30 piping systems designated in the FFA as Category B (i.e., existing tank systems with secondary containment). Based on the findings of the Design Demonstrations for the Remaining 19 Category B Tank Systems, (DOE/OR/03-1150 \& D2), three tank systems originally designated as Category $\mathrm{B}$ have been redesignated as Category $\mathrm{C}$ (i.e., existing tank systems without secondary containment). The design demonstrations were developed using information obtained from design drawings (as-built when available), construction specifications, and interviews with facility operators. Each design demonstration addresses system conformance to the requirements of the FFA (Appendix F, Section C). Deficiencies or restrictions regarding the ability to demonstrate that each of the containment systems conforms to FFA requirements are noted in the discussion of each piping system and presented in Table 2.0-1. 
Design Demonstrations - Category B Tank Systems (Piping)

This document presents design demonstrations conducted of liquid low-level waste (LLLW) storage tank systems located at the Oak Ridge National Laboratory (ORNL). ORNL is part of the United States Department of Energy's (DOE's) Oak Ridge Reservation located southwest of the city of Oak Ridge, Tennessee. The laboratory has conducted research in energy-related fields since 1943. The facilities used to conduct the research include nuclear reactors, chemical pilot plants, research laboratories, radioisotope production laboratories, and support facilities. These facilities have produced a variety of radioactive and/or hazardous wastes that have been stored and transported through an extensive network of piping and tankage.

Demonstration of the design of these tank systems has been stipulated by the Federal Facility Agreement (FFA) between the United States Environmental Protection Agency (EPA)Region IV, the Tennessee Department of Environment and Conservation (TDEC), and the DOE. The FFA establishes four categories of tank systems:

Category A-New or Replacement Tank Systems with Secondary Containment, Category B-Existing Tank Systems with Secondary Containment, Category C-Existing Tank Systems Without Secondary Containment, and Category D-Existing Tank Systems That are Removed from Service.

This document provides a design demonstration of the secondary containment and ancillary equipment of 30 piping systems designated in the FFA as Category B. Three tank systems originally designated as Category B have been redesignated as Category C. The design demonstration for each system is presented in Section 2. These design demonstrations were developed using information obtained from the design drawings (as-built when available), construction specifications, and interviews with facility operators. The assessments assume that each piping system was constructed in accordance with the design drawings and construction specifications for that system unless specified otherwise. Each design demonstration addresses system conformance to the requirements of the FFA (Appendix F, Section C). 
Individual design demonstrations of the secondary containment of 30 piping systems designated as FFA Category B systems are included in Sections 2.1 through 2.30. Three tank systems originally designated as Category $\mathrm{B}$ have been redesignated. If additional information is identified for a specific system, the section containing the assessment of that containment system may be revised and reissued.

The objective of each assessment is to demonstrate that the design of the secondary containment system meets the requirements of Appendix F, Section C of the FFA. Three piping systems (WC-20, F-201 and F-501) have deficiencies which do not fully meet the secondary containment requirements and have been redesignated as Category C. Deficiencies or restrictions regarding the ability to demonstrate that the remaining 27 containment systems conform to FFA requirements have been noted in the discussion of each requirement.

A matrix identifying the deficiencies associated with each piping system and the name of the project which will provide the requisite corrective action is presented in Table 2.0-1. 
TABLE 2.0-1 CONTAINMENT SYSTEM DEFICIENCIES

\begin{tabular}{|c|c|c|c|c|c|c|c|c|c|c|}
\hline $\begin{array}{l}\text { TANK } \\
\text { SYSTEM } \\
\text { (SECTION) }\end{array}$ & $\begin{array}{l}\text { DEFICIENCY } \\
\text { CONTAINMENT }\end{array}$ & $\begin{array}{l}\quad \text { A } \\
\text { SINGLY } \\
\text { CONTAINED } \\
\text { PIPING }\end{array}$ & \begin{tabular}{l}
\multicolumn{1}{c}{ B } \\
SECONDAAY \\
CONTAINMENT \\
PROTECTIVE \\
LINER OR \\
COATING NOT \\
PROVIDED
\end{tabular} & $\begin{array}{l}\quad \text { C } \\
\text { SECONDARY } \\
\text { CONTAINMENT } \\
\text { MATERIAL NOT } \\
\text { COMPATIBLE } \\
\text { WITH WASTE }\end{array}$ & \begin{tabular}{l}
\multicolumn{1}{c}{ D } \\
PIPING \\
PENETRATION \\
SLEEVES NOT \\
COMPATIBLE \\
WITH WASTE
\end{tabular} & $\begin{array}{l}\quad \text { E } \\
\text { LEAK } \\
\text { OETECTION } \\
\text { SYSTEM } \\
\text { NOT } \\
\text { PROVIDED }\end{array}$ & $\begin{array}{l}\quad \boldsymbol{F} \\
\text { MEANS OF } \\
\text { LIOUID } \\
\text { REMOVAL } \\
\text { NOT } \\
\text { PROVIDED }\end{array}$ & $\begin{array}{l}\quad \mathbf{G} \\
\text { DRAIN SYSTEM } \\
\text { MAY TRANSFER } \\
\text { LLLW TO AN } \\
\text { INAPPROPRIATE } \\
\text { SYSTEM }\end{array}$ & $\begin{array}{l}\quad \mathbf{H} \\
\text { INADEQUATE } \\
\text { CATHODIC } \\
\text { PROTECTION }\end{array}$ & $\begin{array}{l}\text { PROSECT NAME FOR CORRECTIVE ACTION } \\
\text { FOR PROUECT COMPLEMON DATE, SEE (CURRENT) } \\
\text { MPLEMENTAMON PLAN FOR LUW TANK } \\
\text { SYSTEMS. }\end{array}$ \\
\hline \multirow{10}{*}{$\begin{array}{l}\text { B-2.T } \\
(2.1)\end{array}$} & UNDERGROUND PIPING & $x$ & & & & & & & $x$ & $\begin{array}{l}\text { A: Melton Valley LLLW-CAT Sys. Upgrado } \\
\text { H: Melton Valley LLWW-CAT Sys. Upgrade }\end{array}$ \\
\hline & EMBEDDED PIPING & $x$ & & & & & & & & A: Melion Valley LLLW-CAT Sys. Upgrade \\
\hline & PITOT TUBE PIT & & $x$ & & & $x$ & $x$ & & & $\begin{array}{l}\text { 8: Melton Valley LLLW.CAT Sys. Upgrade } \\
\text { E: Melton Valley LLLW.CAT Sys. Upgrade } \\
\text { F: Melton Valloy LLLW.CAT Sys. Upgrade }\end{array}$ \\
\hline & NORTH VALVE PIT & & $x$ & & & & & & & B: Melton Valley LLLLW.CAT Sys. Upgrado \\
\hline & CELL F CORRIDOR & & & $x$ & & & & $x$ & & $\begin{array}{l}\text { C: Metton Valloy LUW-CAT Sys. Upgrade } \\
\text { G: Methon Valloy LUW-CAT Sys. Upgrade }\end{array}$ \\
\hline & $\begin{array}{l}\text { OPERATNG AREA } \\
\text { NO. } 119\end{array}$ & & & $x$ & & $x$ & & $x$ & & $\begin{array}{l}\text { C: Melton Valloy LLLW-CAT Sys. Upgrado } \\
\text { E: Metton Valley LLLW-CAT Sys. Upgrade } \\
\text { G: Meken Velloy LIIW-CAT Sys. Upgrade }\end{array}$ \\
\hline & CELLL G PUMP ROOM & & & $x$ & & & & $x$ & & $\begin{array}{l}\text { C: Mekton Valloy LLLW-CAT Sys. Upgrade } \\
\text { G: Mellon Valley LLLW.CAT Sys. Upgrade }\end{array}$ \\
\hline & $\begin{array}{l}\text { ROOM } 214 \\
\text { DECONTAMINATION PAN }\end{array}$ & & & & & $x$ & & $x$ & & $\begin{array}{l}\text { E: Metton Valley LLW-CAT Sys. Upgrade } \\
\text { G: Molton Valley LUW.CAT Sys. Upgrado }\end{array}$ \\
\hline & MOCK.UP AREA NO. 305 & & & $x$ & & $x$ & & $x$ & & $\begin{array}{l}\text { C: Mothon Valley LLLW.CAT Sys. Upgrade } \\
\text { E: Metton Valley LLW-CAT Sys. Upgrade } \\
\text { G: Metion Valley LLWW-CAT Sys. Upgrade }\end{array}$ \\
\hline & OPERATNG CELLS B \& D & & & & & $x$ & & & & E: Molton Valley LLLW-CAT Sys. Upgrado \\
\hline \multirow{2}{*}{$\begin{array}{l}\text { B-3.T } \\
(2.2)\end{array}$} & EMBEDDED PIPING & $x$ & & & & & & & & $\begin{array}{l}\text { A: Piping is out of sonice and capped. } \\
\text { Vanos are tagged out. }\end{array}$ \\
\hline & UNDERGROUND CMP & & & $x$ & & $x$ & $x$ & & $x$ & $\begin{array}{c}\text { C. E. F, H: Piping is out of service and capped. } \\
\text { Valves are tagged out. }\end{array}$ \\
\hline
\end{tabular}


TABLE 2.0-1

CONTAINMENT SYSTEM DEFICIENCIES

\begin{tabular}{|c|c|c|c|c|c|c|c|c|c|c|}
\hline $\begin{array}{l}\text { TANK } \\
\text { SYSTEM } \\
\text { (SECTION) }\end{array}$ & $\begin{array}{l}\text { CONTAINMENT } \\
\text { AREA }\end{array}$ & $\begin{array}{l}\quad \text { A } \\
\text { SINGLY } \\
\text { CONTAINED } \\
\text { PIPING }\end{array}$ & $\begin{array}{l}\text { B } \\
\text { SECONDARY } \\
\text { CONTAINMENT } \\
\text { PROTECTIVE } \\
\text { LINER OR } \\
\text { COATING NOT } \\
\text { PROVIDED } \\
\end{array}$ & $\begin{array}{l}\quad \text { C } \\
\text { SECONDARY } \\
\text { CONTAINMENT } \\
\text { MATERIAL NOT } \\
\text { COMPATIBLE } \\
\text { WTH WASTE }\end{array}$ & $\begin{array}{l}\text { D } \\
\text { PIPING } \\
\text { PENETRATION } \\
\text { SLEEVES NOT } \\
\text { COMPATBLE } \\
\text { WITH WASTE. }\end{array}$ & $\begin{array}{l}\quad \text { E } \\
\text { LEAK } \\
\text { DETECTION } \\
\text { SYSTEM } \\
\text { NOT } \\
\text { PROVIDEO }\end{array}$ & $\begin{array}{l}\quad \text { F } \\
\text { MEANS OF } \\
\text { LIQUID } \\
\text { REMOVAL } \\
\text { NOT } \\
\text { PROVIDED }\end{array}$ & $\begin{array}{l}\quad \text { G } \\
\text { DRAN SYSTEM } \\
\text { MAY TRANSFER } \\
\text { LUW TO AN } \\
\text { INAPPROPRIATE } \\
\text { SYSTEM }\end{array}$ & \begin{tabular}{l}
\multicolumn{1}{c}{ H } \\
INADEQUATE \\
CATHODIC \\
PROTECTION
\end{tabular} & $\begin{array}{l}\text { PROUECT NAME FOR CORRECTIVE ACTION } \\
\text { FOR PROIECT COMPLETON DATE, SEE (CURRENT) } \\
\text { IMPLEMENTATION PLAN FOR LUW TANK } \\
\text { SYSTEMS. }\end{array}$ \\
\hline \multirow{6}{*}{$\begin{array}{l}C .6-T \\
(2.3)\end{array}$} & UNDERGROUND PIPING & $x$ & & & & & & & $x$ & $\begin{array}{l}\text { A: Molton Valley LLLW.CAT Sys. Upgrado } \\
\text { H: Monon Valloy LLLW-CAT Sys. Upgrado }\end{array}$ \\
\hline & $\begin{array}{l}\text { EMBEDDED PIPING } \\
\text { (2 SEPARATE LINES } \\
\text { FROM TANK C-6-T TO } \\
\text { BLDG. 7930) }\end{array}$ & $x$ & & & & & & & & $\begin{array}{l}\text { A: MELTON VALLEY LLLW.CAT Sys. Upgrade } \\
\text { A: Piping is out of service and cappod. } \\
\text { Vales are taggoed out. }\end{array}$ \\
\hline & UNDERGROUND CMP & & & $x$ & & $x$ & $x$ & & $x$ & $\begin{array}{c}\text { C, E, F, H: Piping is out of service and cappod. } \\
\text { Valves are tagged out. }\end{array}$ \\
\hline & OPERATING CELL D & & & & & $x$ & & & & E: Molton Valloy LLLW-CAT Sys. Upgrado \\
\hline & CELL G PUMP ROOM & & & $x$ & & & & $x$ & & $\begin{array}{l}\text { C: Metton Valloy LLLW-CAT Sys. Upgrado } \\
\text { G: Melton Valtey LIW.CAT Sys. Upgrade }\end{array}$ \\
\hline & MOCK-UP AREA NO. 305 & & & $x$ & & $x$ & & $x$ & & $\begin{array}{l}\text { C: Motton Valloy LLLW.CAT Sys. Upgrado } \\
\text { E: Metton Valloy LLWW.CAT Sys. Upgrade } \\
\text { G: Metton Valloy LLWW.CAT Sys. Upgrado }\end{array}$ \\
\hline $\begin{array}{l}C-1 \\
(2.4)\end{array}$ & EMBEDDED PIPING & $x$ & & & & & & & & A. Soo Note 1 on Pago 2.0 .5 \\
\hline $\begin{array}{l}C .2 \\
(2.5)\end{array}$ & EMBEDDED PIPING & $x$ & & & & & & & & A. Soo Note 1 on Page 2.0 .5 \\
\hline \multirow{2}{*}{$\begin{array}{l}F-126 \\
(2.7)\end{array}$} & UNDERGROUND PIPING & $x$ & & & & & & & $x$ & $\begin{array}{l}\text { A: Morton Valloy LLLW-CAT Sys. Upgrado } \\
\text { H: Motton Valloy LLLW-CAT Sys. Upgrado }\end{array}$ \\
\hline & MVCT BOX NO. 1 & & & & & $x$ & $x$ & & & $\begin{array}{l}\text { E: Motton Valtoy LLLW-CAT Sys. Upgrado } \\
\text { F: Molton Valley LLLW.CAT Sys. Upgrado }\end{array}$ \\
\hline \multirow{2}{*}{$\begin{array}{l}L \cdot 11 \\
(2.10)\end{array}$} & $\begin{array}{l}\text { UNDERGROUND \& } \\
\text { EMBEDDED PIPING }\end{array}$ & $x$ & & & & & & & $x$ & $\begin{array}{l}\text { A. ORNL Process Waste Troatment Facility } \\
\text { H: ORNL Process Wasto Treatment Facility }\end{array}$ \\
\hline & $\begin{array}{l}\text { TANK VAULT L- } 11 \text { WALL } \\
\text { PENETRATIONS }\end{array}$ & & & & $x$ & & & & & D: ORNL Procoss Waste Treatment Facilty \\
\hline $\begin{array}{l}P-3 \\
(2.12)\end{array}$ & UNDERGROUND PIPING & $x$ & & & & & & & $x$ & $\begin{array}{l}\text { A: GPP.FFA Compliance Work, 8ldg. 3019A } \\
\text { H: GPP.FFA Complianco Work, Bldg. 3019A }\end{array}$ \\
\hline $\begin{array}{l}T-13 \\
(2.14)\end{array}$ & EMBEDDED PIPING & $x$ & & & & & & & & A. Soe Note I on Pago 2.0-5 \\
\hline
\end{tabular}

$X=$ Deficiency Stuted in Document 
TABLE 2.0-1

CONTAINMENT SYSTEM DEFICIENCIES

\begin{tabular}{|c|c|c|c|c|c|c|c|c|c|c|}
\hline $\begin{array}{l}\text { TANK } \\
\text { SYSTEM } \\
\text { (SECTION) }\end{array}$ & $\begin{array}{l}\text { DEFICIENCY } \\
\text { COREA }\end{array}$ & $\begin{array}{l}\quad \text { A } \\
\text { SINGLY } \\
\text { CONTAINED } \\
\text { PIPING }\end{array}$ & \begin{tabular}{l}
\multicolumn{1}{c}{ B } \\
SECONDARY \\
CONTAINMENT \\
PROTECTIVE \\
LINER OR \\
COATING NOT \\
PROVIDED
\end{tabular} & $\begin{array}{l}\quad \text { C } \\
\text { SECONDARY } \\
\text { CONTAINMENT } \\
\text { MATERIAL NOT } \\
\text { COMPATIBLE } \\
\text { WITH WASTE }\end{array}$ & \begin{tabular}{l}
\multicolumn{1}{c}{ D } \\
PIPING \\
PENETRATION \\
SLEEVES NOT \\
COMPATIBLE \\
WITH WASTE
\end{tabular} & $\begin{array}{l}\quad \text { E } \\
\text { LEAK } \\
\text { DETECTION } \\
\text { SYSTEM } \\
\text { NOT } \\
\text { PROVIDED }\end{array}$ & $\begin{array}{l}\quad \text { F } \\
\text { MEANS OF } \\
\text { UQUID } \\
\text { REMOVAL } \\
\text { NOT } \\
\text { PROVIDED }\end{array}$ & $\begin{array}{l}\quad \text { G } \\
\text { DRAIN SYSTEM } \\
\text { MAY TRANSFER } \\
\text { LLWW TO AN } \\
\text { INAPPROPRIATE } \\
\text { SYSTEM }\end{array}$ & \begin{tabular}{l}
\multicolumn{1}{c}{$\mathrm{H}$} \\
INADEOUATE \\
CATHODIC \\
PROTECTION
\end{tabular} & $\begin{array}{l}\text { PROJECT NAME FOR CORRECTIVE ACTION } \\
\text { FOR PROIECT COMPLEMON DATE, SEE (CURRENT } \\
\text { IMPLEMENTATON PLAN FOR LLW TANK } \\
\text { SYSTEMS. }\end{array}$ \\
\hline $\begin{array}{l}W \cdot 21 \\
(2.16)\end{array}$ & $\begin{array}{l}\text { TANK VAULT W-2t WALL } \\
\text { PENETRATIONS } \\
\text { (EMBEDDED PIPING) }\end{array}$ & $x$ & & & & & & & & A: Soo Noto 1 on Pago 2.0.5. \\
\hline $\begin{array}{l}W \cdot 22 \\
(2.17)\end{array}$ & $\begin{array}{l}\text { CONCRETE WALL } \\
\text { PENETRATIONS } \\
\text { (EMBEDDED PIPING) }\end{array}$ & $x$ & & & & & & & & A: See Note 1 on Page 2.0-5. \\
\hline \multirow{3}{*}{$\begin{array}{l}\text { W.23 } \\
(2.18)\end{array}$} & $\begin{array}{l}\text { CONCRETE WALL } \\
\text { PENETRATIONS } \\
\text { (EMEEDDED PIPING) }\end{array}$ & $x$ & & & & & & & & A: Seo Note 1 on Page 2.0.5. \\
\hline & $\begin{array}{l}\text { DOUBLE WALL } \\
\text { UNDERGROUND PIPING }\end{array}$ & & & & & & & & $x$ & $\begin{array}{l}\text { H: Upgrade Cathodic Protection Systoms. Phase : } \\
\text { schioduled for completion in Fiscal Year } 1995 .\end{array}$ \\
\hline & $\begin{array}{l}\text { EVAPORATOR ANNEX } \\
\text { VALVE PIT NO. } 1\end{array}$ & & & & & $x$ & $x$ & & & $\begin{array}{l}\text { E: East Evaporator Valve Pil Upgrado-GPP } \\
\text { F: East Evaporator Valve Pit Upgrado-GPP }\end{array}$ \\
\hline $\begin{array}{l}\text { W.24 } \\
\text { (2.19) } \\
\text { THROUGH } \\
\text { W.31 } \\
(2.26)\end{array}$ & $\begin{array}{l}\text { TANK VAULT WALL } \\
\text { PENETRATIONS } \\
\text { (EMBEDDED PIPING) }\end{array}$ & $x$ & & & & & & & & A: Soo Nerio i an Pagso $20-5$. \\
\hline \multirow{5}{*}{$\begin{array}{l}\text { TRANSFER } \\
\text { LINES } \\
(2.27)\end{array}$} & EMBEDDED PIPING & $x$ & & & & & & & & A: Soo Note 1 on Pago 20.5 \\
\hline & $\begin{array}{l}\text { DOUBLE WALL } \\
\text { UNOERGROUND PIPING }\end{array}$ & & & & & & & & $x$ & $\begin{array}{l}\text { H: Upgrade Cathodic Protection Systoms. Phase } 1 \\
\text { schedulod for completion in Fiscal Year } 1995 .\end{array}$ \\
\hline & VALVE BOX AT TANK W-G & & & & & & $x$ & . & & F: W.6 Valve Box Upgrado-GPP \\
\hline & $\begin{array}{l}\text { SOUTH PARKING LOT } \\
\text { VALVE BOX }\end{array}$ & & $x$ & & & $x$ & $x$ & & & $\begin{array}{l}\text { B: Incinerator Orive Valve Box Upgrado-GPP } \\
\text { E: Incineralor Drive Valve Box Upgrado-GPP } \\
\text { F: Incinerato Drive Valve Box Upgrado-GPP }\end{array}$ \\
\hline & ICPL VALVE BOX NO. 1 & & & & & & $x$ & & & F: Incineralor Drive Valve Box Upgrado-GPP \\
\hline
\end{tabular}

$X=$ Deficiency Stated in Document 
TABLE 2.0-1

CONTAINMENT SYSTEM DEFICIENCIES

\begin{tabular}{|c|c|c|c|c|c|c|c|c|c|c|}
\hline $\begin{array}{l}\text { TANK } \\
\text { SYSTEM } \\
\text { (SECTION) }\end{array}$ & CONTAINMENT & $\begin{array}{l}\quad \text { A } \\
\text { SINGLY } \\
\text { CONTAINED } \\
\text { PIPING }\end{array}$ & $\begin{array}{l}\quad \text { B } \\
\text { SECONDARY } \\
\text { CONTAINMENT } \\
\text { PROTECTIVE } \\
\text { UNEER OR } \\
\text { COATING NOT } \\
\text { PROVIDED }\end{array}$ & \begin{tabular}{l}
\multicolumn{1}{c}{ C } \\
SECONDARY \\
CONTAINMENT \\
MATERIAL NOT \\
COMPATIBLE \\
WITH WASTE
\end{tabular} & $\begin{array}{l}\text { D } \\
\text { PIPING } \\
\text { PENETRATION } \\
\text { SLEEVES NOT } \\
\text { COMPATIBLE } \\
\text { WITH WASTE }\end{array}$ & $\begin{array}{l}\quad \text { E } \\
\text { LEAK } \\
\text { DETECTON } \\
\text { SYSTEM } \\
\text { NOT } \\
\text { PROVIOED }\end{array}$ & $\begin{array}{l}\quad \text { F } \\
\text { MEANS OF } \\
\text { LUUID } \\
\text { REMOVAL } \\
\text { NOT } \\
\text { PROVIDED }\end{array}$ & $\begin{array}{l}\quad \text { G } \\
\text { DRAN SYSTEM } \\
\text { MAY TRANSFER } \\
\text { LUW TO AN } \\
\text { INAPPROPRIATE } \\
\text { SYSTEM }\end{array}$ & \begin{tabular}{l}
\multicolumn{1}{c}{$\boldsymbol{H}$} \\
INADEQUATE \\
CATHODIC \\
PROTECTION
\end{tabular} & $\begin{array}{l}\text { PROJECT NAME FOR CORRECTIVE ACTION } \\
\text { FOR PROUECT COMPLITON DATE, SEE (CURRENT) } \\
\text { MMPLEMENTATON PLAN FOR LUW TANK } \\
\text { SYSTEMS. }\end{array}$ \\
\hline \multirow[t]{3}{*}{$\begin{array}{l}S .223 \\
(2.28)\end{array}$} & UNDERGROUND PIPING & $x$ & & & & & & & $x$ & $\begin{array}{l}\text { A. Piphg is schooduled to be taxon out of sonvioe. } \\
\text { H: Upgrade Cathodic Protoction Systoms. Phase } 2 \\
\text { schedulod for completion in Fiscal Year } 1996 .\end{array}$ \\
\hline & $\begin{array}{l}\text { DOUBLE WALL } \\
\text { UNDERGROUND PIPING }\end{array}$ & & & & & & & & $x$ & $\begin{array}{l}\text { H: Upgrade Cathodic Protoction Systoms. Phase } 2 \\
\text { schodulod for completion in Fiscal Year } 1996 .\end{array}$ \\
\hline & $\begin{array}{l}\text { TANK VAULT \& CELL } \\
\text { WALL PENETRATIONS } \\
\text { (EMBEDDED PIPING) }\end{array}$ & $x$ & & & & & & & & A: Soe Noto 1 below \\
\hline $\begin{array}{l}s .324 \\
(2.29)\end{array}$ & EMBEDDED PIPING & $x$ & & & & & & & & A: Soe Noto 1 betow \\
\hline $\begin{array}{l}\text { S-523 } \\
(2.30)\end{array}$ & EMBEDDED PIPING & $x$ & & & & & & & & A: Soo Note 1 botow \\
\hline
\end{tabular}

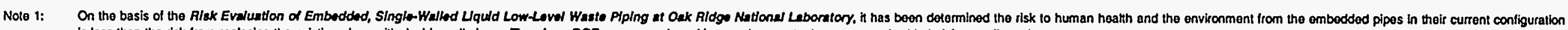
is less than the risk from replacing the existing pipos with double wall plpes. Therefore, DOE recommends making no changes to the current ombedsed piping configuration. 


\subsubsection{Tank System Summary}

Tank System B-2-T is located near the Radiochemical Engineering Development Center (REDC) (Building 7930) at the Melton Valley High Flux Isotope Reactor Complex (Figures 2.1-1 and 2.1-2). The tank system piping is schedule 40S, ASME SA-240, type 304L stainless steel (SS) and is routed from Tank Vault B-2-T (Waste Tank Pit that also contains Tanks B-3-T and C-6-T) through the Radioactive Hot Drain (RHD) Line Pit and outside underground to the Melton Valley Collection and Transfer System (MVCTS) main transfer line. Additional system piping is routed from Tank Vault B-2-T outside underground beneath Building 7930 and extends into areas within Building 7930 .

Tank System B-2-T piping is used to transfer liquid low-level waste (LLLW) from the Building 7930 Radioactive Hot Drain-Hot Offgas (RHD-HOG) System to Tank B-2-T and from Tank B-2-T to the MVCTS and is classified as a Federal Facility Agreement Category B tank system.

\subsubsection{Standards for Pipe Assessment of Tank Systems}

\subsubsection{Tank System Piping Description and Design Standards}

\section{Tank System Piping Description}

Tank System B-2-T piping extends from Tank Vault B-2-T, near the southwest corner of Building 7930, to within Building 7930 and to a main transfer line connected to the MVCTS. The piping system is under the control of the REDC and is operated by the Chemical Technology Division.

Tank System B-2-T piping is constructed of $3 / 4^{\prime \prime}, 1^{\prime \prime}, 1-1 / 2^{\prime \prime}, 2^{\prime \prime}, 4^{\prime \prime}$, and $6^{\prime \prime}, 304 \mathrm{~L}$ SS with a maximum design temperature and pressure of $130^{\circ} \mathrm{F}$ and $150 \mathrm{psig}$. Tank System B-2-T piping has the capacity to contain a maximum volume of $408 \mathrm{gal}$.

\section{Design Standards}

The applicable codes and standards used for Tank System B-2-T piping and the associated secondary containment systems are identified herein. The codes and standards listed are those identified on either the design drawings or the construction specifications.

AEC-Oak Ridge Office, Minimum Safety Requirements;

Air Moving and Conditioning Association (AMCA) Standards Handbook-Publication 99; AMCA Fans and Systems-Publication 201;

AMCA Directory-Publication 261;

American Concrete Institute; 
American Concrete Pipe Association;

American Conference of Governmental Industrial Hygienists;

American Society of Heating, Refrigeration, and Air Conditioning Engineers (ASHRAE) Handbook of Fundamentals;

American Society of Mechanical Engineers (ASME) Boiler and Pressure Vessel Code, Sections II (SA-240), IV, VII, VIII, and IX;

American Society for Testing and Materials A93, A244, A307, C39, C78, C138, C143, and D1752;

American Standards Association Safety Code for Building Construction;

ASHRAE Guide and Data Book-Applications;

ASHRAE Guide and Data Book-Equipment;

ASHRAE Handbook-Systems;

Atomic Energy Commission (AEC) General Design Criteria, Appendix 63;

Factory Mutual Engineering Corporation;

Instrument Society of America;

National Electric Code;

National Fire Protection Association (NFPA) No. 90A-Air Conditioning and Ventilating Systems;

NFPA No. 91-Blower and Exhaust Systems;

Occupational Safety and Health Administration; and

Underwriters Laboratories Inc.

\subsubsection{Generic Description of Piping Contents}

Tank System B-2-T piping is designed to transfer LLLW from the Building 7930 RHD-HOG System to Tank B-2-T and from Tank B-2-T to a main transfer line connected to the MVCTS. The primary source of LLLW is Cell G in Building 7930. These wastes may include a variety of dilute acids, bases, and organics. The tank system may contain radioactive materials from the REDC.

The analytical data (Figure 2.1-3) of waste stream contaminants from the generators are representative of waste transferred through Tank System B-2-T piping. 


\subsubsection{Pipe Corrosion Protection Measures}

Piping inside Tank Vault B-2-T, the RHD Line Pit, and Building 7930 is not in direct contact with the soil or water. Cathodic protection measures are not required for external corrosion.

The piping that is routed outside underground is singly contained, and the external surfaces are exposed to the soil and water. Protective coatings or cathodic protection measures are not present in the section of outside underground piping from Tank Vault B-2-T to Building 7930.

The cathodic protection for the piping leading from the RHD Line Pit to the connection at the MVCTS main transfer line is included in the Facility Manager's Cathodic Protection System No. 5. The galvanic anode cathodic protection system consists of magnesium anodes, test stations, and connecting wire as shown on the cathodic protection drawing C-20013-EA-003D. The system was installed in May 1972.

The system is not considered adequate because electrical isolating devices were not called out for the pipe termination points. Harco Technologies determined that insulating gaskets were not present during its 1990 surveys. In addition, the cathodic protection field testing performed in 1991 indicated that $60 \%$ of the pipe was not receiving adequate corrosion control. The lack of electrical isolation of the outside underground pipe from the interior piping and depleted anode beds are contributing factors in the resultant lack of corrosion control. In 1991, Harco completed the engineering design to upgrade the existing system to protect the piping.

\subsubsection{Documented Age of Tank System}

Tank System B-2-T piping was originally installed in 1965. The section of piping between the RHD Line Pit and the MVCTS main transfer line was installed in 1972.

\subsubsection{Standards for Containment/Release Detection}

Tank System B-2-T piping incorporates approximately $1240^{\prime}$ of outside underground and embedded piping that is singly contained. The singly contained areas are omitted from discussion in the following sections that address secondary containment.

2.1.3.1 Constructed of or Lined with Materials That are Compatible with Stored Waste(s) or Substance(s) to Be Placed in the Tank System and Shall Have Sufficient Strength and Thickness to Prevent Failure

Tank System B-2-T piping is single-wall, schedule 40S, type 304L SS pipe. The piping is routed outside underground from Tank Vault B-2-T to the MVCTS main transfer line and to areas within Building 7930. Areas of secondary containment are discussed below. 
Design Demonstrations - Category B Tank Systems (Piping)

\section{Tank Vault B-2-T}

The assessment of the secondary containment system for Tank Vault B-2-T is presented in the Design Demonstrations for Tank B-2-T. That assessment concludes that Tank Vault B-2-T is coated with materials that are compatible with the waste and designed to prevent migration of waste into the concrete.

\section{$\underline{\text { RHD Line Pit }}$}

The RHD Line Pit floor is coated with a 30-mil-thick system of Amercoat 66 epoxy. The concrete walls of the RHD Line Pit are coated with a 5-mil-thick system of Amercoat 99 vinyl emulsion. According to the manufacturer's specifications, the Amercoat 66 and Amercoat 99 coatings are compatible with the waste and designed to prevent migration of waste into the concrete.

\section{Areas Within Building 7930}

\section{Pitot Tube Pit}

The Pitot Tube Pit floor and walls are not coated or lined with materials that are compatible with the waste and designed to prevent migration of waste into the concrete.

\section{North Valve Pit}

The North Valve Pit floor and walls are not coated or lined with materials that are compatible with the waste and designed to prevent migration of waste into the concrete.

\section{Cell F Corridor}

The floor of the Cell F Corridor is coated with a 20-mil-thick system of Amercoat 74. According to the manufacturer's specifications, the Amercoat 74 system is compatible with the waste and designed to prevent migration of waste into the concrete. The concrete walls of the Cell F Corridor are coated with a 6-mil-thick system of Amercoat 88. According to the manufacturer's specifications, the Amercoat 88 system is not compatible with the waste and is not designed to prevent migration of waste into the concrete. According to the manufacturer, this coating system does not provide the appropriate resistance to chemicals and radiation.

\section{Operating Area No. 119}

The concrete floor in Operating Area No. 119 is covered with vinyl asbestos tiles and is not provided with a protective liner or coating that is compatible with the waste and designed to prevent migration of waste into the concrete. The trench, drain, and covers are coated with a 20-mil-thick system of Amercoat 74. According to the manufacturer's specifications, the Amercoat 74 system is compatible with the waste and designed to prevent migration of waste into the concrete. The walls of Operating Area No. 119 are coated with a 6-mil-thick system of Amercoat 88. According to the manufacturer's 
Design Demonstrations - Category B Tank Systems (Piping)

specifications, the Amercoat 88 system is not compatible with the waste and is not designed to prevent migration of waste into the concrete.

\section{Cell G Pump Room}

The concrete floor, trench, drain, and covers are coated with a 20-mil-thick system of Amercoat 74. According to the manufacturer's specifications, the Amercoat 74 system is compatible with the waste and designed to prevent migration of waste into the concrete. The concrete and masonry walls are coated with a 6-mil-thick system of Amercoat 88. According to the manufacturer's specifications, the Amercoat 88 system is not compatible with the waste and is not designed to prevent migration of waste into the concrete.

\section{Room 214 Decontamination Pan}

The Decontamination Pan in Maintenance Operating Area No. 214 is lined with 1/4", 304L SS plate, which is the same material as that used for the piping. The SS decontamination pan lining is compatible with the waste and designed to prevent migration of waste into the concrete.

\section{Mock-Up Area No. 305}

The concrete floor and the exposed ferrous metal embedded in the floor are coated with a 20-mil-thick system of Amercoat 74. According to the manufacturer's specifications, the Amercoat 74 system is compatible with the waste and designed to prevent migration of waste into the concrete. The concrete and masonry walls are coated with a 6-mil-thick system of Amercoat 88. According to the manufacturer's specifications, the Amercoat 88 system is not compatible with the waste and is not designed to prevent migration of waste into the concrete.

\section{Operating Cells B, C, D, and G}

Operating Cells B, C, D, and G are lined with 304L SS plate. The floor and trench linings are $1 / 4^{\prime \prime}$ thick; the wall lining is $3 / 16^{\prime \prime}$ thick; and the trench sumps are constructed of capped, $4 "$ diameter, schedule 10S, type 304L SS pipe. All components are constructed of the same material as that used for the piping. Therefore, the SS cell lining material is compatible with the waste and designed to prevent migration of waste into the concrete.

\section{Operating Cell E}

The floor and trench in Cell E are lined with 1/4" thick, 304L SS plate. The sump is constructed of capped, 4" diameter, schedule 10S, type 304L SS pipe. The walls in Cell E are lined with $3 / 16^{\prime \prime}$ thick, 304L SS that extends $1^{\prime} 0^{\prime \prime}$ up from the floor lining. The remainder of the walls are coated with a 12-mil-thick system of Amercoat 66. The SS lining material, which is the same material as that used for the piping, is compatible with the waste and designed to prevent migration of waste into the concrete. According to the manufacturer's specifications, the Amercoat 66 coating is also compatible with the waste and designed to prevent migration of waste into the concrete. 
Design Demonstrations - Category B Tank Systems (Piping)

\section{Operating Cell F}

The concrete floor is coated with a 30-mil-thick system of Amercoat 66, and the walls are coated with a 5-mil-thick system of Amercoat 99 . According to the manufacturer's specifications, the Amercoat 66 and Amercoat 99 systems are compatible with the waste and designed to prevent migration of waste into the concrete.

The assessment concludes that the interior surfaces of Tank Vault B-2-T, RHD Line Pit, and Operating Cell F; the floors in Cell F Corridor, the Cell G Pump Room, and Mock-Up Area No. 305; and the trench in Operating Area No. 119 are coated with systems that are compatible with the waste and designed to prevent migration of waste into the concrete. In addition, the Room 214 Decontamination Pan and Operating Cells B, C, D, E, and G are lined with 304L SS, which is also compatible with the waste and designed to prevent migration of waste into the concrete.

Areas of secondary containment that are not coated or lined with materials that are compatible with the waste and are not designed to prevent migration of waste into the concrete include the Pitot Tube Pit; the North Valve Pit; the walls of Cell F Corridor, the Cell G Pump Room, and Mock-Up Area No. 305; and the walls and floor of Operating Area No. 119.

\subsubsection{Placed on Foundation or Base Capable of Providing Support to the Secondary Containment System}

\section{$\underline{\text { Tank Vault B-2-T }}$}

The assessment of the secondary containment system for Tank Vault B-2-T is presented in the Design Demonstrations for Tank B-2-T. That assessment concludes that the vault foundation is properly designed to support the secondary containment system.

\section{$\underline{\text { RHD Line Pit }}$}

The RHD Line Pit foundation is a $7^{\prime} 6^{\prime \prime} \times 9^{\prime} 0^{\prime \prime} \times 1^{\prime} 0^{\prime \prime}$ thick, reinforced concrete base slab that rests on compacted backfill.

\section{Areas Within Building 7930}

\section{Pitot Tube Pit}

The Pitot Tube Pit foundation is a $6^{\prime} 8^{\prime \prime} \times 7^{\prime} 8^{\prime \prime} \times 1^{\prime} 0^{\prime \prime}$ thick, reinforced concrete base slab that rests on stabilized aggregate. 


\section{North Valve Pit}

The North Valve Pit foundation is a $13^{\prime} 2^{\prime \prime} \times 17^{\prime} 2^{\prime \prime} \times 11^{\prime \prime} 4^{\prime \prime}$ thick, reinforced concrete base slab designed to rest on undisturbed soil. In the event of overexcavation, the base slab is designed to rest on concrete backfill.

\section{Cell F Corridor}

The Cell $\mathrm{F}$ Corridor foundation is a $1^{\prime} 0$ " thick, "L"-shaped, reinforced concrete slab that rests on compacted backfill.

\section{Operating Area No. 119}

The Operating Area No. 119 foundation is a 6" thick, reinforced concrete slab that rests on stabilized aggregate.

\section{Cell G Pump Room}

The Cell G Pump Room foundation is a 6" thick, "L"-shaped; reinforced concrete slab that rests on undisturbed soil.

\section{Room 214 Decontamination Pan}

The Room 214 Decontamination Pan foundation is an approximately $9^{\prime} 0^{\prime \prime} \times 10^{\prime} 0^{\prime \prime} \times 4^{\prime \prime}$ thick, reinforced concrete slab that rests on a structural concrete slab within Building 7930 .

Mock-Up Area No. 305

The Mock-Up Area No. 305 foundation is a combination of $4^{\prime} 9^{\prime \prime}$ thick, reinforced concrete plugs and a $5^{\prime \prime} 0^{\prime \prime}$ thick, reinforced concrete slab that rests on the outer and inner walls of Cells C, D, E, and G.

\section{Operating Cells B, C, D, and G}

The foundation of Operating Cell B is an $8^{\prime \prime}$ thick, reinforced concrete slab that rests on the walls of Operating Cell $\mathrm{F}$ and Cell $\mathrm{F}$ Corridor in addition to stabilized aggregate. The foundations of Operating Cells $C$ and $D$ are $8^{\prime \prime}$ thick, reinforced concrete slabs supported by $18^{\prime \prime} \times 30^{\prime \prime}$ thick, reinforced concrete beams. The foundation of Operating Cell G is an $8^{\prime \prime}$ thick, reinforced concrete slab that rests on stabilized aggregate backfill.

\section{Operating Cell E}

The Operating Cell E foundation is an 8 " thick, reinforced concrete slab that rests on stabilized aggregate backfill. 
Design Demonstrations - Category B Tank Systems (Piping)

\section{Operating Cell F}

The Operating Cell $\mathrm{F}$ foundation is an $8^{\prime \prime}$ thick, reinforced concrete slab that rests on stabilized aggregate backfill.

The assessment concludes that Tank Vault B-2-T; the RHD Line Pit; the Pitot Tube Pit; the North Valve Pit; the Cell F Corridor; Operating Area No. 119; the Cell G Pump Room; the Room 214 Decontamination Pan; Mock-Up Area No. 305; and Operating Cells B, C, D, E, F, and G are properly designed to support the secondary containment systems.

\subsubsection{Provided with a Leak Detection System That is Designed and Operated to Detect Failure of Either Primary or Secondary Containment Structure or the Presence of Any Measurable Release of Hazardous or Radioactive Constituents}

\section{Tank Vault B-2-T}

The assessment of the secondary containment system for Tank Vault B-2-T is presented in the Design Demonstrations for Tank B-2-T. That assessment concludes that the vault is provided with a leak detection system.

\section{$\underline{\text { RHD Line Pit }}$}

The RHD Line Pit is a coated area. Any leakage within the line pit flows by gravity to a sump in Tank Vault B-2-T. Accumulation in the sump will be detected by a level indicator that will activate an alarm in the operating area of Building 7930.

\section{Areas Within Building 7930}

\section{Pitot Tube Pit}

The Pitot Tube Pit is not provided with a leak detection system.

\section{North Valve Pit}

Any leakage within the valve pit flows by gravity to a $12^{\prime \prime} \times 12^{\prime \prime} \times 6^{\prime \prime}$ sump located within the valve pit. Accumulation will be detected by a level indicator that will activate an alarm in the operating area of Building 7930.

\section{Cell F Corridor}

Any leakage within the corridor flows by gravity to a $4^{\prime \prime}$ diameter, schedule 10S, type 304L SS, capped pipe sump that is $1^{\prime} 0^{\prime \prime}$ deep and is located in the corridor floor. Accumulation in the sump will be detected by a level indicator that will activate an alarm in the operating area of Building 7930. 


\section{Operating Area No. 119}

Operating Area No. 119 is not provided with a leak detection system.

\section{Cell G Pump Room}

Any leakage within the Cell G Pump Room flows by gravity to a trench and continues to a 6" diameter, schedule 10S, type 304L SS, capped pipe sump that is $2^{\prime} 0^{\prime \prime}$ deep and is located in the bottom of the collection trench. Accumulation in the sump will be detected by a level indicator that will activate an alarm in the operating area of Building 7930.

\section{Room 214 Decontamination Pan}

The Room 214 Decontamination Pan is an SS-lined area. Any leakage within the pan flows by gravity to a 6" diameter by 6" deep, 304L SS floor drain that transfers fluids to the Process Waste Drain (PWD) System. The Room 214 Decontamination Pan is not provided with a leak detection system.

\section{Mock-Up Area No. 305}

Any leakage within the area flows by gravity to a $3^{\prime \prime}$ diameter, PWD floor drain. Mock-Up Area No. 305 is not provided with a leak detection system.

\section{Operating Cells B, C, D, and G}

Cells B, C, D, and G are SS-lined areas. Any leakage within the cells will flow by gravity to a low point within each cell. Cells $B$ and $D$ are not provided with leak detection systems. Cells $C$ and $\mathrm{G}$ are provided with level indicators that will detect accumulation and activate alarms located in the operating area of Building 7930.

\section{Operating Cell $\mathbf{E}$}

Cell $\mathrm{E}$ is a lined and coated area. Any leakage in the cell will flow by gravity to a sump. Accumulation in the sump will be detected by a level indicator that will activate an alarm located in the operating area of Building 7930.

\section{Operating Cell F}

Cell $\mathrm{F}$ is a coated area. Any leakage in the area will flow by gravity to a sump. Accumulation in the sump will be detected by a level indicator that will activate an alarm located in the operating area of Building 7930.

The assessment concludes that Tank Vault B-2-T; the RHD Line Pit; the North Valve Pit; the Cell F Corridor; the Cell G Pump Room; and Cells C, E, F, and G are provided with leak detection. 
However, the Pitot Tube Pit, Operating Area No. 119, the Room 214 Decontamination Pan, Mock-Up Area No. 305, and Cells B and D are not provided with leak detection systems.

\subsubsection{Sloped or Otherwise Designed or Operated to Drain and Remove Liquids Resulting from Leaks, Spills, or Precipitation}

\section{Tank Vault B-2-T}

The assessment of the secondary containment system for Tank Vault B-2-T is presented in the Design Demonstrations for Tank B-2-T. That assessment concludes that the secondary containment is sloped and designed to drain and remove liquids resulting from leaks, spills, or precipitation.

\section{RHD Line Pit}

The RHD Line Pit floor is sloped to a 2 " diameter, 304L SS drain that transfers liquids to the sump in Tank Vault B-2-T. The sump provides a low point to drain liquids to an instrumented location. A pumping system is provided to remove liquids that accumulate in the sump.

\section{Areas Within Building 7930}

\section{Pitot Tube Pit}

The Pitot Tube Pit is not designed or provided with a means to drain or otherwise remove liquids resulting from leaks, spills, or precipitation.

\section{North Valve Pit}

The North Valve Pit floor is sloped to a $12^{\prime \prime} \times 12^{\prime \prime} \times 6^{\prime \prime}$ concrete sump. The sump provides a low point within the valve pit to drain liquids to an instrumented location. A pumping system is provided to remove liquids that accumulate in the sump.

\section{Cell F Corridor}

The corridor floor is sloped to a 4 " diameter sump. The sump provides a low point within the corridor to drain liquids to an instrumented location. A pumping system is provided to remove liquids that accumulate in the sump.

An additional sump is located in the corridor at a high point in the finished floor, and collects rainwater from stairwell \#6 and the freight elevator pit through pipes passing below floor elevation. In the event of a leak in the piping system during the transfer of liquids, it would flow to the low point corridor sump, trigger an alarm, and by operating procedure requirements the transfer is discontinued not allowing an overflow to the rainwater sump. 


\section{Operating Area No. 119}

The Operating Area No. 119 floor is sloped to a trench. The trench provides a low point within the area to divert-liquids to a drain point. In addition, a safety shower drain is mounted flush in the floor. The liquids gravity flow from the trench and drain into the PWD system.

\section{Cell G Pump Room}

The Cell G Pump Room floor is sloped to a trench and several $3^{\prime \prime}$ diameter floor drains. The trench and drains divert liquids to a 6 " diameter, schedule 10S, type 304L SS, capped pipe sump. The sump provides a low point within the pump room to drain liquids to an instrumented location. A pumping system is provided to remove liquids that accumulate in the sump.

An additional sump is located in the pump room at a high point in the finished floor, and collects rainwater from stairwell \#7 through pipes passing below floor elevation. In the event of a leak in the piping system during the transfer of liquids, it would flow to the low point pump room sump, trigger an alarm, and by operating procedure requirements the transfer is discontinued not allowing an overflow to the rainwater sump.

\section{Room 214 Decontamination Pan}

The Room 214 Decontamination Pan floor is sloped to PWD drains mounted flush in the floor. The drains provide a low point within the decontamination pan to divert liquids to a drain point. The liquids flow from the drains into the PWD system.

\section{Mock-Up Area No. 305}

The Mock-Up Area No. 305 floor is sloped to PWD drains mounted flush in the floor. The drains provide a low point within the Mock-Up Area to divert liquids to a drain point. The liquids flow from the drains into the PWD system.

\section{Operating Cells B, C, D, and G}

The floors in Cells B, C, and D are sloped to trapped floor drains centrally located in the cells. The floor in Cell $G$ is sloped to a $6^{\prime \prime}$ diameter sump. The drains and sump provide low points within the cells to drain liquids. A pumping system is provided for the sump to remove the liquid accumulation, and the floor drains gravity feed to Tank C-6-T.

\section{Operating Cell E}

The floor in Cell $\mathrm{E}$ is sloped to a $4^{\prime \prime}$ diameter sump. The sump provides a low point within the cell to drain liquids to an instrumented location. A pumping system is provided to remove liquids that accumulate in the sump. 


\section{Operating Cell F}

The floor in Cell $\mathrm{F}$ is sloped to a $4^{\prime \prime}$ diameter sump. The sump provides a low point within the cell to drain liquids to an instrumented location. A pumping system is provided to remove liquids that accumulate in the sump.

The assessment concludes that the secondary containments for Tank Vault B-2-T; the RHD Line Pit; the North Valve Pit; the Cell F Corridor; Operating Area No. 119; the Cell G Pump Room; the Room 214 Decontamination Pan; Mock-Up Area No. 305; and Operating Cells B, C, D, E, F, and G are sloped and designed to drain and remove liquids resulting from leaks, spills, or precipitation. The Pitot Tube Pit, however, is not designed or provided with a means to drain or otherwise remove liquids resulting from leaks, spills, or precipitation.

\subsubsection{Supplemental Information}

\subsubsection{Ancillary Equipment}

Tank B-2-T is constructed of 304L SS, which is the same material as that used in the piping system, and is located in Tank Vault B-2-T, which provides secondary containment. The support equipment is exposed to the same liquids as other components of the tank system; therefore, $304 \mathrm{~L}$ SS is an acceptable material for the support equipment.

\subsubsection{Waste Acceptance Criteria}

Radioactively contaminated liquid wastes at the Oak Ridge National Laboratory (ORNL) are generated by various activities within the research and operating divisions. These activities include radiochemical processing, routine hot cell operations and decontamination, and various waste treatment and environmental protection processes. The variations in composition of the waste streams are limited by the waste acceptance criteria that specify activity and concentration limits for waste discharged into the LLLW system. The Waste Acceptance Criteria for Liquid Waste Treatment Systems at the Oak Ridge National Laboratory (Oak Ridge National Laboratory, 1991), dated July 1991, is a guide for liquid waste generators to determine the proper means of disposal for LLLW. The criteria provide future discharge guidelines for the LLLW system, which includes Tank System B-2-T. 
Design Demonstrations - Category B Tank Systems (Piping)

\subsubsection{References}

Binford, F. T., and S. D. Orfi. 1979. The Intermediate-Level Liquid Waste System at the Oak Ridge National Laboratory Description and Safety Analysis. ORNL/TM-6959. Oak Ridge National Laboratory.

Ebasco, and Main. May 14, 1993. Design Demonstrations-Category B Tank Systems, Revision 2. DOE Contract No. DE-AC05-91OR21928. Oak Ridge National Laboratory.

Energy Systems Drawing A-20998-Y-125-E, Architectural, Plan, Cell Area at First Floor, Dated 1/15/65 (No Revision No.).

Energy Systems Drawing A-20998-Y-126-E-1, Architectural, Plan, Cell Area at Second Floor, Revision 1.

Energy Systems Drawing A-20998-Y-127-E-3, Architectural, Plan, Cell Area at Third Floor, Revision 3.

Energy Systems Drawing A-20998-Y-128-E-1, Architectural, Cell Area, Sections, Sheet 1, Revision 1.

Energy Systems Drawing A-20998-Y-129-E, Architectural, Cell Area, Sections, Sheet 2, Dated 1/15/65 (No Revision No.).

Energy Systems Drawing A-20998-Y-143-E-3, Architectural, Cell Sleeves and Service Tube Details, Revision 3.

Energy Systems Drawing A-20998-Y-101-E-1, Architectural, Finish Schedule, Revision 1.

Energy Systems Drawing A-20998-Y-119-E-1, Architectural, Fuel Storage Basin and Misc. Details, Revision 1.

Energy Systems Drawing A-20998-Y-148-E, Architectural, Misc. Cell Details, Sheet 4, Dated 1/15/65 (No Revision No.).

Energy Systems Drawing A-20998-Y-115-E, Architectural, Misc. Interior Details, Dated 1/15/65 (No Revision No.).

Energy Systems Drawing A-20998-Y-130-E-1, Architectural, Penetrations Cell "F" and Details, Revision 1.

Energy Systems Drawing A-20998-Y-131-E-1, Architectural, Penetrations Interior Cell "B", Revision 1. 
Energy Systems Drawing A-20998-Y-132-E-1, Architectural, Penetrations Interior Cell "C", Sheet 1, Revision 1.

Energy Systems Drawing A-20998-Y-133-E-1, Architectural, Penetrations Interior Cell "C", Sheet 2, Revision 1.

Energy Systems Drawing A-20998-Y-134-E-1, Architectural, Penetrations Interior Cell "D", Sheet 1, Revision 1 .

Energy Systems Drawing A-20998-Y-135-E-1, Architectural, Penetrations Interior Cell "D", Sheet 2, Revision 1.

Energy Systems Drawing A-20998-Y-136-E-2, Architectural, Penetrations Interior Cell "E", Sheet 1, Revision 2.

Energy Systems Drawing A-20998-Y-137-E-2, Architectural, Penetrations Interior Cell "E", Sheet 2, Revision 2.

Energy Systems Drawing A-20998-Y-138-E, Architectural, Penetrations Interior Cell "G", Sheet 1, Dated 1/15/65 (No Revision No.).

Energy Systems Drawing A-20998-Y-139-E-1, Architectural, Penetrations Interior Cell "G", Sheet 2 , Revision 1.

Energy Systems Drawing A-20998-Y-124-E-2, Architectural, Plan, Cell Area at Basement, Revision 2.

Energy Systems Drawing A-20998-Y-107-E, Architectural, Sections and Misc. Details, Dated 1/15/65 (No Revision No.).

Energy Systems Drawing A-20998-Y-106-E, Architectural, Sections, Sheet 1, Dated 1/15/65 (No Revision No.).

Energy Systems Drawing S-20998-Y-217-E-2, Cell Elevations and Sections, Sheet 1, Revision 2.

Energy Systems Drawing H-20998-Y-325-E-1, Cell Exhaust and H.O.G. Filter Pit, H.O.G., Fans H.O.G. Fans, Plan and Detail, Revision 1.

Energy Systems Drawing C-20998-Y-012-E-2, Civil, Site Plan Details, Sheet 1, Revision 2.

Energy Systems Drawing C-20998-Y-015-E-1, Civil, Utility Details, Sheet 1, Revision 1.

Energy Systems Drawing H-20998-Y-306-E, Control Diagrams Cell Ventilation and Miscellaneous Systems, Revision C. 
Energy Systems Drawing A-20998-Y-102-E-1, Door Schedule and Details, Revision 1.

Energy Systems Drawing H-20998-Y-329-E, Equipment Schedule, Sheet 3, Dated 1/15/65 (No Revision No.).

Energy Systems Drawing S-20998-Y-210-E, First Floor Plan, Dated 1/15/65 (No Revision No.).

Energy Systems Drawing H-20998-Y-302-E-A, Flow Diagram, Heating, Ventilating and Air Conditioning, Revision A.

Energy Systems Drawing P-20998-Y-404-E, Flow Diagram RHD, RHDR and PWD Systems, Sheet 2, Revision 1.

Energy Systems Drawing S-20998-Y-208-E, Foundation and Basement Plan, Revision 1.

Energy Systems Drawing C-20013-EA-003-D, Plan and Profile, Sheet 3, As-Built, Dated 9/8/73 (No Revision No.).

Energy Systems Drawing S-20998-Y-224-E, Radioactive Waste and Filter Pits, Sheet 2, Dated 1/15/65 (No Revision No.).

Energy Systems Drawing S-20998-Y-213-E, Stairs and Miscellaneous Details, Dated 1/15/65 (No Revision No.).

Energy Systems Drawing S-20998-Y-212-E-1, Wall Sections and Details, Revision 1.

Energy Systems Drawing P-20998-Y-413-E, Waste Piping, Details, Sheet 1, Dated 1/15/65 (No Revision No.).

Energy Systems Drawing P-20998-Y-428-E-1, Waste Pit Piping, Details, Sheet 1, Revision 1.

Energy Systems Drawing P-20998-Y-405-E-3, Waste Piping, Below First Floor, Part Plan-North, Revision 3.

Energy Systems Drawing P-20998-Y-406-E-2, Waste Piping, Below First Floor, Part Plan-South, Revision 2.

Energy Systems Drawing P-20998-Y-407-E-2, Waste Piping, First Floor, Part Plan-North, Revision 2.

Energy Systems Drawing P-20998-Y-408-E-2, Waste Piping, First Floor, Part Plan-South, Revision 2. 
Energy Systems Drawing P-20998-Y-409-E-1, Waste Piping, Second Floor, Part Plan-North, Revision 1.

Energy Systems Drawing P-20998-Y-410-E-2, Waste Piping, Second Floor, Part Plan-South, Revision 2.

Energy Systems Drawing P-20998-Y-411-E, Waste Piping, Third Floor and Roof, Part Plan-North, Dated 1/15/65 (No Revision No.).

Energy Systems Drawing P-20998-Y-412-E, Waste Piping, Third Floor and Roof, Part Plan-South, Dated 1/15/65 (No Revision No.).

Harco Technologies Corporation. June 1990. Resurvey of the Cathodic Protection Systems, Oak Ridge National Laboratories, United States Department of Energy, Oak Ridge, Tennessee. Martin Marietta Energy Systems, Inc.

Harco Technologies Corporation. September 1991. Cathodic Protection System Upgrade Design Underground ILW Line, ILW Line 7920/7930 to 7567, System No. 5. Oak Ridge National Laboratories, United States Department of Energy, Oak Ridge, Tennessee. Martin Marietta Energy Systems, Inc.

King, Notz, and Bigelow. 1987. Safety Analysis: TURF, Building 7930. ORNL/TM-9505. Oak Ridge National Laboratory.

LLLW Generator Survey 1990 for Building 7930.

Oak Ridge National Laboratory. 1991. Waste Acceptance Criteria for Liquid Waste Treatment Systems at the Oak Ridge National Laboratory. WM-WMCO-201. Department of Waste Minimization Planning and Certification.

R. M. Parson Co. 1977. Natural Disturbance Analysis of Buildings 7930 and 3019. Document No. X-OE-23.

Robinson, S. M., S. M. DePaoli, and A. B. Walker. 1991. Federal Facility Agreement Contingency, Upgrade, and Replacement Plans for the ORNL Active Low-Level Radioactive Waste Tank System. ORNL/TM-11795. Oak Ridge National Laboratory.

Specifications for the Construction of Thorium-Uranium Fuel Cycle Development Facility Building 7930. Invitation No. 401-65-4A. 


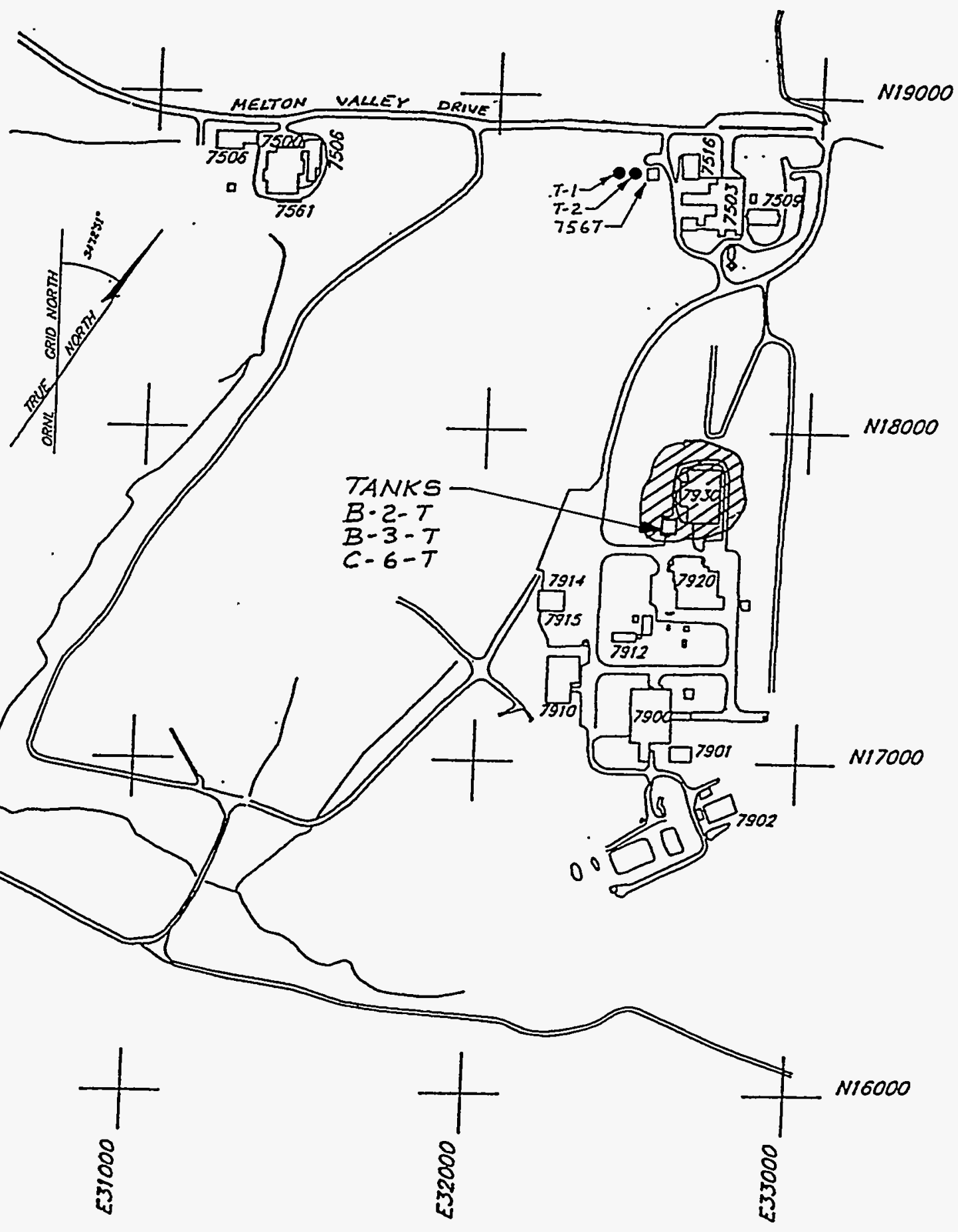




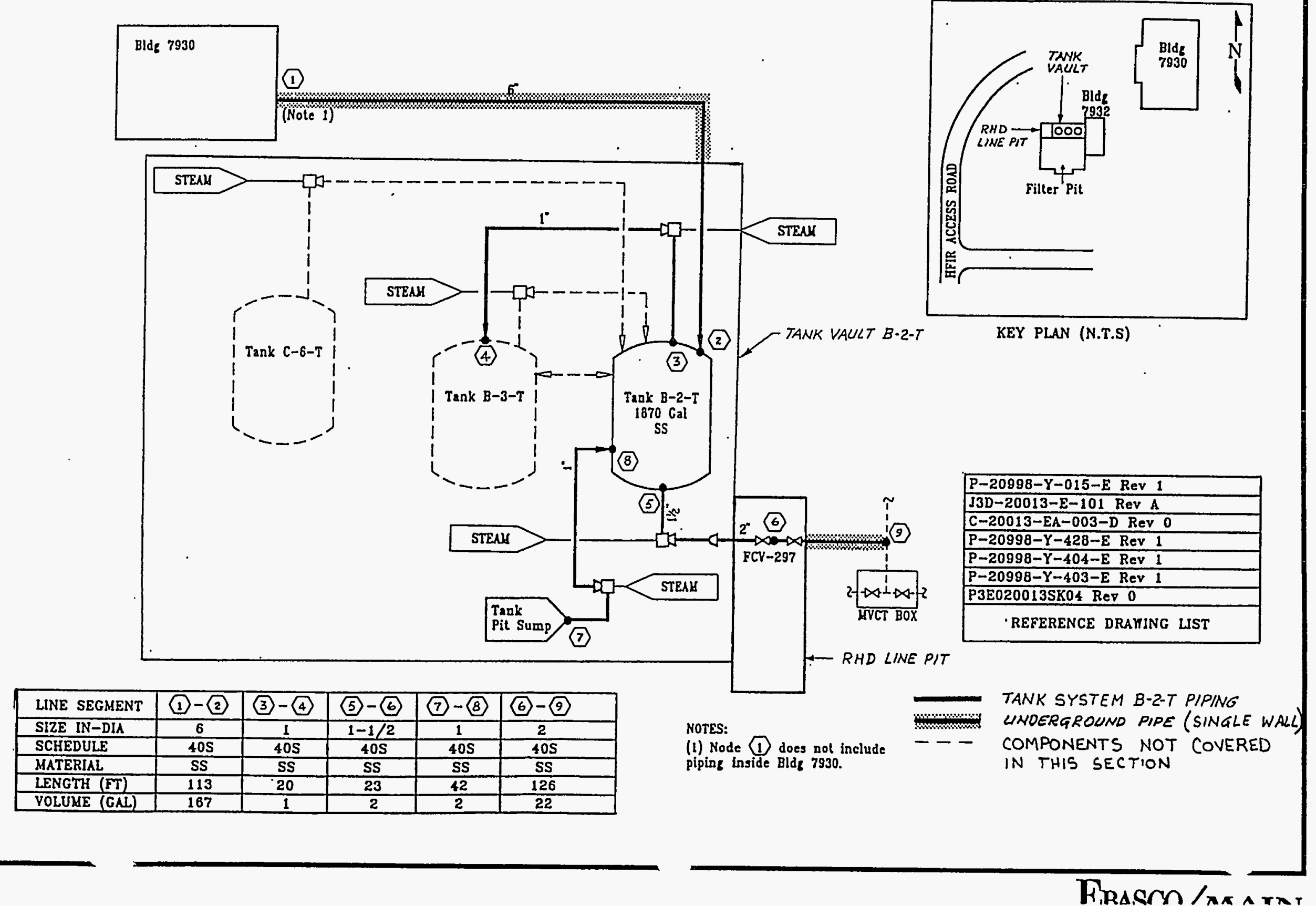


WASTE STREAM CONTAMINANTS:

(a) Isotopes:

Cf-252 .

(b) Quantities

$0.5 \mathrm{mg} /$ year

Other $\mathrm{Cf}$

Trace

(b) Others (i.e. acids, bases, organics, cleaners, etc.)

acidified butyrates

nitric acid (dilute)

palladium tetrammine di-hydrate

hydrazine decomposition products
$824.9 \mathrm{~g} /$ year

Trace

Trace

Trace 


\subsubsection{Tank System Summary}

Tank System B-3-T is located near the Radiochemical Engineering Development Center (REDC) (Building 7930) at the Melton Valley High Flux Isotope Reactor Complex (Figures 2.2-1 and 2.2-2). The tank system piping is schedule 40S, ASME SA-240, type 304L stainless steel (SS) and is routed from Tank Vault B-3-T (Waste Tank Pit that also contains Tanks B-2-T and C-6-T) to the Radioactive Hot Drain (RHD) Line Pit and from Tank Vault B-3-T outside underground to beneath Building 7930 and further into Building 7930.

Tank System B-3-T piping is used as process piping for the Radioactive Hot Drain Recoverable (RHDR) System and is classified as a Federal Facility Agreement Category B tank system.

\subsubsection{Tank System Piping Description and Design Standards}

\section{Tank System Piping Description}

Tank System B-3-T piping extends from Tank Vault B-3-T, near the southwest corner of Building 7930, to within Building 7930 and from Tank Vault B-3-T to the RHD Line Pit. The piping system is under the control of the REDC and is operated by the Chemical Technology Division.

Tank System B-3-T piping is constructed of 1", 1-1/2", and 3", 304L SS with a maximum design pressure and temperature of $150 \mathrm{psig}$ and $400^{\circ} \mathrm{F}$. Tank System B-3-T piping has a maximum volume of $10 \mathrm{gal}$.

A section of the 1" SS piping is routed through an 18-gauge, galvanized, helically corrugated metal pipe (CMP); and the combination is designed to be installed outside underground between Tank Vault B-3-T and Building 7930. The CMP isolates the $1^{\prime \prime}$ SS piping from direct contact with the soil or water, and in so doing, the CMP indirectly acts as a secondary containment structure.

\section{Design Standards}

The applicable codes and standards used for Tank System B-3-T piping and its associated secondary containment systems are identified herein. The codes and standards listed are those identified on either the design drawings or the construction specifications.

AEC-Oak Ridge Office, Minimum Safety Requirements;

Air Moving and Conditioning Association (AMCA) Standards Handbook-Publication 99; AMCA Fans and Systems-Publication 201; 
AMCA Directory-Publication 261;

American Concrete Institute;

American Concrete Pipe Association;

American Conference of Governmental Industrial Hygienists;

American Society of Heating, Refrigeration, and Air Conditioning Engineers (ASHRAE) Handbook of Fundamentals;

American Society of Mechanical Engineers (ASME) Boiler and Pressure Vessel Code, Sections II (SA-240), IV, VII, VIII, and IX;

American Society for Testing and Materials A93, A244, A307, C39, C78, C138, C143, and D1752;

American Standards Association Safety Code for Building Construction;

ASHRAE Guide and Data Book-Applications;

ASHRAE Guide and Data Book-Equipment;

ASHRAE Handbook-Systems;

Atomic Energy Commission (AEC) General Design Criteria, Appendix 63;

Factory Mutual Engineering Corporation;

Instrument Society of America;

National Electric Code;

National Fire Protection Association (NFPA) No. 90A-Air Conditioning and Ventilating Systems;

NFPA No. 91-Blower and Exhaust Systems;

Occupational Safety and Health Administration; and

Underwriters Laboratories Inc.

\subsubsection{Generic Description of Piping Contents}

Tank System B-3-T piping was designed to transfer liquid low-level waste (LLLW) to Cell G. The pipe leading into Cell $G$ is out of service and is capped off, and Tank System B-3-T piping currently serves Tank B-3-T, an LLLW overflow tank for the Building 7930 RHD-HOG System. These 
Design Demonstrations - Category B Tank Systems (Piping)

wastes may include a variety of dilute acids, bases, and organics. The system may contain radioactive materials from the REDC.

The analytical data (Figure 2.2-3) of waste stream contaminants from the generators are representative of waste transferred through Tank System B-3-T piping. However, at the present time no transfers are made to Tank B-3-T.

\subsubsection{Pipe Corrosion Protection Measures}

Piping inside Tank Vault B-3-T, the RHD Line Pit, and Building 7930 is not in direct contact with the soil or water. In addition, SS piping located within a section of 18-gauge, galvanized CMP installed outside underground between Tank Vault B-3-T and Building 7930 is also not in direct contact with the soil or water. Cathodic protection measures for SS piping in these areas are not required for external corrosion protection. However, the CMP is in direct contact with the soil and water and is not provided with protective coatings or cathodic protection.

\subsubsection{Documented Age of Tank System}

Tank System B-3-T piping was installed in 1965.

\subsubsection{Standards for Containment/Release Detection}

Tank System B-3-T piping incorporates approximately $18^{\prime}$ of embedded piping within Building 7930 that is singly contained. The singly contained areas are omitted from discussion in the following sections that address secondary containment.

2.2.3.1 Constructed of or Lined with Materials That are Compatible with Stored Waste(s) or Substance(s) to Be Placed in the Tank System and Shall Have Sufficient Strength and Thickness to Prevent Failure

Tank System B-3-T piping is single-wall, schedule 40S, type 304L SS pipe that is routed outside underground from Tank Vault B-3-T to areas within Building 7930 and from Tank Vault B-3-T to the RHD Line Pit. Areas of secondary containment are discussed below.

\section{Tank Vault B-3-T}

The assessment of the secondary containment for Tank Vault B-3-T is presented in the Design Demonstrations for Tank B-3-T. That assessment concludes that Tank Vault B-3-T is coated with materials that are compatible with the waste and designed to prevent migration of waste into the concrete. 
Design Demonstrations - Category B Tank Systems (Piping)

\section{Outside Underground CMP}

Approximately $250^{\prime}$ of galvanized CMP shrouds a $1^{\prime \prime}$ diameter, schedule 40S, type 304L SS pipe in Tank System B-3-T. The $1^{\prime \prime}$ SS line is centrally supported within the CMP. The galvanized CMP is not constructed of material that is compatible with the waste.

\section{RHDR Valve Pocket}

The Radioactive Hot Drain Recoverable (RHDR) Valve Pocket located in Building 7930 is coated with a 5-mil-thick system of Amercoat 99 vinyl emulsion on the floor and walls. According to manufacturer's specifications, the Amercoat 99 coating is compatible with the waste and designed to prevent migration of waste into the concrete.

\section{Operating Cell G}

Operating Cell $G$ is lined with $304 \mathrm{~L}$ SS plate. The floor and trench linings are $1 / 4$ " thick; the wall lining is 3/16" thick; and the trench sumps are constructed of capped, 4" diameter, schedule 10S, type 304L SS pipe. The SS lining material is the same material as that used for the piping. Therefore, the SS cell lining material is compatible with the waste and designed to prevent migration of waste into the concrete.

\section{$\underline{\text { RHD Line Pit }}$}

The RHD Line Pit floor is coated with a 30-mil-thick system of Amercoat 66 epoxy. The concrete walls of the RHD Line Pit are coated with a 5-mil-thick system of Amercoat 99 vinyl emulsion. According to manufacturer's specifications, the Amercoat 66 and Amercoat 99 coatings are compatible with the waste and designed to prevent migration of waste into the concrete.

The assessment concludes that the tank vault, valve pocket, operating cell, and line pit are lined or coated with materials that are compatible with the waste and designed to prevent migration of waste into the concrete. The CMP, however, is not compatible with the waste.

2.2.3.2 Placed on Foundation or Base Capable of Providing Support to the Secondary Containment System

\section{$\underline{\text { Tank Vault B-3-T }}$}

The assessment of the secondary containment system for Tank Vault B-3-T is presented in the Design Demonstrations for Tank B-3-T. That assessment concludes that the vault foundation is properly designed to support the secondary containment system. 


\section{RHDR Valve Pocket}

The RHDR Valve Pocket foundation consists of an $8^{\prime \prime}$ thick, reinforced concrete slab that rests on stabilized aggregate.

\section{Operating Cell G}

The Operating Cell $\mathrm{G}$ foundation is an $8^{\prime \prime}$ thick, reinforced concrete slab that rests on stabilized aggregate.

\section{RHD line Pit}

The RHD Line Pit foundation is a $7^{\prime} 6^{\prime \prime} \times 9^{\prime} 0^{\prime \prime} \times 1^{\prime} 0^{\prime \prime}$ thick, reinforced concrete base slab that rests on compacted backfill.

The assessment concludes that the tank vault, valve pocket, operating cell, and line pit are properly designed to support the secondary containment systems.

2.2.3.3 Provided with a Leak Detection System That is Designed and Operated to Detect Failure of Either Primary or Secondary Containment Structure or the Presence of Any Measurable Release of Hazardous or Radioactive Constituents

\section{Tank Vault B-3-T}

The assessment of the secondary containment system for Tank Vault B-3-T is presented in the Design Demonstrations for Tank B-3-T. That assessment concludes that the vault is provided with a leak detection system.

\section{Outside Underground CMP}

A leak detection system for the CMP could not be identified in the design drawings or construction specifications.

\section{RHDR Valve Pocket}

The valve pocket floor is sloped to an SS cove scupper. Any leakage within the area will flow by gravity to the scupper and continue through a 1", 304L SS pipe to the Cell G Pump Room sump. Liquid accumulation in the sump will be detected by a level sensor that will activate an alarm in the operating area of Building 7930.

\section{Operating Cell G}

The cell is SS-lined and sloped to a 6 "diameter, 304L SS sump where accumulation of liquid will be detected by a level sensor that will activate an alarm in the operating area of Building 7930 . 
Design Demonstrations - Category B Tank Systems (Piping)

\section{RHD Line Pit}

The line pit floor is a coated area. Any leakage within the area flows by gravity through a 2 " diameter, SS pipe to a sump in Tank Vault B-3-T. Accumulation of liquid in the sump will be detected by a level sensor that will activate an alarm in the operating area of Building 7930.

The assessment concludes that the tank vault, valve pocket, operating cell, and line pit are provided with leak detection. The CMP is not provided with a leak detection system.

\subsubsection{Sloped or Otherwise Designed or Operated to Drain and Remove Liquids Resulting from Leaks, Spills, or Precipitation}

\section{Tank Vault B-3-T}

The assessment of the secondary containment system for Tank Vault B-3-T is presented in the Design Demonstrations for Tank B-3-T. That assessment concludes that the secondary containment is sloped and designed to drain and remove liquids resulting from leaks, spills, or precipitation.

\section{Outside Underground CMP}

The CMP is sloped towards Tank Vault B-3-T; however, the CMP is not provided with a means to drain or otherwise remove liquids that may accumulate in the CMP.

\section{$\underline{\text { RHDR Valve Pocket }}$}

The valve pocket floor slopes to an SS cove scupper that slopes to an SS drain. The drain piping leads into a 6" diameter, 304L SS, capped pipe sump. A pumping system is provided to remove liquids that accumulate in the sump.

\section{Operating Cell G}

The operating cell floor is sloped to a centrally located collection trench that slopes to a 6 " diameter, 304L SS, capped pipe sump. The sump provides a low point within the cell to drain liquids to an instrumented location. A pumping system is provided to remove liquids that accumulate in the sump.

\section{$\underline{\text { RHD Line Pit }}$}

The line pit floor slopes to an SS drain that leads to a sump located in Tank Vault B-3-T. The sump provides a low point to drain liquids to an instrumented location. A pumping system is provided to remove liquids that accumulate in the sump.

The assessment concludes that the secondary containment structures for the tank vault, valve pocket, operating cell, and line pit are sloped and designed to drain and remove liquids resulting from leaks, spills, or precipitation. The outside underground CMP is sloped, but it is not provided with a means to drain and remove liquids. 


\subsubsection{Ancillary Equipment}

Tank B-3-T is constructed of 304L SS, which is the same material as that used in the piping system, and is located in Tank Vault B-3-T, which provides secondary containment. The support equipment is exposed to the same liquids as other components of the tank system; therefore, 304L SS is an acceptable material for the support equipment.

\subsubsection{Waste Acceptance Criteria}

Radioactively contaminated liquid wastes at the Oak Ridge National Laboratory (ORNL) are generated by various activities within the research and operating divisions. These activities include radiochemical processing, routine hot cell operations and decontaminations, and various waste treatment and environmental protection processes. The variations in composition of the waste streams are limited by the waste acceptance criteria that specify activity and concentration limits for waste discharged into the LLLW system. The Waste Acceptance Criteria for Liquid Waste Treatment Systems at the Oak Ridge National Laboratory (Oak Ridge National Laboratory, 1991), dated July 1991, is a guide for liquid waste generators to determine the proper means of disposal for LLLW. The criteria provide future discharge guidelines for the LLLW system, which includes Tank System B-3-T. 
Design Demonstrations - Category B Tank Systems (Piping)

\subsubsection{References}

Binford, F. T., and S. D. Orfi. 1979. The Intermediate-Level Liquid Waste System at the Oak Ridge National Laboratory Description and Safety Analysis. ORNL/TM-6959. Oak Ridge National Laboratory.

Ebasco, and Main. May 14, 1993. Design Demonstrations-Category B Tank Systems, Revision 2. DOE Contract No. DE-AC05-91OR21928. Oak Ridge National Laboratory.

Energy Systems Drawing A-20998-Y-128-E-1, Architectural, Cell Area, Sections, Revision 1.

Energy Systems Drawing A-20998-Y-143-E-3, Architectural, Cell Sleeves and Service Tube Details, Revision 3.

Energy Systems Drawing A-20998-Y-147-E-1, Architectural, Misc. Cell Details, Sheet 3, Revision 1.

Energy Systems Drawing A-20998-Y-115-E, Architectural, Misc. Interior Details, Dated 1/15/65 (No Revision No.).

Energy Systems Drawing A-20998-Y-124-E-2, Architectural, Plan, Cell Area at Basement, Revision 2.

Energy Systems Drawing H-20998-Y-325-E-1, Cell Exhaust and H.O.G. Filter Pit, H.O.G. Fans Plan and Details, Revision 1.

Energy Systems Drawing C-20998-Y-015-E-1, Civil Utility Details, Sheet 1, Revision 1.

Energy Systems Drawing H-20998-Y-302-E-A, Flow Diagram HVAC, Revision A.

Energy Systems Drawing P-20998-Y-404-E, Flow Diagram RHD, RHDR and PWD Systems, Sheet 2, Revision 1.

Energy Systems Drawing P-20998-Y-403-E-1, Flow Diagram RHD-HOG, RHDR and PWD Systems, Sheet 1 , Revision 1.

Energy Systems Drawing S-20998-Y-224-E, Radioactive Waste and Filter Pits, Sheet 2, Dated 1/15/64 (No Revision No.).

Energy Systems Drawing S-20998-Y-212-E-1, Wall Sections and Details, Revision 1.

Energy Systems Drawing P-20998-Y-405-E-3, Waste Piping, Below First Floor Part Plan V4, 34 North, Revision 3. 
Energy Systems Drawing P-20998-Y-413-E, Waste Piping Details, Sheet 1, Dated 1/15/65 (No Revision No.).

Energy Systems Drawing P-20998-Y-428-E-1, Waste Pit Piping Details, Sheet 1, Revision 1.

Energy Systems Drawing P-20998-Y-430-E-1, Waste Pit Piping Details, Sheet 3, Revision 1.

King, Notz, and Bigelow. 1987. Safety Analysis: TURF: Building 7930. ORNL/TM-9505. Oak Ridge National Laboratory.

LLLW Generator Survey 1990 for Building 7930.

Oak Ridge National Laboratory. Specification for the Construction of Thorium-Uranium Fuel Cycle Development Facility Building 7930. Invitation No. 401-65-4A.

Oak Ridge National Laboratory. 1991. Waste Acceptance Criteria for Liquid Waste Treatment Systems at the Oak Ridge National Laboratory. WM-WMCO-201. Department of Waste Minimization Planning and Certification.

R. M. Parson Co. 1979. Natural Disturbance Analysis of Buildings 7930 and 3019. Document No. X-OE-23.

Robinson, S. M., S. M. DePaoli, and A. B. Walker. 1991. Federal Facility Agreement Contingency, Upgrade, and Replacement Plans for the ORNL Active Low-Level Radioactive Waste Tank System. ORNL/TM-11795. Oak Ridge National Laboratory. 
Figure 2.2-1

Location of Tank System B-3-T Piping

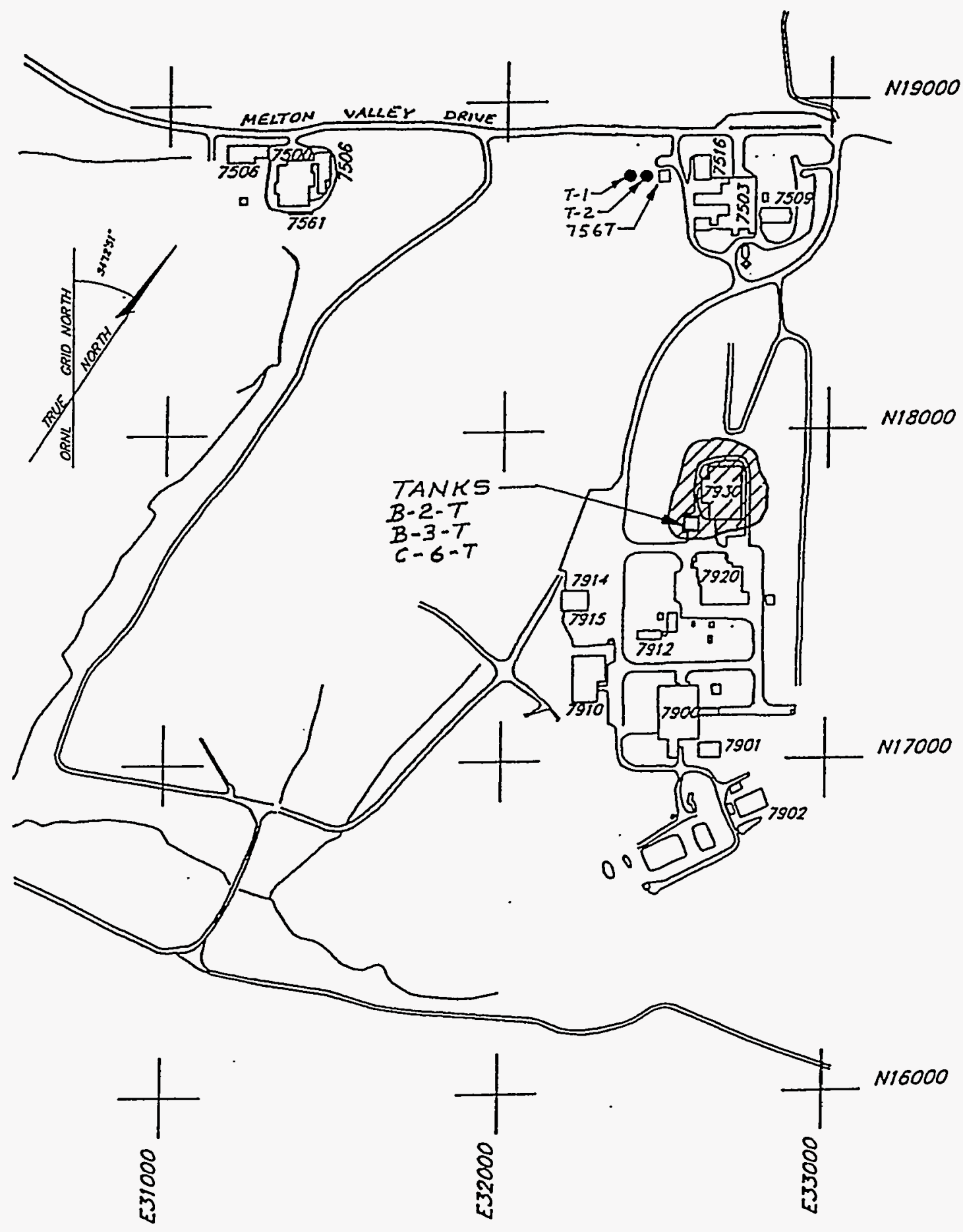

Frasmo/axatar 


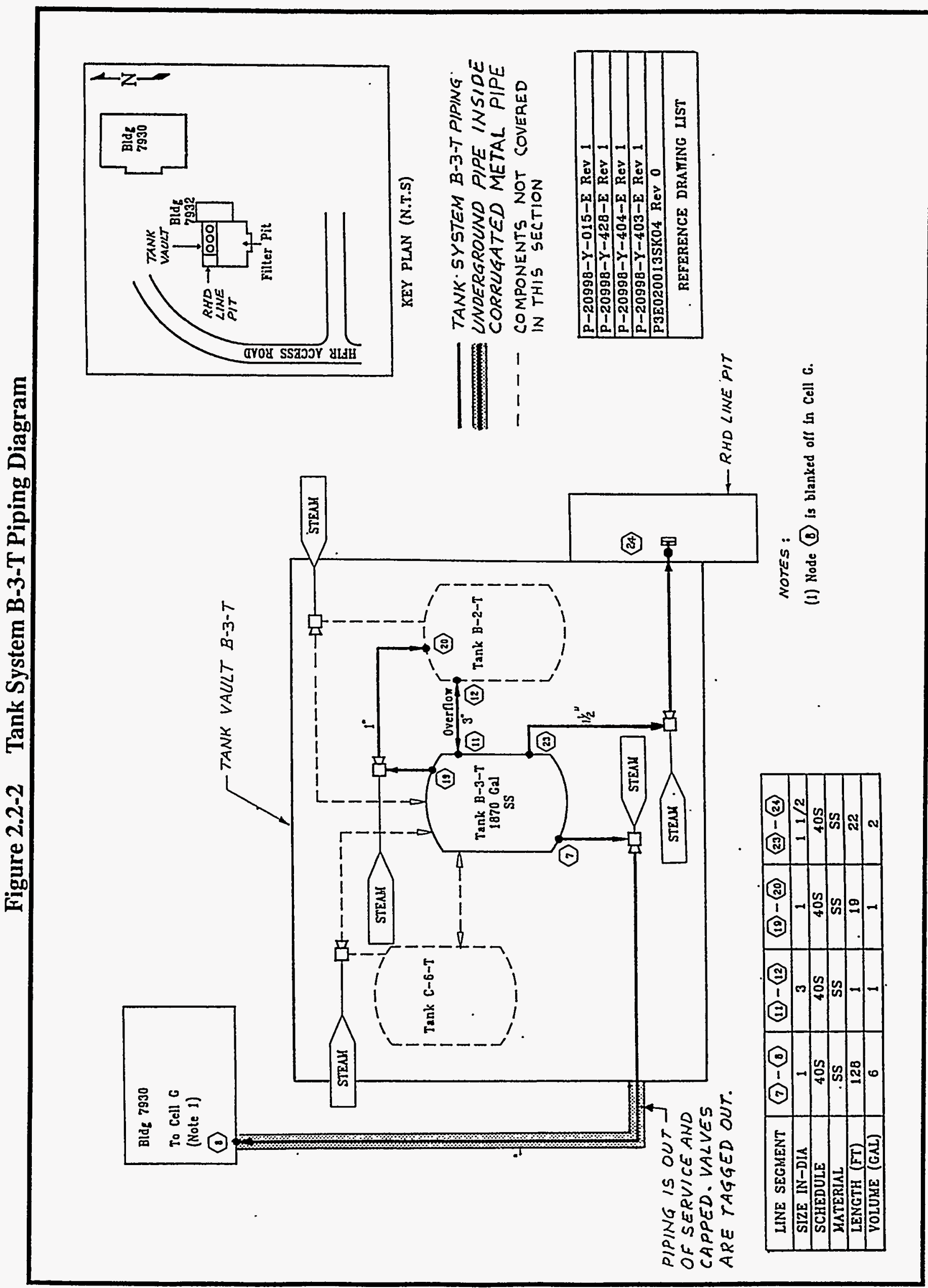


WASTE STREAM CONTAMINANTS:

(a) Isotopes:

$$
\text { Cf-252 }
$$

(b) Quantities $0.5 \mathrm{mg} /$ year

Other $\mathrm{Cf}$

Trace

(b) Othẹrs (i.e. acids, bases, organics, cleaners, etc.)

\begin{tabular}{c} 
acidified butyrates \\
nitric acid (dilute) \\
\hline
\end{tabular}

palladium tetrammine di-hydrate

hydrazine decomposition products

$824.9 \mathrm{~g} /$ year

Trace

Trace

Trace 


\section{Tank System C-6-T Piping}

\subsubsection{Tank System Summary}

Tank System C-6-T is located near the Radiochemical Engineering Development Center (REDC) (Building 7930) in the Melton Valley High Flux Isotope Reactor Complex (Figures 2.3-1 and 2.3-2). The tank system piping is schedule 40S, ASME SA-240, type 304L stainless steel (SS); is routed from Tank Vault C-6-T (Waste Tank Pit that also contains Tanks B-2-T and B-3-T) outside underground to beneath Building 7930; and terminates in areas within Building 7930.

Tank System C-6-T piping is used to transfer liquid low-level waste (LLLW) from the Building 7930 Radioactive Hot Drain Recoverable (RHDR) System to Tank C-6-T and is classified as a Federal Facility Agreement Category B tank system.

\subsubsection{Standards for Pipe Assessment of Tank Systems}

\subsubsection{Tank System Piping Description and Design Standards}

\section{Tank System Piping Description}

Tank System C-6-T piping extends from Tank Vault C-6-T, near the southwest corner of Building 7930 to within Building 7930. The piping system is under the control of the REDC and is operated by the Chemical Technology Division.

Tank System C-6-T piping is constructed of $1 / 2^{\prime \prime}, 1^{\prime \prime}, 1-1 / 2^{\prime \prime}, 2^{\prime \prime}$, and 3", 304L SS with a maximum design temperature and pressure of $338^{\circ} \mathrm{F}$ and 150 psig. Tank System C-6-T piping has a maximum volume of $154 \mathrm{gal}$.

A section of the $1^{\prime \prime}$ SS piping is routed through an 18-gauge, galvanized, helically corrugated metal pipe (CMP); and the combination is designed to be installed outside underground between Tank Vault C-6-T and Building 7930. The CMP isolates the 1" SS piping from direct contact with the soil or water, and in so doing, the CMP indirectly acts as a secondary containment structure.

\section{Design Standards}

The applicable codes and standards used for Tank System C-6-T piping and its associated secondary containment systems are identified herein. The codes and standards listed are those identified on either the design drawings or the construction specifications.

AEC-Oak Ridge Office, Minimum Safety Requirements;

Air Moving and Conditioning Association (AMCA) Standards Handbook-Publication 99;

AMCA Fans and Systems-Publication 201; 
AMCA Directory-Publication 261;

American Concrete Institute;

American Concrete Pipe Association;

American Conference of Governmental Industrial Hygienists;

American Society of Heating, Refrigeration, and Air Conditioning Engineers (ASHRAE) Handbook of Fundamentals;

American Society of Mechanical Engineers (ASME) Boiler and Pressure Vessel Code, Sections II (SA-240), IV, VII, VIII, and IX;

American Society for Testing and Materials A93, A244, A307, C39, C78, C138, C143, and D1752;

American Standards Association Safety Code for Building Construction;

ASHRAE Guide and Data Book-Applications;

ASHRAE Guide and Data Book-Equipment;

ASHRAE Handbook-Systems;

Atomic Energy Commission (AEC) General Design Criteria, Appendix 63;

Factory Mutual Engineering Corporation;

Instrument Society of America;

National Electric Code;

National Fire Protection Association (NFPA) No. 90A-Air Conditioning and Ventilating Systems;

NFPA No. 91-Blower and Exhaust Systems;

Occupational Safety and Health Administration; and

Underwriters Laboratories Inc.

\subsubsection{Generic Description of Piping Contents}

Tank System C-6-T piping is designed to transfer LLLW to and from the Building 7930 RHDR System and Tank C-6-T. The pipe that transfers LLLW to Cell G is out of service and is capped off. The primary source of LLLW is Cell G in Building 7930. These wastes may include a variety 
of dilute acids, bases, and organics. The tank system may contain radioactive materials from the REDC.

The analytical data (Figure 2.3-3) of waste stream contaminants from the generators are representative of waste transferred through Tank System C-6-T. However, at the present time no transfers are made to Tank C-6-T.

\subsubsection{Pipe Corrosion Protection Measures}

Piping inside Tank Vault C-6-T and Building 7930 is not in direct contact with the soil or water. In addition, SS piping located within a section of 18-gauge, galvanized, CMP installed outside underground between Tank Vault C-6-T and Building 7930 is also not in direct contact with the soil or water. Cathodic protection for SS piping in these areas is not required for external corrosion protection. However, the CMP and a section of SS piping routed outside underground between Tank Vault C-6-T and Building 7930 are in direct contact with the soil and water, and these pipes are not provided with protective coatings or cathodic protection.

\subsubsection{Documented Age of Tank System}

Tank System C-6-T was installed in 1965.

\subsubsection{Standards for Containment/Release Detection}

Tank System C-6-T piping incorporates approximately $510^{\prime}$ of piping that is singly contained. The singly contained areas are omitted from discussion in the following sections that address secondary containment. The omitted areas include the 3 " diameter outside underground SS piping and the embedded piping within Building 7930.

2.3.3.1 Constructed of or Lined with Materials That are Compatible with Stored Waste(s) or Substance(s) to Be Placed in the Tank System and Shall Have Sufficient Strength and Thickness to Prevent Failure

Tank System C-6-T piping is single-wall, schedule 40S, type 304L SS pipe. The piping is routed outside underground from Tank Vault C-6-T to areas within Building 7930. Areas of secondary containment are discussed below.

\section{Tank Vault C-6-T}

The assessment of the secondary containment system for Tank Vault C-6-T is presented in the Design Demonstrations for Tank C-6-T. That assessment concludes that Tank Vault C-6-T is coated with materials that are compatible with the waste and designed to prevent migration of waste into the concrete. 
Design Demonstrations - Category B Tank Systems (Piping)

\section{Outside Underground CMP}

Approximately $250^{\prime}$ of galvanized CMP shrouds a $1^{\prime \prime}$ diameter, schedule $40 \mathrm{~S}$, type $304 \mathrm{~L}$ SS pipe in Tank System C-6-T. The $1^{\prime \prime}$ SS line is centrally supported within the CMP. The galvanized CMP is not constructed of material that is compatible with the waste.

\section{Areas Within Building 7930}

\section{Operating Cells C, D, E, and G}

Operating Cells C, D, and G are lined with 304L SS plate. The floor and trench linings are $1 / 4^{\prime \prime}$ thick; the wall linings are 3/16" thick; and the trench sumps are constructed of capped, 4 " diameter, schedule 10S, type 304L SS pipe. The SS cell lining material is the same material as that used for the piping. Therefore, the SS cell lining material is compatible with the waste and designed to prevent migration of waste into the concrete.

The floor and trench in Operating Cell E are lined with $1 / 4^{\prime \prime}$ thick, 304L SS plate. The sump is constructed of capped, 4" diameter, schedule 10S, type 304L SS pipe. The walls in Cell E are lined with $3 / 16^{\prime \prime}$ thick, 304L SS that extends $1^{\prime} 0^{\prime \prime}$ from the floor lining. The remainder of the walls are coated with a 12-mil-thick system of Amercoat 66 . The SS lining material is the same material as that used for the piping. Therefore, it is compatible with the waste and designed to prevent migration of waste into the concrete. According to manufacturer's specifications, the Amercoat 66 coating is compatible with the waste and designed to prevent migration of waste into the concrete.

\section{Waste Ejector Pocket and RHDR Valve Pocket}

The Waste Ejector Pocket and the RHDR Valve Pocket located in Building 7930 are both coated with a 5-mil-thick system of Amercoat 99 on the floors and walls. According to the manufacturer's specifications, the Amercoat 99 coating is compatible with the waste and designed to prevent migration of waste into the concrete.

\section{Cell G Pump Room}

The concrete floor, trench, drain, and covers are coated with a 20-mil-thick system of Amercoat 74. According to the manufacturer's specifications, the Amercoat 74 system is compatible with the waste and designed to prevent migration of waste into the concrete. The concrete and masonry walls are coated with a 6-mil-thick system of Amercoat 88. According to the manufacturer's specifications, the Amercoat 88 system is not compatible with the waste and is not designed to prevent migration of waste into the concrete. According to the manufacturer, this coating system does not provide the appropriate resistance to chemicals and radiation. 
Mock-Up Area No. 305

The concrete floor and the exposed ferrous metal embedded in the floor are coated with a 20-mil-thick system of Amercoat 74. According to the manufacturer's specifications, the Amercoat 74 system is compatible with the waste and designed to prevent migration of waste into the concrete. The concrete and masonry walls are coated with a 6-mil-thick system of Amercoat 88. According to the manufacturer's specifications, the Amercoat 88 system is not compatible with the waste and is not designed to prevent migration of waste into the concrete.

The assessment concludes that Tank Vault C-6-T; Operating Cells C, D, E, and G; the Waste Ejector Pocket; the RHDR Valve Pocket; and the floors of Cell G Pump Room and Mock-Up Area No. 305 are coated or lined with materials that are compatible with the waste and designed to prevent migration of waste into the concrete. However, the walls of Cell G Pump Room and Mock-Up Area No. 305 are not constructed of or lined with materials that are compatible with the waste and that will prevent migration of waste into the concrete. The galvanized CMP is not constructed of material that is compatible with the waste.

\subsubsection{Placed on Foundation or Base Capable of Providing Support to the Secondary} Containment System

\section{Tank Vault C-6-T}

The assessment of the secondary containment system for Tank Vault C-6-T is presented in the Design Demonstrations for Tank C-6-T. That assessment concludes that the vault foundation is properly designed to support the secondary containment system.

\section{Areas Within Building 7930}

\section{Operating Cells C, D, E, and G}

The foundations of Operating Cells $\mathrm{C}$ and $\mathrm{D}$ are $8^{\prime \prime}$ thick, reinforced concrete slabs supported by $18^{\prime \prime} \times 30^{\prime \prime}$ thick, reinforced concrete beams that span reinforced concrete footers that are placed on undisturbed shale. The floors of Operating Cells $E$ and $G$ are 8 " thick, reinforced concrete slabs that rest on stabilized aggregate backfill.

\section{Waste Ejector Pocket and RHDR Valve Pocket}

The Waste Ejector Pocket and RHDR Valve Pocket foundations consist of $8^{\prime \prime}$ thick, reinforced concrete slabs that rest on stabilized aggregate backfill.

\section{Cell G Pump Room}

The Cell G Pump Room foundation is a 6" thick, "L"-shaped, reinforced concrete slab that rests on undisturbed soil. 
Mock-Up Area No. 305

The foundation of Mock-Up Area No. 305 is a combination of $4^{\prime} 9^{\prime \prime}$ thick, reinforced concrete plugs and a $5^{\prime} 0^{\prime \prime}$ thick, reinforced concrete slab that rests on the outer and inner walls of Cells C, D, E, and $G$.

The assessment concludes that Tank Vault C-6-T; Operating Cells C, D, E, and G; the Waste Ejector Pocket; the RHDR Valve Pocket; the Cell G Pump Room; and Mock-Up Area No. 305 foundations are properly designed to support the secondary containment systems.

2.3.3.3 Provided with a Leak Detection System That is Designed and Operated to Detect Failure of Either Primary or Secondary Containment Structure or the Presence of Any Measurable Release of Hazardous or Radioactive Constituents

\section{Tank Vault C-6-T}

The assessment of the secondary containment system for Tank Vault C-6-T is presented in the Design Demonstrations for Tank C-6-T. That assessment concludes that the vault is provided with a leak detection system.

\section{Outside Underground CMP}

A leak detection system for the outside underground CMP could not be identified in the design drawings or construction specifications.

\section{Areas Within Building 7930}

\section{Operating Cells C, D, E, and G}

The floors of Operating Cells C, D, E, and G are sloped to collection trenches located within each cell. The collection trenches in Cells $C$ and $D$ slope to trapped floor drains, and the collection trenches in Cells $E$ and $G$ slope to sumps. The sumps in Cells $E$ and $G$ and the drain in Cell $C$ are provided with level sensors that will detect accumulation and activate alarms located in the operating area of Building 7930. Cell D is not provided with a leak detection system.

\section{Waste Ejector Pocket and RHDR Valve Pocket}

The Waste Ejector Pocket and RHDR Valve Pocket floors are sloped to SS cove scuppers that divert liquids through 1", 304L SS pipes to the Cell G Pump Room sump. Liquid accumulation in the sump will be detected by a level sensor that will activate an alarm in the operating area of Building 7930. 
Design Demonstrations - Category B Tank Systems (Piping)

\section{Cell G Pump Room}

The Cell G Pump Room floor is sloped to a collection trench that slopes to a sump located in the bottom of the trench. Liquid accumulation in the sump will be detected by a level sensor that will activate an alarm in the operating area of Building 7930.

Mock-Up Area No. 305

The Mock-Up Area No. 305 floor is provided with 3" diameter, Process Waste Drain (PWD) floor drains; however, Mock-Up Area No. 305 is not provided with a leak detection system.

The assessment concludes that Tank Vault C-6-T; Operating Cells C, E, and G; the Waste Ejector Pocket; the RHDR Valve Pocket; and the Cell G Pump Room are provided with leak detection. However, the outside underground CMP, Operating Cell D, and Mock-Up Area No. 305 are not provided with leak detection systems.

2.3.3.4 Sloped or Otherwise Designed or Operated to Drain and Remove Liquids Resulting from Leaks, Spills, or Precipitation

\section{Tank Vault C-6-T}

The assessment of the secondary containment system for Tank Vault C-6-T is presented in the Design Demonstrations for Tank C-6-T. That assessment concludes that the secondary containment is sloped and designed to drain and remove liquids resulting from leaks, spills, or precipitation.

\section{Outside Underground CMP}

The CMP is sloped towards Tank Vault C-6-T; however, the CMP is not provided with a means to drain or otherwise remove liquids.

\section{Areas Within Building 7930}

\section{Operating Cells C, D, E, and G}

The floors in Operating Cells $\mathrm{C}$ and $\mathrm{D}$ are sloped to centrally located floor trenches that slope to trapped drains. The floors in Cells $\mathrm{E}$ and $\mathrm{G}$ are sloped to centrally located floor trenches that slope to sumps incorporated in the bottom of the trenches. The sumps and drains provide low points within the cells to drain liquids. Pumping systems are provided to remove the accumulation from the sumps, and the floor drains gravity feed to Tank C-6-T. 


\section{Waste Ejector Pocket and RHDR Valve Pocket}

The Waste Ejector Pocket and RHDR Valve Pocket floors are sloped to centrally located, SS cove scuppers. The scuppers transfer liquids out of the pockets through 1" diameter, 304L SS pipes by gravity flow to the Cell G Pump Room sump.

\section{Cell G Pump Room}

The Cell G Pump Room floor is sloped to a trench and several 3" diameter floor drains. The trench and drains divert liquids to a 6" diameter, schedule 10S, type 304L SS, capped pipe sump. The sump provides a low point within the pump room to drain liquids to an instrumented location. A pumping system is provided to remove liquids that accumulate in the sump.

An additional sump is located in the pump room at a high point in the finished floor, and collects rainwater from stairwell \#7 through pipes passing below floor elevation. In the event of a leak in the piping system during the transfer of liquids, it would flow to the low point pump room sump, trigger an alarm, and by operating procedure requirements the transfer is discontinued not allowing an overflow to the rainwater sump.

\section{Mock-Up Area No. 305}

The Mock-Up Area No. 305 floor is sloped to PWD drains mounted flush in the floor. The drains provide a low point within the Mock-Up Area to divert liquids to a drain point. The liquids flow from the drains into the PWD system.

The assessment concludes that the secondary containments for Tank Vault C-6-T; Operating Cells C, D, E, and G; the Waste Ejector Pocket; the RHDR Valve Pocket; the Cell G Pump Room; and Mock-Up Area No. 305 are sloped and designed to drain and remove liquids resulting from leaks, spills, or precipitation. The outside underground CMP is sloped, but it is not provided with a means to drain and remove liquids.

\subsubsection{Supplemental Information}

\subsubsection{Ancillary Equipment}

Tank C-6-T is constructed of 304L SS, which is the same material as that used in the piping system, and is located in Tank Vault C-6-T, which provides secondary containment. The support equipment is exposed to the same liquids as other components of the tank system; therefore, 304L SS is an acceptable material for the support equipment. 


\subsubsection{Waste Acceptance Criteria}

Radioactively contaminated liquid wastes at the Oak Ridge National Laboratory (ORNL) are generated by various activities within the research and operating divisions. These activities include radiochemical processing, routine hot cell operations and decontamination, and various waste treatment and environmental protection processes. The variations in composition of the waste streams are limited by the waste acceptance criteria that specify activity and concentration limits for waste discharged into the LLLW system. The Waste Acceptance Criteria for Liquid Waste Treatment Systems at the Oak Ridge National Laboratory (Oak Ridge National Laboratory, 1991), dated July 1991, is a guide for liquid waste generators to determine the proper means of disposal for LLLW. The criteria provide future discharge guidelines for the LLLW system, which includes Tank System C-6-T. 
Design Demonstrations - Category B Tank Systems (Piping)

\subsubsection{References}

Binford, F. T., and S. D. Orfi. 1979. The Intermediate-Level Liquid Waste System at the Oak Ridge National Laboratory Description and Safety Analysis. ORNL/TM-6959. Oak Ridge National Laboratory.

Ebasco, and Main. May 14, 1993. Design Demonstrations-Category B Tank Systems, Revision 2. DOE Contract No. DE-AC05-91OR21928. Oak Ridge National Laboratory.

Energy Systems Drawing A-20998-Y-128-E-1, Architectural, Cell Area, Sections, Sheet 1, Revision 1.

Energy Systems Drawing A-20998-Y-129-E, Architectural, Cell Area, Sections, Sheet 2, Dated 1/15/65 (No Revision No.).

Energy Systems Drawing A-20998-Y-143-E-3, Architectural, Cell Sleeves and Service Tube Details, Revision 3.

Energy Systems Drawing A-20998-Y-101-E-1, Architectural, Finish Schedule, Revision 1.

Energy Systems Drawing A-20998-Y-119-E-1, Architectural, Fuel Storage Basin and Misc. Details, Revision 1.

Energy Systems Drawing A-20998-Y-148-E, Architectural, Misc. Cell Details, Sheet 4, Dated 1/15/65 (No Revision No.).

Energy Systems Drawing A-20998-Y-115-E, Architectural, Misc. Interior Details, Dated 1/15/65 (No Revision No).

Energy Systems Drawing A-20998-Y-130-E-1, Architectural, Penetrations Cell "F" and Details, Revision 1.

Energy Systems Drawing A-20998-Y-131-E-1, Architectural, Penetrations Interior Cell "B", Revision 1.

Energy Systems Drawing A-20998-Y-132-E-1, Architectural, Penetrations Interior Cell "C", Sheet 1, Revision 1.

Energy Systems Drawing A-20998-Y-133-E-1, Architectural, Penetrations Interior Cell "C", Sheet 2, Revision 1.

Energy Systems Drawing A-20998-Y-134-E-1, Architectural, Penetrations Interior Cell "D", Sheet 1, Revision 1. 
Energy Systems Drawing A-20998-Y-135-E-1, Architectural, Penetrations Interior Cell "D", Sheet 2, Revision 1.

Energy Systems Drawing A-20998-Y-136-E-2, Architectural, Penetrations Interior Cell "E", Sheet 1, Revision 2.

Energy Systems Drawing A-20998-Y-137-E-2, Architectural, Penetrations Interior Cell "E", Sheet 2, Revision 2.

Energy Systems Drawing A-20998-Y-138-E, Architectural, Penetrations Interior Cell "G", Sheet 1, Dated 1/15/65 (No Revision No.).

Energy Systems Drawing A-20998-Y-139-E-1, Architectural, Penetrations Interior Cell "G", Sheet 2 , Revision 1.

Energy Systems Drawing A-20998-Y-124-E-2, Architectural, Plan, Cell Area at Basement, Revision 2.

Energy Systems Drawing A-20998-Y-125-E, Architectural, Plan, Cell Area at First Floor, Dated 1/15/65 (No Revision No.).

Energy Systems Drawing A-20998-Y-126-E-1, Architectural, Plan, Cell Area at Second Floor, Revision 1.

Energy Systems Drawing A-20998-Y-127-E-3, Architectural, Plan, Cell Area at Third Floor, Revision 3.

Energy Systems Drawing A-20998-Y-107-E, Architectural, Sections and Misc. Details, Dated 1/15/65 (No Revision No.).

Energy Systems Drawing A-20998-Y-106-E, Architectural, Sections, Sheet 1, Dated 1/15/65 (No Revision No.).

Energy Systems Drawing S-20998-Y-217-E-2, Cell Elevations and Sections, Sheet 1, Revision 2.

Energy Systems Drawing C-20998-Y-012-E-2, Civil, Site Plan Details, Sheet 1, Revision 2.

Energy Systems Drawing C-20998-Y-015-E-1, Civil, Utility Details, Sheet 1, Revision 1.

Energy Systems Drawing H-20998-Y-306-E, Control Diagrams Cell Ventilation and Miscellaneous Systems, Revision C.

Energy Systems Drawing H-20998-Y-329-E, Equipment Schedule, Sheet 3, Dated 1/15/65 (No Revision No.). 
Design Demonstrations - Category B Tank Systems (Piping)

Energy Systems Drawing P-20998-Y-404-E, Flow Diagram RHD, RHDR and PWD Systems, Sheet 2, Revision 1.

Energy Systems Drawing S-20998-Y-208-E, Foundation and Basement Plan, Revision 1.

Energy Systems Drawing S-20998-Y-213-E, Stairs and Miscellaneous Details, Dated 1/15/65 (No Revision No.).

Energy Systems Drawing S-20998-Y-212-E-1, Wall Sections and Details, Revision 1.

Energy Systems Drawing P-20998-Y-413-E, Waste Piping, Details, Sheet 1, Dated 1/15/65 (No Revision No.).

Energy Systems Drawing P-20998-Y-428-E-1, Waste Pit Piping, Details, Sheet 1, Revision 1.

Energy Systems Drawing P-20998-Y-405-E-3, Waste Piping, Below First Floor, Part Plan—North, Revision 3.

Energy Systems Drawing P-20998-Y-406-E-2, Waste Piping, Below First Floor, Part Plan-South, Revision 2.

Energy Systems Drawing P-20998-Y-407-E-2, Waste Piping, First Floor, Part Plan-North, Revision 2.

Energy Systems Drawing P-20998-Y-408-E-2, Waste Piping, First Floor, Part Plan-South, Revision 2.

Energy Systems Drawing P-20998-Y-409-E-1, Waste Piping, Second Floor, Part Plan-North, Revision 1.

Energy Systems Drawing P-20998-Y-410-E-2, Waste Piping, Second Floor, Part Plan-South, Revision 2.

Energy Systems Drawing P-20998-Y-411-E, Waste Piping, Third Floor and Roof, Part Plan-North, Dated 1/15/65 (No Revision No.).

Energy Systems Drawing P-20998-Y-412-E, Waste Piping, Third Floor and Roof, Part Plan-South, Dated 1/15/65 (No Revision No.).

King, Notz, and Bigelow. 1987. Safety Analysis: TURF, Building 7930. ORNL/TM-9505. Oak Ridge National Laboratory.

LLLW Generator Survey 1990 for Building 7930. 
Oak Ridge National Laboratory. 1991. Waste Acceptance Criteria for Liquid Waste Treatment Systems at the Oak Ridge National Laboratory. WM-WMCO-201. Department of Waste Minimization Planning and Certification.

R. M. Parson Co. 1977. Natural Disturbance Analysis of Buildings 7930 and 3019. Document No. X-OE-23.

Robinson, S. M., S. M. DePaoli, and A. B. Walker. 1991. Federal Facility Agreement Contingency, Upgrade, and Replacement Plans for the ORNL Active Low-Level Radioactive Waste Tank System. ORNL/TM-1 1795. Oak Ridge National Laboratory.

Specifications for the Construction of Thorium-Uranium Fuel Cycle Development Facility Building 7930. 
Figure 2.3-1

Location of Tank System C-6-T Piping

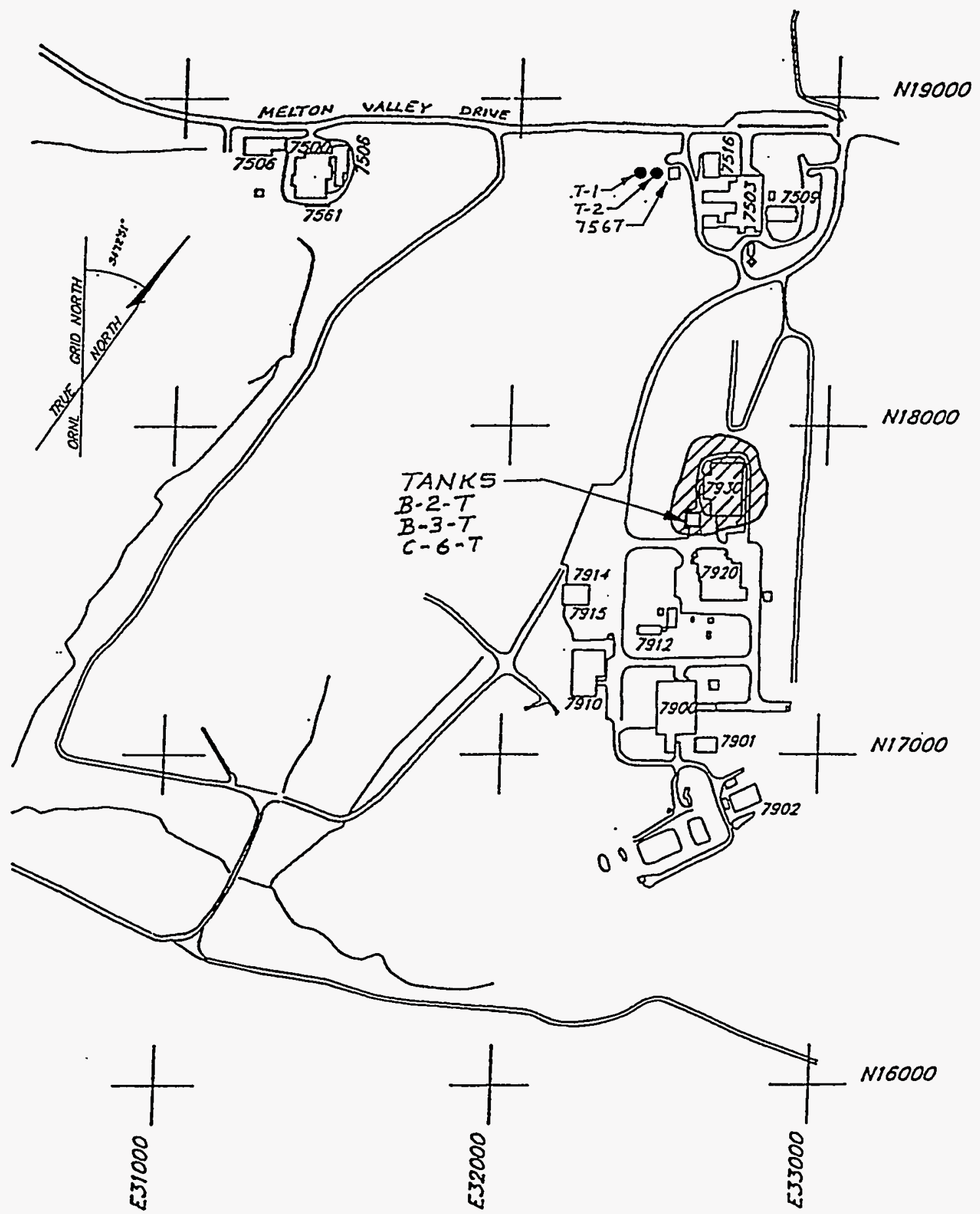




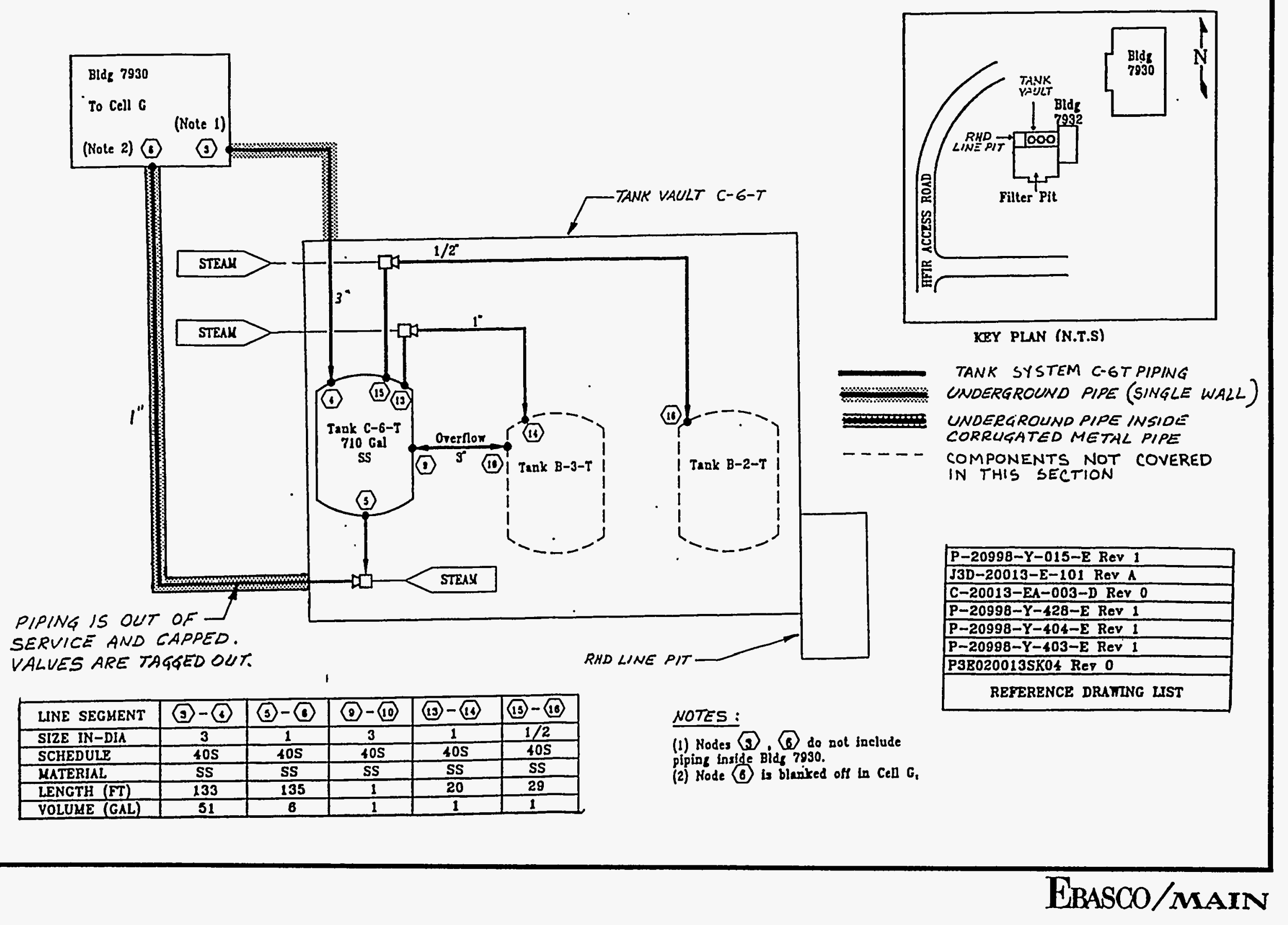




\section{WASTE STREAM CONTAMINANTS:}
(a) Isotopes:
$\mathrm{Cf}-252$
(b) Quantities
$0.5 \mathrm{mg} /$ year
Other Cf
Trace

(b) Others (i.e. acids, bases, organics, cleaners, etc.)

$\frac{\text { acidified butyrates }}{\text { nitric acid (dilute) }}$
palladium tetrammine di-hydrate
hydrazine decomposition products

\begin{tabular}{c}
824.9 g/year \\
\hline Trace \\
\hline Trace \\
\hline Trace \\
\hline
\end{tabular}




\section{$2.4 \quad$ Tank System C-1 Piping}

\subsubsection{Tank System Summary}

Tank System C-1 is located near the liquid low-level waste (LLLW) Evaporator (Building 2531) at the main Bethel Valley Complex (Figure 2.4-1). The tank system piping is schedule 40S, ASME SA-240, type 304L stainless steel (SS) and is routed from Tank Vault C-1 to Valve Pit 2VP-3 (Figure 2.4-2). Tank System C-1 piping is used to transfer concentrate from the LLLW Evaporator to the Melton Valley Storage Tanks and is classified as a Federal Facility Agreement (FFA) Category B tank system.

\subsubsection{Standards for Pipe Assessment of Tank Systems}

\subsubsection{Tank System Piping Description and Design Standards}

\section{Tank System Piping Description}

Tank System C-1 piping is located near Building 2531 and is routed from Tank Vault C-1 to Valve Pit 2VP-3. The piping system is used and managed by the Waste Management and Remedial Actions Division.

Tank System C-1 piping is constructed of $1-1 / 2^{\prime \prime}, 304 \mathrm{~L}$ SS with a maximum design pressure and temperature of $150 \mathrm{psig}$ and $400^{\circ} \mathrm{F}$. Tank System C-1 piping has a maximum volume of $9 \mathrm{gal}$.

\section{Design Standards}

The applicable codes and standards used for Tank System C-1 piping and its associated secondary containment systems are identified herein. The codes and standards listed are those identified on either the design drawings or the construction specifications.

American Concrete Institute 318, Building Code Requirements for Reinforced Concrete;

American Society of Mechanical Engineers (ASME) Boiler and Pressure Vessel Code, Sections II (SA-240) and VIII;

American Society for Testing and Materials C94, C175, A15, A185, A240, A262, A214, A182, A269, A276, A312, A371, A376, A403, E94, E142, E165, A7, A325, A245, A141, A53, A167, $\mathrm{A} 403, \mathrm{~A} 312, \mathrm{~B} 68, \mathrm{~A} 234, \mathrm{~A} 120, \mathrm{C} 200, \mathrm{~A} 181$, and A213;

American Standards Association Standard B31.1, Code for Pressure Piping.

Atomic Energy Commission Safety Code; 
Design Demonstrations - Category B Tank Systems (Piping)

Federal Specifications 55A666, 55A701, HHF191, HHC581, R381, HHF201, HHC591, TTC655, and LLLF321;

Institute of Electrical and Electronic Engineers Standards;

Underwriters Laboratories Inc.; and

Unfired Pressure Vessels (1962 edition).

\subsubsection{Generic Description of Piping Contents}

Tank System C-1 was designed to collect high-level waste generated at the Oak Ridge National Laboratory (ORNL). However, because no significant quantities of high-level waste were ever generated, this system was repiped to serve as a LLLW concentrate transfer system. LLLW is generated from a variety of facilities at ORNL including reactors, radioactive fuel processing areas, radioisotope processing areas, decontamination operations, hot cells, and radiochemical laboratories. The waste generators collect the waste, which is then transferred to LLLW Evaporator Feed Tank W-22. Any waste found to be acidic is adjusted to basic with sodium hydroxide in the generator collection tanks or in the evaporator feed tank, which precipitates most of the transuranic waste components and heavy metals. The waste is then processed through the evaporator; and the concentrate is transferred to Tanks C-1, C-2, W-21, and W-23 before it is sent to the Melton Valley Storage Tanks.

Tank System C-1 piping transfers LLLW to and from Tank C-1. Because of the lack of a convenient access point, Tank C-1 has not been sampled. However, Tank W-23, which is also used to store LLLW concentrate, has been sampled. Because both Tank W-23 and Tank C-1 are used to collect LLLW concentrate from the evaporator, it is logical to assume that the characteristics of the waste stored in Tank W-23 should be similar to those of the waste transferred through Tank System C-1.

The liquid waste supernate sampled in Tank W-23 ranges in color from pale to deep yellow with high $\mathrm{Ph}(11-13)$ sodium/potassium nitrate salt solutions and should be similar to the waste concentrate expected to be found in Tank C-1 (Figure 2.4-3). Based on radiation levels found in Tank W-23 and the historical use of Tank C-1 as an evaporation feed tank, Tank System C-1 piping may contain radioactive materials (Figure 2.4-4).

\subsubsection{Pipe Corrosion Protection Measures}

Piping inside Tank Vault C-1 and Valve Pit 2VP-3 has no direct contact with the soil or water. Cathodic protection measures are not required for external corrosion. 


\subsubsection{Documented Age of Tank System}

Tank System C-1 piping was installed in 1964.

\subsubsection{Standards for Containment/Release Detection}

2.4.3.1 Constructed of or Lined with Materials That are Compatible with Stored Waste(s) or Substance(s) to Be Placed in the Tank System and Shall Have Sufficient Strength and Thickness to Prevent-Failure

Tank System C-1 piping is single-wall, schedule 40S, type 304L SS pipe that is routed from Tank Vault C-1 to Valve Pit 2VP-3. Each area is discussed below. The piping penetrations from Tank Vault C- 1 to Valve Pit 2VP-3 are singly contained, 1-1/2", schedule 40S, type 304L SS pipes that are embedded in the concrete wall to a length of $3^{\prime 2} 2^{\prime \prime}$.

\section{$\underline{\text { Tank Vault C-1 }}$}

The assessment of the secondary containment system for Tank Vault C-1 is presented in the Design Demonstrations for Tank C-1. That assessment concludes that Tank Vault C-1 is coated with materials that are compatible with the waste and designed to prevent migration of waste into the concrete.

\section{Valve Pit 2VP-3}

The bottom of Valve Pit 2VP-3 is lined with 16-gauge (1/16"), 304L SS, with sidewalls that project $4^{\prime} 0^{\prime \prime}$ up the valve pit. The valve pit walls above the SS liner are provided with a system of Carboline 193 epoxy. The SS valve pit lining material is the same material as that used for the piping. Therefore, the lining is compatible with the waste and designed to prevent migration of waste into the concrete. According to manufacturer's specifications, the valve pit's epoxy coating is also compatible with the waste and designed to prevent migration of waste into the concrete.

The assessment concludes that the tank vault and valve pit are coated or lined with materials that are compatible with the waste and designed to prevent migration of waste into the concrete.

\subsubsection{Placed on Foundation or Base Capable of Providing Support to the Secondary Containment System}

\section{$\underline{\text { Tank Vault C-1 }}$}

The assessment of the secondary containment system for Tank Vault C-1 is presented in the Design Demonstrations for Tank $\mathrm{C}-1$. That assessment concludes that the vault foundation is properly designed to support the secondary containment system. 


\section{Valve Pit 2VP-3}

The valve pit foundation is an $18^{\prime} 2^{\prime \prime} \times 27^{\prime} 4^{\prime \prime} \times 1^{\prime} 2^{\prime \prime}$ thick, reinforced concrete base slab that rests on limestone.

The assessment concludes that the tank vault and valve pit foundations are properly designed to support the secondary containment systems.

2.4.3.3 Provided with a Leak Detection System That is Designed and Operated to Detect Failure of Either Primary or Secondary Containment Structure or the Presence of Any Measurable Release of Hazardous or Radioactive Constituents

\section{Tank Vault C-1}

The assessment of the secondary containment system for Tank Vault $\mathrm{C}-1$ is presented in the Design Demonstrations for Tank $\mathrm{C}-1$. That assessment concludes that the vault is provided with a leak detection system.

\section{Valve Pit 2VP-3}

The Valve Pit 2VP-3 floor is sloped to a 16-gauge (1/16"), 304L SS-lined sump where accumulation of liquid will be detected by a level sensor that will activate an alarm in the Waste Operations Control Center (Building 3130).

The assessment concludes that the tank vault and valve pit are provided with leak detection.

\subsubsection{Sloped or Otherwise Designed or Operated to Drain and Remove Liquids Resulting from Leaks, Spills, or Precipitation}

\section{Tank Vault C-1}

The assessment of the secondary containment system for Tank Vault C-1 is presented in the Design Demonstrations for Tank C-1. That assessment concludes that the secondary containment is sloped and designed to drain and remove liquids resulting from leaks, spills, or precipitation.

\section{Valve Pit 2VP-3}

The Valve Pit 2VP-3 floor is sloped to a 304L SS-lined sump. The sump provides a low point within the valve pit to drain liquids to an instrumented location. A pumping system is provided to remove liquids that accumulate in the sump.

The assessment concludes that the secondary containments for the tank vault and valve pit are sloped and designed to drain and remove liquids resulting from leaks, spills, or precipitation. 


\subsubsection{Supplemental Information}

\subsubsection{Ancillary Equipment}

Tank C- 1 is constructed of 304L SS, which is the same material as that used in the piping system, and is located in Tank Vault C-1, which provides secondary containment. The support equipment is exposed to the same liquids as other components of the tank system; therefore, 304L SS is an acceptable material for the support equipment.

\subsubsection{Waste Acceptance Criteria}

Radioactively contaminated liquid wastes at ORNL are generated by various activities within the research and operating divisions. These activities include radiochemical processing, routine hot cell operations and decontaminations, and various waste treatment and environmental protection processes. The variations in composition of the waste streams are limited by the waste acceptance criteria that specify activity and concentration limits for waste discharged into the LLLW system. The Waste Acceptance Criteria for Liquid Waste Treatment Systems at the Oak Ridge National Laboratory (Oak Ridge National Laboratory, 1991), dated July 1991, is a guide for liquid waste generators to determine the proper means of disposal for LLLW. The criteria provide future discharge guidelines for the LLLW system, which includes Tank System C-1. 
Design Demonstrations - Category B Tank Systems (Piping)

\subsection{5}

References

Binford, F. T., and S. D. Orfi. 1979. The Intermediate-Level Liquid Waste System at the Oak Ridge National Laboratory Description and Safety Analysis. ORNL/TM-6959. Oak Ridge National Laboratory.

Ebasco, and Main. May 14, 1993. Design Demonstrations-Category B Tank Systems, Revision 2. DOE Contract No. DE-AC05-91OR21928. Oak Ridge National Laboratory.

Energy Systems Drawing D-52563, 50,000-Gal High-Level Liquid Waste Tanks C-1 and C-2 Detail Sheet 1, Revision 2.

Energy Systems Drawing E-S-52711, Cells 1 and 2 Stainless Steel Liners and Tank Vault Details, Revision 2.

Energy Systems Drawing D-55001, Control Flow Diagram C-1 and C-2 Tank Vault, Revision 1.

Energy Systems Drawing D-55003, Control Flow Diagram Cell, Revision 3.

Energy Systems Drawing D-55002, Control Flow Diagram Cell 2 and Valve Pit, Revision 5.

Energy Systems Drawing C-40307, Criteria Storage Tank Vault, Dated 1/30/62 (No Revision No.).

Energy Systems Drawing S-20237-YB-010-E, Evaporator Annex Plan, Sections and Details, Stainless Steel Liner, Revision 2.

Energy Systems Drawing S3E-20237-B013, Extended Vault Plan, Sections and Details, Revision 1.

Energy Systems Drawing E-F-52685, Footing Tunnel Drains and Sump Pit, Revision 1.

Energy Systems Drawing C-20237-EA-001-D, Grading Plan, Dated 3/20/63 (No Revision No.).

Energy Systems Drawing D-52589, High-Level Waste Tank Cell Piping, Sheet 1, Revision 4.

Energy Systems Drawing D-52591, High-Level Waste Tank Cell Piping, Sheet 3, Revision 3.

Energy Systems Drawing D-52761, Offgas and Cell Ventilation Filter Pits Details, Revision 1.

Energy Systems Drawing P3E-20237-C021, Piping Details Evaporator Service Tank Area, Revision 1.

Energy Systems Drawing P3E-20237-C020, Piping Plan Building 2531 Area, Revision 0.

Energy Systems Drawing D-52608, Sample Flow Sheet, Revision 3. 
Energy Systems Drawing D-52750, Sampling Room Foundation Plan and Sections, Revision 1.

Energy Systems Drawing E-S-52712, Tank Storage Vault and Retaining Wall Details, Revision 2.

Energy Systems Drawing D-52757, Tank Vault Cover Plug Location Plan and Details, Revision 1.

Energy Systems Drawing E-S-52714, Wall Penetrations, Sheet 1, Revision 6.

Energy Systems Drawing D-52606, Waste Evaporator Building Cell 1 and 2 Process Flowsheet, Revision 4.

Energy Systems Drawing D-52604, Waste Evaporator Building Cell 1 and 2 Service Flowsheet, Revision 3.

Hertel, J. P. 1964. Procedure for Mass Spec. Leak Test. Job 3-127.

Oak Ridge National Laboratory. 1991. Waste Acceptance Criteria for Liquid Waste Treatment Systems at the Oak Ridge National Laboratory. WM-WMCO-201. Department of Waste Minimization Planning and Certification.

Peretz, F. J., et al. 1986. Characterization of Low-Level Liquid Wastes at the Oak Ridge National Laboratory. ORNL/TM-10218. Oak Ridge National Laboratory.

Procurement Specifications. 1963. High-Level Liquid Waste Tanks C-1 and C-2. XSP-68A.

Risk Evaluation of Embedded, Single-Walled Liquid Low-Level Waste Piping at Oak Ridge National Laboratory.

Robinson, S. M., S. M. DePaoli, and A. B. Walker. 1991. Federal Facility Agreement Contingency, Upgrade, and Replacement Plans for the ORNL Active Low-Level Radioactive Waste Tank System. ORNL/TM-11795. Oak Ridge National Laboratory.

Sears, M. B., et al. 1990. Sampling and Analysis of Radioactive Liquid Waste and Sludges in the Melton Valley and Evaporator Facility Storage Tanks at ORNL. ORNL/TM-11652. Oak Ridge National Laboratory.

Specifications for Construction of Intermediate-Level Waste Facilities for the Energy Research and Development Administration. Invitation No. EY-77-B-05-5350.

Technical Specifications for the Construction of Improvements to Radioactive Liquid Waste System, Phase I, Building 2531. 


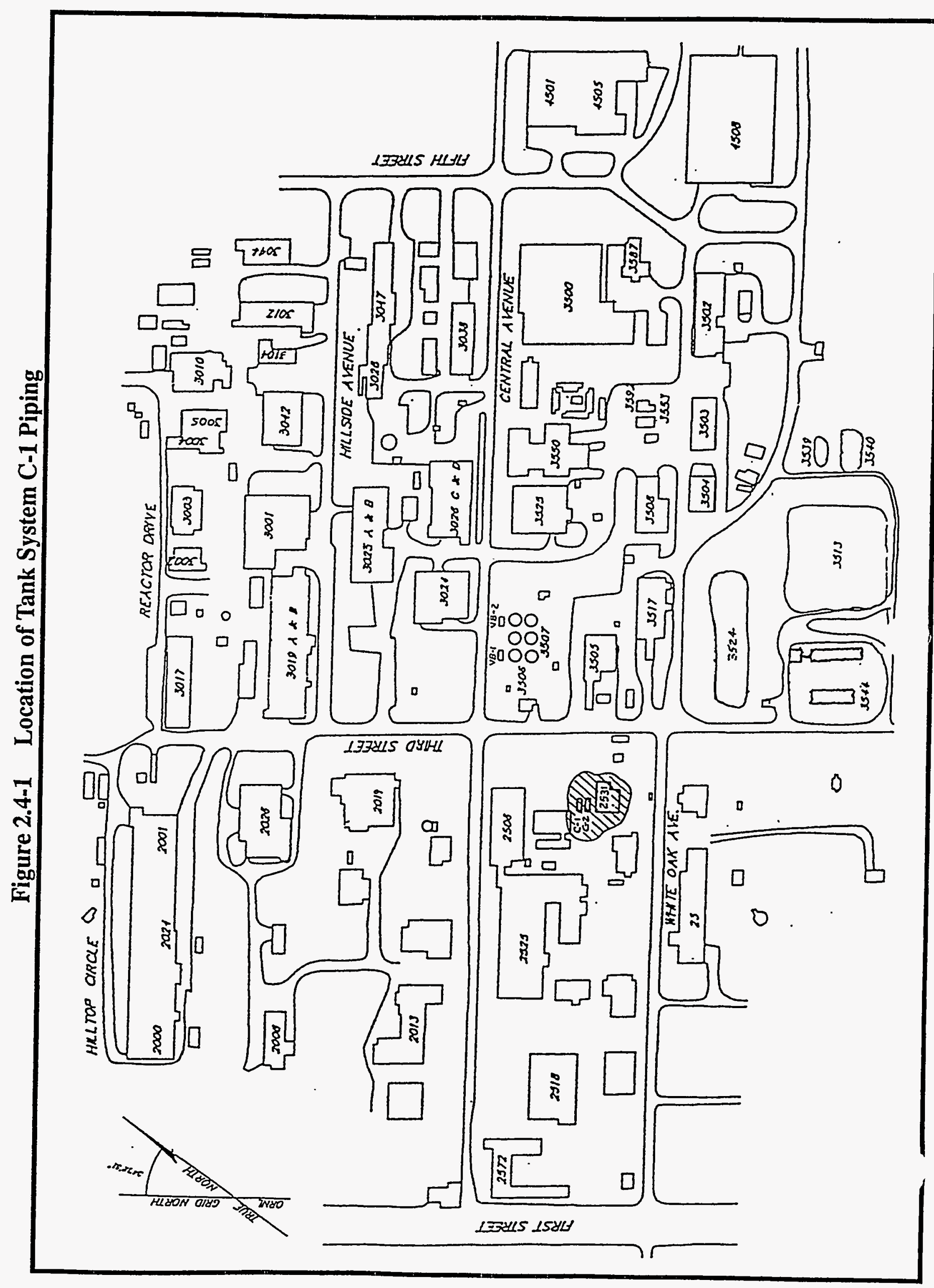


Figure 2.4-2 Tank System C-1 Piping Diagram
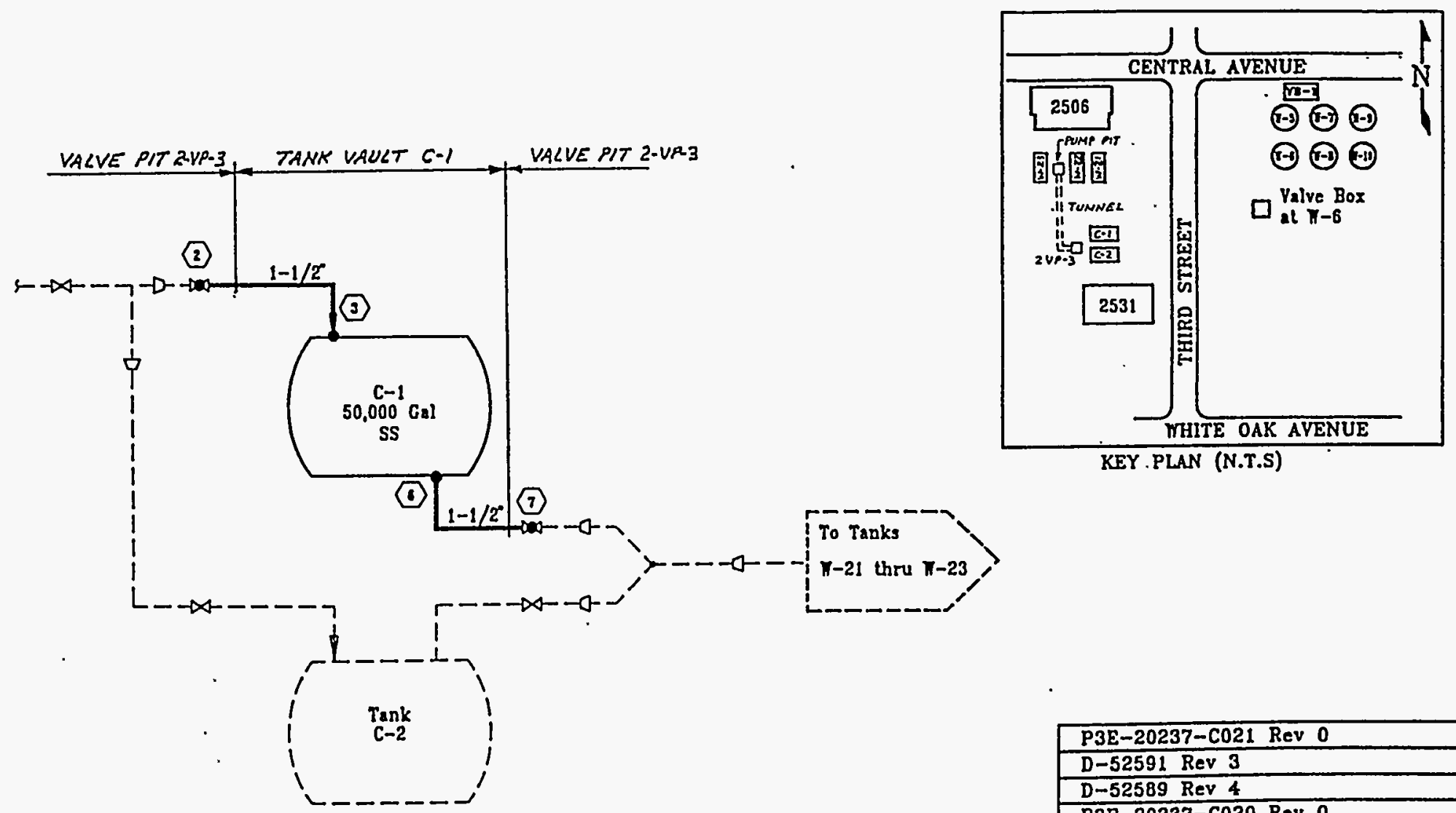

\begin{tabular}{|l|c|c|}
\hline LINE SEGMENT & 2 - (3) & $(6-0)$ \\
\hline SIZE IN-DIA & $1-1 / 2$ & $1-1 / 2$ \\
\hline SCHEDULE & $40 S$ & $40 S$ \\
\hline MATERIAL & SS & SS \\
\hline LENGTH (FT) & 48 & 34 \\
\hline YOLUUE (GAL) & 5 & 4 \\
\hline
\end{tabular}

TANK SYSTEM C-1 PIPING

- - - COMPONENTS NOT COVERED IN THIS SECTION 


\section{ANALYTICAL DATA FOR ANALYTICAL DATA FOR LIQUID SAMPLE \\ SLUDGE SAMPLE}

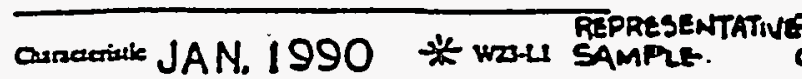

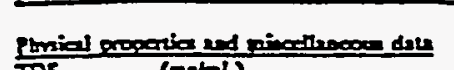

TDS (

Is $\quad$ (othel)

IC (Gent)

TC (me)

TOC (ERL)

$A_{B}(\square, L)$

$\begin{array}{ll}\lambda_{1} & (\omega \Omega L) \\ B_{2} & (\square L L)\end{array}$

Cl (๓R)

Cr (mel)

$\begin{array}{ll}\mathrm{H}_{3} & (\mathrm{NL} /) \\ \mathrm{Ni} & (\mathrm{ag})\end{array}$

ib (

Se $\quad(\square \Omega)$

In (N)

$N$ (1)

B ( $12 L)$

$C_{2} \quad(m \Omega)$

Co $(m \Omega)$

$\therefore$ (mนl)

Ms (mel)

is (mEL)

Si $\quad$ (mil)

Th (aIL)

U (mL/)

Anions

Caloride $M$

Fuoride $\mathrm{MD}$

Pritate

Sulbie $(M)$

Alaliniry

$\mathrm{pH}$

$H^{\circ} \quad M$

$\mathrm{OH}_{3}^{2} \quad \mathrm{MO}$

$\mathrm{HCO}^{\circ}$

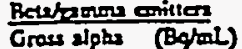

Groes bets (Boyl)

"C (BqDL)

"Ce (Bgthl)

"Co (Bght)

"NG (BAtaL)

"I"Ev (Bq/L)

(Bchl)

${ }_{H}$ (Bgtrl)

"NO (B\&/LL)

${ }^{100}$ Ru (BqhL)

NSe (BgtrL)

ANphs amiltm

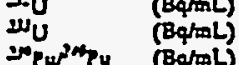

II)

" $\mathrm{Cm}$ (B\&/mL)

* No data for tank C- 1 W23 SHOWN AS A REP. S'AMPLE

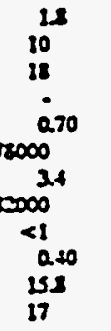

0.10

$<0.053$

$<0053$

Q.0.1

128.

0.15

0.70

$230 x+01$

$402+05$

$635 e+01$

$<$ liketos.

ciletor

$4.03 e+03$

$436 e+05$

$<21 x+02$

$<1.6+02$

<2set02

$1.19+02$

$373 x+03$

$4.12 x+02$

$<t .0 x+02$

$4.00 x+\infty$

$1000<+\infty$

$6.00 x+\infty$

$390 x+01$

$4.00 c+\infty$

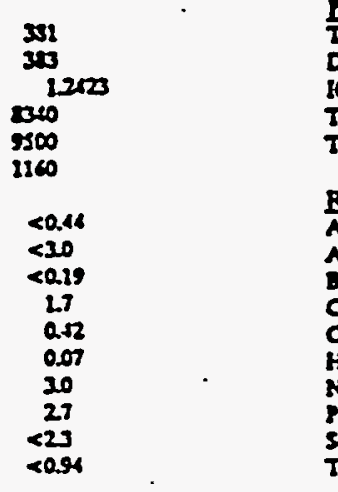

Cunatiate JAN, 1990 * WO-S PAPREStNTATWE

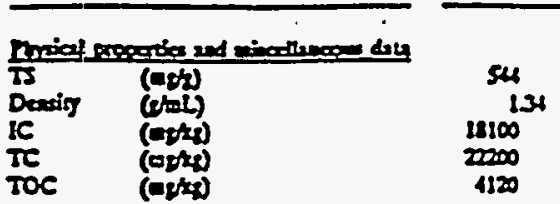

RORA

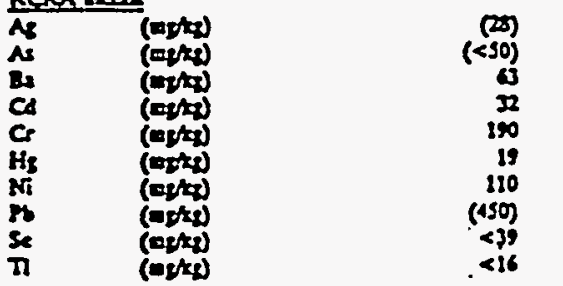

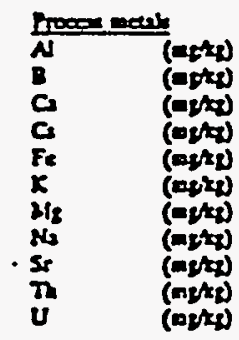

$2 \infty 0$
210

35000

1900.

10000

10000

$\underset{100}{200}$

17000

\section{Revpanarioninon}

Gross alpha (Cat)

Grows bets (Bor)

"C (Bq)

14ce (सभi)

लC (Bक

wa (Ber

WG (Bor)

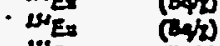

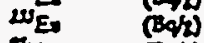

Mro (CH,

(eqp)

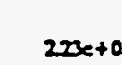

$667 c+\infty$

$305 e+02$

$<27 e+a r$

$232 x+05$

$<\mathrm{Set03}$

issetos

$72 x+05$

$\therefore$ silictos

$1.21 e+05$

$<7.02+03$

$<62 e+04$

$22 k+06$

Noh comition

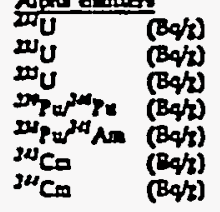

l.1ketor

$<28 x+04$

l.16e+or

$321 \mathrm{et}$ or

$<26+04$

LEGEND:

TSD - TOTAL DISSOLVED SOLIDS

TS - TOTAL SOLIDS

IC - INORGANIC CARBON

TC - TOTAL CARBON

TOC-TOTAL ORGANIC CARBON 


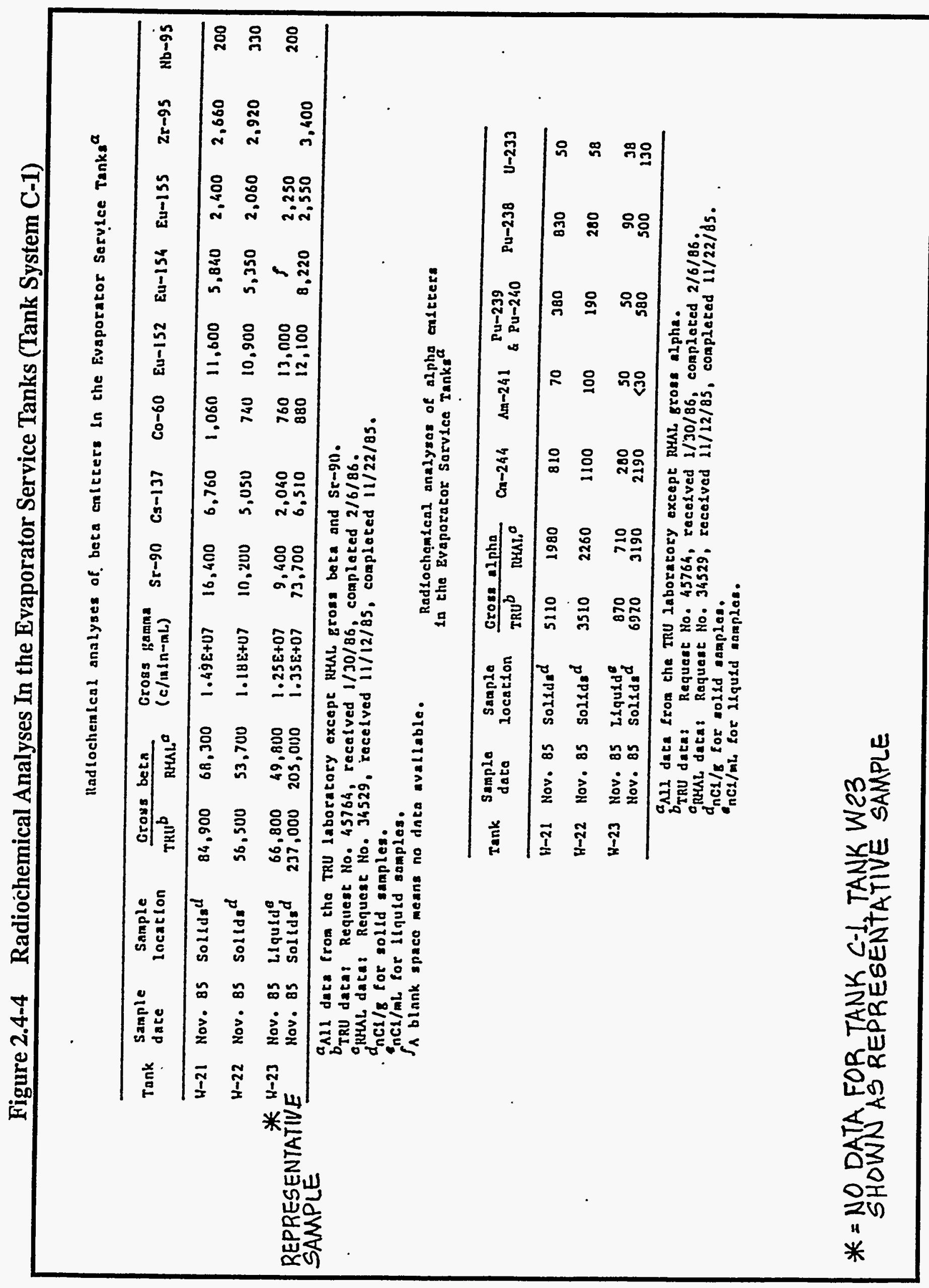




\subsection{1}

\section{Tank System Summary}

Tank System C-2 is located near the liquid low-level waste (LLLW) Evaporator (Building 2531) at the main Bethel Valley Complex (Figure 2.5-1). The tank system piping is schedule 40S, ASME SA-240, type 304L stainless steel (SS) and is routed from Tank Vault C-2 through Valve Pit 2VP-3 and Pipe Tunnel 2 to the Control House Pump Pit (Figure 2.5-2). Tank System C-2 piping is used to transfer concentrate from the LLLW Evaporator to the Melton Valley Storage Tanks and is classified as a Federal Facility Agreement (FFA) Category B tank system.

\subsubsection{Standards for Pipe Assessment of Tank Systems}

\subsubsection{Tank System Piping Description and Design Standards}

\section{Tank System Piping Description}

Tank System C-2 piping is located near Building 2531 and is routed from Tank Vault C-2 through Valve Pit 2VP-3 and Pipe Tunnel 2 to the Control House Pump Pit. The piping system is used and managed by the Waste Management and Remedial Actions Division.

Tank System C-2 piping is constructed of 1-1/2", 2", and 4", 304L SS with a maximum design pressure and temperature of $150 \mathrm{psig}$ and $400^{\circ} \mathrm{F}$. Tank System C-2 piping has a maximum volume of $34 \mathrm{gal}$.

\section{Design Standards}

The applicable codes and standards used for Tank System C-2 piping and its associated secondary containment systems are identified herein. The codes and standards listed are those identified on either the design drawings or the construction specifications.

American Concrete Institute 318, Building Code Requirements for Reinforced Concrete;

American Society of Mechanical Engineers (ASME) Boiler and Pressure Vessel Code, Sections II (SA-240) and VIII;

American Society for Testing and Materials C94, C175, A15, A185, A240, A262, A214, A182, A269, A276, A312, A371, A376, A403, E94, E142, E165, A7, A325, A245, A141, A53, A167, $\mathrm{A} 403, \mathrm{~A} 312, \mathrm{~B} 68, \mathrm{~A} 234, \mathrm{~A} 120, \mathrm{C} 200, \mathrm{~A} 181$, and A213;

American Standards Association Standard B31.1, Code for Pressure Piping.

Atomic Energy Commission Safety Code; 
Design Demonstrations - Category B Tank Systems (Piping)

Federal Specifications 55A666, 55A701, HHF191, HHC581, R381, HHF201, HHC591, TTC655, and LLLF321;

Institute of Electrical and Electronic Engineers Standards;

Underwriters Laboratories Inc.; and

Unfired Pressure Vessels (1962 edition).

\subsubsection{Generic Description of Piping Contents}

Tank System C-2 piping was designed to transfer high-level waste generated at the Oak Ridge National Laboratory (ORNL). However, because no significant quantities of high-level waste were ever generated, this system was repiped to serve as a LLLW concentrate transfer system. LLLW is generated from a variety of facilities at ORNL including reactors, radioactive fuel processing areas, radioisotope processing areas, decontamination operations, hot cells, and radiochemical laboratories. The waste generators collect the waste, which is then transferred to LLLW Evaporator Feed Tank W-22. Any waste found to be acidic is adjusted to basic with sodium hydroxide in the generator collection tanks or in the evaporator feed tank, which precipitates most of the transuranic waste components and heavy metals. The waste is then processed through the evaporator; and the concentrate is transferred to Tanks C-1, C-2, W-21, and W-23 before it is sent to the Melton Valley Storage Tanks.

Tank System C-2 piping transfers LLLW to and from Tank C-2. Because of the lack of a convenient access point, Tank C-2 has not been sampled. However, Tank W-23, which is also used to store LLLW concentrate, has been sampled. Because both Tank W-23 and Tank C-2 are used to collect LLLW concentrate from the evaporator, it is logical to assume that the characteristics of the waste stored in Tank W-23 should be similar to those of the waste transferred through Tank System C-2.

The liquid waste supernate sampled in Tank W-23 ranges in color from pale to deep yellow with high $\mathrm{Ph}(11-13)$ sodium/potassium nitrate salt solutions and should be similar to the waste concentrate expected to be found in Tank C-2 (Figure 2.5-3). Based on radiation levels found in Tank W-23 and the historical use of Tank C-2 as an evaporator feed tank, Tank System C-2 piping may contain radioactive materials (Figure 2.5-4).

\subsubsection{Pipe Corrosion Protection Measures}

Piping inside Tank Vault C-2, Valve Pit 2VP-3, Pipe Tunnel 2, and the Control House Pump Pit has no direct contact with the soil or water. Cathodic protection measures are not required for external corrosion.

\subsubsection{Documented Age of Tank System}

Tank System C-2 piping was installed in 1964. 
Design Demonstrations - Category B Tank Systems (Piping)

Standards for Containment/Release Detection

2.5.3.1 Constructed of or Lined with Materials That are Compatible with Stored Waste(s) or Substance(s) to Be Placed in the Tank System and Shall Have Sufficient Strength and Thickness to Prevent Failure

Tank System C-2 piping is single-wall, schedule 40S, type 304L SS that is routed from Tank Vault C-2 through Valve Pit 2VP-3 and Pipe Tunnel 2 to the Control House Pump Pit. Each area is discussed below. The piping penetrations from Tank Vault C-2 to Valve Pit 2VP-3 are singly contained, 1-1/2", schedule 40S, type 304L SS pipes that are embedded in the concrete wall to a length of $3^{\prime} 2^{\prime \prime}$. The pipe penetration from Pipe Tunnel 2 to the pump pit is a singly contained, $2^{\prime \prime}$, schedule $40 \mathrm{~S}$, type $304 \mathrm{~L}$ SS pipe that is embedded in the concrete wall to a length of $2^{\prime} 0^{\prime \prime}$.

\section{Tank Vault C-2}

The assessment of the secondary containment system for Tank Vault C-2 is presented in the Design Demonstrations for Tank C-2. That assessment concludes that Tank Vault C-2 is coated with materials that are compatible with the waste and designed to prevent migration of waste into the concrete.

\section{Valve Pit 2VP-3}

The bottom of Valve Pit 2VP-3 is lined with 16-gauge (1/16"), 304L SS, with sidewalls that project $4^{\prime} 0^{\prime \prime}$ up the valve pit. The valve pit walls above the SS liner are provided with a system of Carboline 193 epoxy. The SS valve pit lining material is the same material as that used for the piping. Therefore, the lining is compatible with the waste and designed to prevent migration of waste into the concrete. According to manufacturer's specifications, the valve pit's epoxy coating is also compatible with the waste and designed to prevent migration of waste into the concrete.

\section{Pipe Tunnel 2}

The bottom of Pipe Tunnel 2 is lined with 16-gauge (1/16"), 304L SS, with sidewalls that project up to the pipe tunnel roof. The SS pipe tunnel lining material is the same material as that used for the piping. Therefore, the lining is compatible with the waste and designed to prevent migration of waste into the concrete.

\section{Control House Pump Pit}

The bottom of the pump pit is lined with 16-gauge (1/16"), 304L SS, with sidewalls that project $3^{\prime} 0^{\prime \prime}$ up the pump pit. The pump pit walls above the SS liner are provided with a 30-mil-thick system of Amercoat 66 epoxy. The SS pump pit lining material is the same material as that used for the piping. Therefore, the lining is compatible with the waste and designed to prevent migration of waste into the concrete. According to manufacturer's specifications, the pump pit's epoxy coating is also compatible with the waste and designed to prevent migration of waste into the concrete. 
The assessment concludes that the tank vault, valve pit, pipe tunnel, and pump pit are coated or lined with materials that are compatible with the waste and designed to prevent migration of waste into the concrete.

\subsubsection{Placed on Foundation or Base Capable of Providing Support to the Secondary Containment System}

\section{Tank Vault C-2}

The assessment of the secondary containment system for Tank Vault C-2 is presented in the Design Demonstrations for Tank C-2. That assessment concludes that the vault foundation is properly designed to support the secondary containment system.

\section{Valve Pit 2VP-3}

The valve pit foundation is an $18^{\prime} 2^{\prime \prime} \times 27^{\prime} 4^{\prime \prime} \times 1^{\prime} 2^{\prime \prime}$ thick, reinforced concrete base slab that rests on limestone.

\section{Pipe Tunnel 2}

The pipe tunnel foundation is a $9^{\prime} 6^{\prime \prime} \times 63^{\prime} 8^{\prime \prime} \times 1^{\prime} 0^{\prime \prime}$ thick, reinforced concrete base slab that rests on limestone.

\section{Control House Pump Pit}

The pump pit foundation is a $21^{\prime} 0^{\prime \prime} \times 40^{\prime} 0^{\prime \prime} \times 2^{\prime} 0^{\prime \prime}$ thick, reinforced concrete base slab that rests on limestone.

The assessment concludes that the tank vault, valve pit, pipe tunnel, and pump pit foundations are properly designed to support the secondary containment systems.

\subsubsection{Provided with a Leak Detection System That is Designed and Operated to Detect Failure of Either Primary or Secondary Containment Structure or the Presence of Any Measurable Release of Hazardous or Radioactive Constituents}

\section{Tank Vault C-2}

The assessment of the secondary containment system for Tank Vault C-2 is presented in the Design Demonstrations for Tank C-2. That assessment concludes that the vault is provided with a leak detection system. 


\section{Valve Pit 2VP-3}

The Valve Pit 2VP-3 floor is sloped to a 16-gauge (1/16"), 304L SS-lined sump where accumulation of liquid will be detected by a level sensor that will activate an alarm in the Waste Operations Control Center (Building 3130).

\section{Pipe Tunnel 2}

The Pipe Tunnel 2 floor is sloped to a 16-gauge (1/16"), 304L SS-lined sump. Any liquid that flows to the Pipe Tunnel 2 sump will continue to flow to the Control House Pump Pit sump through a 4", schedule 40S, type 304L SS, sump drain pipe. The pump pit sump is lined with 16-gauge (1/16"), 304L SS; and accumulation of liquid will be detected by a level sensor that will activate an alarm in the Waste Operations Control Center (Building 3130).

\section{Control House Pump Pit}

The pump pit floor is sloped to a 16-gauge (1/16"), 304L SS-lined sump where accumulation of liquid will be detected by a level sensor that will activate an alarm in the Waste Operations Control Center (Building 3130).

The assessment concludes that the tank vault, valve pit, pipe tunnel, and pump pit are provided with leak detection.

\subsubsection{Sloped or Otherwise Designed or Operated to Drain and Remove Liquids} Resulting from Leaks, Spills, or Precipitation

\section{Tank Vault C-2}

The assessment of the secondary containment system for Tank Vault C-2 is presented in the Design Demonstrations for Tank C-2. That assessment concludes that the secondary containment is sloped and designed to drain and remove liquids resulting from leaks, spills, or precipitation.

\section{Valve Pit 2VP-3}

The Valve Pit 2VP-3 floor is sloped to a 304L SS-lined sump. The sump provides a low point within the valve pit to drain liquids to an instrumented location. A pumping system is provided to remove liquids that accumulate in the sump.

\section{Pipe Tunnel 2}

The pipe tunnel floor is sloped to a 304L SS-lined sump. Any liquid that flows to the pipe tunnel sump will continue to flow to the pump pit sump through a sump drain pipe. The pump pit sump provides a low point to drain liquids to an instrumented location. A pumping system is provided to remove liquids that accumulate in the sump. 


\section{Control House Pump Pit}

The pump pit floor is sloped to a 304L SS-lined sump. The sump provides a low point within the pump pit to drain liquids to an instrumented location. A pumping system is provided to remove liquids that accumulate in the sump.

The assessment concludes that the secondary containments for the tank vault, valve pit, pipe tunnel, and pump pit are sloped and designed to drain and remove liquids resulting from leaks, spills, or precipitation.

\subsubsection{Supplemental Information}

\subsubsection{Ancillary Equipment}

Tank C-2 is constructed of $304 \mathrm{~L}$ SS, which is the same material as that used in the piping system, and is located in Tank Vault C-2, which provides secondary containment. The support equipment is exposed to the same liquids as other components of the tank system; therefore, 304L SS is an acceptable material for the support equipment.

\subsubsection{Waste Acceptance Criteria}

Radioactively contaminated liquid wastes at ORNL are generated by various activities within the research and operating divisions. These activities include radiochemical processing, routine hot cell operations and decontaminations, and various waste treatment and environmental protection processes. The variations in composition of the waste streams are limited by the waste acceptance criteria that specify activity and concentration limits for waste discharged into the LLLW system. The Waste Acceptance Criteria for Liquid Waste Treatment Systems at the Oak Ridge National Laboratory (Oak Ridge National Laboratory, 1991), dated July 1991, is a guide for liquid waste generators to determine the proper means of disposal for LLLW. The criteria provide future discharge guidelines for the LLLW system, which includes Tank System C-2. 
Design Demonstrations - Category B Tank Systems (Piping)

2.5.5

References

Binford, F. T., and S. D. Orfi. 1979. The Intermediate-Level Liquid Waste System at the Oak Ridge National Laboratory Description and Safety Analysis. ORNL/TM-6959. Oak Ridge National Laboratory.

Ebasco, and Main. May 14, 1993. Design Demonstrations-Category B Tank Systems, Revision 2. DOE Contract No. DE-AC05-91OR21928. Oak Ridge National Laboratory.

Energy Systems Drawing D-52563, 50,000-Gal High-Level Liquid Waste Tanks C-1 and C-2 Detail, Sheet 1, Revision 2.

Energy Systems Drawing E-S-52711, Cells 1 and 2 Stainless Steel Liners and Tank Vault Details, Revision 2.

Energy Systems Drawing D-55001, Control Flow Diagram C-1 and C-2 Tank Vault, Revision 1.

Energy Systems Drawing D-55003, Control Flow Diagram Cell, Revision 3.

Energy Systems Drawing D-55002, Control Flow Diagram Cell 2 and Valve Pit, Revision 5.

Energy Systems Drawing C-40307, Criteria Storage Tank Vault, Dated 1/30/62 (No Revision No.).

Energy Systems Drawing S-20237-YB-010-E, Evaporator Annex Plan, Sections and Details Stainless Steel Liner, Revision 2.

Energy Systems Drawing S3E-20237-B013, Extended Vault Plan, Sections and Details, Revision 0.

Energy Systems Drawing E-F-52685, Footing Tunnel Drains and Sump Pit, Revision 1.

Energy Systems Drawing C-20237-EA-001-D, Grading Plan, Dated 3/20/63 (No Revision No.).

Energy Systems Drawing D-52589, High-Level Waste Tank Cell Piping, Sheet 1, Revision 4.

Energy Systems Drawing D-52591, High-Level Waste Tank Cell Piping, Sheet 3, Revision 3.

Energy Systems Drawing D-52761, Offgas and Cell Ventilation Filter Pits Details, Revision 1.

Energy Systems Drawing P3E-20237-C021, Piping Details Evaporator Service Tank Area, Revision 0.

Energy Systems Drawing P3E-20237-C020, Piping Plan Building 2531 Area, Revision 0.

Energy Systems Drawing D-52608, Sample Flow Sheet, Revision 3. 
Design Demonstrations - Category B Tank Systems (Piping)

Energy Systems Drawing D-52750, Sampling Room Foundation Plan and Sections, Revision 1.

Energy Systems Drawing E-S-52712, Tank Storage Vault and Retaining Wall Details, Revision 2.

Energy Systems Drawing D-52757, Tank Vault Cover Plug Location Plan and Details, Revision 1.

Energy Systems Drawing E-S-52714, Wall Penetrations, Sheet 1, Revision 6.

Energy Systems Drawing D-52606, Waste Evaporator Building Cell 1 and 2 Process Flowsheet, Revision 4.

Energy Systems Drawing D-52604, Waste Evaporator Building Cell 1 and 2 Service Flowsheet, Revision 3.

Hertel, J. P. 1964. Procedure for Mass Spec. Leak Test. Job 3-127.

Oak Ridge National Laboratory. 1991. Waste Acceptance Criteria for Liquid Waste Treatment Systems at the Oak Ridge National Laboratory. WM-WMCO-201. Department of Waste Minimization Planning and Certification.

Peretz, F. J., et al. 1986. Characterization of Low-Level Liquid Wastes at the Oak Ridge National Laboratory. ORNL/TM-10218. Oak Ridge National Laboratory.

Procurement Specifications. 1963. High-Level Liquid Waste Tanks C-1 and C-2. XSP-68A.

Risk Evaluation of Embedded, Single-Walled Liquid Low-Level Waste Piping at Oak Ridge National Laboratory.

Robinson, S. M., S. M. DePaoli, and A. B. Walker. 1991. Federal Facility Agreement Contingency, Upgrade, and Replacement Plans for the ORNL Active Low-Level Radioactive Waste Tank System. ORNL/TM-11795. Oak Ridge National Laboratory.

Sears, M. B., et al. 1990. Sampling and Analysis of Radioactive Liquid Waste and Sludges in the Melton Valley and Evaporator Facility Storage Tanks at ORNL. ORNL/TM-11652. Oak Ridge National Laboratory.

Specifications for Construction of Intermediate-Level Waste Facilities for the Energy Research and Development Administration. Invitation No. EY-77-B-05-5350.

Technical Specifications for the Construction of Improvements to Radioactive Liquid Waste System, Phase I, Building 2531. 


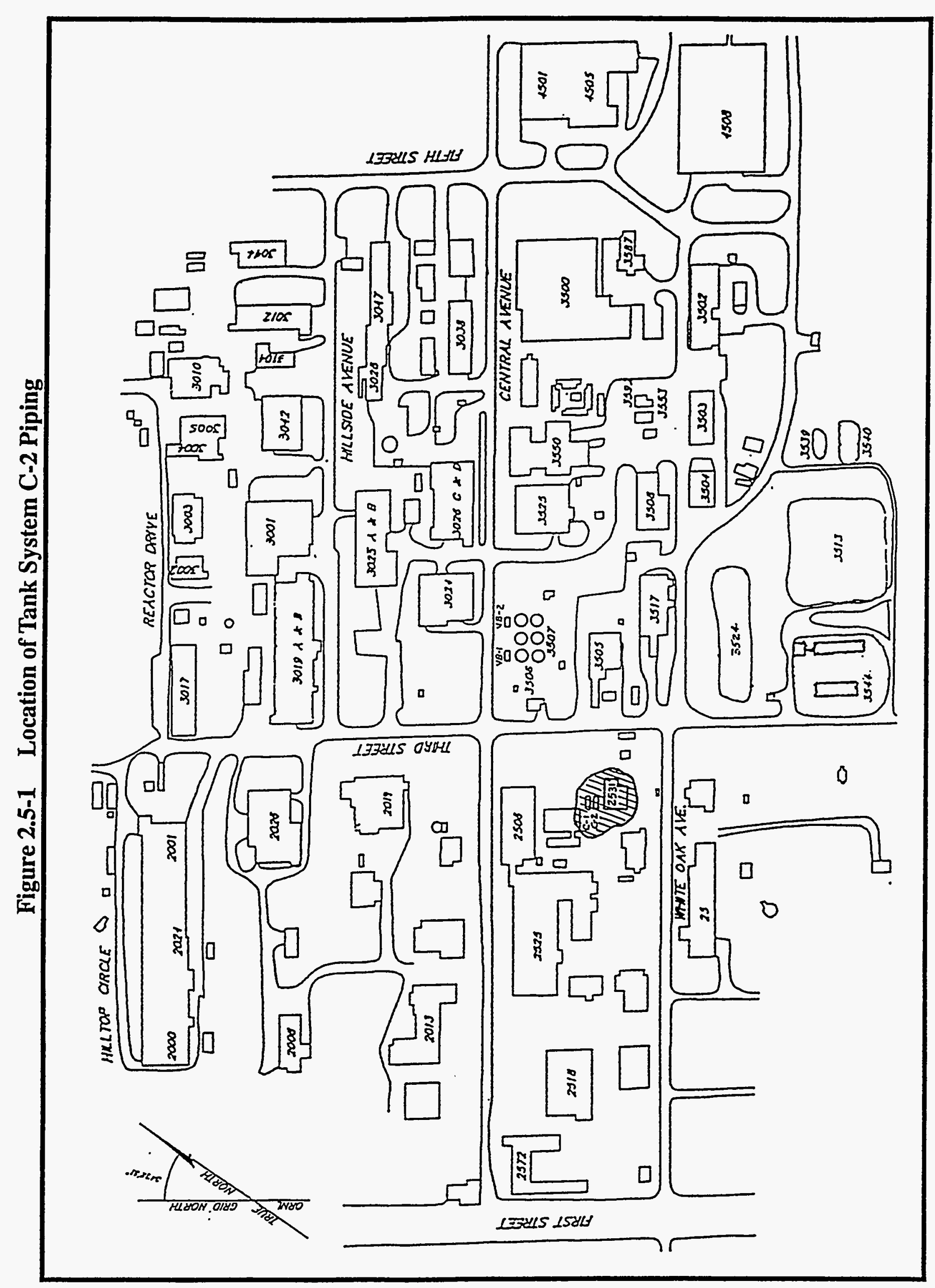




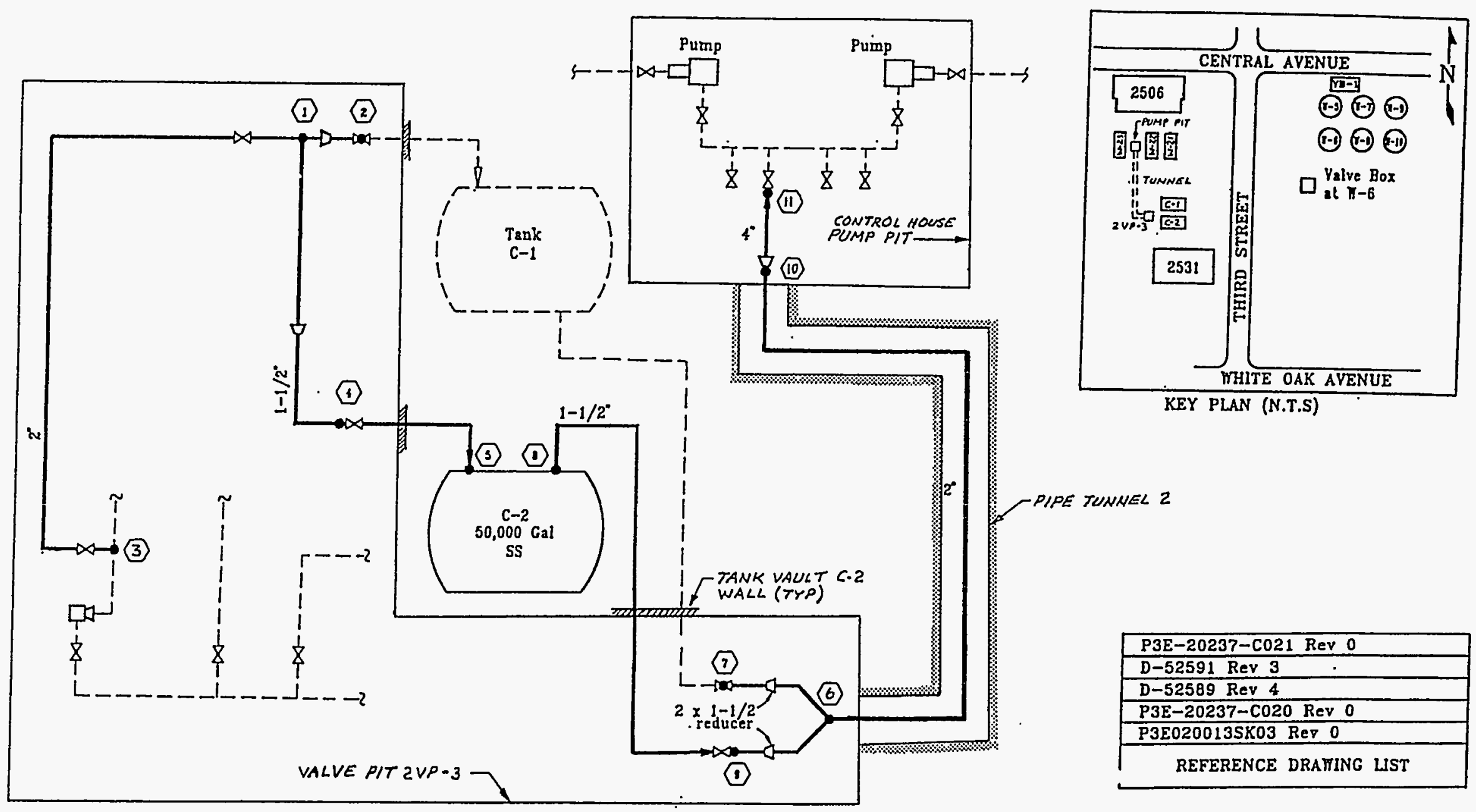

\begin{tabular}{|c|c|c|c|c|c|c|c|c|}
\hline LINE SEGMENT & (3) -1 & (1) -2 & (1) - (1) & (4) -5 & (7) -6 & (a) - (8) & (6) -10 & (10)-(11) \\
\hline SIZE IN-DIA & 2 & 2 & 2 & $1-1 / 2$ & 2 & $1-1 / 2$ & 2 & 4 \\
\hline SCHEDULE & $40 S$ & $40 \mathrm{~S}$ & $40 S$ & $40 \mathrm{~S}$ & 105 & $40 S$ & $40 \mathrm{~S}$ & $40 S$ \\
\hline MATERIAL & SS & SS & SS & SS & SS & $S^{\circ}$ & SS & SS \\
\hline LENGTH $(\overline{F T})$ & 5 & $<1$ & $<1$ & 49 & $<1$ & 34 & 115 & $<1$ \\
\hline VOLUME (GAL) & 1 & $<1$ & $<1$ & 5 & $<1$ & 4 & 20 & $<1$ \\
\hline
\end{tabular}

TANK SYSTEM C.2 PIPING PIPE IN UNDERGROUNO TUNNEL

\%

COMPONENTS NOT COVERED IN THIS SECTION 
Figure 2.5-3

Analytical Data for Liquid and Sludge Samples (Tank System C-2)
ANALYTICAL DATA FOR
ANALYTICAL DATA FOR LIQUID SAMPLE SLUDGE SAMPLE

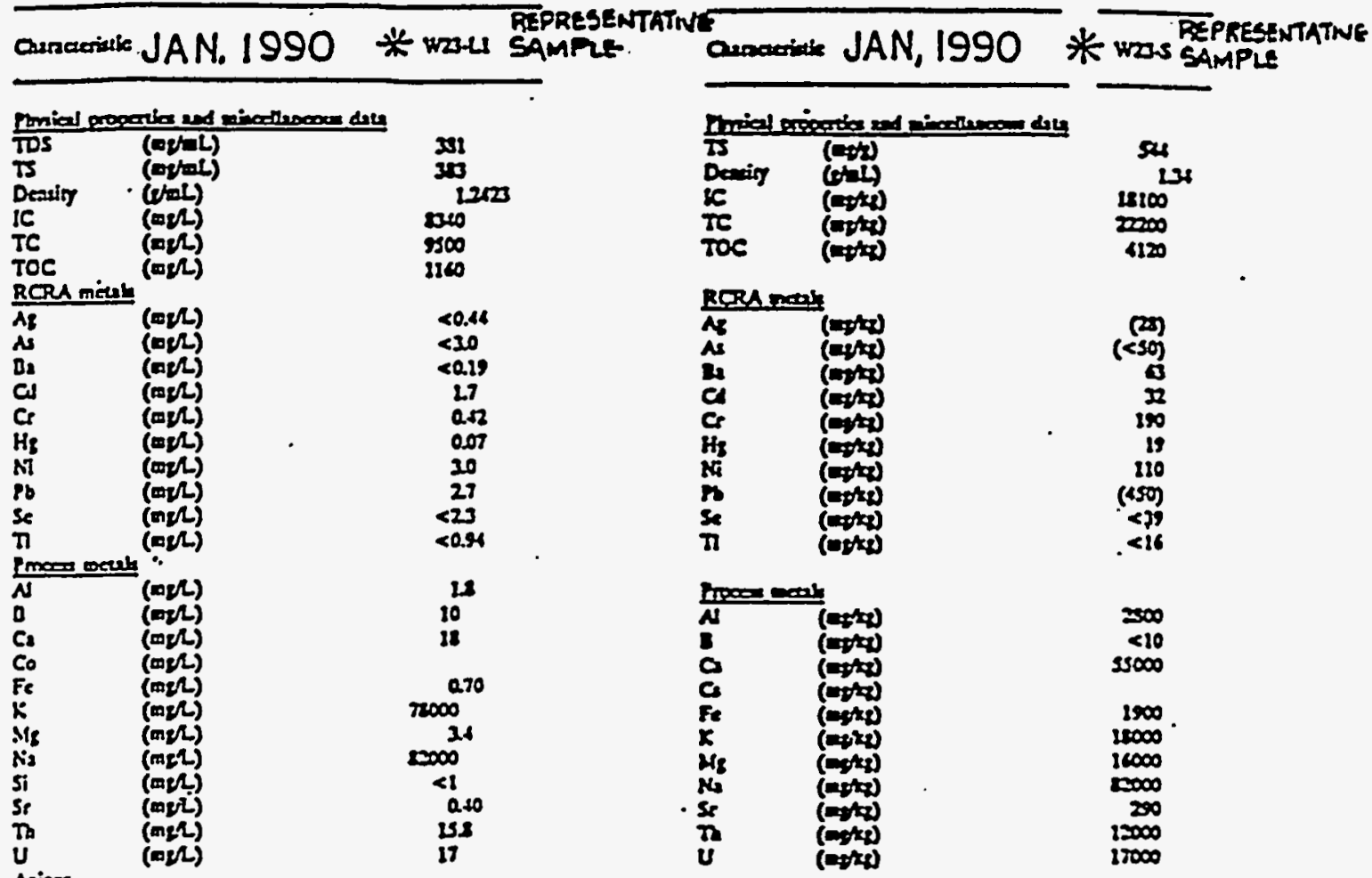

\begin{tabular}{|c|c|c|}
\hline $\begin{array}{l}\text { Caloride } \\
\text { Fuaride } \\
\text { Nitrite } \\
\text { Phouphate } \\
\text { Sullate }\end{array}$ & $\begin{array}{l}M \\
\stackrel{M}{M} \\
\stackrel{M}{M}\end{array}$ & $\begin{array}{c}0.10 \\
<0.053 \\
323 \\
<0.053 \\
0.011\end{array}$ \\
\hline Dinlula & & 128 \\
\hline 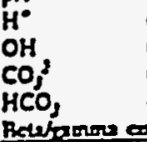 & 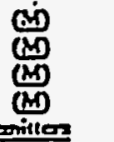 & $\begin{array}{l}0.25 \\
0.70\end{array}$ \\
\hline 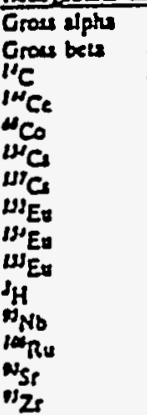 & 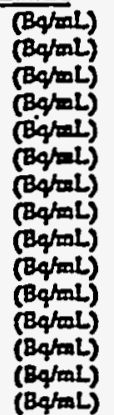 & 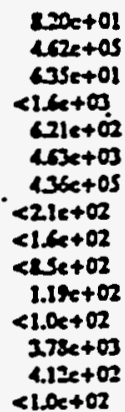 \\
\hline 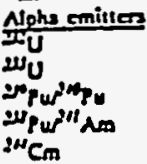 & $\begin{array}{l}\text { (Bq/mL) } \\
(B q / m L) \\
(B q / m L) \\
(B q / m L) \\
(B q / m L)\end{array}$ & $\begin{array}{l}4.00 x+\infty \\
600 x+\infty \\
600<+\infty \\
3.00<+01 \\
100<+\infty\end{array}$ \\
\hline
\end{tabular}

Rearba: incison

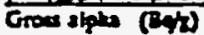

Grow bea (Brit)

"C

we. (19h)

(4)

(B)

(1)

WE: (EN)

$\omega_{E_{2}} \quad(2+4)$

(Ex)

$\lim _{R_{2}}$

oz (1)

$22 x+05$

$607 e+\infty$

$36 \mathrm{Se}_{\mathrm{T}}+\mathrm{OZ}$

$<2.7 e+$ or

$2 \pi x+0 s$

$<\mathrm{CSe}_{\mathrm{s}+03}$

LSe+os

7 7et os

Silcetos

2zlet os

$<x+03$

$<02 e+08$

$2 \pi k+\infty$

Nohe colions

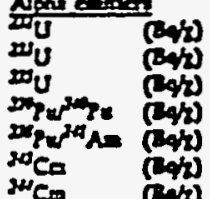

cesetos

Lisktor

$<2 x+04$

Liketor

$<26+04$

i.67e+05

LEGEND:

TSD - TOTAL DISSOLVED SOLIDS

TS - TOTAL SOLIDS

IC - INORGANIC CARBON

TC - TOTAL CARBON

* no data for tank c-2, tank W23 SHOWN AS A REP. SAMPLE

TOC - TOTAL ORGANIC CARBON 
Figure 2.5-4 Radiochemical Analyses In the Evaporator Service Tanks (Tank System C-2)

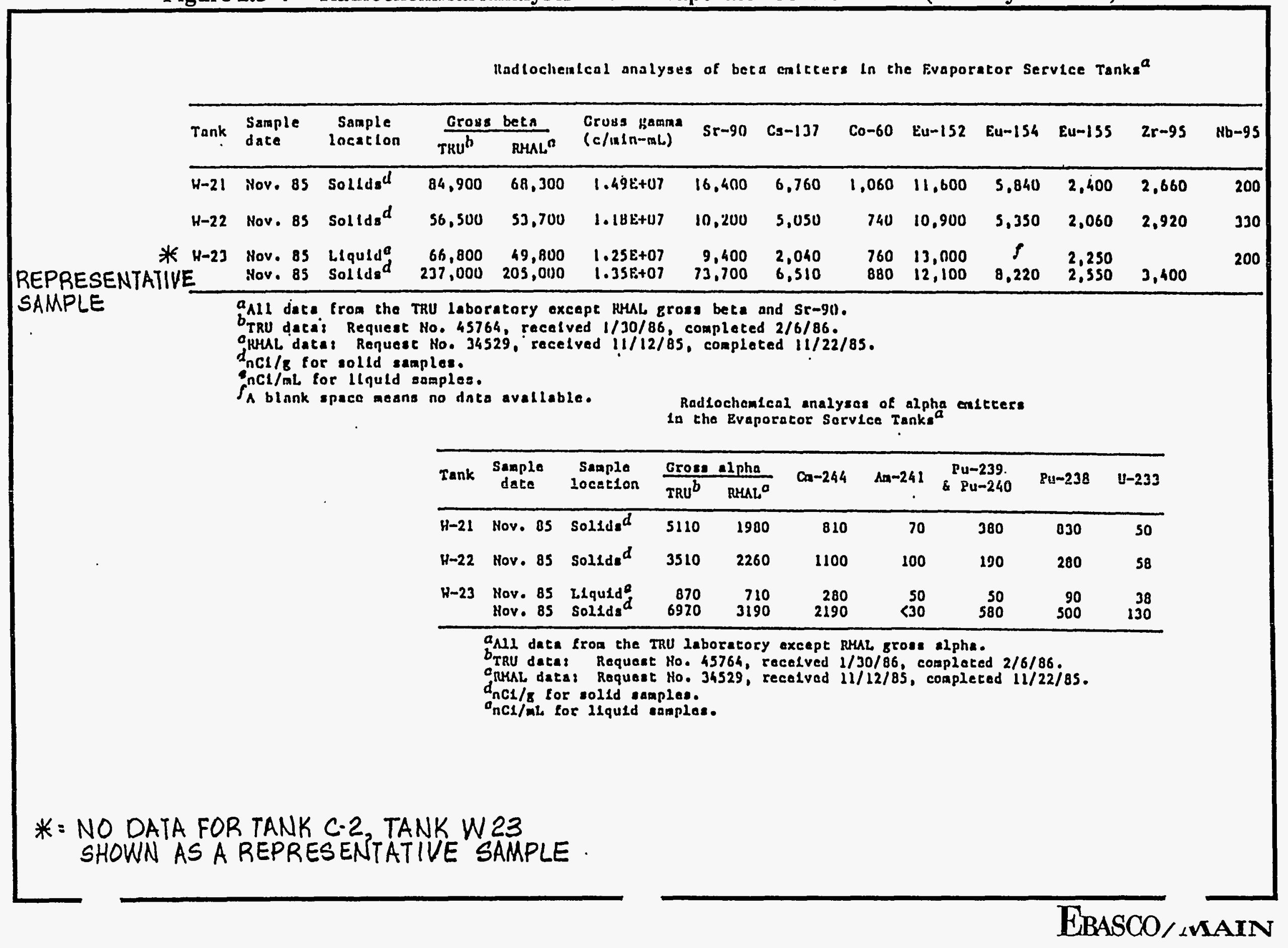




\subsubsection{Tank System Summary}

Tank System F-111 is located in Building 7920 of the Radiochemical Engineering Development Center (REDC) (Figures 2.6-1 and 2.6-2). The tank system piping is schedule 40S, ASME SA-240, type $304 \mathrm{~L}$ stainless steel (SS) and $3 / 8^{\prime \prime}$ zircaloy tubing (wall thickness $0.049^{\prime \prime}$ ). The piping is routed from Tank Vault F-111 through the Cell 7 Tank Pit to Cubicle 7 in Building 7920. Tank System F-111 piping is used to transfer liquid low-level waste (LLLW) from Cubicle 7 to Tank F-111, to Tank F-126 (via cubicle 7) and occasionally through Tank F-115 to Tank F-126 and is classified as a Federal Facility Agreement Category B tank system.

\subsubsection{Standards for Pipe Assessment of Tank Systems}

\subsubsection{Tank System Piping Description and Design Standards}

\section{$\underline{\text { Tank System Piping Description }}$}

Tank System F-111 piping is routed from Tank Vault F-111 through the Cell 7 Tank Pit to Cubicle 7 in Building 7920. The piping system is under the control of the Radiochemical Engineering Development Center (REDC) and is operated by the Chemical Technology Division. Tank System F-111 piping is constructed of $1 / 2^{\prime \prime}, 304 \mathrm{~L}$ SS and $3 / 8^{\prime \prime}$ zircaloy tubing (wall thickness $\left.0.049^{\prime \prime}\right)$. The piping system has a maximum volume of less than 2 gal.

\section{$\underline{\text { Design Standards }}$}

The applicable codes and standards used for Tank System F-111 piping and its associated secondary containment systems are identified herein. The codes and standards listed are those identified on either the design drawings or the construction specifications.

AEC-Oak Ridge Office, Minimum Safety Requirements;

Air Moving and Conditioning Association (AMCA) Standards Handbook-Publication 99;

AMCA Directory—Publication 261;

AMCA Fans and Systems-Publication 201;

American Conference of Governmental Industrial Hygienists;

American Concrete Institute 318-56, 604-56, and 613-54;

American Concrete Pipe Association; 
Design Demonstrations - Category B Tank Systems (Piping)

American Society of Heating, Refrigeration, and Air Conditioning Engineers (ASHRAE) Handbook of Fundamentals;

American Society of Mechanical Engineers (ASME) Boiler and Pressure Vessel Code, Sections II (SA-240), IV, V, VIII, and IX;

American Society for Testing and Materials C39, C144, D1190, D1751, A93, A245, and A307;

ASHRAE Guide and Data Book-Applications;

ASHRAE Guide and Data Book-Equipment;

ASHRAE Handbook-Systems;

Atomic Energy Commission (AEC) General Design Criteria, Appendix 63;

Factory Mutual Engineering Corporation;

Instrumentation Society of America.

National Electric Code;

National Fire Protection Association (NFPA) No. 90A-Air Conditioning and Ventilating Systems;

NFPA No. 91-Blower and Exhaust Systems;

Occupational Safety and Health Administration;

State of Tennessee Department of Transportation Specifications; and

Underwriters Laboratories Inc.;

\subsubsection{Generic Description of Piping Contents}

Tank System F-111 piping is designed to serve as an LLLW process collection system for Building 7920. Its primary source of LLLW is water used in equipment flushing procedures and high $\mathrm{Ph}$ dejacketing waste solutions transferred from Tank $\mathrm{T}-70$. These wastes may include a variety of dilute acids, bases, and organics. The tank may contain radioactive materials from Building 7920 .

The analytical data (Figure 2.6-3) of waste stream contaminants from the generators are representative of the waste transferred through Tank System F-111. 
Design Demonstrations - Category B Tank Systems (Piping)

\subsubsection{Pipe Corrosion Protection Measures}

Tank System F-111 piping is located within Building 7920 and has no direct contact with the soil or water. Cathodic protection measures are not required for external corrosion.

\subsubsection{Documented Age of Tank System}

Tank System F-111 piping was installed in 1966.

\subsubsection{Standards for Containment/Release Detection}

2.6.3.1 Constructed of or Lined with Materials That are Compatible with Stored Waste(s) or Substance(s) to Be Placed in the Tank System and Shall Have Sufficient Strength and Thickness to Prevent Failure

Tank System F-111 piping is single-wall, schedule 40S, type 304L SS and 3/8" zircaloy tubing that is routed from Tank Vault F-111 through the Cell 7 Tank Pit to Cubicle 7 in Building 7920. Each area is discussed below. The piping penetrations from Tank Vault F-111 to the Cell 7 Tank Pit are routed through a $4^{\prime}-5^{\prime \prime}$ long, SS, interpit piping plug assembly. The piping plug has sealed end plates and provides containment for any leaks within the plug. The secondary containment areas on either side of the plug have leak detection and liquid removal systems. Therefore, in the event of a leak, any liquid that would penetrate through the plug would be contained, detected, and removed.

\section{Tank Vault F-111}

The assessment of the secondary containment system for Tank Vault F-111 is presented in the Design Demonstrations for Tank F-111. That assessment concludes that Tank Vault F-111 is provided with a coating and lining system that is compatible with the waste and designed to prevent migration of waste into the concrete.

\section{Cell 7 Tank Pit}

The Cell 7 Tank Pit bottom is lined with $1 / 4$ " Hastelloy " $\mathrm{C}$ " plate, and its sidewalls are lined with $1 / 8$ " Hastelloy " $\mathrm{C}$ " plate. The vault walls above the Hastelloy " $\mathrm{C}$ " liner are provided with a system of Amercoat 74 epoxy. The Hastelloy " $\mathrm{C}$ " cell lining material is compatible with the waste and designed to prevent migration of waste into the concrete. According to manufacturer's specifications, the cell's epoxy coating is compatible with the waste and designed to prevent migration of waste into the concrete.

\section{Cubicle 7}

Cubicle 7 is a complete $304 \mathrm{~L}$ SS enclosure. The SS material is compatible with the waste and designed to prevent migration of waste into the concrete. 
Design Demonstrations - Category B Tank Systems (Piping)

The assessment concludes that the tank vault, tank pit, and cubicle are coated or lined with materials that are compatible with the waste and designed to prevent migration of waste into the concrete.

\subsubsection{Placed on Foundation or Base Capable of Providing Support to the Secondary Containment System}

\section{Tank Vault F-111}

The assessment of the secondary containment system for Tank Vault F-111 is presented in the Design Demonstrations for Tank F-111. That assessment concludes that the vault foundation is properly designed to support the secondary containment system.

\section{Cell 7 Tank Pit}

The Cell 7 Tank Pit foundation is a $9^{\prime} 0^{\prime \prime} \times 7^{\prime} 0^{\prime \prime} \times 2^{\prime} 6^{\prime \prime}$ thick, reinforced concrete base slab resting on bedrock.

\section{Cubicle 7}

The SS enclosure is welded to structural steel members that are embedded in reinforced concrete walls.

The assessment concludes that the tank vault, tank pit, and cubicle foundations are properly designed to support the secondary containment system.

2.6.3.3 Provided with a Leak Detection System That is Designed and Operated to Detect Failure of Either Primary or Secondary Containment Structure or the Presence of Any Measurable Release of Hazardous or Radioactive Constituents

\section{Tank Vault F-111}

The assessment of the secondary containment system for Tank Vault F-111 is presented in the Design Demonstrations for Tank F-111. That assessment concludes that the vault is provided with a leak detection system.

\section{Cell 7 Tank Pit}

The Cell 7 Tank Pit floor is sloped to a Hastelloy "C" lined sump where accumulation of liquid will be detected by a level sensor that will activate an alarm in the operating area of Building 7920.

\section{Cubicle 7}

The Cubicle 7 floor is sloped to an SS-lined sump where accumulation of liquid will be detected by a level sensor that will activate an alarm in the operating area of Building 7920. 
The assessment concludes that the tank vault, tank pit, and cubicle are provided with leak detection systems.

\subsubsection{Sloped or Otherwise Designed or Operated to Drain and Remove Liquids Resulting from Leaks, Spills, or Precipitation}

\section{Tank Vault F-111}

The assessment of the secondary containment system for Tank Vault F-111 is presented in the Design Demonstrations for Tank F-111. That assessment concludes that the secondary containment is sloped and designed to drain and remove liquids resulting from leaks, spills, or precipitation.

\section{Cell 7 Tank Pit}

The Cell 7 Tank Pit floor is sloped to a Hastelloy " $C$ " lined sump. The sump provides a low point within the tank pit to drain liquids to an instrumented location. A pumping system is provided to remove liquids that accumulate in the sump.

\section{Cubicle 7}

Cubicle 7 is sloped to an SS-lined sump. The sump provides a low point within the cubicle to drain liquids to an instrumented location. A pumping system is provided to remove liquids that accumulate in the sump.

The assessment concludes that the secondary containments for the tank vault, tank pit, and cubicle are sloped and designed to drain and remove liquids resulting from leaks, spills, or precipitation.

\subsubsection{Supplemental Information}

\subsubsection{Ancillary Equipment}

Tank F-111 is constructed of $304 \mathrm{~L}$ SS, which is the same material as that used in the piping system, and is located in Tank Vault F-111, which provides secondary containment. The jet ejectors associated with Tank System F-111 are constructed of 304L SS, which is the same material as that used in the tank and piping system, and are located in the tank vault, which provides secondary containment. The support equipment is exposed to the same liquids as other components of the tank system; therefore, 304L SS is an acceptable material for the support equipment.

\subsubsection{2}

\section{Waste Acceptance Criteria}

Radioactively contaminated liquid wastes at the Oak Ridge National Laboratory (ORNL) are generated by various activities within the research and operating divisions. These activities include radiochemical processing, routine hot cell operations and decontaminations, and various waste treatment and environmental protection processes. The variations in composition of the waste streams are limited by the waste acceptance criteria that specify activity and concentration limits for 
waste discharged into the LLLW system. The Waste Acceptance Criteria for Liquid Waste Treatment Systems at the Oak Ridge National Laboratory (Oak Ridge National Laboratory, 1991), dated July 1991, is a guide for liquid waste generators to determine the proper means of disposal for LLLW. The criteria provide future discharge guidelines for the LLLW system, which includes Tank System F-111. 
Design Demonstrations - Category B Tank Systems (Piping)

\subsubsection{References}

Binford, F. T., and S. D. Orfi. 1979. The Intermediate-Level Liquid Waste System at the Oak Ridge National Laboratory Description and Safety Analysis. ORNL/TM-6959. Oak Ridge National Laboratory.

Catalytic Construction Company. Specification for the Construction of Transuranium Processing Plant Building 7920. Invitation No. 401-63-11A. Oak Ridge National Laboratory.

Chemical Technology Division. 1978. Quality Assurance Procedure Manual.

Ebasco, and Main. May 14, 1993. Design Demonstrations-Category B Tank Systems, Revision 2. DOE Contract No. DE-AC05-91OR21928. Oak Ridge National Laboratory.

Energy Systems Drawing 2397-V-246, Concrete, Cell Plan and Elevation, Revision 4.

Energy Systems Drawing 2397-V-247, Concrete, Cell Elevation and Sections, Revision 7.

Energy Systems Drawing 2397-V-248, Concrete, Cell Sections and Details, Revision 4.

Energy Systems Drawing 2397-V-303, Equipment Arrangement, Plan and Section, Revision 2.

Energy Systems Drawing 2397-V-225, Floor Plan, Waste System Pit, Revision 3.

Energy Systems Drawing 2397-V-52, Grading and Paving Plan, Revision 3.

Energy Systems Drawing 2397-V-801, Instrument Flow Diagram, Process Waste System, Revision 1.

Energy Systems Drawing 2397-V-305, Piping, Plan, and Sections, Revision 5.

Energy Systems Drawing 2397-V-306, Piping, Plan, and Sections, Revision 3.

Energy Systems Drawing 2397-V-03, Vessel Off Gas and Cell Cubicle Vents, Revision 5.

Energy Systems Drawing 2397-V-08, Waste Disposal System, Flow Diagram, Sheet 3, Revision 4.

Energy Systems Drawing E52178, Waste Pit Process Piping Plan, Revision 9.

Energy Systems Drawing E52179, Waste Pit Process Piping Sections, Revision 6.

King, et al. 1984. Safety Analysis: Transuranium Processing Plant, Building 7920. ORNL/TM-7688. Oak Ridge National Laboratory.

LLLW Generator Survey 1990 for Building 7920. 
Oak Ridge National Laboratory. 1991. Waste Acceptance Criteria for Liquid Waste Treatment Systems at the Oak Ridge National Laboratory. WM-WMCO-201. Department of Waste Minimization Planning and Certification.

Peretz, F. J., et al. 1986. Characterization of Low-Level Liquid Wastes at the Oak Ridge National Laboratory. ORNL/TM-10218. Oak Ridge National Laboratory.

Robinson, S. M., S. M. DePaoli, and A. B. Walker. 1991. Federal Facility Agreement Contingency, Upgrade, and Replacement Plans for the ORNL Active Low-Level Radioactive Waste Tank System. ORNL/TM-11795. Oak Ridge National Laboratory. 


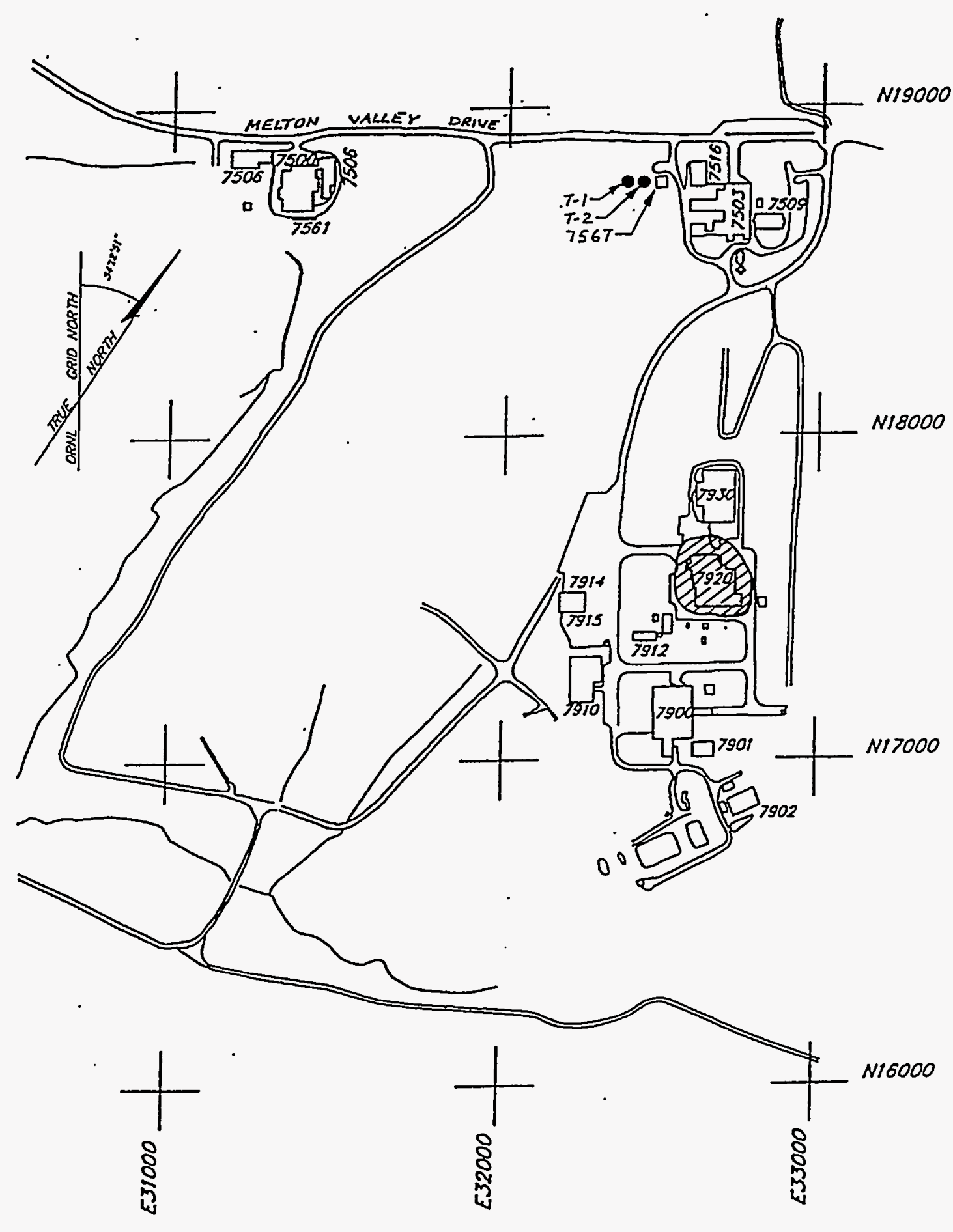


Figure 2.6-2 Tank System F-111 Piping Diagram
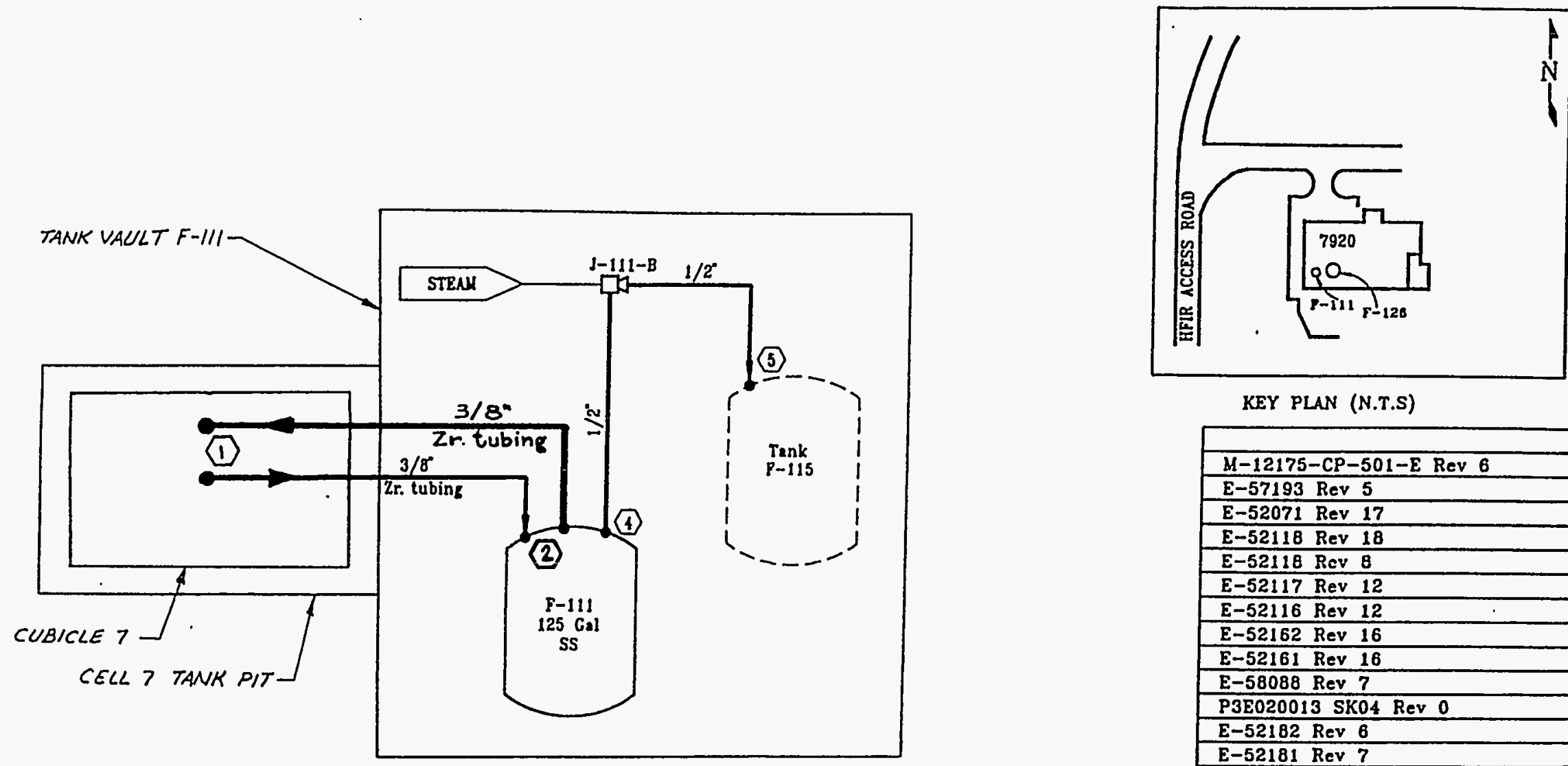

KEY PLAN (N.T.S)

\begin{tabular}{|c|}
\hline$M-12175-C P-501-E$ Rev 6 \\
\hline E-57193 Rev 5 \\
\hline E-52071 Rev 17 \\
\hline E-52118 Rev 18 \\
\hline$E-52118$ Rev 8 \\
\hline E-52117 Rev 12 \\
\hline$E-52116$ Rev 12 \\
\hline E-52162 Rev 16 \\
\hline$E-52161$ Rev 16 \\
\hline$E-58088$ Rev 7 \\
\hline P3E020013 SK04 Rev 0 \\
\hline$E-52182$ Rev 6 \\
\hline E-52181 Rev 7 \\
\hline$E-52179$ Rev 6 \\
\hline E-52178 Rev 9 \\
\hline REFERENCE DRATING \\
\hline
\end{tabular}

\begin{tabular}{|l|c|c|}
\hline LINE SEGMENT & $1-2$ & $1-3$ \\
\hline SIZE IN-DIA & $3 / 8$ & $1 / 2$ \\
\hline SCHEDULE & $.049^{\prime}$ WALL & $40 S$ \\
\hline HATERIAL & $2 \mathrm{r}$ & SS \\
\hline LENGTH (FT) & 45 & 19 \\
\hline VOLUME (GAL) & $<1$ & $<1$ \\
\hline
\end{tabular}


WASTE STREAM CONTAMINANTS:

(a) Isotopes: $\underline{\mathrm{Cm}-244}$

Cf-252

SI-90

Tc-99

Cs -137

Am-241

Am - 243
Quantities:Trace

Trace

Trace

Trace

Trace

Trace

Trace

(b) Others (i.è. acids, bases, organics, cleaners, etc.)

sodium nitrate
nitric acid
sodium hydroxide
potassium iodide
ferrous chloride
ferrous sulfate

Trace

Trace

Trace

Trace

Trace

Trace

thenoyltrifluoroacetone (TIA)

Trace 
Design Demonstrations - Category B Tank Systems (Piping)

\subsubsection{Tank System Summary}

Tank System F-126 is located in Building 7920 of the Radiochemical Engineering Development Center (REDC) (Figures 2.7-1 and 2.7-2). The tank system piping is schedule 40S, ASME SA-240, type 304L stainless steel (SS) and zircaloy tubing (wall thickness $0.049^{\prime \prime}$ ). The piping is routed from Tank Vault F-126 to numerous locations as follows: through the Cell 7 Tank Pit to Cubicle 7, to a pipe tunnel within Building 7920, outside underground through the Melton Valley Collection and Transfer (MVCT) Box No. 1, and further outside underground to the Diversion Box. Tank System F-126 piping is used to transfer liquid low-level waste (LLLW) from Building 7920 to the Diversion Box and is classified as a Federal Facility Agreement Category B tank system.

\subsubsection{Standards for Pipe Assessment of Tank Systems}

\subsubsection{Tank System Piping Description and Design Standards}

\section{Tank System Piping Description}

Tank System F-126 piping is located in Building 7920 and is routed from Tank Vault F-126 to numerous locations as follows: through the Cell 7 Tank Pit to Cubicle 7, to a pipe tunnel within Building 7920, outside underground through the MVCT Box No. 1, and further outside underground to the Diversion Box. The piping system is under the control of the Radiochemical Engineering Development Center (REDC) and operated by the Chemical Technology Diversion.

Tank System F-126 piping is constructed of $1 / 4^{\prime \prime}, 1 / 2^{\prime \prime}, 1^{\prime \prime}$, and 2"; schedule 40S; type 304L SS piping and $3 / 8^{\prime \prime}, 1 / 2^{\prime \prime}$, and $3 / 4^{\prime \prime}$ zircaloy tubing (wall thickness $0.049^{\prime \prime}$ ). Tank System F-126 piping has a maximum volume of $281 \mathrm{gal}$.

\section{$\underline{\text { Design Standards }}$}

The applicable codes and standards used for Tank System F-126 piping and its associated secondary containment systems are identified herein. The codes and standards listed are those identified on either the design drawings or the construction specifications.

AEC-Oak Ridge Office, Minimum Safety Requirements;

Air Moving and Conditioning Association (AMCA) Standards Handbook-Publication 99;

AMCA Fans and Systems-Publication 201;

AMCA Directory-Publication 261;

American Society for Testing and Materials C39, C144, D1190, D1751, A93, A245, and A307; 
American Conference of Governmental Industrial Hygienists;

American Concrete Pipe Association;

American Concrete Institute 318-56, 604-56, and 613-54;

American Society of Heating, Refrigeration, and Air Conditioning Engineers (ASHRAE) Handbook of Fundamentals;

American Society of Mechanical Engineers (ASME) Boiler and Pressure Vessel Code, Sections II (SA-240), IV, V, VIII, and IX;

ASHRAE Guide and Data Book-Equipment;

ASHRAE Handbook-Systems;

ASHRAE Guide and Data Book-Applications;

Atomic Energy Commission (AEC) General Design Criteria, Appendix 63;

Factory Mutual Engineering Corporation;

Instrument Society of America;

National Electric Code;

National Fire Protection Association (NFPA) No. 90A-Air Conditioning and Ventilating Systems;

NFPA No. 91-Blower and Exhaust Systems;

Occupational Safety and Health Administration; and

Underwriters Laboratories Inc.

\subsubsection{Generic Description of Piping Contents}

Tank System F-126 is designed to serve as an LLLW process collection system for Building 7920. The primary source of LLLW is spent caustic from the scrubber, an aqueous acidic waste stream from the batch liquid-liquid extraction process in Tank F-115, and neutralized organic wastes. These wastes may include a variety of dilute acids, bases, and organics. The tank may contain radioactive materials from Building 7920.

The analytical data (Figure 2.7-3) of waste stream contaminants from the generators are representative of the waste transferred through Tank System F-126. 


\subsubsection{Pipe Corrosion Protection Measures}

Piping inside Building 7920, MVCT Box No. 1, and the Diversion Box has no direct contact with the soil or water. Cathodic protection measures are not required for external corrosion.

Piping outside underground from Building 7920 to MVCT Box No. 1 and from MVCT Box No. 1 to the Diversion Box is singly contained piping and is provided with cathodic protection, which is included in the Facility Manager's Cathodic Protection System No. 5. The system consists of magnesium anodes, test stations, and connecting wire as shown on cathodic protection drawings $C$ 20013-EA-001D, C-20013-EA-002D, and C-20013-EA-003D. The system was installed in May 1972.

The system is not considered adequate because electrical isolating devices were not called out for the pipe termination points. Harco Technologies determined that insulating gaskets were not present during its 1990 surveys. In addition, the cathodic protection field testing performed in 1991 indicates that $49 \%$ of the pipe was not receiving adequate corrosion control. The lack of electrical isolation of the outside underground pipe from the interior piping and depleted anode beds are contributing factors in the resultant lack of corrosion control. In 1991, Harco completed the engineering design to upgrade the existing system to protect the piping.

\subsubsection{Documented Age of Tank System}

Tank System F-126 piping was originally installed in 1966. The section of piping between Building 7920 and the Diversion Box was installed in 1972.

\subsubsection{Standards for Containment/Release Detection}

Tank System F-126 piping incorporates approximately $1500^{\prime}$ of outside underground piping that is singly contained. The singly contained areas are omitted from discussion in the following sections that address secondary containment.

2.7.3.1 Constructed of or Lined with Materials That are Compatible with Stored Waste(s) or Substance(s) to Be Placed in the Tank System and Shall Have Sufficient Strength and Thickness to Prevent Failure

Tank System F-126 piping is single-wall, schedule 40S, type 304L SS and zircaloy tubing that is routed from Tank Vault F-126 to numerous locations as follows: through the Cell 7 Tank Pit to Cubicle 7, to a pipe tunnel within Building 7920, outside underground through MVCT Box No. 1, and further outside underground to the Diversion Box. Each area is discussed below. The piping penetrations from Tank Vault F-126 to the Cell 7 Tank Pit and Pipe Tunnel are routed through a $4^{\prime} 5^{\prime \prime}$ long, SS, interpit piping plug assembly. The piping plug has sealed end plates and provides containment for any leaks within the plug. The secondary containment areas on either side of the plug have leak detection and liquid removal systems. Therefore, in the event of a leak, any liquid that would penetrate through the plug would be contained, detected, and removed. 


\section{Tank Vault F-126}

The assessment of the secondary containment system for Tank Vault F-126 is presented in the Design Demonstrations for Tank F-126. That assessment concludes that Tank Vault F-126 is provided with a coating and lining system that is compatible with the waste and designed to prevent migration of waste into the concrete.

\section{Cell 7 Tank Pit}

The Cell 7 Tank Pit bottom is lined with $1 / 4$ ", Hastelloy " $\mathrm{C}$ " plate; and its sidewalls are lined with 1/8", Hastelloy " $\mathrm{C}$ " plate. The vault walls above the Hastelloy " $\mathrm{C}$ " liner are provided with a system of Amercoat 74 epoxy. The Hastelloy " $\mathrm{C}$ " cell lining material is compatible with the waste and designed to prevent migration of waste into the concrete. According to manufacturer's specifications, the cell's epoxy coating is compatible with the waste and designed to prevent migration of waste into the concrete.

\section{Cubicle 7}

Cubicle 7 is a complete $304 \mathrm{~L}$ SS enclosure. The material of construction is compatible with the waste and designed to prevent migration of waste into the concrete.

\section{Pipe Tunnel}

The surfaces of the pipe tunnel are provided with a system of Amercoat 74 epoxy in combination with a Thalco 1522 woven glass coating. According to manufacturer's specifications, the pipe tunnel's epoxy coating is compatible with the waste and designed to prevent migration of waste into the concrete.

\section{Melton Valley Collection and Transfer Box No. 1}

The bottom of MVCT Box No. 1 is lined with 16-gauge (1/16"), 304L SS, with sidewalls that project $4^{\prime} 3^{\prime \prime}$ up the valve box. The SS lining material is compatible with the waste and designed to prevent migration of waste into the concrete.

\section{Diversion Box}

The Diversion Box is provided with an 11-gauge (1/8"), 304L SS liner that projects $3^{\prime} 11^{\prime \prime}$ up the box walls. The SS lining material is compatible with the waste and designed to prevent migration of waste into the concrete.

The assessment concludes that the tank vault, tank pit, cubicle, pipe tunnel, collection and transfer box, and Diversion Box are coated or lined with materials that are compatible with the waste and designed to prevent migration of waste into the concrete. 


\subsubsection{Placed on Foundation or Base Capable of Providing Support to the Secondary Containment System}

\section{Tank Vault F-126}

The assessment of the secondary containment system for Tank Vault F-126 is presented in the Design Demonstrations for Tank F-126. That assessment concludes that the vault foundation is properly designed to support the secondary containment system.

\section{Cell 7 Tank Pit}

The Cell 7 Tank Pit foundation is a $7^{\prime} 0^{\prime \prime} \times 9^{\prime} 0^{\prime \prime} \times 2^{\prime} 6^{\prime \prime}$ thick, reinforced concrete base slab resting on bedrock.

\section{Cubicle 7}

The SS enclosure is welded to structural steel members that are embedded in reinforced concrete walls.

\section{Pipe Tunnel}

The Pipe Tunnel foundation is an $87^{\prime} 0^{\prime \prime} \times 12^{\prime} 2^{\prime \prime} \times 2^{\prime} 0^{\prime \prime}$ thick, reinforced concrete base slab resting on bedrock.

\section{Melton Valley Collection and Transfer Box No. 1}

The MVCT Box No. 1 foundation is a $4^{\prime} 0^{\prime \prime} \times 4^{\prime} 0^{\prime \prime} \times 1^{\prime} 0^{\prime \prime}$ thick, reinforced concrete base slab that rests on bedrock.

\section{Diversion Box}

The Diversion Box foundation is a $6^{\prime} 4^{\prime \prime} \times 6^{\prime} 10^{\prime \prime} \times 1^{\prime} 2^{\prime \prime}$ thick, reinforced concrete slab.

The assessment concludes that the tank vault, tank pit, cubicle, pipe tunnel, collection and transfer box, and Diversion Box foundations are properly designed to support the secondary containment system. 
2.7.3.3 Provided with a Leak Detection System That is Designed and Operated to Detect Failure of Either Primary or Secondary Containment Structure or the Presence of Any Measurable Release of Hazardous or Radioactive Constituents

\section{Tank Vault F-126}

The assessment of the secondary containment system for Tank Vault F-126 is presented in the Design Demonstrations for Tank F-126. That assessment concludes that the vault is provided with a leak detection system.

\section{Cell 7 Tank Pit}

The Cell 7 Tank Pit floor is sloped to a Hastelloy "C" lined sump where accumulation of liquid will be detected by a level sensor that will activate an alarm in the operating area of Building 7920 .

\section{Cubicle 7}

The Cubicle 7 floor is sloped to an SS-lined sump where accumulation of liquid will be detected by a level sensor that will activate an alarm in the operating area of Building 7920.

\section{Pipe Tunnel}

The Pipe Tunnel floor is sloped to an SS-lined sump where accumulation of liquid will be detected by a level sensor that will activate an alarm in the operating area of Building 7920 .

\section{Melton Valley Collection and Transfer Box No. 1}

MVCT Box No. 1 is sloped to an SS-lined sump where accumulation of liquid is collected. The sump is not provided with a leak detection system.

\section{Diversion Box}

The LLLW transferred to the Diversion Box is contained in the SS-lined portion of the box and flows by gravity to Tanks T-1 and T-2. A leak detection system is not required.

The assessment concludes that the tank vault, tank pit, cubicle, and pipe tunnel are provided with a leak detection system. A leak detection system is not required for the Diversion Box. The collection and transfer box, however, is not provided with a leak detection system. 


\title{
2.7.3.4
}

\author{
Sloped or Otherwise Designed or Operated to Drain and Remove Liquids \\ Resulting from Leaks, Spills, or Precipitation
}

\section{$\underline{\text { Tank Vault F-126 }}$}

The assessment of the secondary containment system for Tank Vault F-126 is presented in the Design Demonstrations for Tank F-126. That assessment concludes that the secondary containment is sloped and designed to drain and remove liquids resulting from leaks, spills, or precipitation.

\section{Cell 7 Tank Pit}

The Cell 7 Tank Pit floor is sloped to a Hastelloy " $C$ " lined sump. The sump provides a low point within the tank pit to drain liquids to an instrumented location. A pumping system is provided to remove liquids that accumulate in the sump.

\section{Cubicle 7}

Cubicle 7 is sloped to an SS-lined sump. The sump provides a low point within the cubicle to drain liquids to an instrumented location. A pumping system is provided to remove liquids that accumulate in the sump.

\section{Pipe Tunnel}

The Pipe Tunnel is sloped to an SS-lined sump. The sump provides a low point within the pipe tunnel to drain liquids to an instrumented location. A pumping system is provided to remove liquids that accumulate in the sump.

\section{Melton Valley Collection and Transfer Box No. 1}

MVCT Box No. 1 is sloped to an SS-lined sump. The sump provides a low point within the collection and transfer box to drain liquids. A pumping system is not provided to remove liquids that accumulate in the sump.

\section{Diversion Box}

The Diversion Box is SS-lined and sloped to an SS drain. The drain provides a low point within the box to divert liquids that will flow to Tanks T-1 and T-2.

The assessment concludes that the tank vault, tank pit, cubicle, pipe tunnel, and Diversion Box are sloped and designed to drain and remove liquids resulting from leaks, spills, or precipitation. MVCT Box No. 1 is sloped and designed to drain liquids resulting from leaks, spills, or precipitation; however, a pumping system is not provided to remove liquids. 


\subsubsection{Supplemental Information}

\subsubsection{Ancillary Equipment}

Tank F-126 is constructed of 304L SS, which is the same material as that used in the piping system, and is located in Tank Vault F-126, which provides secondary containment. The pump associated with Tank System F-126 is constructed of 304L SS, which is the same material as that used for the tank. The support equipment is exposed to the same liquids as other components of the tank system; therefore, 304L SS is an acceptable material for the support equipment.

\subsubsection{Waste Acceptance Criteria}

Radioactively contaminated liquid wastes at the Oak Ridge National Laboratory (ORNL) are generated by various activities within the research and operating divisions. These activities include radiochemical processing, routine hot cell operations and decontaminations, and various waste treatment and environmental protection processes. The variations in composition of the waste streams are limited by the waste acceptance criteria that specify activity and concentration limits for waste discharged into the LLLW system. The Waste Acceptance Criteria for Liquid Waste Treatment Systems at the Oak Ridge National Laboratory (Oak Ridge National Laboratory, 1991), dated July 1991, is a guide for liquid waste generators to determine the proper means of disposal for LLLW. The criteria provide future discharge guidelines for the LLLW system, which includes Tank System F-126. 
Design Demonstrations - Category B Tank Systems (Piping)

\subsubsection{References}

Binford, F. T., and S. D. Orfi. 1979. The Intermediate-Level Liquid Waste System at the Oak Ridge National Laboratory Description and Safety Analysis. ORNL/TM-6959. Oak Ridge National Laboratory.

Catalytic Construction Company. Specification for the Construction of Transuranium Processing Plant Building 7920. Invitation No. 401-63-11A. Oak Ridge National Laboratory.

Chemical Technology Division. 1978. Quality Assurance Procedure Manual.

Ebasco, and Main. May 14, 1993. Design Demonstrations-Category B Tank Systems, Revision 2. DOE Contract No. DE-AC05-91OR21928. Oak Ridge National Laboratory.

Energy Systems Drawing 2397-V-246, Concrete, Cell Plan and Elevation, Revision 4.

Energy Systems Drawing 2397-V-247, Concrete, Cell Elevation and Sections, Revision 7.

Energy Systems Drawing 2397-V-248, Concrete, Cell Sections and Details, Revision 4.

Energy Systems Drawing 2397-V-303, Equipment Arrangement, Plan and Section, Revision 2.

Energy Systems Drawing 2397-V-225, Floor Plan, Waste System Pit, Revision 3.

Energy Systems Drawing 2397-V-52, Grading and Paving Plan, Revision 3.

Energy Systems Drawing 2397-V-801, Instrument Flow Diagram, Process Waste System, Revision 1.

Energy Systems Drawing 2397-V-305, Piping, Plan, and Sections, Revision 5.

Energy Systems Drawing 2397-V-306, Piping, Plan, and Sections, Revision 3.

Energy Systems Drawing 2397-V-03, Vessel Off Gas and Cell Cubicle Vents, Revision 5.

Energy Systems Drawing 2397-V-08, Waste Disposal System, Flow Diagram, Sheet 3, Revision 4.

Energy Systems Drawing E52178, Waste Pit Process Piping Plan, Revision 9.

Energy Systems Drawing E52179, Waste Pit Process Piping Sections, Revision 6.

Energy Systems Drawing C-20013-EA-001-D, Plan and Profile, Sheet 1, As-Built, Dated 9/5/73 (No Revision No.).

Energy Systems Drawing C-20013-EA-002-D, Plan and Profile, Sheet 2, As-Built, Dated 9/5/73 (No Revision No.). 
Energy Systems Drawing C-20013-EA-003-D, Plan and Profile, Sheet 3, As-Built, Dated 9/5/73 (No Revision No.).

Harco Technologies Corporation. June 1990. Resurvey of the Cathodic Protection Systems, Oak Ridge National Laboratories, United States Department of Energy, Oak Ridge, Tennessee. Martin Marietta Energy Systems, Inc.

Harco Technologies Corporation. September 1991. Cathodic Protection System Upgrade Design Underground ILW Line, ILW Line 7920/7930 to 7567, System No. 5. Oak Ridge National Laboratories, United States Department of Energy, Oak Ridge, Tennessee. Martin Marietta Energy Systems, Inc.

King, et al. 1984. Safety Analysis: Transuranium Processing Plant, Building 7920. ORNL/TM-7688. Oak Ridge National Laboratory.

LLLW Generator Survey 1990 for Building 7920.

Oak Ridge National Laboratory. 1991. Waste Acceptance Criteria for Liquid Waste Treatment Systems at the Oak Ridge National Laboratory. WM-WMCO-201. Department of Waste Minimization Planning and Certification.

Peretz, F. J., et al. 1986. Characterization of Low-Level Liquid Wastes at the Oak Ridge National Laboratory. ORNL/TM-10218. Oak Ridge National Laboratory.

Robinson, S. M., S. M. DePaoli, and A. B. Walker. 1991. Federal Facility Agreement Contingency, Upgrade, and Replacement Plans for the ORNL Active Low-Level Radioactive Waste Tank System. ORNL/TM-11795. Oak Ridge National Laboratory. 


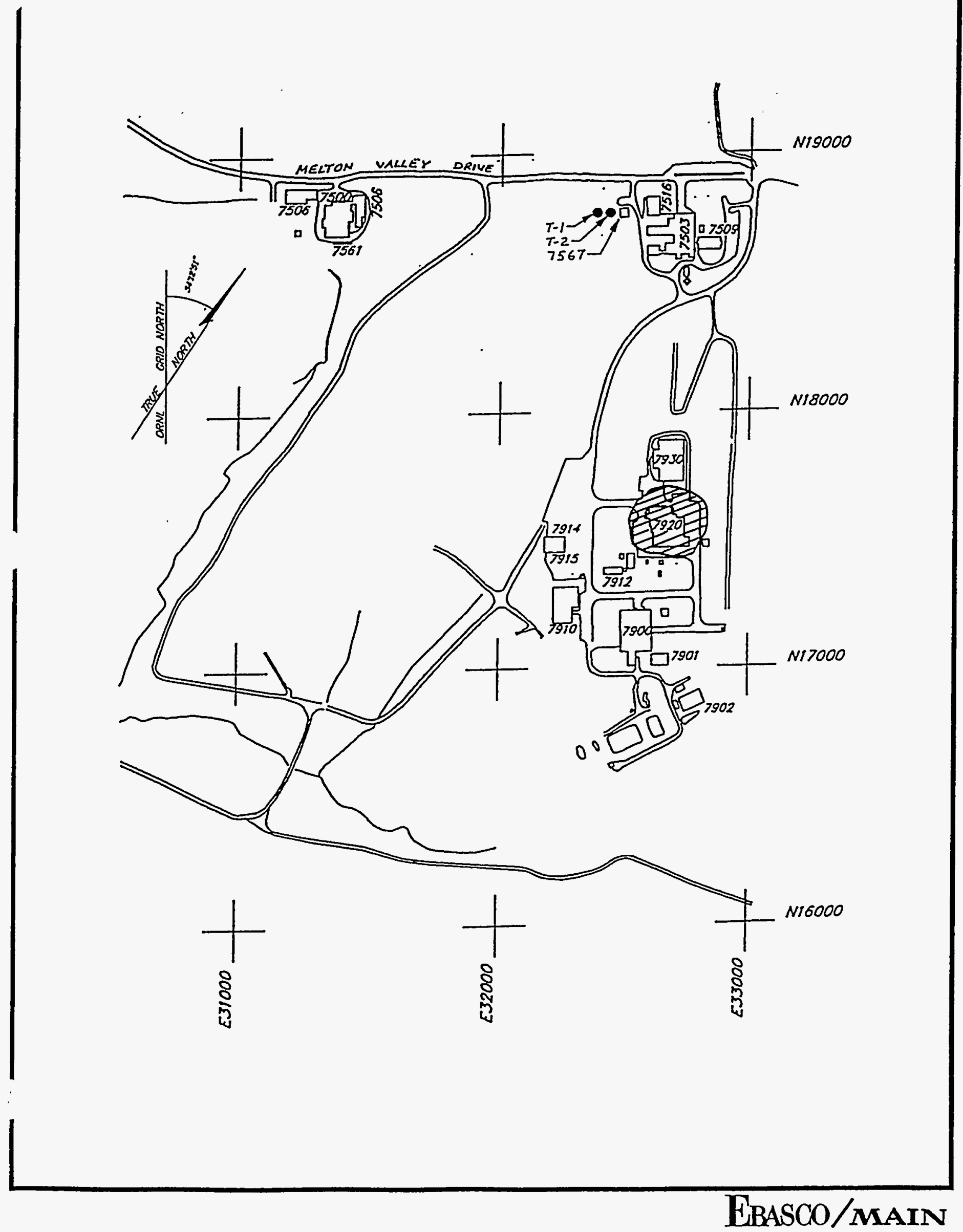


Figure 2.7-2 Tank System F-126 Piping Diagram

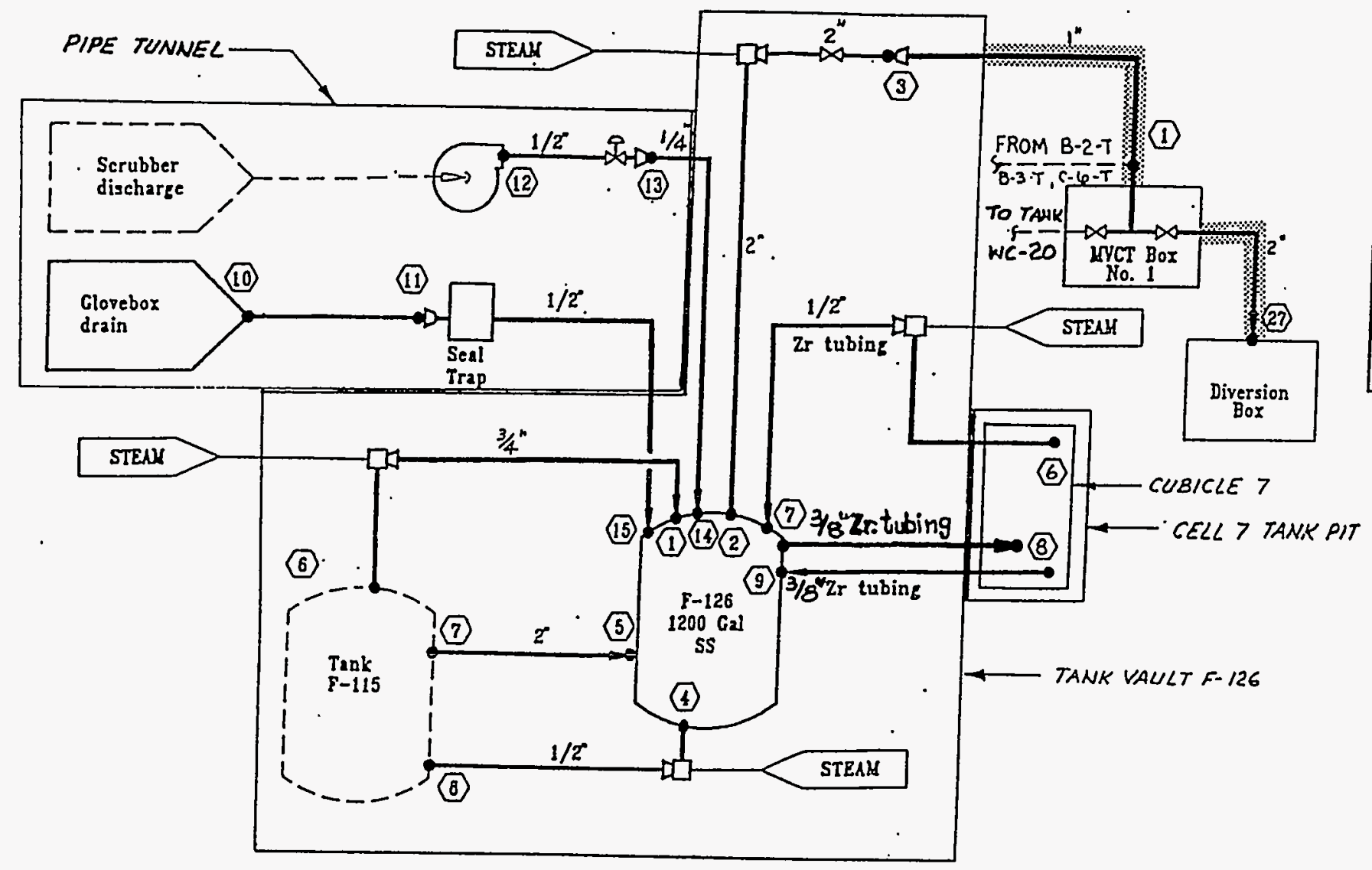

- TANX SYSTEM F-126 PIPING

UNDERGROUND PIPE (SINGLE WALL)

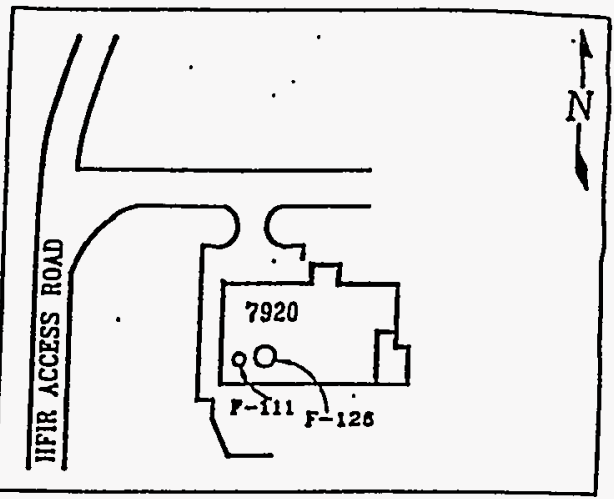

KE'Y PLAN (N.T.S)

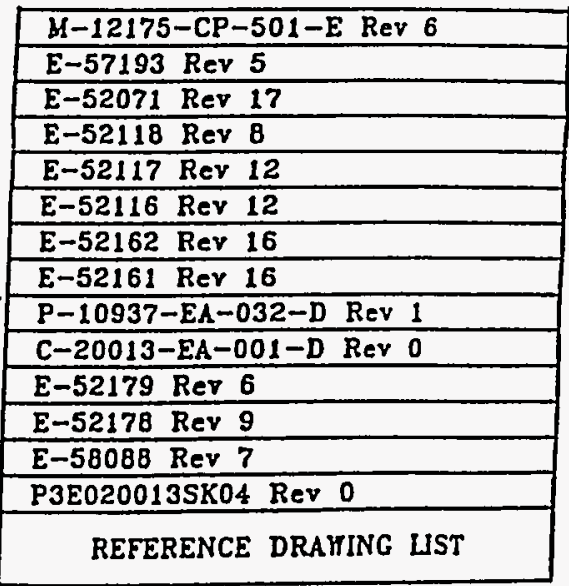

- - COMPONENTS NOT COVERED IN THIS SECTION

\begin{tabular}{|c|c|c|c|c|c|c|c|c|c|c|c|c|}
\hline LINE SEGMENT & (3) $-(7)$ & (8) -0 & (10) - (11) & (113) - (13) & (7) - (3) & (4) - (8) & (6) - (1) & (12) - (19) & (19) $-(14)$ & (2) - (3) & (5)-1) & (1) - (27) \\
\hline SIZE IN-DIA & $1 / 2$ & $3 / 8$ & 2 & $1 / 2$ & 2 & $1 / 2$ & $3 / 4$ & $1 / 2$ & $1 / 4$ & 1 & 2 & 2 \\
\hline MATERIAL & $\mathrm{Z}_{\mathrm{r}}$ & $\mathrm{zr}$ & SS & SS & SS & SS & $\mathrm{Zr}$ & SS & SS & SS & SS & SS \\
\hline LENGTH (FT) & 40 & 40 & 11 & 20 & 2 & 9 & 8 & 35 & 30 & 196 & 230 & 1273 \\
\hline
\end{tabular}


WASTE STREAM CONTAMINANTS:

(a) Isotopes: $\mathrm{Cm}-244,245,246,247$

Cf $-250,251,252$

$\operatorname{Sr}-90$

\begin{tabular}{c}
$\mathrm{Sr}-90$ \\
\hline $\mathrm{Tc}-99$ \\
\hline $\mathrm{Cs}-137$ \\
\hline
\end{tabular}

$\mathrm{Am}-241,242,243$ (b) Quantities

Trace

Trace

Trace

Trace

Trace

Trace

(b) Others (i.e. acids, bases, organics, cleaners, etc.)

\begin{tabular}{c} 
sodium nitrate \\
\hline nitric acid. \\
\hline sodium hydroxide \\
\hline potassium iodide \\
\hline ferrous chloride \\
\hline ferrous sulfate \\
\hline
\end{tabular}

Trace

Trace

Trace

Trace

Trace

Trace

thenoyltrifluoroacetone (TTA)

Trace 
Based on the findings of the Design Demonstrations for the Remaining 19 Category B Tank Systems, (DOE/OR/03-1150 \& D2), Tank System F-201, originally designated as Category B, has been redesignated as Category $\mathrm{C}$ by FFA Modification Request Change Control Number FFA-PM/93-008, June 23, 1994. However, this section of the original Design Demonstrations has been retained for reference.

\subsubsection{Tank System Summary}

Tank System F-201 is located near the High Radiation Level Examination Laboratory (Building 3525) at the main Bethel Valley Complex (Figures 2.8-1 and 2.8-2). The tank system piping is constructed of schedule 40S, ASME SA-240, type 304L stainless steel (SS); is routed from Tank Vault F-201 outside underground to beneath Building 3525; and terminates in areas within Building 3525. Tank System F-201 piping is used to transfer liquid low-level waste (LLLW) from the Radioactive Hot Drain (RHD) System to Tank F-201 and is classified as a Federal Facility Agreement Category B tank system.

\subsubsection{Standards for Pipe Assessment of Tank Systems}

2.8.2.1 Tank System Piping Description and Design Standards

\section{$\underline{\text { Tank System Piping Description }}$}

Tank System F-201 piping is located near Building 3525 and is routed from Tank Vault F-201 to areas within Building 3525. The piping system is used and managed by the Metals and Cereamics Division.

Tank System F-201 piping consists of 1-1/2", schedule 40S, type 304L SS and 6," 8," and 10"; schedule 10S; type 304L SS with a maximum design pressure and temperature of $150 \mathrm{psig}$ and $400^{\circ} \mathrm{F}$ for the schedule $40 \mathrm{~S}$ piping and $15 \mathrm{psig}$ and $150^{\circ} \mathrm{F}$ for the schedule $10 \mathrm{~S}$ piping. Tank System F-201 piping has a maximum volume of $192 \mathrm{gal}$.

\section{Design Standards}

The applicable codes and standards used for Tank System F-201 piping and its associated secondary containment systems are identified herein. The codes and standards listed are those identified on either the design drawings or the construction specifications.

American Concrete Institute 318, 315, and 604;

American Society for Testing and Materials A15, A185, C31, C33, C39, C76, C94, C192, D155, A401, A53, A74, A106, A107, A120, A181, A182, A193, A217, A234, A298, A312, A338, B75, $\mathrm{A} 240$, and $\mathrm{A} 403$; 
American Society of Mechanical Engineers (ASME) Boiler and Pressure Vessel Code, Sections II (SA-240) and VIII; and Federal Specifications HHF191, HHF341, QQS632, SSA281, SSC164, SSC192, and UUP264.

\subsubsection{Generic Description of Piping Contents}

Tank System F-201 piping is designed to transfer LLLW from drainage fixtures within Building 3525 to Tank F-201. LLLW is produced during the decontamination and cleanup of the hot cells used in the disassembly and examination process. The tank system may contain radioactive materials from Building 3525 .

The analytical data (Figure 2.8-3) of the waste stream contaminants from the generators are representative of the waste transferred through Tank System F-201 piping.

\subsubsection{Pipe Corrosion Protection Measures}

Piping inside Tank Vault F-201 and Building 3525 is not in direct contact with the soil or water. Cathodic protection measures are not required for external corrosion.

The piping that is routed outside underground is singly contained, and the external surfaces are exposed to the soil and water. Protective coatings or cathodic protection measures are not present in the outside underground piping.

\subsubsection{Documented Age of Tank System}

Tank System F-201 piping was installed in 1962.

\subsubsection{Standards for Containment/Release Detection}

Tank System F-201 piping incorporates approximately $355^{\prime}$ of outside underground and embedded piping that is singly contained. The singly contained areas are omitted from discussion in the following sections that address secondary containment.

\subsubsection{Constructed of or Lined with Materials That are Compatible with Stored Waste(s) or Substance(s) to Be Placed in the Tank System and Shall Have Sufficient Strength and Thickness to Prevent Failure}

Tank System F-201 piping is single-wall, schedule 10S and schedule 40S, type 304L SS pipe. The piping is routed from Tank Vault F-201 outside underground to the flush-mounted floor drain and storage wells located in Charging Area No. 130 and to the Cell Exhaust Fan Room. There is no piping routed within Charging Area No. 130. Areas of secondary containment are discussed below. 


\section{Tank Vault F-201}

The assessment of the secondary containment system for Tank Vault F-201 is presented in the Design Demonstrations for Tank F-201. That assessment concludes that Tank Vault F-201 is not coated or lined with materials that are compatible with the waste and designed to prevent migration of waste into the concrete.

\section{Cell Exhaust Fan Room}

The Cell Exhaust Fan Room is not coated or lined with materials that are compatible with the waste and designed to prevent migration of waste into the concrete.

The assessment concludes that the tank vault and the Cell Exhaust Fan Room are not coated or lined with materials that are compatible with the waste and designed to prevent migration of waste into the concrete.

2.8.3.2 Placed on Foundation or Base Capable of Providing Support to the Secondary Containment System

Tank Vault F-201

The assessment of the secondary containment system for Tank Vault F-201 is presented in the Design Demonstrations for Tank F-201. That assessment concludes that the vault foundation is properly designed to support the secondary containment system.

\section{Cell Exhaust Fan Room}

The Cell Exhaust Fan Room foundation is a $9^{\prime \prime}$ thick, reinforced concrete base slab designed to rest on a $2^{\prime \prime}$ thick, concrete base that rests on crushed limestone.

The assessment concludes that the tank vault and Cell Exhaust Fan Room foundations are properly designed to support the secondary containment system.

2.8.3.3 Provided with a Leak Detection System That is Designed and Operated to Detect Failure of Either Primary or Secondary Containment Structure or the Presence of Any Measurable Release of Hazardous or Radioactive Constituents

\section{Tank Vault F-201}

The assessment of the secondary containment system for Tank Vault F-201 is presented in the Design Demonstrations for Tank F-201. That assessment concludes that the vault is not provided with a leak detection system. 
Design Demonstrations - Category B Tank Systems (Plping)

\section{Cell Exhaust Fan Room}

The Cell Exhaust Fan Room is not provided with a leak detection system.

The assessment concludes that the tank vault and Cell Exhaust Fan Room are not provided with a system that will detect leaks.

\subsubsection{Sloped or Otherwise Designed or Operated to Drain and Remove Liquids} Resulting from Leaks, Spills, or Precipitation

\section{Tank Vault F-201}

The assessment of the secondary containment system for Tank Vault F-201 is presented in the Design Demonstrations for Tank F-201. That assessment concludes that the secondary containment is sloped and designed to drain and remove liquids resulting from leaks, spills, or precipitation.

\section{Cell Exhaust Fan Room}

The floor in the Cell Exhaust Fan Room is sloped towards 2" diameter floor drains. The liquids are collected by the floor drains and transferred to a $2^{\prime} 6^{\prime \prime}$ diameter by $4^{\prime} 6^{\prime \prime}$ deep, steel sump embedded in the floor of the basement. The sump was formerly equipped with a sump pump that transferred the liquids into the Process Drain Hot system. The sump pump has since been removed and replaced with a temporary system that currently transfers accumulation into Tank F-201.

The assessment concludes that the secondary containments for the tank vault and Cell Exhaust Fan Room are sloped and designed to drain and remove liquids resulting from leaks, spills, or precipitation.

\subsubsection{Supplemental Information}

\subsubsection{Ancillary Equipment}

Tank F-201 is constructed of 304L SS, which is the same material as that used in the piping system, and is located in Tank Vault F-201, which provides secondary containment. The support equipment is exposed to the same liquids as other components of the tank system; therefore, 304L SS is an acceptable material for the support equipment.

\subsubsection{Waste Acceptance Criteria}

Radioactively contaminated liquid wastes at the Oak Ridge National Laboratory (ORNL) are generated by various activities within the research and operating divisions. These activities include radiochemical processing, routine hot cell operations and decontamination, and various waste treatment and environmental protection processes. The variations in composition of the waste streams are limited by the waste acceptance criteria that specify activity and concentration limits for waste discharged into the LLLW system. The Waste Acceptance Criteria for Liquid Waste 
Treatment Systems at the Oak Ridge National Laboratory (Oak Ridge National Laboratory, 1991), dated July 1991, is a guide for liquid waste generators to determine the proper means of disposal for LLLW. The criteria provide future discharge guidelines for the LLLW system, which includes Tank System F-201. 
Design Demonstrations - Category B Tank Systems (Piping)

\subsubsection{References}

Binford, F. T., and S. D. Orfi. 1979. The Intermediate-Level Liquid Waste System at the Oak Ridge National Laboratory Description and Safety Analysis. ORNL/TM-6959. Oak Ridge National Laboratory.

Ebasco, and Main. May 14, 1993. Design Demonstrations-Category B Tank Systems, Revision 2. DOE Contract No. DE-AC05-91OR21928. Oak Ridge National Laboratory.

Energy Systems Drawing S20566-Y-109-E-R4, Cell, Block Plans, Revision 4.

Energy Systems Drawing S20566-Y-106-E-R3, First Floor Plan, Revision 3.

Energy Systems Drawing S20566-Y-103-E-R2, Foundation, Basement Plan and Details, Revision 2.

Energy Systems Drawing H20566-Y-224-E-R, H.V. and A.C., Cells, Ductwork Sections and Details, Revision C.

Energy Systems Drawing H20566-Y-220-E, H.V. and A.C., Cells, Ductwork, Sheet 3, Revision G.

Energy Systems Drawing P20566-Y-403-E-R, Piping Drains, Hot and Low-Level Areas, First Floor Plan and Sections, Revision 2.

Energy Systems Drawing A20566-Y-002-E-R1, Plan, Basement, Revision 1.

Energy Systems Drawing P20566-Y-412-E, Plumbing and Standpipe Foundation, Basement and First Floor Plans, Revision 3.

Energy Systems Drawing H20566-Y-218-E-R-2, Radioactive Off Gas Pit and RHD Pit, Revision 2.

Hertel, J. P. 1964. Procedure for Mass Spec. Leak Test. Job 3-127.

LLLW Generator Survey 1990 for Building 3525

Oak Ridge National Laboratory. 1991. Waste Acceptance Criteria for Liquid Waste Treatment Systems at the Oak Ridge National Laboratory. WM-WMCO-201. Department of Waste Minimization Planning and Certification.

Peretz, F. J., et al. 1986. Characterization of Low-Level Liquid Wastes at the Oak Ridge National Laboratory. ORNL/TM-10218. Oak Ridge National Laboratory.

Robinson, S. M., S. M. DePaoli, and A. B. Walker. 1991. Federal Facility Agreement Contingency, Upgrade, and Replacement Plans for the ORNL Active Low-Level Radioactive Waste Tank System. ORNL/TM-11795. Oak Ridge National Laboratory. 
Technical Specifications for the Construction of High Radiation Level Examination Laboratory Building 3525. 


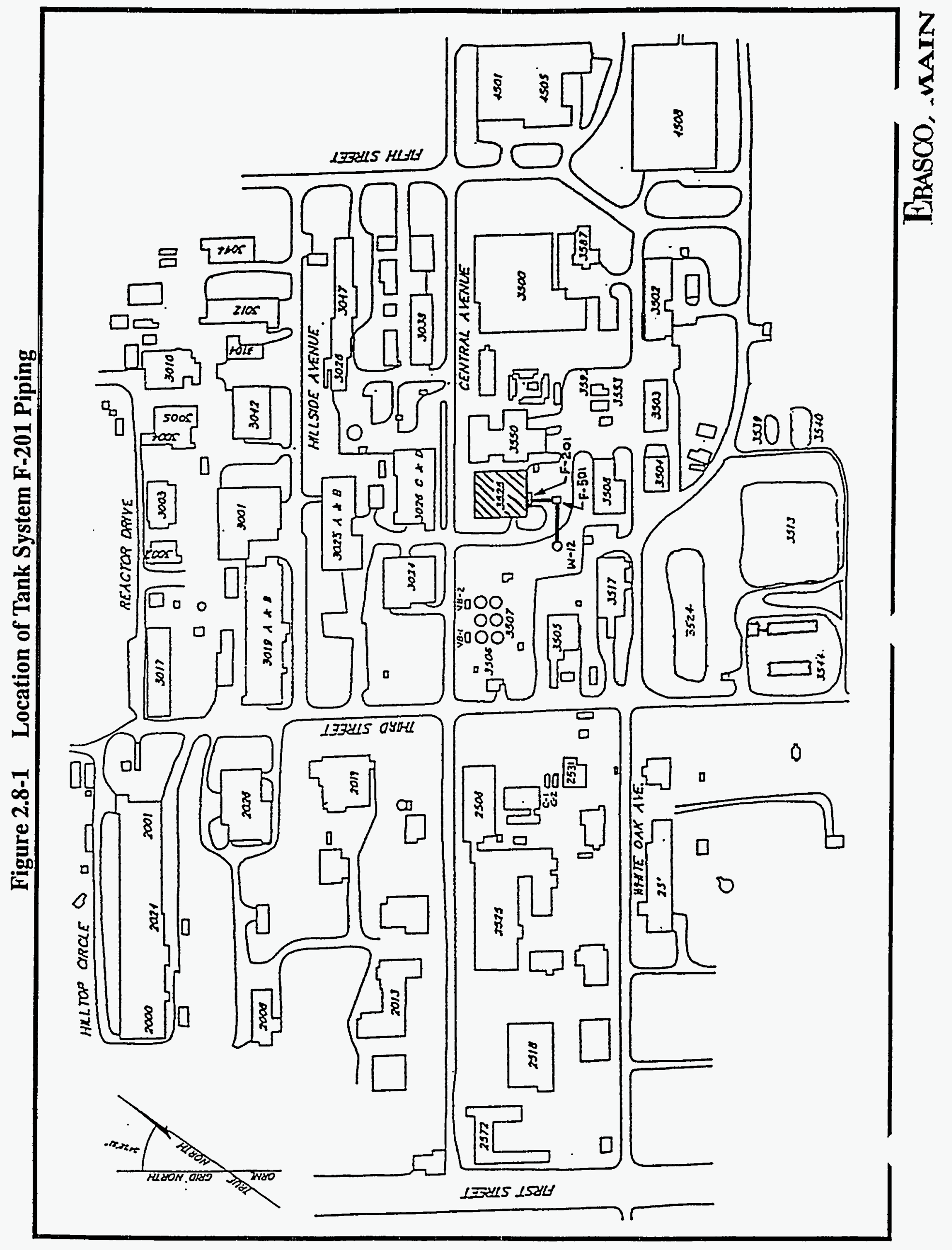


Figure 2.8-2 Tank System F-201 Piping Diagram

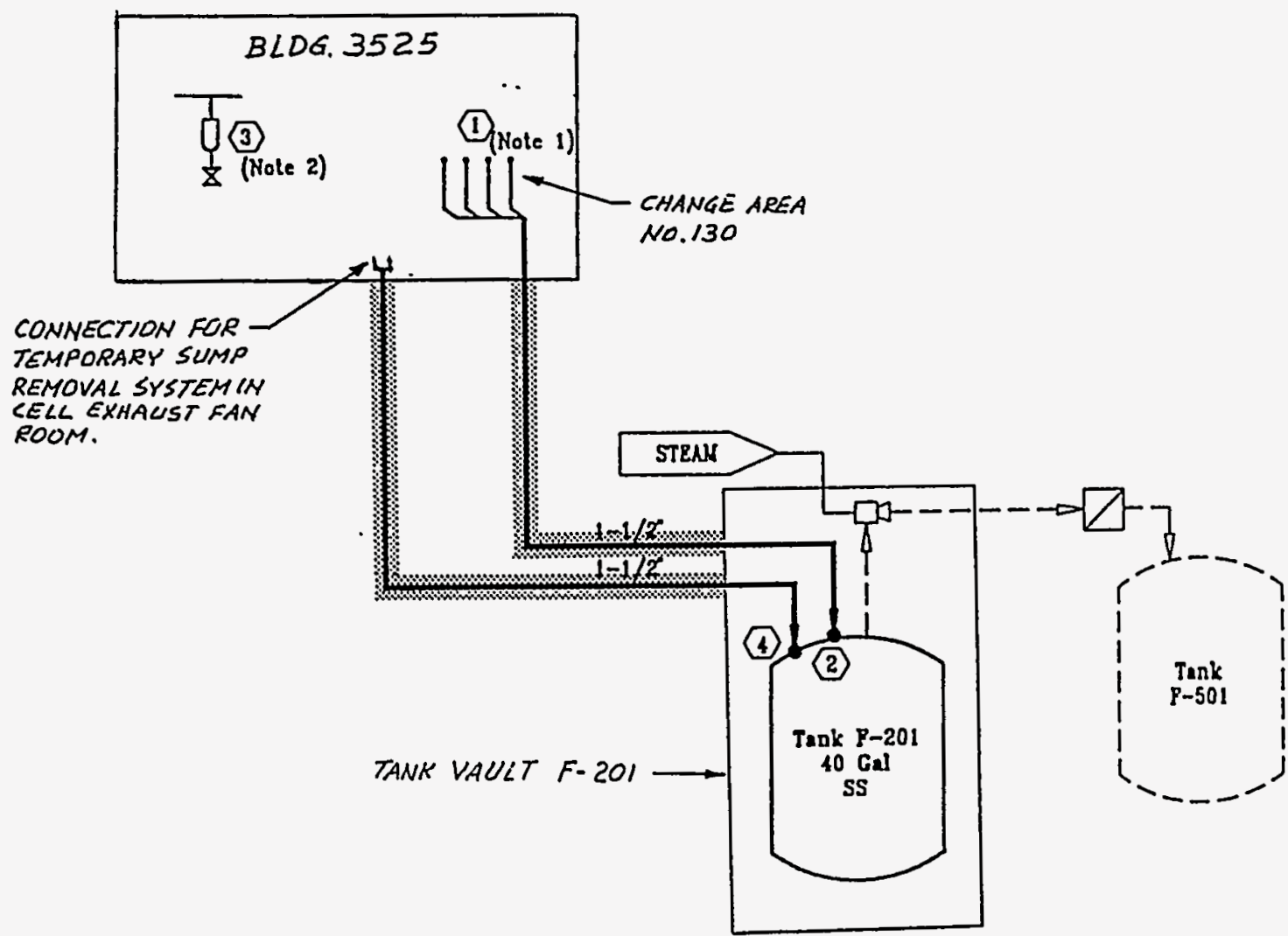

NOTES:

(1) Node (1)inckudes 4 embedded drain headers

from the Charging Areas. Each header connects

to six embedded storage wells. Six of the storage wells are constructed of a $4^{\prime} 2^{\circ}$ length of $8^{\circ}$ schedute

$10 S$ type 304L SS and a $3^{\prime} 00^{\circ}$ length of $10^{\circ}$ schedule 10S type 304L SS. The remaining eighteen storage wells are constructed of a $4^{\prime} 2^{\circ}$ length of $6^{\circ}$ schedule

$10 S$ type 304L SS and a $3^{\prime} 0^{\circ}$ ength of $8^{\circ}$ schedule

$10 S$ type 304L SS. Ret. drawings $P-20566-Y-403-E$ and $M-20566-Y-311-E$.

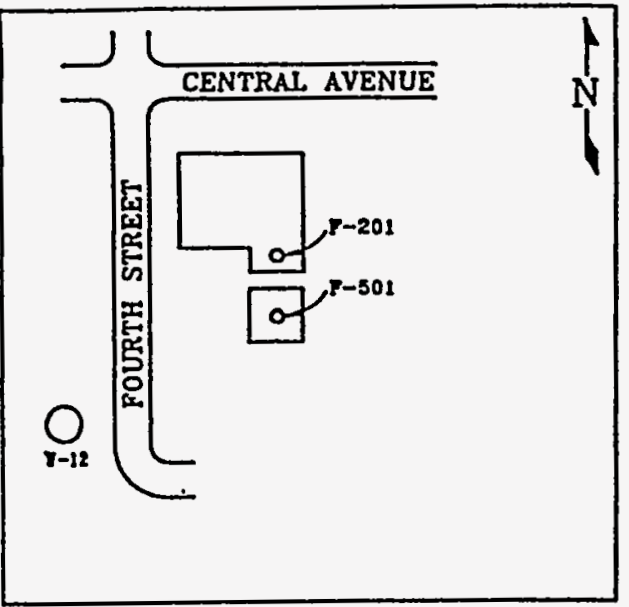

KEY PLAN (N.T.S)

\begin{tabular}{|l|c|c|}
\hline LINE SEGMENT & $(1)-2$ & $3-(1)$ \\
\hline SIZE IN-DIA & $1-1 / 2$ & $1-1 / 2$ \\
\hline SCHEDULE & $40 S$ & $40 S$ \\
\hline HATERIAL & SS & SS \\
\hline LENGTH (FT) & 135 & 65 \\
\hline YOLUXE (GNL) & 14 & 7 \\
\hline
\end{tabular}

(2) Node (3) is the corinection to off-gas drain pots at Bldg 3525 column lines (2) and (G), Reference drawing $P-20566-Y-403-E$. 
WASTE STREAM CONTAMINANTS:

(a) Isotopes:

$U-233$

$U-235$

$U-238$

$\mathrm{Pu}-239$

Th-232

$\mathrm{Kr}-85$

Cs -137 (b) Quantities Trace

Trace

Trace

Trace

Trace

Trace

$50.00 \mathrm{Ci} /$ year

(b) Others (i.e. acids, bases, organics, cleaners, etc.)

\begin{tabular}{c}
$\frac{\text { nitric acid }}{\text { sodium hydroxide }}$ \\
\hline Mr. Clean \\
\hline sodium bisulfate \\
\hline
\end{tabular}

$5.0 \mathrm{gal} / \mathrm{year}$

$5.0 \mathrm{gal} /$ year

$5.0 \mathrm{gal} / \mathrm{year}$

$200.0 \mathrm{gal} / \mathrm{year}$ 
Based on the findings of the Design Demonstrations for the Remaining 19 Category B Tank Systems, (DOE/OR/03-1150 \& D2), Tank System F-501, originally designated as Category B, has been redesignated as Category $C$ by FFA Modification Request Change Control Number FFA-PM/93-008, June 23, 1994. However, this section of the original Design Demonstrations has been retained for reference.

\subsubsection{Tank System Summary}

Tank System F-501 is located near the High Radiation Level Examination Laboratory (Building 3525) at the main Bethel Valley Complex (Figures 2.9-1 and 2.9-2). The tank system piping is schedule 40S, ASME SA-240, type 304L stainless steel (SS) and is routed from Tank Vault F-501 outside underground to Tank Vault F-201, Tank W-12, and areas within Building 3525.

Tank System F-501 piping is used to transfer liquid low-level waste (LLLW) from the Building 3525 Radioactive Hot Drain (RHD) System and Tank F-201 to Tank F-501 and from Tank F-501 to Tank W-12 and is classified as a Federal Facility Agreement Category B tank system.

\subsubsection{Standards for Pipe Assessment of Tank Systems}

\subsubsection{Tank System Piping Description and Design Standards}

\section{Tank System Piping Description}

Tank System F-501 piping is located in the vicinity of Building 3525 and is routed from Tank Vault F-501 outside underground to Tank Vault F-201, Tank W-12, and areas within Building 3525. The piping system is used and managed by the Metals and Ceramics Division.

Tank System F-501 piping is constructed of 1", 1-1/2", 2", 3", and 4"; schedule 40S; type 304L SS with a maximum design pressure and temperature of 150 psig and $200^{\circ} \mathrm{F}$. Tank System F-501 has a maximum volume of $154 \mathrm{gal}$.

\section{$\underline{\text { Design Standards }}$}

The applicable codes and standards used for Tank System F-501 piping and its associated secondary containment systems are identified herein. The codes and standards listed are those identified on either the design drawings or the construction specifications.

American Concrete Institute 315, 318, and 604;

American Society for Testing and Materials A15, A185, C31, C33, C39, C76, C94, C192, D155, A40.1, A53, A74, A106, A107, A120, A181, A182, A193, A217, A234, A298, A312, A338, B75, A240, and A403; 
Design Demonstrations - Category B Tank Systems (Piping)

American Society of Mechanical Engineers (ASME) Boiler and Pressure Vessel Code, Sections II (SA-240) and VIII;

Federal Specifications HHF191, HHF341, QQS632, SSA281, SSC164, SSC192, and UUP264; and National Fire Prevention Association.

\subsubsection{Generic Description of Piping Contents}

Tank System F-501 piping was designed to transfer LLLW from within Building 3525 to Tank Vault F-501, from Tank Vault F-201 to Tank Vault F-501, and from Tank Vault F-501 to Tank W-12. LLLW is produced during the decontamination and cleanup of the hot cells used in the disassembly and examination process. The tank system may contain radioactive materials from Building 3525 .

The analytical data (Figure 2.9-3) of the waste stream contaminants from the generators are representative of the waste transferred through Tank System F-501 piping.

\subsubsection{Pipe Corrosion Protection Measures}

Piping inside Tank Vault F-501, Tank Vault F-201, and Building 3525 has no direct contact with the soil or water. Cathodic protection measures are not required for external corrosion.

The piping that is routed outside underground is singly contained, and the external surfaces are exposed to the soil and water. Protective coatings or cathodic protection measures are not present in the outside underground piping.

\subsubsection{Documented Age of Tank System}

Tank System F-501 piping was installed in 1964.

\subsubsection{Standards for Containment/Release Detection}

Tank System F-501 incorporates approximately $665^{\prime}$ of outside underground and embedded piping that is singly contained. These singly contained areas are omitted from discussion in the following sections that address secondary containment.

2.9.3.1 Constructed of or Lined with Materials That are Compatible with Stored Waste(s) or Substance(s) to Be Placed in the Tank System and Shall Have Sufficient Strength and Thickness to Prevent Failure

Tank System F-501 piping is single-wall, schedule 40S, type 304L SS. The piping is routed from Tank Vault F-501 outside underground to Tank Vault F-201, Tank W-12, and areas within Building 3525. Areas of secondary containment are discussed below. 
Design Demonstrations - Category B Tank Systems (Piping)

\section{Tank Vaults F-501 and F-201}

The assessments of the secondary containment systems for Tank Vaults F-501 and F-201 are presented in the Design Demonstrations for Tanks F-501 and F-201. Those assessments conclude that Tank Vaults F-501 and F-201 are not coated or lined with materials that are compatible with the waste and designed to prevent migration of waste into the concrete.

\section{Areas Within Building 3525}

\section{H\&V Equipment Room No. 209}

Heating and Ventilation (H\&V) Equipment Room No. 209 is not provided with a liner or a protective coating on the concrete that is designed to prevent migration of waste into the concrete.

\section{Airlock No. 206}

Airlock No. 206 is not provided with a liner or a protective coating on the concrete that is designed to prevent migration of waste into the concrete.

\section{Charging Area No. 130}

The floor in Charging Area No. 130 is lined with 3/16" thick, 304L SS that extends $6^{\prime \prime}$ up the walls. The SS lining material, which is the same material as that used for the piping, is compatible with the waste and designed to prevent migration of the waste into the concrete.

\section{Operating Area No. 201}

Operating Area No. 201 is not provided with a liner or a protective coating on the concrete that is designed to prevent migration of waste into the concrete.

The assessment concludes that Charging Area No. 130 is lined with materials that are compatible with the waste and designed to prevent migration of waste into the concrete. However, Tank Vaults F-501 and F-201, H\&V Equipment Room No. 209, Airlock No. 206, and Operating Area No. 201 are not provided with a liner or a protective coating on the concrete that will prevent migration of waste into the concrete.

\subsubsection{Placed on Foundation or Base Capable of Providing Support to the Secondary Containment System}

\section{Tank Vaults F-501 and F-201}

The assessments of the secondary containment systems for Tank Vaults F-501 and F-201 are presented in the Design Demonstrations for Tanks F-501 and F-201. Those assessments conclude that the vault foundations are properly designed to support the secondary containment systems. 


\section{Areas Within Building 3525}

\section{H\&V Equipment Room No. 209}

The secondary containment foundation for H\&V Equipment Room No. 209 is constructed of reinforced concrete slabs supported on a structural steel frame. The concrete is designed with a minimum 28-day compressive strength of 3000 psi.

\section{Airlock No. 206}

The secondary containment foundation for Airlock No. 206 is constructed of reinforced concrete slabs supported on a structural steel frame. The concrete is designed with a minimum 28-day compressive strength of 3000 psi.

\section{Charging Area No. 130}

The secondary containment foundation for Charging Area No. 130 is constructed of reinforced concrete that rests on crushed stone. The concrete is designed with a minimum 28-day compressive strength of 3000 psi.

\section{Operating Area No. 201}

The secondary containment foundation for Operating Area No. 201 is constructed of reinforced concrete slabs supported on a structural steel frame. The concrete is designed with a minimum 28-day compressive strength of 3000 psi.

The assessment concludes that Tank Vaults F-501 and F-201, H\&V Equipment Room No. 209, Airlock No. 206, Charging Area No. 130, and Operating Area No. 201 foundations are properly designed to support the secondary containment systems.

2.9.3.3 Provided with a Leak Detection System That is Designed and Operated to Detect Failure of Either Primary or Secondary Containment Structure or the Presence of Any Measurable Release of Hazardous or Radioactive Constituents

\section{Tank Vaults F-501 and F-201}

The assessments of the secondary containment systems for Tank Vaults F-501 and F-201 are presented in the Design Demonstrations for Tanks F-501 and F-201. Those assessments conclude that Tank Vault F-501 is provided with a leak detection system; however, Tank Vault F-201 is not provided with a leak detection system. 


\section{Areas Within Building 3525}

H\&V Equipment Room No. 209

H\&V Equipment Room No. 209 is not provided with a leak detection system.

Airlock No. 206

Airlock No. 206 is not provided with a leak detection system.

Charging Area No. 130

Charging Area No. 130 is not provided with a leak detection system.

Operating Area No. 201

Operating Area No. 201 is not provided with a leak detection system.

The assessment concludes that Tank Vault F-501 is provided with leak detection; however, Tank Vault F-201, H\&V Equipment Room No. 209, Airlock No. 206, Charging Area No. 130, and Operating Area No. 201 are not provided with leak detection.

2.9.3.4 Sloped or Otherwise Designed or Operated to Drain and Remove Liquids Resulting from Leaks, Spills, or Precipitation

\section{Tank Vaults F-501 and F-201}

The assessments of the secondary containment systems for Tank Vaults F-501 and F-201 are presented in the Design Demonstrations for Tanks F-501 and F-201. Those assessments conclude that the secondary containments are sloped and designed to drain and remove liquids resulting from leaks, spills, or precipitation.

\section{Areas Within Building $\mathbf{3 5 2 5}$}

\section{H\&V Equipment Room No. 209}

The floor in H\&V Equipment Room No. 209 is not sloped or otherwise designed to remove liquids.

\section{Airlock No. 206}

The floor in Airlock No. 206 is sloped to a 304L SS floor drain. The drain provides a low point within the air lock to route liquids to the Process Hot Drain (PHD) System. 


\section{Charging Area No. 130}

Charging Area No. 130 has two, type 304L SS drains installed flush in the SS-lined floor. The drain located near the middle, south edge of the cell directs collected fluids to the RHD System. The other drain, located near the southeast corner of the cell, is a safety shower drain that transfers waste to the PHD System.

\section{Operating Area No. 201}

Operating Area No. 201 has two drains installed flush in the concrete floor. The drains direct waste to the PHD System.

The assessment concludes that the secondary containment areas for Tank Vaults F-501 and F-201 and Airlock No. 206 are sloped and designed to drain and remove liquids resulting from leaks, spills, or precipitation. Charging Area No. 130 and Operating Area No. 201 have drains but are not sloped. H\&V Equipment Room No. 209 is not sloped or otherwise designed to remove liquids resulting from leaks, spills, or precipitation.

\subsubsection{Supplemental Information}

\subsubsection{Ancillary Equipment}

Tank F-501 is constructed of 304L SS, which is the same material as that used in the piping system, and is located in Tank Vault F-501, which provides secondary containment. Tank F-201 is constructed of $304 \mathrm{~L}$ SS, which is the same material as that used in the piping system, and is located in Tank Vault F-201, which provides secondary containment. The support equipment is exposed to the same liquids as other components of the tank system; therefore, 304L SS is an acceptable material for the support equipment.

\subsubsection{Waste Acceptance Criteria}

Radioactively contaminated liquid wastes at the Oak Ridge National Laboratory (ORNL) are generated by various activities within the research and operating divisions. These activities include radiochemical processing, routine hot cell operations and decontamination, and various waste treatment and environmental protection processes. The variations in composition of the waste streams are limited by the waste acceptance criteria that specify activity and concentration limits for waste discharged into the LLLW system. The Waste Acceptance Criteria for Liquid Waste Treatment Systems at the Oak Ridge National Laboratory (Oak Ridge National Laboratory, 1991), dated July 1991, is a guide for liquid waste generators to determine the proper means of disposal for LLLW. The criteria provide future discharge guidelines for the LLLW system, which includes Tank System F-501. 


\subsubsection{References}

Binford, F. T., and S. D. Orfi. 1979. The Intermediate-Level Liquid Waste System at the Oak Ridge National Laboratory Description and Safety Analysis. ORNL/TM-6959. Oak Ridge National Laboratory.

Ebasco, and Main. May 14, 1993. Design Demonstrations-Category B Tank Systems, Revision 2. DOE Contract No. DE-AC05-91OR21928. Oak Ridge National Laboratory.

Energy Systems Drawing M20566-Y-311-E, 6" and 8" Floor Storage Wells, Dated 6/23/59 (No Revision No.).

Energy Systems Drawing S-20566-Y-109-E-R4, Cell, Block Plans, Revision 4.

Energy Systems Drawing S-20566-Y-110-E-R3, Cell Elevations, Sheet 1, Revision 3.

Energy Systems Drawing S-20566-Y-111-E-R1, Cell Elevations, Sheet 2, Revision 1.

Energy Systems Drawing S-20566-Y-114-E-R3, Cell Liner, Plate Details, Sheet 1, Revision 3.

Energy Systems Drawing S-20566-Y-115-E-R3, Cell Liner, Plate Details, Sheet 2, Revision 3.

Energy Systems Drawing S-20566-Y-112-E, Cell Sections and Details, Dated 4/21/60 (No Revision No.).

Energy Systems Drawing S-20566-Y-103-E-R2, Foundation, Basement Plan and Details, Revision 2.

Energy Systems Drawing P20566-Y-400-E, General Arrangement of Process Hot and RHD Drain Systems, Plan First Floor, Cell Area, Dated 9/4/59 (No Revision No.).

Energy Systems Drawing 1343-M-501, General Arrangement, RHD Tank System, Dated 4/25/61 (No Revision No.).

Energy Systems Drawing H20566-Y-224-E-R, H.V. and A.C., Cells, Ductwork Sections and Details, Revision C.

Energy Systems Drawing H20566-Y-223-E-R-3, H.V. and A.C., Upper Levels, Ductwork, Sheet 2, Revision 3.

Energy Systems Drawing P20566-Y-403-E-R, Piping Drains, Hot and Low Level Areas, First Floor, Plan and Sections, Revision 2.

Energy Systems Drawing P20566-Y-404-E-R1, Piping Drains, Hot and Low Level Areas, Second Floor, Plan and Sections, Revision 1. 
Energy Systems Drawing P20566-Y-405-E-R1, Piping Drains, Hot and Low Level Areas, Upper Level, Plan and Sections, Revision 1.

Energy Systems Drawing 1343-M-502, R.H.D. Tank System, Details and Profile of RHD Transfer Pipeline, Dated 4/25/61 (No Revision No.).

Energy Systems Drawing 1343-H-501, R.H.D. Tank System Concrete Plans, Sections and Details, Revision 2.

Energy Systems Drawing 1343-L-501, R.H.D. Tank System Strainer Arrangement, Dated 4/25/61 (No Revision No.).

Energy Systems Drawing H20566-Y-218-E-R-2, Radioactive OffGas Pit and RHD Pit, Revision 2.

Energy Systems Drawing P20566-Y-401-E-R4, Yard Piping, Plan, Revision 4.

Hertel, J. P. 1964. Procedure for Mass Spec. Leak Test. Job 3-127.

Oak Ridge National Laboratory. 1991. Waste Acceptance Criteria for Liquid Waste Treatment Systems at the Oak Ridge National Laboratory. WM-WMCO-201. Department of Waste Minimization Planning and Certification.

Peretz, F. J., et al. 1986. Characterization of Low-Level Liquid Wastes at the Oak Ridge National Laboratory. ORNL/TM-10218. Oak Ridge National Laboratory.

Robinson, S. M., S. M. DePaoli, and A. B. Walker. 1919. Federal Facility Agreement Contingency, Upgrade, and Replacement Plans for the ORNL Active Low-Level Radioactive Waste Tank System. ORNL/TM/11795. Oak Ridge National Laboratory.

Technical Specifications for the Construction of High Radiation Level Examination Laboratory Building 3525. 
Figure 2.9-1 Location of Tank System F-501 Piping

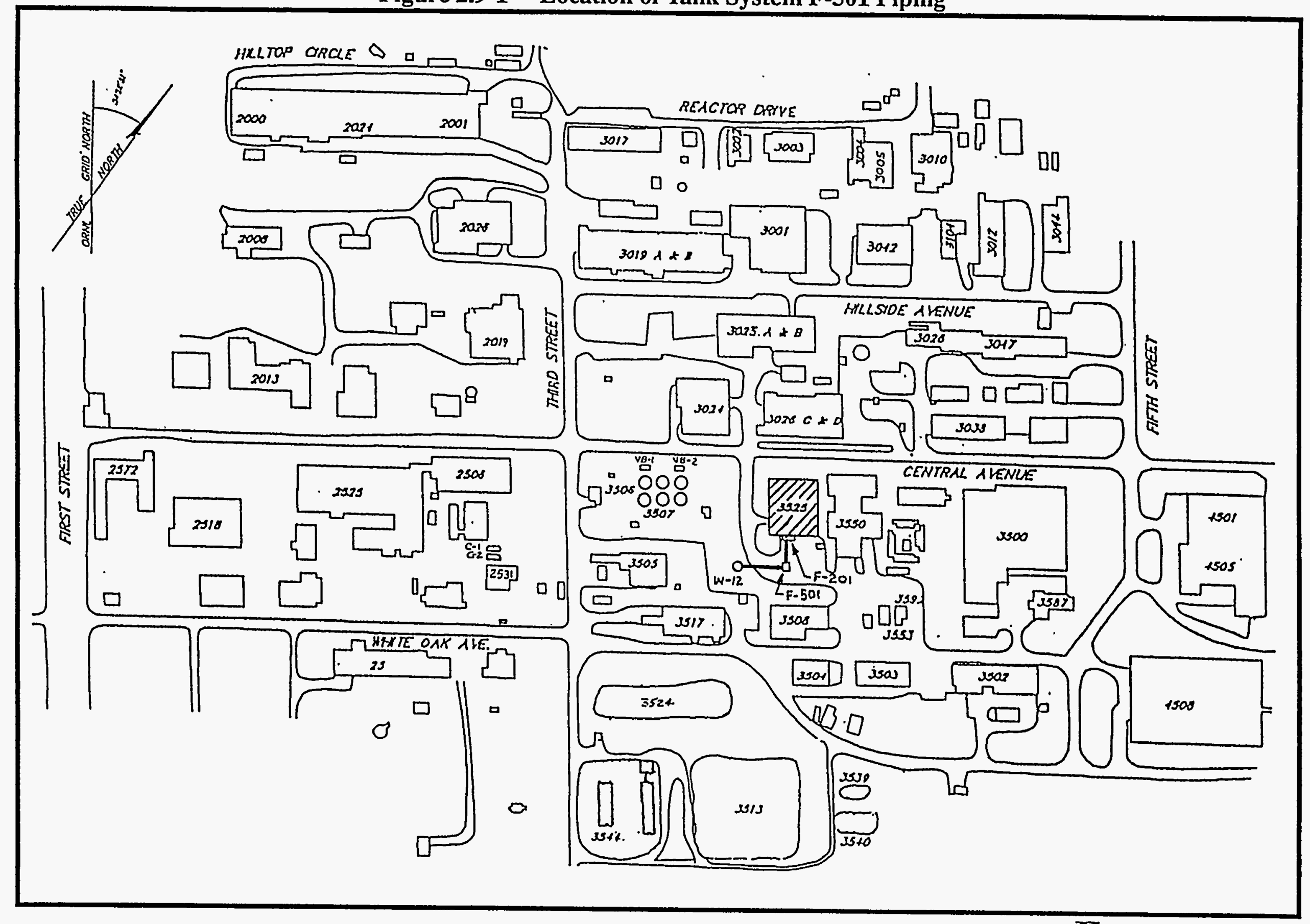

Ebasco/Main 


\section{Figure 2.9-2 Tank System F-501 Piping Diagram}

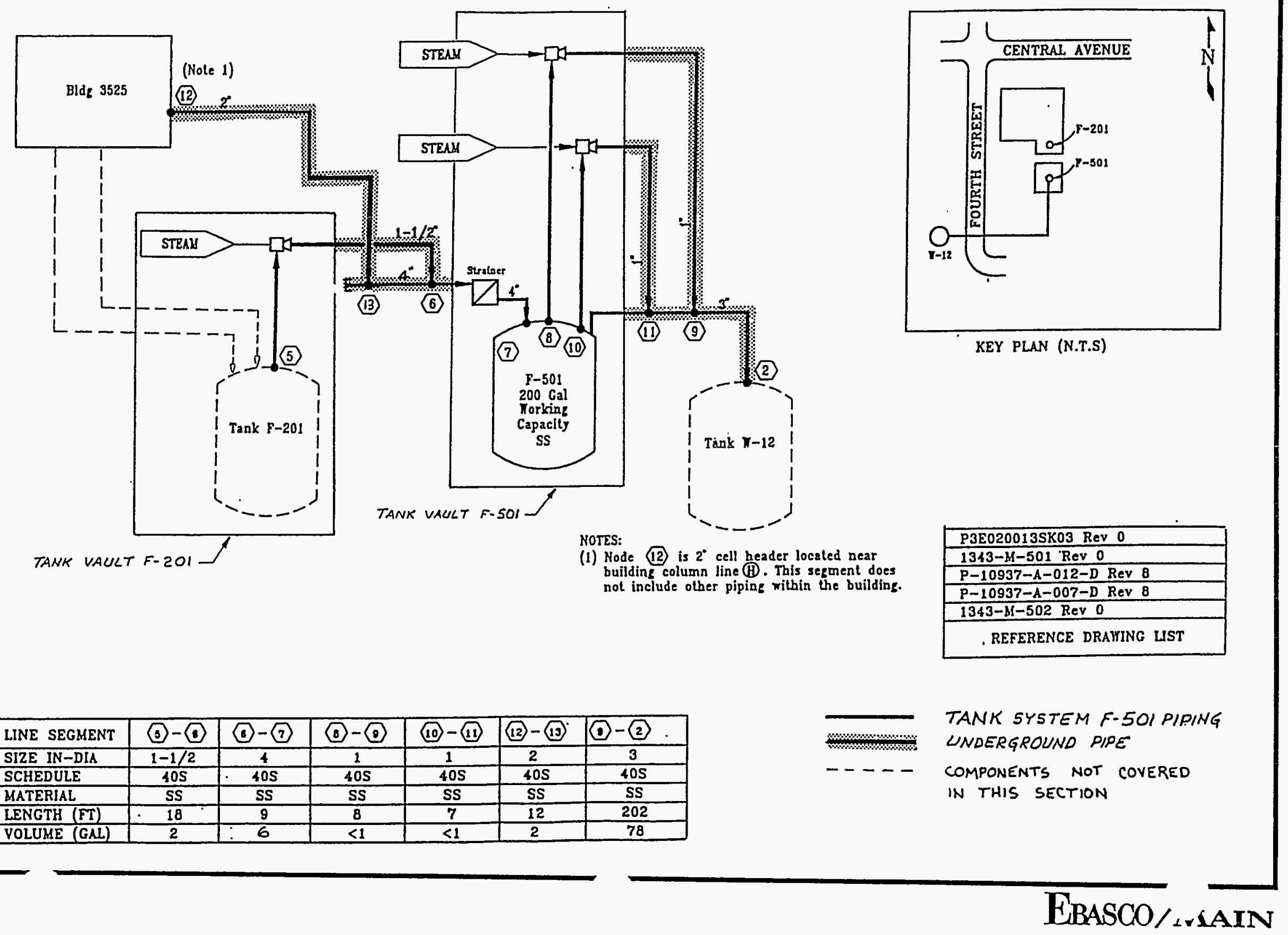


WASTE STREAM CONTAMINANTS:

(a) Isotopes:

$\frac{U-235}{U-238}$

\begin{tabular}{c}
$\mathrm{Pu}-239$ \\
\hline $\mathrm{Th}-232$ \\
\hline $\mathrm{Kr}-85$ \\
\hline $\mathrm{Cs}-137$ \\
\hline
\end{tabular}

(b) Others (i.e. acids, bases, organics, cleaners, etc.)

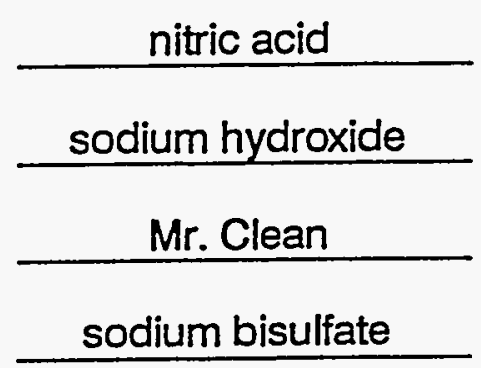

(b) Quantities Trace Trace Trace Trace Trace Trace

$\frac{\text { Trace }}{50.00 \mathrm{Ci} / \text { year }}$

\begin{tabular}{c}
$5.0 \mathrm{gal} /$ year \\
\hline $5.0 \mathrm{gal} /$ year \\
\hline $5.0 \mathrm{gal} /$ year \\
\hline $200.0 \mathrm{gal} /$ year \\
\hline
\end{tabular}




\subsection{Tank System L-11 Piping}

\subsubsection{Tank System Summary}

Tank System L-11 is located at the Process Waste Treatment Plant (PWTP) (Building 3544) in the main Bethel Valley Complex (Figures 2.10-1 and 2.10-2). The tank system piping is schedule 40S, ASME SA-240, type 304L stainless steel (SS) and is routed outside underground from Tank Vault L-11 to Valve Box No. 1. Tank System L-11 piping is used to transfer concentrates from the liquid low-level waste (LLLW) Evaporator to Valve Box No. 1 and is classified as a Federal Facility Agreement Category B tank system.

\subsubsection{Standards for Pipe Assessment of Tank Systems}

\subsubsection{Tank System Piping Description and Design Standards}

\section{Tank System Piping Description}

Tank System L-11 piping is located at Building 3544 and is routed underground from Tank Vault L-11 to Valve Box No. 1. The piping system is used and managed by the Waste Management and Remedial Action Division.

Tank System L-11 piping is constructed of 3/4", 1-1/2," and 3", 304L SS with a maximum design pressure and temperature of $150 \mathrm{psig}$ and $400^{\circ} \mathrm{F}$. Tank System L-11 piping has a maximum volume of $122 \mathrm{gal}$.

\section{Design Standards}

The applicable codes and standards used for Tank System L-11 piping and its associated secondary containment systems are identified herein. The codes and standards listed are those identified on either the design drawings or the construction specifications.

AEC-Oak Ridge Office, Minimum Safety Requirements;

Air Moving and Conditioning Association (AMCA) Standards Handbook-Publication 99;

AMCA Directory-Publication 261;

AMCA Fans and Systems-Publication 201;

American National Standards Institute B16.5, B16.9, B16.11, B16.14, B16.3, B16.1, A21.6, A21.1, A21.11, A21.4, A21.10, B16.18, A112.5.1, B16.12, B16.22, and B31.3;

American Society of Mechanical Engineers (ASME) Boiler and Pressure Vessel Code, Sections II (SA-240) and VIII; 
American Conference of Governmental Industrial Hygienists;

American Society of Heating, Refrigeration, and Air Conditioning Engineers (ASHRAE) Handbook of Fundamentals;

American Concrete Institute;

American Concrete Pipe Association;

American Standards Association Safety Code for Building Construction;

American Society for Testing and Materials C39, C78, C138, C143, and D1752;

ASHRAE Guide and Data Book-Applications;

ASHRAE Handbook-Systems;

ASHRAE Guide and Data Book-Equipment;

Atomic Energy Commission (AEC) General Design Criteria, Appendix 63;

Factory Mutual Engineering Corporation;

Instrument Society of America;

National Electric Code;

National Fire Protection Association (NFPA) No. 90A-Air Conditioning and Ventilating Systems;

NFPA No. 91-Blower and Exhaust Systems;

Occupational Safety and Health Administration; and

Underwriters Laboratories Inc.

\subsubsection{Generic Description of Piping Contents}

Tank System L-11 piping is designed to collect LLLW process waste from the L-10 PWTP Evaporator Tank in Building 3544. These wastes may include a variety of dilute acids, bases, organics, and radioactive materials.

The analytical data (Figure 2.10-3) of waste stream contaminants from the generators are representative of the waste transferred through Tank System L-11 piping. 


\subsubsection{Pipe Corrosion Protection Measures}

Piping inside Tank Vault L-11 and Valve Box No. 1 has no direct contact with the soil or water. Cathodic protection measures are not required for external corrosion.

Tank System L-11 outside underground piping is singly contained, 304L SS. Approximately 500' of the underground pipe is encased in concrete and has no cathodic protection. The remaining 500' of underground pipe is buried in direct contact with the soil and water and is partially cathodically protected.

The cathodic protection for the outside underground LLLW piping between Tank Vault L-11 (Building 3544) and Valve Box No. 1 is included in the Facility Manager's Cathodic Protection System No. 9. The galvanic anode cathodic protection system consists of magnesium anodes, test stations, and connecting wire as shown in cathodic protection drawings E-21246-ED-023 and E-21246-ED-024. The system was installed in July 1974. The cathodic protection system as shown on the construction drawings reviewed is considered to be inadequate because electrical isolation of the buried piping system is not shown on these construction drawings.

Harco Technologies determined that insulating gaskets were not present during its 1990 surveys, and the cathodic protection current requirements through field testing in 1991 indicate that $44 \%$ of the piping is not receiving adequate corrosion control. This is due mainly to the lack of electrical isolation devices used between the interior piping and the outside underground piping, and is also because of the destroyed anode beds. In 1991, Harco completed the engineering design to upgrade the existing system to protect the piping.

\subsubsection{Documented Age of Tank System}

Tank System L-11 piping was installed in 1974.

\subsubsection{Standards for Containment/Release Detection}

Tank System L-1 1 incorporates approximately 1000' of outside underground and embedded piping that is singly contained. The singly contained areas are omitted from discussion in the following sections that address secondary containment.

2.10.3.1 Constructed of or. Lined with Materials That are Compatible with Stored Waste(s) or Substance(s) to Be Placed in the Tank System and Shall Have Sufficient Strength and Thickness to Prevent Failure

Tank System L-11 piping is single-wall, schedule 40S, type 304L SS that is routed outside underground from Tank Vault L-11 to Valve Box No. 1. Each area is discussed below. The piping penetration at Tank Vault L-11 is a 1-1/2" diameter, schedule 40S, type 304L SS pipe that passes through a carbon steel sleeve embedded in the concrete wall. The space between the pipe and sleeve is packed with oakum and bitumastic seal. The carbon steel sleeve is not compatible with the waste. 


\section{Tank Vault L-11}

The assessment of the secondary containment system for Tank Vault L-11 is presented in the Design Demonstrations for Tank L-11. That assessment concludes that Tank Vault L-11 is coated and lined with materials that are compatible with the waste and designed to prevent migration of waste into the concrete.

\section{Valve Box No. 1}

The bottom of Valve Box No. 1 is lined with 16-gauge (1/16"), 304L SS, with sidewalls that project $2^{\prime} 0^{\prime \prime}$ up the valve box walls. The SS valve box lining material is compatible with the waste and designed to prevent migration of waste into the concrete.

The assessment concludes that the tank vault and valve box are coated or lined with materials that are compatible with the waste and designed to prevent migration of waste into the concrete.

2.10.3.2 Placed on Foundation or Base Capable of Providing Support to the Secondary Containment System

\section{Tank Vault L-11}

The secondary containment system for Tank Vault L-11 is presented in the Design Demonstrations for Tank L-11. That assessment concludes that the vault foundation is properly designed to support the secondary containment system.

\section{$\underline{\text { Valve Box No. } 1}$}

The valve box foundation is a $6^{\prime} 8^{\prime \prime} \times 19^{\prime} 2^{\prime \prime} \times 10^{\prime \prime}$ thick, reinforced concrete base slab that rests on limestone.

The assessment concludes that the tank vault and valve box foundations are properly designed to support the secondary containment system.

2.10.3.3 Provided with a Leak Detection System That is Designed and Operated to Detect Failure of Either Primary or Secondary Containment Structure or the Presence of Any Measurable Release of Hazardous or Radioactive Constituents

\section{Tank Vault L-11}

The assessment of the secondary containment system for Tank Vault L-11 is presented in the Design Demonstrations for Tank L-11. That assessment concludes that the vault is provided with a leak detection system. 
Design Demonstrations - Category B Tank Systems (Piping)

\section{Valve Box No. 1}

The Valve Box No. 1 floor is sloped to a 16-gauge $\left(1 / 16^{\prime \prime}\right)$, 304L SS-lined sump where accumulation of liquid will be detected by a level sensor that will activate an alarm in the Waste Operations Control Center (Building 3130).

The assessment concludes that the tank vault and valve box are provided with leak detection.

2.10.3.4 Sloped or Otherwise Designed or Operated to Drain and Remove Liquids Resulting from Leaks, Spills, or Precipitation

\section{Tank Vault L-11}

The assessment of the secondary containment system for Tank Vault L-11 is presented in the Design Demonstrations for Tank L-11. That assessment concludes that the secondary containment is sloped and designed to drain and remove liquids resulting from leaks, spills, or precipitation.

\section{Valve Box No. 1}

The Valve Box No. 1 floor is sloped to a 304L SS-lined sump. The sump provides a low point within the valve box to drain liquids to an instrumented location. A pumping system is provided to remove liquids that accumulate in the sump.

The assessment concludes that the secondary containment for the tank vault and valve box are sloped and designed to drain and remove liquids resulting from leaks, spills, or precipitation.

\subsubsection{Supplemental Information}

\subsubsection{Ancillary Equipment}

Tank L-11 is constructed of 304L SS, which is the same material as that used in the piping system, and is located in Tank Vault L-11, which provides secondary containment. The pumps associated with Tank System L-11 are constructed of 304L SS, which is the same material as that used in the tank and piping system, and are located in the Tank Vault L-11. The support equipment is exposed to the same liquids as other components of the tank system; therefore, 304L SS is an acceptable material for the support equipment.

\subsubsection{Waste Acceptance Criteria}

Radioactively contaminated liquid wastes at the Oak Ridge National Laboratory (ORNL) are generated by various activities within the research and operating divisions. These activities include radiochemical processing, routine hot cell operations and decontaminations, and various waste treatment and environmental protection processes. The variations in composition of the waste streams are limited by the waste acceptance criteria that specify activity and concentration limits for waste discharged into the LLLW system. The Waste Acceptance Criteria for Liquid Waste 
Treatment Systems at the Oak Ridge National Laboratory (Oak Ridge National Laboratory, 1991), dated July 1991, is a guide for liquid waste generators to determine the proper means of disposal for LLLW. The criteria provide future discharge guidelines for the LLLW system, which includes Tank System L-11. 


\subsubsection{References}

Construction Specification for Clarifier Foundation and Containment Work Order A-2991G-G1. November 11, 1985.

Ebasco, and Main. May 14, 1993. Design Demonstrations-Category B Tank Systems, Revision 2. DOE Contract No. DE-AC05-91OR21928. Oak Ridge National Laboratory.

Energy Systems Drawing A-21246-EE-018, General Structural Notes, Revision 1.

Energy Systems Drawing C-20013-EA-029-E, Waste Collection Header Connector Plan, Revision C.

Energy Systems Drawing C-20013-EA-031-E, Waste Collection Header Valve Boxes Piping Details, Revision E.

Energy Systems Drawing C-20013-EA-033-E, Waste Collection Header Valve Boxes Liner and Sleeve Details, Revision E.

Energy Systems Drawing C-21246-EA-018-D, Underground Piping Plan Detail and General Notes, Revision 1.

Energy Systems Drawing C-21246-EA-021-D, PWC Pipeline, Plan and Profile, Sheet 1, Dated 2/22/74 (No. Revision No).

Energy Systems Drawing C-21246-EA-022-D, PWC Pipeline, Plan and Profile, Sheet 2, Revision 1.

Energy Systems Drawing E-21246-ED-023-D, PWC Pipeline Cathodic Protection, Sheet 1, Revision 0.

Energy Systems Drawing E-21246-ED-024-D, PWC Pipeline Cathodic Protection, Sheet 2, Revision 0.

Energy Systems Drawing H-21246-EG-003-D, Heating and Ventilating Flow and Control Diagram, Revision 0.

Energy Systems Drawing I-21246-EI-015, Instrumentation Systems, Revision C.

Energy Systems Drawing I-21246-EI-017-D, Instrumentation System Diagram, Sheet 3 of 3, Revision B.

Energy Systems Drawing M-21246-EE-028, Process Equipment Layout Plan, Revision 0.

Energy Systems Drawing P-21246-EC-010-D, Building and Pad Drain System Plan, Revision 3.

Energy Systems Drawing P-21246-EC-011-D, Process Waste Sump Plan and Details, Revision 2. 
Design Demonstrations - Category B Tank Systems (Piping)

Energy Systems Drawing P-21246-EE-003-D, Process Engineering Flowsheet No. 2, Revision 4.

Energy Systems Drawing P-21246-EE-031-D, Ion Exchange Room Process Piping Plan and Elevation, F-F, Revision 5.

Energy Systems Drawing P-21246-EE-032-D, Ion Exchange Room Process Piping Elevation, G-G and $\mathrm{H}-\mathrm{H}$, Revision 3.

Energy Systems Drawing S-21246-EB-014-D, Concrete Sections, Sheet 2, Revision A.

Energy Systems Drawing S-21246-EB-015-D, Concrete Sections, Sheet 3, Revision 0.

Harco Technologies Corporation. June 1990. Resurvey of the Cathodic Protection Systems, Oak Ridge National Laboratories, United States Department of Energy, Oak Ridge, Tennessee. Martin Marietta Energy Systems, Inc.

Harco Technologies Corporation. July 1991. Cathodic Protection System Upgrade Design Underground ILW Line 3544 to 3507, System No. 9. Oak Ridge National Laboratories, United States Department of Energy, Oak Ridge, Tennessee. Martin Marietta Energy Systems, Inc.

LLLW Generator Survey 1990 for Building 3544.

Oak Ridge National Laboratory. May 9, 1974. Specification for the Construction of Process Waste Treatment Plant Building 3544. Invitation No. 401-74-13A.

Oak Ridge National Laboratory. 1991. Waste Acceptance Criteria for Liquid Waste Treatment Systems at the Oak Ridge National Laboratory. WM-WMCO-201. Department of Waste Minimization Planning and Certification.

Robinson, S. M., S. M. DePoali, and A. B. Walker. 1991. Federal Facility Agreement Contingency Upgrade, and Replacement Plans for the ORNL Active Low-Level Radioactive Waste Tank System. ORNL/TM-1 1795. Oak Ridge National Laboratory. 
Figure 2.10-1 Location of Tank System L-11 Piping

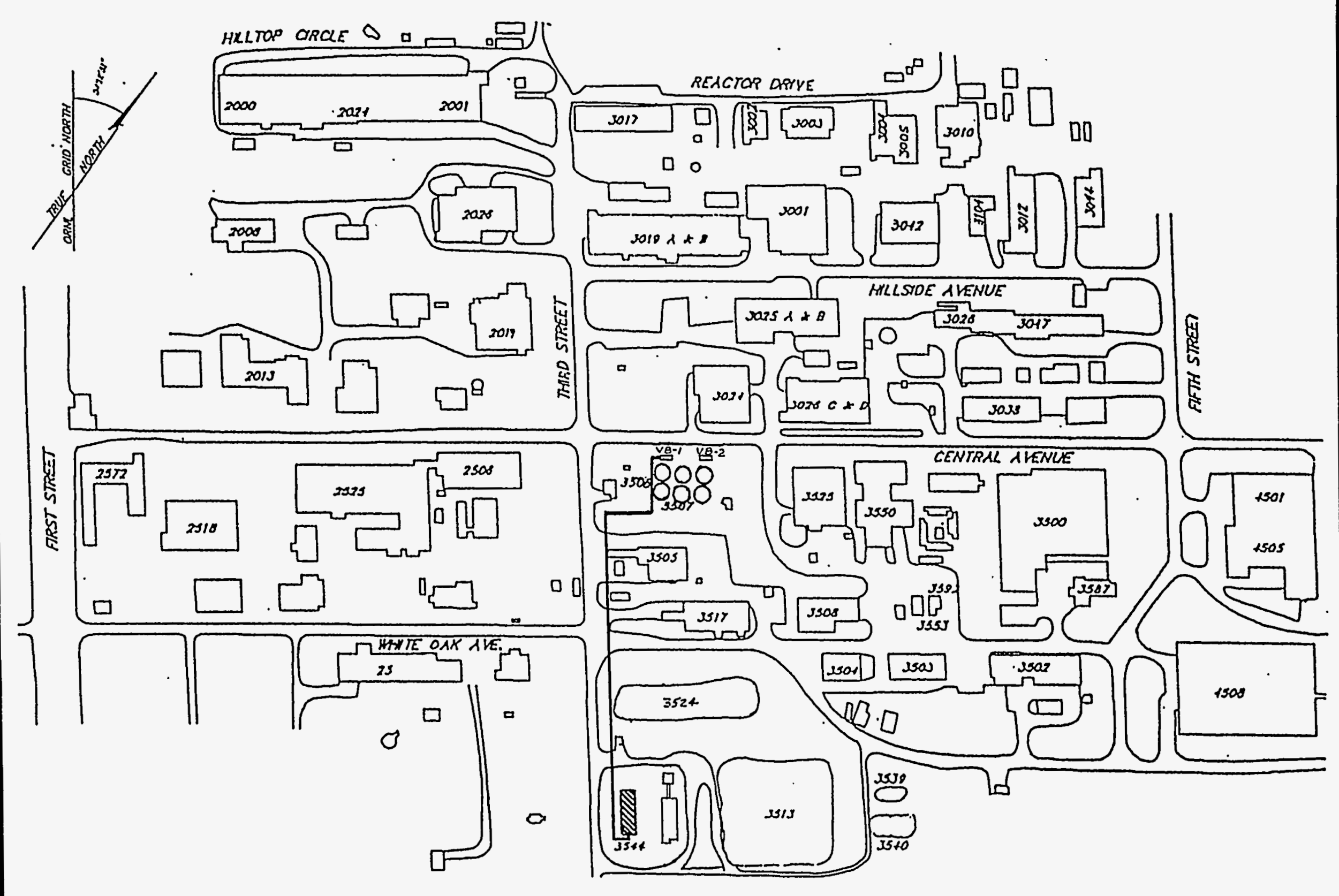




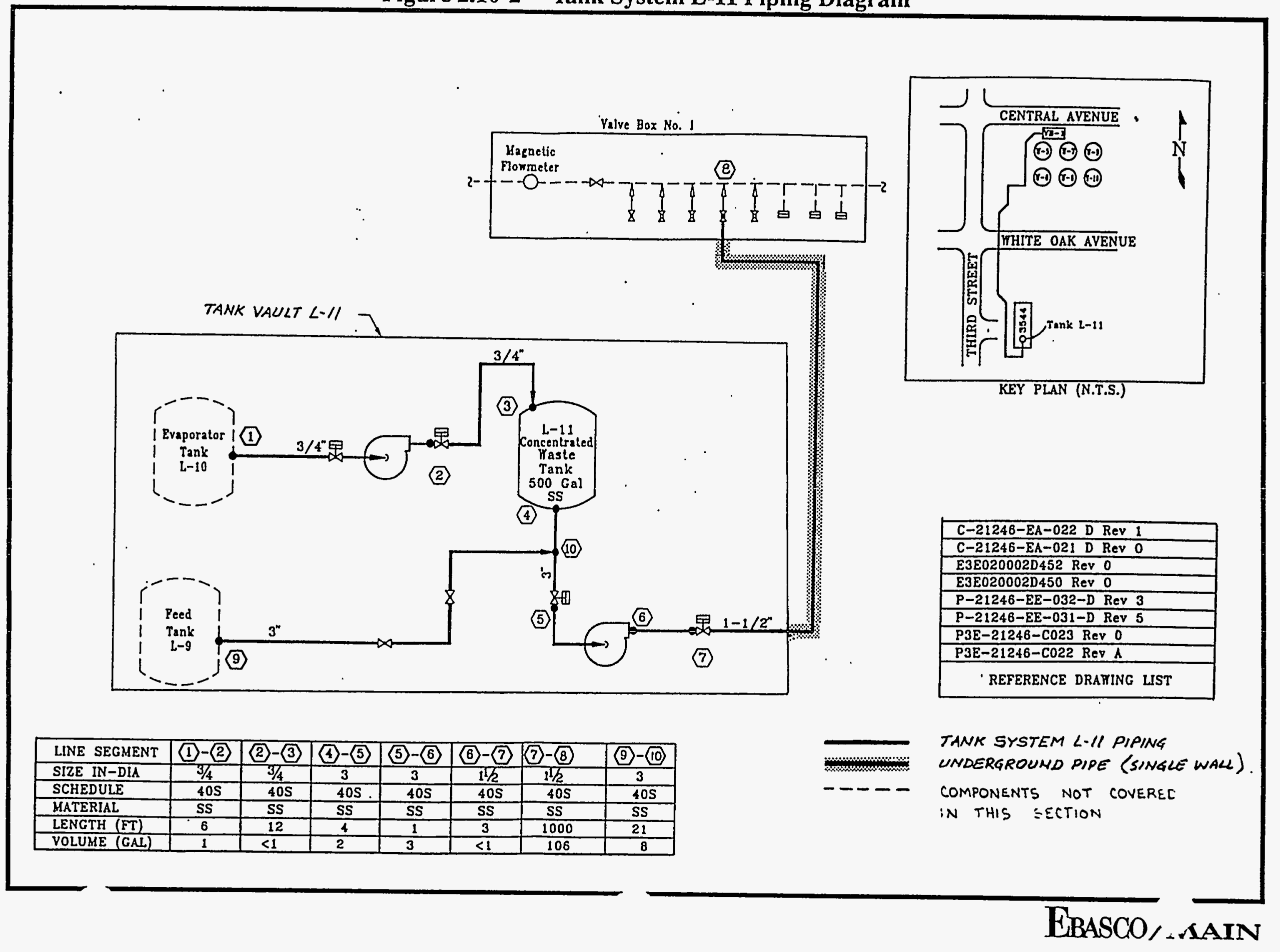


WASTE STREAM CONTAMINANTS:

(a) Isotopes:all

Quantities:Trace

(b) 'Others (i.e. acids, bases, organics, cleaners, etc.)

nitric acid (3N)

sodium hydroxide (50 8 )
$2000.0 \mathrm{gal} /$ year

$440.0 \mathrm{gal} /$ year 
2.11.1

\section{Tank System Summary}

Tank System N-71 is located at the Radiochemical Development Facility (Building 3019) at the main Bethel Valley Complex (Figures 2.11-1 and 2.11-2). The tank system piping is schedule 40S, ASME SA-240, type 304L stainless steel (SS) and is routed from the southwest area of Building 3019 to Tank Vault N-71. Tank System N-71 piping is used to transfer the liquid low-level waste (LLLW) from the Building 3019 west drain header to Tank N-71 and further to Tank P-3 and is classified as a Federal Facility Agreement Category B tank system.

\subsubsection{Standards for Pipe Assessment of Tank Systems}

\subsubsection{Tank System Piping Description and Design Standards}

\section{Tank System Piping Description}

Tank System N-71 piping is located in Building 3019 and is routed from the southwest area of Building 3019 to Tank Vault $\mathrm{N}-71$. The piping system is used and managed by the Chemical Technology Division and is part of the Bethel Valley LLLW system.

Tank System N-71 piping is constructed of 1/2" and 2", 304L SS with a maximum design pressure and temperature of $150 \mathrm{psig}$ and $125^{\circ} \mathrm{F}$. Tank System N-71 piping has a maximum volume of 80 gal.

\section{Design Standards}

The applicable codes and standards used for Tank System N-71 piping and its associated secondary containment systems are identified herein. The codes and standards listed are those identified on either the design drawings or the construction specifications.

AEC-Oak Ridge Office, Minimum Safety Requirements;

American Concrete Institute;

American Society for Testing and Materials;

American Society of Mechanical Engineers (ASME) Boiler and Pressure Vessel Code, Section II (SA-240);

Atomic Energy Commission (AEC) General Design Criteria;

Instrument Society of America;

National Fire Protection Association; 
National Plumbing Code; and

Underwriters Laboratories Inc.

\subsubsection{Generic Description of Piping Content}

Tank System N-71 piping is designed to serve as a radioactive LLLW laboratory transfer piping system for the Building 3019 southwest drain header. LLLW includes raffinates from extraction processes; overheads from evaporation processes; and liquids left after analyses, decontamination solutions, and bench-scale experimental processes. The wastes may also include a variety of laboratory-generated acids and bases, typically nitric and caustic.

The analytical data (Figure 2.11-3) of waste stream contaminants from the generators are representative of the waste transferred through Tank System N-71 piping.

\subsubsection{Pipe Corrosion Protection Measures}

Piping inside the southwest area of Building 3019 and Tank Vault N-71 has no direct contact with the soil or water. Cathodic protection measures are not required for external corrosion.

\subsubsection{Documented Age of Tank System}

Tank System N-71 piping was installed in 1954.

\subsubsection{Standards for Containment/Release Detection}

2.11.3.1 Constructed of or Lined with Materials That are Compatible with Stored Waste(s) or Substance(s) to Be Placed in the Tank System and Shall Have Sufficient Strength and Thickness to Prevent Failure

Tank System N-71 piping is single-wall, schedule 40S, type 304L SS that is routed inside Building 3019 from the southwest area to Tank Vault N-71. Areas of secondary containment are discussed below.

\section{Tank Vault N-71}

The assessment of the secondary containment system for Tank Vault N-71 is presented in the Design Demonstrations for Tank N-71. That assessment concludes that Tank Vault N-71 is lined with materials that are compatible with the waste and designed to prevent migration of waste into the concrete. 


\section{Southwest Area of Building 3019}

The southwest area of Building 3019 is constructed of reinforced concrete and provided with a coating on the concrete. The piping in the area is aboveground and visually inspected. In the event of a leak, the liquid would be manually removed.

The assessment concludes that the tank vault is lined with materials that are compatible with the waste and designed to prevent migration of waste into the concrete. The southwest area of Building 3019 is an aboveground visually inspected area.

2.11.3.2 Placed on Foundation or Base Capable of Providing Support to the Secondary Containment System

\section{Tank Vault N-71}

The assessment of the secondary containment system for Tank Vault N-71 is presented in the Design Demonstrations for Tank N-71. That assessment concludes that the vault foundation is properly designed to support the secondary containment system.

\section{Southwest Area of Building 3019}

The foundation base in the southwest area of Building 3019 is an 18" thick, reinforced concrete base slab that was designed with a minimum 28-day compressive strength of 3000 psi.

The assessment concludes that the tank vault and the southwest area foundations are properly designed to support the secondary containment system.

2.11.3.3 Provided with a Leak Detection System That is Designed and Operated to Detect Failure of Either Primary or Secondary Containment Structure or the Presence of Any Measurable Release of Hazardous or Radioactive Constituents

\section{Tank Vault N-71}

The assessment of the secondary containment system for Tank Vault N-71 is presented in the Design Demonstrations for Tank $\mathrm{N}-71$. That assessment concludes that the vault is provided with a leak detection system.

\section{Southwest Area of Building 3019}

Leak detection is performed by visual inspection of the piping system conducted once each operating day.

The assessment concludes that the tank vault is provided with a leak detection system. Leak detection of the piping system is performed by visual inspection once each operating day in the southwest area of Building 3019. 
Design Demonstrations - Category B Tank Systems (Piping)

2.11.3.4 Sloped or Otherwise Designed or Operated to Drain and Remove Liquids Resulting from Leaks, Spills, or Precipitation

\section{Tank Vault N-71}

The assessment of the secondary containment system for Tank Vault N-71 is presented in the Design Demonstrations for Tank N-71. That assessment concludes that the secondary containment is sloped and designed to drain and remove liquids resulting from leaks, spills, or precipitation.

\section{Southwest Area of Building 3019}

The floor in the southwest area of Building 3019 is sloped to low points and has permanently plugged drains. The piping in the area is aboveground and visually inspected. In the event of a leak, the liquid would be manually removed.

The assessment concludes that the tank vault is sloped and designed to drain and remove liquids resulting from leaks, spills, or precipitation. The southwest area floor is sloped to low points. The piping in the area is aboveground and visually inspected. In the event of a leak, the liquid would be manually removed.

\subsubsection{Supplemental Information}

\subsubsection{Ancillary Equipment}

Tank N-71 is constructed of 304L SS, which is the same material as that used in the piping system, and is located in Tank Vault N-71, which provides secondary containment. The support equipment is exposed to the same liquids as other components of the tank system; therefore, type 304L SS is an acceptable material for the support equipment.

\subsubsection{Waste Acceptance Criteria}

Radioactively contaminated liquid wastes at the Oak Ridge National Laboratory (ORNL) are generated by various activities within the research and operating division. These activities include radiochemical processing, routine hot cell operations and decontaminations, and various waste treatment and environmental protection processes. The variations in composition of the waste streams are limited by the waste acceptance criteria that specify activity and concentration limits for waste discharged into the LLLW system. The Waste Acceptance Criteria for Liquid Waste Treatment Systems at the Oak Ridge National Laboratory (Oak Ridge National Laboratory, 1991), dated July 1991, is a guide for liquid waste generators to determine the proper means of disposal for LLLW. The criteria provide future discharge guidelines for the LLLW system, which includes Tank System N-71. 
Design Demonstrations - Category B Tank Systems (Piping)

\subsubsection{References}

Binford, F. T., and S. D. Orfi. 1979. The Intermediate-Level Liquid Waste System at the Oak Ridge National Laboratory Description and Safety Analysis. ORNL/TM-6959. Oak Ridge National Laboratory.

Ebasco, and Main. May 14, 1993. Design Demonstrations-Category B Tank Systems, Revision 2. DOE Contract No. DE-AC05-91OR21928. Oak Ridge National Laboratory.

Energy Systems Drawing D-10616, Basement Plan, Revision C.

Energy Systems Drawing D-14161, Cell 5 Plan and Details, Dated 7/2/53 (No Revision No.).

Energy Systems Drawing I-11203, Cell 6 Piping Elevations "B-B" and "C-C", Dated 4/27/54 (No Revision No.).

Energy Systems Drawing D-11201, Cell 6 Process Piping Plans, Revision 1.

Energy Systems Drawing E-2354, Cell 6 and 7 Piping Lower Plan and Section D-D, Dated 5/1/47 (No Revision No.).

Energy Systems Drawing D-14165, Cell 6 and 7 Plan and Details, Revision 2.

Energy Systems Drawing D-14167, Cell 6 and 7 Sections and Details, Revision 2.

Energy Systems Drawing D-14168, Cell 6 and 7 Sections and Details, Revision 1.

Energy Systems Drawing D-14169, Cell 6 and 7 Sections and Details, Revision 1.

Energy Systems Drawing E-11731, Cell 7 Piping Flowsheet, Sheet 2, Revision 2.

Energy Systems Drawing D-17188, Drain Piping for Cell 6 and 7, Revision 1.

Energy Systems Drawing D-23534, Equipment Layout Cell 6 and 7 Lower Plan, Revision 3.

Energy Systems Drawing D-14534, Equipment Layout Make-Up Area Plan, Revision 3.

Energy Systems Drawing D-14535, Equipment Layout Make-Up Area Section A-A, Revision 2.

Energy Systems Drawing M-12229-CP-047-D, Equipment Layout Plan, Revision 1.

Energy Systems Drawing M-12229-CP-049-D, Equipment Layout Section, Dated 4/31/71 (No Revision No.). 
Energy Systems Drawing E-55205, Isometric Piping SW Corner Cell 7, Dated 10/62 (No Revision No.).

Energy Systems Drawing D-10619, North and South Elevations, Revision E.

Energy Systems Drawing D-10615, Plot Plan, Revision E.

Energy Systems Drawing E-5393, Process Drain System Plan, Revision 3.

Energy Systems Drawing D-10667, Site Plan and Details, Revision B.

Energy Systems Drawing D-14185, Tank Supports Plan and Details, Revision 1.

Energy Systems Drawing H-20327-EG-075-E, Ventilation Flow Diagram, Revision 0.

Energy Systems Drawing D-40310, Waste Catch Tank, Dated 1/7/54 (No Revision No.).

Energy Systems Drawing D-40311, Waste Catch Tank Details, Dated 1/11/54 (No Revision No.).

LLLW Generator Survey 1990 for Building 3019.

Oak Ridge National Laboratory. 1984. Final Safety Analysis Report for the Radiochemical Processing Plant (RPP). ORNL/CF-81/37. Oak Ridge National Laboratory.

Oak Ridge National Laboratory. 1991. Waste Acceptance Criteria for Liquid Waste Treatment Systems at the Oak Ridge National Laboratory. WM-WMCO-201. Department of Waste Minimization Planning and Certification.

Peretz, F. J., et al. 1986. Characterization of Low-Level Liquid Wastes at the Oak Ridge National Laboratory. ORNL/TM-10218. Oak Ridge National Laboratory.

R. M. Parsons Co. 1977. National Disturbance Analysis of Buildings 7930 and 3019. Document No. X-OE-23.

Robinson, S. M., S. M. DePaoli, and A. B. Walker. 1991. Federal Facilities Agreement Contingency, Upgrade, and Replacement Plans for the ORNL Active Low-Level Radioactive Waste Tank System. ORNL/TM-11795. Oak Ridge National Laboratory. 


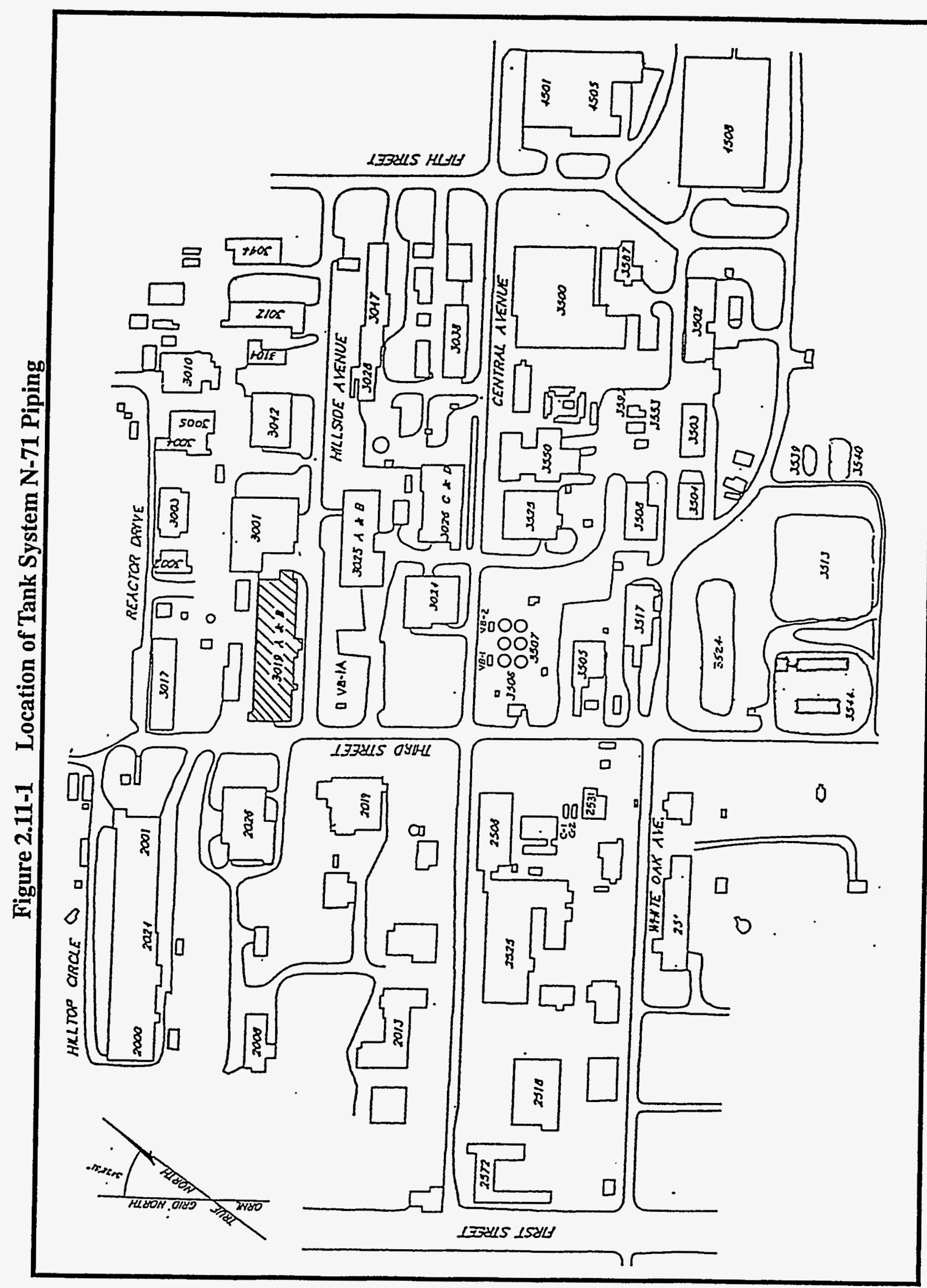




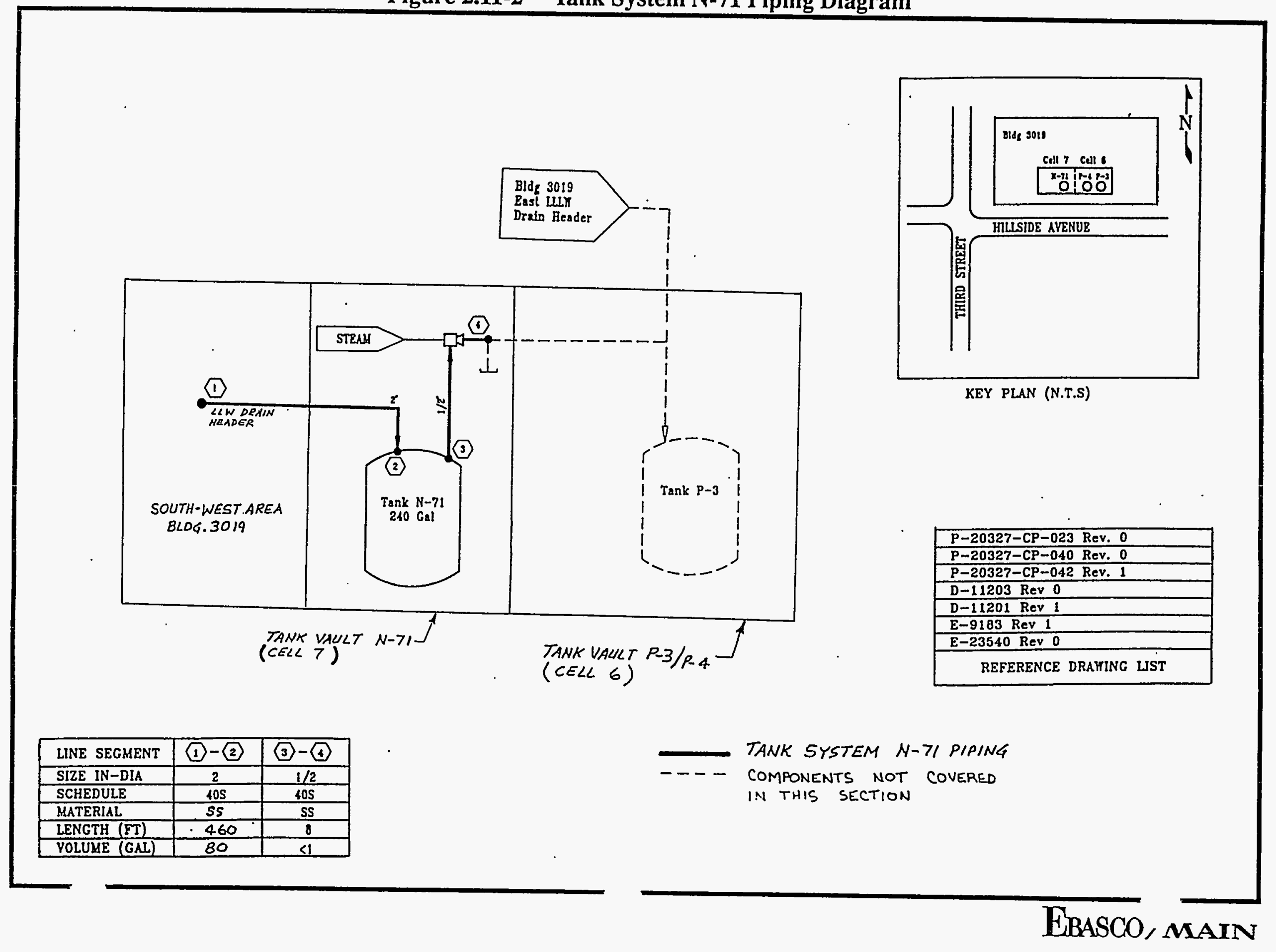


WASTE STREAM CONTAMINANTS:

(a) Isotopes:
$\mathrm{Sr}-90$

Cs-137

\begin{tabular}{c} 
Cs-137 \\
\hline$U-235$ \\
\hline$U-238$ \\
\hline$U-233$ \\
\hline$T h-232$ \\
\hline
\end{tabular}

(b) Quantities Trace

Trace

\begin{tabular}{c} 
Trace \\
\hline $0.4 \mathrm{~g} /$ year \\
\hline $50.0 \mathrm{~g} /$ year \\
\hline $1.0 \mathrm{~g} /$ year \\
\hline $100.0 \mathrm{~g} /$ year \\
\hline
\end{tabular}

(b) Others (i.e. acids, bases, organics, cleaners, etc.) nitric acid
$4.7 \mathrm{Kg} /$ year 
Tank System P-3 is located at the Radiochemical Development Facility (Building 3019) at the main Bethel Valley Complex (Figures 2.12-1 and 2.12-2). The tank system piping is constructed of schedule 40S, ASME SA-240, type 347 and 304L stainless steel (SS); is routed outside underground from Tank Vault P-3/P-4 to Valve Box-1A; and continues outside underground to Valve Box No. 1. The piping is also routed inside the building from Tank Vault P-3/P-4 to Tank Vault N-71 and from Tank Vault P-3/P-4 to Cells 1, 2, 3, and 5 and to the east, central, and west tunnels. The Tank System P-3 piping is used to transfer liquid low-level waste (LLLW) outside underground from Building 3019 to Valve Box No. 1 and is classified as a Federal Facility Agreement Category B tank system.

\subsubsection{Standards for Pipe Assessment of Tank Systems}

\subsubsection{Tank System Piping Description and Design Standards}

\section{Tank System Piping Description}

Tank System P-3 piping is located at Building 3019, is routed outside underground from Tank Vault P-3/P-4 to Valve Box-1A, and continues outside underground to Valve Box No. 1. The piping is also routed inside the building from Tank Vault P-3/P-4 to Tank Vault N-71 and from Tank Vault P-3/P-4 to Cells $1,2,3$, and 5 and to the east, central, and west tunnels. The piping system is used and managed by the Chemical Technology Division and is part of the Bethel Valley LLLW system.

Tank System P-3 piping is constructed of $1^{\prime \prime}, 2^{\prime \prime}$, and $3^{\prime \prime}, 347$ and 304L SS with a maximum design pressure and temperature of $150 \mathrm{psig}$ and $125^{\circ} \mathrm{F}$. Tank System P-3 piping has a maximum volume of 295 gal.

\section{Design Standards}

The applicable codes and standards used for Tank System P-3 piping and its associated secondary containment systems are identified herein. The codes and standards listed are those identified on either the design drawings or the construction specifications.

AEC-Oak Ridge Office, Minimum Safety Requirements;

American Concrete Institute;

American Society for Testing and Materials;

American Society of Mechanical Engineers (ASME) Boiler and Pressure Vessel Code, Section II (SA-240); 
Atomic Energy Commission (AEC) General Design Criteria;

Instrument Society of America;

National Fire Protection Association;

National Plumbing Code; and

Underwriters Laboratories Inc.

\subsubsection{Generic Description of Piping Contents}

Tank System P-3 piping is designed to serve as part of a radioactive LLLW process transfer piping system from Tank P-3 and the east drain header in Building 3019 to Valve Box No. 1. The LLLW includes raffinates from extraction processes, overheads from evaporation processes, and liquids left after analyses and bench-scale experimental processes. The waste may also include a variety of laboratory-generated acids and bases, typically nitric and caustic.

The analytical data (Figure 2.12-3) of waste stream contaminants from the generators are representative of the waste transferred through Tank System P-3.

\subsubsection{Pipe Corrosion Protection Measures}

Piping inside Tank Vault P-3/P-4; Tank Vault N-71; Cells 1, 2, 3, and 5; the east, central, and west tunnels; Valve Box-1A; and Valve Box No. 1 has no direct contact with the soil or water. Cathodic protection measures are not required for external corrosion.

The section of piping that is routed outside underground from Tank Vault P-3/P-4 to Valve Box-1A is singly contained, schedule 40S, type 347 SS, with the exterior surfaces of the pipe in direct contact with the soil and water. Protective coatings or cathodic protection measures are not present in this section of underground piping.

The section of piping that is routed outside underground from Valve Box-1A to Valve Box No. 1 is doubly contained. The core pipe is schedule 40S, type 304L SS; and the jacket is schedule 10S, type 304L SS. The exterior of the jacket is in direct contact with the soil and water and is provided with cathodic protection as described below.

The cathodic protection for the outside underground LLLW piping between Valve Box-1A and Valve Box No. 1 is included in the Facility Manager's Cathodic Protection System No. 20. A galvanic anode cathodic protection system was installed in 1984. The system is made up of magnesium anodes, test stations, and connecting wire as shown on the installation drawings E3E20013D021 and E3E20013D022. The design of the cathodic protection system called for electrical isolation devices to be installed. The cathodic protection system design, as shown on the drawings reviewed, is considered to be adequate. 
The cathodic protection test report and survey performed in 1990 and 1991 indicate overall effective cathodic protection on the piping except for $10^{\prime}$ of pipe at the end near Valve Box-1A.

\subsubsection{Documented Age}

Tank System P-3 piping was placed in operation in 1954. The section of piping between Valve Box-1A and Valve Box No. 1 was installed in 1984.

\subsubsection{Standards for Containment/Release Detection}

Tank System P-3 piping incorporates approximately $290^{\prime}$ of outside underground piping that is singly contained and approximately $430^{\prime}$ of outside underground piping that is doubly contained. The singly contained area is omitted from discussion in the following sections that address secondary containment.

2.12.3.1 Constructed of or Lined with Materials That are Compatible with Stored Waste(s) or Substance(s) to Be Placed in the Tank System and Shall Have Sufficient Strength and Thickness to Prevent Failure

Tank System P-3 piping is single-wall, schedule 40S, type 347 and type 304L SS, with a section of piping that is double wall. The jacket of the double-wall piping is schedule 10S, type 304L SS. The piping is routed outside underground from Tank Vault P-3/P-4 to Valve Box-1A and continues outside underground to Valve Box No. 1. The piping is also routed from Tank Vault P-3/P-4 to Tank Vault N-71 and from Tank Vault P-3/P-4 to Cells 1, 2, 3, and 5 and to the east, central, and west tunnels. Each area is discussed below. The piping penetrations in the cell and tunnel walls are routed through stainless steel sleeves that are embedded in the concrete walls. The annulus of the sleeves are sealed with an unspecified material. The stainless steel sleeves are compatible with the waste. The piping penetrations from Tank Vault P-3/P-4 to outside underground and from Valve Box-1A to outside underground are routed through stainless steel sleeves embedded in the concrete walls. The annulus of the sleeves are sealed with oakum and bitumastic seal. The stainless steel sleeves are compatible with the waste.

\section{Tank Vaults P-3/P-4 and N-71}

The assessments of the secondary containment systems for Tank Vaults P-3/P-4 and N-71 are presented in the Design Demonstrations for Tanks P-3, P-4, and N-71. Those assessments conclude that the tank vaults are lined with materials that are compatible with the waste and designed to prevent migration of waste into the concrete.

\section{East Area Building 3019}

The east area of Building 3019 consists of Cells 1, 2, 3, and 5; the East Tunnel; the Center Tunnel; and the West Tunnel. The bottom of each of the cells and tunnels are lined with 11-gauge (1/8"), $304 \mathrm{~L} \mathrm{SS}$, with sidewalls that project 4 " up the walls. The SS lining material is compatible with the waste and designed to prevent migration of waste into the concrete. 
Design Demonstrations - Category B Tank Systems (Piping)

\section{Valve Box-1A}

The bottom of Valve Box-1A is lined with 16-gauge (1/16"), 304L SS, which projects $2^{\prime} 0^{\prime \prime}$ up the valve box sidewalls. The SS lining material is compatible with the waste and designed to prevent migration of waste into the concrete.

\section{Valve Box No. 1}

The bottom of Valve Box No. 1 is lined with 16-gauge (1/16"), 304L SS, which projects $2^{\prime} 0^{\prime \prime}$ up the valve box sidewalls. The SS lining material is compatible with the waste and designed to prevent migration of waste into the concrete.

\section{Outside Underground Piping}

The jacket of the outside underground, double-wall pipe is schedule 10S, type 304L SS. The secondary containment material is compatible with the waste.

The assessment concludes that the tank vaults, the east area of Building 3019, and the valve boxes are lined with materials that are compatible with the waste and designed to prevent migration of waste into the concrete. The assessment concludes that the jacket of the double-wall pipe is constructed of a material that is compatible with the waste.

\subsubsection{Placed on Foundation or Base Capable of Providing Support to the Secondary Containment System}

\section{Tank Vaults P-3/P-4 and N-71}

The assessments of the secondary containment systems for Tank Vaults P-3/P-4 and N-71 are presented in the Design Demonstrations for Tanks P-3, P-4, and N-71. Those assessments conclude that the vault foundations are properly designed to support the secondary containment system.

\section{East Area Building 3019}

The foundation for each cell and tunnel in the east area of Building 3019 is an $18^{\prime \prime}$ thick, reinforced concrete base slab designed with a minimum 28-day compressive strength of 3000 psi.

\section{Valve Box-1A}

The valve box foundation is a $7^{\prime} 0^{\prime \prime} \times 16^{\prime} 0^{\prime \prime}$ with a $12^{\prime \prime}$ thick, reinforced concrete base slab that rests on limestone.

\section{Valve Box No. 1}

The valve box foundation is a $6^{\prime} 8^{\prime \prime} \times 19^{\prime} 2^{\prime \prime} \times 10^{\prime \prime}$ thick, reinforced concrete base slab that rests on limestone. 
The assessment concludes that the tank vaults, the east area of Building 3019, and the valve boxes are properly designed to support the secondary containment systems.

\subsubsection{Provided with a Leak Detection System That is Designed and Operated to Detect Failure of Either Primary or Secondary Containment Structure or the Presence of Any Measurable Release of Hazardous or Radioactive Constituents}

\section{Tank Vaults P-3/P-4 and N-71}

The assessments of the secondary containment systems for Tank Vaults P-3/P-4 and N-71 are presented in the Design Demonstrations for Tanks P-3, P-4, and N-71. Those assessments conclude that the vaults are provided with a leak detection system.

\section{East Area Building 3019}

The secondary containment of each cell and tunnel is sloped to an 11-gauge (1/8"), 304L SS-lined sump where accumulation of liquid will be detected by a level sensor that will activate an alarm in the operating area of Building 3019.

\section{Valve Box-1A}

The Valve Box-1A floor is sloped to a 16-gauge $\left(1 / 16^{\prime \prime}\right)$, 304L SS-lined sump where accumulation of liquid will be detected by a level sensor that will activate an alarm in the Waste Operations Control Center (Building 3130).

\section{Valve Box No. 1}

The Valve Box No. 1 floor is sloped to a 16-gauge ( $\left.1 / 16^{\prime \prime}\right)$, 304L SS-lined sump where accumulation of liquid will be detected by a level sensor that will activate an alarm in the Waste Operations Control Center (Building 3130).

\section{Outside Underground Piping}

The doubly contained underground piping associated with this system is provided with a nitrogenblanketed leak detection system.

The assessment concludes that the tank vaults, the east area of Building 3019, Valve Box-1A, Valve Box No. 1, and the doubly contained underground piping are provided with leak detection systems. 
Design Demonstrations - Category B Tank Systems (Piping)

2.12.3.4 Sloped or Otherwise Designed or Operated to Drain and Remove Liquids Resulting from Leaks, Spills, or Precipitation

\section{Tank Vaults P-3/P-4 and N-71}

The assessments of the secondary containment systems for Tank Vaults P-3/P-4 and N-71 are presented in the Design Demonstrations for Tanks P-3, P-4, and N-71. Those assessments conclude that the secondary containments are sloped and designed to drain and remove liquids resulting from leaks, spills, or precipitation.

\section{East Area Building 3019}

The secondary containment of each cell and tunnel floor is sloped to a 304L SS-lined sump. The sump provides a low point to drain liquids to an instrumented location. A pumping system is provided to remove liquids resulting from leaks, spills, or precipitation.

\section{Valve Box-1A}

The Valve Box-1A floor is sloped to a 304L SS-lined sump. The sump provides a low point within the valve box to drain liquids to an instrumented location. A pumping system is provided to remove liquids resulting from leaks, spills, or precipitation.

\section{Valve Box No. 1}

The Valve Box No. 1 floor is sloped to a 304L SS-lined sump. The sump provides a low point within the valve box to drain liquids to an instrumented location. A pumping system is provided to remove liquids resulting from leaks, spills, or precipitation.

\section{Outside Underground Piping}

The doubly contained outside underground piping is sloped and provided with a valved nitrogen tap connection at the low point of the line. In the event of a leak, the nitrogen line would be disconnected and the liquid would be removed through the valved connection.

The assessment concludes that the tank vaults, the east area of Building 3019 , Valve Box-1A, Valve Box No. 1, and the doubly contained underground piping are sloped and designed to drain and remove liquids resulting from leaks, spills, or precipitation.

\subsubsection{Supplemental Information}

\subsubsection{Ancillary Equipment}

Tank P-3 is constructed of 347 SS, which is the same material to that used in the piping system, and is located in Tank Vault P-3/P-4, which provides secondary containment. The support equipment 
is exposed to the same liquids as other components of the tank system; therefore, 347 SS is an acceptable material for the support equipment.

\subsubsection{Waste Acceptance Criteria}

Radioactively contaminated liquid wastes at the Oak Ridge National Laboratory (ORNL) are generated by various activities within the research and operating divisions. These activities include radiochemical processing, routine hot cell operations and decontaminations, and various waste treatment and environmental protection processes. The variations in composition of the waste streams are limited by the waste acceptance criteria that specify activity and concentration limits for waste discharged into the LLLW system. The Waste Acceptance Criteria for Liquid Waste Treatment Systems at the Oak Ridge National Laboratory (Oak Ridge National Laboratory, 1991), dated July 1991, is a guide for liquid waste generators to determine the proper means of disposal for LLLW. The criteria provide future discharge guidelines for the LLLW system, which includes Tank System P-3. 


\subsubsection{References}

Binford, F. T., and S. D. Orfi. 1979. The Intermediate-Level Liquid Waste System at the Oak Ridge National Laboratory Description and Safety Analysis. ORNL/TM-6959. Oak Ridge National Laboratory.

Ebasco, and Main. May 14, 1993. Design Demonstrations-Category B Tank Systems, Revision 2. DOE Contract No. DE-AC05-91OR21928. Oak Ridge National Laboratory.

Energy Systems Drawing D-10616, Basement Plan, Revision C.

Energy Systems Drawing D-14161, Cell 5 Plan and Details, Dated 7/2/53 (No Revision No.).

Energy Systems Drawing D-11203, Cell 6 Piping Elevations "B-B" and "C-C", Dated 4/27/54 (No Revision No.).

Energy Systems Drawing D-11201, Cell 6 Process Piping Plans, Revision 1.

Energy Systems Drawing E-2354, Cell 6 and 7 Piping Lower Plan and Section D-D, Dated 5/1/47 (No Revision No.).

Energy Systems Drawing D-14165, Cell 6 and 7 Plan and Details, Revision 2.

Energy Systems Drawing D-14167, Cell 6 and 7 Sections and Details, Revision 2.

Energy Systems Drawing D-14168, Cell 6 and 7 Sections and Details, Revision 1.

Energy Systems Drawing D-14169, Cell 6 and 7 Sections and Details, Revision 1.

Energy Systems Drawing E-11731, Cell 7 Piping Flowsheet, Sheet 2, Revision 2.

Energy Systems Drawing D-17188, Drain Piping for Cell 6 and 7, Revision 1.

Energy Systems Drawing D-23534, Equipment Layout Cell 6 and 7 Lower Plan, Revision 3.

Energy Systems Drawing D-14534, Equipment Layout Make-Up Area Plan, Revision 3.

Energy Systems Drawing D-14535, Equipment Layout Make-Up Area Section A-A, Revision 2.

Energy Systems Drawing M-12229-CP-047-D, Equipment Layout Plan, Revision 1.

Energy Systems Drawing M-12229-CP-049-D, Equipment Layout Section, Dated 4/31/71 (No Revision No.). 
Design Demonstrations - Category B Tank Systems (Piping)

Energy Systems Drawing E-55205, Isometric Piping SW Corner Cell 7, Dated 10/62 (No Revision No.).

Energy Systems Drawing D-10619, North and South Elevations, Revision E.

Energy Systems Drawing P3E-20013-C-013, Piping Details Double Contained Pipe, Revision 0.

Energy Systems Drawing P3E-20013-C-014, Piping Details Double Contained Pipe, Revision 0.

Energy Systems Drawing P3E-20013-C-011, Piping Plan Double Contained Pipe, Revision 0.

Energy Systems Drawing D-10615, Plot Plan, Revision E.

Energy Systems Drawing E-5393, Process Drain System Plan, Revision 3.

Energy Systems Drawing D-10667, Site Plan and Details, Revision B.

Energy Systems Drawing D-14185, Tank Supports Plan and Details, Revision 1.

Energy Systems Drawing H-20327-EG-075-E, Ventilation Flow Diagram, Revision 0.

Energy Systems Drawing D-40310, Waste Catch Tank, Dated 1/7/54 (No Revision No.).

Energy Systems Drawing D-40311, Waste Catch Tank Details, Dated 1/11/54 (No Revision No.).

Energy Systems Drawing E3E20013D021, Cathodic Protection Plan, Revision 0.

Energy Systems Drawing E3E20013D022, Cathodic Protection Plan, Revision 0.

Harco Technologies Corporation. August 1991. Cathodic Protection System Upgrade Design Underground ILW Lines, VLV Box IA to VLV Box I, System No. 20. Oak Ridge National Laboratories, United States Department of Energy, Oak Ridge, Tennessee. Martin Marietta Energy Systems, Inc.

Harco Technologies Corporation. June 1990. Resurvey of the Cathodic Protection Systems, Oak Ridge National Laboratories, United States Department of Energy, Oak Ridge, Tennessee. Martin Marietta Energy Systems, Inc.

Kenner, K., Ebasco. August 27, 1993. Record of Telephone Conversation with M. Peet, Martin Marietta Energy Systems, Inc. Re: Addition of leak detection and liquid removal system to Valve Box-1A.

LLLW Generator Survey 1990 for Building 3019. 
Oak Ridge National Laboratory. 1984. Final Safety Analysis Report for the Radiochemical Processing Plant (RPP). ORNL/CF-81/37. Oak Ridge National Laboratory.

Oak Ridge National Laboratory. 1991. Waste Acceptance Criteria for Liquid Waste Treatment Systems at the Oak Ridge National Laboratory. WM-WMCO-201. Department of Waste Minimization Planning and Certification.

Peretz, F. J., et al. 1986. Characterization of Low-Level Liquid Wastes at the Oak Ridge National Laboratory. ORNL/TM-10218. Oak Ridge National Laboratory.

R. M. Parsons Co. 1977. National Disturbance Analysis of Buildings 7930 and 3019. Document No. X-OE-23.

Robinson, S. M., S. M. DePaoli, and A. B. Walker. 1991. Federal Facility Agreement Contingency, Upgrade, and Replacement Plans for the ORNL Active Low-Level Radioactive Waste Tank System. ORNL/TM-11795. Oak Ridge National Laboratory. 







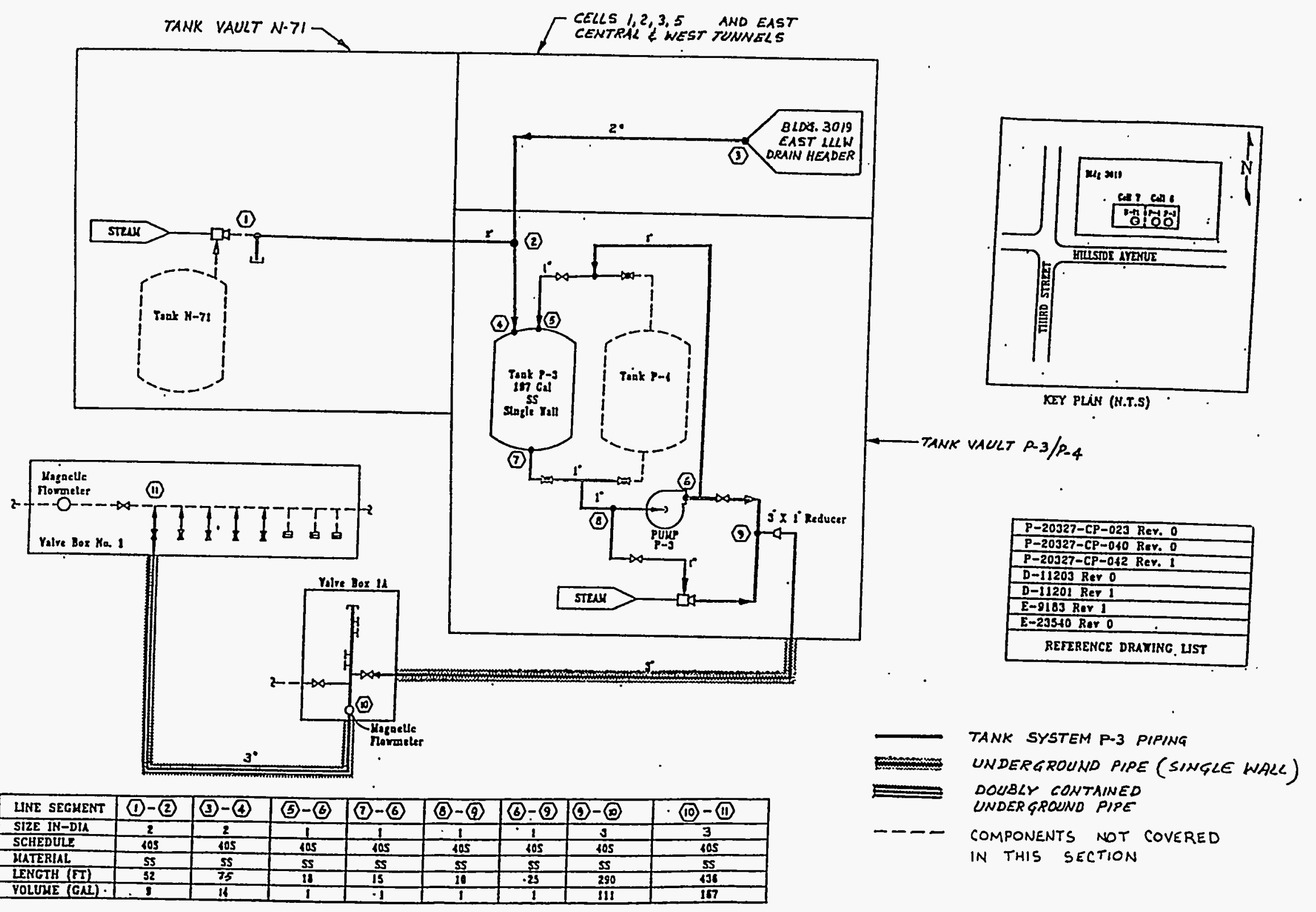


WASTE STREAM CONTAMINANTS:

(a) Isotopes:

\begin{tabular}{c}
$\mathrm{sr}-90$ \\
\hline $\mathrm{Cs}-137$ \\
\hline$U-235$ \\
\hline$U-238$ \\
\hline$U-233$ \\
\hline$T h-232$ \\
\hline
\end{tabular}

(b) Quantities

Trace

Trace

\begin{tabular}{c} 
Trace \\
\hline $0.4 \mathrm{~g} /$ year \\
\hline $50.0 \mathrm{~g} /$ year \\
\hline $1.0 \mathrm{~g} /$ year \\
\hline $100.0 \mathrm{~g} /$ year \\
\hline
\end{tabular}

(b) Others (i.e. acids, bases, organics, cleaners, etc.) nitric acid 


\section{$2.13 \quad$ Tank System P-4 Piping}

\subsubsection{Tank System Summary}

Tank System P-4 is located at the Radiochemical Development Facility (Building 3019) at the main Bethel Valley Complex (Figures 2.13-1 and 2.13-2). The tank system piping is schedule 40S, ASME SA-240, type 347 stainless steel (SS) and is routed within Tank Vault P-3/P-4. The Tank System P-4 piping is used to transfer liquid low-level waste (LLLW) to and from Tank P-4 and is classified as a Federal Facility Agreement Category B tank system.

\subsubsection{Standards for Pipe Assessment of the Tank System}

\subsubsection{Tank System Piping Description and Design Standards}

\section{Tank System Piping Description}

Tank System P-4 piping is routed within Tank Vault P-3/P-4, which is located in Building 3019. The piping system is used and managed by the Chemical Technology Division and is part of the Bethel Valley LLLW system.

Tank System P-4 piping is constructed of $1^{\prime \prime}, 347$ SS with a maximum design pressure and temperature of $150 \mathrm{psig}$ and $125^{\circ} \mathrm{F}$. Tank System P-4 piping has a maximum volume of 1 gal.

\section{$\underline{\text { Design Standards }}$}

The applicable codes and standards used for Tank System P-4 piping and its associated secondary containment system are identified herein. The codes and standards listed are those identified on either the design drawings or the construction specifications.

AEC-Oak Ridge Office, Minimum Safety Requirements;

American Concrete Institute;

American Society of Mechanical Engineers (ASME) Boiler and Pressure Vessel Code, Section II (SA-240);

American Society for Testing and Materials;

American Welding Society;

Atomic Energy Commission (AEC) General Design Criteria;

Concrete Reinforcing Steel Institute; 
Instrument Society of America;

National Fire Protection Association;

National Plumbing Code; and

Underwriters Laboratories Inc.

\subsubsection{Generic Description of Piping Content}

Tank System P-4 piping is designed to serve as part of a radioactive LLLW laboratory transfer piping system for Building 3019. LLLW includes raffinates from extraction processes; overheads from evaporation processes; and liquids left after analyses, decontamination solutions, and bench-scale experimental processes. The wastes may also include a variety of laboratory-generated acids and bases, typically nitric and caustic.

The analytical data (Figure 2.13-3) of waste stream contamination from the generators are representative of waste transferred through the Tank System P-4 piping.

\subsubsection{Pipe Corrosion Protection Measures}

Piping inside Tank Vault P-3/P-4 has no direct contact with the soil or water. Cathodic protection measures are not required for external corrosion.

\subsubsection{Documented Age of Tank System}

Tank System P-4 piping was installed in 1954.

\subsubsection{Standards for Containment/Release Detection}

2.13.3.1 Constructed of or Lined with Materials That are Compatible with Stored Waste(s) or Substance(s) to Be Placed in the Tank System and Shall Have Sufficient Strength and Thickness to Prevent Failure

Tank System P-4 piping is single-wall, schedule 40S, type 347 SS that is routed within Tank Vault P-3/P-4. The area is discussed below.

\section{Tank Vault P-3/P-4}

The assessments of the secondary containment system for Tank Vault P-3/P-4 are presented in the Design Demonstrations for Tanks P-3 and P-4. Those assessments conclude that Tank Vault P-3/P-4 is lined with materials that are compatible with the waste and designed to prevent migration of waste into the concrete. 
Design Demonstrations - Category B Tank Systems (Piping)

2.13.3.2 Placed on Foundation or Base Capable of Providing Support to the Secondary Containment System

\section{$\underline{\text { Tank Vault P-3/P-4 }}$}

The assessments of the secondary containment system for Tank Vault P-3/P-4 are presented in the Design Demonstrations for Tanks P-3 and P-4. Those assessments conclude that the vault foundation is properly designed to support the secondary containment system.

2.13.3.3 Provided with a Leak Detection System That is Designed and Operated to Detect Failure of Either Primary or Secondary Containment Structure or the Presence of Any Measurable Release of Hazardous or Radioactive Constituents

\section{$\underline{\text { Tank Vault P-3/P-4 }}$}

The assessments of the secondary containment system for Tank Vault P-3/P-4 are presented in the Design Demonstrations for Tanks P-3 and P-4. Those assessments conclude that the vault is provided with a leak detection system.

2.13.3.4 Sloped or Otherwise Designed or Operated to Drain and Remove Liquids Resulting from Leaks, Spills, or Precipitation

\section{Tank Vault P-3/P-4}

The assessments of the secondary containment system for Tank Vault P-3/P-4 are presented in the Design Demonstrations for Tanks P-3 and P-4. Those assessments conclude that the secondary containment is sloped and designed to drain and remove liquids resulting from leaks, spills, or precipitation.

\subsubsection{Supplemental Information}

\subsubsection{Ancillary Equipment}

Tank P-4 is constructed of 347 SS, which is the same material as that used in the piping system, and is located in Tank Vault P-3/P-4, which provides secondary containment. The support equipment is exposed to the same liquids as other components of the tank system; therefore, 347 SS is an acceptable material for the support equipment.

\subsubsection{Waste Acceptance Criteria}

Radioactively contaminated liquid wastes at the Oak Ridge National Laboratory (ORNL) are generated by various activities within the research and operating divisions. These activities include radiochemical processing, routine hot cell operations and decontaminations, and various waste treatment and environmental protection processes. The variations in composition of the waste streams are limited by the waste acceptance criteria that specify activity and concentration limits for 
waste discharged into the LLLW system. The Waste Acceptance Criteria for Liquid Waste Treatment Systems at the Oak Ridge National Laboratory (Oak Ridge National Laboratory, 1991), dated July 1991, is a guide for liquid waste generators to determine the proper means of disposal for LLLW. The criteria provide future discharge guidelines for the LLLW system, which includes Tank System P-4. 


\subsubsection{References}

Binford, F. T., and S. D. Orfi. 1979. The Intermediate-Level Liquid Waste System at the Oak Ridge National Laboratory Description and Safety Analysis. ORNL/TM-6959. Oak Ridge National Laboratory.

Ebasco, and Main. May 14, 1993. Design Demonstrations-Category B Tank Systems, Revision 2. DOE Contract No. DE-AC05-91OR21928. Oak Ridge National Laboratory.

Energy Systems Drawing D-10616, Basement Plan, Revision C.

Energy Systems Drawing D-14161, Cell 5 Plan and Details, Dated 7/2/53 (No Revision No.).

Energy Systems Drawing D-11203, Cell 6 Piping Elevations "B-B" and "C-C", Dated 4/27/54 (No Revision No.).

Energy Systems Drawing D-11201, Cell 6 Process Piping Plans, Revision 1.

Energy Systems Drawing E-2354, Cell 6 and 7 Piping Lower Plan and Section D-D, Dated 5/1/47 (No Revision No.).

Energy Systems Drawing D-14165, Cell 6 and 7 Plan and Details, Revision 2.

Energy Systems Drawing D-14167, Cell 6 and 7 Sections and Details, Revision 2.

Energy Systems Drawing D-14168, Cell 6 and 7 Sections and Details, Revision 1.

Energy Systems Drawing D-14169, Cell 6 and 7 Sections and Details, Revision 1.

Energy Systems Drawing E-1 1731, Cell 7 Piping Flowsheet, Sheet 2, Revision 2.

Energy Systems Drawing D-17188, Drain Piping for Cell 6 and 7, Revision 1.

Energy Systems Drawing D-23534, Equipment Layout Cell 6 and 7 Lower Plan, Revision 3.

Energy Systems Drawing D-14534, Equipment Layout Make-Up Area Plan, Revision 3.

Energy Systems Drawing D-14535, Equipment Layout Make-Up Area Section A-A, Revision 2.

Energy Systems Drawing M-12229-CP-047-D, Equipment Layout Plan, Revision 1.

Energy Systems Drawing M-12229-CP-049-D, Equipment Layout Section, Dated 4/31/71 (No Revision No.). 
Design Demonstrations - Category B Tank Systems (Piping)

Energy Systems Drawing E-55205, Isometric Piping SW Corner Cell 7, Dated 10/62 (No Revision No.).

Energy Systems Drawing D-10619, North and South Elevations, Revision E.

Energy Systems Drawing D-10615, Plot Plan, Revision E.

Energy Systems Drawing E-5393, Process Drain System Plan, Revision 3.

Energy Systems Drawing D-10667, Site Plan and Details, Revision B.

Energy Systems Drawing D-14185, Tank Supports Plan and Details, Revision 1.

Energy Systems Drawing H-20327-EG-075-E, Ventilation Flow Diagram, Revision 0.

Energy Systems Drawing D-40310, Waste Catch Tank, Dated 1/7/54 (No Revision No.).

Energy Systems Drawing D-40311, Waste Catch Tank Details, Dated 1/11/54 (No Revision No.).

LLLW Generator Survey 1990 for Building 3019.

Oak Ridge National Laboratory. 1984. Final Safety Analysis Report for the Radiochemical Processing Plant (RPP). ORNL/CF-81/37. Oak Ridge National Laboratory.

Oak Ridge National Laboratory. 1991. Waste Acceptance Criteria for Liquid Waste Treatment Systems at the Oak Ridge National Laboratory. WM-WMCO-201. Department of Waste Minimization Planning and Certification.

Peretz, F. J., et al. 1986. Characterization of Low-Level Liquid Wastes at the Oak Ridge National Laboratory. ORNL/TM-10218. Oak Ridge National Laboratory.

R. M. Parsons Co. 1977. National Disturbance Analysis of Buildings 7930 and 3019. Document No. X-OE-23.

Robinson, S. M., S. M. DePaoli, and A. B. Walker. 1991. Federal Facility Agreement Contingency, Upgrade, and Replacement Plans for the ORNL Active Low-Level Radioactive Waste Tank System. ORNL/TM-11795. Oak Ridge National Laboratory. 


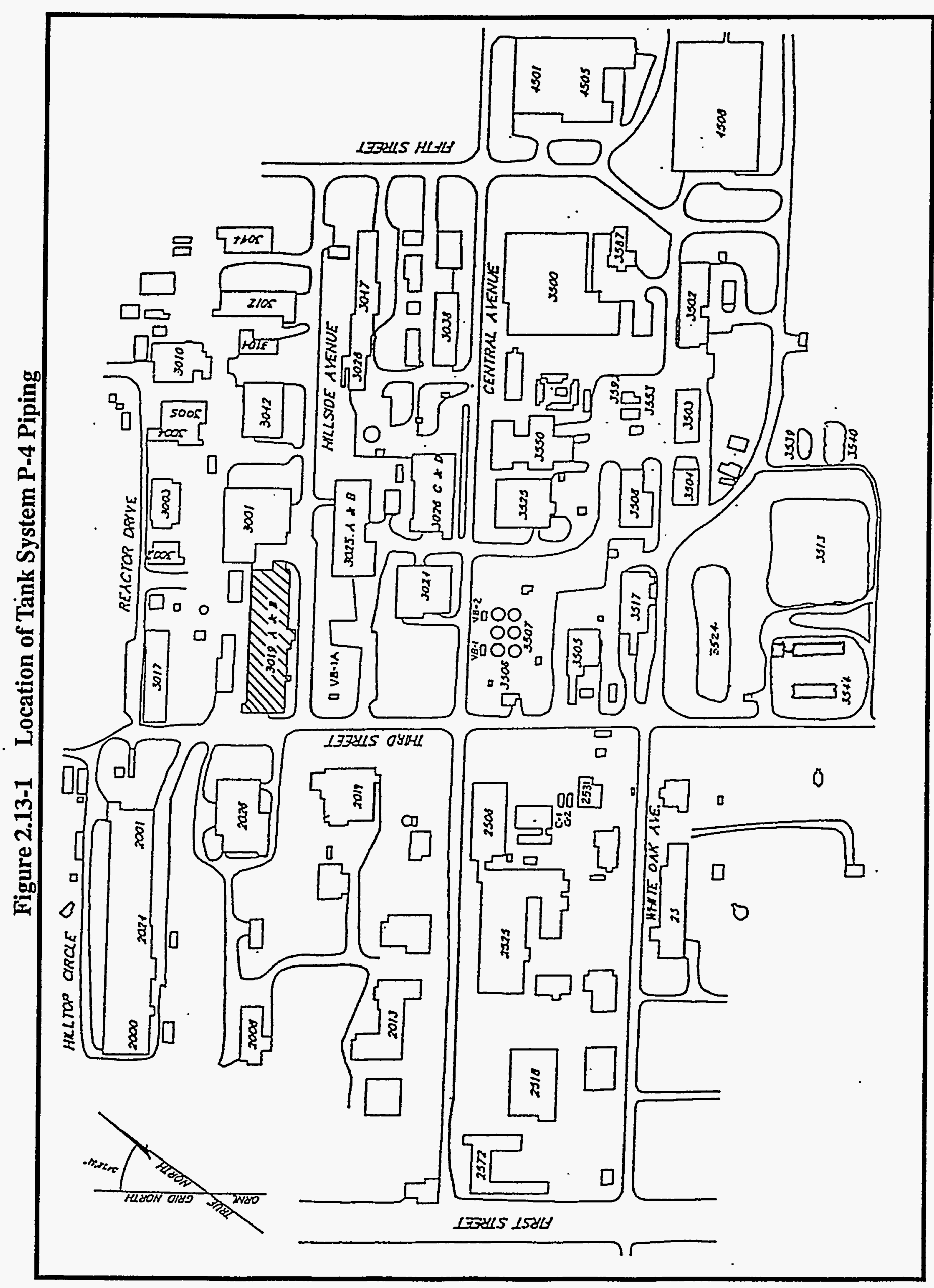


Figure 2.13-2 Tank System P-4 Piping Diagram

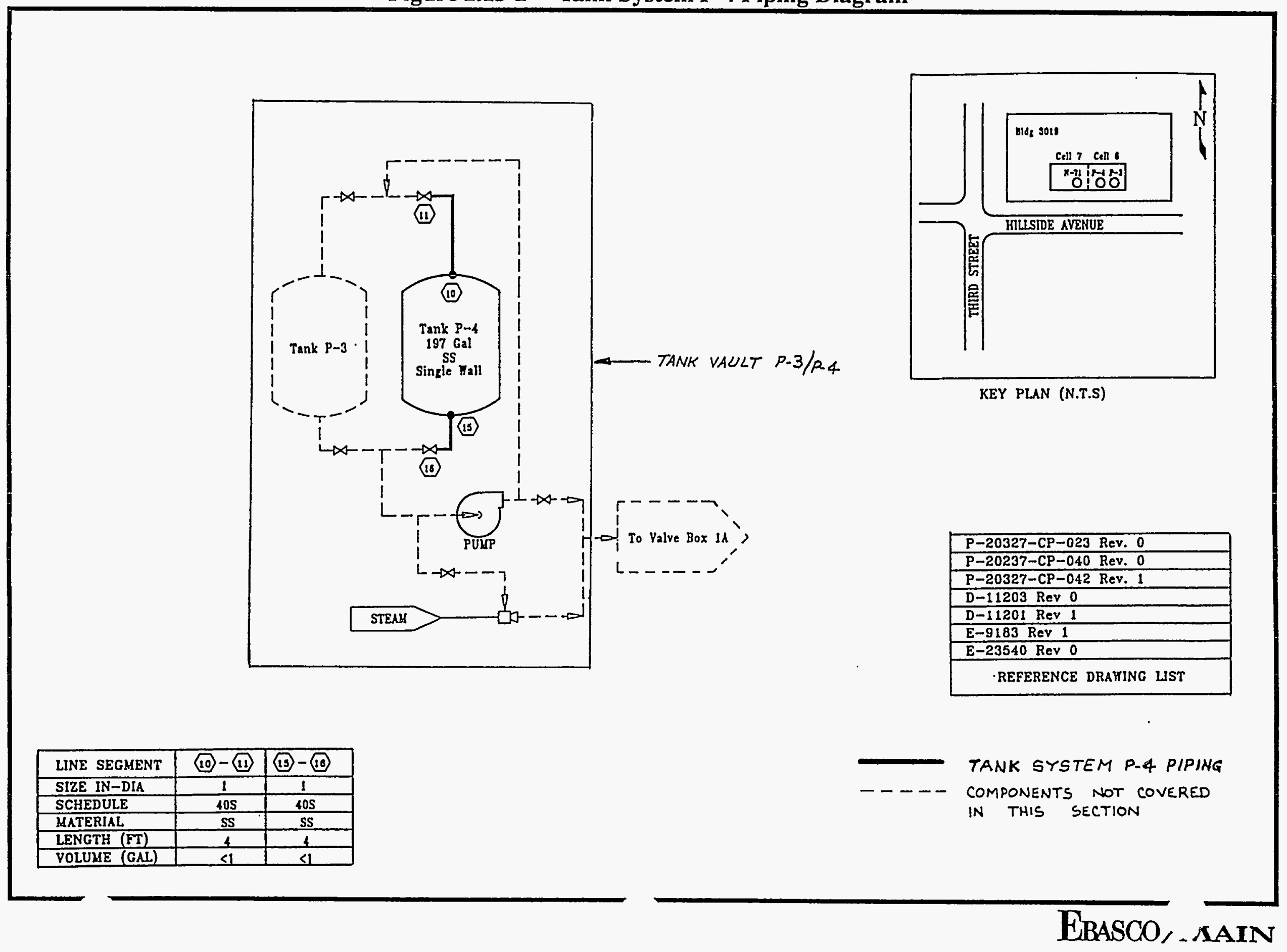


WASTE STREAM CONTAMINANTS:

(a) Isotopes:

$\mathrm{Sr}-90$

Cs -137

$U-235$

$\mathrm{U}-238$

$U-233$

Th-232

(b) Others (i.e. acids, bases, organics, cleaners, etc.)

nitric acid

(b) Quantities Trace Trace

\begin{tabular}{c} 
Trace \\
\hline 0.4 g/year \\
\hline $50.0 \mathrm{~g} /$ year \\
\hline $1.0 \mathrm{~g} /$ year \\
\hline $100.0 \mathrm{~g} /$ year \\
\hline
\end{tabular}

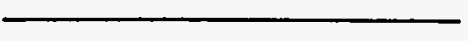

nitric acid


Tank System T-13 Piping

\subsubsection{Tank System Summary}

Tank System T-13 is located in the New Hydrofracture Facility (NHF) at Building 7860 in the main Melton Valley Complex (Figures 2.14-1 and 2.14-2). The tank system piping is schedule 40, polyvinyl chloride (PVC) pipe and schedule 40S, ASME SA-240, type 304L stainless steel (SS) and is routed from Tank Vault T-13 to the Metering Pit and Mixing Cell of the NHF. An additional, singly contained, embedded pipe is routed from Tank Vault T-13 to several floor drains within Building 7860. Tank System T-13 piping is used to transfer liquid low-level waste (LLLW) concentrate from the Hydrofracture Facility Process Tanks and is classified as a Federal Facility Agreement (FFA) Category B tank system.

\subsubsection{Standards for Pipe Assessment of Tank Systems}

\subsubsection{Tank System Piping Description and Design Standards}

\section{Tank System Piping Description}

Tank System T-13 piping is located at Building 7860 and is routed from Tank Vault T-13 to the Metering Pit and Mixing Cell of the NHF. An additional, singly contained, embedded pipe is routed from Tank Vault T-13 to several floor drains within Building 7860. The piping system is used and managed by the Waste Management and Remedial Actions Division.

Tank System T-13 piping is constructed of $3^{\prime \prime}$, schedule 40, PVC pipe and 2", 3", 4", and 6"; schedule 40S; type 304L SS pipe with a maximum design pressure and temperature of 150 psig and $125^{\circ} \mathrm{F}$. Tank System T-13 piping has a maximum volume of 151 gal.

\section{$\underline{\text { Design Standards }}$}

The applicable codes and standards used for Tank System T-13 piping and its associated secondary containment systems are identified herein. The codes and standards listed are those identified on either the design drawings or the construction specifications.

AEC-Oak Ridge Office, Minimum Safety Requirements;

AMCA Directory-Publication 261;

AMCA Fans and Systems-Publication 201;

Air Moving and Conditioning Association (AMCA) Standards Handbook—Publication 99;

American Conference of Governmental Industrial Hygienists;

American Concrete Institute 301-72; 
American Concrete Pipe Association;

American National Standards Institute;

American Society for Testing and Materials A48, C91, C139, C144, and D1751;

American Society of Heating, Refrigeration, and Air Conditioning Engineers (ASHRAE) Handbook of Fundamentals;

American Society of Mechanical Engineers (ASME) Boiler and Pressure Vessel Code, Sections II (SA-240) and VIII;

American Standards Association Standard B31.1-1955, Code for Pressure Piping;

ASHRAE Guide and Data Book-Applications;

ASHRAE Guide and Data Book-Equipment;

ASHRAE Handbook-Systems;

Atomic Energy Commission (AEC) General Design Criteria, Appendix 63;

Factory Mutual Engineering Corporation;

Instrument Society of America;

National Fire Protection Association (NFPA) No. 90A-Air Conditioning and Ventilating Systems;

NFPA No. 91-Blower and Exhaust Systems;

Nuclear Safety Information Center 65-Design, Construction, and Testing of High Efficiency Air Filtration Systems for Nuclear Applications;

Occupational Safety and Health Administration;

Sheet Metal and Air Conditioning Contractors National Association (SMACNA) High Velocity Duct Construction Standards and Low Velocity Standards;

SMACNA Ducted Electric Heat Guide for Air Handling Systems; and

Unfired Pressure Vessels (1962 edition). 


\subsubsection{Generic Description of Piping Contents}

Tank System T-13 piping is designed to serve as a waste piping system for the NHF and was previously used as a feed tank for LLLW to be used in the solidification process. The tank system is not presently used for programmatic waste; however, the tank system piping transfers groundwater.

\subsubsection{Pipe Corrosion Protection Measures}

Piping inside Tank Vault T-13, the Metering Pit, and the Mixing Cell has no direct contact with the soil or water. Cathodic protection measures are not required for external corrosion.

\subsubsection{Documented Age of Tank System}

Tank System T-13 piping was installed in 1979.

\subsubsection{Standards for Containment/Release Detection}

Tank System T-13 piping incorporates approximately $60^{\prime}$ of embedded piping that is singly contained. The singly contained areas are omitted from discussion in the following sections that address secondary containment.

2.14.3.1 Constructed of or Lined with Materials That are Compatible with Stored Waste(s) or Substance(s) to Be Placed in the Tank System and Shall Have Sufficient Strength and Thickness to Prevent Failure

Tank System T-13 piping is single-wall, schedule 40 PVC and schedule 40S, type 304L SS that is routed from Tank Vault T-13 to the Metering Pit and Mixing Cell of the NHF. An additional, singly contained, embedded pipe is routed from Tank Vault T-13 to several floor drains within Building 7860. The areas of secondary containment are discussed below.

\section{Tank Vault T-13}

The assessment of the secondary containment system for Tank Vault T-13 is presented in the Design Demonstrations for Tank T-13. That assessment concludes that Tank Vault T-13 is lined with materials that are compatible with the waste and designed to prevent migration of waste into the concrete.

\section{Metering Pit}

The bottom of the Metering Pit is lined with 11-gauge (1/8"), 304L SS, with sidewalls that project $2{ }^{\prime} 3^{\prime \prime}$ up the Metering Pit. The Metering Pit walls above the SS liner are provided with a three-coat system of Amercoat 99 epoxy. The SS lining material is compatible with the waste and designed to prevent migration of waste into the concrete. According to manufacturer's specifications, the Metering Pit's epoxy coating is compatible with the waste and designed to prevent migration of waste into the concrete. 


\section{Mixing Cell}

The bottom of the Mixing Cell is lined with 11-gauge (1/8"), 304L SS, with sidewalls that project $2^{\prime} 3^{\prime \prime}$ up the Mixing Cell. The Mixing Cell walls above the SS liner are provided with a three-coat system of Amercoat 99 epoxy. The SS lining material is compatible with the waste and designed to prevent migration of waste into the concrete. According to manufacturer's specifications, the Mixing Cell's epoxy coating is compatible with the waste and designed to prevent migration of waste into the concrete.

The assessment concludes that the tank vault, Metering Pit, and Mixing Cell are coated or lined with materials that are compatible with the waste and designed to prevent migration of waste into the concrete.

\subsubsection{Placed on Foundation or Base Capable of Providing Support to the Secondary Containment System}

\section{$\underline{\text { Tank Vault T-13 }}$}

The assessment of the secondary containment system for Tank Vault T-13 is presented in the Design Demonstrations for Tank T-13. That assessment concludes that the vault foundation is properly designed to support the secondary containment system.

\section{$\underline{\text { Metering Pit }}$}

The Metering Pit foundation is a $20^{\prime} 0^{\prime \prime} \times 12^{\prime} 0^{\prime \prime} \times 1^{\prime} 4^{\prime \prime}$ thick, reinforced concrete base slab that rests on $4^{\prime \prime}$ of crushed stone on top of limestone.

\section{Mixing Cell}

The Mixing Cell foundation is a $23^{\prime} 0^{\prime \prime} \times 18^{\prime} 0^{\prime \prime} \times 1^{\prime} 4^{\prime \prime}$ thick, reinforced concrete base slab that rests on $4^{\prime \prime}$ of crushed stone on top of limestone.

The assessment concludes that the tank vault, Metering Pit, and Mixing Cell foundations are properly designed to support the secondary containment systems.

2.14.3.3 Provided with a Leak Detection System That is Designed and Operated to Detect Failure of Either Primary or Secondary Containment Structure or the Presence of Any Measurable Release of Hazardous or Radioactive Constituents

\section{$\underline{\text { Tank Vault T-13 }}$}

The assessment of the secondary containment system for Tank Vault T-13 is presented in the Design Demonstrations for Tank T-13. That assessment concludes that the vault is provided with a leak detection system. 
Design Demonstrations - Category B Tank Systems (Piping)

\section{Metering Pit}

The Metering Pit floor is sloped to a 6", schedule 40S 304L SS floor drain pipe that is gravity fed into the Tank Vault T-13 sump. The tank vault sump is provided with a leak detection system.

\section{Mixing Cell}

The Mixing Cell floor is sloped to a 6", schedule 40S, type 304L SS floor drain pipe that is gravity fed directly into Tank T-13. The assessment of the secondary containment system for Tank T-13 concludes that Tank $\mathrm{T}-13$ is provided with a tank level monitor.

The assessment concludes that the tank vault, Metering Pit, and Mixing Cell are provided with leak detection.

\subsubsection{Sloped or Otherwise Designed or Operated to Drain and Remove Liquids Resulting from Leaks, Spills, or Precipitation}

\section{$\underline{\text { Tank Vault T-13 }}$}

The assessment of the secondary containment system for Tank Vault T-13 is presented in the Design Demonstrations for Tank T-13. That assessment concludes that the secondary containment is sloped and designed to drain and remove liquids resulting from leaks, spills, or precipitation.

\section{Metering Pit}

The Metering Pit floor is sloped to a 6", schedule 40S, type 304L SS floor drain pipe that is gravity fed into the Tank Vault T-13 sump. The sump provides a low point to drain liquids to an instrumented location. A pumping system is provided to remove liquids that accumulate in the sump.

\section{$\underline{\text { Mixing Cell }}$}

The Mixing Cell floor is sloped to a 6", schedule 40S, type 304L SS floor drain pipe that is gravity fed directly into Tank T-13. The tank provides a low point to drain liquids to an instrumented location.

The assessment concludes that the secondary containments for the tank vault, Metering Pit, and Mixing Cell are sloped and designed to drain and remove liquids resulting from leaks, spills, or precipitation. 


\subsubsection{Supplemental Information}

\subsubsection{Ancillary Equipment}

Tank T-13 is constructed of 304L SS, which is the same material as that used in the piping system, and is located in Tank Vault T-13, which provides secondary containment. The pumps associated with the Tank System T-13 piping are constructed of 304L SS, which is the same material as that used in Tank T-13 and the piping system, and are located in Tank Vault T-13, which provides secondary containment. The support equipment is exposed to the same liquids as other components of the tank system; therefore, 304L SS is an acceptable material for the support equipment.

\subsubsection{Waste Acceptance Criteria}

Radioactively contaminated liquid wastes at the Oak Ridge National Laboratory (ORNL) are generated by various activities within the research and operating divisions. These activities include radiochemical processing, routine hot cell operations and decontaminations, and various waste treatment and environmental protection processes. The variations in composition of the waste streams are limited by the waste acceptance criteria that specify activity and concentration limits for waste discharged into the LLLW system. The Waste Acceptance Criteria for Liquid Waste Treatment Systems at the Oak Ridge National Laboratory (Oak Ridge National Laboratory, 1991), dated July 1991 , is a guide for liquid waste generators to determine the proper means of disposal for LLLW. The criteria provide future discharge guidelines for the LLLW system, which includes Tank System T-13. 


\subsubsection{References}

Ebasco, and Main. May 14, 1993. Design Demonstrations-Category B Tank Systems, Revision 2. DOE Contract No. DE-AC05-91OR21928. Oak Ridge National Laboratory.

Energy Systems Drawing A3E-21255-B011, Hydrofracture Building 7860, Sections, Revision F.

Energy Systems Drawing A3E-21255-B015, Hydrofracture Building 7860, Stainless Steel Liner Details 1, Revision C.

Energy Systems Drawing C3E-21255-A010, Site Plan Grading Section 1, Revision B.

Energy Systems Drawing H3E-21255-G002, Hydrofracture Building 7860, Environmental Control Flow Diagram, Revision C.

Energy Systems Drawing I3E-21255-E003, Instrumentation Diagram Liquid Process, Revision H.

Energy Systems Drawing P3E-21255-C017, Liquid Flow Diagram, Revision D.

Energy Systems Drawing P3E-21255-C020, Process Piping, Mixing and Injection Pump Cells Plan, Revision $\mathrm{H}$.

Energy Systems Drawing P3E-21255-C021, Process Piping, Well Cell Plan and Section, Revision E.

Energy Systems Drawing P3E-21255-C022, Process Piping, Injection Pump Cells, Mixing Cell and Well Cell Section, Revision F.

Energy Systems Drawing P3E-21255-C023, Process Piping, Mixing Cell and Injection Pump Cells Sections, Revision E.

Energy Systems Drawing P3E-21255-C024, Process Piping, Mixing Cell, and Slotting Waste Pit Section, Revision E.

Energy Systems Drawing P3E-21255-CO38, Process Piping Slotting Waste Collection Tank T-13, Revision D.

Energy Systems Drawing S3E-21255-B001, Hydrofracture Building, 7860 Foundation Plan, Revision C.

Energy Systems Drawing S3E-21255-B003, Hydrofracture Building 7860, Mixing Cell and Injection Pump Cell Plan, Revision C.

Energy Systems Drawing S3E-21255-B005, Hydrofracture Building 7860, Mixing Cell and Injection Pump Cells Wall Elevations, Revision F. 
Energy Systems Drawing S3E-21255-B007, Hydrofracture Building 7860, Well Cell, Wall Elevations, Revision C.

Energy Systems Drawing S3E-21255-B010, Slotting Waste Pit and Metering Pit Plan and Wall Elevations, Revision C.

Energy Systems Drawing S3E-21255-B01 1, Slotting Waste Pit and Metering Pit Sections and Details, Revision C.

Energy Systems Drawing S3E-21255-B028, General Structural Notes, Revision B.

Oak Ridge National Laboratory. The Specifications for the Construction of New Hydrofracture Facility. Invitation No. DE-AC05-790R20319.

Oak Ridge National Laboratory. 1991. Waste Acceptance Criteria for Liquid Waste Treatment Systems at the Oak Ridge National Laboratory. WM-WMCO-201. Department of Waste Minimization Planning and Certification.

Risk Evaluation of Embedded, Single-Walled Liquid Low-Level Waste Piping at Oak Ridge National Laboratory.

Robinson, S. M., S. M. DePaoli, and A. B. Walker. 1991. Federal Facility Agreement Contingency, Upgrade, and Replacement Plans for the ORNL Active Low-Level Radioactive Waste Tank System. ORNL/TM-11795. Oak Ridge National Laboratory. 


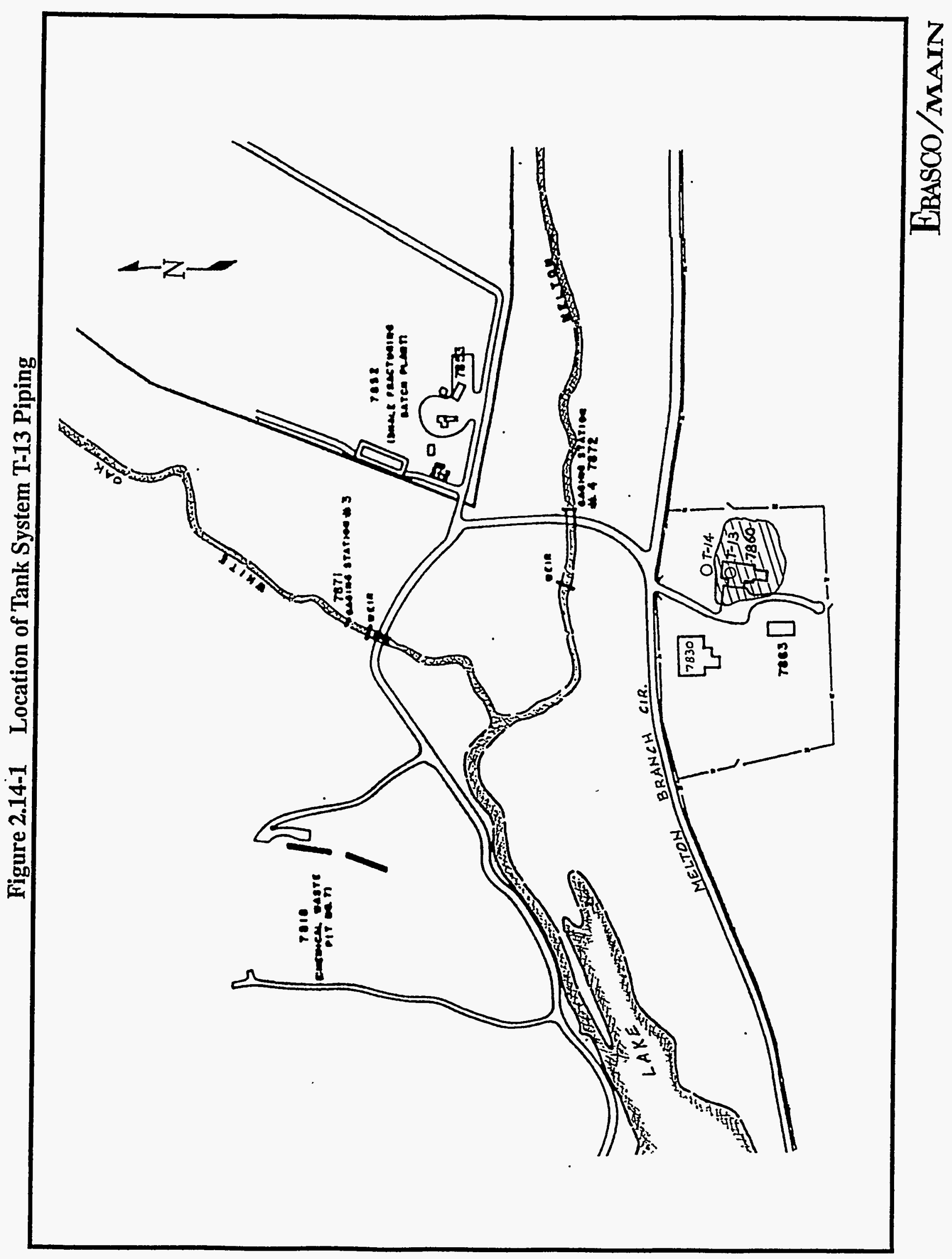




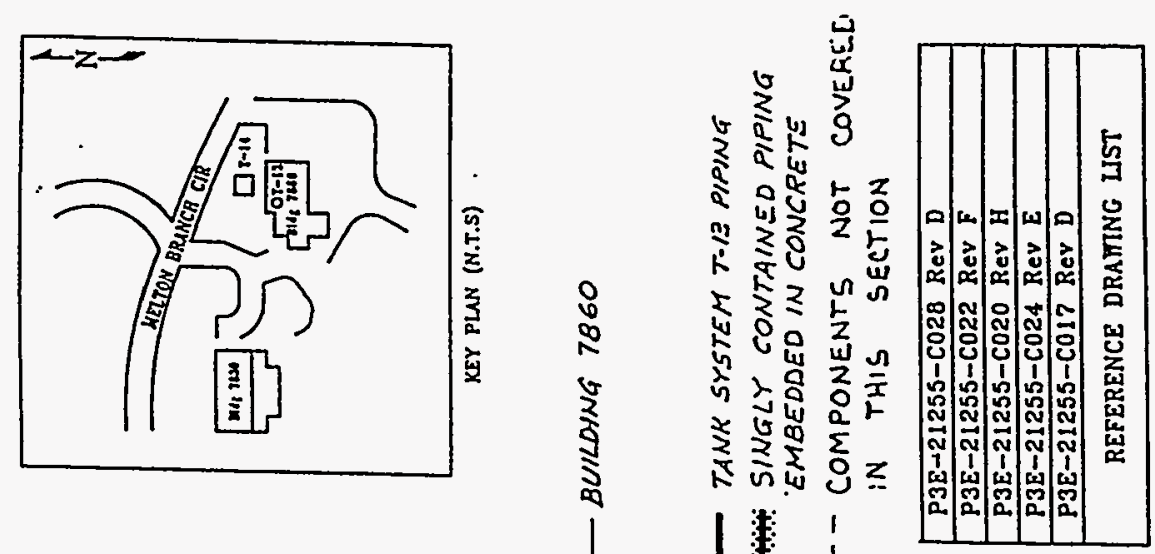


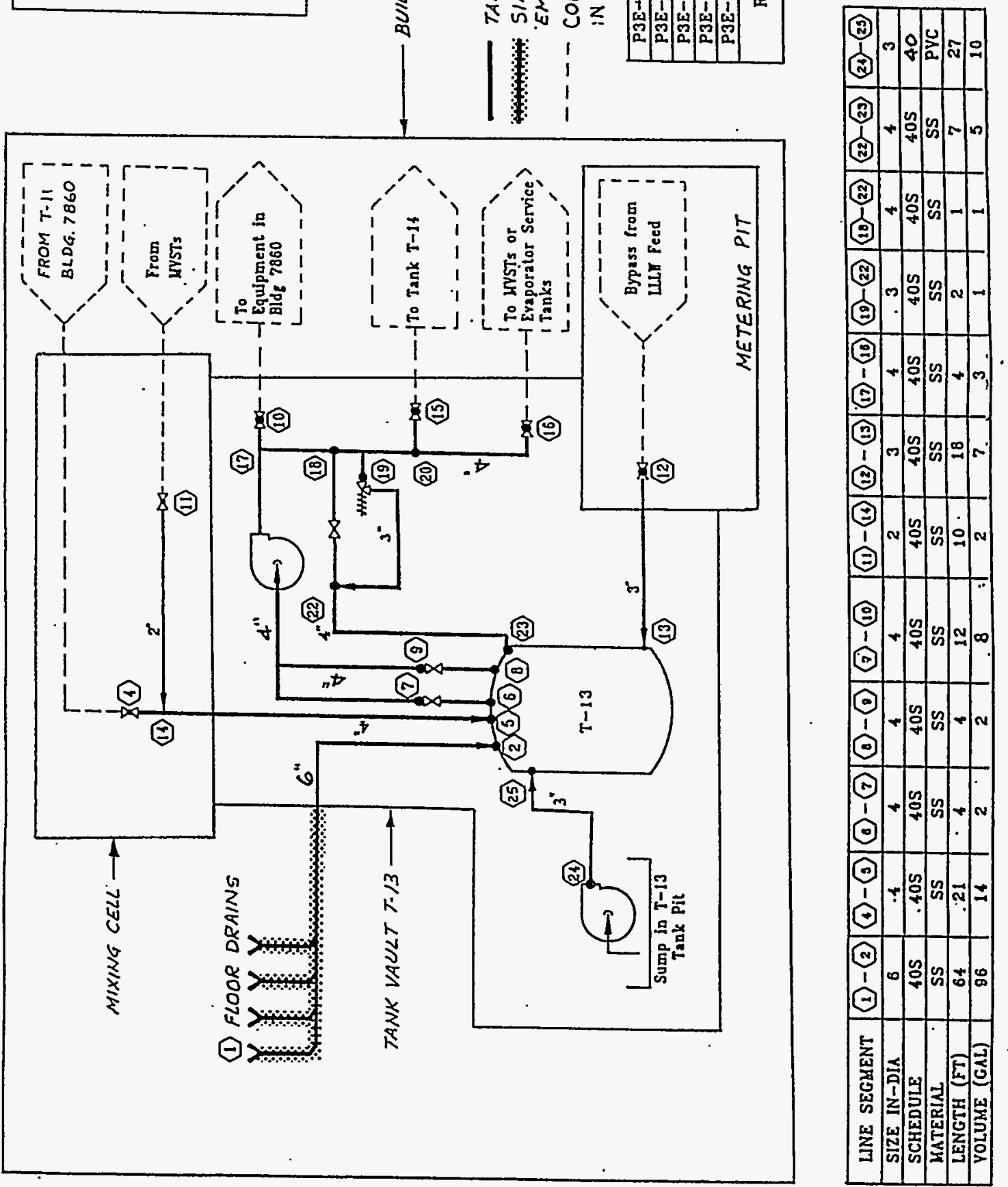


\subsection{Tank System WC-20 Piping}

Based on the findings of the Design Demonstrations for the Remaining 19 Category B Tank System, (DOE/OR/03-1150 \& D2), Tank System WC-20, originally designated as Category B, has been redesignated as Category $\mathrm{C}$ by FFA Modification Request Change Control Number FFA-PM/93-008, June 23, 1994. However, this section of the original Design Demonstrations has been retained for reference.

\subsubsection{Tank System Summary}

Tank System WC-20 is located near the Melton Valley Storage Tank Facility (Building 7569) (Figures 2.15-1 and 2.15-2). The tank system piping is schedule 40S, ASME SA-240, type 304L stainless steel (SS). The piping is routed underground from Melton Valley Collection and Transfer (MVCT) Box No. 1 to Tank Vault WC-20 and continues underground from Tank Vault WC-20 to the Building 7567 Pump House. From the pump house, the piping is routed underground to the South Parking Lot Valve Box (also known as the Incinerator Drive Valve Box) at Bethel Valley (Figure 2.15-3). Tank System WC-20 piping is used to transfer liquid low-level waste (LLLW) to and from Tank WC-20 and is classified as a Federal Facility Agreement Category B tank system.

2.15.2 Standards for Pipe Assessment of Tank Systems

\subsubsection{Tank System Piping Description and Design Standards}

\section{Tank System Piping Description}

Tank System WC-20 piping is located near Building 7569 and is routed underground from MVCT Box No. 1 to Tank Vault WC-20. The piping continues underground from Tank Vault WC-20 to the Building 7567 Pump House. From the pump house, the piping is routed underground to the South Parking Lot Valve Box. The piping system is used and managed by the Waste Management and Remedial Actions Division.

Tank System WC-20 piping is constructed of 2" and 4", 304L SS with a maximum design pressure and temperature of $150 \mathrm{psig}$ and $300^{\circ} \mathrm{F}$. Tank System WC-20 piping has the capacity to contain a maximum volume of 704 gal.

\section{$\underline{\text { Design Standards }}$}

The applicable codes and standards used for Tank System WC-20 piping and its associated secondary containment systems are identified herein. The codes and standards listed are those identified on either the design drawings or the construction specifications.

AEC-Oak Ridge Office, Minimum Safety Requirements;

Air Moving and Conditioning Association (AMCA) Standards Handbook-Publication 99; 
AMCA Directory-Publication 261;

AMCA Fans and Systems-Publication 201;

American Concrete Institute 301-72;

American Concrete Pipe Association;

American Conference of Governmental Industrial Hygienists;

American National Standards Institute;

American Society for Testing and Materials A48, A262-70, C91, C144, and D1751;

American Society of Heating, Refrigeration, and Air Conditioning Engineers (ASHRAE) Handbook of Fundamentals;

American Society of Mechanical Engineers (ASME) Boiler and Pressure Vessel Code, Sections II (SA-240), V, VIII, and IX;

ASHRAE Guide and Data Book-Applications;

ASHRAE Guide and Data Book-Equipment;

ASHRAE Handbook-Systems;

Atomic Energy Commission (AEC) General Design Criteria, Appendix 63;

Factory Mutual Engineering Corporation;

Instrument Society of America;

National Electric Code;

National Fire Protection Association (NFPA) No. 90A-Air Conditioning and Ventilating Systems;

NFPA No. 91-Blower and Exhaust Systems;

Nuclear Safety Information Center 65-Design, Construction, and Testing of High Efficiency Air Filtration Systems for Nuclear Applications;

Occupational Safety and Health Administration;

Sheet Metal and Air Conditioning Contractors National Association (SMACNA) High Velocity Duct Construction Standards and Low Velocity Standards; 
SMACNA Ducted Electric Heat Guide for Air Handling Systems;

UCC-ND Engineering Standards;

UCC-ND General Design Criteria, Y-EF-53;

UCC-ND Technical Specifications;

Underwriters Laboratories Inc.; and

Union Carbide Corporation Nuclear Division (UCC-ND) Standards, Sections 303, 401, 411, 702, and 924.04 .

\subsubsection{Generic Description of Piping Contents}

Tank System WC-20 is designed to transfer LLLW generated at Buildings 7920 and 7930 to Tank WC-20. LLLW is produced from radiochemical operations designed to recover isotopes produced from irradiated High Flux Isotope Reactor targets and other sources. These wastes may include a variety of dilute acids, bases, and organics. The tank may contain radioactive materials from the Radiochemical Engineering Development Center, which is the main contributor of transuranic radionuclides in the LLLW system. The analytical data (Figure 2.15-4) of waste stream contaminants from the generators are representative of waste transferred through Tank System WC-20 piping.

\subsubsection{Pipe Corrosion Protection Measures}

Piping inside MVCT Box No. 1, Tank Vault WC-20, the Building 7567 Pump House, and the South Parking Lot Valve Box has no direct contact with the soil or water. Cathodic protection measures are not required for external corrosion.

The outside underground piping for Tank System WC-20 is made up of two cathodically protected systems of piping.

The first system is between the Building 7567 Pump House and the South Parking Lot Valve Box. The piping is included in the Facility Manager's Cathodic Protection System No. 6B. The galvanic anode cathodic protection system consists of magnesium anodes, test stations, and connection wire as shown on cathodic protection drawings C-20013-EA-007 and C-20013-EA-013 through C-20013-EA-018. The system was installed in May 1972.

The system as shown on the construction drawings reviewed is not considered to be adequate because there are no indications of electrical isolation devices being required at the ends of the buried piping on any of the construction drawings that were reviewed. Harco Technologies determined that insulating gaskets were not present during its 1990 surveys, and the cathodic protection field testing performed in 1991 indicate that $39 \%$ of the piping is not receiving adequate corrosion control. This 
is due primarily to the piping being electrically shorted and in part to depleted anode beds. In 1991, Harco completed the engineering design to upgrade the existing system.

The second system is between the Building 7567 Pump House and MVCT Box No. 1. The piping is included in the Facility Manager's Cathodic Protection System No. 17. The system consists of magnesium anodes, test stations, and connecting wire as shown on drawing E-20854-ED-003. The system was installed in June 1976. Insulating flanges were called for on the drawings reviewed. The design of the cathodic protection system as shown on the construction drawings is considered to be adequate.

The cathodic protection test report and survey performed in 1990 and 1991 indicate that the entire line is effectively protected except in the immediate vicinity of Tank WC-20. This may be due to a shorted connection or the concrete footing contacting the pipe.

\subsubsection{Documented Age of Tank System}

Part of Tank System WC-20 piping was originally installed in 1972. The remaining part of the piping was installed in 1976.

\subsubsection{Standards for Containment/Release Detection}

Tank System WC-20 piping incorporates approximately $3801^{\prime}$ of outside underground piping that is singly contained and approximately $205^{\prime}$ of outside underground piping that is doubly contained. The singly contained area is omitted from discussion in the following sections that address secondary containment.

\subsubsection{Constructed of or Lined with Materials That are Compatible with Stored Waste(s) or Substance(s) to Be Placed in the Tank System and Shall Have Sufficient Strength and Thickness to Prevent Failure}

Tank System WC-20 piping is single-wall, schedule 40S, type 304L SS with a section of piping that is double wall. The jacket of the double-wall piping is schedule 10S, type 304L SS. The piping is routed underground from MVCT Box No. 1 to Tank Vault WC-20. The piping continues underground from Tank Vault WC-20 to the Building 7567 Pump House. From the pump house, the piping is routed underground to the South Parking Lot Valve Box. Each area is discussed below.

\section{Outside Underground Piping}

The piping routed underground from MVCT Box No. 1 to Tank Vault WC-20 is doubly contained. The jacket of the outside underground, double-wall pipe is 304L SS. The secondary containment material is compatible with the waste. 


\section{MVCT Box No. 1}

The bottom of MVCT Box No. 1 is lined with 16-gauge (1/16"), 304L SS, which is the same material as that used for the piping, with sidewalls that project $4^{\prime} 3^{\prime \prime}$ up the valve box. The valve box walls above the SS liner are provided with a 30-mil-thick system of Amercoat 66 epoxy. The SS valve box lining material is compatible with the waste and designed to prevent migration of waste into the concrete. According to manufacturer's specifications, the valve box's epoxy coating is compatible with the waste and designed to prevent migration of waste into the concrete.

\section{Tank Vault WC-20}

The assessment of the secondary containment system for Tank Vault WC-20 is presented in the Design Demonstrations for Tank WC-20. That assessment concludes that Tank Vault WC-20 is lined with materials that are compatible with the waste and designed to prevent migration of waste into the concrete.

\section{Building 7567 Pump House}

The bottom and sidewalls of the pump house, up $5^{\prime} 0^{\prime \prime}$ from the bottom are lined with 11-gauge $\left(1 / 8^{\prime \prime}\right)$, 304L SS, which is the same material as that used for the piping. The SS lining material is compatible with the waste and designed to prevent migration of waste into the concrete.

\section{South Parking Lot Valve Box}

The South Parking Lot Valve Box is not coated or lined with materials that are compatible with the waste and designed to prevent migration of waste into the concrete.

The assessment concludes that the MVCT Box No. 1, Tank Vault WC-20, and Building 7567 Pump House are coated or lined with materials that are compatible with the waste and designed to prevent migration of waste into the concrete. The assessment concludes that the jacket of the underground piping is compatible with the waste. The South Parking Lot Valve Box, however, is not coated or lined with materials that are compatible with the waste and designed to prevent migration of waste into the concrete.

\subsubsection{Placed on Foundation or Base Capable of Providing Support to the Secondary Containment System}

\section{MVCT Box No. 1}

The MVCT Box No. 1 foundation is a $4^{\prime} 0^{\prime \prime} \times 4^{\prime} 0^{\prime \prime} \times 1^{\prime} 0^{\prime \prime}$ thick, reinforced concrete base slab that rests on limestone. 


\section{Tank Vault WC-20}

The assessment of the secondary containment system for Tank Vault WC-20 is presented in the Design Demonstrations for Tank WC-20. That assessment concludes that the vault foundation is properly designed to support the secondary containment system.

\section{Building 7567 Pump House}

The Building 7567 Pump House foundation is a $9^{\prime} 3^{\prime \prime} \times 8^{\prime} 4^{\prime \prime} \times 1^{\prime} 0^{\prime \prime}$ thick, reinforced concrete base slab that rests on limestone.

\section{South Parking Lot Valve Box}

The valve box foundation is a $5^{\prime} 0^{\prime \prime} \times 5^{\prime} 0^{\prime \prime} \times 1^{\prime} 0^{\prime \prime}$ thick, reinforced concrete base slab that rests on limestone.

The assessment concludes that the valve boxes, tank vault, and pump house foundations are properly designed to support the secondary containment systems.

\subsubsection{Provided with a Leak Detection System That is Designed and Operated to Detect Failure of Either Primary or Secondary Containment Structure or the Presence of Any Measurable Release of Hazardous or Radioactive Constituents}

\section{Outside Underground Piping}

The doubly contained underground piping associated with this system is provided with a nitrogenblanketed leak detection system.

\section{MVCT Box No. 1}

A leak detection system for MVCT Box No. 1 could not be identified in the design drawings or construction specifications.

\section{Tank Vault WC-20}

The assessment of the secondary containment system for Tank Vault WC-20 is presented in the Design Demonstrations for Tank WC-20. That assessment concludes that the vault is provided with a leak detection system.

\section{Building 7567 Pump House}

The Building 7567 Pump House floor is sloped to a 16-gauge (1/16"), 304L SS-lined sump. Accumulation of liquid will be detected by a level sensor that will activate an alarm in the Waste Operations Control Center (Building 3130). 


\section{South Parking Lot Valve Box}

A leak detection system for the South Parking Lot Valve Box could not be identified from the design drawings or construction specifications.

The assessment concludes that the underground piping, tank vault, and pump house, are provided with leak detection, but that MVCT Box No. 1 and the South Parking Lot Valve Box do not have leak detection systems.

2.15.3.4 Sloped or Otherwise Designed or Operated to Drain and Remove Liquids Resulting from Leaks, Spills, or Precipitation

\section{Outside Underground Piping}

The doubly contained outside underground piping is sloped and provided with $1 / 2^{\prime \prime}$ drain test connections to remove liquids resulting from leaks.

\section{MVCT Box No. 1}

The MVCT Box No. 1 floor is sloped to a 304L SS-lined sump. The sump provides a low point within the valve box to drain liquids. A pumping system is not provided to remove liquids that accumulate in the sump.

\section{Tank Vault WC-20}

The assessment of the secondary containment system for Tank Vault WC-20 is presented in the Design Demonstrations for Tank WC-20. That assessment concludes that the secondary containment is sloped and designed to drain and remove liquids resulting from leaks, spills, or precipitation.

\section{Building 7567 Pump House}

The pump house floor is sloped to a 304L SS-lined sump. The sump provides a low point within the pump house to drain liquids to an instrumented location. A pumping system is provided to remove liquids that accumulate in the sump.

\section{South Parking Lot Valve Box}

The valve box floor is sloped to a sump. The sump provides a low point within the valve box to drain liquids. A pumping system is not provided to remove liquids that accumulate in the sump.

The assessment concludes that the secondary containments for the underground piping, tank vault, and pump house are sloped and designed to drain and remove liquids resulting from leaks, spills, or precipitation. MVCT Box No. 1 and the South Parking Lot Valve Box are sloped and designed to drain liquids. Pumping systems are not provided to remove liquids that accumulate in the sumps. 


\subsubsection{Supplemental Information}

\subsubsection{Ancillary Equipment}

Tank WC-20 is constructed of 304L SS, which is the same material as that used in the piping system, and is located in Tank Vault WC-20, which provides secondary containment. The pumps associated with Tank System WC-20 are constructed of 304L SS, which is the same material as that used in the tank and piping system, and are located in the pump house, which provides secondary containment. The support equipment is exposed to the same liquids as other components of the tank system; therefore, 304L SS is an acceptable material for the support equipment.

\subsubsection{Waste Acceptance Criteria}

Radioactively contaminated liquid wastes at the Oak Ridge National Laboratory (ORNL) are generated by various activities within the research and operating divisions. These activities include radiochemical processing, routine hot cell operations and decontaminations, and various waste treatment and environmental protection processes. The variations in composition of the waste streams are limited by the waste acceptance criteria that specify activity and concentration limits for waste discharged into the LLLW system. The Waste Acceptance Criteria for Liquid Waste Treatment Systems at the Oak Ridge National Laboratory (Oak Ridge National Laboratory, 1991), dated July 1991, is a guide for liquid waste generators to determine the proper means of disposal for LLLW. The criteria provide future discharge guidelines for the LLLW system, which includes Tank System WC-20. 


\subsubsection{References}

Binford, F. T., and S. D. Orfi. 1979. The Intermediate-Level Liquid Waste System at the Oak Ridge National Laboratory Description and Safety Analysis. ORNL/TM-6959. Oak Ridge National Laboratory.

Ebasco, and Main. May 14, 1993. Design Demonstrations-Category B Tank Systems, Revision 2. DOE Contract No. DE-AC05-91OR21928. Oak Ridge National Laboratory.

Energy Systems Drawing D-52563, 50,000-Gal High-Level Liquid Waste Tanks C-1 and C-2 Detail Sheet 1, Revision 2.

Energy Systems Drawing E-20854-ED-003, Cathodic Protection of Melton Valley Collection Tank, Revision E.

Energy Systems Drawing E-S-52711, Cells Nos. 1 and 2 Stainless Steel Liners and Tank Vault Details, Revision 2.

Energy Systems Drawing D-5001, Control Flow Diagram C-1 and C-2 Tank Vault, Dated 11/18/48 (No Revision No.).

Energy Systems Drawing D-55003, Control Flow Diagram Cell, Revision 3.

Energy Systems Drawing D-55002, Control Flow Diagram Cell 2 and Valve Pit, Revision 5.

Energy Systems Drawing C-40307, Criteria Storage Tank Vault, Dated 1/30/62 (No Revision No.).

Energy Systems Drawing S-20237-YB-010-E, Evaporator Annex Plan Sections and Details Stainless Steel Liner, Revision 2.

Energy Systems Drawing S3E-20237-B013, Extended Vault Plan Sections and Details, Dated 4/10/84 (No Revision No.).

Energy Systems Drawing D-52502, Floor Liner and Sump Plans, Sections, and Details, Revision 1.

Energy Systems Drawing E-F-52685, Footing Tunnel Drains and Sump Pit, Revision 1.

Energy Systems Drawing D-34551, High-Level Waste Facility Engineering Flowsheet No. 4, Dated 5/17/61 (No Revision No.).

Energy Systems Drawing D-52589, High-Level Waste Tank Cell Piping Sheet 1, Revision 4.

Energy Systems Drawing D-52591, High-Level Waste Tank Cell Piping Sheet 3, Revision 3. 
Energy Systems Drawing C-20854-YA-002E, Melton Valley Collection Tank, Excavation and Sections, Revision D.

Energy Systems Drawing I-20854-YE-003-E, Melton Valley Collection Tank, Instrument Flow Diagram Process, Revision G.

Energy Systems Drawing I-20854-YE-001-E, Melton Valley Collection Tank, Instrument Flow Diagram Ventilation, Revision G.

Energy Systems Drawing S-20854-YB-004-E, Melton Valley Collection Tank, Miscellaneous Sections and Details, Revision B.

Energy Systems Drawing P-20854-YC-002-E, Melton Valley Collection Tank, Piping Plan and Sections at Existing Building 7567, Revision C.

Energy Systems Drawing S-20854-YB-002E, Melton Valley Collection Tank, Sections of Concrete Vault and Valve Pit, Revision E.

Energy Systems Drawing C-20854-YA-001E, Melton Valley Collection Tank, Site and Grading Plan, Revision F.

Energy Systems Drawing S-20854-YB-006E, Melton Valley Collection Tank, Tank Plan, Section and Detail, Revision 3.

Energy Systems Drawing P-20854-YC-001-E, Melton Valley Collection Tank, Tank WC-20 Control Room and Valve Pit Tank Piping Plan and Sections, Revision C.

Energy Systems Drawing C-20854-YA-003-E, Melton Valley Collection Tank, Utility Plan, Sheet 1 , Revision $\mathrm{H}$.

Energy Systems Drawing P-20854-YC-004-E, Melton Valley Collection Tank, Valve Box Tie In, Details and Sections, Revision D.

Energy Systems Drawing D-52761, Offgas and Cell Ventilation Filter Pits, Revision 1.

Energy Systems Drawing H-20854-EG-001, Pump Pit Exhaust System Plan, Sections and Details, Dated 3/4/66 (No Revision No.).

Energy Systems Drawing P3E-20237-C021, Piping Details Evaporator Service Tank Area, Dated 2/22/84 (No Revision No.).

Energy Systems Drawing P3E-20237-C020, Piping Plan Building 2531 Area, Dated 4/10/84 (No Revision No.).

Energy Systems Drawing D-52608, Sample Flow Sheet, Revision 3. 
Design Demonstrations - Category B Tank Systems (Piping)

Energy Systems Drawing D-52750, Sampling Room Foundation Plan and Sections, Revision 1.

Energy Systems Drawing C-20854-EA-003-D, Site Plan Auger Hole, Location TRU-Turf Collection Tank WC-20, Dated 6/21/74 (No Revision No.).

Energy Systems Drawing E-S-52712, Tank Storage Vault and Retaining Wall Details, Revision 2.

Energy Systems Drawing D-52757, Tank Vault Cover Plug Location Plan and Details, Revision 1.

Energy Systems Drawing X-20854, TRU and TURF 10,000 Gal Tank Flow Sheet, EE 001 D, Dated 1/29/73 (No Revision No.).

Energy Systems Drawing E-S-52714, Wall Penetrations, Sheet 1, Revision 6.

Energy Systems Drawing D-52606, Waste Evaporator Building Cell 1 and 2 Process Flowsheet, Revision 6.

Energy Systems Drawing D-52604, Waste Evaporator Building Cell 1 and 2 Service Flowsheet, Revision 3.

Energy Systems Drawing C-20013-EA-007, Plan and Profile, Sheet 2 of 9, As-Built, Revision A.

Energy Systems Drawing C-20013-EA-013, Plan and Profile, Sheet 4 of 9, As-Built, Revision A.

Energy Systems Drawing C-20013-EA-014, Plan and Profile, Sheet 5 of 9, As-Built, Dated 8/27/73 (No Revision No.).

Energy Systems Drawing C-20013-EA-015, Plan and Profile, Sheet 6 of 9, As-Built, Dated 8/27/73 (No Revision No.).

Energy Systems Drawing C-20013-EA-016, Plan and Profile, Sheet 7 of 9, As-Built, Dated 8/27/73 (No Revision No.).

Energy Systems Drawing C-20013-EA-017, Plan and Profile, Sheet 8 of 9, As-Built, Dated 8/27/73 (No Revision No.).

Energy Systems Drawing C-20013-EA-018, Plan and Profile, Sheet 9 of 9, As-Built, Revision 1.

Harco Technologies Corporation. June 1990. Resurvey of the Cathodic Protection Systems, Oak Ridge National Laboratory, United States Department of Energy, Oak Ridge, Tennessee. Martin Marietta Energy Systems, Inc.

Harco Technologies Corporation. July 1991. Cathodic Protection System Upgrade Design Underground ILW Line 7567 to 3507, System No. 6. Oak Ridge National Laboratories, United Stated Department of Energy, Oak Ridge, Tennessee. Martin Marietta Energy Systems, Inc. 
Harco Technologies Corporation. August 1991. Cathodic Protection System Upgrade Design Underground ILW Lines, ILW Line 7569 to 7567, System No. 17. Oak Ridge National Laboratories, United States Department of Energy, Oak Ridge, Tennessee. Martin Marietta Energy Systems, Inc.

Hertel, J. P. 1964. Procedure for Mass Spec. Leak Test. Job 3-127.

Oak Ridge National Laboratory. 1991. Waste Acceptance Criteria for Liquid Waste Treatment Systems at the Oak Ridge National Laboratory. WM-WMCO-201. Department of Waste Minimization Planning and Certification.

Peretz, F. J., et al. 1986. Characterization of Low-Level Liquid Wastes at the Oak Ridge National Laboratory. ORNL/TM-10218. Oak Ridge National Laboratory.

Procurement Specifications. 1963. High-Level Liquid Waste Tanks C-1 and C-2. XSP-68A.

Robinson, S. M., S. M. DePaoli, and A. B. Walker. 1991. Federal Facility Agreement Contingency, Upgrade, and Replacement Plans for the ORNL Active Low-Level Radioactive Waste Tank System. ORNL/TM-1 1795. Oak Ridge National Laboratory.

Samborn, Steketee, Otis, and Evans, Inc. 1975. Intermediate-Level Waste Management Facilities Title I Report (Book 1 and 2), Holifield National Laboratory, Oak Ridge, Tennessee. Oak Ridge National Laboratory.

Specifications for Construction of Intermediate-Level Waste Facilities for the Energy Research and Development Administration. Invitation No. EY-77-B-05-5350.

Technical Specifications for the Construction of Improvements to Radioactive Liquid Waste System, Phase I, Building 2531.

Waste Generator Survey for Buildings 7920 and 7930. 
Figure 2.15-1

Location of Tank System WC-20 Piping, Sheet 1

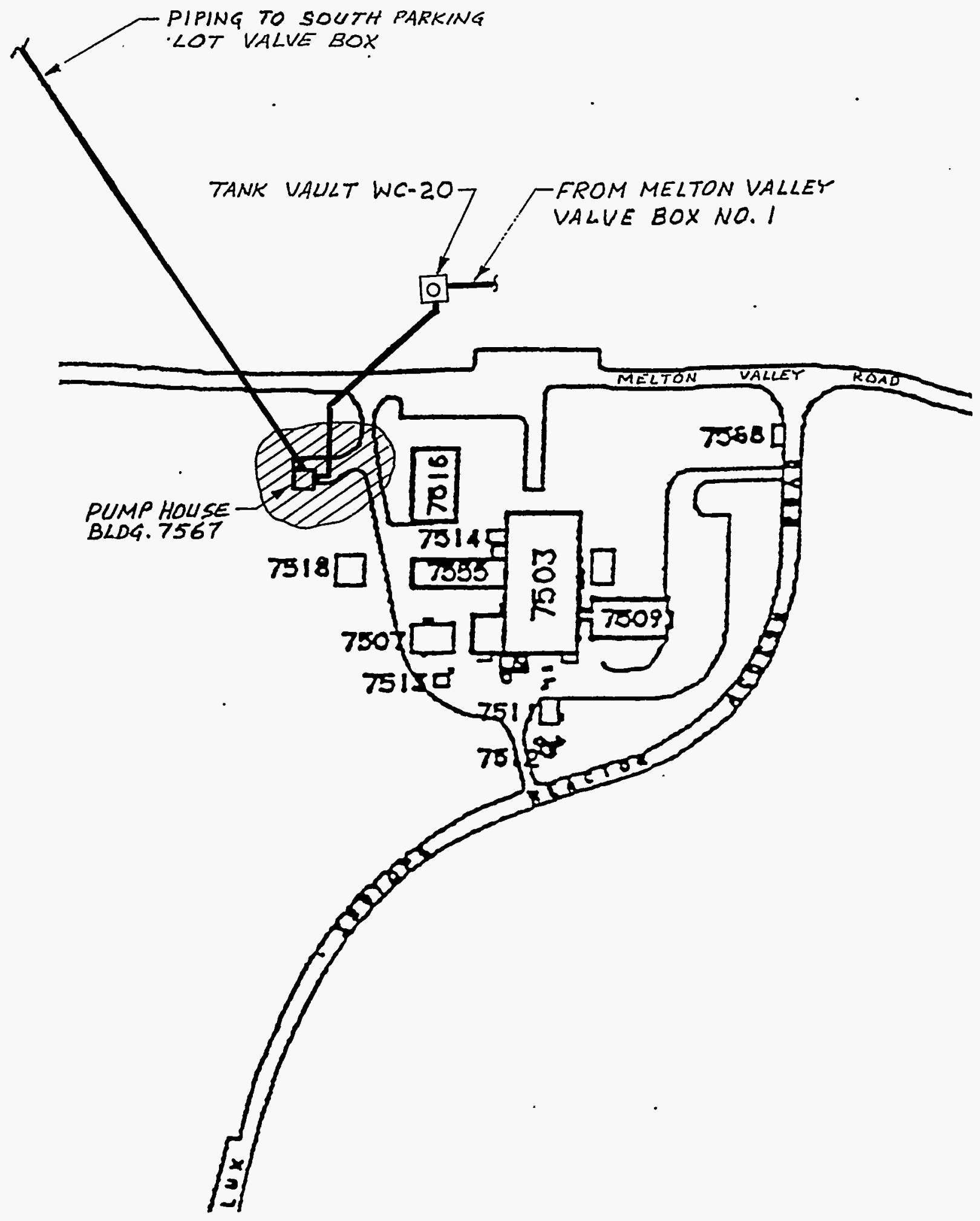




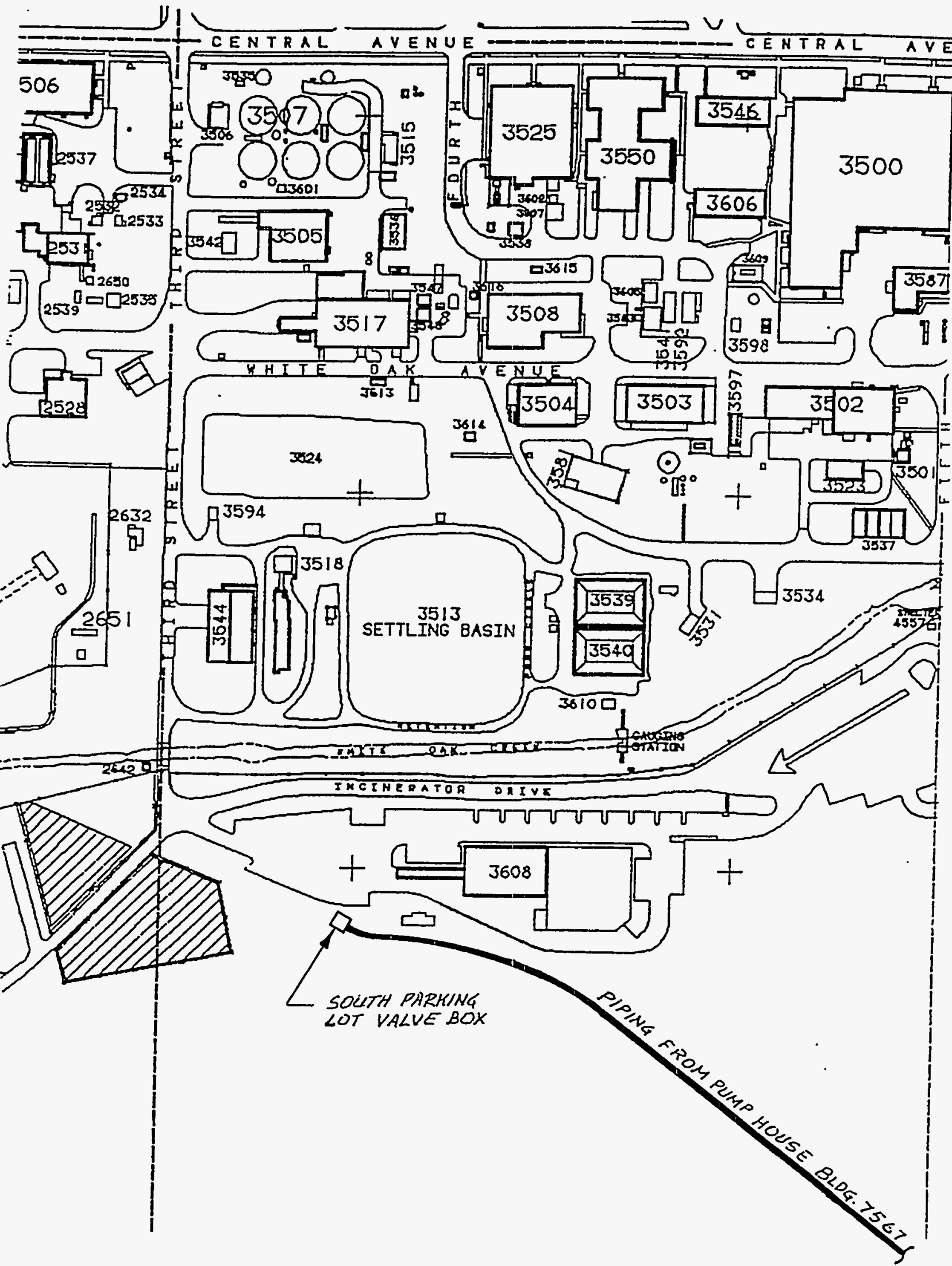



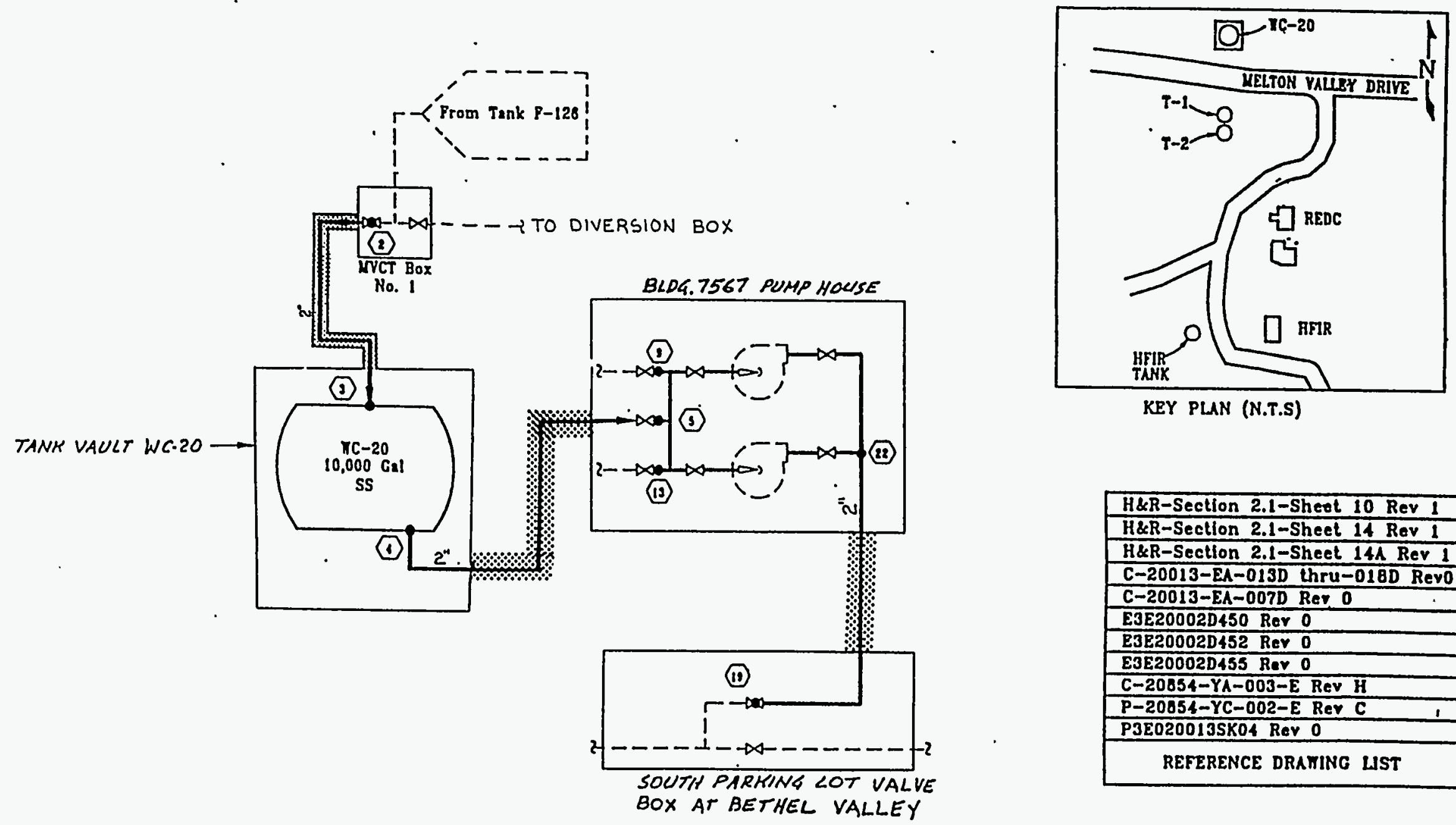

KEY PLAN (N.T.S)

\begin{tabular}{|c|}
\hline H\&R-Section 2.1-Sheet 10 Rev 1 \\
\hline K\&R-Section 2.1-Sheet 14 Rev 1 \\
\hline H\&R-Section 2.1-Sheel $14 \lambda$ Rer $I$ \\
\hline C-20013-EA-013D thru-018D Revo \\
\hline C-20013-EA-007D Rer 0 \\
\hline E3E20002D450 Rer 0 \\
\hline E3E20002D452 Rer 0 \\
\hline E3E20002D455 Rer 0 \\
\hline$C-20854-Y A-003-E$ ReV $H$ \\
\hline$P-20054-Y C-002-E$ Rer C \\
\hline P3E020013SKO4 ReV 0 \\
\hline REFERENCE DRATING LST \\
\hline
\end{tabular}

\begin{tabular}{|l|c|c|c|c|c|}
\hline LINE SEGMENT & $(2)-(3)$ & $(1)-(3)$ & $(12-(22$ & $(13)-(22$ & $22-(10)$ \\
\hline SIZE IN-DIA & 2 & 2 & 2 & 4 & 2 \\
\hline SCHEDULE & $10 S$ & $40 S$ & $40 S$ & $10 S$ & $40 S$ \\
\hline MATERINL & SS & SS & SS & SS & SS \\
\hline LENGTH (FT) & 205 & 280 & 16 & 10 & 3521 \\
\hline YOLUME (GAL) & 36 & 49 & 3 & 3 & 613 \\
\hline
\end{tabular}

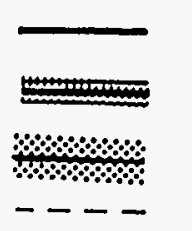

TANK SYSTEM W'C-2O PIPING

DOUBLY CONTAINED UNDERGROUND PIPING

SINGLY CONTAINED UNOERGROUND PIFING COMPONENTS NOT COVERED IN THIS SECTION 
WASTE STREAM CONTAMINANTS:

(a) Isotopes: $\mathrm{Cm}-244,245,246,247$

(b) Quantities Trace

\begin{tabular}{c}
$\frac{C f-250,251,252}{\mathrm{Sr}-90}$ \\
\hline $\mathrm{Tc}-99$ \\
\hline $\mathrm{Cs}-137$ \\
$\mathrm{Am}-241,242,243$ \\
\hline
\end{tabular}

\begin{tabular}{c} 
Trace \\
\hline Trace \\
\hline Trace \\
\hline Trace \\
\hline Trace \\
\hline Trace
\end{tabular}

(b) Others (i.e. acids, bases, organics, cleaners, etc.)

\begin{tabular}{c}
$\frac{\text { sodium nitrate }}{\text { nitric acid }}$ \\
$\frac{\text { sodium hydroxide }}{\text { potassium iodide }}$ \\
\hline ferrous chloride \\
ferrous sulfate \\
thenoyltrifluoroacetone (TTA)
\end{tabular}

\begin{tabular}{c} 
Trace \\
\hline Trace \\
\hline Trace \\
\hline Trace \\
\hline Trace \\
\hline Trace \\
\hline Trace
\end{tabular}




\section{$2.16 \quad$ Tank System W-21 Piping}

\subsubsection{Tank System Summary}

Tank System W-21 is located near the Evaporator Building 2531 and near the center of the main Bethel Valley Complex (Figures 2.16-1 and 2.16-2). The tank system piping is schedule 40S, ASME SA-240, type 304L stainless steel (SS) and is routed from Tank Vault W-21/W-22 to the Control House Pump Pit and Valve Box No. 3. Tank System W-21 piping is used to transfer concentrate for the Evaporator and is classified as a Federal Facility Agreement (FFA) Category B tank system.

\subsubsection{Standards for Pipe Assessment of Tank Systems}

\subsubsection{Tank System Piping Description and Design Standards}

\section{Tank System Piping Description}

Tank System W-21 piping is located near the Evaporator Building 2531 and is routed from Tank Vault W-21/W-22 to the Control House Pump Pit and Valve Box No. 3. The piping system is used and managed by the Waste Management and Remedial Actions Division.

Tank System W-21 piping is constructed of 2" and 4", 304L SS with a maximum design pressure and temperature of $150 \mathrm{psig}$ and $300^{\circ} \mathrm{F}$. Tank System W-21 piping has the capacity to contain a maximum volume of $91 \mathrm{gal}$.

\section{$\underline{\text { Design Standards }}$}

The applicable codes and standards used for Tank System W-21 piping and its associated secondary containment system are identified herein. The codes and standards listed are those identified on either the design drawings or the construction specifications.

AEC-Oak Ridge Office, Minimum Safety Requirements;

Air Moving and Conditioning Association (AMCA) Standards Handbook-Publication 99;

AMCA Directory-Publication 261;

AMCA Fans and Systems-Publication 201;

American Concrete Institute 301-72;

American Concrete Pipe Association;

American Conference of Governmental Industrial Hygienists; 
American National Standards Institute;

American Society for Testing and Materials A48, A262-70, C91, C144, and D1751;

American Society of Heating, Refrigeration, and Air Conditioning Engineers (ASHRAE) Handbook of Fundamentals;

American Society of Mechanical Engineers (ASME) Boiler and Pressure Vessel Code, Sections II (SA-240), V, VIII, and IX;

ASHRAE Guide and Data Book-Applications;

ASHRAE Guide and Data Book-Equipment;

ASHRAE Handbook-Systems;

Atomic Energy Commission (AEC) General Design Criteria, Appendix 63;

Factory Mutual Engineering Corporation;

National Electric Code;

National Fire Protection Association (NFPA) No. 90A-Air Conditioning and Ventilating Systems;

NFPA No. 91-Blower and Exhaust Systems;

Nuclear Safety Information Center 65-Design, Construction, and Testing of High Efficiency Air Filtration Systems for Nuclear Applications;

Occupational Safety and Health Administration;

Sheet Metal and Air Conditioning Contractors National Association (SMACNA) High Velocity Duct Construction Standards and Low Velocity Standards;

SMACNA Ducted Electric Heat Guide for Air Handling Systems;

UCC-ND Engineering Standards;

UCC-ND General Design Criteria, Y-EF-53;

UCC-ND Technical Specifications;

Underwriters Laboratories Inc.; and 
Union Carbide Corporation Nuclear Division (UCC-ND) Standards, Sections 303, 401, 411, 702, and 914.04.

\subsubsection{Generic Description of Piping Contents}

Tank System W-21 piping is designed to serve Tank W-21, which is designed as an evaporator feed tank. Because of a general lack of storage capacity in the Melton Valley Tank Farm Complex, Tank W-21 has also been used as a Process Waste Treatment Plant concentrate storage tank and as a liquid low-level waste (LLLW) concentrate storage tank. LLLW is generated from a variety of facilities at the Oak Ridge National Laboratory (ORNL), including reactors, radioactive fuel processing areas, radioisotope processing areas, decontamination operations, hot cells, and radiochemical laboratories. The waste generators collect the waste, which is then transferred to the Evaporator Feed Tank W-22 (and formerly Tank W-21). Any waste found to be acidic is adjusted to basic with sodium hydroxide in the generator collection tanks or in the evaporator feed tank. This $\mathrm{Ph}$ adjustment causes most of the transuranic waste components and heavy metals to precipitate out of solution.

The liquid waste supernate is single phase and ranges in color from pale to deep yellow with sodium/potassium nitrate salt solutions. The principal metals found in the sludges are sodium, potassium, calcium, magnesium, uranium, and thorium. The sludge contains radioactive materials that produce radiation levels of 1.0-1.5 rem per hour (R/h) (Figure 2.16-3).

The analytical data (Figure 2.16-4) of waste samples are representative of the waste received by Tank W-21; however, the composition of the waste in the Tank W-21 system may vary depending upon the experiments conducted by the waste generators.

\subsubsection{Pipe Corrosion Protection Measures}

Piping inside Tank Vault W-21/W-22, the Control House Pump Pit, and Valve Box No. 3 has no direct contact with the soil or water. Cathodic protection measures are not required for external corrosion.

\subsubsection{Documented Age of Tank System}

Tank System W-21 piping was installed in 1980.

\subsubsection{Standards for Containment/Release Detection}

2.16.3.1 Constructed of or Lined with Materials That are Compatible with Stored Waste(s) or Substance(s) to Be Placed in the Tank System and Shall Have Sufficient Strength and Thickness to Prevent Failure

Tank System W-21 piping is single-wall, schedule 40S, type 304L SS that is routed between Tank Vault W-21/W-22, the Control House Pump Pit, and Valve Box No. 3. Each area is discussed below. The piping penetrations from Tank Vault W-21/W-22 to the Control House Pump Pit and 
Valve Box No. 3 are singly contained, schedule 40S, type 304L SS pipes that are embedded in the concrete wall at varying lengths.

\section{Tank Vault W-21/W-22}

The assessments of the secondary containment system for Tank Vault W-21/W-22 are presented in the Design Demonstrations for Tanks W-21 and W-22. Those assessments conclude that Tank Vault W-21/W-22 is coated and lined with materials that are compatible with the waste and designed to prevent migration of waste into the concrete.

\section{Control House Pump Pit}

The bottom of the pump pit is lined with 16-gauge $\left(1 / 16^{\prime \prime}\right), 304 \mathrm{~L} \mathrm{SS}$, which is the same material as that used for the piping, with sidewalls that project $3^{\prime} 0^{\prime \prime}$ up the pump pit. The pump pit walls above the SS liner are provided with a 30-mil-thick system of Amercoat 66 epoxy. The SS pump pit lining material is compatible with the waste and designed to prevent migration of waste into the concrete. According to manufacturer's specifications, the pump pit's epoxy coating is compatible with the waste and designed to prevent migration of waste into the concrete.

\section{Valve Box No. 3}

The bottom of Valve Box No. 3 is lined with 16-gauge (1/16"), 304L SS, which is the same material as that used for the piping, with sidewalls that project $4^{\prime} 3^{\prime \prime}$ up the valve box. The valve box walls above the SS liner are provided with a 30-mil-thick system of Amercoat 66 epoxy. The SS valve box lining material is compatible with the waste and designed to prevent migration of waste into the concrete. According to manufacturer's specifications, the valve box's epoxy coating is also compatible with the waste and designed to prevent migration of waste into the concrete.

The assessment concludes that the tank vault, pump pit, and valve box are coated and lined with materials that are compatible with the waste and designed to prevent migration of waste into the concrete.

\subsubsection{Placed on Foundation or Base Capable of Providing Support to the Secondary Containment System}

\section{Tank Vault W-21/W-22}

The assessments of the secondary containment system for Tank Vault W-21/W-22 are presented in the Design Demonstrations for Tanks W-21 and W-22. Those assessments conclude that the vault foundation is properly designed to support the secondary containment system. 


\section{Control House Pump Pit}

The pump pit foundation is a $21^{\prime} 0^{\prime \prime} \times 40^{\prime} 0^{\prime \prime} \times 2^{\prime} 0^{\prime \prime}$ thick, reinforced concrete base slab that rests on limestone.

\section{Valve Box No. 3}

The valve box foundation is an $8^{\prime} 6^{\prime \prime} \times 11^{\prime} 0^{\prime \prime} \times 2^{\prime} 0^{\prime \prime}$ thick, reinforced concrete base slab that rests on limestone.

The assessment concludes that the tank vault, pump pit, and valve box foundations are properly designed to provide support to the secondary containment systems.

2.16.3.3 Provided with a Leak Detection System That is Designed and Operated to Detect Failure of Either Primary or Secondary Containment Structure or the Presence of Any Measurable Release of Hazardous or Radioactive Constituents

\section{Tank Vault W-21/W-22}

The assessments of the secondary containment system for Tank Vault W-21/W-22 are presented in the Design Demonstrations for Tanks W-21 and W-22. Those assessments conclude that the vault is provided with a leak detection system.

\section{Control House Pump Pit}

The pump pit floor is sloped to a 16-gauge (1/16"), 304L SS-lined sump where accumulation of liquid will be detected by a level sensor that will activate an alarm in the Waste Operations Control Center (Building 3130).

\section{Valve Box No. 3}

The Valve Box No. 3 floor is sloped to a 16-gauge (1/16"), 304L SS-lined sump where accumulation of liquid is transferred via a gravity fed drain line to a 304L SS-lined sump in Tank Vault-W-21/W-22. Accumulation of liquid in the tank vault sump will be detected by a level sensor that will activate alarms in the Evaporator Control Room and Waste Operations Control Center (Building 3130).

The assessment concludes that the tank vault, pump pit, and valve box are provided with leak detection. 
2.16.3.4 Sloped or Otherwise Designed or Operated to Drain and Remove Liquids Resulting from Leaks, Spills, or Precipitation

\section{Tank Vault W-21/W-22}

The assessments of the secondary containment system for Tank Vault W-21/W-22 are presented in the Design Demonstrations for Tanks W-21 and W-22. Those assessments conclude that the secondary containment is sloped and designed to drain and remove liquids resulting from leaks, spills, or precipitation.

\section{Control House Pump Pit}

The pump pit floor is sloped to a 304L SS-lined sump. The sump provides a low point within the pump pit to drain liquids to an instrumented location. A pumping system is provided to remove liquids that accumulate in the sump.

\section{Valve Box No. 3}

The valve box floor is sloped to a 304L SS-lined sump. Liquid that flows to the valve box sump will continue to flow to the Tank Vault W-21/W-22 sump through a sump drain pipe. The tank vault sump provides a low point to drain liquids to an instrumented location. A pumping system is provided to remove liquids that accumulate in the sump.

The assessment concludes that the secondary containments for the tank vault, pump pit, and valve box are sloped and designed to drain and remove liquids resulting from leaks, spills, or precipitation.

\subsubsection{Supplemental Information}

\subsubsection{Ancillary Equipment}

Tank W-21 is constructed of 304L SS, which is the same material as that used in the piping system, and is located in Tank Vault W-21/W-22, which provides secondary containment. The support equipment is exposed to the same liquids as other components of the tank system; therefore, 304L SS is an acceptable material for the support equipment.

\subsubsection{Waste Acceptance Criteria}

Radioactively contaminated liquid wastes at ORNL are generated by various activities within the research and operating divisions. These activities include radiochemical processing, routine hot cell operations and decontaminations, and various waste treatment and environmental protection processes. The variations in composition of the waste streams are limited by the waste acceptance criteria that specify activity and concentration limits for waste discharged into the LLLW system. The Waste Acceptance Criteria for Liquid Waste Treatment Systems at the Oak Ridge National Laboratory (Oak Ridge National Laboratory, 1991), dated July 1991, is a guide for liquid waste 
generators to determine the proper means of disposal for LLLW. The criteria provide future discharge guidelines for the LLLW system, which includes Tank System W-21. 


\subsubsection{References}

Binford, F. T., and S. D. Orfi. 1979. The Intermediate-Level Liquid Waste System at the Oak Ridge National Laboratory Description and Safety Analysis. ORNL/TM-6959. Oak Ridge National Laboratory.

Ebasco, and Main. July 20, 1992. Design Demonstrations-Category B Tank Systems, Revision 2. DOE Contract No. DE-AC05-91OR21928. Oak Ridge National Laboratory.

Energy Systems Drawing I-202-YE-105-E, Evaporator Service Tanks Instrument Flow Diagram, Title I Issue, Revision 3.

Energy Systems Drawing P-20237-YE-079-E, Evaporator Service Tanks Piping Flow Diagram, Process, Revision 3.

Energy Systems Drawing P-20237-YC-029-E, Evaporator Service Tanks Piping Sections and Details, Tanks W-21, W-22, and W-23, Revision 3.

Energy Systems Drawing S-20237-YB-035-E, Evaporator Service Tanks Plan and Sections and Details Stainless Steel Liner, Revision 2.

Energy Systems Drawing P-20237-YC-028-E, Evaporator Services Tanks Plan Piping Tanks W-21, W-22, and W-23, Revision 3.

Energy Systems Drawing S-20237-YB-019-E, Evaporator Service Tanks Section and Details of Concrete Vault, Revision 2.

Energy Systems Drawing P-20237-YC-031-E, Evaporator Service Tanks Tank Piping Sections and Details, Sheet 2, Tanks W-21, W-22 and W-23, Revision 2.

Energy Systems Drawing P-20237-YC-032-E, Evaporator Service Tanks Tank Piping Section and Details, Sheet 3, Revision 2.

Oak Ridge National Laboratory. 1991. Waste Acceptance Criteria for Liquid Waste Treatment Systems at the Oak Ridge National Laboratory. WM-WMCO-201. Department of Waste Minimization Planning and Certification.

Peretz, F. J., et al. 1986. Characterization of Low-Level Liquid Wastes at the Oak Ridge National Laboratory. ORNL/TM-10218. Oak Ridge National Laboratory.

Risk Evaluation of Embedded, Single-Walled Liquid Low-Level Waste Piping at Oak Ridge National Laboratory. 
Robinson, S. M., S. M. DePaoli, and A. B. Walker. 1991. Federal Facility Agreement Contingency, Upgrade, and Replacement Plans for the ORNL Active Low-Level Radioactive Waste Tank System. ORNL/TM-11795. Oak Ridge National Laboratory.

Samborn, Steketee, Otis and Evans, Inc. July 1975. Intermediate-Level Waste Management Facilities Design Calculations (Sheets 1 to 69) Tanks W-21 Through W-31. Prepared by Samborn, Steketee, Otis and Evans, Inc., Toledo, Ohio, for Oak Ridge National Laboratory.

Samborn, Steketee, Otis and Evans, Inc. July 1975. Intermediate-Level Waste Management Facilities Title I Report (Books 1 and 2). Holifield National Laboratory, Oak Ridge, Tennessee. Prepared by Samborn, Steketee, Otis and Evans, Inc., Toledo, Ohio, for Oak Ridge National Laboratory.

Samborn, Steketee, Otis and Evans, Inc. December 1975. Special Design Calculations Tank Freezing Analysis, Solvent-Flammability Hazard, Nitrogen Purge, Thermal Pipe Stresses in Vault, Seismic Analysis Tornado Loading Analysis. Prepared by Samborn, Steketee, Otis and Evans, Inc., Toledo, Ohio, for Oak Ridge National Laboratory.

Sears, M. B., et al. 1990. Sampling an Analysis of Radioactive Liquid Wastes and Sludges in the Melton Valley and Evaporator Facility Storage Tanks at ORNL. ORNL/TM-11652. Oak Ridge National Laboratory.

Specifications for Construction of Intermediate-Level Waste Facilities for the Energy Research and Development Administration. Invitation No. EY-77-B-05-5350.

Technical Specifications for the Construction of Improvements to Radioactive Liquid Waste System, Phase I, Building 2531. 


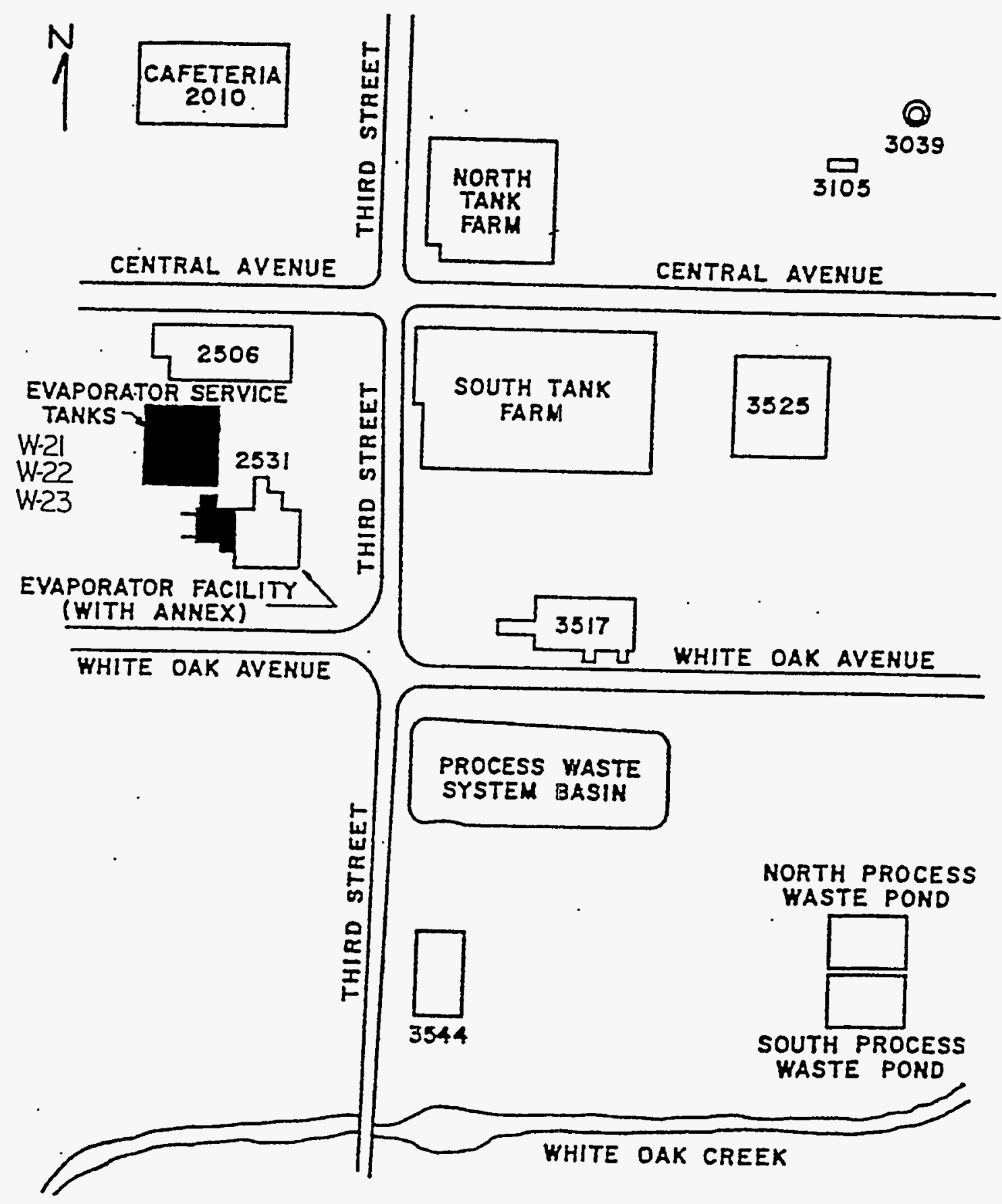


Figure 2.16-2 Tank System W-21 Piping Diagram

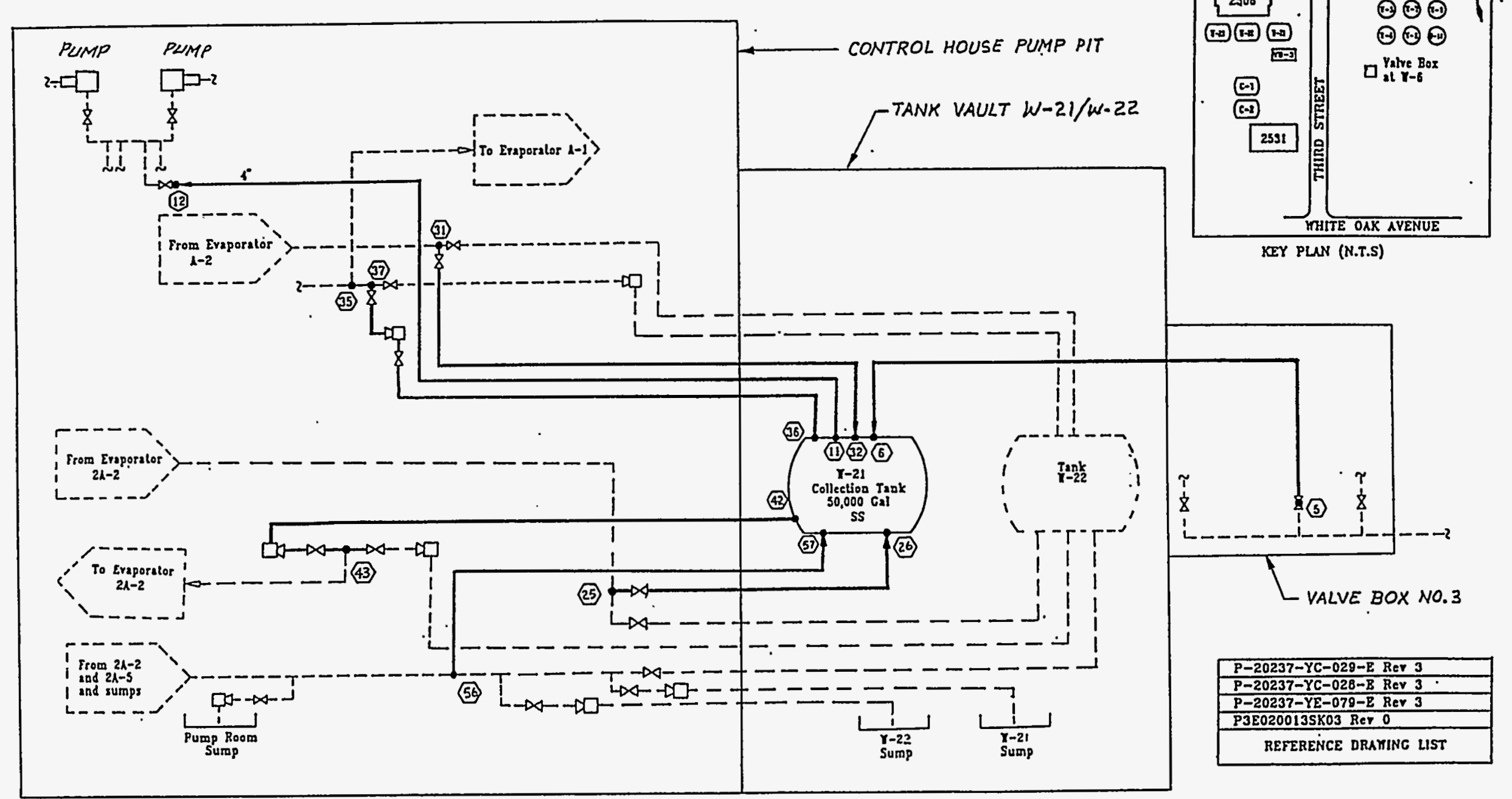

\begin{tabular}{|c|c|c|c|c|c|c|c|}
\hline LNE SEGMENT & (3) $-(1)$ & (11) - (12) & (31) - (197) & (12) - (12) & (23) - (20) & (12) - (19) & (11) - (57) \\
\hline SIZE $\mathrm{N}-\mathrm{DU}$ & 4 & 4 & 2 & 2 & 2 & 2 & 2 \\
\hline SCHEDULE & 605 & $40 S$ & $40 S$ & $40 S$ & 105 & $10 \mathrm{~S}$ & 605 \\
\hline MUTERIAL & sS & SS & SS & SS & $S S$ & SS & SS \\
\hline LENGTH (FT) & 22 & 41 & 47 & 19 & 51 & 47 & 88 \\
\hline YOLUHE (GAL) & 15 & 27 & 8 & 9 & 9 & 8 & 15 \\
\hline
\end{tabular}

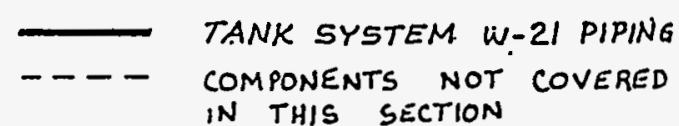

EBASCO/MaIN 


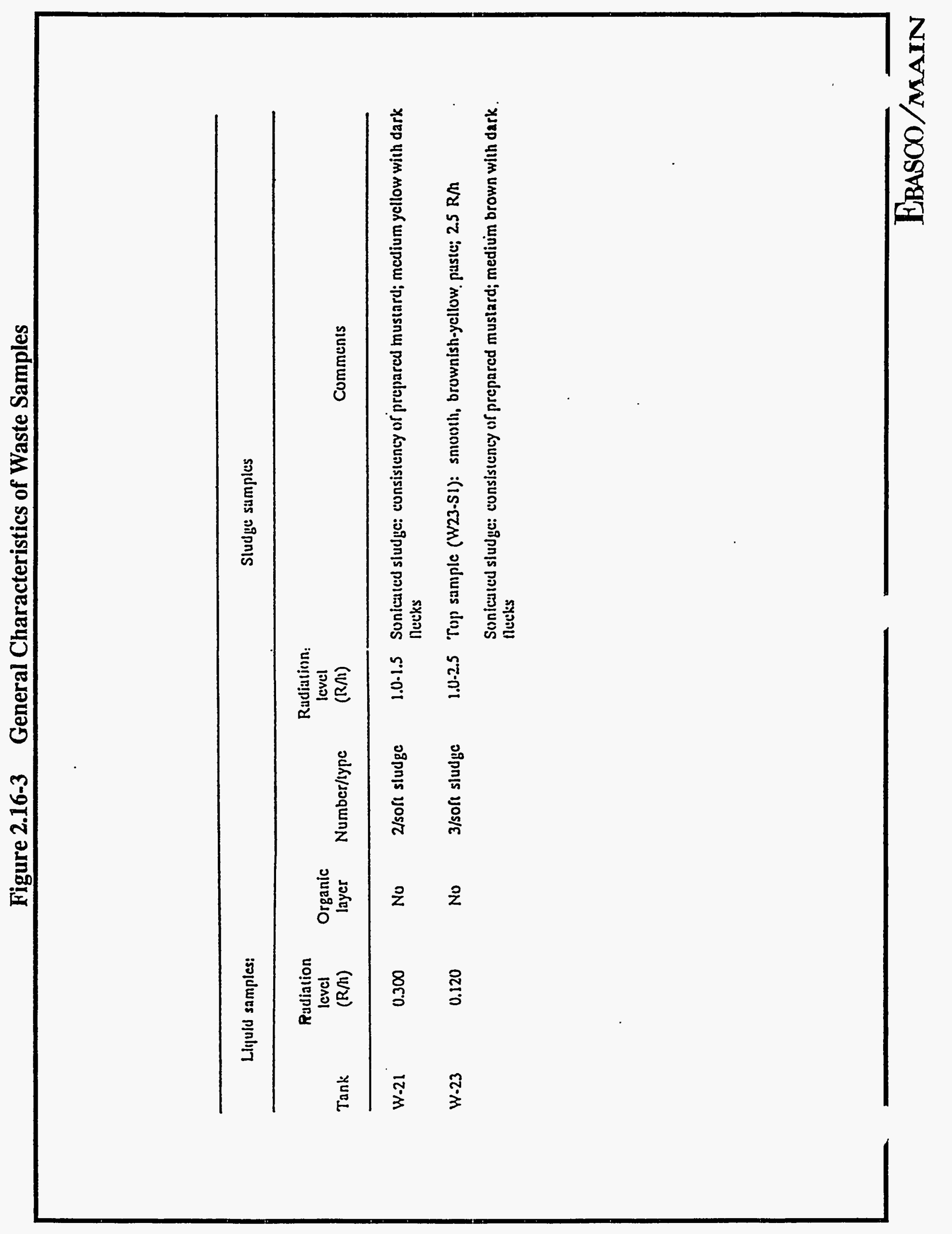


Figure 2.16-4

Analytical Data for Liquid and Sludge Samples

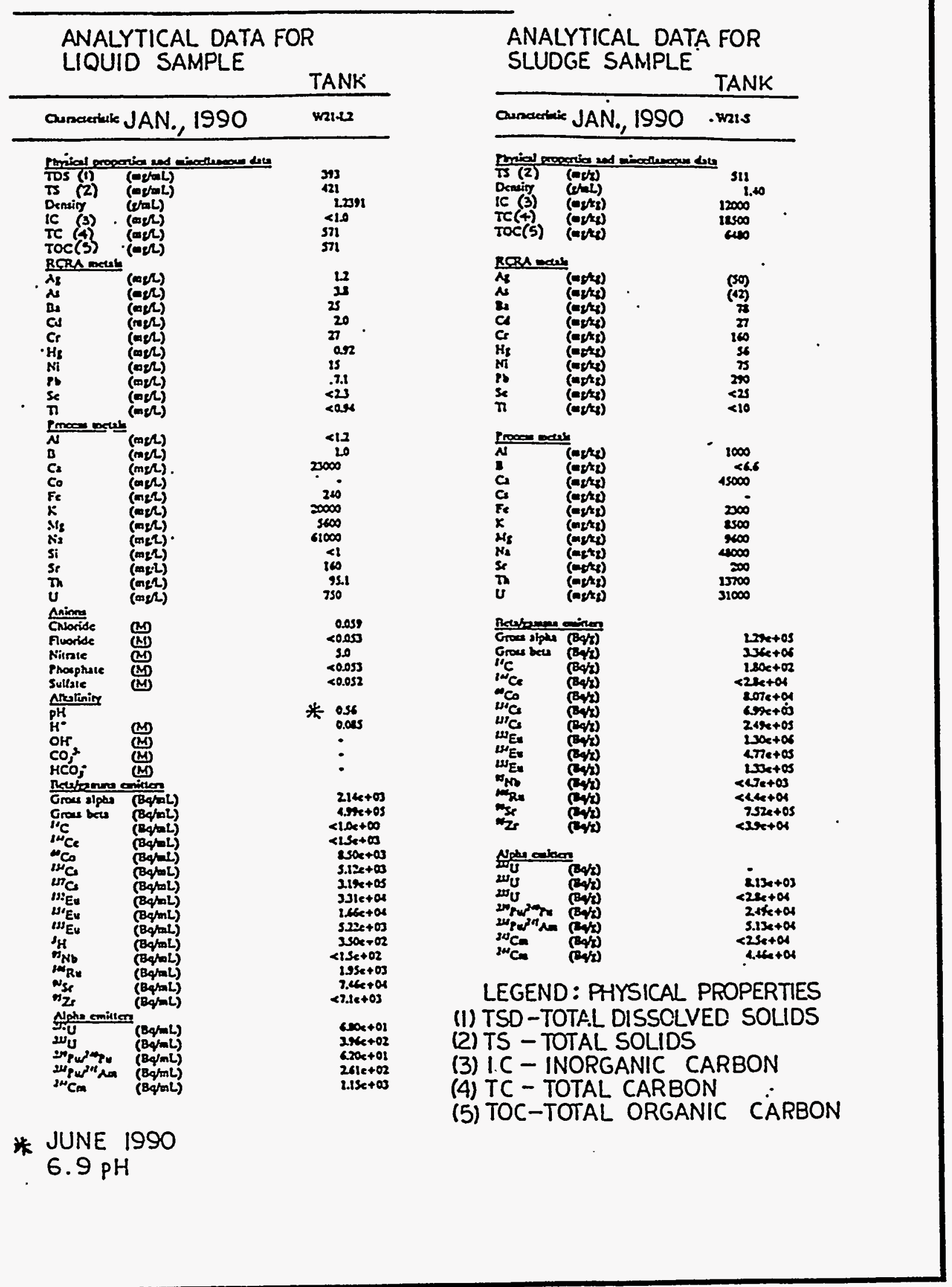


Design Demonstrations - Category B Tank Systems (Piping)

\subsection{Tank System W-22 Piping}

\subsubsection{Tank System Summary}

Tank System W-22 is located near the Evaporator Building 2531 and near the center of the main Bethel Valley Complex (Figures 2.17-1 and 2.17-2). The tank system piping is schedule 40S, ASME SA-240, type 304L stainless steel (SS). Piping is routed from Tank Vault W-21/W-22 through the Control House Pump Pit, into Pipe Tunnel 2 where it is routed into Valve Pit 2VP-3, and outside underground where it continues into the Valve Pit East of Building 2531. Additional piping is routed from the Control House Pump Pit into Tank Vault W-23. Piping is also routed from Tank Vault W-21/W-22 through Valve Box No. 3, outside underground, through Valve Box No. 1, then outside underground to Valve Box No. 2. Tank System W-22 piping is used as a liquid low-level waste (LLLW) transfer system for Tank W-22 and is classified as a Federal Facility Agreement (FFA) Category B tank system.

\subsubsection{Standards for Pipe Assessment of Tank Systems}

\subsubsection{Tank System Piping Description and Design Standards}

\section{Tank System Piping Description}

Tank System W-22 piping is located north of Evaporator Building 2531 and is routed from Tank Vault W-21/W-22 to several areas as follows: from Tank Vault W-21/W-22 through the Control House Pump Pit, into Pipe Tunnel 2 where it is routed into Valve Pit 2VP-3, and outside underground where it continues into the Valve Pit East of Building 2531. Additional piping is routed from the Control House Pump Pit into Tank Vault W-23. Piping is also routed from Tank Vault W-21/W-22 through Valve Box No. 3, outside underground, through Valve Box No. 1, then outside underground to Valve Box No. 2. The piping system is used and managed by the Waste Management and Remedial Actions Division.

Tank System W-22 piping is constructed of 2", 4", and 6", 304L SS with a maximum design pressure and temperature of $150 \mathrm{psig}$ and $300^{\circ} \mathrm{F}$. Tank System W-22 piping has the capacity to contain a maximum volume of 891 gal.

\section{$\underline{\text { Design Standards }}$}

The applicable codes and standards used for Tank System W-22 piping and its associated secondary containment systems are identified herein. The codes and standards listed are those identified on either the design drawings or the construction specifications.

AEC-Oak Ridge Office, Minimum Safety Requirements;

Air Moving and Conditioning Association (AMCA) Standards Handbook-Publication 99;

AMCA Directory-Publication 261; 
AMCA Fans and Systems-Publication 201;

American Concrete Institute 301-72;

American Concrete Pipe Association;

American Conference of Governmental Industrial Hygienists;

American National Standards Institute;

American Society for Testing and Materials A48, A262-70, C91, C144, and D1751;

American Society of Heating, Refrigeration, and Air Conditioning Engineers (ASHRAE) Handbook of Fundamentals;

American Society of Mechanical Engineers (ASME) Boiler and Pressure Vessel Code, Sections II (SA-240), V, VIII, and IX;

ASHRAE Guide and Data Book-Applications;

ASHRAE Guide and Data Book-Equipment;

ASHRAE Handbook-Systems;

Atomic Energy Commission (AEC) General Design Criteria, Appendix 63;

Factory Mutual Engineering Corporation;

Instrument Society of America;

National Electric Code;

National Fire Protection Association (NFPA) No. 90A-Air Conditioning and Ventilating Systems;

NFPA No. 91-Blower and Exhaust Systems;

Nuclear Safety Information Center 65-Design, Construction, and Testing of High Efficiency Air Filtration Systems for Nuclear Applications;

Occupational Safety and Health Administration;

Sheet Metal and Air Conditioning Contractors National Association (SMACNA) High Velocity Duct Construction Standards and Low Velocity Standards;

SMACNA Ducted Electric Heat Guide for Air Handling Systems; 
UCC-ND Engineering Standards;

UCC-ND General Design Criteria, Y-EF-53;

UCC-ND Technical Specifications;

Underwriters Laboratories Inc.; and

Union Carbide Corporation Nuclear Division (UCC-ND) Standards, Sections 303, 401, 411, 702, and 914.04.

\subsubsection{Generic Description of Piping Contents}

Tank System W-22 piping is designed as an LLLW transfer system for Tank W-22, an LLLW collection tank for the main Oak Ridge National Laboratory (ORNL) complex in Bethel Valley and Melton Valley. The waste solution generators are "hot" sinks and drains in research and development laboratories, radiochemical pilot plants, and nuclear reactors located at ORNL. The waste solutions discharged from the source buildings are transferred to and monitored in collection tanks that are distributed throughout the ORNL complex. LLLW from the collection tanks is transferred to the Evaporator Feed Tank W-22 via the Tank System W-22 piping for processing at the low-level waste evaporator. Tank W-23 collects the concentrated waste after processing.

The liquid waste supernate is single phase and ranges in color from pale to deep yellow with high $\mathrm{Ph}$ (11-13) sodium/potassium nitrate salt solutions. The principal metals found in the tank are sodium, potassium, calcium, magnesium, uranium, and thorium, with a low level of aluminum and iron. The sludge contains radioactive materials that produce radiation levels of approximately $1.0-2.0$ rem per hour $(R / h)$.

The analytical data (Figures 2.17-3 and 2.17-4) of waste solution samples from the generators are representative of waste received by Tank W-22; however, the composition of the waste transferred in the Tank W-22 system may vary depending upon the experiments conducted by the waste generators.

\subsubsection{Pipe Corrosion Protection Measures}

The piping inside Tank Vault W-21/W-22, Tank Vault W-23, the Control House Pump Pit, Pipe Tunnel 2, Valve Pit 2VP-3, Valve Box No. 3, the Valve Pit East of Building 2531, and Valve Boxes Nos. 1 and 2 has no direct contact with the soil or water. Cathodic protection measures are not required for external corrosion.

The outside underground piping for Tank System W-22 is provided with two cathodic protection systems to minimize external corrosion.

The first system is provided for piping that extends from Valve Box No. 3 near Tank W-21 to Valve Box No. 2. The piping is included in the Facility Manager's Cathodic Protection System No. 15. 
The system consists of magnesium anodes, test stations, and connecting wire as shown on cathodic protection drawings E-20013-ED-006-E and E-20013-ED-007-E. The cathodic protection system was installed in June 1976. The system shown on the drawings mentioned above is considered adequate. The cathodic protection test report and survey performed in 1990 and 1991 indicate that the piping is receiving adequate corrosion control.

The second system is provided for piping that extends between Pipe Tunnel 2 and the Valve Pit East of Building 2531. The piping is included in the Facility Manager's Cathodic Protection System No. 16. The system consists of an impressed current type cathodic protection system as shown on the cathodic protection drawing E-20237-ED-008-E. The system was installed in June 1976. The design of the cathodic protection system does not indicate test stations on the construction drawing; however, the cathodic protection test reports and surveys performed in 1990 and 1991 indicate that the majority of the piping discussed is effectively protected against corrosion.

\subsubsection{Documented Age of Tank System}

Tank System W-22 piping was installed in 1976.

\subsubsection{Standards for Containment/Release Detection}

Tank System W-22 piping incorporates approximately $60^{\prime}$ of embedded wall piping penetrations that are singly contained. The singly contained areas are omitted from discussion in the following sections that address secondary containment.

2.17.3.1 Constructed of or Lined with Materials That are Compatible with Stored Waste(s) or Substance(s) to Be Placed in the Tank System and Shall Have Sufficient Strength and Thickness to Prevent Failure

Tank System W-22 piping is single-wall, schedule 40S, type 304L SS, except for the outside underground piping that is routed from Valve Box No. 3 to Valve Box No. 1, from Valve Box No. 1 to Valve Box No. 2, and from Pipe Tunnel 2 to the Valve Pit East of Building 2531, which is double-wall piping with a schedule 10S, type 304L SS jacket. The piping is routed from Tank Vault W-21/W-22 through the Control House Pump Pit, into Pipe Tunnel 2 where it is routed into Valve Pit 2VP-3, and outside underground where it continues into the Valve Pit East of Building 2531. Additional piping is routed from the Control House Pump Pit into Tank Vault W-23. Piping is also routed from Tank Vault W-21/W-22 through Valve Box No. 3, outside underground, through Valve Box No. 1, then outside underground to Valve Box No. 2. Each area is discussed below.

\section{Tank Vaults W-21/W-22 and W-23}

The assessments of the secondary containment systems for Tank Vaults W-21/W-22 and W-23 are presented in the Design Demonstrations for Tanks W-21, W-22, and W-23. Those assessments conclude that the tank vaults are coated and lined with materials that are compatible with the waste and designed to prevent migration of waste into the concrete. 


\section{Control House Pump Pit}

The bottom of the pump pit is lined with 16-gauge (1/16"), 304L SS, which is the same material as that used in the piping, with sidewalls that project $3^{\prime} 0^{\prime \prime}$ up the pump pit walls. The pump pit walls above the SS liner are provided with a 30-mil-thick system of Amercoat 66 epoxy. The SS pump pit lining material is compatible with the waste and designed to prevent migration of waste into the concrete. According to manufacturer's specifications, the pump pit's epoxy coating is compatible with the waste and designed to prevent migration of waste into the concrete.

\section{Pipe Tunnel 2}

The bottom of Pipe Tunnel 2 is lined with 16-gauge (1/16"), 304L SS, which is the same material as that used in the piping, with sidewalls that project up to the pipe tunnel roof. The SS pipe tunnel lining material is compatible with the waste and designed to prevent migration of waste into the concrete.

\section{Valve Pit 2VP-3}

The bottom of Valve Pit 2VP-3 is lined with 16-gauge (1/16"), 304L SS, which is the same material as that used in the piping, with sidewalls that project $4^{\prime} 0^{\prime \prime}$ up the valve pit walls. The valve pit walls above the SS liner are provided with a system of Carboline 193 epoxy. The SS valve pit lining material is compatible with the waste and designed to prevent migration of waste into the concrete. According to manufacturer's specifications, the valve pit's epoxy coating is compatible with the waste and designed to prevent migration of waste into the concrete.

\section{Outside Underground Piping}

The jacket of the outside underground, double-wall pipe is schedule 10S, type 304L SS. The pipe jacket material is compatible with the waste.

\section{Valve Box No. 3}

The bottom of Valve Box No. 3 is lined with 16-gauge (1/16"), 304L SS, which is the same material as that used in the piping, with sidewalls that project $4^{\prime} 3^{\prime \prime}$ up the valve box walls. The valve box walls above the SS liner are provided with a 30-mil-thick system of Amercoat 66 epoxy. The SS valve box lining material is compatible with the waste and designed to prevent migration of waste into the concrete. According to manufacturer's specifications, the valve box's epoxy coating is compatible with the waste and designed to prevent migration of waste into the concrete.

\section{Valve Pit East of Building 2531}

The floor and walls of the valve pit are provided with a system of Amercoat 99. According to manufacturer's specifications, the valve pit's epoxy coating is compatible with the waste and designed to prevent migration of waste into the concrete. 


\section{Valve Box No. 1}

The bottom of the valve box is lined with 16-gauge $\left(1 / 16^{\prime \prime}\right), 304 \mathrm{~L}$ SS, which is the same material as that used in the piping, with sidewalls that project approximately $2^{\prime} 0^{\prime \prime}$ up the valve box walls. The SS valve box lining material is compatible with the waste and designed to prevent migration of waste into the concrete.

\section{Valve Box No. 2}

The bottom of the valve box is lined with 16-gauge (1/16"), 304L SS, which is the same material as that used in the piping, with sidewalls that project approximately $2^{\prime} 0^{\prime \prime}$ up the valve box walls. The SS valve box lining material is compatible with the waste and designed to prevent migration of waste into the concrete.

The assessment concludes that the tank vaults, pump pit, pipe tunnel, valve pits, and valve boxes are coated or lined with materials that are compatible with the waste and designed to prevent migration of waste into the concrete. The assessment concludes that the underground piping jacket is compatible with the waste.

\subsubsection{Placed on Foundation or Base Capable of Providing Support to the Secondary Containment System}

\section{Tank Vaults W-21/W-22 and W-23}

The assessments of the secondary containment systems for Tank Vaults W-21/W-22 and W-23 are presented in the Design Demonstrations for Tanks W-21, W-22, and W-23. Those assessments conclude that the vault foundations are properly designed to support the secondary containment systems.

\section{Control House Pump Pit}

The pump pit foundation is a $21^{\prime} 0^{\prime \prime} \times 40^{\prime} 0^{\prime \prime} \times 2^{\prime} 0^{\prime \prime}$ thick, reinforced concrete base slab that rests on limestone.

\section{Pipe Tunnel 2}

The pipe tunnel foundation is a $9^{\prime} 6^{\prime \prime} \times 63^{\prime} 8^{\prime \prime} \times 1^{\prime} 0^{\prime \prime}$ thick, reinforced concrete base slab that rests on limestone.

\section{Valve Pit 2VP-3}

The valve pit foundation is an $18^{\prime} 2^{\prime \prime} \times 27^{\prime} 4^{\prime \prime} \times 1^{\prime} 2^{\prime \prime}$ thick, reinforced concrete base slab that rests on limestone. 


\section{Valve Box No. 3}

The valve box foundation is an $8^{\prime} 6^{\prime \prime} \times 11^{\prime} 0^{\prime \prime} \times 2^{\prime} 0^{\prime \prime}$ thick, reinforced concrete base slab that rests on limestone.

\section{Valve Pit East of Building 2531}

The valve pit foundation is a $13^{\prime} 0^{\prime \prime} \times 14^{\prime} 0^{\prime \prime} \times 8^{\prime \prime}$ thick, reinforced concrete base slab that rests on limestone.

\section{Valve Box No. 1}

The valve box foundation is a $6^{\prime} 8^{\prime \prime} \times 19^{\prime} 2^{\prime \prime} \times 10^{\prime \prime}$ thick, reinforced concrete base slab that rests on limestone.

\section{Valve Box No. 2}

The valve box foundation is a $6^{\prime} 8^{\prime \prime} \times 14^{\prime} 4^{\prime \prime} \times 10^{\prime \prime}$ thick, reinforced concrete base siab that rests on limestone.

The assessment concludes that the tank vaults, pump pit, pipe tunnel, valve pits, and valve boxes have foundations that are properly designed to support the secondary containment systems.

2.17.3.3 Provided with a Leak Detection System That is Designed and Operated to Detect Failure of Either Primary or Secondary Containment Structure or the Presence of Any Measurable Release of Hazardous or Radioactive Constituents

\section{Tank Vaults W-21/W-22 and W-23}

The assessments of the secondary containment systems for Tank Vaults W-21/W-22 and W-23 are presented in the Design Demonstrations for Tanks W-21, W-22, and W-23. Those assessments conclude that the tank vaults are provided with leak detection systems.

\section{Control House Pump Pit}

The pump pit floor is sloped to a 16-gauge (1/16"), 304L SS-lined sump where accumulation of liquid will be detected by a level sensor that will activate an alarm in the Waste Operations Control Center (Building 3130).

\section{Pipe Tunnel 2}

The Pipe Tunnel 2 floor is sloped to a 16-gauge (1/16"), 304L SS-lined sump. Liquid that flows to the Pipe Tunnel 2 sump will continue to flow to the Control House Pump Pit sump through a 4", schedule $40 \mathrm{~S}$, type $304 \mathrm{~L}$ SS sump drain pipe. The pump pit sump is lined with 16-gauge (1/16"), 
304L SS; and accumulation of liquid will be detected by a level sensor that will activate an alarm in the Waste Operations Control Center (Building 3130).

\section{Valve Pit 2VP-3}

The Valve Pit 2VP-3 floor is sloped to a 16-gauge (1/16"), 304L SS-lined sump where accumulation of liquid will be detected by a level sensor that will activate an alarm in the Waste Operations Control Center (Building 3130).

\section{Outside Underground Piping}

All underground piping associated with this system is provided with a nitrogen-blanketed leak detection system.

\section{Valve Box No. 3}

Valve Box No. 3 has a 16-gauge (1/16"), 304L SS-lined sump. Liquid that flows to the valve box sump will continue to flow through a drain line to a 304L SS-lined sump in Tank Vault W-21/W-22. Accumulation of liquid in the Tank Vault W-21/W-22 sump will be detected by a level sensor that will activate alarms in the Evaporator Control Room and the Waste Operations Control Center (Building 3130).

\section{Valve Pit East of Building 2531}

The valve pit is sloped to a coated sump where accumulation of liquid will be detected by a level sensor that will activate an alarm in the Waste Operations Control Center (Building 3130).

\section{Valve Box No. 1}

The valve box floor is sloped to a 16-gauge (1/16"), 304L SS-lined sump where accumulation of liquid will be detected by a level sensor that will activate an alarm in the Waste Operations Control Center (Building 3130).

\section{Valve Box No. 2}

The valve box floor is sloped to a 16-gauge $\left(1 / 16^{\prime \prime}\right)$, 304L SS-lined sump where accumulation of liquid will be detected by a level sensor that will activate an alarm in the Waste Operations Control Center (Building 3130).

The assessment concludes that the tank vaults, pump pit, pipe tunnel, valve pits, underground piping, and valve boxes are provided with leak detection. 
Design Demonstrations - Category B Tank Systems (Piping)

2.17.3.4 Sloped or Otherwise Designed or Operated to Drain and Remove Liquids Resulting from Leaks, Spills, or Precipitation

\section{Tank Vaults W-21/W-22 and W-23}

The assessments of the secondary containment systems for Tank Vaults W-21/W-22 and W-23 are presented in the Design Demonstrations for Tanks W-21, W-22, and W-23. Those assessments conclude that the secondary containment systems are sloped and designed to drain and remove liquids resulting from leaks, spills, or precipitation.

\section{Control House Pump Pit}

The pump pit floor is sloped to a 304L SS-lined sump. The sump provides a low point within the pump pit to drain liquids to an instrumented location. A pumping system is provided to remove liquids that accumulate in the sump.

\section{Pipe Tunnel 2}

The pipe tunnel floor is sloped to a 304L SS-lined sump. Liquid that flows to the pipe tunnel sump will continue to flow to the pump pit sump through a sump drain pipe. The pump pit sump provides a low point to drain liquids to an instrumented location. A pumping system is provided to remove liquids that accumulate in the sump.

\section{Valve Pit 2VP-3}

The valve pit floor is sloped to a 304L SS-lined sump. The sump provides a low point within the valve pit to drain liquids to an instrumented location. A pumping system is provided to remove liquids that accumulate in the sump.

\section{Outside Underground Piping}

All outside underground piping is sloped and provided with $1 / 2^{\prime \prime}$ drain test connections to remove liquids resulting from leaks.

\section{Valve Box No. 3}

The valve box floor is sloped to a 304L SS-lined sump. Liquid that flows to the valve box sump will continue to flow to the Tank Vault W-21/W-22 sump through a sump drain pipe. The tank vault sump provides a low point to drain liquids to an instrumented location. A pumping system is provided to remove liquids that accumulate in the sump. 


\section{Valve Pit East of Building 2531}

The valve pit floor is sloped to a coated sump. The sump provides a low point within the valve pit to drain liquids to an instrumented location. A pumping system is provided to remove liquids that accumulate in the sump.

\section{Valve Box No. 1}

The valve box floor is sloped to a 304L SS-lined sump. The sump provides a low point within the valve box to drain liquids to an instrumented location. A pumping system is provided to remove liquids that accumulate in the sump.

\section{Valve Box No. 2}

The valve box floor is sloped to a $304 \mathrm{~L}$ SS-lined sump. The sump provides a low point within the valve box to drain liquids to an instrumented location. A pumping system is provided to remove liquids that accumulate in the sump.

The assessment concludes that the tank vaults, pump pit, pipe tunnel, valve pits, underground piping, and valve boxes are sloped and designed to drain and remove liquids resulting from leaks, spills, or precipitation.

\subsubsection{Supplemental Information}

\subsubsection{Ancillary Equipment}

Tank W-22 is constructed of 304L SS, which is the same material as that used in the piping system, and is located in Tank Vault W-21/W-22, which provides secondary containment. The support equipment is exposed to the same liquids as other components of the tank system; therefore, 304L SS is an acceptable material for the support equipment.

\subsubsection{Waste Acceptance Criteria}

Radioactively contaminated liquid wastes at ORNL are generated by various activities within the research and operating divisions. These activities include radiochemical processing, routine hot cell operations and decontaminations, and various waste treatment and environmental protection processes. The variations in composition of the waste streams are limited by the waste acceptance criteria that specify activity and concentration limits for waste discharged into the LLLW system. The Waste Acceptance Criteria for Liquid Waste Treatment Systems at the Oak Ridge National Laboratory (Oak Ridge National Laboratory, 1991), dated July 1991, is a guide for liquid waste generators to determine the proper means of disposal for LLLW. The criteria provide future discharge guidelines for the LLLW system, which includes Tank System W-22. 


\subsubsection{References}

Binford, F. T., and S. D. Orfi. 1979. The Intermediate-Level Liquid Waste System at the Oak Ridge National Laboratory Description and Safety Analysis. ORNL/TM-6959. Oak Ridge National Laboratory.

Ebasco, and Main. July 20, 1992. Design Demonstrations-Category B Tank Systems, Revision 2. DOE Contract No. DE-AC05-91OR21928. Oak Ridge National Laboratory.

Energy Systems Drawing E-S-52709, Cell and Valve Pit, Sections and Details, Revision 1.

Energy Systems Drawing I-202-YE-105-E, Evaporator Service Tanks Instrument Flow Diagram, Title I Issue, Revision 3.

Energy Systems Drawing P-20237-YE-079-E, Evaporator Service Tanks Piping Flow Diagram, Process, Revision 3.

Energy Systems Drawing P-20237-YC-029-E, Evaporator Service Tanks Piping Sections and Details Tanks W-21, W-22, and W-23, Revision 3.

Energy Systems Drawing S-20237-YB-035-E, Evaporator Service Tanks Plan and Sections and Details Stainless Steel Liner, Revision 2.

Energy Systems Drawing P-20237-YC-028-E, Evaporator Services Tanks Plan Piping Tanks W-21, W-22, and W-23, Revision 3.

Energy Systems Drawing S-20237-YB-019-E, Evaporator Service Tanks Sections and Details of Concrete Vault, Revision 2.

Energy Systems Drawing P-20237-YC-031-E, Evaporator Service Tanks Tank Piping Sections and Details Sheet 2 Tanks W-21, W-22 and W-23, Revision 2.

Energy Systems Drawing P3E-20013-C013, Piping Details Double Contained Pipe, Revision 0.

Energy Systems Drawing S3E-20013-B005, External Piping for TWPF Evaporator Service Tanks Valve Pit Modifications Plan and Sections, Revision 0.

Energy Systems Drawing D-52600, Valve Pit Piping, Revision B.

Energy Systems Drawing C-20013-EA-032, Waste Collection Header Valve Boxes Concrete Details, Revision B.

Energy Systems Drawing C-20013-EA-033, Waste Collection Header Valve Boxes Liner and Sleeve Drains, Revision B. 
Energy Systems Drawing D-52606, Waste Evaporator Building Cell 1 and 2 Process Flow Sheet, Revision 4.

Energy Systems Drawing D-52604, Waste Evaporator Buildings Cell 1 and 2 Service Flow Sheet, Revision 3.

Energy Systems Drawing E-20013-ED-006, Waste Collection Header Cathodic Protection, Sheet 1, Revision 0.

Energy Systems Drawing E-20013-ED-007, Waste Collection Header Cathodic Protection, Sheet 2 , Revision 0.

Energy Systems Drawing E-20237-ED-008, Evaporator Annex and Service Tanks Cathodic Protection, Revision 0.

Harco Technologies Corporation. June 1990. Resurvey of the Cathodic Protection Systems, Oak Ridge National Laboratory, United States Department of Energy, Oak Ridge, Tennessee. Martin Marietta Energy Systems, Inc.

Harco Technologies Corporation. July 1991. Cathodic Protection System Upgrade Design Underground ILW Lines VLV Box 1 to 2531 and 2537, System No. 16. Oak Ridge National Laboratories, United States Department of Energy, Oak Ridge, Tennessee. Martin Marietta Energy Systems, Inc.

Oak Ridge National Laboratory. 1991. Waste Acceptance Criteria for Liquid Waste Treatment Systems at the Oak Ridge National Laboratory. WM-WMCO-201. Department of Waste Minimization Planning and Certification.

Risk Evaluation of Embedded, Single-Walled Liquid Low-Level Waste Piping at Oak Ridge National Laboratory.

Robinson, S. M., S. M. DePaoli, and A. B. Walker. 1991. Federal Facility Agreement Contingency, Upgrade, and Replacement Plans for the ORNL Active Low-Level Radioactive Waste Tank System. ORNL/TM-11795. Oak Ridge National Laboratory. 


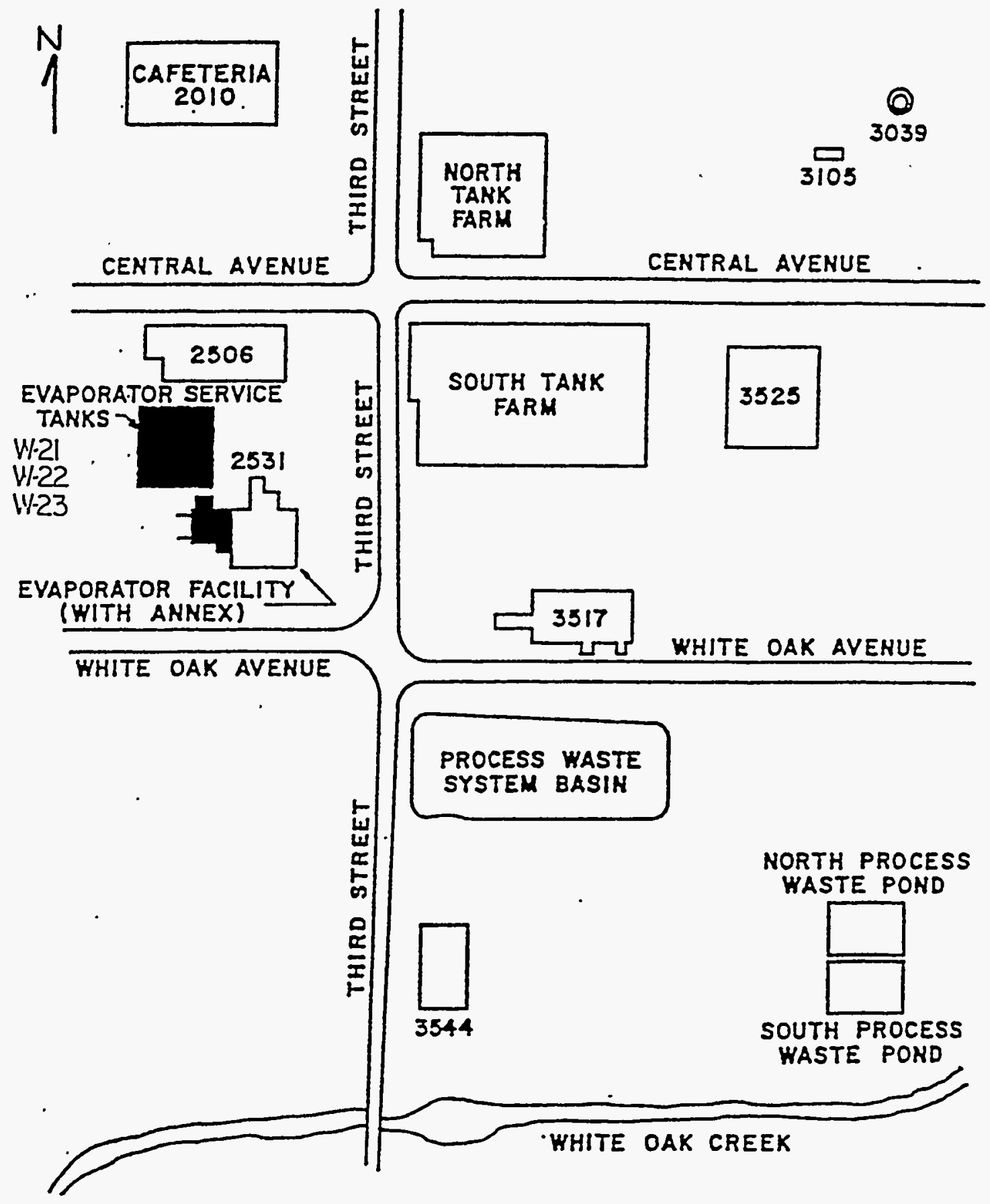




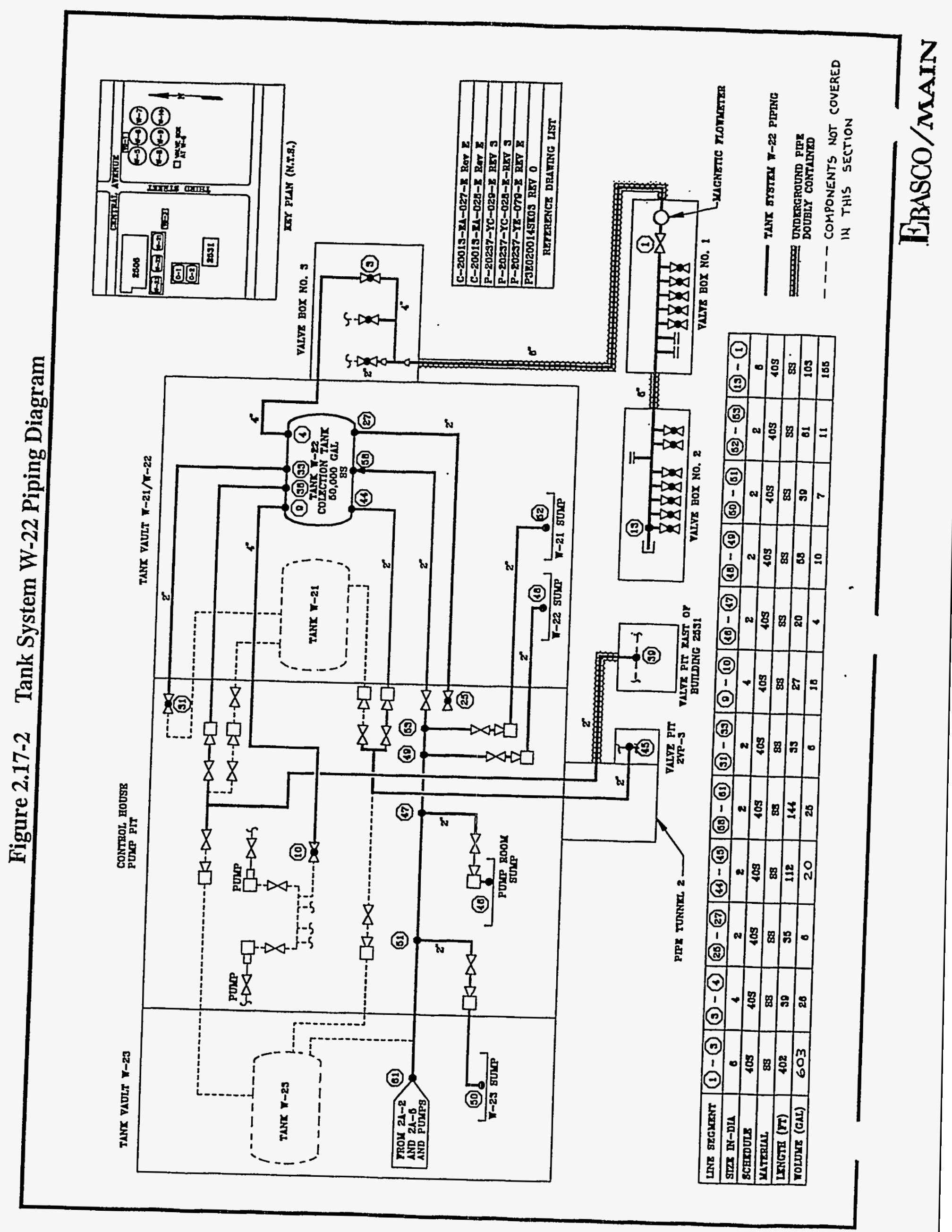


Figure 2.17-3 Radiochemical Analyses In the Evaporator Service Tanks

lladiocheralcal analysts of, beta cratecers In the Evaporator Service Tanks ${ }^{a}$

\begin{tabular}{|c|c|c|c|c|c|c|c|c|c|c|c|c|c|}
\hline Tank & $\begin{array}{l}\text { Sample } \\
\text { date }\end{array}$ & $\begin{array}{l}\text { Sample } \\
\text { Iocacion }\end{array}$ & $\frac{\text { Gross }}{\text { THU }^{b}}$ & $\frac{\text { beta }}{\text { RHALC }}$ & $\begin{array}{l}\text { Gruss hamiaa } \\
(c / m \perp n-m L)\end{array}$ & Sr -90 & $C s-137$ & Co-60 & $E u-152$ & $E u-154$ & $E u-155$ & $2 r-95$ & $\mathrm{Nb}-95$ \\
\hline$|W-2|$ & Nov. 85 & Sollds $s^{d}$ & 84,900 & 68,300 & $1.49 E+07$ & 16.400 & 6,760 & 1,060 & 11,600 & 5,840 & 2,400 & 2,660 & 200 \\
\hline$W-22$ & Nov. 85 & Sollds ${ }^{d}$ & 56,500 & 53,700 & 1.18E+U7 & 10,200 & 5,050 & 740 & 10,900 & 5,350 & 2,060 & 2,920 & 330 \\
\hline$H-23$ & $\begin{array}{l}\text { Nov. } 85 \\
\text { Nov. } 85\end{array}$ & $\begin{array}{l}\text { Llquide } \\
\text { Sollds }\end{array}$ & $\begin{array}{r}66,800 \\
237,000\end{array}$ & $\begin{array}{r}49,800 \\
205,000\end{array}$ & $\begin{array}{l}1.25 E+07 \\
1.35 E+07\end{array}$ & $\begin{array}{r}9,400 \\
73,700\end{array}$ & $\begin{array}{l}2.040 \\
6,510\end{array}$ & $\begin{array}{l}760 \\
880\end{array}$ & $\begin{array}{l}13,000 \\
12,100\end{array}$ & $\begin{array}{c}f \\
8,220\end{array}$ & $\begin{array}{l}2,250 \\
2,550\end{array}$ & 3,400 & 200 \\
\hline
\end{tabular}

$a_{111}$ data trom the TRU laboratory except RMuL gross beta and $5 r-90$.

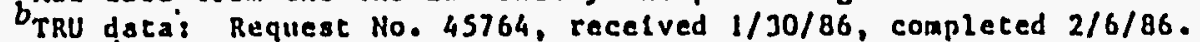

CIHAL data: Request No. 34529 , recelved $11 / 12 / 85$, completed $11 / 22 / 85$.

$d_{\mathrm{nCl} / \mathrm{g} \text { for solld samples. }}$

$a_{n C 1 / m L}$ for llquld samples.

SA blank space means no dnta avallable:

Radloclicinteal analyses of alpha calters

in the Evaporator Service Tanks

\begin{tabular}{|c|c|c|c|c|c|c|c|c|c|}
\hline Tank & $\begin{array}{l}\text { Sample } \\
\text { date }\end{array}$ & $\begin{array}{l}\text { Sample } \\
\text { location }\end{array}$ & $\frac{\text { Cross }}{\text { TRU }^{b}}$ & $\frac{\text { alpha }}{\text { Rusita }}$ & $C_{r a}-244$ & $\Lambda m-241$ & $\begin{array}{c}\text { Pu-239. } \\
\& \quad P u-240\end{array}$ & $\mathrm{Pu}-23 \mathrm{~B}$ & $U-233$ \\
\hline $\mid 1-2 L$ & Nov. 85 & Sol1ds $d$ & 5110 & 1900 & 810 & 70 & 380 & 030 & so \\
\hline $\mathrm{H}-22$ & Nov. 85 & Sol1ds $d$ & 3510 & 2260 & 1100 & 100 & 190 & 280 & 58 \\
\hline$K-23$ & $\begin{array}{l}\text { Nov. } 85 \\
\text { Nov. } 85\end{array}$ & $\begin{array}{l}\text { Llquidd } \\
\text { Sol1ds }\end{array}$ & $\begin{array}{r}870 \\
697.0\end{array}$ & $\begin{array}{r}710 \\
3190\end{array}$ & $\begin{array}{r}280 \\
2190\end{array}$ & $\begin{array}{r}50 \\
<30\end{array}$ & $\begin{array}{r}50 \\
580\end{array}$ & $\begin{array}{r}90 \\
500\end{array}$ & $\begin{array}{r}30 \\
130\end{array}$ \\
\hline
\end{tabular}

a 11 data from the TRU laboratory except RHAl gross alpha.

TruU data: Request Ho. 45764, recelved $1 / 30 / 06$, conpleted $2 / 6 / 86$.

onmal data: Roquest No. 34529 , recelved $1 / / 12 / 85$, conpleced $1 / / 22 / 85$.

$d_{n C 1 / 8}$ for solld samples.

nCl/al for liquid samples. 


\section{ANALYTICAL DATA FOR \\ ANALYTICAL DATA FOR LIQUIO SAMPLE SLUDGE SAMPLE}

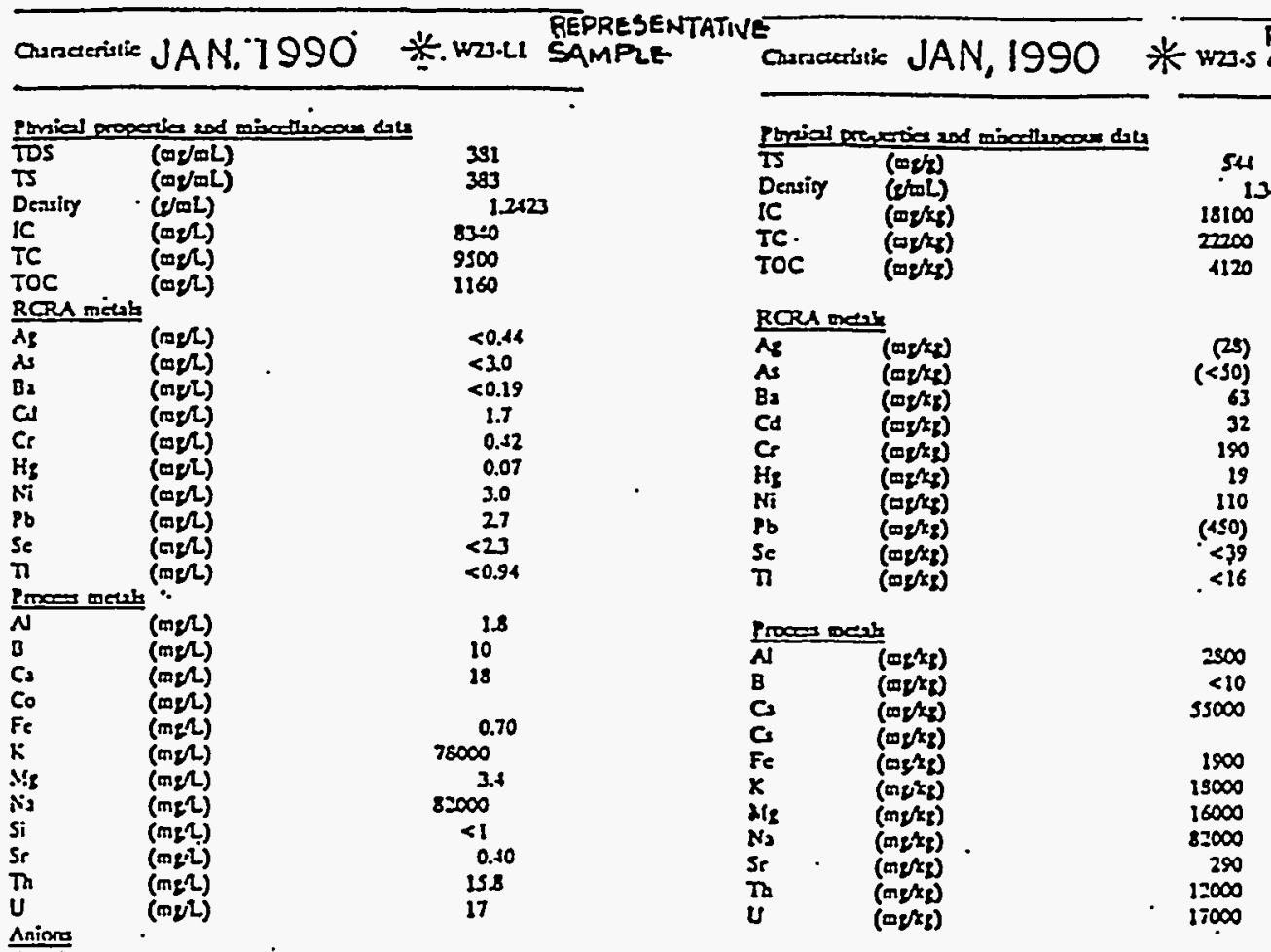

REPRESENTATIVE

Retrfamenareminon

Groses Ilpha (Bq/8)

Groes beta (Bq/s)

"C (BQ

INCe (Bq/8)

जCo $(B / z)$

"II $\mathrm{G}$ (B/\%)

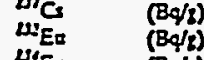

W"Ev (B/t)

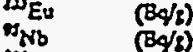

$8.20 x+01$

$4.62 e+05$

$6.35 e+01$

$<1.6 c+03$

$\log ^{R u} \quad(B q / 2)$

Gross bet2 (B/OrL)

"C (BqLL)

$621 c+0$

$\infty_{Z 2} \quad(B / z)$

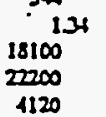

"Co (Bष/)

"I'C (Bghal)

Npha uminion

"MG (B)

$136 x+05$

$<21 \mathrm{c}+02$

Wu (Be/s)

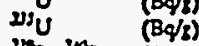

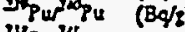

$2 \mathrm{PW}^{2 \mathrm{ta}} \mathrm{Am}(\mathrm{BQ} / \mathrm{s})$

3"1 $\mathrm{Ca}$ (BC/s)

$(25)$
$(<90)$
635

32

190
19

(450)

$<39$
$<16$

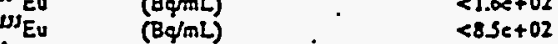

HH (Bq/aL)

$1.19+02$

$<1.0<+02$

$4.12 x+02$

$\begin{array}{ll}n^{2 r} & (B d / m L) \\ n^{2 u} & (B q / m L)\end{array}$

"Zs (Bq/mL)

$(89 / 8)$

$\frac{1}{20} \mathrm{U}$ (Bq/mL)

$1.00+\infty$

$6.00 \times+\infty$

$6.00 x+\infty$

$3.80 x+01$

$4.00 \div+03$

LEGEND:

"Pur"pu (Bg/mL)

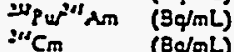

TSD - TOTAL DISSOLVED SOLIDS

TS - TOTAL SOLIDS

IC - INORGANIC CARBON

TC - TOTAL CARBON

* no data for tank w22, Tank

W23 SHOWN AS A REP. S'AMPLE

TOC - TOTAL ORGANIC CARBON 
Tank System W-23 Piping

\subsubsection{Tank System Summary}

Tank System W-23 is located near the Evaporator Building 2531 and near the center of the main Bethel Valley Complex (Figures 2.18-1 and 2.18-2). The tank system piping is constructed of schedule 40S, ASME SA-240, type 304L stainless steel (SS) and is routed from Tank Vault W-23 to the Control House Pump Pit. The piping is routed to several locations from the Control House Pump Pit as follows: to Tank Vault W-21/W-22 and further to Valve Box No. 3, and to Pipe Tunnel 2 and further to Valve Pit 2VP-3 and Evaporator Annex Cell No. 4. An additional line is routed outside underground from Pipe Tunnel 2 to Evaporator Annex Valve Pit No. 1. Tank System W-23 piping is used to transfer concentrate for the Evaporator and is classified as a Federal Facility Agreement (FFA) Category B tank system.

\subsubsection{Standards for Pipe Assessment of Tank Systems}

\subsubsection{Tank System Piping Description and Design Standards}

\section{Tank System Piping Description}

Tank System W-23 piping is located near Building 2531 and is routed from Tank Vault W-23 to the Control House Pump Pit. The piping is routed to several locations from the Control House Pump Pit as follows: to Tank Vault W-21/W-22 and further to Valve Box No. 3, and to Pipe Tunnel 2 and further to Valve Pit 2VP-3 and Evaporator Annex Cell No. 4. An additional line is routed outside underground from Pipe Tunnel 2 to Evaporator Annex Valve Pit No. 1. The piping system is used and managed by the Waste Management and Remedial Actions Division.

Tank System W-23 piping is constructed of 1-1/2," 2," and 4", 304L SS with a maximum design pressure and temperature of $150 \mathrm{psig}$ and $300^{\circ} \mathrm{F}$. Tank System W-23 piping has the capacity to contain a maximum volume of 129 gal.

\section{$\underline{\text { Design Standards }}$}

The applicable codes and standards used for Tank System W-23 piping and its associated secondary containments systems are identified herein. The codes and standards listed are those identified on either the design drawings or the construction specifications.

AEC-Oak Ridge Office, Minimum Safety Requirements;

Air Moving and Conditioning Association (AMCA) Standards Handbook-Publication 99;

AMCA Directory-Publication 261;

AMCA Fans and Systems-Publication 201; 
American Concrete Institute 301-72;

American Concrete Pipe Association;

American Conference of Governmental Industrial Hygienists;

American National Standards Institute.

American Society for Testing and Materials A48, A262-70, C91, C144, and D1751;

American Society of Heating, Refrigeration, and Air Conditioning Engineers (ASHRAE) Handbook of Fundamentals;

American Society of Mechanical Engineers (ASME) Boiler and Pressure Vessel Code, Sections II (SA-240), V, VIII, and IX;

ASHRAE Guide and Data Book-Applications;

ASHRAE Guide and Data Book-Equipment;

ASHRAE Handbook-Systems;

Atomic Energy Commission (AEC) General Design Criteria, Appendix 63;

Factory Mutual Engineering Corporation;

National Electric Code;

National Fire Protection Association (NFPA) No. 90A-Air Conditioning and Ventilating Systems;

NFPA No. 91-Blower and Exhaust Systems;

Nuclear Safety Information Center 65-Design, Construction, and Testing of High Efficiency Air Filtration Systems for Nuclear Applications;

Occupational Safety and Health Administration;

Sheet Metal and Air Conditioning Contractors National Association (SMACNA) High Velocity Duct Construction Standards and Low Velocity Standards;

SMACNA Ducted Electric Heat Guide for Air Handling Systems;

UCC-ND Engineering Standards;

UCC-ND General Design Criteria, Y-EF-53; 
Design Demonstrations - Category B Tank Systems (Piping)

UCC-ND Technical Specifications;

Underwriters Laboratories Inc.; and

Union Carbide Corporation Nuclear Division (UCC-ND) Standards, Sections 303, 401, 411, 702, and 914.04 .

\subsubsection{Generic Description of Piping Contents}

Tank System W-23 piping was designed for and is currently being used with Tank W-23, a concentrate storage tank for the Low-Level Waste Evaporator in the Bethel Valley complex. Liquid low-level waste (LLLW) is generated from a variety of facilities at the Oak Ridge National Laboratory (ORNL) including reactors, radioactive fuel processing areas, radioisotope processing areas, decontamination operations, hot cells, and radiochemical laboratories. The waste generators collect the waste, which is then transferred to the Evaporator Feed Tank, W-22. The waste is concentrated by being processed in the Evaporator by a batch operation until a predetermined specific gravity is reached. After processing, the evaporator bottoms are pumped directly into Tank W-23 for storage with the ability to transfer from Tank W-23 to additional Concentrate Storage Tanks C-1, $\mathrm{C}-2$, and W-24 through W-31.

The liquid waste supernate is single phase and ranges in color from pale to deep yellow with a high $\mathrm{Ph}$ (11-13) sodium/potassium nitrate salt solutions. The principal metals found in the tank sludge are sodium, potassium, calcium, magnesium, uranium, and thorium with a low level of aluminum and iron. The tank contains radioactive materials that produce radiation levels of 1.0-2.5 rem per hour $(\mathrm{R} / \mathrm{h})$ (Figure 2.18-3).

The analytical data (Figure 2.18-4) of waste solution samples from the generators are representative of waste received by Tank W-23; however, the composition of the waste transferred to and stored in Tank W-23 may vary depending upon the experiments conducted by the waste generators.

\subsubsection{Pipe Corrosion Protection Measures}

Piping inside Tank Vault W-23, Tank Vault W-21/W-22, the Control House Pump Pit, Pipe Tunnel 2, Valve Pit 2VP-3, Evaporator Annex Valve Pit No. 1, Evaporator Annex Cell No. 4, and Valve Box No. 3 has no direct contact with the soil or water. Cathodic protection measures are not required for external corrosion.

The cathodically protected outside underground piping associated with Tank System W-23 piping extends from the Building 2531 Evaporator Annex Valve Pit No. 1 to Pipe Tunnel 2. The piping is included in the Facility Manager's Cathodic Protection System No. 16. The system, as installed in June 1976, consists of an impressed current type cathodic protection system as shown on drawing E-20237-ED-008. The design of the system is not considered adequate because test stations are not shown on the installation drawings. 
Design Demonstrations - Category B Tank Systems (Piping)

The cathodic protection test report and survey performed in 1990 and 1991 indicate that test stations were not installed during construction of the system and that some of the piping segments may not be bonded together as shown on the installation drawings. Piping that is discontinuous will be inadequately protected. In 1991, Harco completed an engineering design to install test stations on this piping and the adjacent piping and ducts. Energy Systems' upgrade is shown in Table 2.0-1.

\subsubsection{Documented Age of Tank System}

Tank System W-23 piping was installed in 1976.

\subsubsection{Standards for Containment/Release Detection}

2.18.3.1 Constructed of or Lined with Materials That are Compatible with Stored Waste(s) or Substance(s) to Be Placed in the Tank System and Shall Have Sufficient Strength and Thickness to Prevent Failure

Tank System W-23 piping is single-wall, schedule 40S, type 304L SS. The section of piping that is routed outside underground from Pipe Tunnel 2 to Evaporator Annex Valve Pit No. 1 is double wall with a schedule 10S, type 304L SS jacket. The piping is routed from Tank Vault W-23 to the Control House Pump Pit. The piping is routed to several locations from the Control House Pump Pit as follows: to Tank Vault W-21/W-22 and further to Valve Box No. 3, and to Pipe Tunnel 2 and further to Valve Pit 2VP-3 and Evaporator Annex Cell No. 4. An additional line is routed outside underground from Pipe Tunnel 2 to Evaporator Annex Valve Pit No. 1. Each area is discussed below. The piping penetrations from Tank Vaults W-23 and W-21/W-22 to the Control House Pump Pit, from Tank Vault W-21/W-22 to Valve Box No. 3, from the Control House Pump Pit to Pipe Tunnel 2, and from Valve Pit 2VP-3 to the Evaporator Annex Cell No. 4 are singly contained, schedule $40 \mathrm{~S}$, type $304 \mathrm{~L}$ SS pipes embedded in the concrete walls to lengths of $2^{\prime} 0^{\prime \prime}$ and $3^{\prime} 0^{\prime \prime}$.

\section{Tank Vaults W-23 and W-21/W-22}

The assessments of the secondary containment systems for Tank Vaults W-23 and W-21/W-22 are presented in the Design Demonstrations for Tanks W-23, W-21, and W-22. Those assessments conclude that Tank Vaults W-23 and W-21/W-22 are coated and lined with materials that are compatible with the waste and designed to prevent migration of waste into the concrete.

\section{Control House Pump Pit}

The bottom of the pump pit is lined with 16-gauge (1/16"), 304L SS, which is the same material as that used in the piping, with sidewalls that project $3^{\prime} 0^{\prime \prime}$ up the pump pit. The pump pit walls above the SS liner are provided with a 30-mil-thick system of Amercoat 66 epoxy. The SS pump pit lining material is compatible with the waste and designed to prevent migration of waste into the concrete. According to manufacturer's specifications, the pump pit's epoxy coating is compatible with the waste and designed to prevent migration of waste into the concrete. 


\section{Valve Box No. 3}

The bottom of Valve Box No. 3 is lined with 16-gauge (1/16"), 304L SS, which is the same material as that used in the piping, with sidewalls that project $4^{\prime} 3^{\prime \prime}$ up the valve box. The valve box walls above the SS liner are provided with a system of 30-mil-thick Amercoat 66 epoxy. The SS valve box lining material is compatible with the waste and designed to prevent migration of waste into the concrete. According to manufacturer's specifications, the valve box's epoxy coating is compatible with the waste and designed to prevent migration of waste into the concrete.

\section{Pipe Tunnel 2}

The bottom of Pipe Tunnel 2 is lined with 16-gauge (1/16"), 304L SS, which is the same material as that used in the piping, with sidewalls that project up to the pipe tunnel roof. The SS pipe tunnel lining material is compatible with the waste and designed to prevent migration of waste into the concrete.

\section{Valve Pit 2VP-3}

The bottom of Valve Pit 2VP-3 is lined with 16-gauge (1/16"), 304L SS, which is the same material as that used in the piping, with sidewalls that project $4^{\prime} 0^{\prime \prime}$ up the valve pit. The valve pit walls above the SS liner are provided with a system of Carboline 193 epoxy. The SS valve pit lining material is compatible with the waste and designed to prevent migration of waste into the concrete. According to manufacturer's specifications, the valve pit's epoxy coating is compatible with the waste and designed to prevent migration of waste into the concrete.

\section{Evaporator Annex Cell No. 4}

The bottom of the cell is lined with 16-gauge $\left(1 / 16^{\prime \prime}\right), 304 \mathrm{~L}$ SS, which is the same material as that used in the piping, with sidewalls that project $4^{\prime} 0^{\prime \prime}$ up the cell wall. The walls above the SS liner are provided with a 30-mil-thick system of Amercoat 66 epoxy. The SS cell lining material is compatible with the waste and designed to prevent migration of waste into the concrete. According to manufacturer's specifications, the cell's epoxy coating is compatible with the waste and designed to prevent migration of waste into the concrete.

\section{Outside Underground Piping}

The jacket of the outside underground, double-wall pipe is 304L SS. The selection of secondary containment material is compatible with the waste.

\section{Evaporator Annex Valve Pit No. 1}

The bottom of the valve pit is lined with 16-gauge (1/16"), 304L SS, which is the same material as that used in the piping, with sidewalls that project $6^{\prime} 6^{\prime \prime}$ up the entire valve pit wall. The SS valve pit lining material is compatible with the waste and designed to prevent migration of waste into the concrete. 
The assessment concludes that the tank vaults, pump pit, valve box, pipe tunnel, valve pits, and cell are coated or lined with materials that are compatible with the waste and designed to prevent migration of waste into the concrete. The assessment concludes that the underground piping jacket is compatible with the waste.

\subsubsection{Placed on Foundation or Base Capable of Providing Support to the Secondary Containment System}

\section{Tank Vaults W-23 and W-21/W-22}

The assessments of the secondary containment systems for Tank Vaults W-23 and W-21/W-22 are presented in the Design Demonstrations for Tanks W-23, W-21, and W-22. Those assessments conclude that the vault foundations are properly designed to support the secondary containment system.

\section{Control House Pump Pit}

The pump pit foundation is a $21^{\prime} 0^{\prime \prime} \times 40^{\prime} 0^{\prime \prime} \times 2^{\prime} 0^{\prime \prime}$ thick, reinforced concrete base slab that rests on limestone.

\section{Yalve Box No. 3}

The valve box foundation is an $8^{\prime} 6^{\prime \prime} \times 11^{\prime} 0^{\prime \prime} \times 2^{\prime} 0^{\prime \prime}$ thick, reinforced concrete base slab that rests on limestone.

\section{Pipe Tunnel 2}

The pipe tunnel foundation is a $9^{\prime} 6^{\prime \prime} \times 63^{\prime} 8^{\prime \prime} \times 1^{\prime} 0^{\prime \prime}$ thick, reinforced concrete base slab that rests on limestone.

\section{Valve Pit 2VP-3}

The valve pit foundation is an $18^{\prime} 2^{\prime \prime} \times 27^{\prime} 4^{\prime \prime} \times 1^{\prime} 2^{\prime \prime}$ thick, reinforced concrete base slab that rests on limestone.

\section{Evaporator Annex Cell No. 4}

The cell foundation is a $20^{\prime} 0^{\prime \prime} \times 24^{\prime} 11^{\prime \prime} \times 3^{\prime} 0^{\prime \prime}$ thick, reinforced concrete base slab that rests on limestone.

\section{Evaporator Annex Valve Pit No. 1}

The valve pit foundation is a $7^{\prime} 0^{\prime \prime} \times 8^{\prime} 5^{\prime \prime} \times 10^{\prime \prime}$ thick, reinforced concrete base slab that rests on limestone and concrete footings. 
The assessment concludes that the tank vaults, pump pit, valve box, pipe tunnel, valve pits, and cell foundations are properly designed to support the secondary containment systems.

\subsubsection{Provided with a Leak Detection System That is Designed and Operated to Detect Failure of Either Primary or Secondary Containment Structure or the Presence of Any Measurable Release of Hazardous or Radioactive Constituents}

\section{Tank Vaults W-23 and W-21/W-22}

The assessments of the secondary containment systems for Tank Vaults W-23 and W-21/W-22 are presented in the Design Demonstrations for Tanks W-23, W-21, and W-22. Those assessments conclude that Tank Vaults W-23 and W-21/W-22 are provided with leak detection systems.

\section{Control House Pump Pit}

The pump pit floor is sloped to a 16-gauge $\left(1 / 16^{\prime \prime}\right)$, 304L SS-lined sump where accumulation of liquid will be detected by a level sensor that will activate an alarm in the Waste Operations Control Center (Building 3130).

\section{Valve Box No. 3}

Valve Box No. 3 has a 16-gauge (1/16"), 304L SS-lined collection sump where accumulation of liquid is transferred via a gravity-fed drain line to a 304L SS-lined sump in Tank Vault W-21/W-22. Accumulation of liquid in the tank vault sump will be detected by a level sensor that will activate alarms in the Evaporator Control Room and Waste Operations Control Center (Building 3130).

\section{Pipe Tunnel 2}

The Pipe Tunnel 2 floor is sloped to a 16-gauge (1/16"), 304L SS-lined sump. Liquid that flows to the Pipe Tunnel 2 sump will continue to flow to the Control House Pump Pit sump through a 4", schedule $40 \mathrm{~S}$, type $304 \mathrm{~L}$ SS sump drain pipe. The pump pit sump is lined with 16-gauge (1/16"), 304L SS; and accumulation of liquid will be detected by a level sensor that will activate an alarm in the Waste Operations Control Center (Building 3130).

\section{Valve Pit 2VP-3}

The Valve Pit 2VP-3 floor is sloped to a 16-gauge (1/16"), 304L SS-lined sump where accumulation of liquid will be detected by a level sensor that will activate an alarm in the Waste Operations Control Center (Building 3130).

\section{Evaporator Annex Cell No. 4}

The Evaporator Annex Cell No. 4 floor is sloped to a 16-gauge (1/16"), 304L SS-lined sump where accumulation of liquid will be detected by a level sensor that will activate an alarm in the Waste Operations Control Center (Building 3130). 
Design Demonstrations - Category B Tank Systems (Piping)

\section{Outside Underground Piping}

All underground piping associated with this system is provided with a nitrogen-blanketed leak detection system.

\section{Evaporator Annex Valve Pit No. 1}

A leak detection system for Evaporator Annex Valve Pit No. 1 could not be identified from the design drawings or construction specifications.

The assessment concludes that the tank vaults, pump pit, valve box, pipe tunnel, Valve Pit 2VP-3, cell, and underground piping are provided with leak detection. The Evaporator Annex Valve Pit No. 1 is not provided with a leak detection system.

2.18.3.4 Sloped or Otherwise Designed or Operated to Drain and Remove Liquids Resulting from Leaks, Spills, or Precipitation

\section{Tank Vaults W-23 and W-21/W-22}

The assessments of the secondary containment systems for Tank Vaults W-23 and W-21/W-22 are presented in the Design Demonstrations for Tanks W-23, W-21, and W-22. Those assessments conclude that the secondary containments are sloped and designed to drain and remove liquids resulting from leaks, spills, or precipitation.

\section{Control House Pump Pit}

The pump pit floor is sloped to a 304L SS-lined sump. The sump provides a low point within the pump pit to drain liquids to an instrumented location. A pumping system is provided to remove liquids that accumulate in the sump.

\section{Valve Box No. 3}

The valve box floor is sloped to a 304L SS-lined sump. Liquid that flows to the valve box sump will continue to flow to the Tank Vault W-21/W-22 sump through a sump drain pipe. The tank vault sump provides a low point to drain liquids to an instrumented location. A pumping system is provided to remove liquids that accumulate in the sump.

\section{Pipe Tunnel 2}

The pipe tunnel floor is sloped to a 304L SS-lined sump. Liquid that flows to the pipe tunnel sump will continue to flow to the pump pit sump through a sump drain pipe. The pump pit sump provides a low point to drain liquids to an instrumented location. A pumping system is provided to remove liquids that accumulate in the sump. 


\section{Valve Pit 2VP-3}

The Valve Pit 2VP-3 floor is sloped to a 304L SS-lined sump. The sump provides a low point within the valve pit to drain liquids to an instrumented location. A pumping system is provided to remove liquids that accumulate in the sump.

\section{Evaporator Annex Cell No. 4}

The Evaporator Annex Cell is sloped to a 304L SS-lined sump. The sump provides a low point within the cell to drain liquids to an instrumented location. A pumping system is provided to remove liquids that accumulate in the sump.

\section{Outside Underground Piping}

All outside underground piping is provided with $1 / 2^{\prime \prime}$ drain test connections to remove liquids resulting from leaks.

\section{Evaporator Annex Valve Pit No. 1}

The Evaporator Annex Valve Pit is sloped to a 304L SS-lined sump. The sump provides a low point within the valve pit to drain liquids. Evaporator Annex Valve Pit No. 1 is not provided with a means to remove liquids that accumulate in the sump.

The assessment concludes that the secondary containments for the tank vaults, pump pit, valve box, pipe tunnel, Valve Pit 2VP-3, cell, and underground piping are sloped and designed to drain and remove liquids resulting from leaks, spills, or precipitation. Evaporator Annex Valve Pit No. 1 is not provided with a means to remove accumulation of liquids.

\subsubsection{Supplemental Information}

\subsubsection{Ancillary Equipment}

Tank W-23 is constructed of 304L SS, which is the same material as that used in the piping system, and is located in Tank Vault W-23, which provides secondary containment. The support equipment is exposed to the same liquids as other components of the tank system; therefore, 304L SS is an acceptable material for the support equipment.

\subsubsection{Waste Acceptance Criteria}

Radioactively contaminated liquid wastes at ORNL are generated by various activities within the research and operating divisions. These activities include radiochemical processing, routine hot cell operations and decontaminations, and various waste treatment and environmental protection processes. The variations in composition of the waste streams are limited by the waste acceptance criteria that specify activity and concentration limits for waste discharged into the LLLW system. The Waste Acceptance Criteria for Liquid Waste Treatment Systems at the Oak Ridge National 
Laboratory (Oak Ridge National Laboratory, 1991), dated July 1991, is a guide for liquid waste generators to determine the proper means of disposal for LLLW. The criteria provide future discharge guidelines for the LLLW system, which includes Tank System W-23. 
Design Demonstrations - Category B Tank Systems (Piping)

\subsubsection{References}

Binford, F. T., and S. D. Orfi. 1979. The Intermediate-Level Liquid Waste System at the Oak Ridge National Laboratory Description and Safety Analysis. ORNL/TM-6959. Oak Ridge National Laboratory.

Ebasco, and Main. July 20, 1992. Design Demonstrations-Category B Tank Systems, Revision 2. DOE Contract No. DE-AC05-91OR21928. Oak Ridge National Laboratory.

Energy Systems Drawing P-20237-YC-005-E, Cell 3, Cell 4 and Service Tunnel Piping, Plan, Revision 4.

Energy Systems Drawing P-20237-YC-016-E, East Valve Box Piping Plan and Sections, Revision 2.

Energy Systems Drawing I-20237-YE-105-E, Evaporator Service Tanks Instrument Flow Diagram, Title I Issue, Revision 3.

Energy Systems Drawing P-20237-YE-079-E, Evaporator Service Tanks Piping Flow Diagram, Process, Revision 3.

Energy Systems Drawing P-20237-YE-080-E, Evaporator Service Tanks Piping Flow Diagram, Service, Revision 3.

Energy Systems Drawing P-20237-YC-029-E, Evaporator Service Tanks Piping Sections and Details Tanks W-21, W-22, and W-23, Revision 3.

Energy Systems Drawing S-20237-YB-035-E, Evaporator Service Tanks Plan and Sections and Details Stainless Steel Liner, Revision 2.

Energy Systems Drawing S-20237-YB-016-E, Evaporator Service Tanks Plan, Elevation and Nozzle Schedule, Revision 3.

Energy Systems Drawing P-20237-YC-028-E, Evaporator Services Tanks Plan Piping Tanks W-21, W-22, and W-23, Revision 3.

Energy Systems Drawing S-20237-YB-019-E, Evaporator Service Tanks Sections and Details of Concrete Vault, Revision 2.

Energy Systems Drawing P-20237-YC-031-E, Evaporator Service Tanks Tank Piping Sections and Details Sheet 2 Tanks W-21, W-22 and W-23, Revision 2.

Energy Systems Drawing P-20237-YC-032-E, Evaporator Service Tanks Tank Piping Sections and Details Sheet 3, Revision 2.

Energy Systems Drawing I-20237-YE-001-E, Instrument Flow Diagram, Ventilation, Revision 1. 
Design Demonstrations - Category B Tank Systems (Piping)

Energy Systems Drawing I-20237-YE-043-E, Instrument Flow Diagram, Ventilation, Revision 1.

Energy Systems Drawing S-20237-YB-020-E, Miscellaneous Sections and Details, Revision 1.

Energy Systems Drawing S-20237-YB-015-E, Piping Tunnel to Service Tank, Revision 1.

Energy Systems Drawing P-20237-YC-019-E, Process Pipe Tunnel Plan and Sections, Revision 3.

Energy Systems Drawing C-20237-YA-007-E, Process, Service Piping Plan Sheet 1, Revision 3.

Energy Systems Drawing C-20237-YA-009-E, Process, Service Piping Plan Sheet 3, Revision 2.

Energy Systems Drawing P-20237-YA-010-E, Process, Service Piping Profiles Sheet 4, Revision 2.

Energy Systems Drawing S-20237-YB-019-E, Sections and Details of Concrete Vault, Revision 2.

Energy Systems Drawing P-20237-YC-030-E, Tank Piping, Sections and Details, Sheet 1, Tanks W-21, W-22, W-23, Revision 3.

Energy Systems Drawing P-20237-YC-004-E, Valve Pit 2VP-3 Piping, Plan and Sections, Revision 3.

Energy Systems Drawing E-20237-ED-008, Evaporator Annex and Service Tanks Cathodic Protection, Revision 0.

Harco Technologies Corporation. June 1990. Resurvey of the Cathodic Protection Systems, Oak Ridge National Laboratory, United States Department of Energy, Oak Ridge, Tennessee. Martin Marietta Energy System, Inc.

Harco Technologies Corporation. July 1991. Cathodic Protection System Upgrade Design Underground ILW Lines VLV Box 1 to 2531 and 2537, System No. 16. Oak Ridge National Laboratories, United States Department of Energy, Oak Ridge, Tennessee. Martin Marietta Energy Systems, Inc.

Oak Ridge National Laboratory. 1991. Waste Acceptance Criteria for Liquid Waste Treatment Systems at the Oak Ridge National Laboratory. WM-WMCO-201. Department of Waste Minimization Planning and Certification.

Peretz, F. J., et al. 1986. Characterization of Low-Level Liquid Wastes at the Oak Ridge National Laboratory. ORNL/TM-10218. Oak Ridge National Laboratory.

Risk Evaluation of Embedded, Single-Walled Liquid Low-Level Waste Piping at Oak Ridge National Laboratory. 
Samborn, Steketee, Otis and Evans, Inc. July 1975. Intermediate Level Waste Management Facilities Design Calculations (Sheets 1 to 69) Tanks W-21 Through W-31. Prepared by Samborn, Steketee, Otis and Evans, Inc., Toledo, Ohio for Oak Ridge National Laboratory.

Samborn, Steketee, Otis and Evans, Inc. July 1975. Intermediate Level Waste Management Facilities Title I Report (Books 1 and 2). Holifield National Laboratory, Oak Ridge, Tennessee. Prepared by Samborn, Steketee, Otis and Evans, Inc., Toledo, Ohio of Oak Ridge National Laboratory.

Samborn, Steketee, Otis and Evans, Inc. December 1975. Special Design Calculations Tank Freezing Analysis, Solvent-Flammability Hazard, Nitrogen Purge, Thermal Pipe Stresses in Vault, Seismic Analysis Tornado Loading Analysis. Prepared by Samborn, Steketee, Otis and Evans, Inc., Toledo, Ohio for Oak Ridge National Laboratory.

Sears, M. B. et al., 1990. Sampling an Analysis of Radioactive Liquid Wastes and Sludges in the Melton Valley and Evaporator Facility Storage Tanks at ORNL. ORNL/TM-11652. Oak Ridge National Laboratory. 


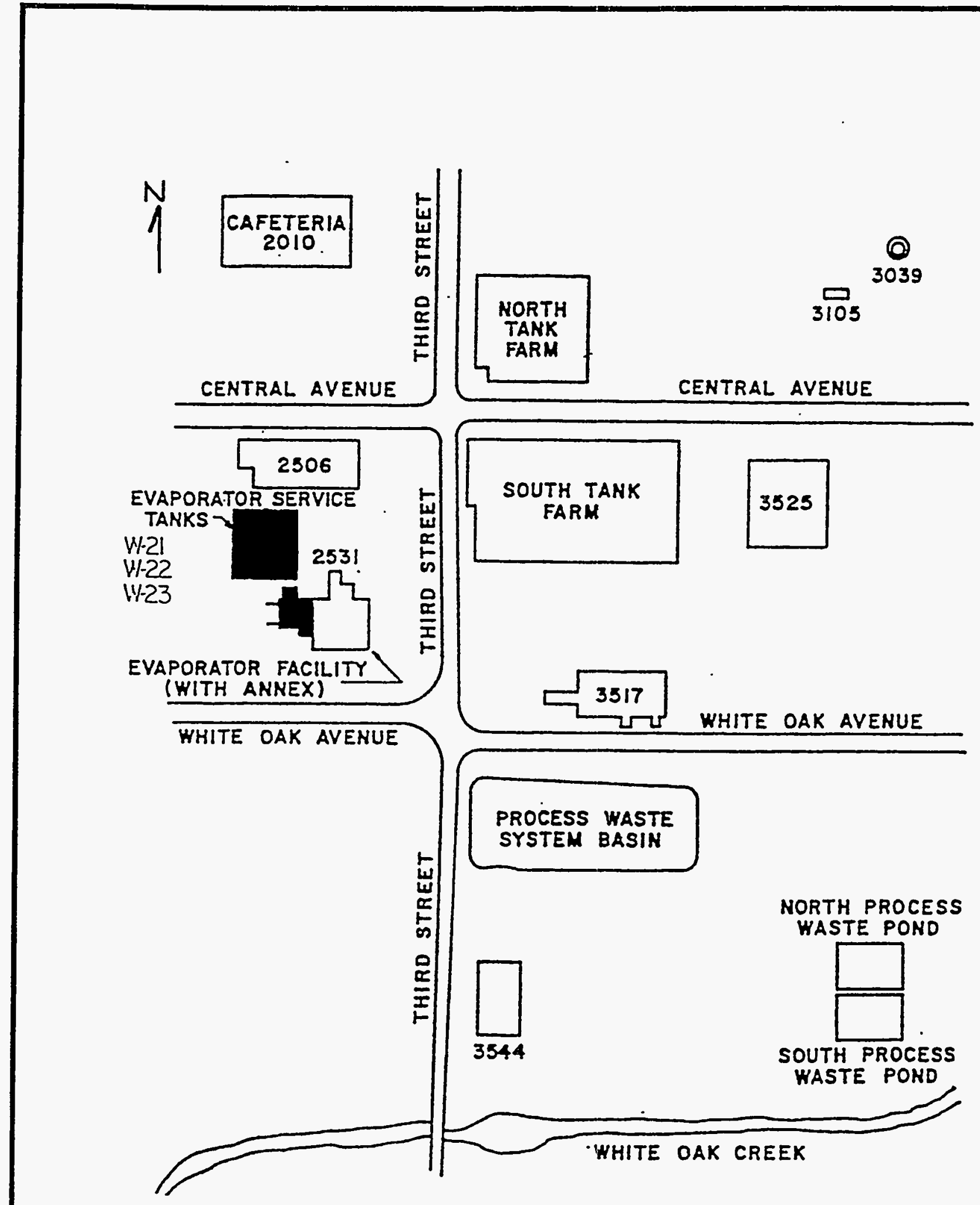


Figure 2.18-2 Tank System W-23 Piping Diagram

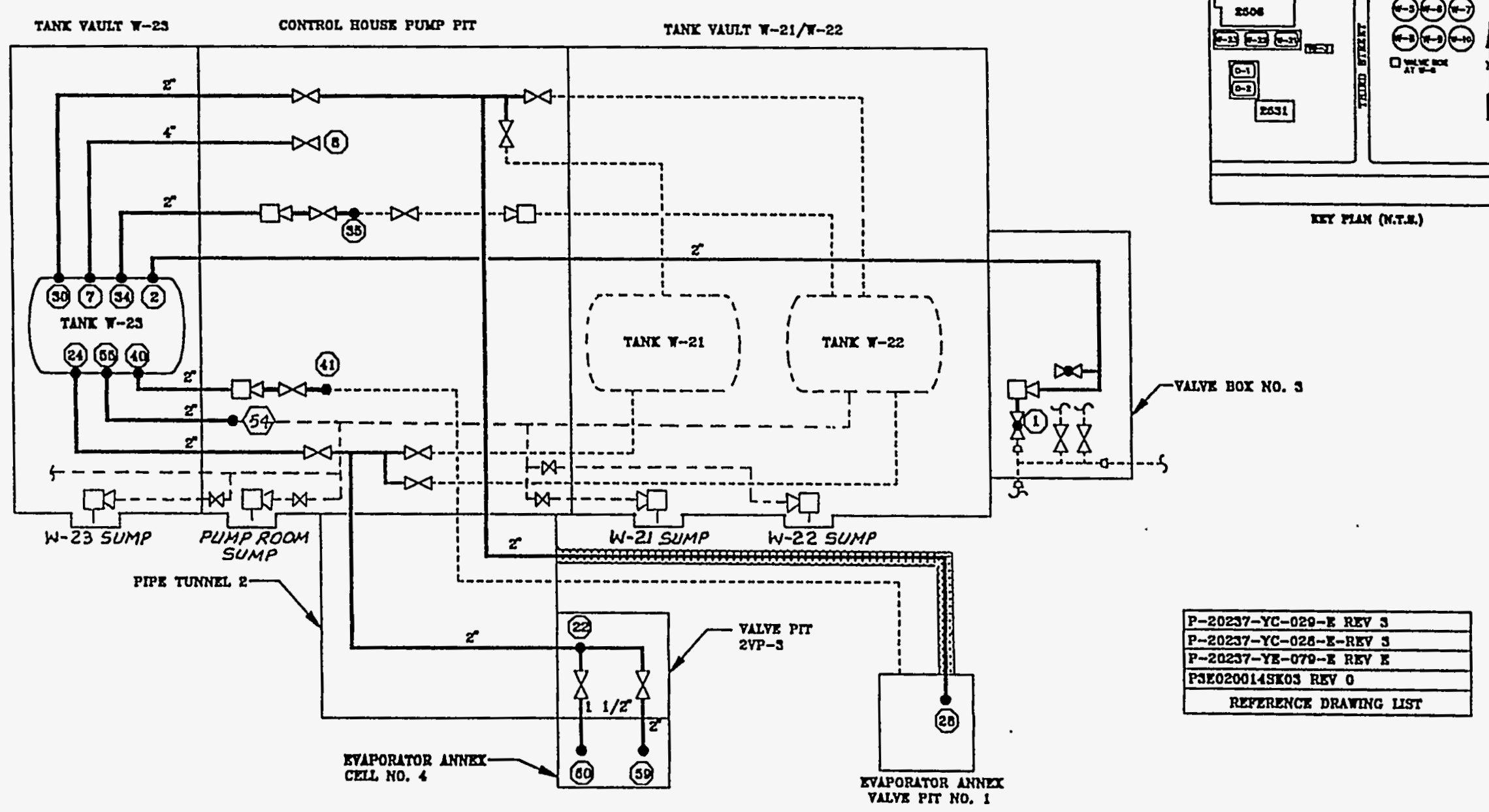

\begin{tabular}{|c|c|c|c|c|c|c|c|c|c|}
\hline LOVE SEGIMANT & (1) - (2) & (7)-(8) & (22) - (2) & (20) - (20) & (3) - (16) & (10) $-(4)$ & (6) - (6) & (6) - (2) & (6) - 22 \\
\hline Sgax $\mathrm{Dy}-\mathrm{DL}$ & 2 & 4 & 2 & 2 & 2 & 2 & 2 & $11 / 2$ & 2 \\
\hline SCEESDURS & 103 & 409 & 103 & 103 & 109 & 103 & 603 & 109 & 108 \\
\hline LATLRILL & 89 & 89 & 98 & 89 & 89 & 88 & 89 & 88 & 89 \\
\hline LONGTH (FT) & 148 & 18 & 112 & 223 & 20 & 60 & as & 20 & 27 \\
\hline TOLUVMI (CAL) & 28 & 12 & 20 & 58 & 8 & 0 & 11 & $\mathbf{3}$ & 0 \\
\hline
\end{tabular}

THKK SYSTzu T-23 PTPDEC

ONDERGROUND PIPE (DOUBLE WALL)

- - - - - COMPONENTS NOT COVERED

IN THIS SECTION 


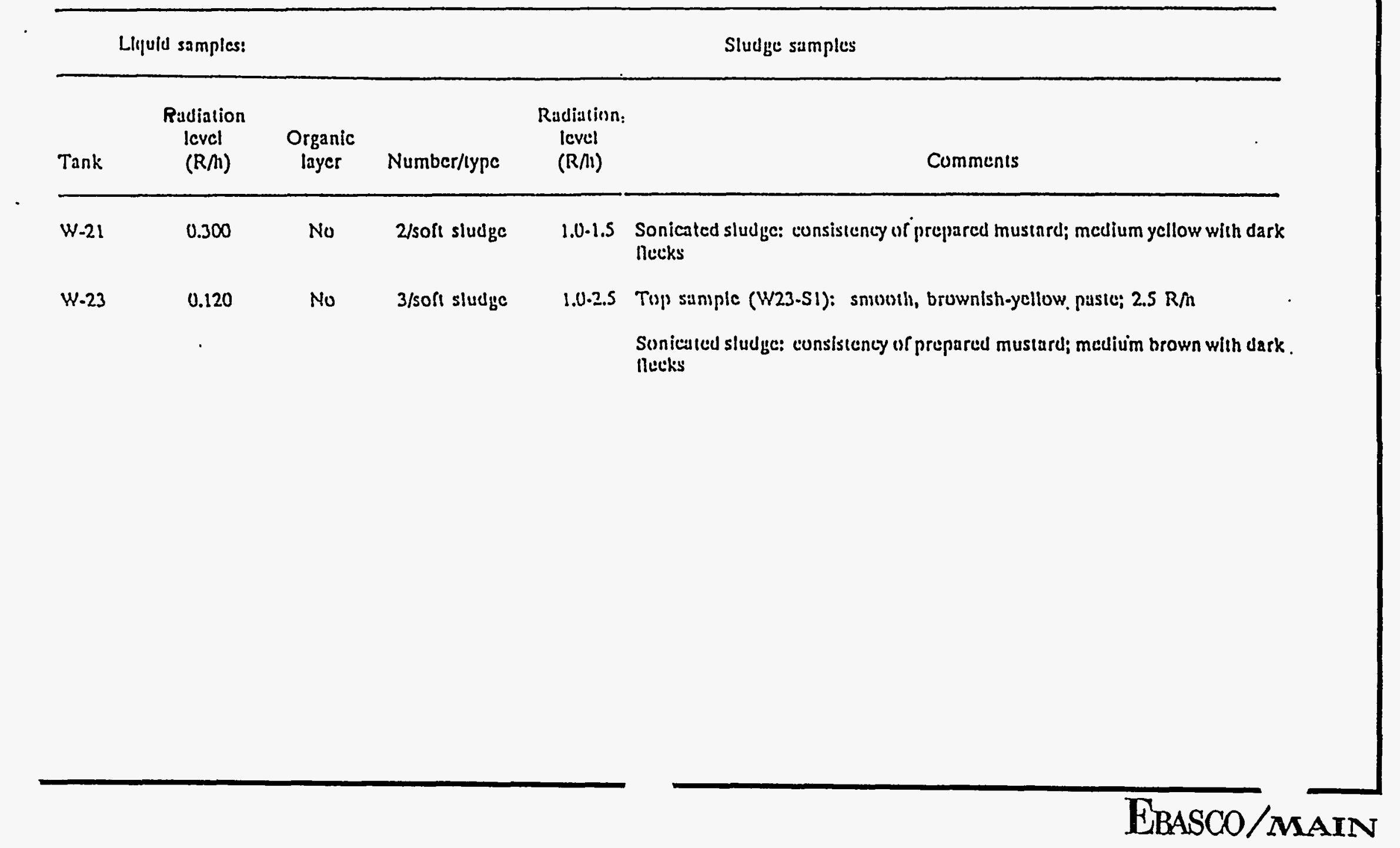




\section{ANALYTICAL DATA FOR LIQUID SAMPLE}

\begin{tabular}{|c|c|c|}
\hline \multicolumn{2}{|c|}{ Chszateristic JAN, 1990} & \$23.LI \\
\hline \multicolumn{3}{|c|}{ 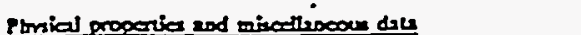 } \\
\hline IDS & (avbl) & 331 \\
\hline is & (a) & 383 \\
\hline Densing & $(y / m)$ & 1.2423 \\
\hline $\begin{array}{l}\text { IC } \\
\text { TC }\end{array}$ & $\begin{array}{l}(\infty \pi /) \\
(\omega \pi L)\end{array}$ & 9900 \\
\hline \multicolumn{3}{|c|}{ RCRA milats } \\
\hline As & $(\pi / \mathcal{L})$ & $<0.44$ \\
\hline is & $(\infty \Omega)$ & $<3.0$ \\
\hline$B_{2}$ & $($ arel & $<0.19$ \\
\hline as & $(\pi \varepsilon \pi)$ & 1.7 \\
\hline Ce & (mell) & 0.42 \\
\hline $\mathrm{H}_{\mathbf{s}}$ & $( \pm \Omega \Omega)$ & 0.07 \\
\hline $\mathrm{Mi}$ & $(\infty \Omega /)$ & 3.0 \\
\hline Pb & $(m e r)$ & 27 \\
\hline Se & $(n \pi /)$ & $<23$ \\
\hline & (mel) & $<0.94$ \\
\hline \multicolumn{3}{|c|}{ inos meats } \\
\hline$N$ & $(m / 2)$ & 1.8 \\
\hline D & $(m e r)$ & 10 \\
\hline $\mathbf{C}_{\mathbf{2}}$ & $(m e n)$ & 18 \\
\hline Co & $(m / 2)$ & - \\
\hline Fe & (men) & 0.70 \\
\hline$x$ & (mel) & 78000 \\
\hline Mg & (mer) & 3.4 \\
\hline is & (mer) & 82000 \\
\hline si & (men) & $<1$ \\
\hline Si & (meit) & 0.40 \\
\hline Th & $(m e n)$ & ISs \\
\hline & $(m 2 L)$ & 17 \\
\hline \multicolumn{3}{|l|}{ Anime } \\
\hline Chloride & (M) & 0.10 \\
\hline Fuoride & (M) & $<0.053$ \\
\hline Nitrale & (M) & 3.23 \\
\hline Phosphste & (M) & $<0.053$ \\
\hline Sulfale & (M) & 0.081 \\
\hline \multicolumn{2}{|l|}{ Alkalinin } & 128 \\
\hline 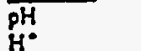 & $(M)$ & 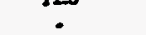 \\
\hline $\mathrm{H}^{\circ}$ & $(M)$ & 0.13 \\
\hline OH: & (M) & 0.70 \\
\hline $\mathrm{HCO}_{j}$ & (M) & \\
\hline \multicolumn{3}{|c|}{ Petafarme conitor } \\
\hline Gross alpha & $(B \& / \pi L)$ & $8.20=+01$ \\
\hline Gross be12 & $(B \& / n L)$ & $4.62 \varepsilon+05$ \\
\hline "c & (Bghts) & $6.35 c+01$ \\
\hline l"ce & (Bg/taL) & $<1.6<+03$ \\
\hline$\omega_{\mathrm{Co}}$ & (Borlon) & $6.21 e+\dot{0} 2$ \\
\hline "co & $(B g / m 2)$ & $4.63 x+03$ \\
\hline "IrC & (Bestoll) & $136 x+05$ \\
\hline II: & $(B C / m L)$ & $<21 c+02$ \\
\hline WU & $(B g / m L)$ & $<1.6 e+02$ \\
\hline $\mathrm{WSU}_{\mathrm{EU}}$ & $(8 \mathrm{~g} / \mathrm{mL})$ & $<8.5 e+02$ \\
\hline${ }^{\mathrm{S}} \mathrm{H}$ & $(B g / m L)$ & $1.19+02$ \\
\hline$\theta_{\text {No }}$ & $\left(B \alpha^{\prime} \propto \mathrm{L}\right)$ & $<1.0<+02$ \\
\hline${ }_{108 u}$ & $(B / \mathrm{mL})$ & $3.78 x+03$ \\
\hline $\mathrm{NSt}_{\mathrm{St}}$ & $(B \Phi / \mathrm{mL})$ & $4.12 x+02$ \\
\hline$n_{\mathrm{Ze}}$ & (Bq/mL) & $<1.0<+02$ \\
\hline \multicolumn{3}{|c|}{ Alphs emilters } \\
\hline تU & $(B q / m L)$ & $1.00<+\infty$ \\
\hline טיני טינ & $(B q / m L)$ & $6.00+\infty+\infty$ \\
\hline Nopur'spu & (Bq/mL) & $6 . \infty x+\infty$ \\
\hline 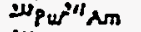 & $(9 \$ / \mathrm{mL})$ & $3.90 x+01$ \\
\hline$" 1 \mathrm{~cm}$ & $(B \Phi / n L)$ & $1.00=+03$ \\
\hline
\end{tabular}

\section{ANALYTICAL DATA FOR} SLUDGE SAMPLE

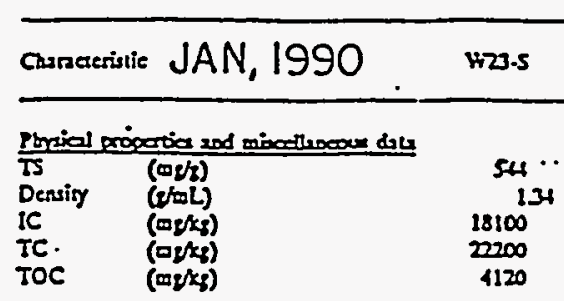

\section{RCRA mentr}

\begin{tabular}{|c|c|c|}
\hline $\begin{array}{l}\mathrm{AB} \\
\text { As } \\
\mathrm{B}_{2} \\
\mathrm{Cd} \\
\mathrm{C} \\
\mathrm{H}_{3} \\
\mathrm{Ni} \\
\mathrm{Pb} \\
\mathrm{Se} \\
\mathrm{T}\end{array}$ & 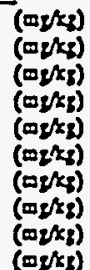 & $\begin{array}{r}(23) \\
(<50) \\
63 \\
32 \\
190 \\
19 \\
110 \\
(4 \leq 0) \\
<39 \\
<16\end{array}$ \\
\hline
\end{tabular}

roosengers

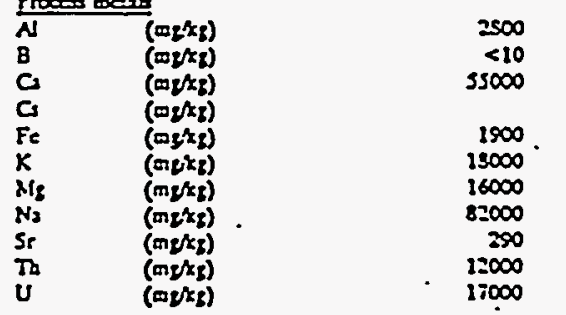

Retaraman cominon

Gross alpha (Bq/z)

Gross bea (Bof)

"C (Bq/)

14Ce (Bd/8)

${ }^{\infty}{ }^{\infty} \mathrm{CO} \quad(\mathrm{Bq} / \mathrm{C})$

"IIC

"ISE

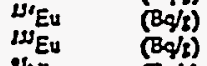

$v_{\text {Nb }} \quad\left(B q_{b}\right)$

sov $(B g / t)$

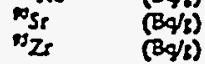

Noha ominer

Noht oningr

لעय Bण

Mpurpu (Be/g)

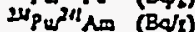

""Ca (B) $\mathrm{Ca}$

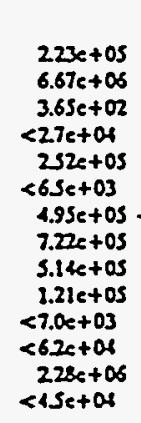

:" $\mathrm{Cr} \quad(B / \mathrm{B})$

$1.18 e+04$

$<2.8 x+$ or

$3.21 \mathrm{tat}$

$<2.6+0+$ or

$1.67 c+05$

LEGEND:

TSD - TOTAL DISSOLVED SOLIDS

TS - TOTAL SOLIDS

IC - INORGANIC CA.RBON

TC - TOTAL CARBON

TOC - TOTAL ORGANIC CAREON 


\subsubsection{Tank System Summary}

Tank System W-24 is located at the Melton Valley Storage Tank Facility (Building 7830) (Figures 2.19-1 and 2.19-2). The tank system piping is schedule 40S, ASME SA-240, type 304L stainless steel (SS) and is routed from a pipe tunnel to Tank Vault W-24 through W-27. Tank System W-24 piping is used to transfer concentrate from the Evaporator to Tanks W-24 through W-31 and is classified as a Federal Facility Agreement (FFA) Category B tank system.

\subsubsection{Standards for Pipe Assessment of Tank Systems}

\subsubsection{Tank System Piping Description and Design Standards}

\section{$\underline{\text { Tank System Piping Description }}$}

Tank System W-24 piping is located at Building 7830 and is routed from a pipe tunnel to Tank Vault W-24 through W-27. The piping system is used and managed by the Waste Management and Remedial Actions Division.

Tank System W-24 piping is constructed of 6", and 4", 304L SS with a maximum design pressure and temperature of $150 \mathrm{psig}$ and $150^{\circ} \mathrm{F}$ for the $6^{\prime \prime}$ line and $300 \mathrm{psig}$ and $150^{\circ} \mathrm{F}$ for the $4^{\prime \prime}$ line. Tank System W-24 piping has a maximum volume of 111 gal.

\section{Design Standards}

The applicable codes and standards used for Tank System W-24 piping and its associated secondary containment systems are identified herein. The codes and standards listed are those identified on either the design drawings or the construction specifications.

AEC-Oak Ridge Office, Minimum Safety Requirements;

Air Moving and Conditioning Association (AMCA) Standards Handbook-Publication 99;

AMCA Directory-Publication 261;

AMCA Fans and Systems-Publication 201;

American Concrete Institute 301-72;

American Concrete Pipe Association;

American National Standards Institute;

American Society for Testing and Materials A48, A262-70, C91, C139, C144, and D1751; 
American Society of Heating, Refrigeration, and Air Conditioning Engineers (ASHRAE) Handbook of Fundamentals;

American Society of Mechanical Engineers (ASME) Boiler and Pressure Vessel Code, Sections II (SA-240), V, VIII, and IX;

ASHRAE Guide and Data Book-Application;

ASHRAE Guide and Data Book-Equipment;

ASHRAE Handbook-Systems;

Atomic Energy Commission (AEC) General Design Criteria, Appendix 63;

Building Code Requirements for Reinforced Concrete;

Factory Mutual Engineering Corporation;

National Electrical Code;

National Fire Protection Association (NFPA) No. 90A-Air Conditioning and Ventilating Systems;

NFPA No. 91-Blower and Exhaust Systems;

Nuclear Safety Information Center 65-Design, Construction and Testing of High Efficiency Air Filtration Systems for Nuclear Application;

Occupational Safety and Health Administration;

Sheet Metal and Air Conditioning Contractors National Association (SMACNA) High Velocity Duct Construction Standards and Low Velocity Standards;

SMACNA Ducted Electric Heat Guide for Air Handling Systems; and

Union Carbide Corporation Nuclear Division (UCC-ND) Standards, Sections 303, 401, 411, 702, and 914.04 .

\subsubsection{Generic Description of Piping Contents}

Tank System W-24 piping was designed to serve as part of an interim storage tank system for the hydrofracture facility. The waste concentrates stored in Tank W-24 were being disposed of as a cement-waste mixture (grout) by injection into shale formations located $800^{\prime}$ to $1100^{\prime}$ below the ground surface using hydrofracture. However, hydrofracture was terminated in 1984, and Tank W-24 has become a waste concentrates storage tank for the liquid low-level waste (LLLW) system. LLLW is generated from a variety of facilities at the Oak Ridge National Laboratory (ORNL) including 
Design Demonstrations - Category B Tank Systems (Piping)

reactors, radioactive fuel processing areas, radioisotope processing areas, decontamination operations, hot cells, and radiochemical laboratories. The waste generators collect the waste, which is then transferred to the LLLW Evaporator for concentration, with transfer of evaporator bottoms to Tanks W-24 through W-31 for storage.

Tank System W-24 piping transfers LLLW to and from Tank W-24. The analytical data (Figure 2.19-3) of the waste samples are representative of the waste received by Tank W-24. The liquid waste supernate sampled in Tank W-24 ranges in color from pale to deep yellow with high $\mathrm{Ph}(11-13)$ sodium/potassium nitrate salt solutions. The principal metals found in the tank sludge were sodium, potassium, calcium, magnesium, uranium, and thorium. The sludge contains radioactive materials that produce a radiation level of 1.2 rem per hour $(\mathrm{R} / \mathrm{h})$ (Figure 2.19-4).

\subsubsection{Pipe Corrosion Protection Measures}

Piping inside the pipe tunnel and Tank Vault W-24 through W-27 has no direct contact with the soil or water. Cathodic protection measures are not required for external corrosion.

\subsubsection{Documented Age of Tank System}

Tank System W-24 piping was installed in 1980.

\subsubsection{Standards for Containment/Release Detection}

2.19.3.1 Constructed of or Lined with Materials That are Compatible with Stored Waste(s) or Substance(s) to Be Placed in the Tank System and Shall Have Sufficient Strength and Thickness to Prevent Failure

Tank System W-24 piping is single-wall, schedule 40S, type 304L SS and is routed from a pipe tunnel to Tank Vault W-24 through W-27. Each area is discussed below. The piping penetrations from the pipe tunnel to Tank Vault W-24 through W-27 are singly contained, 4" and 6", schedule $40 \mathrm{~S}$, type $304 \mathrm{~L}$ SS pipes embedded in the concrete wall to a length of $3^{\prime} 0^{\prime \prime}$.

\section{Pipe Tunnel}

The bottom of the pipe tunnel is lined with 16-gauge $\left(1 / 16^{\prime \prime}\right), 304 \mathrm{~L} \mathrm{SS}$, which is the same material as that used in the piping, with sidewalls that project $3^{\prime} 0^{\prime \prime}$ up the pipe tunnel. The SS pipe tunnel lining material is compatible with the waste and designed to prevent migration of waste into the concrete.

\section{Tank Vault W-24 Through W-27}

The assessments of the secondary containment system for Tank Vault W-24 through W-27 are presented in the Design Demonstrations for Tanks W-24 through W-27. Those assessments conclude that Tank Vault W-24 through W-27 is lined with materials that are compatible with the waste and designed to prevent migration of waste into the concrete. 
Design Demonstrations - Category B Tank Systems (Piping)

The assessment concludes that the pipe tunnel and tank vault are lined with materials that are compatible with the waste and designed to prevent migration of waste into the concrete.

\subsubsection{Placed on Foundation or Base Capable of Providing Support to the Secondary Containment System}

\section{Pipe Tunnel}

The pipe tunnel foundation is a $20^{\prime} 3^{\prime \prime} \times 133^{\prime} 6^{\prime \prime} \times 1^{\prime} 6^{\prime \prime}$ thick, reinforced concrete base slab that rests on limestone.

\section{Tank Vault W-24 Through W-27}

The assessments of the secondary containment system for Tank Vault W-24 through W-27 are presented in the Design Demonstrations for Tanks W-24 through W-27. Those assessments conclude that the vault foundation is properly designed to support the secondary containment system.

The assessment concludes that the pipe tunnel and tank vault foundations are properly designed to support the secondary containment systems.

2.19.3.3 Provided with a Leak Detection System That is Designed and Operated to Detect Failure of Either Primary or Secondary Containment Structure or the Presence of Any Measurable Release of Hazardous or Radioactive Constituents

\section{Pipe Tunnel}

The pipe tunnel floor is sloped to a 16-gauge (1/16"), 304L SS-lined sump where accumulation of liquid will be detected by a pneumatic level indicator that will activate alarms in the Evaporator Service Tanks Control Room and Waste Operations Control Center (Building 3130).

\section{Tank Vault W-24 Through W-27}

The assessments of the secondary containment system for Tank Vault W-24 through W-27 are presented in the Design Demonstrations for Tanks W-24 through W-27. Those assessments conclude that the vault is provided with a leak detection system.

The assessment concludes that the pipe tunnel and tank vault are provided with leak detection. 
Design Demonstrations - Category B Tank Systems (Piping)

2.19.3.4 Sloped or Otherwise Designed or Operated to Drain and Remove Liquids Resulting from Leaks, Spills, or Precipitation

\section{Pipe Tunnel}

The pipe tunnel floor is sloped to a 304L SS-lined sump. The sump provides a low point within the pipe tunnel to drain liquids to an instrumented location. A pumping system is provided to remove liquids that accumulate in the sump.

\section{Tank Vault W-24 Through W-27}

The assessments of the secondary containment system for Tank Vault W-24 through W-27 are presented in the Design Demonstrations for Tanks W-24 through W-27. Those assessments conclude that the secondary containment is sloped and designed to drain and remove liquids resulting from leaks, spills, or precipitation.

The assessment concludes that the secondary containments for the pipe tunnel and the tank vault are sloped and designed to drain and remove liquids resulting from leaks, spills, or precipitation.

\subsubsection{Supplemental Information}

\subsubsection{Ancillary Equipment}

Tank W-24 is constructed of 304L SS, which is the same material as that used in the piping system, and is located in Tank Vault W-24 through W-27, which provides secondary containment. The support equipment is exposed to the same liquids as other components of the tank system; therefore, $304 \mathrm{~L}$ SS is an acceptable material for the support equipment.

\subsubsection{Waste Acceptance Criteria}

Radioactively contaminated liquid wastes at ORNL are generated by various activities within the research and operating divisions. These activities include radiochemical processing, routine hot cell operations and decontaminations, and various waste treatment and environmental protection processes. The variations in composition of the waste streams are limited by the waste acceptance criteria that specify activity and concentration limits for waste discharged into the LLLW system. The Waste Acceptance Criteria for Liquid Waste Treatment Systems at the Oak Ridge National Laboratory (Oak Ridge National Laboratory, 1991), dated July 1991, is a guide for liquid waste generators to determine the proper means of disposal for LLLW. The criteria provide future discharge guidelines for the LLLW system, which includes Tank System W-24. 
Design Demonstrations - Category B Tank Systems (Piping)

\subsubsection{References}

Binford, F. T., and S. D. Orfi. 1979. The Intermediate Level Liquid Waste System at the Oak Ridge National Laboratory Description and Safety Analysis. ORNL/TM-6959. Oak Ridge National Laboratory.

Ebasco, and Main. July 20, 1992. Design Demonstrations-Category B Tank Systems, Revision 2. DOE Contract No. DE-AC05-91OR21928. Oak Ridge National Laboratory.

Energy Systems Drawing P3E-21247-C012, Melton Valley Waste Storage Tanks, Piping Modifications Pump Room and Pipe Gallery Modifications, Revision A.

Energy Systems Drawing P3E-21247-C013, Melton Valley Waste Storage Tanks, Piping Modifications, Sections, Revision A.

Energy Systems Drawing P3E-21247-C014, Melton Valley Waste Storage Tanks, Piping Modifications, Sections, Revision A.

Energy Systems Drawing P-21247-YE-026-E, Waste Storage Tanks, Piping Flow Diagram-Process, Sheet 1, Revision G.

Energy Systems Drawing P-21247-YC-002-E, Waste Storage Tanks, Piping Plan, Revision B.

Energy Systems Drawing S-21247-YB-002-E, Waste Storage Tanks, Plan and Detail for Control House and Pump Room, Revision D.

Energy Systems Drawing S-21247-YB-001-E, Waste Storage Tanks, Plan Concrete Vault, Revision C.

Energy Systems Drawing P-21247-YC-003-E, Waste Storage Tanks, Pump Room Piping Plan, Revision G.

Energy Systems Drawing S-21247-YB-003-E, Waste Storage Tanks, Sections and Details of Concrete Vault, Revision D.

Energy Systems Drawing P-21247-YC-004-E, Waste Storage Tanks, Tank Piping Section, Sheet 1, Revision C.

Energy Systems Drawing P-21247-YC-012-E, Waste Storage Tanks, Tank Piping Section, Sheet 2, Revision B.

Energy Systems Drawing P-21247-YC-001-E, Waste Storage Tanks, Tanks, Pump Room and Tunnel Piping Plan, Revision E. 
Energy Systems Drawing P-21247-YC-011-E, Waste Storage Tanks, Tanks, Pump Room Piping Section, Sheet 2, Revision D.

Oak Ridge National Laboratory. 1991. Waste Acceptance Criteria for Liquid Waste Treatment Systems at the Oak Ridge National Laboratory. WM-WMCO-201. Department of Waste Minimization Planning and Certification.

Peretz, F. J., et al. 1986. Characterization of Low-Level Liquid Wastes at the Oak Ridge National Laboratory. ORNL/TM-10218. Oak Ridge National Laboratory.

Risk Evaluation of Embedded, Single-Walled Liquid Low-Level Waste Piping at Oak Ridge National Laboratory.

Robinson, S. M., S. M. DePaoli, and A. B. Walker. 1991. Federal Facility Agreement Contingency, Upgrade, and Replacement Plans for the ORNL Active Low-Level Radioactive Waste Tank System. Oak Ridge National Laboratory. ORNL/TM-11795. Oak Ridge National Laboratory. 


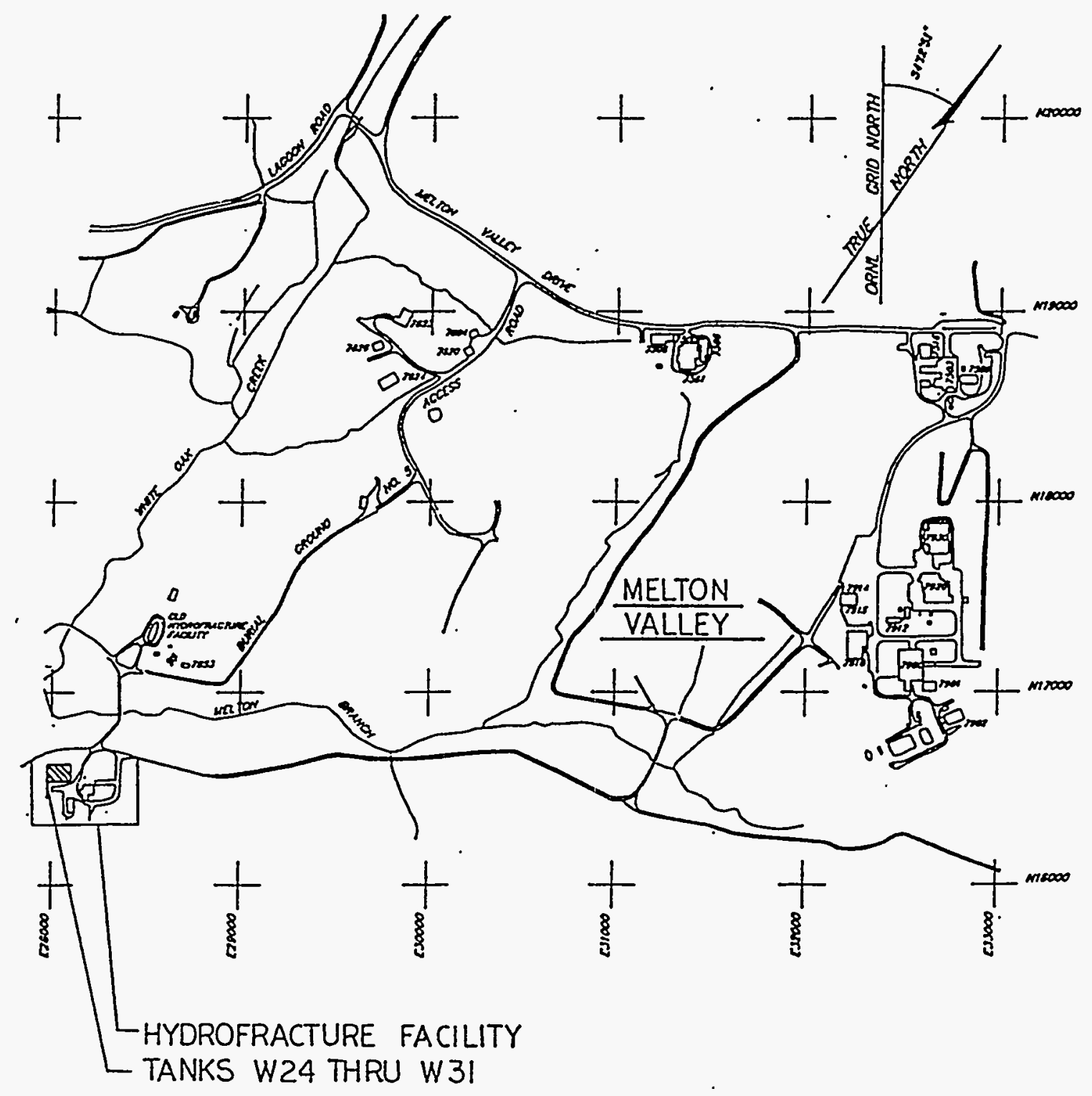


Figure 2.19-2 Tank System W-24 Piping Diagram

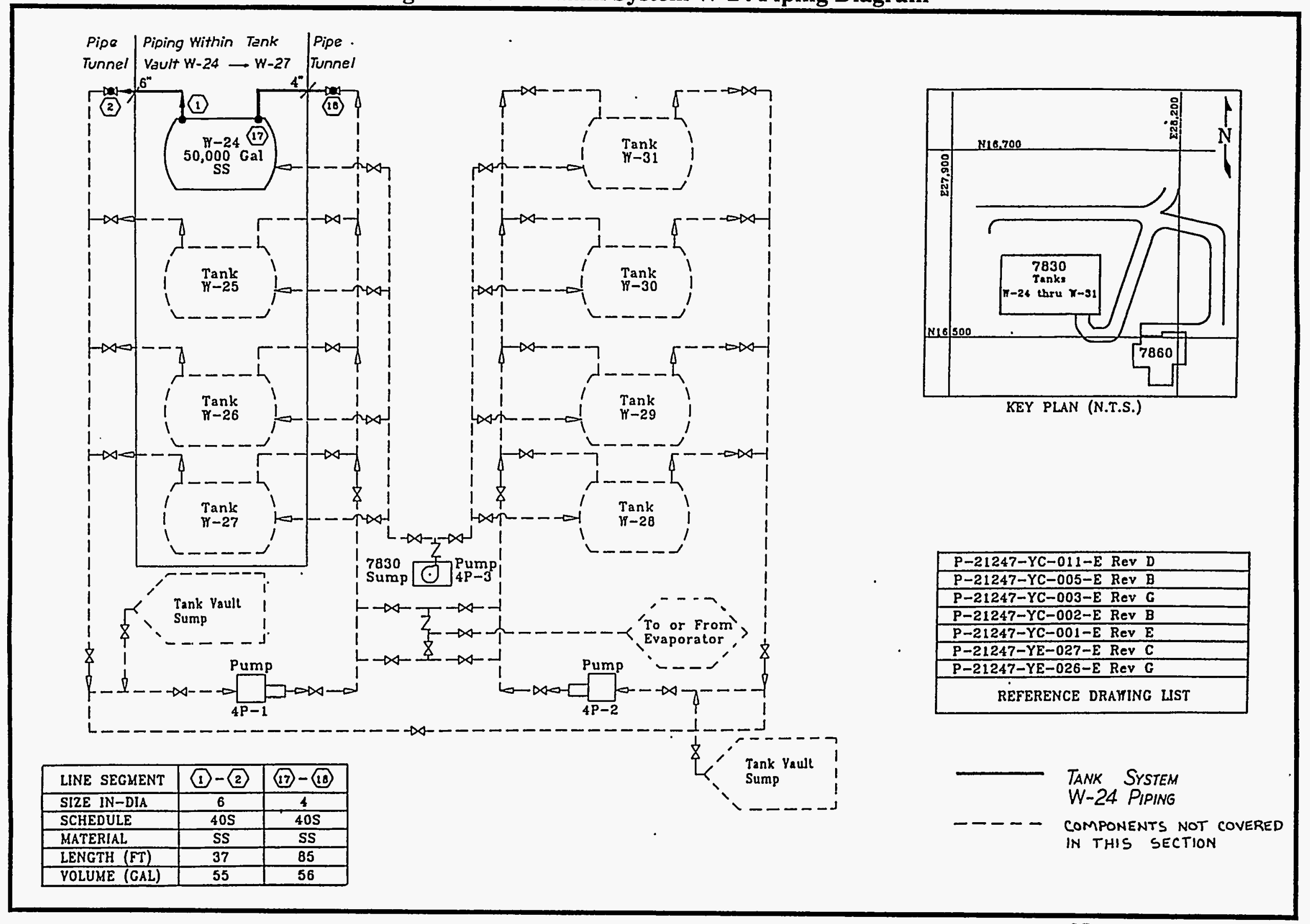

$\mathrm{E}_{B A S C O / M A I N}$ 
ANALYTICAL DATA FOR LIQUID SAMPLE

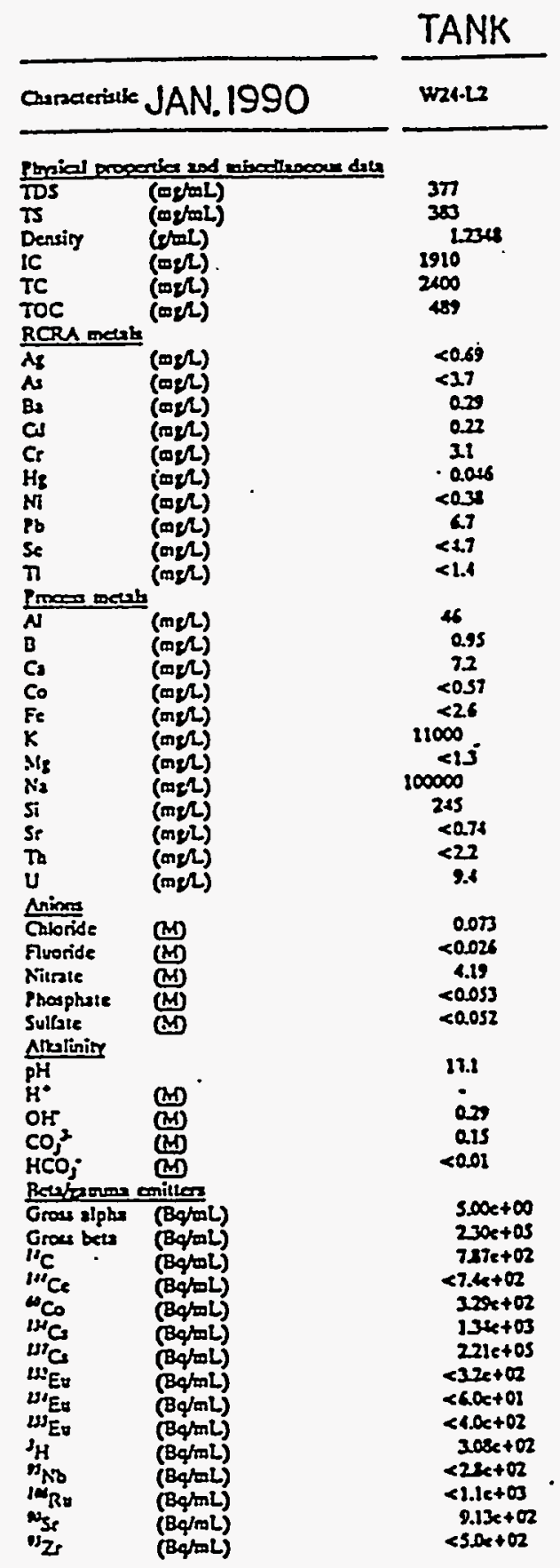

ANALYTICAL DATA FOR SLUDGE SAMPLE

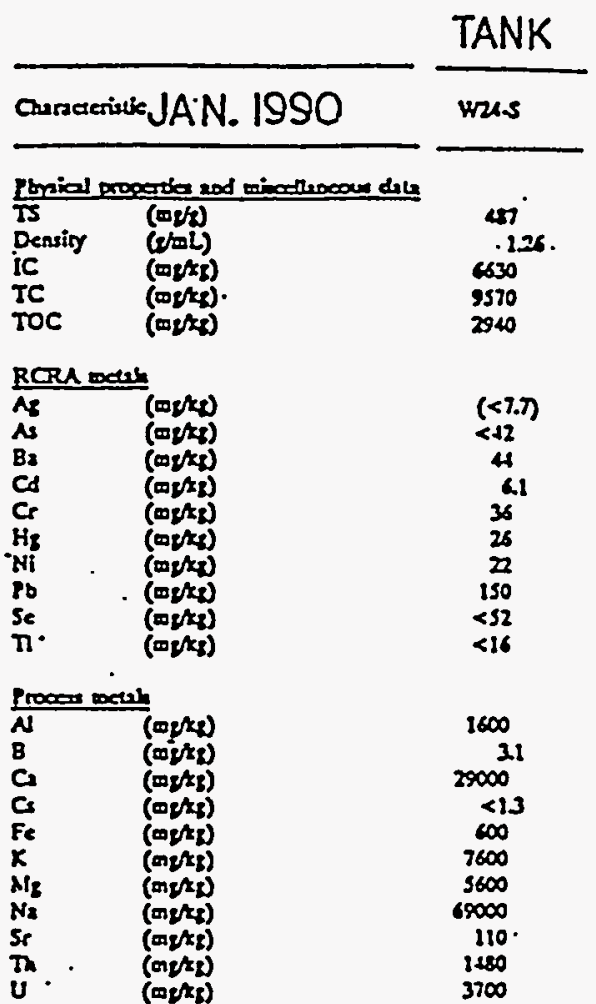

Besabang cointar

Groes alphe (Bot)

Grous bes: (Bqh)

"C (Ba/t)

"Ce (B\&/t)

Co (Bot)

"WG

WEs (Bqh).

INE (Bof)

${ }_{W N B} \quad(B)$

IN⿴囗十 (Bqh)

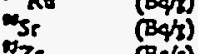

\section{Nphu comiters}

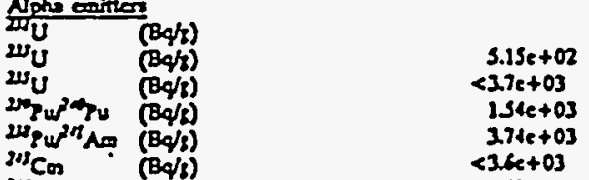

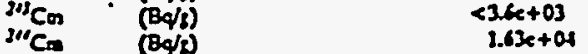

LEGEND: PHYSICAL PROPERTIES TDS - TOTAL DISSOLVED.SOLIDS

TS - TOTAL SOLIDS

IC - INORGANIC CARBON

TC - TOTAL CARBON

TOC TOTAL ORGANIC CARBON 


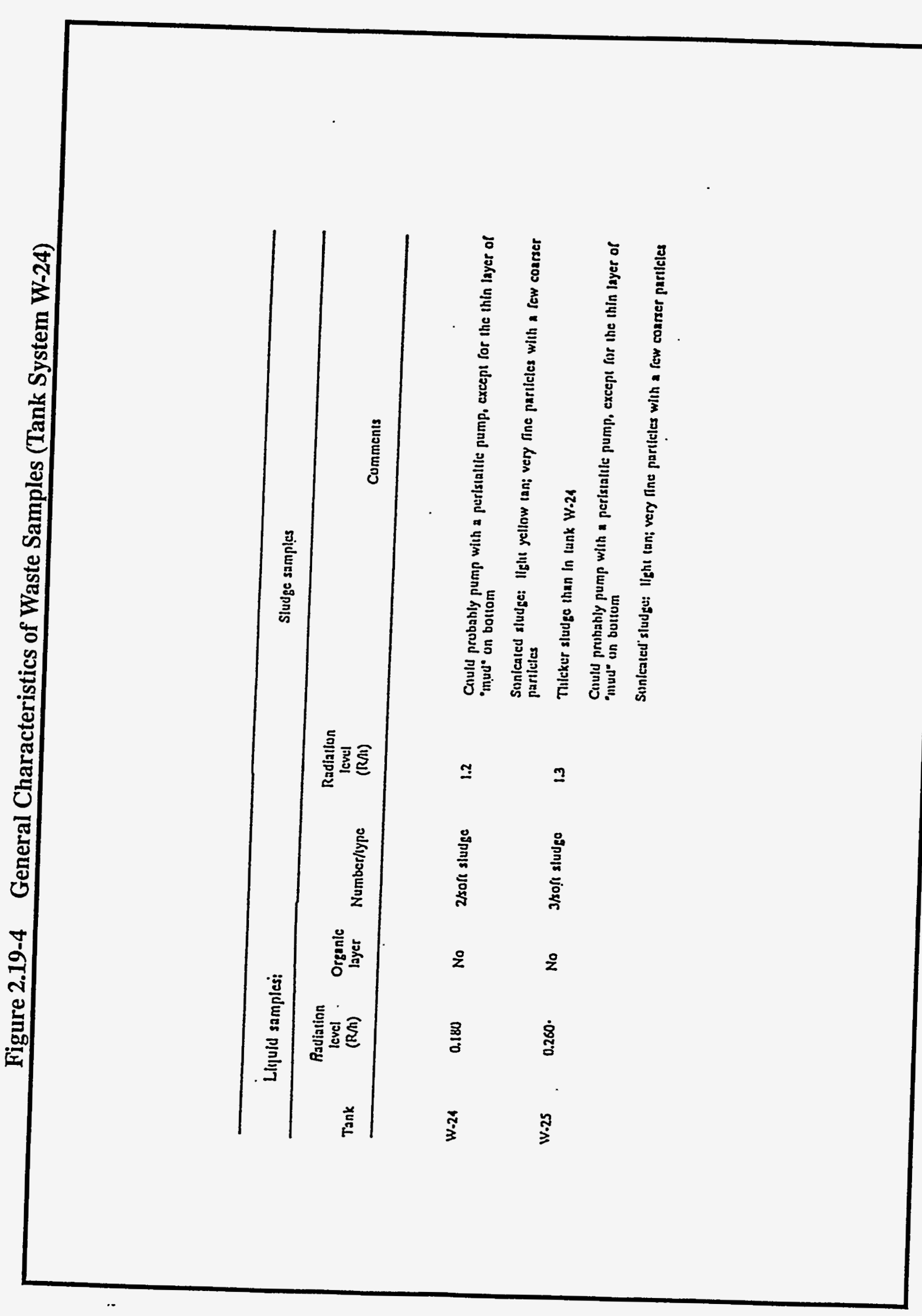




\section{$2.20 \quad$ Tank System W-25 Piping}

\subsubsection{Tank System Summary}

Tank System W-25 is located at the Melton Valley Storage Tank Facility (Building 7830) (Figures 2.20-1 and 2.20-2). The tank system piping is schedule 40S, ASME SA-240, type 304L stainless steel (SS) and is routed from a pipe tunnel to Tank Vault W-24 through W-27. Tank System W-25 piping is used to transfer concentrate from the Evaporator to Tanks W-24 through W-31 and is classified as a Federal Facility Agreement (FFA) Category B tank system.

\subsubsection{Standards for Pipe Assessment of Tank Systems}

\subsubsection{Tank System Piping Description and Design Standards}

\section{Tank System Piping Description}

Tank System W-25 piping is located at Building 7830 and is routed from a pipe tunnel to Tank Vault W-24 through W-27. The piping system is used and managed by the Waste Management and Remedial Actions Division.

Tank System W-25 piping is constructed of 6", and 4", 304L SS with a maximum design pressure and temperature of $150 \mathrm{psig}$ and $150^{\circ} \mathrm{F}$ for the $6^{\prime \prime}$ line and $300 \mathrm{psig}$ and $150^{\circ} \mathrm{F}$ for the $4^{\prime \prime}$ line. Tank System W-25 piping has the capacity to contain a maximum volume of $150 \mathrm{gal}$.

\section{Design Standards}

The applicable codes and standards used for Tank System W-25 piping and its associated secondary containment systems are identified herein. The codes and standards listed are those identified on either the design drawings or the construction specifications.

AEC-Oak Ridge Office, Minimum Safety Requirements;

Air Moving and Conditioning Association (AMCA) Standards Handbook-Publication 99;

AMCA Directory-Publication 261;

AMCA Fans and Systems-Publication 201;

American Concrete Institute 301-72;

American Concrete Pipe Association;

American Society for Testing and Materials A48, A262-70, C91, C139, C144, and D1751.; 
Design Demonstrations - Category B Tank Systems (Piping)

American Society of Heating, Refrigeration, and Air Conditioning Engineers (ASHRAE) Handbook of Fundamentals;

American Society of Mechanical Engineers (ASME) Boiler and Pressure Vessel Code, Sections II (SA-240), V, VIII, and IX;

ASHRAE Guide and Data Book-Application;

ASHRAE Guide and Data Book-Equipment;

ASHRAE Handbook—Systems;

Atomic Energy Commission (AEC) General Design Criteria, Appendix 63;

Factory Mutual Engineering Corporation;

National Electrical Code;

National Fire Protection Association (NFPA) No. 90A-Air Conditioning and Ventilating Systems;

NFPA No. 91-Blower and Exhaust Systems;

Occupational Safety and Health Administration; and

Underwriters Laboratories Inc.

\subsubsection{Generic Description of Piping Contents}

Tank System W-25 piping was designed to serve as part of an interim storage tank system for the hydrofracture facility. The waste concentrates stored in Tank W-25 were being disposed of as a cement-waste mixture (grout) by injection into shale formations located $800^{\prime}$ to $1100^{\prime}$ below the ground surface using hydrofracture. However, hydrofracture was terminated in 1984, and Tank W-25 has become a waste concentrates storage tank for the liquid low-level waste (LLLW) system. LLLW is generated from a variety of facilities at the Oak Ridge National Laboratory (ORNL) including reactors, radioactive fuel processing areas, radioisotope processing areas, decontamination operations, hot cells, and radiochemical laboratories. The waste generators collect the waste, which is then transferred to the LLLW Evaporator for concentration, with transfer of evaporator bottoms to Tanks W-24 through W-31 for storage.

Tank System W-25 piping transfers LLLW to and from Tank W-25. The analytical data (Figure 2.20-3) of the waste samples are representative of the waste received by Tank W-25. The liquid waste supernate sampled in Tank W-25 ranges in color from pale to deep yellow with high $\mathrm{Ph}$ (11-13) sodium/potassium nitrate salt solutions. The principal metals found in the tank sludge were sodium, potassium, calcium, magnesium, uranium, and thorium. The sludge contains radioactive materials that produce a radiation level of $1.3 \mathrm{rem}$ per hour $(\mathrm{R} / \mathrm{h})($ Figure 2.20-4). 
Design Demonstrations - Category B Tank Systems (Piping)

\subsubsection{Pipe Corrosion Protection Measures}

Piping inside the pipe tunnel and Tank Vault W-24 through W-27 has no direct contact with the soil or water. Cathodic protection measures are not required for external corrosion.

\subsubsection{Documented Age of Tank System}

Tank System W-25 piping was installed in 1980.

\subsubsection{Standards for Containment/Release Detection}

2.20.3.1 Constructed of or Lined with Materials That are Compatible with Stored Waste(s) or Substance(s) to Be Placed in the Tank System and Shall Have Sufficient Strength and Thickness to Prevent Failure

Tank System W-25 piping is single-wall, schedule 40S, type 304L SS that is routed from a pipe tunnel to Tank Vault W-24 through W-27. Each area is discussed below. The piping penetrations from the pipe tunnel to Tank Vault W-24 through W-27 are singly contained, 4" and 6", schedule $40 \mathrm{~S}$, type $304 \mathrm{~L}$ SS pipes embedded in the concrete wall to a length of $3^{\prime} 0^{\prime \prime}$.

\section{Pipe Tunnel}

The bottom of the pipe tunnel is lined with 16 -gauge $\left(1 / 16^{\prime \prime}\right), 304 \mathrm{~L} \mathrm{SS}$, which is the same material as that used in the piping, with sidewalls that project $3^{\prime} 0^{\prime \prime}$ up the pipe tunnel. The SS pipe tunnel lining material is compatible with the waste and designed to prevent migration of waste into the concrete.

\section{Tank Vault W-24 Through W-27}

The assessments of the secondary containment system for Tank Vault W-24 through W-27 are presented in the Design Demonstrations for Tanks W-24 through W-27. Those assessments conclude that Tank Vault W-24 through W-27 is lined with materials that are compatible with the waste and designed to prevent migration of waste into the concrete.

The assessment concludes that the pipe tunnel and tank vault are lined with materials that are compatible with the waste and designed to prevent migration of waste into the concrete.

\subsubsection{Placed on Foundation or Base Capable of Providing Support to the Secondary Containment System}

\section{Pipe Tunnel}

The pipe tunnel foundation is a $20^{\prime} 3^{\prime \prime} \times 133^{\prime} 6^{\prime \prime} \times 1^{\prime} 6^{\prime \prime}$ thick, reinforced concrete base slab that rests on limestone. 
Design Demonstrations - Category B Tank Systems (Piping)

\section{Tank Vault W-24 Through W-27}

The assessments of the secondary containment system for Tank Vault W-24 through W-27 are presented in the Design Demonstrations for Tanks W-24 through W-27. Those assessments conclude that the vault foundation is properly designed to support the secondary containment system.

The assessment concludes that the pipe tunnel and tank vault foundations are properly designed to support the secondary containment systems.

2.20.3.3 Provided with a Leak Detection System That is Designed and Operated to Detect Failure of Either Primary or Secondary Containment Structure or the Presence of Any Measurable Release of Hazardous or Radioactive Constituents

\section{Pipe Tunnel}

The pipe tunnel floor is sloped to a 16-gauge $\left(1 / 16^{\prime \prime}\right)$, 304L SS-lined sump where accumulation of liquid will be detected by a pneumatic level indicator that will activate alarms in the Evaporator Service Tanks Control Room and Waste Operations Control Center (Building 3130).

\section{Tank Vault W-24 Through W-27}

The assessments of the secondary containment system for Tank Vault W-24 through W-27 are presented in the Design Demonstrations for Tanks W-24 through W-27. Those assessments conclude that the vault is provided with a leak detection system.

The assessment concludes that the pipe tunnel and tank vault are provided with leak detection.

\subsubsection{Sloped or Otherwise Designed or Operated to Drain and Remove Liquids} Resulting from Leaks, Spills, or Precipitation

\section{$\underline{\text { Pipe Tunnel }}$}

The pipe tunnel floor is sloped to a 304L SS-lined sump. The sump provides a low point within the pipe tunnel to drain liquids to an instrumented location. A pumping system is provided to remove liquids that accumulate in the sump.

\section{Tank Vault W-24 Through W-27}

The assessments of the secondary containment system for Tank Vault W-24 through W-27 are presented in the Design Demonstrations for Tanks W-24 through W-27. Those assessments conclude that the secondary containment is sloped and designed to drain and remove liquids resulting from leaks, spills, or precipitation.

The assessment concludes that the secondary containments for the pipe tunnel and the tank vault are sloped and designed to drain and remove liquids resulting from leaks, spills, or precipitation. 


\subsubsection{Supplemental Information}

\subsubsection{Ancillary Equipment}

Tank W-25 is constructed of $304 \mathrm{~L} \mathrm{SS,} \mathrm{which} \mathrm{is} \mathrm{the} \mathrm{same} \mathrm{material} \mathrm{as} \mathrm{that} \mathrm{used} \mathrm{in} \mathrm{the} \mathrm{piping} \mathrm{system,}$ and is located in Tank Vault W-24 through W-27, which provides secondary containment. The support equipment is exposed to the same liquids as other components of the tank system; therefore, $304 \mathrm{~L}$ SS is an acceptable material for the support equipment.

\subsubsection{Waste Acceptance Criteria}

Radioactively contaminated liquid wastes at ORNL are generated by various activities within the research and operating divisions. These activities include radiochemical processing, routine hot cell operations and decontaminations, and various waste treatment and environmental protection processes. The variations in composition of the waste streams are limited by the waste acceptance criteria that specify activity and concentration limits for waste discharged into the LLLW system. The Waste Acceptance Criteria for Liquid Waste Treatment Systems at the Oak Ridge National Laboratory (Oak Ridge National Laboratory, 1991), dated July 1991, is a guide for liquid waste generators to determine the proper means of disposal for LLLW. The criteria provide future discharge guidelines for the LLLW system, which includes Tank System W-25. 
Design Demonstrations - Category B Tank Systems (Piping)

\subsubsection{References}

Binford, F. T., and S. D. Orfi. 1979. The Intermediate Level Liquid Waste System at the Oak Ridge National Laboratory Description and Safety Analysis. ORNL/TM-6959. Oak Ridge National Laboratory.

Ebasco, and Main. July 20, 1992. Design Demonstrations-Category B Tank Systems, Revision 2. DOE Contract No. DE-AC05-91OR21928. Oak Ridge National Laboratory.

Energy Systems Drawing P3E-21247-C012, Melton Valley Waste Storage Tanks, Piping Modifications Pump Room and Pipe Gallery Modifications, Revision A.

Energy Systems Drawing P3E-21247-C013, Melton Valley Waste Storage Tanks, Piping Modifications, Sections, Revision A.

Energy Systems Drawing P3E-21247-C014, Melton Valley Waste Storage Tanks, Piping Modifications, Sections, Revision A.

Energy Systems Drawing P-21247-YE-026-E, Waste Storage Tanks, Piping Flow Diagram, Process, Sheet 1 , Revision $\mathrm{G}$.

Energy Systems Drawing P-21247-YE-027-E, Waste Storage Tanks, Piping Flow Diagram, Process, Sheet 1, Revision C.

Energy Systems Drawing P-21247-YC-002-E, Waste Storage Tanks, Piping Plan, Revision B.

Energy Systems Drawing S-21247-YB-002-E, Waste Storage Tanks, Plan and Detail for Control House and Pump Room, Revision D.

Energy Systems Drawing S-21247-YB-001-E, Waste Storage Tanks, Plan Concrete Vault, Revision C.

Energy Systems Drawing P-21247-YC-003-E, Waste Storage Tanks, Pump Room Piping Plan, Revision G.

Energy Systems Drawing S-21247-YB-003-E, Waste Storage Tanks, Sections and Details of Concrete Vault, Revision D.

Energy Systems Drawing P-21247-YC-004-E, Waste Storage Tanks, Tank Piping Section, Sheet 1, Revision C.

Energy Systems Drawing P-21247-YC-012-E, Waste Storage Tanks, Tank Piping Section, Sheet 2, Revision B. 
Energy Systems Drawing P-21247-YC-001-E, Waste Storage Tanks, Tanks, Pump Room and Tunnel Piping Plan, Revision E.

Energy Systems Drawing P-21247-YC-011-E, Waste Storage Tanks, Tanks, Pump Room Piping Section, Sheet 2, Revision D.

Oak Ridge National Laboratory. 1991. Waste Acceptance Criteria for Liquid Waste Treatment Systems at the Oak Ridge National Laboratory. WM-WMCO-201. Department of Waste Minimization Planning and Certification.

Peretz, F. J., et al. 1986. Characterization of Low-Level Liquid Wastes at the Oak Ridge National Laboratory. ORNL/TM-10218. Oak Ridge National Laboratory.

Risk Evaluation of Embedded, Single-Walled Liquid Low-Level Waste Piping at Oak Ridge National Laboratory.

Robinson, S. M., S. M. DePaoli, and A. B. Walker. 1991. Federal Facility Agreement Contingency, Upgrade, and Replacement Plans for the ORNL Active Low-Level Radioactive Waste Tank System. ORNL/TM-1 1795. Oak Ridge National Laboratory. 
Figure 2.20-1

Location of Tank System W-25 Piping

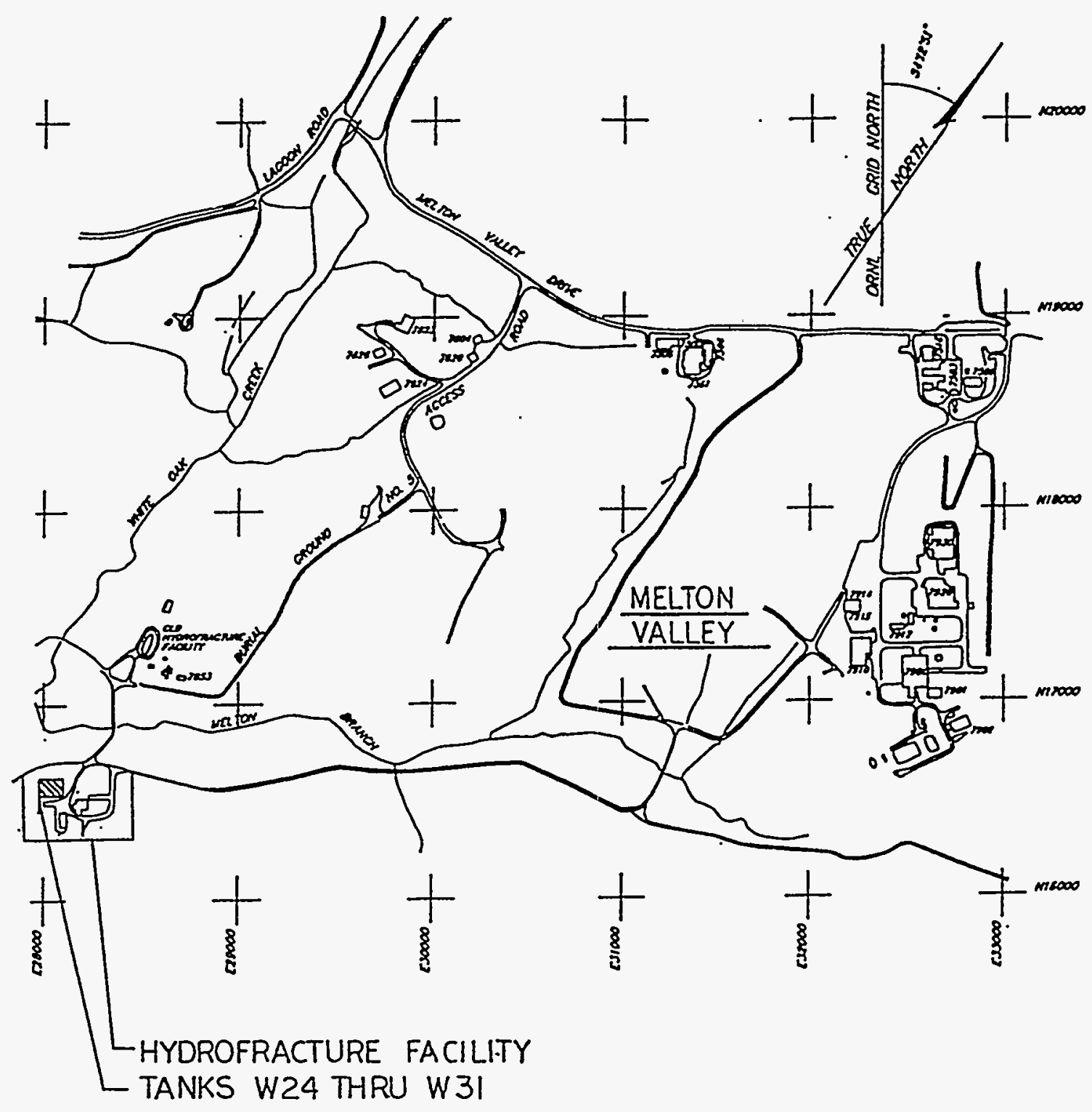


Figure 2.20-2 Tank System W-25 Piping Diagram

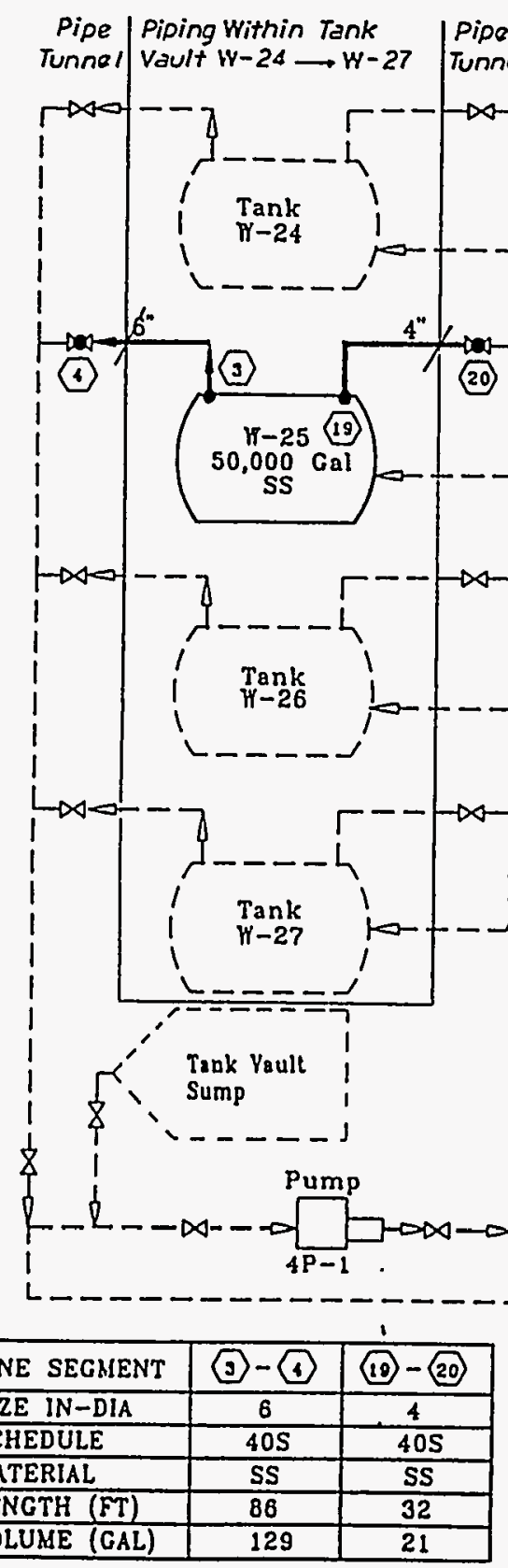

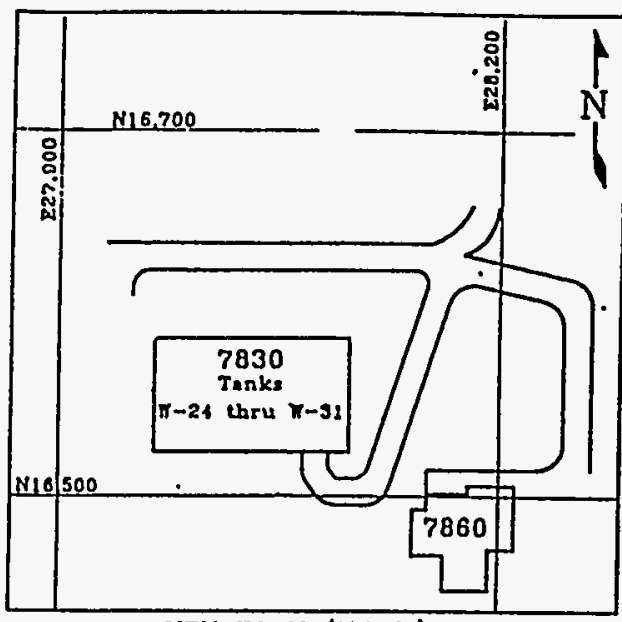

KEY PLAN (N.T.S.)

\begin{tabular}{|c|}
\hline$P-21247-Y C-011-E$ Rev $D$ \\
\hline$P-21247-Y C-005-E$ Rev $B$ \\
\hline$P-21247-Y C-003-E$ Rev G \\
\hline$P-21247-Y C-002-E$ Rev $B$ \\
\hline$P-21247-Y C-001-E$ Rev E \\
\hline$P-21247-Y E-027-E$ Rev $C$ \\
\hline$P-21247-Y E-026-E$ Rev G \\
\hline REFERENCE DRAWING LIST
\end{tabular}

TANK SYSTEM W-25 PIPING

COMPONENTS NOT COVERED IN THIS SECTION 
ANALYTICAL DATA FOR LIQUID SAMPLE

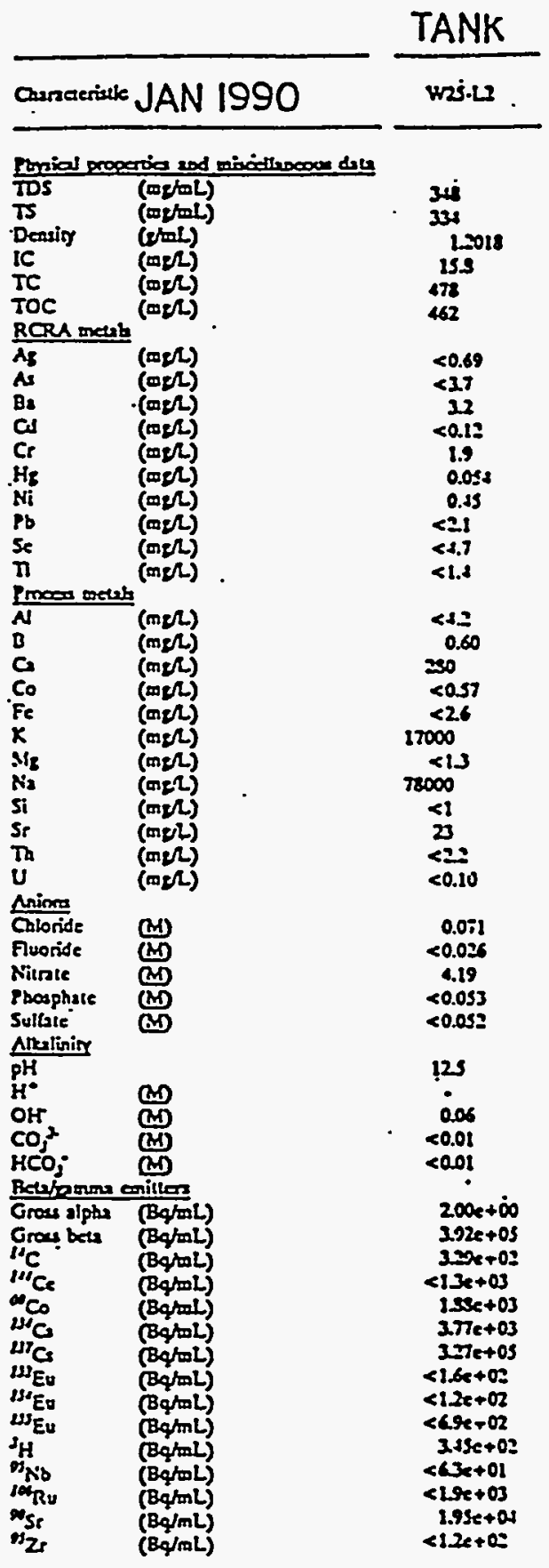

ANALYTICAL DATA FOR SLUDGE SAMPLE

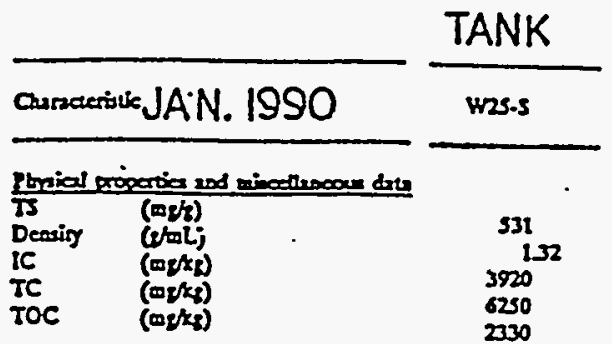

\section{RORA well}

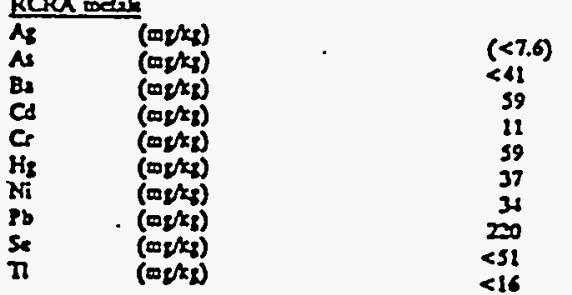

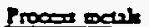

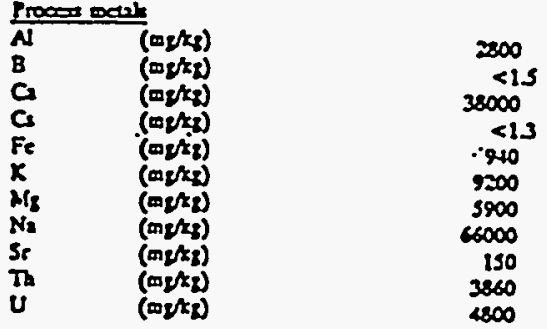

\section{Metatamen coirlor}

Grous Ipha (Bg/t)

Grous bea (Bgt)

"C (Bel)

"WCe (Bg/)

"co (Boh)

"IC. (Bat)

"WE ED (Boh)

L'E: (Bg/)

${ }_{\mathrm{Mb}}$ (Ba)

IME (BqD)

$\begin{array}{ll}n_{\text {st }} & (B q /) \\ v_{Z r} & (B q / b)\end{array}$

4800

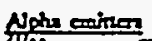

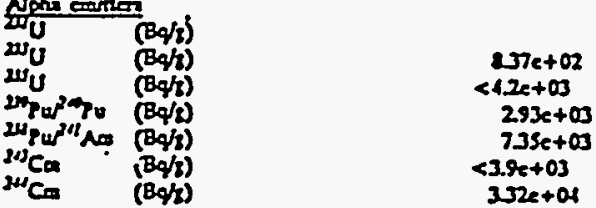

LEGEND: PHYSICAL PROPERTIES TDS - TOTAL DISSOLVED SOLIDS

TS - TOTAL SOLIDS

IC - INORGANIC CARBON

TC - TOTAL CARBON

TOC TOTAL ORGANIC CARBON 
Figure 2.20-4 General Characteristics of Waste Samples (Tank System W-25)

\begin{tabular}{|c|c|c|c|c|c|}
\hline & Lijuld sampl & & & & Sluuge samples \\
\hline Tank & $\begin{array}{l}\text { Padialion } \\
\text { level } \\
\text { (RM) }\end{array}$ & $\begin{array}{c}\text { Organle } \\
\text { layer }\end{array}$ & Numbcrhync & $\begin{array}{l}\text { Rudlation } \\
\text { ICvil } \\
\text { (RMI) }\end{array}$ & Cumments \\
\hline
\end{tabular}

0.180

No 2kofl sludge

1.2

Cuuld prubahly pump with a peristaltic pump, except for the thin layer of 'mud" un-bollom

Sunicaledisludge: lighl yellow tan; very Ane partlcles whill a few coarser partlules

W.25 No Jsoft slutige 0.260 Tilcker sluugo thun in tunk W.24

Could probahly pump with a peristalite pump, exeept fir the thin layer of "inud" un beotiom

Sunlesled sludgu: light ian: very finc particles with a few coarser particles 


\section{Tank System W-26 Piping}

\subsubsection{Tank System Summary}

Tank System W-26 is located at the Melton Valley Storage Tank Facility (Building 7830) (Figures 2.21-1 and 2.21-2). The tank system piping is schedule 40S, ASME SA-240, type 304L stainless steel (SS) and is routed from a pipe tunnel to Tank Vault W-24 through W-27. Tank System W-26 piping is used to transfer concentrate from the Evaporator to Tanks W-24 through W-31 and is classified as a Federal Facility Agreement (FFA) Category B tank system.

\subsubsection{Standards for Pipe Assessment of Tank Systems}

\subsubsection{Tank System Piping Description and Design Standards}

\section{Tank System Piping Description}

Tank System W-26 piping is located at Building 7830 and is routed from a pipe tunnel to Tank Vault W-24 through W-27. The piping system is used and managed by the Waste Management and Remedial Actions Division.

Tank System W-26 piping is constructed of 6" and 4", 304L SS with a maximum design pressure and temperature of $150 \mathrm{psig}$ and $150^{\circ} \mathrm{F}$ for the $6^{\prime \prime}$ line and $300 \mathrm{psig}$ and $150^{\circ} \mathrm{F}$ for the $4^{\prime \prime}$ line. Tank System W-26 piping has the capacity to contain a maximum volume of $111 \mathrm{gal}$.

\section{Design Standards}

The applicable codes and standards used for Tank System W-26 piping and its associated secondary containment systems are identified herein. The codes and standards listed are those identified on either the design drawings or the construction specifications.

AEC-Oak Ridge Office, Minimum Safety Requirements;

Air Moving and Conditioning Association (AMCA) Standards Handbook-Publication 99; AMCA Directory-Publication 261;

AMCA Fans and Systems-Publication 201;

American Concrete Institute 301-72;

American Concrete Pipe Association;

American Society for Testing and Materials A48, A262-70, C91, C139, C144, and D1751; 
Design Demonstrations - Category B Tank Systems (Piping)

American Society of Heating, Refrigeration, and Air Conditioning Engineers (ASHRAE) Handbook of Fundamentals;

American Society of Mechanical Engineers (ASME) Boiler and Pressure Vessel Code, Sections II (SA-240), V, VIII, and IX;

ASHRAE Guide and Data Book-Application;

ASHRAE Guide and Data Book-Equipment;

ASHRAE Handbook-Systems;

Atomic Energy Commission (AEC) General Design Criteria, Appendix 63;

Factory Mutual Engineering Corporation;

National Electrical Code;

National Fire Protection Association (NFPA) No. 90A-Air Conditioning and Ventilating Systems;

NFPA No. 91-Blower and Exhaust Systems;

Occupational Safety and Health Administration; and

Underwriters Laboratories Inc.

\subsubsection{Generic Description of Piping Contents}

Tank System W-26 piping was designed to serve as part of an interim storage tank system for the hydrofracture facility. The waste concentrates stored in Tank W-26 were being disposed of as a cement-waste mixture (grout) by injection into shale formations located 800 to $1100^{\prime}$ below the ground surface using hydrofracture. However, hydrofracture was terminated in 1984, and Tank W-26 has become a waste concentrates storage tank for the liquid low-level waste (LLLW) system. LLLW is generated from a variety of facilities at the Oak Ridge National Laboratory (ORNL) including reactors, radioactive fuel processing areas, radioisotope processing areas, decontamination operations, hot cells, and radiochemical laboratories. The waste generators collect the waste, which is then transferred to the LLLW Evaporator for concentration, with transfer of evaporator bottoms to Tanks W-24 through W-31 for storage.

Tank System W-26 piping transfers LLLW to and from Tank W-26. The analytical data (Figure 2.21-3) of waste samples are representative of the waste received by Tank W-26. The liquid waste supernate sampled in Tank W-26 ranges in color from pale to deep yellow with high $\mathrm{Ph}$ (11-13) sodium/potassium nitrate salt solutions. The principal metals found in the tank sludge were sodium, potassium, calcium, magnesium, uranium, and thorium. The sludge contains radioactive materials that produce a radiation level of $0.8-2.0 \mathrm{rem}$ per hour $(\mathrm{R} / \mathrm{h})$ (Figure 2.21-4). 


\subsubsection{Pipe Corrosion Protection Measures}

Piping inside the pipe tunnel and Tank Vault W-24 through W-27 has no direct contact with the soil or water. Cathodic protection measures are not required for external corrosion.

\subsubsection{Documented Age of Tank System}

Tank System W-26 piping was installed in 1980.

\subsubsection{Standards for Containment/Release Detection}

2.21.3.1 Constructed of or Lined with Materials That are Compatible with Stored Waste(s) or Substance(s) to Be Placed in the Tank System and Shall Have Sufficient Strength and Thickness to Prevent Failure

Tank System W-26 piping is single-wall, schedule 40S, type 304L SS that is routed from a pipe tunnel to Tank Vault W-24 through W-27. Each area is discussed below. The piping penetrations from the pipe tunnel to Tank Vault W-24 through W-27 are singly contained, 4" and 6", schedule $40 \mathrm{~S}$, type $304 \mathrm{~L}$ SS pipes embedded in the concrete wall to a length of $3^{\prime} 0^{\prime \prime}$.

\section{Pipe Tunnel}

The bottom of the pipe tunnel is lined with 16-gauge (1/16"), 304L SS, which is the same material as that used in the piping, with sidewalls that project $3^{\prime} 0^{\prime \prime}$ up the pipe tunnel. The SS pipe tunnel lining material is compatible with the waste and designed to prevent migration of waste into the concrete.

\section{Tank Vault W-24 Through W-27}

The assessments of the secondary containment system for Tank Vault W-24 through W-27 are presented in the Design Demonstrations for Tanks W-24 through W-27. Those assessments conclude that Tank Vault W-24 through W-27 is lined with materials that are compatible with the waste and designed to prevent migration of waste into the concrete.

The assessment concludes that the pipe tunnel and tank vault are lined with materials that are compatible with the waste and designed to prevent migration of waste into the concrete.

\subsubsection{Placed on Foundation or Base Capable of Providing Support to the Secondary Containment System}

\section{Pipe Tunnel}

The pipe tunnel foundation is a $20^{\prime} 3^{\prime \prime} \times 133^{\prime} 6^{\prime \prime} \times 1^{\prime} 6^{\prime \prime}$ thick, reinforced concrete base slab that rests on limestone. 


\section{Tank Vault W-24 Through W-27}

The assessments of the secondary containment system for Tank Vault W-24 through W-27 are presented in the Design Demonstrations for Tanks W-24 through W-27. Those assessments conclude that the vault foundation is properly designed to support the secondary containment system.

The assessment concludes that the pipe tunnel and tank vault foundations are properly designed to support the secondary containment systems.

2.21.3.3 Provided with a Leak Detection System That is Designed and Operated to Detect Failure of Either Primary or Secondary Containment Structure or the Presence of Any Measurable Release of Hazardous or Radioactive Constituents

\section{Pipe Tunnel}

The pipe tunnel floor is sloped to a 16-gauge (1/16"), 304L SS-lined sump where accumulation of liquid will be detected by a pneumatic level indicator that will activate alarms in the Evaporator Service Tanks Control Room and Waste Operations Control Centers (Building 3130).

\section{Tank Vault W-24 Through W-27}

The assessments of the secondary containment system for Tank Vault W-24 through W-27 are presented in the Design Demonstrations for Tanks W-24 through W-27. Those assessments conclude that the vault is provided with a leak detection system.

The assessment concludes that the pipe tunnel and tank vault are provided with leak detection.

\subsubsection{Sloped or Otherwise Designed or Operated to Drain and Remove Liquids} Resulting from Leaks, Spills, or Precipitation

\section{Pipe Tunnel}

The pipe tunnel floor is sloped to a 304L SS-lined sump. The sump provides a low point within the pipe tunnel to drain liquids to an instrumented location. A pumping system is provided to remove liquids that accumulate in the sump.

\section{Tank Vault W-24 Through W-27}

The assessments of the secondary containment system for Tank Vault W-24 through W-27 are presented in the Design Demonstrations for Tanks W-24 through W-27. Those assessments conclude that the secondary containment is sloped and designed to drain and remove liquids resulting from leaks, spills, or precipitation.

The assessment concludes that the secondary containments for the pipe tunnel and the tank vault are sloped and designed to drain and remove liquids resulting from leaks, spills, or precipitation. 


\subsubsection{Supplemental Information}

\subsubsection{Ancillary Equipment}

Tank W-26 is constructed of 304L SS, which is the same material as that used in the piping system, and is located in Tank Vault W-24 through W-27, which provides secondary containment. The support equipment is exposed to the same liquids as other components of the tank system; therefore, $304 \mathrm{~L}$ SS is an acceptable material for the support equipment.

\subsubsection{Waste Acceptance Criteria}

Radioactively contaminated liquid wastes at ORNL are generated by various activities within the research and operating divisions. These activities include radiochemical processing, routine hot cell operations and decontaminations, and various waste treatment and environmental protection processes. The variations in composition of the waste streams are limited by the waste acceptance criteria that specify activity and concentration limits for waste discharged into the LLLW system. The Waste Acceptance Criteria for Liquid Waste Treatment Systems at the Oak Ridge National Laboratory (Oak Ridge National Laboratory, 1991), dated July 1991, is a guide for liquid waste generators to determine the proper means of disposal for LLLW. The criteria provide future discharge guidelines for the LLLW system, which includes Tank System W-26. 
Design Demonstrations - Category B Tank Systems (Piping)

\subsubsection{References}

Binford, F. T., and S. D. Orfi. 1979. The Intermediate Level Liquid Waste System at the Oak Ridge National Laboratory Description and Safety Analysis. ORNL/TM-6959. Oak Ridge National Laboratory.

Ebasco, and Main. July 20, 1992. Design Demonstrations-Category B Tank Systems, Revision 2. DOE Contract No. DE-AC05-91OR21928. Oak Ridge National Laboratory.

Energy Systems Drawing P3E-21247-C012, Melton Valley Waste Storage Tanks, Piping Modifications Pump Room and Pipe Gallery Modifications, Revision A.

Energy Systems Drawing P3E-21247-C013, Melton Valley Waste Storage Tanks, Piping Modifications, Sections, Revision A.

Energy Systems Drawing P3E-21247-C014, Melton Valley, Waste Storage Tanks, Piping Modifications, Sections, Revision A.

Energy Systems Drawing P-21247-YE-026-E, Waste Storage Tanks, Piping Flow Diagram-Process, Sheet 1, Revision G.

Energy Systems Drawing P-21247-YE-027-E, Waste Storage Tanks, Piping Flow Diagram-Process, Sheet 1, Revision C.

Energy Systems Drawing P-21247-YC-002-E, Waste Storage Tanks, Piping Plan, Revision B.

Energy Systems Drawing S-21247-YB-002-E, Waste Storage Tanks, Plan and Detail for Control House and Pump Room, Revision D.

Energy Systems Drawing S-21247-YB-001-E, Waste Storage Tanks, Plan Concrete Vault, Revision C.

Energy Systems Drawing P-21247-YC-003-E, Waste Storage Tanks, Pump Room Piping Plan, Revision G.

Energy Systems Drawing S-21247-YB-003-E, Waste Storage Tanks, Sections and Details of Concrete Vault, Revision D.

Energy Systems Drawing P-21247-YC-004-E, Waste Storage Tanks, Tank Piping Section, Sheet 1, Revision C.

Energy Systems Drawing P-21247-YC-012-E, Waste Storage Tanks, Tank Piping Section, Sheet 2, Revision B. 
Energy Systems Drawing P-21247-YC-001-E, Waste Storage Tanks, Tanks, Pump Room and Tunnel Piping Plan, Revision E.

Energy Systems Drawing P-21247-YC-011-E, Waste Storage Tanks, Tanks, Pump Room Piping Section, Sheet 2, Revision D.

Oak Ridge National Laboratory. 1991. Waste Acceptance Criteria for Liquid Waste Treatment Systems at the Oak Ridge National Laboratory. WM-WMCO-201. Department of Waste Minimization Planning and Certification.

Peretz, F. J., et al. 1986. Characterization of Low-Level Liquid Wastes at the Oak Ridge National Laboratory. ORNL/TM-10218. Oak Ridge National Laboratory.

Risk Evaluation of Embedded, Single-Walled Liquid Low-Level Waste Piping at Oak Ridge National Laboratory.

Robinson, S. M., S. M. DePaoli, and A. B. Walker. 1991. Federal Facility Agreement Contingency, Upgrade, and Replacement Plans for the ORNL Active Low-Level Radioactive Waste Tank System. ORNL/TM-11795. Oak Ridge National Laboratory. 


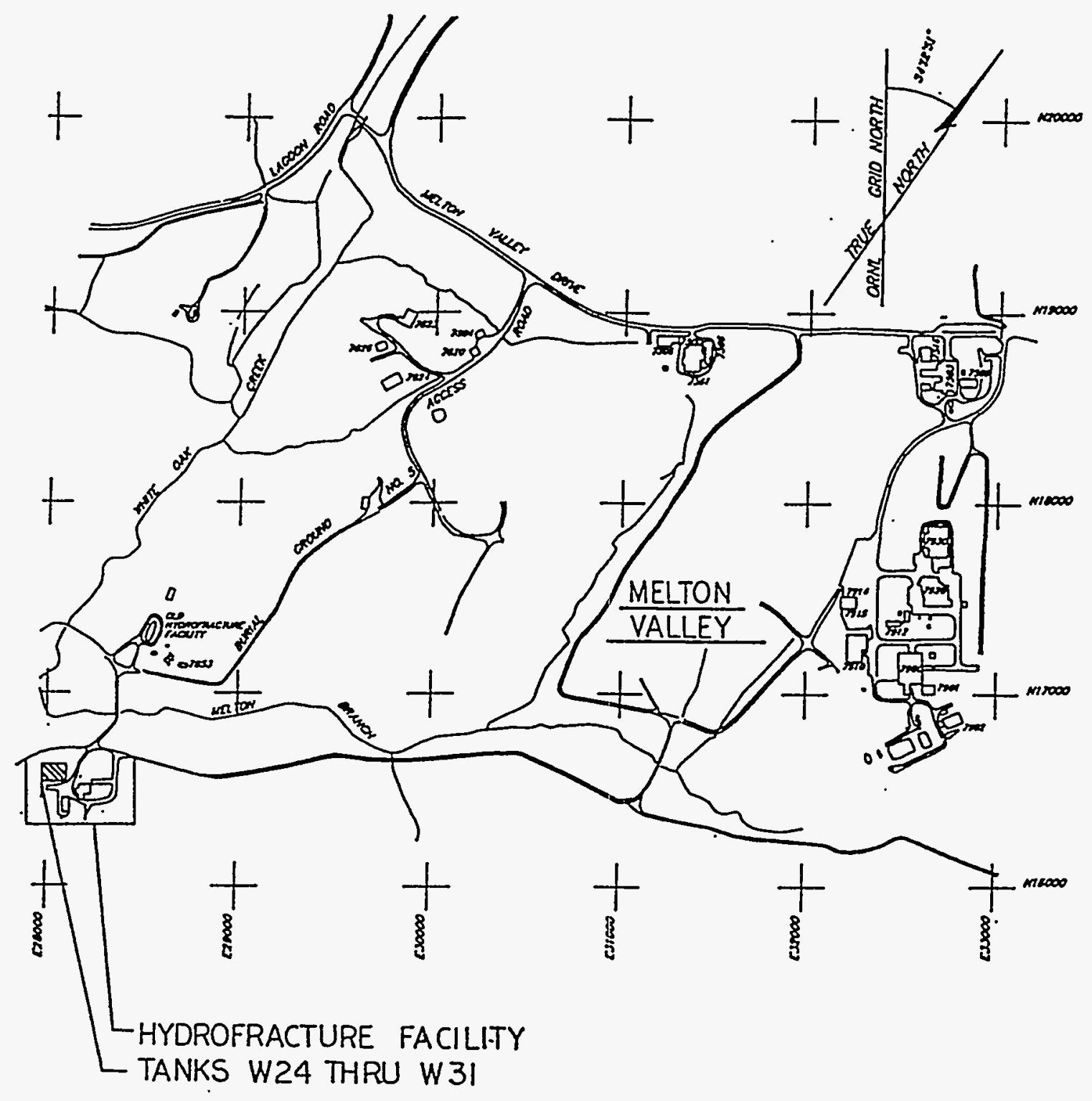


Figure 2.21-2 Tank System W-26 Piping Diagram
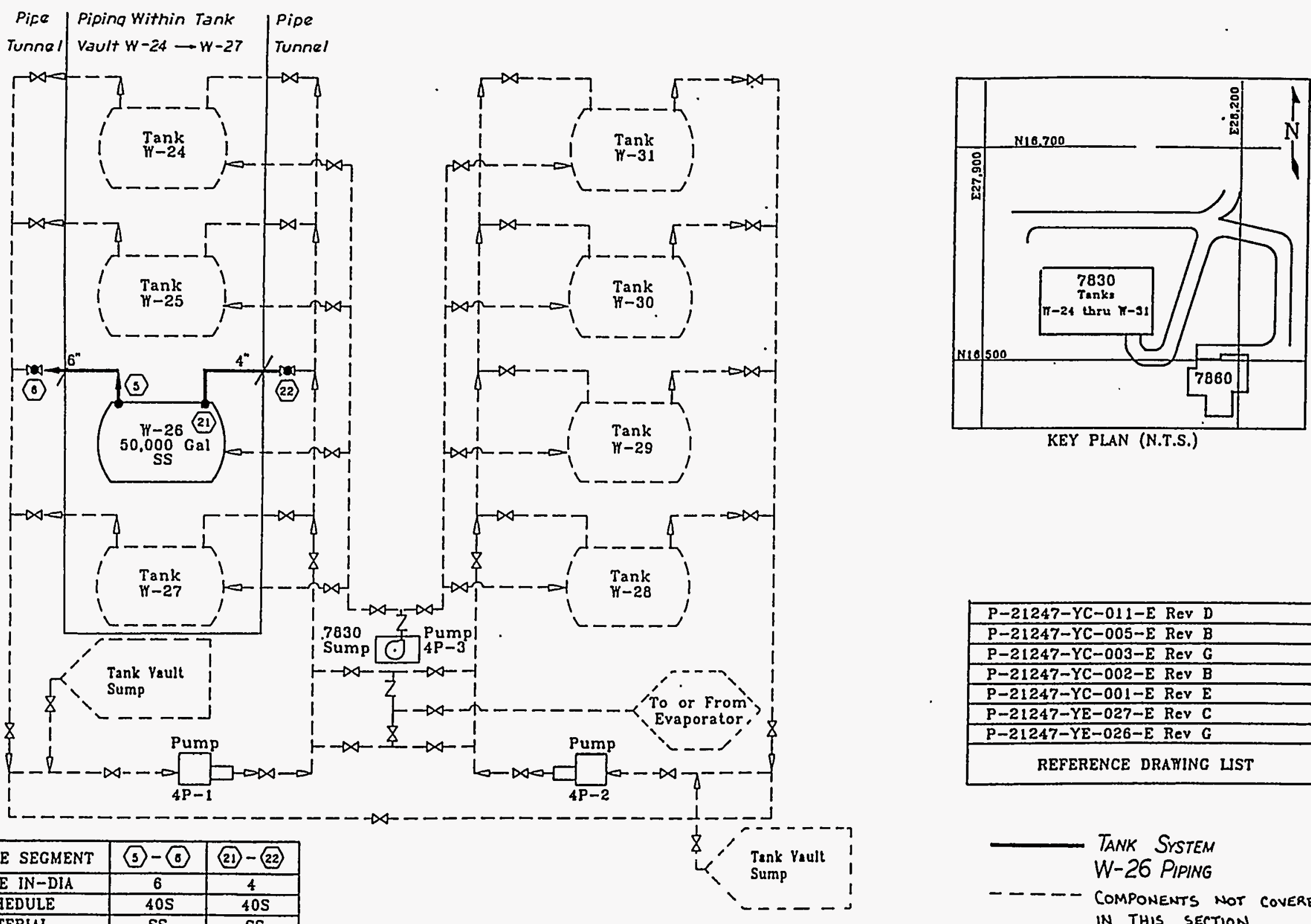

KEY PLAN (N.T.S.)

\begin{tabular}{|c|}
\hline$P-21247-Y C-011-E$ Rev $D$ \\
\hline$P-21247-Y C-005-E$ Rev $B$ \\
\hline$P-21247-Y C-003-E$ Rev $G$ \\
\hline$P-21247-Y C-002-E$ ReV $B$ \\
\hline$P-21247-Y C-001-E$ ReV $E$ \\
\hline$P-21247-Y E-027-E$ ReV $C$ \\
\hline$P-21247-Y E-026-E$ ReV G \\
\hline REFERENCE DRAFING LIST \\
\hline
\end{tabular}

\begin{tabular}{|l|c|c|}
\hline LINE SEGMENT & 5 - (0) & (21)- 22 \\
\hline SIZE IN-DIA & 6 & 4 \\
\hline SCHEDULE & $40 S$ & $40 S$ \\
\hline MIATERIAL & SS & SS \\
\hline LENGTH (FT) & 37 & 85 \\
\hline YOLUME (GAL) & 55 & 56 \\
\hline
\end{tabular}

TANK SYSTEM W-26 PIPING

COMPONENTS NOT COVERED IN THIS SECTION

EBASCO/MaIN 
ANALYTICAL DATA FOR
LIQUID SAMPLE

TANK

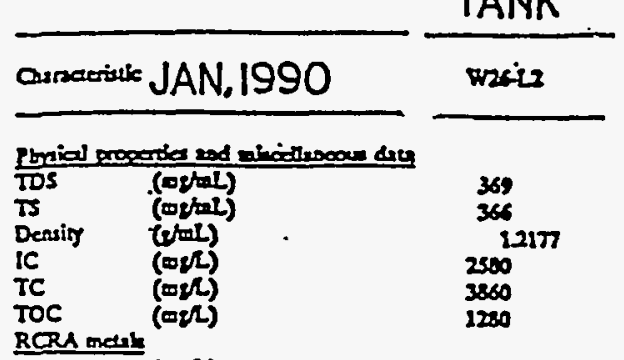

Rishand

As (ars)

B. (a)

G (men)

Cr (mel)

$\mathrm{NI} \quad($ ar)

Pb (a)

Se $(\infty 2)$

Imosh mesh

N (nis)

B $\quad(\infty \Omega)$

Co $(\infty 2 \Omega)$

Fe (mel)

$\mathrm{X}$ (mel)

I/s (men)

S1 (mer)

St $\quad$ (nes)

U. $\quad(m e \Omega)$

Anions

Caloride $\quad M$

Fisoride (M)

Nitrate (M)

Phosphuse (MS

Sulcite $(M$

Artaknir

PH

(M)

$\mathrm{CO}^{2}$

$\mathrm{HCO}_{\mathrm{S}} \mathrm{M}$

Reveranors onitles

Grous atpha (Bemit)

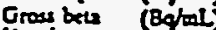

"C Both

"Ac (Bgmel)

WC (Bot)

"IG (Bght)

UIEN (BomL

INEs (BomL

$w_{E \mathrm{D}}$ (BomL)

ग (Bqt)

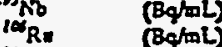

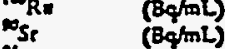

2s (B/mL

Apta mincon :-:

wU (Befl)

210 (Bq/aL)

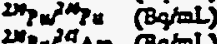

27
32

$<4$

35

20

$<058$

$<26$

31000

35

6000

$\cdot 11.9$

$<0.74$

10

1130

cose

$<0025$

320

$<0.053$

in

$<201$

020

$2.02 x+\infty 3$

$2200+06$

$123 x+02$

$<23 c+03$

$1202+04$

i.3ietor

$207 e+\infty$

$<215+02$

$<24+02$

$<12 x+03$

C.18e+02

$<1,4+02$

$<2 x+\infty$

$40 x+02$

$<27 c+02$

$360 x+08$

$2.20 x+02$

$1.00 x+02$

$200 x+01$

Cise+ol
ANALYTICAL DATA FOR

SLUDGE SAMPLE

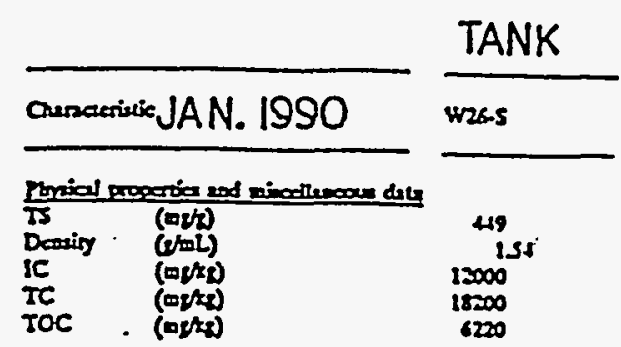

RCRA beth

As. (me/z)

As (Detre)

B. (a)

Cr

$\mathrm{H}_{8} \quad(0,4)$

- ii $\quad(\rightarrow r<)^{2}$

Sb (Ditr)

(30)

6

87
170
170

170

92 $\pi \quad(\infty 1 \times 28)$

Proos od och

\begin{tabular}{|c|c|c|}
\hline 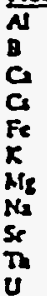 & 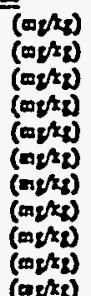 & $\begin{array}{r}7500 \\
<75 \\
36000 \\
2300 \\
25000 \\
11000 \\
51000 \\
120 \\
1360 \\
21100\end{array}$ \\
\hline
\end{tabular}

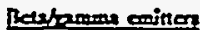

Groes alpha (Bot)

Grous beta $\left(B f_{1}\right)$

"C (B)/D)

"C.

CD (B.t)

"Wa (Bqt)

${ }_{2 D E} \quad(B Q / 2)$

WE: BQh

$\omega_{E=1} \quad(B \%$ h

NO

Min (Ber)

(Bght)

$<5$

7500

36000

2300

$: 5000$

31000

1360
1100

\section{Aprat oniten}

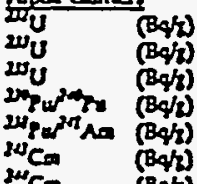

$9.1 x+0$

$5.70 x+0$

$213 x+02$

$1.03<-0.5$

$207_{t+03}$

ciste+0s

4isetos

7 sletor

$<26 e+03$

$<2 s+0 s$

$203 x+06$

$<1.3 e+05$

LEGEND: PHYSICAL PROPERTIES

TDS-TOTAL DISSOLVED SOLIDS

TS - TOTAL SOLIDS

IC - INORGANIC CARBON

TC - TOTAL CARBON

TOC TOTAL ORGANIC CARBON 
Figure 2.21-4 General Characteristics of Waste Samples (Tank System W-26)

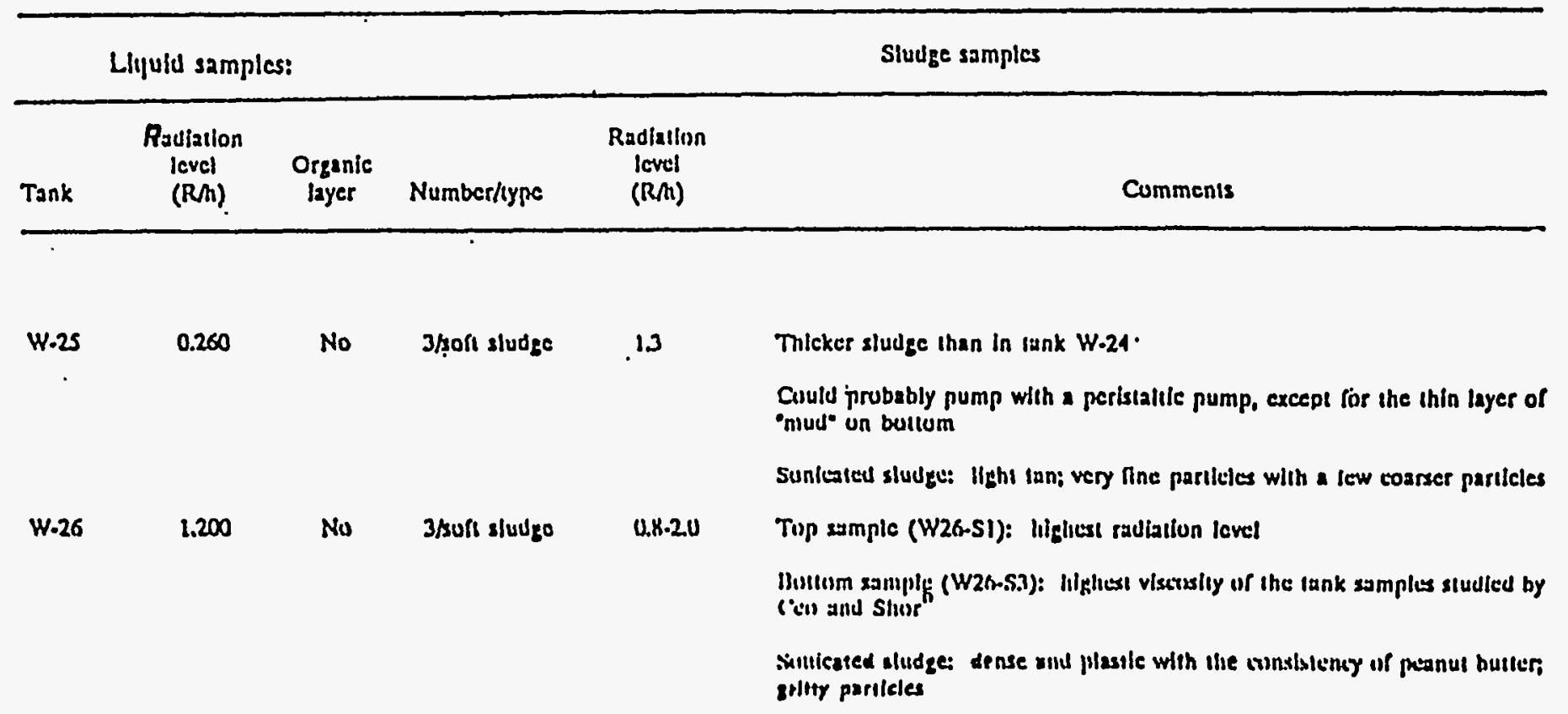




\subsection{Tank System W-27 Piping}

\subsubsection{Tank System Summary}

Tank System W-27 is located at the Melton Valley Storage Tank Facility (Building 7830) (Figures 2.22-1 and 2.22-2). The tank system piping is schedule 40S, ASME SA-240, type 304L stainless steel (SS) and is routed from a pipe tunnel to Tank Vault W-24 through W-27. Tank System W-27 piping is used to transfer concentrate from the Evaporator to Tanks W-24 through W-31 and is classified as a Federal Facility Agreement (FFA) Category B tank system.

\subsubsection{Standards for Pipe Assessment of Tank Systems}

\subsubsection{Tank System Piping Description and Design Standards}

\section{Tank System Piping Description}

Tank System W-27 piping is located at Building 7830 and is routed from a pipe tunnel to Tank Vault W-24 through W-27. The piping system is used and managed by the Waste Management and Remedial Actions Division.

Tank System W-27 piping is constructed of $6^{\prime \prime}$ and $4^{\prime \prime}, 304 \mathrm{~L}$ SS with a maximum design pressure and temperature of $150 \mathrm{psig}$ and $150^{\circ} \mathrm{F}$ for the $6^{\prime \prime}$ line and $300 \mathrm{psig}$ and $150^{\circ} \mathrm{F}$ for the $4^{\prime \prime}$ line. Tank System W-27 piping has the capacity to contain a maximum volume of 150 gal.

\section{$\underline{\text { Design Standards }}$}

The applicable codes and standards used for Tank System W-27 piping and its associated secondary containment systems are identified herein. The codes and standards listed are those identified on either the design drawings or the construction specifications.

AEC-Oak Ridge Office, Minimum Safety Requirements;

Air Moving and Conditioning Association (AMCA) Standards Handbook-Publication 99;

AMCA Directory-Publication 261;

AMCA Fans and Systems-Publication 201;

American Concrete Institute 301-72;

American Concrete Pipe Association;

American Society for Testing and Materials A48, A262-70, C91, C139, C144, and D1751; 
Design Demonstrations - Category B Tank Systems (Piping)

American Society of Heating, Refrigeration, and Air Conditioning Engineers (ASHRAE) Handbook of Fundamentals;

American Society of Mechanical Engineers (ASME) Boiler and Pressure Vessel Code, Sections II (SA-240), V, VIII, and IX.

ASHRAE Guide and Data Book-Application;

ASHRAE Guide and Data Book-Equipment;

ASHRAE Handbook-Systems;

Atomic Energy Commission (AEC) General Design Criteria, Appendix 63;

Factory Mutual Engineering Corporation;

National Electrical Code;

National Fire Protection Association (NFPA) No. 90A-Air Conditioning and Ventilating Systems;

NFPA No. 91-Blower and Exhaust Systems;

Occupational Safety and Health Administration; and

Underwriters Laboratories Inc.

\subsubsection{Generic Description of Piping Contents}

Tank System W-27 piping was designed to serve as part of an interim storage tank system for the hydrofracture facility. The waste concentrates stored in Tank W-27 were being disposed of as a cement-waste mixture (grout) by injection into shale formations located $800^{\prime}$ to $1100^{\prime}$ below the ground surface using hydrofracture. However, hydrofracture was terminated in 1984, and Tank W-27 has become a waste concentrates storage tank for the liquid low-level waste (LLLW) system. LLLW is generated from a variety of facilities at the Oak Ridge National Laboratory (ORNL) including reactors, radioactive fuel processing areas, radioisotope processing areas, decontamination operations, hot cells, and radiochemical laboratories. The waste generators collect the waste, which is then transferred to the LLLW Evaporator for concentration, with transfer of evaporator bottoms to Tanks W-24 through W-31 for storage.

Tank System W-27 piping transfers LLLW to and from Tank W-27. The analytical data (Figure 2.22-3) of the waste samples are representative of the waste received by Tank W-27. The liquid waste supernate sampled in Tank W-27 ranges in color from pale to deep yellow with high $\mathrm{Ph}(11-13)$ sodium/potassium nitrate salt solutions. The principal metals found in the tank sludge were sodium, potassium, calcium, magnesium, uranium, and thorium. The sludge contains radioactive materials that produce a radiation level of $0.2-0.3 \mathrm{rem}$ per hour $(\mathrm{R} / \mathrm{h})$ (see Figure 2.22-4). 


\subsubsection{Pipe Corrosion Protection Measures}

Piping inside the pipe tunnel and Tank Vault W-24 through W-27 has no direct contact with the soil or water. Cathodic protection measures are not required for external corrosion.

\subsubsection{Documented Age of Tank System}

Tank System W-27 piping was installed in 1980.

\subsubsection{Standards for Containment/Release Detection}

2.22.3.1 Constructed of or Lined with Materials That are Compatible with Stored Waste(s) or Substance(s) to Be Placed in the Tank System and Shall Have Sufficient Strength and Thickness to Prevent Failure

Tank System W-27 piping is single-wall, schedule 40S, type 304L SS that is routed from a pipe tunnel to Tank Vault W-24 through W-27. Each area is discussed below. The piping penetrations from the pipe tunnel to Tank Vault W-24 through W-27 are singly contained, 4" and 6", schedule $40 \mathrm{~S}$, type $304 \mathrm{~L}$ SS pipes embedded in the concrete wall to a length of $3^{\prime} 0^{\prime \prime}$.

\section{Pipe Tunnel}

The bottom of the pipe tunnel is lined with 16-gauge $\left(1 / 16^{\prime \prime}\right)$, 304L SS, which is the same material as that used in the piping, with sidewalls that project $3^{\prime} 0^{\prime \prime}$ up the pipe tunnel. The SS pipe tunnel lining material is compatible with the waste and designed to prevent migration of waste into the concrete.

\section{Tank Vault W-24 Through W-27}

The assessments of the secondary containment system for Tank Vault W-24 through W-27 are presented in the Design Demonstrations for Tanks W-24 through W-27. Those assessments conclude that Tank Vault W-24 through W-27 is lined with materials that are compatible with the waste and designed to prevent migration of waste into the concrete.

The assessment concludes that the pipe tunnel and tank vault are lined with materials that are compatible with the waste and designed to prevent migration of waste into the concrete.

2.22.3.2 Placed on Foundation or Base Capable of Providing Support to the Secondary Containment System

\section{Pipe Tunnel}

The pipe tunnel foundation is a $20^{\prime} 3^{\prime \prime} \times 133^{\prime} 6^{\prime \prime} \times 1^{\prime} 6^{\prime \prime}$ thick, reinforced concrete base slab that rests on limestone. 


\section{Tank Vault W-24 Through W-27}

The assessments of the secondary containment system for Tank Vault W-24 through W-27 are presented in the Design Demonstrations for Tanks W-24 through W-27. Those assessments conclude that the vault foundation is properly designed to support the secondary containment system.

The assessment concludes that the pipe tunnel and tank vault foundations are properly designed to support the secondary containment systems.

2.22.3.3 Provided with a Leak Detection System That is Designed and Operated to Detect Failure of Either Primary or Secondary Containment Structure or the Presence of Any Measurable Release of Hazardous or Radioactive Constituents

\section{Pipe Tunnel}

The pipe tunnel floor is sloped to a 16-gauge $\left(1 / 16^{\prime \prime}\right), 304 \mathrm{~L}$ SS-lined sump where accumulation of liquid will be detected by a pneumatic level indicator that will activate alarms in the Evaporator Service Tanks Control Room and Waste Operations Control Center (Building 3130).

\section{Tank Vault W-24 Through W-27}

The assessments of the secondary containment system for Tank Vault W-24 through W-27 are presented in the Design Demonstrations for Tanks W-24 through W-27. Those assessments conclude that the vault is provided with a leak detection system.

The assessment concludes that the pipe tunnel and tank vault are provided with leak detection.

2.22.3.4 Sloped or Otherwise Designed or Operated to Drain and Remove Liquids Resulting from Leaks, Spills, or Precipitation

\section{Pipe Tunnel}

The pipe tunnel floor is sloped to a 304L SS-lined sump. The sump provides a low point within the pipe tunnel to drain liquids to an instrumented location. A pumping system is provided to remove liquids that accumulate in the sump.

\section{Tank Vault W-24 Through W-27}

The assessments of the secondary containment system for Tank Vault W-24 through W-27 are presented in the Design Demonstrations for Tanks W-24 through W-27. Those assessments conclude that the secondary containment is sloped and designed to drain and remove liquids resulting from leaks, spills, or precipitation.

The assessment concludes that the secondary containments for the pipe tunnel and the tank vault are sloped and designed to drain and remove liquids resulting from leaks, spills, or precipitation. 


\subsubsection{Supplemental Information}

\subsubsection{Ancillary Equipment}

Tank W-27 is constructed of 304L SS, which is the same material as that used in the piping system, and is located in Tank Vault W-24 through W-27, which provides secondary containment. The support equipment is exposed to the same liquids as other components of the tank system; therefore, $304 \mathrm{~L}$ SS is an acceptable material for the support equipment.

\subsubsection{Waste Acceptance Criteria}

Radioactively contaminated liquid wastes at ORNL are generated by various activities within the research and operating divisions. These activities include radiochemical processing, routine hot cell operations and decontaminations, and various waste treatment and environmental protection processes. The variations in composition of the waste streams are limited by the waste acceptance criteria that specify activity and concentration limits for waste discharged into the LLLW system. The Waste Acceptance Criteria for Liquid Waste Treatment Systems at the Oak Ridge National Laboratory (Oak Ridge National Laboratory, 1991), dated July 1991, is a guide for liquid waste generators to determine the proper means of disposal for LLLW. The criteria provide future discharge guidelines for the LLLW system, which includes Tank System W-27. 
Design Demonstrations - Category B Tank Systems (Piping)

\subsubsection{References}

Binford, F. T., and S. D. Orfi. 1979. The Intermediate Level Liquid Waste System at the Oak Ridge National Laboratory Description and Safety Analysis. ORNL/TM-6959. Oak Ridge National Laboratory.

Ebasco, and Main. July 20, 1992. Design Demonstrations-Category B Tank Systems, Revision 2. DOE Contract No. DE-AC05-91OR21928. Oak Ridge National Laboratory.

Energy Systems Drawing P3E-21247-C012, Melton Valley Waste Storage Tanks, Piping Modifications Pump Room and Pipe Gallery Modifications, Revision A.

Energy Systems Drawing P3E-21247-C013, Melton Valley Waste Storage Tanks, Piping Modifications, Sections, Revision A.

Energy Systems Drawing P3E-21247-C014, Melton Valley Waste Storage Tanks, Piping Modifications, Sections, Revision A.

Energy Systems Drawing P-21247-YE-026-E, Waste Storage Tanks, Piping Flow Diagram, Process, Sheet 1, Revision G.

Energy Systems Drawing P-21247-YE-027-E, Waste Storage Tanks, Piping Flow Diagram, Process, Sheet 1, Revision C.

Energy Systems Drawing P-21247-YC-002-E, Waste Storage Tanks, Piping Plan, Revision B.

Energy Systems Drawing S-21247-YB-002-E, Waste Storage Tanks, Plan and Detail for Control House and Pump Room, Revision D.

Energy Systems Drawing S-21247-YB-001-E, Waste Storage Tanks, Plan Concrete Vault, Revision C.

Energy Systems Drawing P-21247-YC-003-E, Waste Storage Tanks, Pump Room Piping Plan, Revision G.

Energy Systems Drawing S-21247-YB-003-E, Waste Storage Tanks, Sections and Details of Concrete Vault, Revision D.

Energy Systems Drawing P-21247-YC-004-E, Waste Storage Tanks, Tank Piping Section, Sheet 1 , Revision C.

Energy Systems Drawing P-21247-YC-012-E, Waste Storage Tanks, Tank Piping Section, Sheet 2, Revision B. 
Energy Systems Drawing P-21247-YC-001-E, Waste Storage Tanks, Tanks, Pump Room and Tunnel Piping Plan, Revision E.

Energy Systems Drawing P-21247-YC-011-E, Waste Storage Tanks, Tanks, Pump Room Piping Section, Sheet 2, Revision D.

Oak Ridge National Laboratory. 1991. Waste Acceptance Criteria for Liquid Waste Treatment Systems at the Oak Ridge National Laboratory. WM-WMCO-201. Department of Waste Minimization Planning and Certification.

Peretz, F. J., et al. 1986. Characterization of Low-Level Liquid Wastes at the Oak Ridge National Laboratory. ORNL/TM-10218. Oak Ridge National Laboratory.

Risk Evaluation of Embedded, Single-Walled Liquid Low-Level Waste Piping at Oak Ridge National Laboratory.

Robinson, S. M., S. M. DePaoli, and A. B. Walker. 1991. Federal Facility Agreement Contingency, Upgrade, and Replacement Plans for the ORNL Active Low-Level Radioactive Waste Tank System. ORNL/TM-11795. Oak Ridge National Laboratory. 


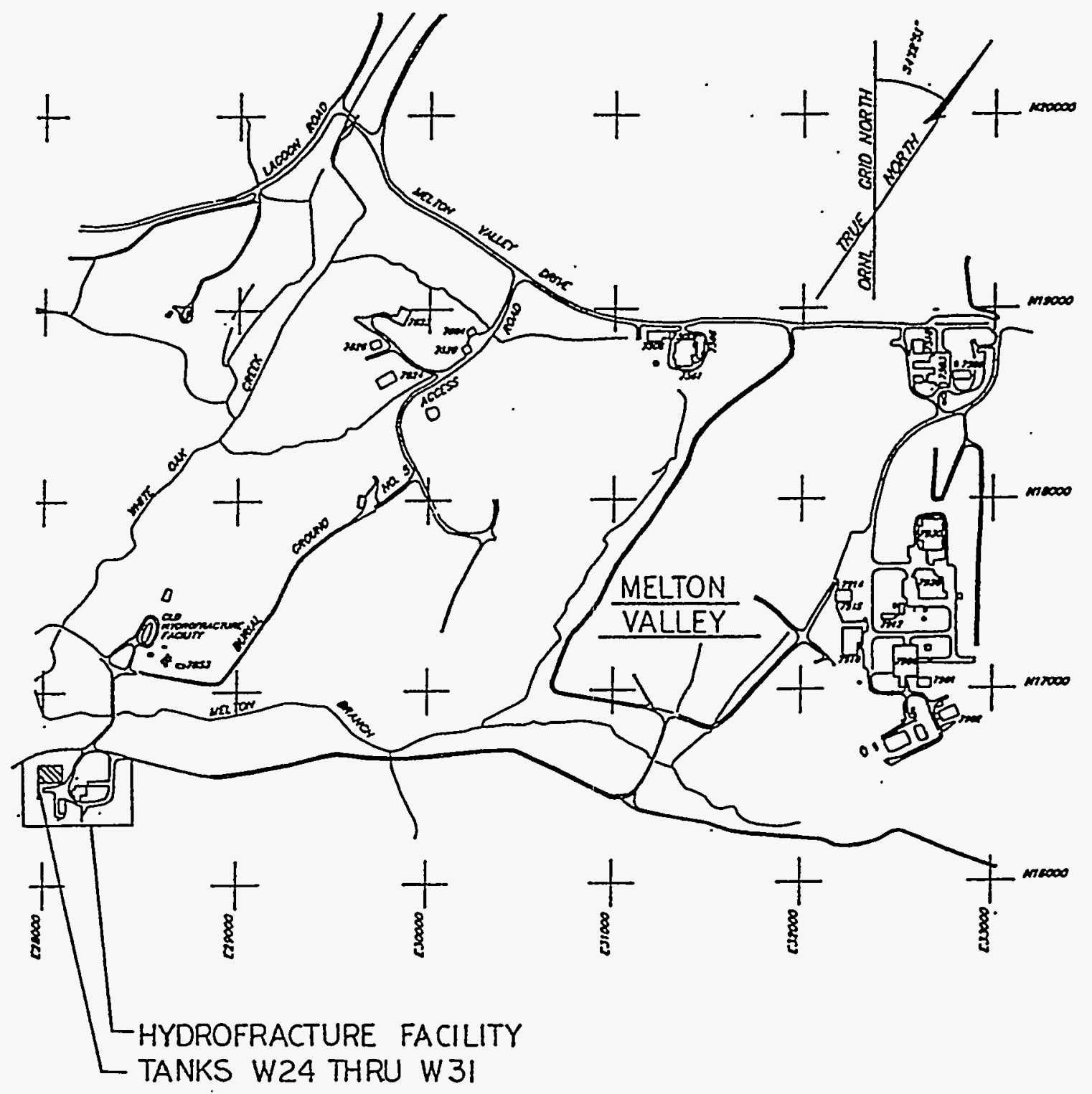


Figure 2.22-2 Tank System W-27 Piping Diagram

Pide | Piping Within Tank |Pipe

iunnal Vault w-24 $\rightarrow W-27$
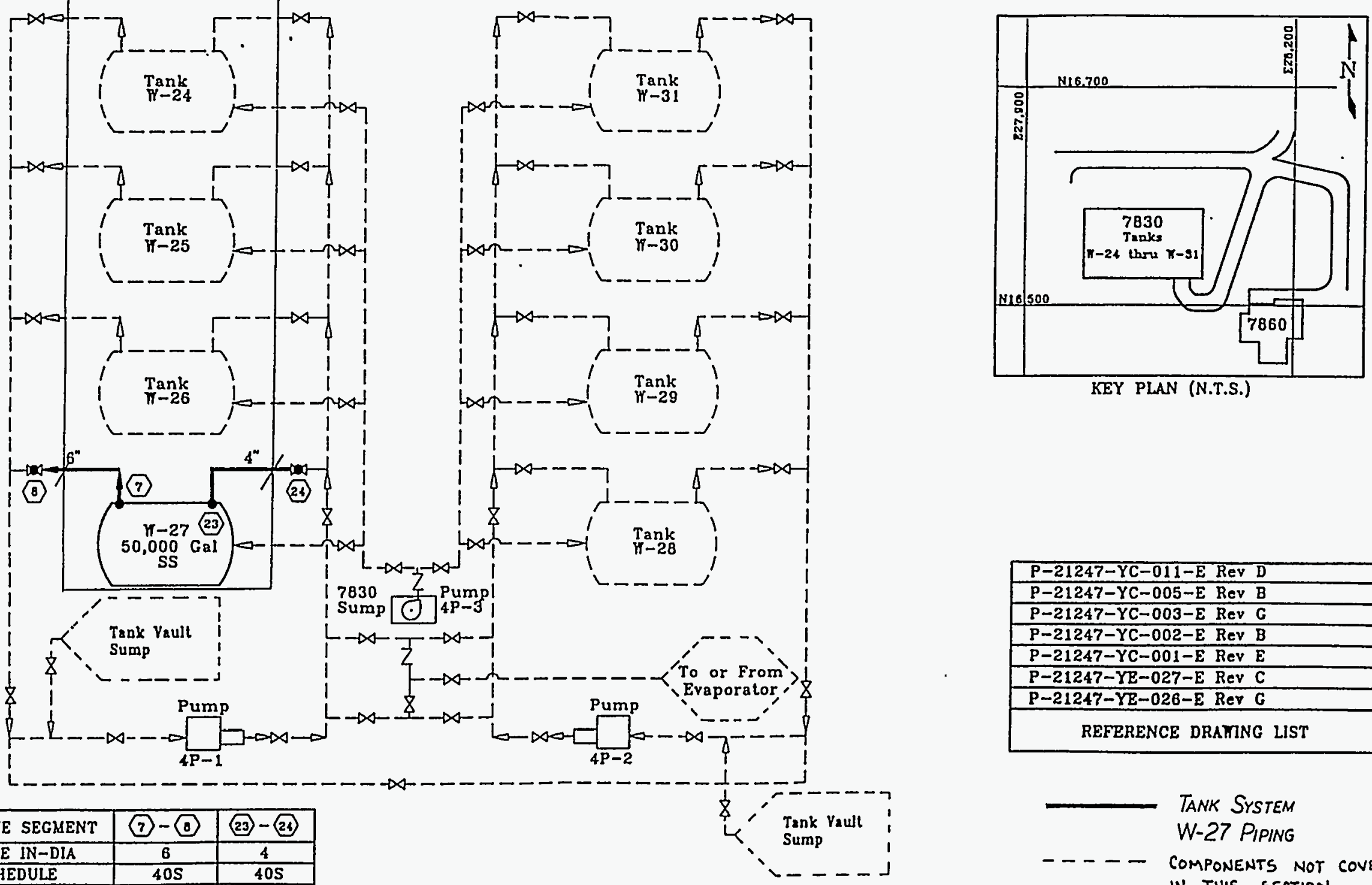

KEY PLAN (N.T.S.)

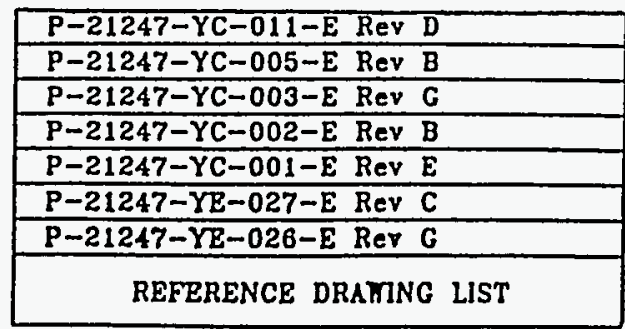

\begin{tabular}{|l|c|c|}
\hline LINE SEGMENT & $(7-0)$ & $23-(26$ \\
\hline SIZE IN-DIA & 6 & 4 \\
\hline SCHEDULE & $40 S$ & $40 S$ \\
\hline BATERIAL & $S S$ & SS \\
\hline LENGTH (FT) & 86 & 32 \\
\hline VOLUNE (GAL) & 129 & 21 \\
\hline
\end{tabular}

Pumpl

$\underbrace{}_{\rightarrow \infty}$

$L_{1} \rightarrow-\frac{1}{3} \rightarrow \infty-$

$\sum_{-\infty, \frac{1}{8} \rightarrow \infty}$

or From,

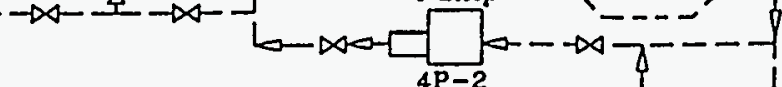

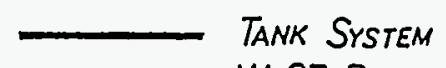

W-27 PIPING

- - - - COMPONENTS NOT COVERED

IN THIS SECTION 
Figure 2.22-3

Analytical Data for Liquid and Sludge Samples (Tank System W-27)

ANALYTICAL DATA FOR LIQUID SAMPLE

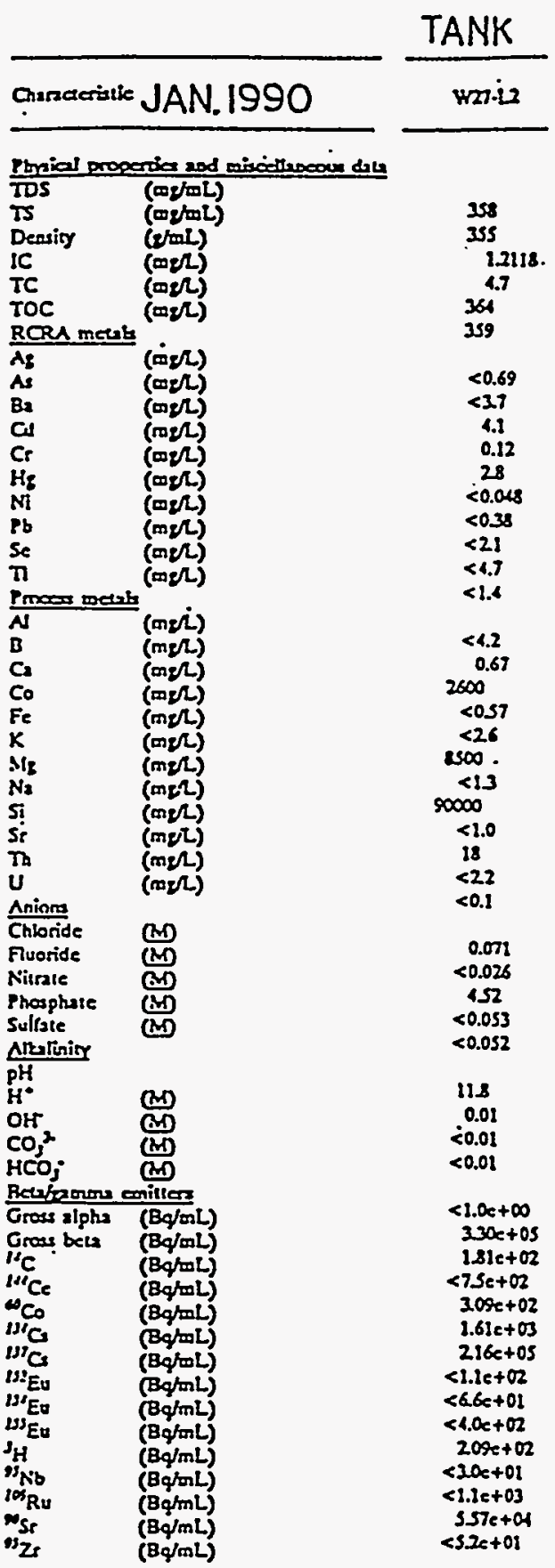

ANALYTICAL DATA FOR SLUDGE SAMPLE

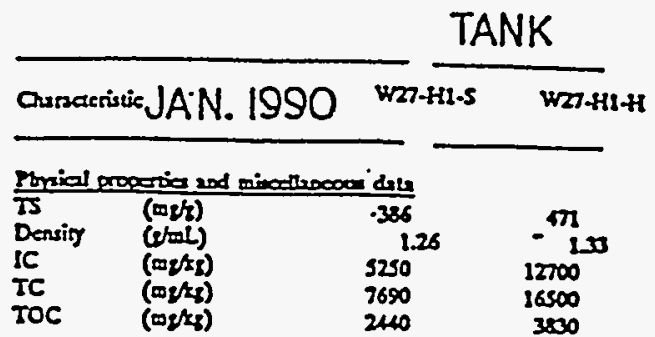

RCRA mail

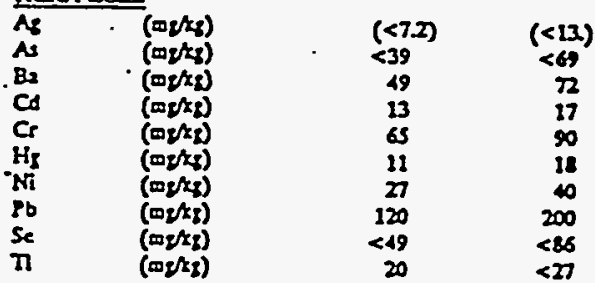

Proogen odis.

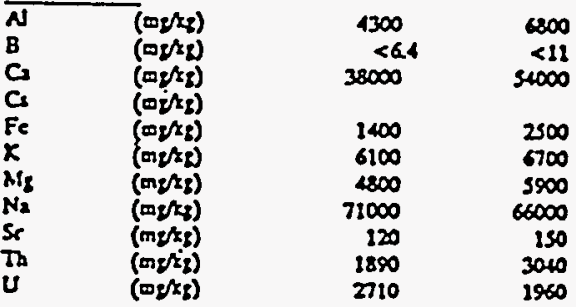

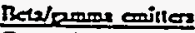

Groes alphx (B/t)

Gross bet (Bd/s)

"C $\mathrm{C}$ (Bo/s)

(A) $\mathrm{Ce} \quad(\mathrm{B} / \mathrm{f})$

4Co (Bo/r)

${ }^{114} \mathrm{C} \quad(\mathrm{Bg} / \mathrm{l})$

"L: $\mathrm{CS}$ (Bo/f)

$\omega_{\text {Ev }}(8 g / 2)$

${ }^{1 w_{\mathrm{E}}} \quad(\mathrm{B} / \mathrm{s})$

${ }^{10} \mathrm{NB} \quad(\mathrm{Bg} / 2)$

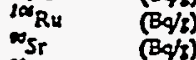

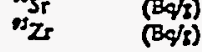

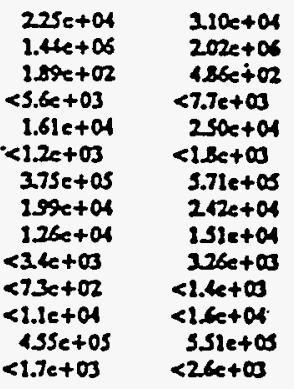

\section{Nphe conitter}

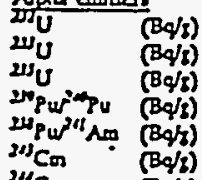

$\begin{array}{ll}{ }^{21} \mathrm{Cm} & \mathrm{Cm} / \mathrm{Cm}) \\ & (B / \mathrm{l})\end{array}$

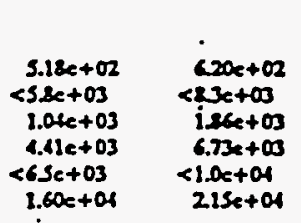

LEGEND: PHYSICAL PROPERTIES

TDS-TOTAL DISSOLYED SOLIDS

TS - TOTAL SOLIDS

IC - INORGANIC CARBON

TC - TOTAL CARBON

TOC TOTAL ORGANIC CARBON 
Figure 2.22-4 General Characteristics of Waste Samples (Tank System W-27)

\begin{tabular}{|c|c|c|c|c|c|}
\hline \multicolumn{3}{|c|}{ Liyuld samples: } & \multicolumn{3}{|r|}{ Sludge samplus. } \\
\hline Tank & $\begin{array}{l}\text { Padialion } \\
\text { Icvel } \\
\text { (RM) }\end{array}$ & $\underset{\substack{\text { Organer } \\
\text { Oranic }}}{ }$ & Numberhype & $\begin{array}{l}\text { Radiation } \\
\text { Ievel } \\
\text { (RA1) }\end{array}$ & Cummenis \\
\hline \multirow[t]{4}{*}{$w \cdot 27$} & $0.160-0.200$ & 0 No & 2rsost sludge & 0.2 & Sample W27.S2:, eppearance of small pleces of concrete In a solier sludgo \\
\hline & & & $\begin{array}{l}\text { J/auger bil } \\
\text { (soff and } \\
\text { hard sludge) }\end{array}$ & 0.3 & 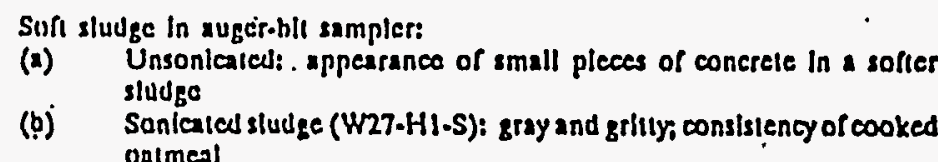 \\
\hline & & & & & 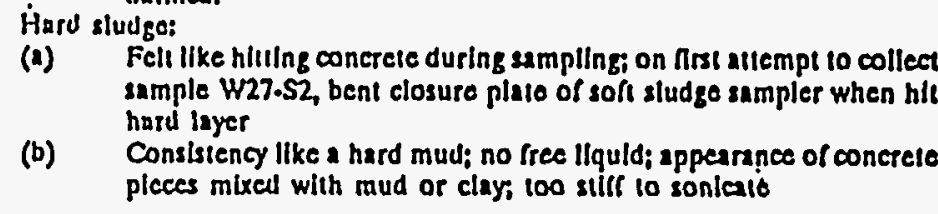 \\
\hline & & & & & 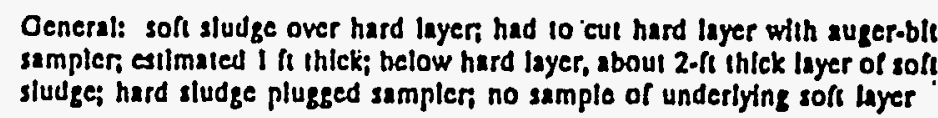 \\
\hline
\end{tabular}




\section{$2.23 \quad$ Tank System W-28 Piping}

\subsubsection{Tank System Summary}

Tank System W-28 is located at the Melton Valley Storage Tank Facility (Building 7830) (Figures 2.23-1 and 2.23-2). The tank system piping is schedule 40S, ASME SA-240, type 304L stainless steel (SS) and is routed from a pipe tunnel to Tank Vault W-28 through W-31. Tank System W-28 piping is used to transfer concentrate from the Evaporator to Tanks W-24 through W-31 and is classified as a Federal Facility Agreement (FFA) Category B tank system.

\subsubsection{Standards for Pipe Assessment of Tank Systems}

\subsubsection{Tank System Piping Description and Design Standards}

\section{Tank System Piping Description}

Tank System W-28 piping is located at Building 7830 and is routed from a pipe tunnel to Tank Vault W-28 through W-31. The piping system is used and managed by the Waste Management and Remedial Actions Division.

Tank System W-28 piping is constructed of 6" and 4", 304L SS with a maximum design pressure and temperature of $150 \mathrm{psig}$ and $150^{\circ} \mathrm{F}$ for the $6^{\prime \prime}$ line and $300 \mathrm{psig}$ and $150^{\circ} \mathrm{F}$ for the $4^{\prime \prime}$ line. Tank System W-28 piping has the capacity to contain a maximum volume of $76 \mathrm{gal}$.

\section{$\underline{\text { Design Standards }}$}

The applicable codes and standards used for Tank System W-28 piping and its associated secondary containment systems are identified herein. The codes and standards listed are those identified on either the design drawings or the construction specifications.

AEC-Oak Ridge Office, Minimum Safety Requirements;

Air Moving and Conditioning Association (AMCA) Standards Handbook-Publication 99;

AMCA Directory-Publication 261;

AMCA Fans and Systems-Publication 201;

American Concrete Institute 301-72;

American Concrete Pipe Association;

American Society for Testing and Materials A48, A262-70, C91, C139, C144, and D1751; 
Design Demonstrations - Category B Tank Systems (Piping)

American Society of Heating, Refrigeration, and Air Conditioning Engineers (ASHRAE) Handbook of Fundamentals;

American Society of Mechanical Engineers (ASME) Boiler and Pressure Vessel Code, Sections II (SA-240), V, VIII, and IX.

ASHRAE Guide and Data Book-Application;

ASHRAE Guide and Data Book-Equipment;

ASHRAE Handbook-Systems;

Atomic Energy Commission (AEC) General Design Criteria, Appendix 63;

Factory Mutual Engineering Corporation;

National Electrical Code;

National Fire Protection Association (NFPA) No. 90A-Air Conditioning and Ventilating Systems;

NFPA No. 91-Blower and Exhaust Systems;

Occupational Safety and Health Administration; and

Underwriters Laboratories Inc.

\subsubsection{Generic Description of Piping Contents}

Tank System W-28 piping was designed to serve as part of an interim storage tank system for the hydrofracture facility. The waste concentrates stored in Tank W-28 were being disposed of as a cement-waste mixture (grout) by injection into shale formations located $800^{\prime}$ to $1100^{\prime}$ below the ground surface using hydrofracture. However, hydrofracture was terminated in 1984, and Tank W-28 has become a waste concentrates storage tank for the liquid low-level waste (LLLW) system. LLLW is generated from a variety of facilities at the Oak Ridge National Laboratory (ORNL) including reactors, radioactive fuel processing areas, radioisotope processing areas, decontamination operations, hot cells, and radiochemical laboratories. The waste generators collect the waste, which is then transferred to the LLLW Evaporator for concentration, with transfer of evaporator bottoms to Tanks W-24 through W-31 for storage.

Tank System W-28 piping transfers LLLW to and from Tank W-28. The analytical data (Figure 2.23-3) of waste samples are representative of the waste received by Tank W-28. The liquid waste supernate sampled in Tank W-28 ranges in color from pale to deep yellow with high $\mathrm{Ph}$ (11-13) sodium/potassium nitrate salt solutions. The principal metals found in the tank sludge were sodium, potassium, calcium, magnesium, uranium, and thorium. The sludge contains radioactive materials that produce a radiation level of $1.2 \mathrm{rem}$ per hour $(\mathrm{R} / \mathrm{h})$ (Figure 2.23-4). 


\subsubsection{Pipe Corrosion Protection Measures}

Piping inside the pipe tunnel and Tank Vault W-28 through W-31 has no direct contact with the soil or water. Cathodic protection measures are not required for external corrosion.

\subsubsection{Documented Age of Tank System}

Tank System W-28 piping was installed in 1980.

\subsubsection{Standards for Containment/Release Detection}

2.23.3.1 Constructed of or Lined with Materials That are Compatible with Stored Waste(s) or Substance(s) to Be Placed in the Tank System and Shall Have Sufficient Strength and Thickness to Prevent Failure

Tank System W-28 piping is single-wall, schedule 40S, type 304L SS that is routed from a pipe tunnel to Tank Vault W-28 through W-31. Each area is discussed below. The piping penetrations from the pipe tunnel to Tank Vault W-28 through W-31 are singly contained, 4" and 6", schedule $40 \mathrm{~S}$, type $304 \mathrm{~L}$ SS pipes embedded in the concrete wall to a length of $3^{\prime} 0^{\prime \prime}$.

\section{Pipe Tunnel}

The bottom of the pipe tunnel is lined with 16-gauge (1/16"), 304L SS, which is the same material as that used in the piping, with sidewalls that project $3^{\prime} 0^{\prime \prime}$ up the pipe tunnel. The SS pipe tunnel lining material is compatible with the waste and designed to prevent migration of waste into the concrete.

\section{Tank Vault W-28 Through W-31}

The assessments of the secondary containment system for Tank Vault W-28 through W-31 are presented in the Design Demonstrations for Tanks W-28 through W-31. Those assessments conclude that Tank Vault W-28 through W-31 is lined with materials that are compatible with the waste and designed to prevent migration of waste into the concrete.

The assessment concludes that the pipe tunnel and tank vault are lined with materials that are compatible with the waste and designed to prevent migration of waste into the concrete.

2.23.3.2 Placed on Foundation or Base Capable of Providing Support to the Secondary Containment System

\section{Pipe Tunnel}

The pipe tunnel foundation is a $20^{\prime} 3^{\prime \prime} \times 133^{\prime} 6^{\prime \prime} \times 1^{\prime} 6^{\prime \prime}$ thick, reinforced concrete base slab that rests on limestone. 
Tank Vault W-28 Through W-31

The assessments of the secondary containment system for Tank Vault W-28 through W-31 are presented in the Design Demonstrations for Tanks W-28 through W-31. Those assessments conclude that the vault foundation is properly designed to support the secondary containment system.

The assessment concludes that the pipe tunnel and tank vault foundations are properly designed to support the secondary containment systems.

2.23.3.3 Provided with a Leak Detection System That is Designed and Operated to Detect Failure of Either Primary or Secondary Containment Structure or the Presence of Any Measurable Release of Hazardous or Radioactive Constituents

\section{Pipe Tunnel}

The pipe tunnel floor is sloped to a 16-gauge (1/16"), 304L SS-lined sump where accumulation of liquid will be detected by a pneumatic level indicator that will activate alarms in the Evaporator Service Tanks Control Room and Waste Operations Control Center (Building 3130).

\section{Tank Vault W-28 Through W-31}

The assessments of the secondary containment system for Tank Vault W-28 through W-31 are presented in the Design Demonstrations for Tanks W-28 through W-31. Those assessments conclude that the vault is provided with a leak detection system.

The assessment concludes that the pipe tunnel and tank vault are provided with leak detection.

2.23.3.4 Sloped or Otherwise Designed or Operated to Drain and Remove Liquids Resulting from Leaks, Spills, or Precipitation

\section{Pipe Tunnel}

The pipe tunnel floor is sloped to a 304L SS-lined sump. The sump provides a low point within the pipe tunnel to drain liquids to an instrumented location. A pumping system is provided to remove liquids that accumulate in the sump.

\section{Tank Vault W-28 Through W-31}

The assessments of the secondary containment system for Tank Vault W-28 through W-31 are presented in the Design Demonstrations for Tanks W-28 through W-31. Those assessments conclude that the secondary containment is sloped and designed to drain and remove liquids resulting from leaks, spills, or precipitation.

The assessment concludes that the secondary containments for the pipe tunnel and the tank vault are sloped and designed to drain and remove liquids resulting from leaks, spills, or precipitation. 


\subsubsection{Supplemental Information}

\subsubsection{Ancillary Equipment}

Tank W-28 is constructed of $304 \mathrm{~L} \mathrm{SS}$, which is the same material as that used in the piping system, and is located in Tank Vault W-28 through W-31, which provides secondary containment. The support equipment is exposed to the same liquids as other components of the tank system; therefore, 304L SS is an acceptable material for the support equipment.

\subsubsection{Waste Acceptance Criteria}

Radioactively contaminated liquid wastes at ORNL are generated by various activities within the research and operating divisions. These activities include radiochemical processing, routine hot cell operations and decontaminations, and various waste treatment and environmental protection processes. The variations in composition of the waste streams are limited by the waste acceptance criteria that specify activity and concentration limits for waste discharged into the LLLW system. The Waste Acceptance Criteria for Liquid Waste Treatment Systems at the Oak Ridge National Laboratory (Oak Ridge National Laboratory, 1991), dated July 1991, is a guide for liquid waste generators to determine the proper means of disposal for LLLW. The criteria provide future discharge guidelines for the LLLW system, which includes Tank System W-28. 
Design Demonstrations - Category B Tank Systems (Piping)

\subsubsection{References}

Binford, F. T., and S. D. Orfi. 1979. The Intermediate Level Liquid Waste System at the Oak Ridge National Laboratory Description and Safety Analysis. ORNL/TM-6959. Oak Ridge National Laboratory.

Ebasco, and Main. July 20, 1992. Design Demonstrations-Category B Tank Systems, Revision 2. DOE Contract No. DE-AC05-91OR21928. Oak Ridge National Laboratory.

Energy Systems Drawing P3E-21247-C012, Melton Valley Waste Storage Tanks, Piping Modifications Pump Room and Pipe Gallery Modifications, Revision A.

Energy Systems Drawing P3E-21247-C013, Melton Valley Waste Storage Tanks, Piping Modifications, Sections, Revision A.

Energy Systems Drawing P3E-21247-C014, Melton Valley Waste Storage Tanks, Piping Modifications, Sections, Revision A.

Energy Systems Drawing P-21247-YE-026-E, Waste Storage Tanks, Piping Flow Diagram, Process, Sheet 1 , Revision G.

Energy Systems Drawing P-21247-YE-027-E, Waste Storage Tanks, Piping Flow Diagram, Process, Sheet 1 , Revision C.

Energy Systems Drawing P-21247-YC-002-E, Waste Storage Tanks, Piping Plan, Revision B.

Energy Systems Drawing S-21247-YB-002-E, Waste Storage Tanks, Plan and Detail for Control House and Pump Room, Revision D.

Energy Systems Drawing S-21247-YB-001-E, Waste Storage Tanks, Plan Concrete Vault, Revision C.

Energy Systems Drawing P-21247-YC-003-E, Waste Storage Tanks, Pump Room Piping Plan, Revision G.

Energy Systems Drawing S-21247-YB-003-E, Waste Storage Tanks, Sections and Details of Concrete Vault, Revision D.

Energy Systems Drawing P-21247-YC-004-E, Waste Storage Tanks, Tank Piping Section, Sheet 1 , Revision C.

Energy Systems Drawing P-21247-YC-012-E, Waste Storage Tanks, Tank Piping Section, Sheet 2, Revision B. 
Energy Systems Drawing P-21247-YC-001-E, Waste Storage Tanks, Tanks, Pump Room and Tunnel Piping Plan, Revision E.

Energy Systems Drawing P-21247-YC-011-E, Waste Storage Tanks, Tanks, Pump Room Piping Section, Sheet 2, Revision D.

Oak Ridge National Laboratory. 1991. Waste Acceptance Criteria for Liquid Waste Treatment Systems at the Oak Ridge National Laboratory. WM-WMCO-201. Department of Waste Minimization Planning and Certification.

Peretz, F. J., et al. 1986. Characterization of Low-Level Liquid Wastes at the Oak Ridge National Laboratory. ORNL/TM-10218. Oak Ridge National Laboratory.

Risk Evaluation of Embedded, Single-Walled Liquid Low-Level Waste Piping at Oak Ridge National Laboratory.

Robinson, S. M., S. M. DePaoli, and A. B. Walker. 1991. Federal Facility Agreement Contingency, Upgrade, and Replacement Plans for the ORNL Active Low-Level Radioactive Waste Tank System. ORNL/TM-11795. Oak Ridge National Laboratory. 


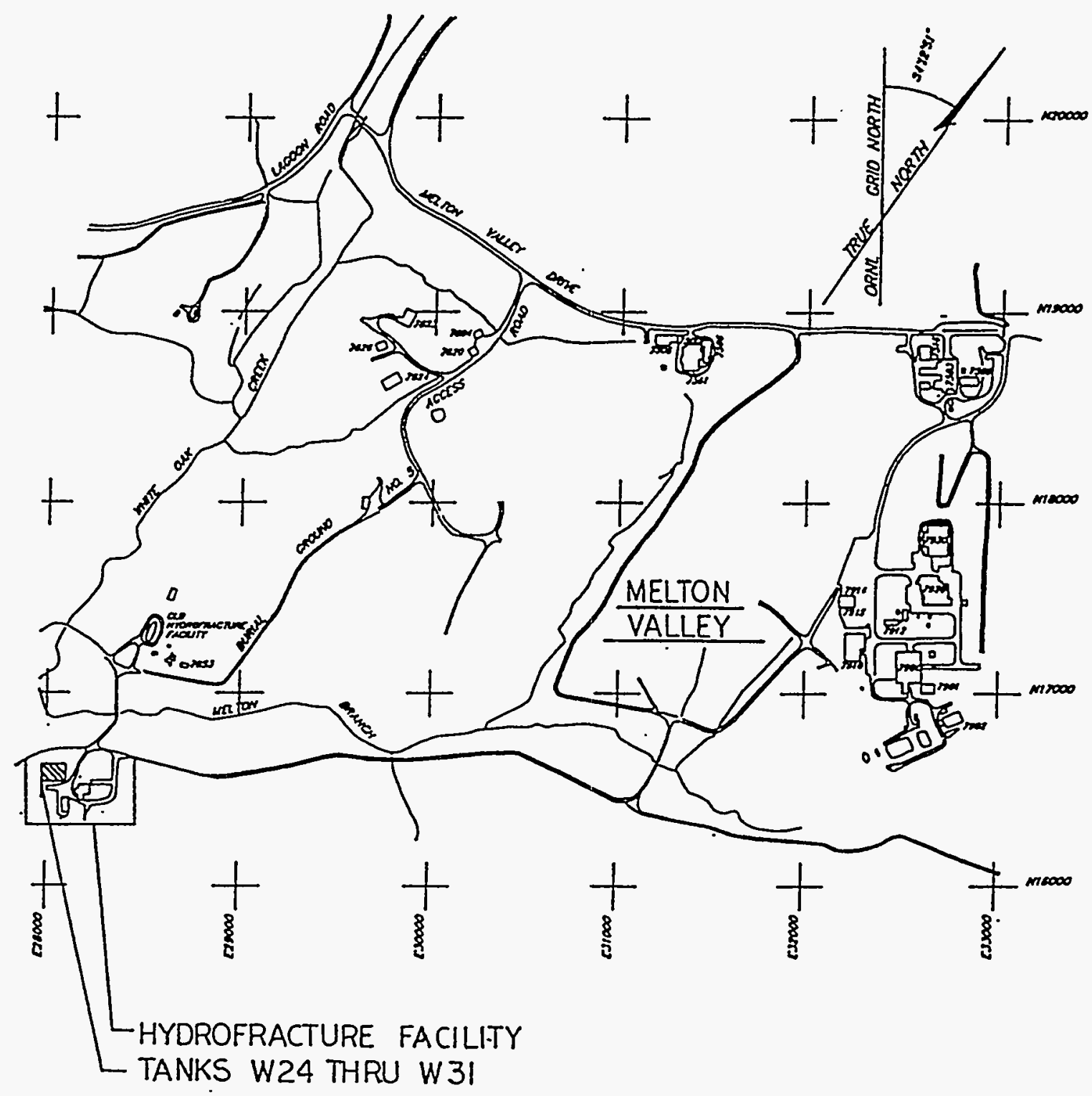


Figure 2.23-2 Tank System W-28 Piping Diagram

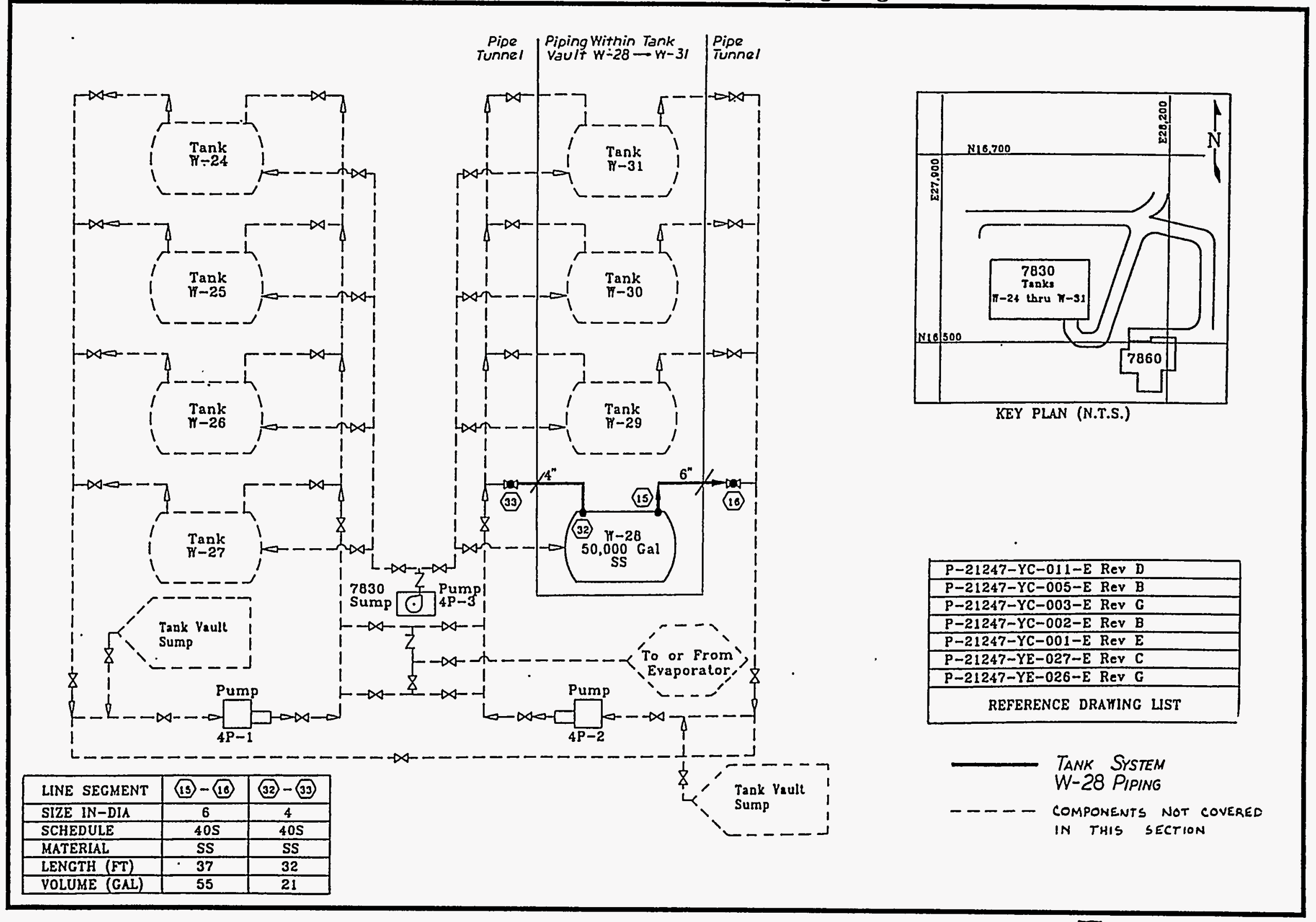

EBASCO/MAIN 
ANALYTICAL DATA FOR LIQUID SAMPLE

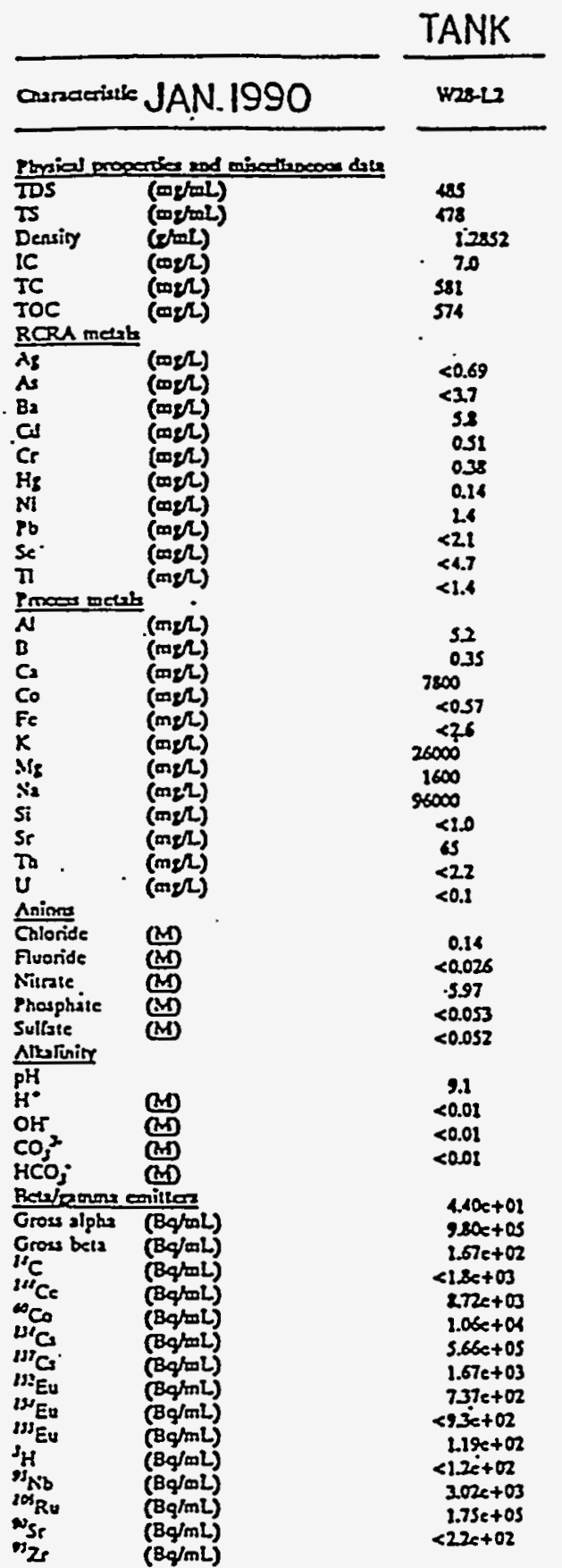

ANALYYTICAL DATA FOR SLUDGE SAMPLE

TANK

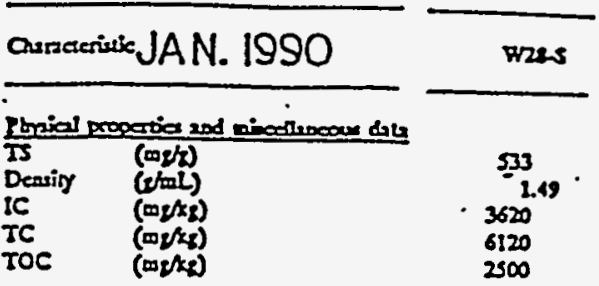

RQRA Deser

\begin{tabular}{|c|c|c|}
\hline $\begin{array}{l}A_{8} \\
A_{s} \\
B_{2} \\
C_{d} \\
C_{r} \\
H_{5} \\
N_{5} \\
P_{b} \\
S_{c} \\
\pi\end{array}$ & 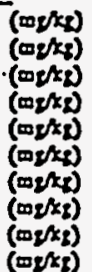 & $\begin{array}{l}\text { (17.) } \\
27 \\
39 \\
26 \\
35 \\
12 \\
62 \\
100 \\
<29 \\
<9\end{array}$ \\
\hline
\end{tabular}

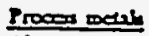

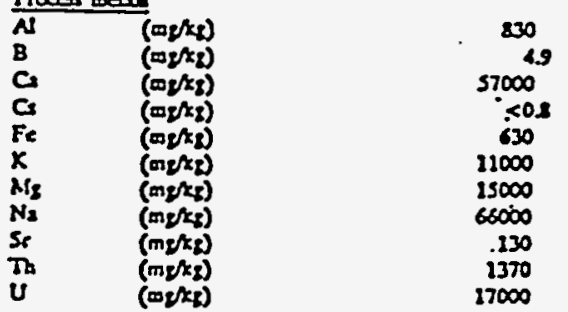

Retefenemi onition

Grous slpha $(84 / k)$

Gross beis (Bq/2)

"C $(\mathrm{B} \phi / 8)$

" ${ }^{2} \mathrm{Ce}$ (Be/s)

"Co (Bgr)

"IIC

WS. (Be/f)

जs Eu $(B g / 2)$

$\omega_{E D}$ (Bq/2)

(Bq)

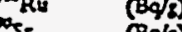

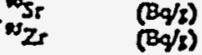

Nphe coiner

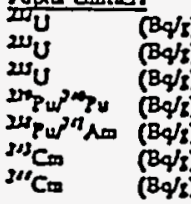

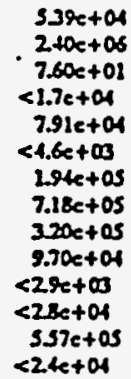

1. $46 e+03$ $336 e+03$ <1.7etor isletos $3.28 \mathrm{se}+03$ ei.te+or $3 x 3+01$

LEGEND: PHYSICAL PROPERTIES TDS - TOTAL DISSOLYED SOLIDS

TS - TOTAL SOLIDS

IC - INORGANIC CARBON

TC - TOTAL CARBON

TOC TOTAL ORGANIC CARBON 
Figure 2.23-4 General Characteristics of Waste Samples (Tank System W-28)

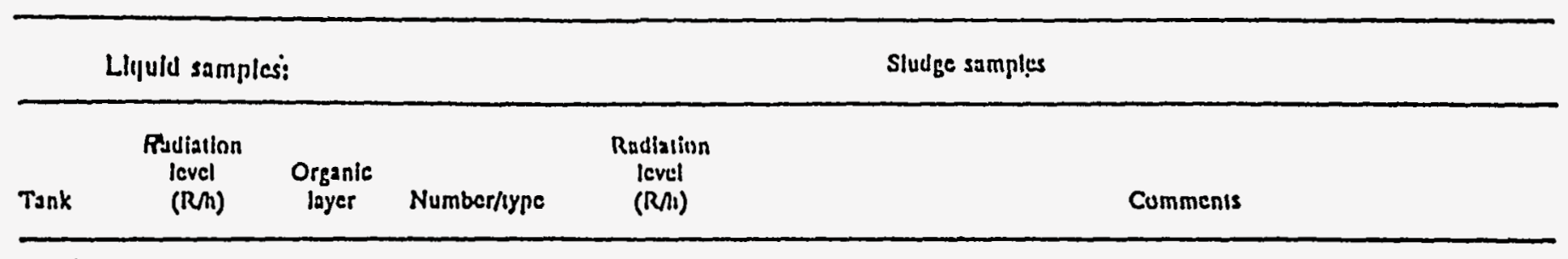

\begin{tabular}{|c|c|c|c|}
\hline$W .28$ & 0.480 & No & $\begin{array}{l}\text { Itsolt sluife } \\
\text { lo the bollami } \\
\text { luok second } \\
\text { sample for more } \\
\text { matcrial }\end{array}$ \\
\hline W-29 & 0.110 & NA & NA \\
\hline W. .111 & 0.111 & NA & NA \\
\hline
\end{tabular}




\section{$2.24 \quad$ Tank System W-29 Piping}

\subsubsection{Tank System Summary}

Tank System W-29 is located at the Melton Valley Storage Tank Facility (Building 7830) (Figures 2.24-1 and 2.24-2). The tank system piping is schedule 40S, ASME SA-240, type 304L stainless steel (SS) and is routed from a pipe tunnel to Tank Vault W-28 through W-31. Tank System W-29 piping is used to transfer concentrate from the Evaporator to Tanks W-24 through W-31 and is classified as a Federal Facility Agreement (FFA) Category B tank system.

\subsubsection{Standards for Pipe Assessment of Tank Systems}

\subsubsection{Tank System Piping Description and Design Standards}

\section{Tank System Piping Description}

Tank System W-29 piping is located at Building 7830 and is routed from a pipe tunnel to Tank Vault W-28 through W-31. The piping system is used and managed by the Waste Management and Remedial Actions Division.

Tank System W-29 piping is constructed of 6" and 4", 304L SS with a maximum design pressure and temperature of $150 \mathrm{psig}$ and $150^{\circ} \mathrm{F}$ for the $6^{\prime \prime}$ line and $300 \mathrm{psig}$ and $150^{\circ} \mathrm{F}$ for the $4^{\prime \prime}$ line. Tank System W-29 piping has the capacity to contain a maximum volume of 158 gal.

\section{$\underline{\text { Design Standards }}$}

The applicable codes and standards used for Tank System W-29 piping and its associated secondary containment systems are identified herein. The codes and standards listed are those identified on either the design drawings or the construction specifications.

AEC-Oak Ridge Office, Minimum Safety Requirements;

Air Moving and Conditioning Association (AMCA) Standards Handbook-Publication 99;

AMCA Directory-Publication 261;

AMCA Fans and Systems-Publication 201;

American Concrete Institute 301-72;

American Concrete Pipe Association;

American Society for Testing and Materials A48, A262-70, C91, C139, C144, and D1751; 
American Society of Heating, Refrigeration, and Air Conditioning Engineers (ASHRAE) Handbook of Fundamentals;

American Society of Mechanical Engineers (ASME) Boiler and Pressure Vessel Code, Sections II (SA-240), V, VIII, and IX.

ASHRAE Guide and Data Book-Application;

ASHRAE Guide and Data Book-Equipment;

ASHRAE Handbook-Systems;

Atomic Energy Commission (AEC) General Design Criteria, Appendix 63;

Factory Mutual Engineering Corporation;

National Electrical Code;

National Fire Protection Association (NFPA) No. 90A-Air Conditioning and Ventilating Systems;

NFPA No. 91-Blower and Exhaust Systems;

Occupational Safety and Health Administration; and

Underwriters Laboratories Inc.

\subsubsection{Generic Description of Piping Contents}

Tank System W-29 piping was designed to serve as part of an interim storage tank system for the hydrofracture facility. The waste concentrates stored in Tank W-29 were being disposed of as a cement-waste mixture (grout) by injection into shale formations located $800^{\prime}$ to $1100^{\prime}$ below the ground surface using hydrofracture. However, hydrofracture was terminated in 1984, and Tank W-29 has become a waste concentrates storage tank for the liquid low-level waste (LLLW) system. LLLW is generated from a variety of facilities at the Oak Ridge National Laboratory (ORNL) including reactors, radioactive fuel processing areas, radioisotope processing areas, decontamination operations, hot cells, and radiochemical laboratories. The waste generators collect the waste, which is then transferred to the LLLW Evaporator for concentration, with transfer of evaporator bottoms to Tanks W-24 through W-31 for storage.

Tank System W-29 piping transfers LLLW to and from Tank W-29. The analytical data (Figure 2.24-3) of waste samples are representative of the waste received by Tank W-29. The liquid waste supernate sampled in Tank W-29 ranges in color from pale to deep yellow with high $\mathrm{Ph}$ (11-13) sodium/potassium nitrate salt solutions. The sludge in Tank W-29 has not been sampled; however, the contents of Tank W-29 should be very similar to the contents of Tank W-28. The principal metals found in the Tank W-28 sludge were sodium, potassium, calcium, magnesium, 
uranium, and thorium. The sludge contains radioactive materials that produce a radiation level of 1.2 rem per hour $(\mathrm{R} / \mathrm{h})$ (Figure 2.24-4).

\subsubsection{Pipe Corrosion Protection Measures}

Piping inside the pipe tunnel and Tank Vault W-28 through W-31 has no direct contact with the soil or water. Cathodic protection measures are not required for external corrosion.

\subsubsection{Documented Age of Tank System}

Tank System W-29 piping was installed in 1980.

\subsubsection{Standards for Containment/Release Detection}

2.24.3.1 Constructed of or Lined with Materials That are Compatible with Stored Waste(s) or Substance(s) to Be Placed in the Tank System and Shall Have Sufficient Strength and Thickness to Prevent Failure

Tank System W-29 piping is single-wall, schedule 40S, type 304L SS that is routed from a pipe tunnel to Tank Vault W-28 through W-31. Each area is discussed below. The piping penetrations from the pipe tunnel to Tank Vault W-28 through W-3I are singly contained, 4" and 6", schedule $40 \mathrm{~S}$, type $304 \mathrm{~L}$ SS pipes embedded in the concrete wall to a length of $3^{\prime} 0^{\prime \prime}$.

\section{Pipe Tunnel}

The bottom of the pipe tunnel is lined with 16-gauge (1/16"), 304L SS, which is the same material as that used in the piping, with sidewalls that project $3^{\prime} 0^{\prime \prime}$ up the pipe tunnel. The SS pipe tunnel lining material is compatible with the waste and designed to prevent migration of waste into the concrete.

\section{Tank Vault W-28 Through W-31}

The assessments of the secondary containment system for Tank Vault W-28 through W-31 are presented in the Design Demonstrations for Tanks W-28 through W-31. Those assessments conclude that Tank Vault W-28 through W-31 is lined with materials that are compatible with the waste and designed to prevent migration of waste into the concrete.

The assessment concludes that the pipe tunnel and tank vault are lined with materials that are compatible with the waste and designed to prevent migration of waste into the concrete. 
Design Demonstrations - Category B Tank Systems (Piping)

2.24.3.2 Placed on Foundation or Base Capable of Providing Support to the Secondary Containment System

\section{Pipe Tunnel}

The pipe tunnel foundation is a $20^{\prime} 3^{\prime \prime} \times 133^{\prime} 6^{\prime \prime} \times 1^{\prime} 6^{\prime \prime}$ thick, reinforced concrete base slab that rests on limestone.

\section{Tank Vault W-28 Through W-31}

The assessments of the secondary containment system for Tank Vault W-28 through W-31 are presented in the Design Demonstrations for Tanks W-28 through W-31. Those assessments conclude that the vault foundation is properly designed to support the secondary containment system.

The assessment concludes that the pipe tunnel and tank vault foundations are properly designed to support the secondary containment systems.

2.24.3.3 Provided with a Leak Detection System That is Designed and Operated to Detect Failure of Either Primary or Secondary Containment Structure or the Presence of Any Measurable Release of Hazardous or Radioactive Constituents

\section{Pipe Tunnel}

The pipe tunnel floor is sloped to a 16-gauge $\left(1 / 16^{\prime \prime}\right)$, 304L SS-lined sump where accumulation of liquid will be detected by a pneumatic level indicator that will activate alarms in the Evaporator Service Tanks Control Room and Waste Operations Control Center (Building 3130).

\section{Tank Vault W-28 Through W-31}

The assessments of the secondary containment system for Tank Vault W-28 through W-31 are presented in the Design Demonstrations for Tanks W-28 through W-31. Those assessments conclude that the vault is provided with a leak detection system.

The assessment concludes that the pipe tunnel and tank vault are provided with leak detection.

2.24.3.4 Sloped or Otherwise Designed or Operated to Drain and Remove Liquids Resulting from Leaks, Spills, or Precipitation

\section{Pipe Tunnel}

The pipe tunnel floor is sloped to a 304L SS-lined sump. The sump provides a low point within the pipe tunnel to drain liquids to an instrumented location. A pumping system is provided to remove liquids that accumulate in the sump. 
Design Demonstrations - Category B Tank Systems (Piping)

\section{Tank Vault W-28 Through W-31}

The assessments of the secondary containment system for Tank Vault W-28 through W-31 are presented in the Design Demonstrations for Tanks W-28 through W-31. Those assessments conclude that the secondary containment is sloped and designed to drain and remove liquids resulting from leaks, spills, or precipitation.

The assessment concludes that the secondary containments for the pipe tunnel and the tank vault are sloped and designed to drain and remove liquids resulting from leaks, spills, or precipitation.

\subsubsection{Supplemental Information}

\subsubsection{Ancillary Equipment}

Tank W-29 is constructed of 304L SS, which is the same material as that used in the piping system, and is located in Tank Vault W-28 through W-31, which provides secondary containment. The support equipment is exposed to the same liquids as other components of the tank system; therefore, $304 \mathrm{~L}$ SS is an acceptable material for the support equipment.

\subsubsection{Waste Acceptance Criteria}

Radioactively contaminated liquid wastes at ORNL are generated by various activities within the research and operating divisions. These activities include radiochemical processing, routine hot cell operations and decontaminations, and various waste treatment and environmental protection processes. The variations in composition of the waste streams are limited by the waste acceptance criteria that specify activity and concentration limits for waste discharged into the LLLW system. The Waste Acceptance Criteria for Liquid Waste Treatment Systems at the Oak Ridge National Laboratory (Oak Ridge National Laboratory, 1991), dated July 1991, is a guide for liquid waste generators to determine the proper means of disposal for LLLW. The criteria provide future discharge guidelines for the LLLW system, which includes Tank System W-29. 


\subsubsection{References}

Binford, F. T., and S. D. Orfi. 1979. The Intermediate Level Liquid Waste System at the Oak Ridge National Laboratory Description and Safety Analysis. ORNL/TM-6959. Oak Ridge National Laboratory.

Ebasco, and Main. July 20, 1992. Design Demonstrations-Category B Tank Systems, Revision 2. DOE Contract No. DE-AC05-91OR21928. Oak Ridge National Laboratory.

Energy Systems Drawing P3E-21247-C012, Melton Valley Waste Storage Tanks, Piping Modifications Pump Room and Pipe Gallery Modifications, Revision A.

Energy Systems Drawing P3E-21247-C013, Melton Valley Waste Storage Tanks, Piping Modifications, Sections, Revision A.

Energy Systems Drawing P3E-21247-C014, Melton Valley Waste Storage Tanks, Piping Modifications, Sections, Revision A.

Energy Systems Drawing P-21247-YE-026-E, Waste Storage Tanks, Piping Flow Diagram, Process, Sheet 1, Revision G.

Energy Systems Drawing P-21247-YE-027-E, Waste Storage Tanks, Piping Flow Diagram, Process, Sheet 1, Revision C.

Energy Systems Drawing P-21247-YC-002-E, Waste Storage Tanks, Piping Plan, Revision B.

Energy Systems Drawing S-21247-YB-002-E, Waste Storage Tanks, Plan and Detail for Control House and Pump Room, Revision D.

Energy Systems Drawing S-21247-YB-001-E, Waste Storage Tanks, Plan Concrete Vault, Revision C.

Energy Systems Drawing P-21247-YC-003-E, Waste Storage Tanks, Pump Room Piping Plan, Revision G.

Energy Systems Drawing S-21247-YB-003-E, Waste Storage Tanks, Sections and Details of Concrete Vault, Revision D.

Energy Systems Drawing P-21247-YC-004-E, Waste Storage Tanks, Tank Piping Section, Sheet 1 , Revision C.

Energy Systems Drawing P-21247-YC-012-E, Waste Storage Tanks, Tank Piping Section, Sheet 2 , Revision B. 
Energy Systems Drawing P-21247-YC-001-E, Waste Storage Tanks, Tanks, Pump Room and Tunnel Piping Plan, Revision E.

Energy Systems Drawing P-21247-YC-011-E, Waste Storage Tanks, Tanks, Pump Room Piping Section, Sheet 2, Revision D.

Oak Ridge National Laboratory. 1991. Waste Acceptance Criteria for Liquid Waste Treatment Systems at the Oak Ridge National Laboratory. WM-WMCO-201. Department of Waste Minimization Planning and Certification.

Peretz, F. J., et al. 1986. Characterization of Low-Level Liquid Wastes at the Oak Ridge National Laboratory. ORNL/TM-10218. Oak Ridge National Laboratory.

Risk Evaluation of Embedded, Single-Walled Liquid Low-Level Waste Piping at Oak Ridge National Laboratory.

Robinson, S. M., S. M. DePaoli, and A. B. Walker. 1991. Federal Facility Agreement Contingency, Upgrade, and Replacement Plans for the ORNL Active Low-Level Radioactive Waste Tank System. ORNL/TM-11795. Oak Ridge National Laboratory. 


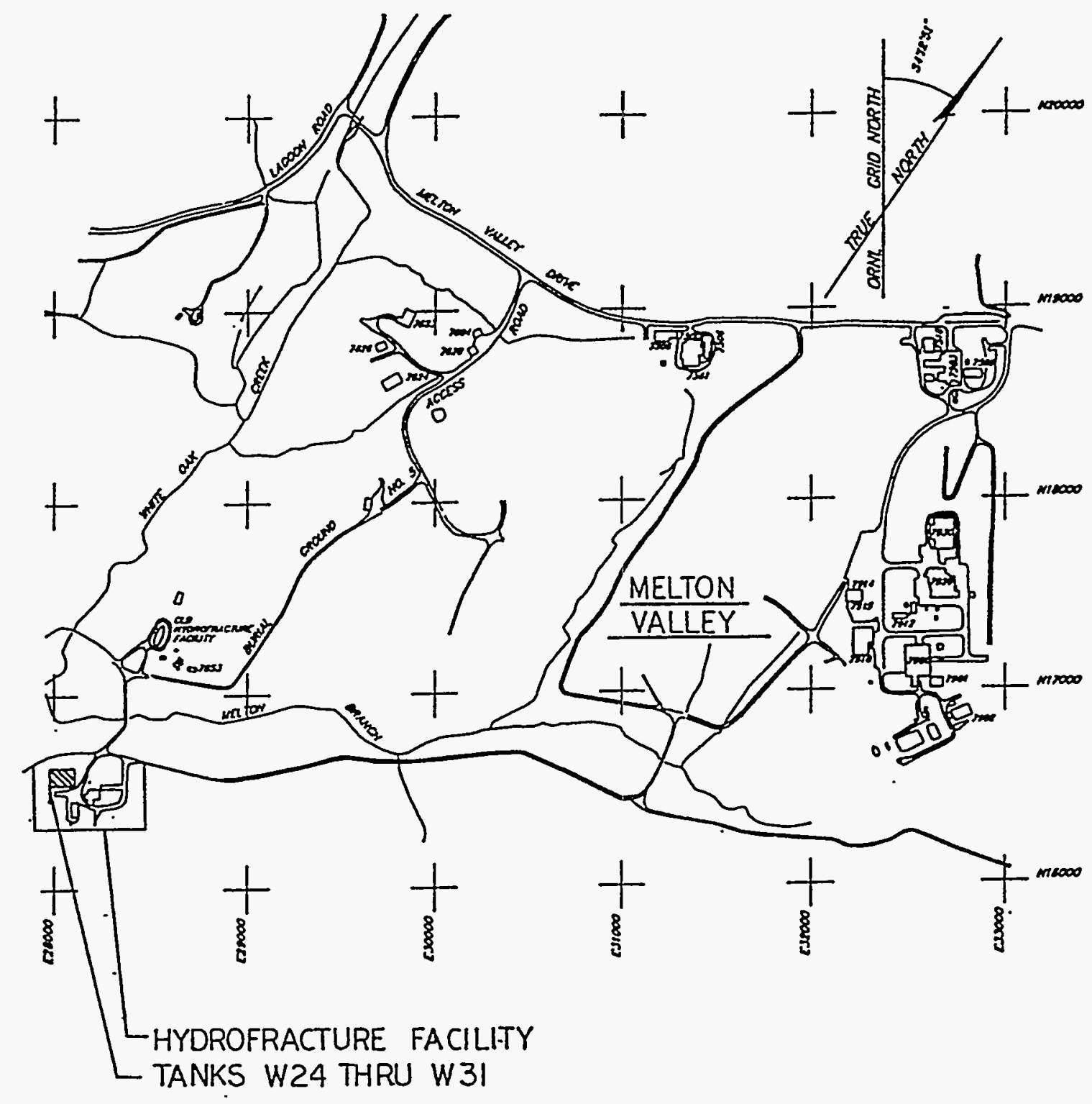


Figure 2.24-2 Tank System W-29 Piping Diagram

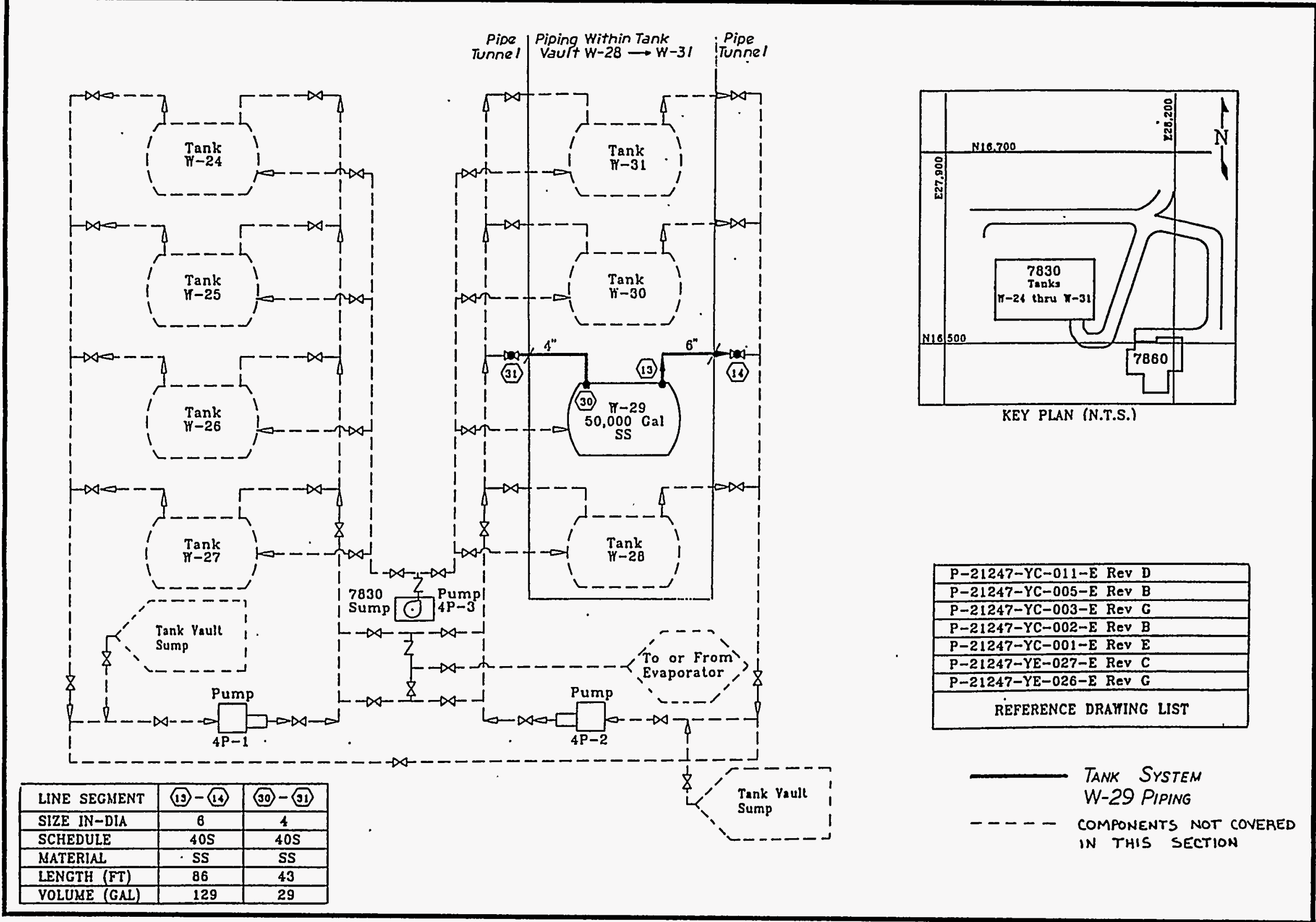

EBasco/Main 
Figure 2.24-3

Analytical Data for Liquid Samples (Tank System W-29)

ANALYTICAL DATA FOR LIQUID SAMPLE

\begin{tabular}{|c|c|c|c|c|}
\hline \multicolumn{2}{|c|}{ Chanceriste JAN. 1990} & w20.L1 & พंzo-L2 & w2sele \\
\hline \multicolumn{5}{|c|}{ 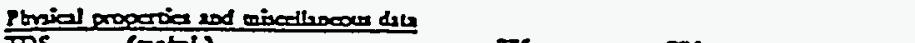 } \\
\hline IDS & $($ antst) & 375 & 376 & 375 \\
\hline Ts & (achl) & $377 \mathrm{ng}$ & 379 & 382 \\
\hline Densiy & $(g / \infty 2)$ & $1=1$ & $1.27 \pi$ & 1.2754 \\
\hline & $(\square / L)$ & 478 & $\$ \pi$ & 456 \\
\hline & $(\square=\pi)$ & 983 & 1060 & 233 \\
\hline \multicolumn{5}{|c|}{ RCRA Deshe } \\
\hline As & $(\varpi \mathscr{L})$ & $<0.69$ & $<0.69$ & $<0.69$ \\
\hline sud & $(\cos \Omega)$ & $<37$ & $<37$ & $<3.7$ \\
\hline Ba & $(n \pi)$ & 1.0 & t.I & 1.0 \\
\hline at & $(\propto ⿻ 上)$ & $<0.12$ & $<0.12$ & $<0.12$ \\
\hline $\mathrm{Cr}_{\boldsymbol{r}}$ & $(n \in L)$ & 24 & 28 & 23 \\
\hline $\mathrm{H}_{5}$ & (mel) & 0.09 & 0.08 & 0.09 \\
\hline $\mathrm{Ni}$ & (mel: & $<0.38$ & $<0.38$ & $<038$ \\
\hline Po & $(\varpi 2 \pi ;$ & $<21$ & $<21$ & 23 \\
\hline Se & $(\square \Omega)$ & $<4.7$ & $<8.7$ & $<4.7$ \\
\hline$n$ & $(\operatorname{man} L)$ & $<1.4$ & $<1.4$ & $<2.4$ \\
\hline \multicolumn{5}{|c|}{ Pmon Desit } \\
\hline त) & $(\pi 2 /)$ & 18 & 18 & 17 \\
\hline B & $(m \Omega \Omega)$ & 0.50 & 0.47 & 0.36 \\
\hline$C_{2}$ & $(m g l)$ & 4.1 & $5 s$ & 36 \\
\hline $\mathbf{F e}$ & $(\operatorname{mg} / L)$ & $<26$ & $<26$ & $<26$ \\
\hline $\boldsymbol{K}$ & (mell) & 10000 & 10000 & 10000 \\
\hline$M_{8}$ & $(m e t)$ & $<13$ & $<13$ & $<13$ \\
\hline$N_{2}$ & $(\approx \Omega \Omega)$ & 110000 & 110000 & 110000 \\
\hline $5 i$ & $(m \varepsilon /)$ & $<1.0$ & $<20$ & $<1.0$ \\
\hline Sr & $(m \varepsilon \Omega)$ & 1.9 & 21 & 1.9 \\
\hline$\pi$ & (mell) & $<1.0$ & $<1.0$ & $<10$ \\
\hline \multirow{2}{*}{\multicolumn{5}{|c|}{ Anions }} \\
\hline & (M) & 0.082 & 0.078 & \\
\hline Fuoride & $M$ & $<0.026$ & $<0.026$ & $<0.025$ \\
\hline Nitrate & (M) & $4.52^{\circ}$ & 452 & 1,52 \\
\hline Pbosphale & (M) & $<0.053$ & $<0.053$ & $<0.053$ \\
\hline Sultate & (M) & $<0.032$ & $<0.052$ & $<0.052$ \\
\hline \multicolumn{5}{|c|}{ Nulinin } \\
\hline $\mathrm{pH}^{\mathrm{H}}$ & & 13.0 & .130 & 130 \\
\hline Ors, & $(M)$ & 0.054 & 0.069 & $\begin{array}{l}0.074 \\
0.054\end{array}$ \\
\hline $\mathrm{CO}^{\mathrm{j}}$ & $(0)$ & 0.083 & 0.040 & 0.054 \\
\hline 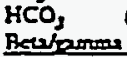 & (4) & $<0.02$ & $<0.01$ & $<0.01$ \\
\hline \multicolumn{5}{|c|}{ 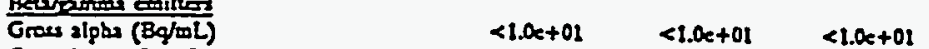 } \\
\hline Groser beis & $(B g h=1)$ & $211 e+0 s$ & $1.98 x+05$ & $\begin{array}{l}209 e+05 \\
5.6 e+01\end{array}$ \\
\hline${ }^{14} \mathrm{Ce}$ & $\begin{array}{l}(B g=L) \\
(B g=L)\end{array}$ & $\begin{array}{l}1.43 x+03 \\
<1.4 x+03\end{array}$ & $\begin{aligned} 73 x+01 \\
<13 x+03\end{aligned}$ & $\begin{array}{r}3.6 e+01 \\
<13 x+03\end{array}$ \\
\hline co & $(B q b L)$ & $6.4 k+02$ & $3.99 t+02$ & $\begin{array}{l}<13 c+03 \\
6.26 c+02\end{array}$ \\
\hline$\mu_{1}$ & $\left(B q^{2}=L^{\prime}\right)$ & $23 l e+03$ & $237 e+03$ & $253 x+03$ \\
\hline G & (Bgist) & $221 e+0 s$ & $223 c+05$ & $216 c+05$ \\
\hline Ev & (Bq/mL) & $<1.6 x+02$ & $<20 x+02$ & $<27 e+02$ \\
\hline Eu & $(B \Psi=L)$ & $<1 S_{e}+02$ & $<1.6 x+02$ & $<1.2 e+02$ \\
\hline${ }_{H}{ }_{H} E_{u}$ & $(B g / m L)$ & $<7.2 c+02$ & $\begin{aligned}<7.1 e+02 \\
2.01 e+02\end{aligned}$ & $\begin{array}{l}<7.2 x+02 \\
201 x+02\end{array}$ \\
\hline $\operatorname{rivb}^{\circ}$ & $\begin{array}{l}(B g / \omega L) \\
(B g / \infty L)\end{array}$ & $\begin{array}{l}201 e+02 \\
<a, t e+0 t\end{array}$ & $\begin{array}{l}2.01 e+0.2 \\
<6.2 x+01\end{array}$ & $<63<+02$ \\
\hline$N_{0} R u$ & $(B q \omega L)$ & $<2,1<+03$ & $<20 z+03$ & $<20<+03$ \\
\hline $\begin{array}{l}3 t \\
n_{25}\end{array}$ & $(B q \sigma L)$ & $2.13 x+03$ & $700 x+03$ & 7.11e+03 \\
\hline & & $<9.3<+01$ & $<1.1 c+02$ & $<10 x+02$ \\
\hline
\end{tabular}

LEGEND: PHYSICAL FROPERTIES TDS - TOTAL DISSOLVED SOLIDS TS - TOTAL. SOLIDS

IC - INORGANIC CARBOM

TC - TOTAL CARBON

TOC TOTAL ORGANIC CARBON 


\begin{tabular}{|c|c|c|c|c|c|}
\hline \multicolumn{2}{|c|}{ Llyuld samples: } & \multicolumn{3}{|c|}{ Sludge samples: } & \multirow[b]{2}{*}{ Comments } \\
\hline Tank & $\begin{array}{l}\text { Radiation } \\
\text { level } \\
(\mathrm{R} / \mathrm{h})\end{array}$ & $\begin{array}{l}\text { Organic } \\
\text { layer }\end{array}$ & Number/type & $\begin{array}{l}\text { Radiation } \\
\text { level } \\
(\mathrm{R} / \mathrm{h})\end{array}$ & \\
\hline \multirow[t]{3}{*}{$W-28$} & 0.480 & No & $.1 /$ sor sludge & 1.2 & $\begin{array}{l}\text { Fluid (weight of to the bollom handle carrled took } \\
\text { second sampler to the sample for more boltom of } \\
\text { thematerial (tank) }\end{array}$ \\
\hline & & & & & $\begin{array}{l}\text { Sludge (W-28-S1): deep yellow; seems } \\
\text { bomogencous }\end{array}$ \\
\hline & & & & & $\begin{array}{l}\text { Sonicated sludge: very finely divided with a few } \\
\text { dark llakes }\end{array}$ \\
\hline$W-29$ & 0.110 & NA & NA & NA & $\begin{array}{l}\text { No sludge sample data for tanks } W-29 \text { and } W-30 \text { is } \\
\text { available; however, the contents of tanks W-29 and } \\
W \cdot 30 \text { should be very similiar to the contents of the } \\
\text { tank W-28. }\end{array}$ \\
\hline$w-30$ & 0.110 & NA & NA & $\mathrm{NA}$ & \\
\hline
\end{tabular}




\subsection{Tank System W-30 Piping}

\subsubsection{Tank System Summary}

Tank System W-30 is located at the Melton Valley Storage Tank Facility (Building 7830) (Figures 2.25-1 and 2.25-2). The tank system piping is schedule 40S, ASME SA-240, type 304L stainless steel (SS) and is routed from a pipe tunnel to Tank Vault W-28 through W-31. Tank System W-30 piping is used to transfer concentrate from the Evaporator to Tanks W-24 through W-31 and is classified as a Federal Facility Agreement (FFA) Category B tank system.

\subsubsection{Standards for Pipe Assessment of Tank Systems}

\subsubsection{Tank System Piping Description and Design Standards}

\section{Tank System Piping Description}

Tank System W-30 piping is located at Building 7830 and is routed from a pipe tunnel to Tank Vault W-28 through W-31. The piping system is used and managed by the Waste Management and Remedial Actions Division.

Tank System W-30 piping is constructed of $6^{\prime \prime}$ and $4^{\prime \prime}, 304 \mathrm{~L}$ SS with a maximum design pressure and temperature of $150 \mathrm{psig}$ and $150^{\circ} \mathrm{F}$ for the $6^{\prime \prime}$ line and $300 \mathrm{psig}$ and $150^{\circ} \mathrm{F}$ for the $4^{\prime \prime}$ line. Tank System W-30 piping has the capacity to contain a maximum volume of 76 gal.

\section{Design Standards}

The applicable codes and standards used for Tank System W-30 piping and its associated secondary containment systems are identified herein. The codes and standards listed are those identified on either the design drawings or the construction specifications.

AEC-Oak Ridge Office, Minimum Safety Requirements;

Air Moving and Conditioning Association (AMCA) Standards Handbook—Publication 99;

AMCA Directory-Publication 261;

AMCA Fans and Systems-Publication 201;

American Concrete Institute 301-72;

American Concrete Pipe Association;

American Society for Testing and Materials A48, A262-70, C91, C139, C144, and D1751; 
Design Demonstrations - Category B Tank Systems (Piping)

American Society of Heating, Refrigeration, and Air Conditioning Engineers (ASHRAE) Handbook of Fundamentals;

American Society of Mechanical Engineers (ASME) Boiler and Pressure Vessel Code, Sections II (SA-240), V, VIII, and IX.

ASHRAE Guide and Data Book-Application;

ASHRAE Guide and Data Book-Equipment;

ASHRAE Handbook-Systems;

Atomic Energy Commission (AEC) General Design Criteria, Appendix 63;

Factory Mutual Engineering Corporation;

National Electrical Code;

National Fire Protection Association (NFPA) No. 90A-Air Conditioning and Ventilating Systems;

NFPA No. 91-Blower and Exhaust Systems;

Occupational Safety and Health Administration; and

Underwriters Laboratories Inc.

\subsubsection{Generic Description of Piping Contents}

Tank System W-30 piping was designed to serve as part of an interim storage tank system for the hydrofracture facility. The waste concentrates stored in Tank W-30 were being disposed of as a cement-waste mixture (grout) by injection into shale formations located $800^{\prime}$ to $1100^{\prime}$ below the ground surface using hydrofracture. However, hydrofracture was terminated in 1984, and Tank W-30 has become a waste concentrates storage tank for the liquid low-level waste (LLLW) system. LLLW is generated from a variety of facilities at the Oak Ridge National Laboratory (ORNL) including reactors, radioactive fuel processing areas, radioisotope processing areas, decontamination operations, hot cells, and radiochemical laboratories. The waste generators collect the waste, which is then transferred to the LLLW Evaporator for concentration, with transfer of evaporator bottoms to Tanks W-24 through W-31 for storage.

Tank System W-30 piping transfers LLLW to and from Tank W-30. The analytical data (Figure 2.25-3) of waste samples are representative of the waste received by Tank W-30. The liquid waste supernate sampled in Tank W-30 ranges in color from pale to deep yellow with high $\mathrm{Ph}$ (11-13) sodium/potassium nitrate salt solutions. The sludge in Tank W-30 has not been sampled; however, the contents of Tank W-30 should be very similar to the contents of Tank W-28. The principal metals found in the Tank W-28 sludge were sodium, potassium, calcium, magnesium, 
Design Demonstrations - Category B Tank Systems (Piping)

uranium, and thorium. The sludge contains radioactive materials that produce a radiation level of 1.2 rem per hour $(\mathrm{R} / \mathrm{h})$ (Figure 2.25-4).

\subsubsection{Pipe Corrosion Protection Measures}

Piping inside the pipe tunnel and Tank Vault W-28 through W-31 has no direct contact with the soil or water. Cathodic protection measures are not required for external corrosion.

\subsubsection{Documented Age of Tank System}

Tank System W-30 piping was installed in 1980.

\subsubsection{Standards for Containment/Release Detection}

2.25.3.1 Constructed of or Lined with Materials That are Compatible with Stored Waste(s) or Substance(s) to Be Placed in the Tank System and Shall Have Sufficient Strength and Thickness to Prevent Failure

Tank System W-30 piping is constructed of single-wall, schedule 40S, type 304L SS that is routed from a pipe tunnel to Tank Vault W-28 through W-31. Each area is discussed below. The piping penetrations from the pipe tunnel to Tank Vault W-28 through W-31 are singly contained, $4^{\prime \prime}$ and $6^{\prime \prime}$, schedule 40S, type 304L SS pipes embedded in the concrete wall to a length of $3^{\prime} 0^{\prime \prime}$.

\section{Pipe Tunnel}

The bottom of the pipe tunnel is lined with 16-gauge $\left(1 / 16^{\prime \prime}\right)$, 304L SS, which is the same material as that used for the piping and which projects $3^{\prime} 0^{\prime \prime}$ up the pipe tunnel sidewall. The SS pipe tunnel lining material is compatible with the waste and designed to prevent migration of waste into the concrete.

\section{Tank Vault W-28 Through W-31}

The assessments of the secondary containment system for Tank Vault W-28 through W-31 are presented in the Design Demonstrations for Tanks W-28 through W-31. Those assessments conclude that Tank Vault W-28 through W-31 is lined with materials that are compatible with the waste and designed to prevent migration of waste into the concrete.

The assessment concludes that the pipe tunnel and tank vault are lined with materials that are compatible with the waste and designed to prevent migration of waste into the concrete. 
2.25.3.2 Placed on Foundation or Base Capable of Providing Support to the Secondary Containment System

\section{$\underline{\text { Pipe Tunnel }}$}

The pipe tunnel foundation is a $20^{\prime} 3^{\prime \prime} \times 133^{\prime} 6^{\prime \prime} \times 1^{\prime} 6^{\prime \prime}$ thick, reinforced concrete base slab that rests on limestone.

\section{Tank Vault W-28 Through W-31}

The assessments of the secondary containment system for Tank Vault W-28 through W-31 are presented in the Design Demonstrations for Tanks W-28 through W-31. Those assessments conclude that the vault foundation is properly designed to support the secondary containment system.

The assessment concludes that the pipe tunnel and tank vault foundations are properly designed to support the secondary containment systems.

2.25.3.3 Provided with a Leak Detection System That is Designed and Operated to Detect Failure of Either Primary or Secondary Containment Structure or the Presence of Any Measurable Release of Hazardous or Radioactive Constituents

\section{Pipe Tunnel}

The pipe tunnel floor is sloped to a 16-gauge $\left(1 / 16^{\prime \prime}\right)$, 304L SS-lined sump where accumulation of liquid will be detected by a pneumatic level indicator that will activate alarms in the Evaporator Service Tanks Control Room and Waste Operations Control Center (Building 3130).

\section{Tank Vault W-28 Through W-31}

The assessments of the secondary containment system for Tank Vault W-28 through W-31 are presented in the Design Demonstrations for Tanks W-28 through W-31. Those assessments conclude that the vault is provided with a leak detection system.

The assessment concludes that the pipe tunnel and tank vault are provided with leak detection.

2.25.3.4 Sloped or Otherwise Designed or Operated to Drain and Remove Liquids Resulting from Leaks, Spills, or Precipitation

\section{Pipe Tunnel}

The pipe tunnel floor is sloped to a 304L SS-lined sump. The sump provides a low point within the pipe tunnel to drain liquids to an instrumented location. A pumping system is provided to remove liquids that accumulate in the sump. 


\section{Tank Vault W-28 Through W-31}

The assessments of the secondary containment system for Tank Vault W-28 through W-31 are presented in the Design Demonstrations for Tanks W-28 through W-31. Those assessments conclude that the secondary containment is sloped and designed to drain and remove liquids resulting from leaks, spills, or precipitation.

The assessment concludes that the secondary containments for the pipe tunnel and the tank vault are sloped and designed to drain and remove liquids resulting from leaks, spills, or precipitation.

\subsubsection{Supplemental Information}

\subsubsection{Ancillary Equipment}

Tank W-30 is constructed of $304 \mathrm{~L} \mathrm{SS,} \mathrm{which} \mathrm{is} \mathrm{the} \mathrm{same} \mathrm{material} \mathrm{as} \mathrm{that} \mathrm{used} \mathrm{in} \mathrm{the} \mathrm{piping} \mathrm{system,}$ and is located in Tank Vault W-28 through W-31, which provides secondary containment. The support equipment is exposed to the same liquids as other components of the tank system; therefore, $304 \mathrm{~L}$ SS is an acceptable material for the support equipment.

\subsubsection{Waste Acceptance Criteria}

Radioactively contaminated liquid wastes at ORNL are generated by various activities within the research and operating divisions. These activities include radiochemical processing, routine hot cell operations and decontaminations, and various waste treatment and environmental protection processes. The variations in composition of the waste streams are limited by the waste acceptance criteria that specify activity and concentration limits for waste discharged into the LLLW system. The Waste Acceptance Criteria for Liquid Waste Treatment Systems at the Oak Ridge National Laboratory (Oak Ridge National Laboratory, 1991), dated July 1991, is a guide for liquid waste generators to determine the proper means of disposal for LLLW. The criteria provide future discharge guidelines for the LLLW system, which includes Tank System W-30. 
Design Demonstrations - Category B Tank Systems (Piping)

\subsubsection{References}

Binford, F. T., and S. D. Orfi. 1979. The Intermediate Level Liquid Waste System at the Oak Ridge National Laboratory Description and Safety Analysis. ORNL/TM-6959. Oak Ridge National Laboratory.

Ebasco, and Main. July 20, 1992. Design Demonstrations-Category B Tank Systems, Revision 2. DOE Contract No. DE-AC05-91OR21928. Oak Ridge National Laboratory.

Energy Systems Drawing P3E-21247-C012, Melton Valley Waste Storage Tanks, Piping Modifications Pump Room and Pipe Gallery Modifications, Revision A.

Energy Systems Drawing P3E-21247-C013, Melton Valley Waste Storage Tanks, Piping Modifications, Sections, Revision A.

Energy Systems Drawing P3E-21247-C014, Melton Valley Waste Storage Tanks, Piping Modifications, Sections, Revision A.

Energy Systems Drawing P-21247-YE-026-E, Waste Storage Tanks, Piping Flow Diagram, Process, Sheet 1, Revision G.

Energy Systems Drawing P-21247-YE-027-E, Waste Storage Tanks, Piping Flow Diagram, Process, Sheet 1, Revision C.

Energy Systems Drawing P-21247-YC-002-E, Waste Storage Tanks, Piping Plan, Revision B.

Energy Systems Drawing S-21247-YB-002-E, Waste Storage Tanks, Plan and Detail for Control House and Pump Room, Revision D.

Energy Systems Drawing S-21247-YB-001-E, Waste Storage Tanks, Plan Concrete Vault, Revision C.

Energy Systems Drawing P-21247-YC-003-E, Waste Storage Tanks, Pump Room Piping Plan, Revision G.

Energy Systems Drawing S-21247-YB-003-E, Waste Storage Tanks, Sections and Details of Concrete Vault, Revision D.

Energy Systems Drawing P-21247-YC-004-E, Waste Storage Tanks, Tank Piping Section, Sheet 1, Revision C.

Energy Systems Drawing P-21247-YC-012-E, Waste Storage Tanks, Tank Piping Section, Sheet 2, Revision B. 
Energy Systems Drawing P-21247-YC-001-E, Waste Storage Tanks, Tanks, Pump Room and Tunnel Piping Plan, Revision E.

Energy Systems Drawing P-21247-YC-011-E, Waste Storage Tanks, Tanks, Pump Room Piping Section, Sheet 2, Revision D.

Oak Ridge National Laboratory. 1991. Waste Acceptance Criteria for Liquid Waste Treatment Systems at the Oak Ridge National Laboratory. WM-WMCO-201. Department of Waste Minimization Planning and Certification.

Peretz, F. J., et al. 1986. Characterization of Low-Level Liquid Wastes at the Oak Ridge National Laboratory. ORNL/TM-10218. Oak Ridge National Laboratory.

Risk Evaluation of Embedded, Single-Walled Liquid Low-Level Waste Piping at Oak Ridge National Laboratory.

Robinson, S. M., S. M. DePaoli, and A. B. Walker. 1991. Federal Facility Agreement Contingency, Upgrade, and Replacement Plans for the ORNL Active Low-Level Radioactive Waste Tank System. ORNL/TM-11795. Oak Ridge National Laboratory. 
Figure 2.25-1

Location of Tank System W-30 Piping

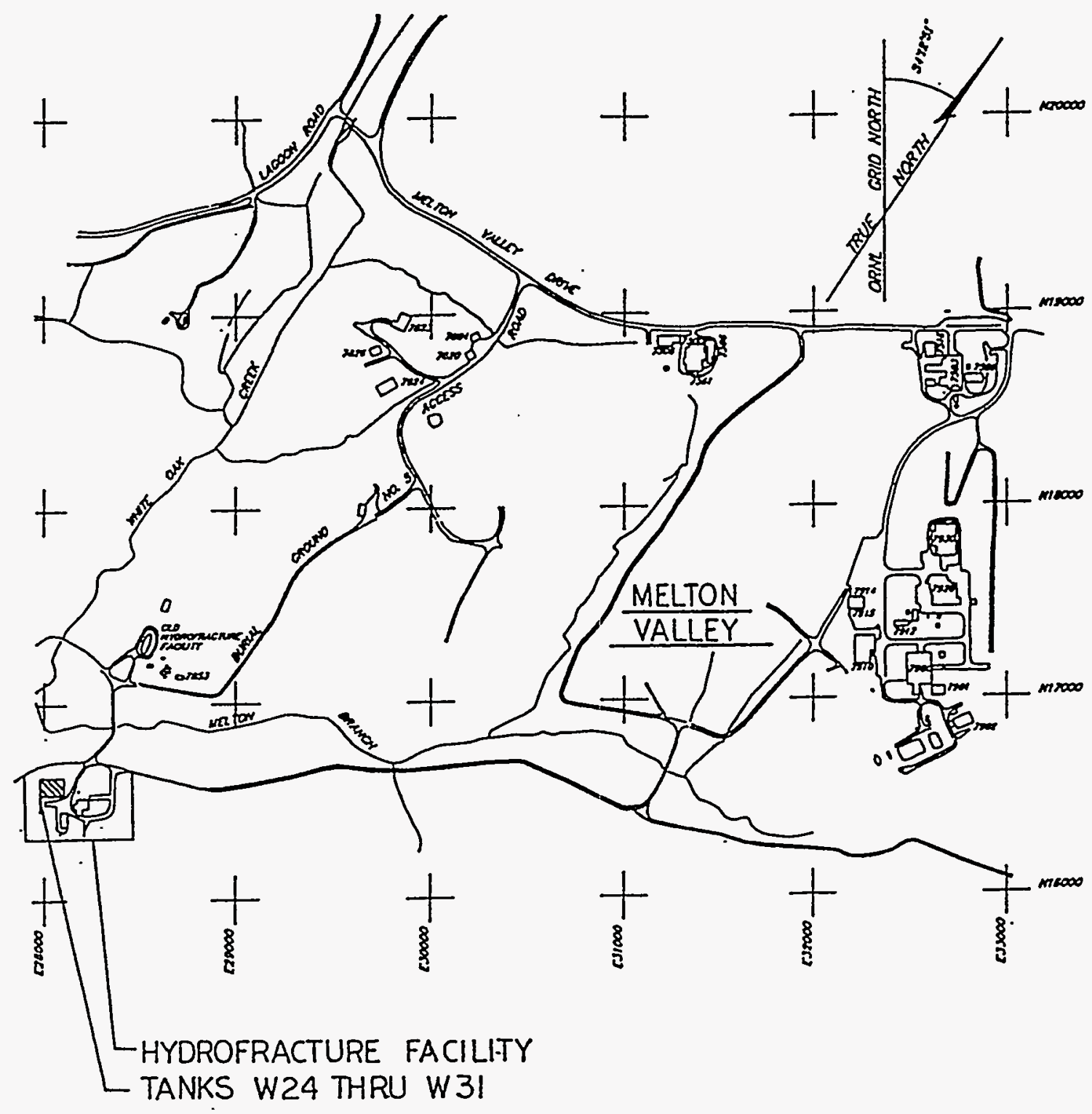


Figure 2.25-2 Tank System W-30 Piping Diagram

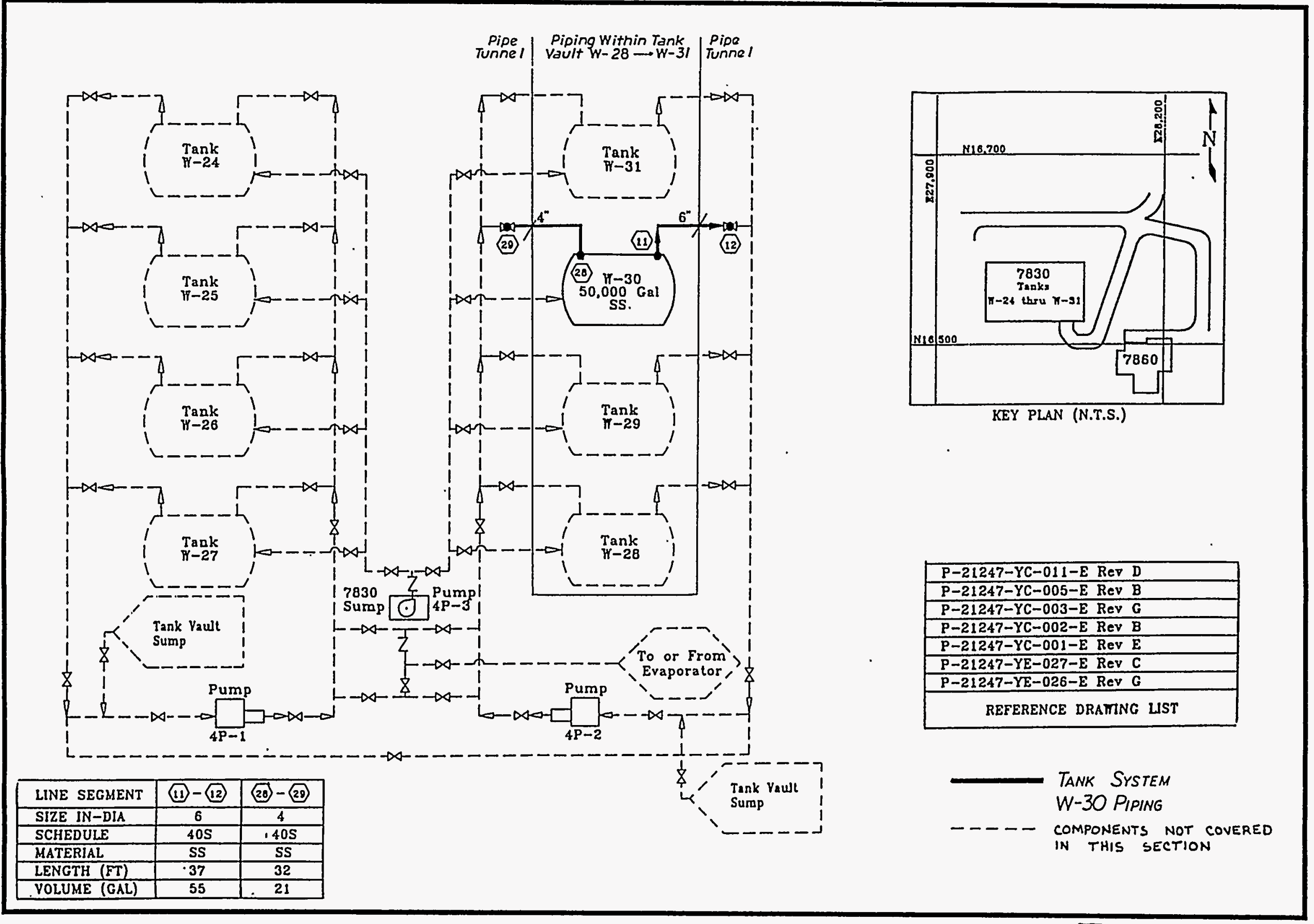

Ebasco/Main 
Figure 2.25-3

Analytical Data for Liquid Samples (Tank System W-30)

ANALYTICAL DATA FOR LIQUID SAMPLE

\begin{tabular}{llll}
\hline Casaceristie JAN! 1990 w30.L1 w30.L2 & w30.L \\
\hline
\end{tabular}

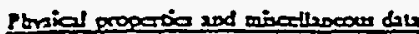

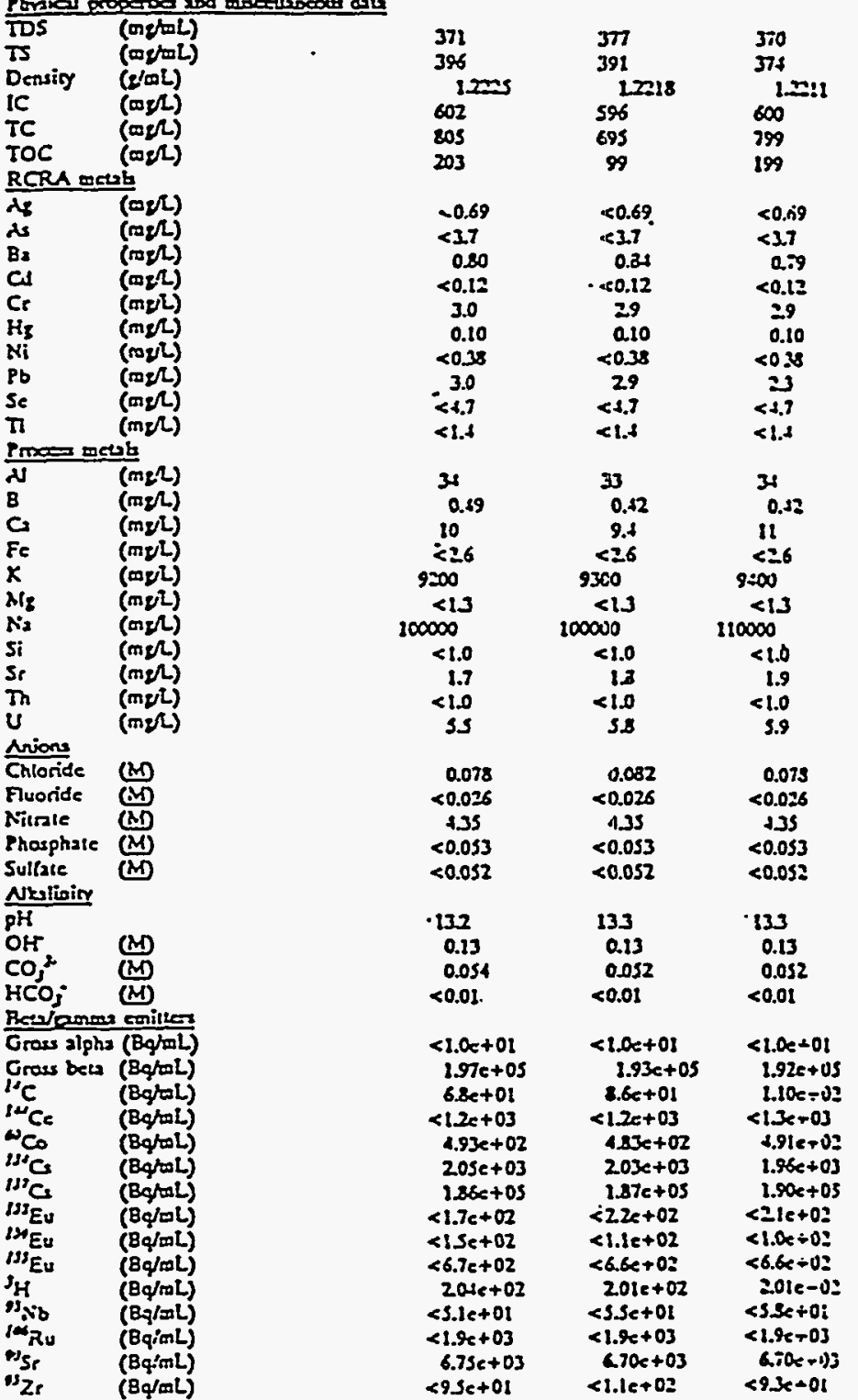

LEGEND: PHYSICAI FROPERTIES

TDS-TOTAL DISSOLYED SOLIDS

TS - TOTAL SOLIOS

IC - INORGANIC CARGON

TC - TOTAL CARBON

TOG - TOTAL ORGANIC CARBON 
Figure 2.25-4 General Characteristics of Waste Samples (Tank System W-30)

Lilulu samples: $\quad$ Sludge samples

\begin{tabular}{|c|c|c|c|c|c|}
\hline Tank & $\begin{array}{l}\text { Radiation } \\
\text { level } \\
\text { (R/h) }\end{array}$ & $\begin{array}{l}\text { Organic } \\
\text { layer }\end{array}$ & Number/type & $\begin{array}{l}\text { Radiation } \\
\text { level } \\
(\mathrm{R} / \mathrm{h})\end{array}$ & Comments \\
\hline \multirow[t]{3}{*}{$W-28$} & 0.480 & No & $.1 /$ soft sludge & 1.2 & $\begin{array}{l}\text { Fuid (weight of to the boltom handle carried took } \\
\text { second sampler to the sample for more bottom of } \\
\text { thematerial (tank) }\end{array}$ \\
\hline & & & & & $\begin{array}{l}\text { Sludge (W-28-S1): deep yellowi seems } \\
\text { homogeneous }\end{array}$ \\
\hline & & & & & $\begin{array}{l}\text { Sonicated sludge: very finely divided with a few } \\
\text { dark nakes }\end{array}$ \\
\hline W-29 & 0.110 & NA & $\mathrm{NA}$ & NA & $\begin{array}{l}\text { No sludge sample data for tanks W-29 and W-30 is } \\
\text { available; however, the contents of tanks W-29 and } \\
\text { W. } 30 \text { should be very similias to the contents of the } \\
\text { tank W-28. }\end{array}$ \\
\hline W-30 & 0.110 & NA & $N A$ & $N A$ & \\
\hline
\end{tabular}




\section{$2.26 \quad$ Tank System W-31 Piping}

\subsubsection{Tank System Summary}

Tank System W-31 is located at the Melton Valley Storage Tank Facility (Building 7830) (Figures 2.26-1 and 2.26-2). The tank system piping is schedule 40S, ASME SA-240, type 304L stainless steel (SS) and is routed from a pipe tunnel to Tank Vault W-28 through W-31. Tank System W-31 piping is used to transfer concentrate from the Evaporator to Tanks W-24 through W-31 and is classified as a Federal Facility Agreement (FFA) Category B tank system.

\subsubsection{Standards for Pipe Assessment of Tank Systems}

\subsubsection{Tank System Piping Description and Design Standards}

\section{Tank System Piping Description}

Tank System W-31 piping is located at Building 7830 and is routed from a pipe tunnel to Tank Vault W-28 through W-31. The piping system is used and managed by the Waste Management and Remedial Actions Division.

Tank System W-31 piping is constructed of $6^{\prime \prime}$ and $4^{\prime \prime}, 304 \mathrm{~L}$ SS with a maximum design pressure and temperature of $150 \mathrm{psig}$ and $150^{\circ} \mathrm{F}$ for the $6^{\prime \prime}$ line and $300 \mathrm{psig}$ and $150^{\circ} \mathrm{F}$ for the $4^{\prime \prime}$ line. Tank System W-31 piping has the capacity to contain a maximum volume of 185 gal.

\section{$\underline{\text { Design Standards }}$}

The applicable codes and standards used for Tank System W-31 piping and its associated secondary containment systems are identified herein. The codes and standards listed are those identified on either the design drawings or the construction specifications.

AEC-Oak Ridge Office, Minimum Safety Requirements;

Air Moving and Conditioning Association (AMCA) Standards Handbook-Publication 99;

AMCA Directory-Publication 261;

AMCA Fans and Systems-Publication 201;

American Concrete Institute 301-72 and 318-71;

American Concrete Pipe Association;

American Society for Testing and Materials A48, A262-70, C91, C139, C144, and D1751; 
Design Demonstrations - Category B Tank Systems (Piping)

American Society of Heating, Refrigeration, and Air Conditioning Engineers (ASHRAE) Handbook of Fundamentals;

American Society of Mechanical Engineers (ASME) Boiler and Pressure Vessel Code, Sections II (SA-240), V, VIII, and IX;

ASHRAE Guide and Data Book-Application;

ASHRAE Guide and Data Book-Equipment;

ASHRAE Handbook-Systems;

Atomic Energy Commission (AEC) General Design Criteria, Appendix 63;

Factory Mutual Engineering Corporation;

National Electrical Code;

National Fire Protection Association (NFPA) No. 90A-Air Conditioning and Ventilating Systems;

NFPA No. 91-Blower and Exhaust Systems;

Occupational Safety and Health Administration;

UCC-ND Engineering Standards Y-EF-538;

Underwriters Laboratories Inc.; and

Union Carbide Corporation Nuclear Division (UCC-ND) Standards, Sections 303, 401, 411, 702, and 914.04.

\subsubsection{Generic Description of Piping Contents}

Tank System W-31 piping was designed to serve as part of an interim storage tank system for the hydrofracture facility. The waste concentrates stored in Tank W-31 were being disposed of as a cement-waste mixture (grout) by injection into shale formations located $800^{\prime}$ to $1100^{\prime}$ below the ground surface using hydrofracture. However, hydrofracture was terminated in 1984, and Tank W-31 has become a waste concentrates storage tank for the liquid low-level waste (LLLW) system. LLLW is generated from a variety of facilities at the Oak Ridge National Laboratory (ORNL) including reactors, radioactive fuel processing areas, radioisotope processing areas, decontamination operations, hot cells, and radiochemical laboratories. The waste generators collect the waste, which is then transferred to the LLLW Evaporator for concentration, with transfer of evaporator bottoms to Tanks W-24 through W-31 for storage. 
Tank System W-31 piping transfers LLLW to and from Tank W-31. The analytical data (Figure 2.26-3) of the waste samples are representative of the waste received by Tank W-31. The liquid waste supernate sampled in Tank W-31 ranges in color from pale to deep yellow with high $\mathrm{pH}$ (11-13) sodium/potassium nitrate salt solutions. The principal metals found in the tank sludge were sodium, potassium, calcium, magnesium, uranium, and thorium. The sludge contains radioactive materials that produce a radiation level of $1.5-2.8 \mathrm{rem}$ per hour $(\mathrm{R} / \mathrm{h})$ (Figure 2.26-4).

\subsubsection{Pipe Corrosion Protection Measures}

Piping inside the pipe tunnel and Tank Vault W-28 through W-31 has no direct contact with the soil or water. Cathodic protection measures are not required for external corrosion.

\subsubsection{Documented Age of Tank System}

Tank System W-31 piping was installed in 1980.

\subsubsection{Standards for Containment/Release Detection}

2.26.3.1 Constructed of or Lined with Materials That are Compatible with Stored Waste(s) or Substance(s) to Be Placed in the Tank System and Shall Have Sufficient Strength and Thickness to Prevent Failure

Tank System W-31 piping is single-wall, schedule 40S, type 304L SS that is routed from a pipe tunnel to Tank Vault W-28 through W-31. Each area is discussed below. The piping penetrations from the pipe tunnel to Tank Vault W-28 through W-31 are singly contained, 4" and 6", schedule $40 \mathrm{~S}$, type 304L SS pipes embedded in the concrete wall to a length of $3^{\prime} 0^{\prime \prime}$.

\section{Pipe Tunnel}

The bottom of the pipe tunnel is lined with 16-gauge (1/16"), 304L SS, which is the same material as that used for the piping and which projects $3^{\prime} 0^{\prime \prime}$ up the pipe tunnel sidewall. The SS pipe tunnel lining material is compatible with the waste and designed to prevent migration of waste into the concrete.

\section{Tank Vault W-28 Through W-31}

The assessments of the secondary containment system for Tank Vault W-28 through W-31 are presented in the Design Demonstrations for Tanks W-28 through W-31. Those assessments conclude that Tank Vault W-28 through W-31 is lined with materials that are compatible with the waste and designed to prevent migration of waste into the concrete.

The assessment concludes that the pipe tunnel and tank vault are lined with materials that are compatible with the waste and designed to prevent migration of waste into the concrete. 
2.26.3.2 Placed on Foundation or Base Capable of Providing Support to the Secondary Containment System

\section{Pipe Tunnel}

The pipe tunnel foundation is a $20^{\prime} 3^{\prime \prime} \times 133^{\prime} 6^{\prime \prime} \times 1^{\prime} 6^{\prime \prime}$ thick, reinforced concrete base slab that rests on limestone.

\section{Tank Vault W-28 Through W-31}

The assessments of the secondary containment system for Tank Vault W-28 through W-31 are presented in the Design Demonstrations for Tanks W-28 through W-31. Those assessments conclude that the vault foundation is properly designed to support the secondary containment system.

The assessment concludes that the pipe tunnel and tank vault foundations are properly designed to support the secondary containment systems.

2.26.3.3 Provided with a Leak Detection System That is Designed and Operated to Detect Failure of Either Primary or Secondary Containment Structure or the Presence of Any Measurable Release of Hazardous or Radioactive Constituents

\section{Pipe Tunnel}

The pipe tunnel floor is sloped to a 16-gauge (1/16"), 304L SS-lined sump where accumulation of liquid will be detected by a pneumatic level indicator that will activate alarms in the Evaporator Service Tanks Control Room and Waste Operations Control Center (Building 3130).

\section{Tank Vault W-28 Through W-31}

The assessments of the secondary containment system for Tank Vault W-28 through W-31 are presented in the Design Demonstrations for Tanks W-28 through W-31. Those assessments conclude that the vault is provided with a leak detection system.

The assessment concludes that the pipe tunnel and tank vault are provided with leak detection.

2.26.3.4 Sloped or Otherwise Designed or Operated to Drain and Remove Liquids Resulting from Leaks, Spills, or Precipitation

\section{Pipe Tunnel}

The pipe tunnel floor is sloped to a 304L SS-lined sump. The sump provides a low point within the pipe tunnel to drain liquids to an instrumented location. A pumping system is provided to remove liquids that accumulate in the sump. 
Design Demonstrations - Category B Tank Systems (Piping)

\section{Tank Vault W-28 Through W-31}

The assessments of the secondary containment system for Tank Vault W-28 through W-31 are presented in the Design Demonstrations for Tanks W-28 through W-31. Those assessments conclude that the secondary containment is sloped and designed to drain and remove liquids resulting from leaks, spills, or precipitation.

The assessment concludes that the secondary containments for the pipe tunnel and the tank vault are sloped and designed to drain and remove liquids resulting from leaks, spills, or precipitation.

\subsubsection{Supplemental Information}

\subsubsection{Ancillary Equipment}

Tank W-31 is constructed of 304L SS, which is the same material as that used in the piping system, and is located in Tank Vault W-28 through W-31, which provides secondary containment. The support equipment is exposed to the same liquids as other components of the tank system; therefore, $304 \mathrm{~L}$ SS is an acceptable material for the support equipment.

\subsubsection{Waste Acceptance Criteria}

Radioactively contaminated liquid wastes at ORNL are generated by various activities within the research and operating divisions. These activities include radiochemical processing, routine hot cell operations and decontaminations, and various waste treatment and environmental protection processes. The variations in composition of the waste streams are limited by the waste acceptance criteria that specify activity and concentration limits for waste discharged into the LLLW system. The Waste Acceptance Criteria for Liquid Waste Treatment Systems at the Oak Ridge National Laboratory (Oak Ridge National Laboratory, 1991), dated July 1991, is a guide for liquid waste generators to determine the proper means of disposal for LLLW. The criteria provide future discharge guidelines for the LLLW system, which includes Tank System W-31. 


\subsubsection{References}

Binford, F. T., and S. D. Orfi. 1979. The Intermediate Level Liquid Waste System at the Oak Ridge National Laboratory Description and Safety Analysis. ORNL/TM-6959. Oak Ridge National Laboratory.

Ebasco, and Main. July 20, 1992. Design Demonstrations-Category B Tank Systems, Revision 2. DOE Contract No. DE-AC05-91OR21928. Oak Ridge National Laboratory.

Energy Systems Drawing P3E-21247-C012, Melton Valley Waste Storage Tanks, Piping Modifications Pump Room and Pipe Gallery Modifications, Revision A.

Energy Systems Drawing P3E-21247-C013, Melton Valley Waste Storage Tanks, Piping Modifications, Sections, Revision A.

Energy Systems Drawing P3E-21247-C014, Melton Valley Waste Storage Tanks, Piping Modifications, Sections, Revision A.

Energy Systems Drawing P-21247-YE-026-E, Waste Storage Tanks, Piping Flow Diagram-Process, Sheet 1, Revision G.

Energy Systems Drawing P-21247-YE-027-E, Waste Storage Tanks, Piping Flow Diagram-Process, Sheet 1, Revision C.

Energy Systems Drawing P-21247-YC-002-E, Waste Storage Tanks, Piping Plan, Revision B.

Energy Systems Drawing S-21247-YB-002-E, Waste Storage Tanks, Plan and Detail for Control Hose and Pump Room, Revision D.

Energy Systems Drawing S-21247-YB-001-E, Waste Storage Tanks, Plan Concrete Vault, Revision C.

Energy Systems Drawing P-21247-YC-003-E, Waste Storage Tanks, Pump Room Piping Plan, Revision G.

Energy Systems Drawing S-21247-YB-003-E, Waste Storage Tanks, Sections and Details of Concrete Vault, Revision D.

Energy Systems Drawing P-21247-YC-004-E, Waste Storage Tanks, Tank Piping Section, Sheet 1, Revision C.

Energy Systems Drawing P-21247-YC-012-E, Waste Storage Tanks, Tank Piping Section, Sheet 2 , Revision B. 
Energy Systems Drawing P-21247-YC-001-E, Waste Storage Tanks, Tanks, Pump Room and Tunnel Piping Plan, Revision E.

Energy Systems Drawing P-21247-YC-011-E, Waste Storage Tanks, Tanks, Pump Room Piping Section, Sheet 2, Revision D.

Oak Ridge National Laboratory. 1991. Waste Acceptance Criteria for Liquid Waste Treatment Systems at the Oak Ridge National Laboratory. WM-WMCO-201. Department of Waste Minimization Planning and Certification.

Peretz, F. J., et al. 1986. Characterization of Low-Level Liquid Wastes at the Oak Ridge National Laboratory. ORNL/TM-10218. Oak Ridge National Laboratory.

Risk Evaluation of Embedded, Single-Walled Liquid Low-Level Waste Piping at Oak Ridge National Laboratory.

Robinson, S. M., S. M. DePaoli, and A. B. Walker. 1991. Federal Facility Agreement Contingency, Upgrade, and Replacement Plans for the ORNL Active Low-Level Radioactive Waste Tank System. ORNL/TM-11795. Oak Ridge National Laboratory. 
Figure 2.26-1

Location of Tank System W-31 Piping

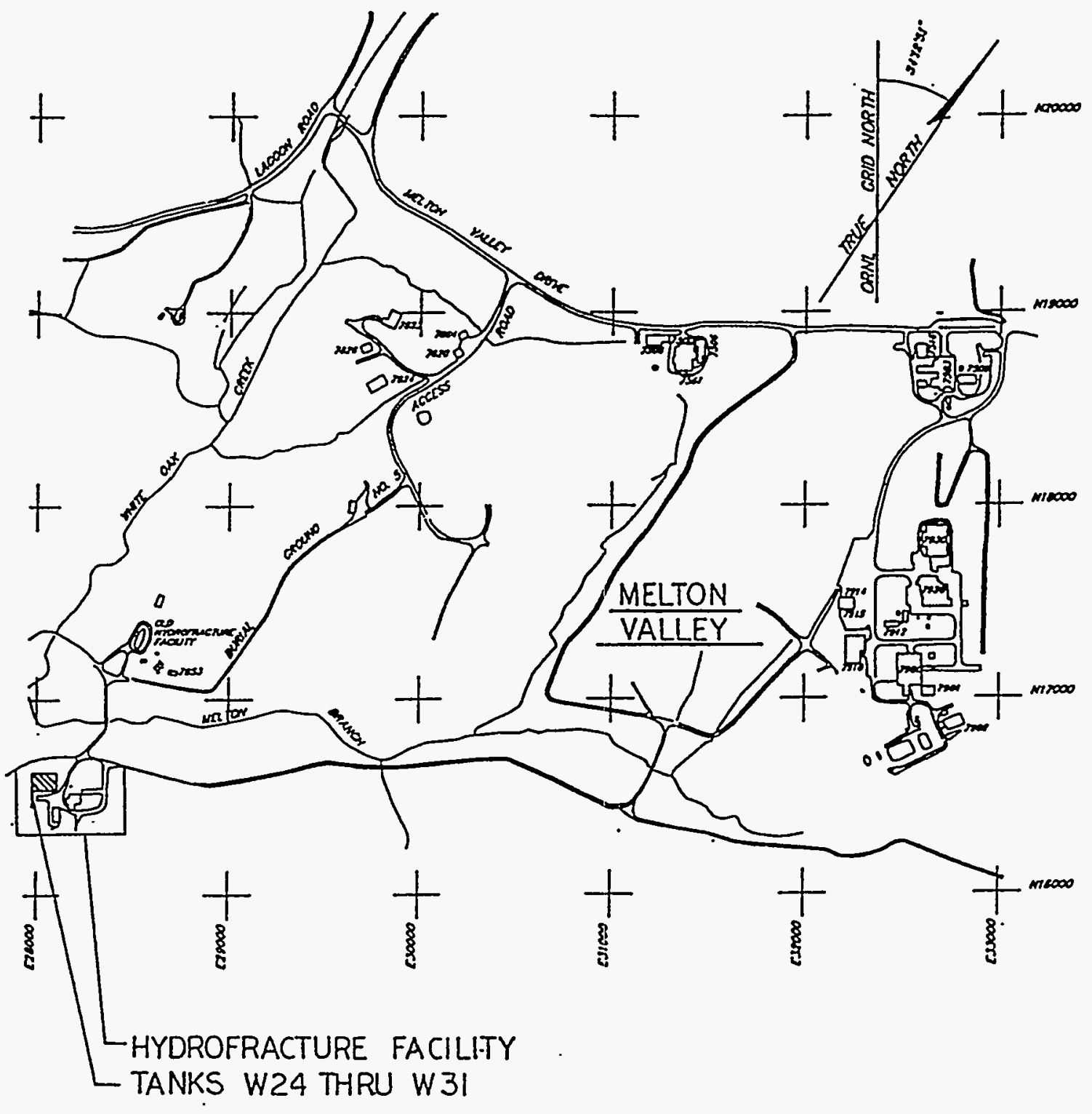

Firaston/matut 
Figure 2.26-2 Tank System W-31 Piping Diagram

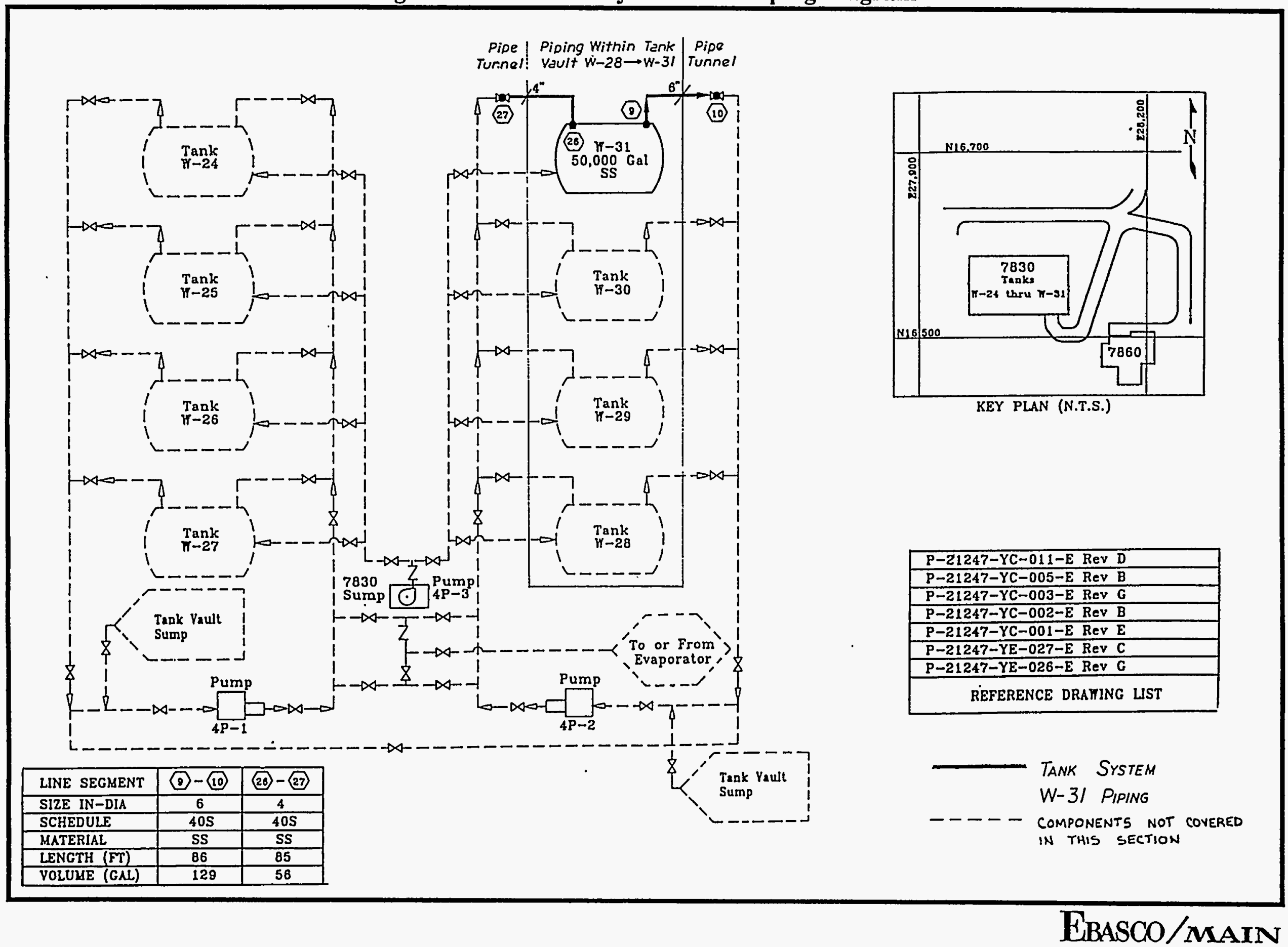




\section{ANALYTICAL DATA FOR LIQUID SAMPLE}

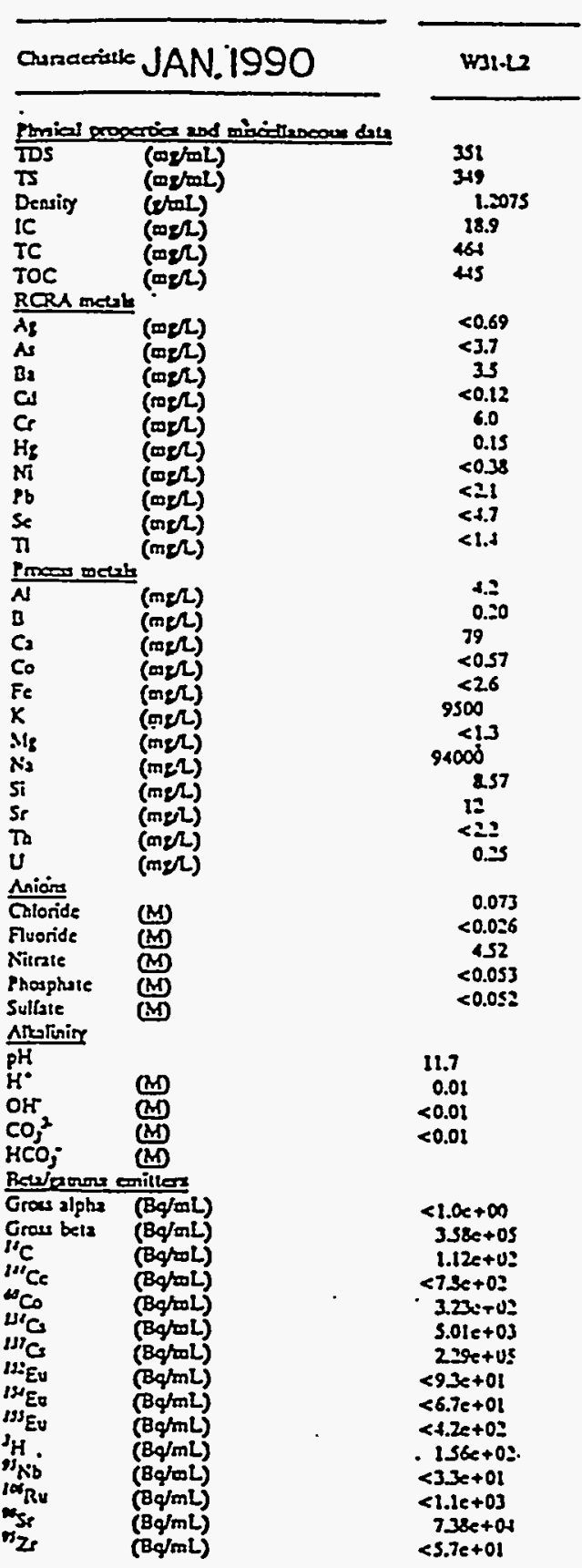

ANALYTICAL DATA FOR SLUDGE SAMPLE

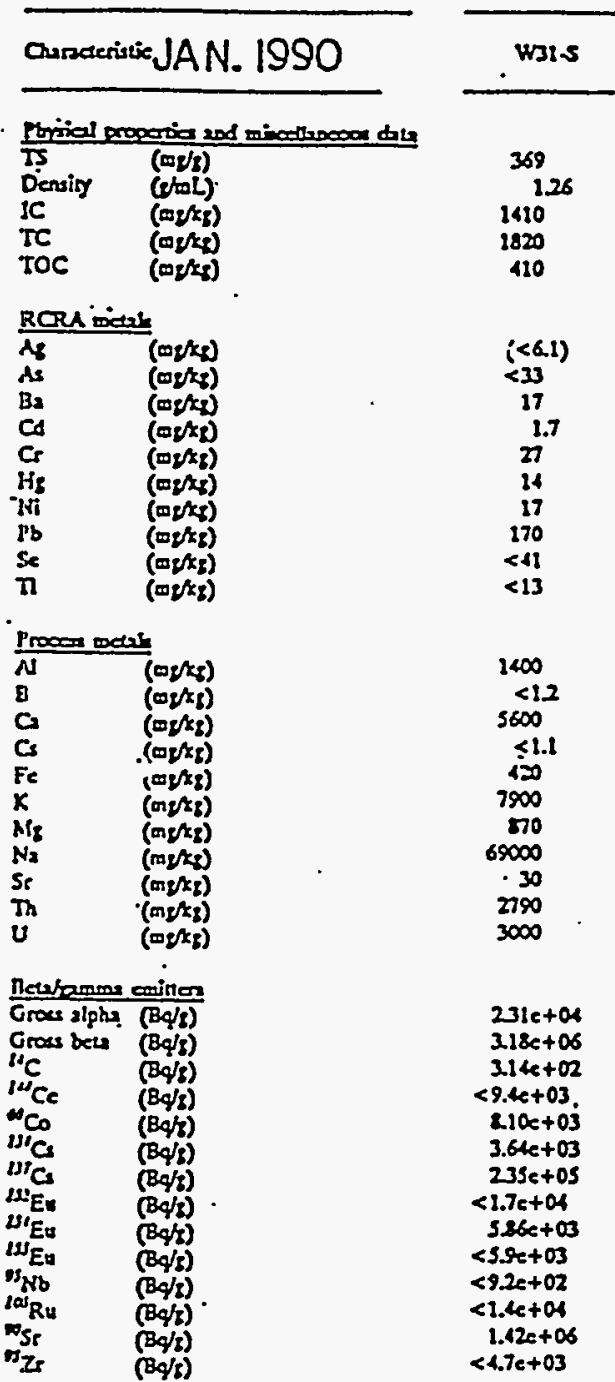

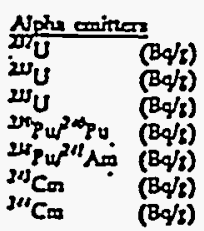

$5.08 c+02$

$<9.7 \dot{e}+03$

$8.78+02$

$243+03$

$<8.4 c+03$

$1.71 e+04$

LEGEND: PHYSICAL PROPERTIES TDS - TOTAL DISSOLYED SOLIDS

TS - TOTAL SOLIDS

IC - INORGANIC CARBON

TC - TUTAL CARBON

TOC - TOTAL ORGANIC CARBON 
Figure 2.26-4 General Characteristics of Waste Samples (Tank System W-31)

\begin{tabular}{|c|c|c|c|c|c|}
\hline \multicolumn{3}{|c|}{ Llyulu samples: } & \multicolumn{3}{|r|}{ Sludge samples } \\
\hline Tank & $\begin{array}{l}\text { Ridlatiun } \\
\text { Icvel } \\
(R / n)\end{array}$ & $\begin{array}{l}\text { Organic } \\
\text { layer }\end{array}$ & Number/lype & $\begin{array}{l}\text { Radialion } \\
\text { lcvel } \\
\text { (RM) }\end{array}$ & Cummenis \\
\hline \multirow[t]{2}{*}{$W \cdot 31$} & 0.180 & No & 2tsoli sluuge & $1.5 \cdot 2.2$ & $\begin{array}{l}\text { Sonicatal sofe sludge: mallum tan, watery sludge; fine and very fine partleles } \\
\text { sepuruted durlng centrifugution }\end{array}$ \\
\hline & & & 1/Mard sludge & 2.8 & Hard sluige: appeurance of clay or mud with a litule gril \\
\hline
\end{tabular}


Design Demonstrations - Category B Tank Systems (Piping)

Transfer Lines Piping System

\subsubsection{Pipe System Summary}

The Transfer Lines Piping System connects the eight Melton Valley Waste Storage Tanks with the five Bethel Valley Evaporator Service Tanks (Figures 2.27-1, 2.27-2, and 2.27-3). The Transfer Lines Piping System is single wall except for the piping that is routed in the South Parking Lot Valve Box (also known as the Incinerator Drive Valve Box) at Bethel Valley, the Interconnecting Pipe Line (ICPL) Valve Box No. 1, and outside underground, which is constructed of double-wall pipe. The core pipe is schedule 40S, ASME SA-240, type 304L stainless steel (SS); and the jacket is schedule 10S, ASME SA-240, type 304L SS. The Transfer Lines Piping System is routed from the Control House Pump Pit through Pipe Tunnel 2 where it penetrates outside underground and continues to the Valve Box at Tank W-6, the South Parking Lot Valve Box, and ICPL Valve Box No. 1. The piping then proceeds outside underground to the Waste Storage Tanks Pipe Tunnel and Pump Pit and further to Tank Vaults W-24 through W-27 and W-28 through W-31. The Transfer Lines Piping System is used to transfer concentrate to and from the above locations and is classified as a Federal Facility Agreement (FFA) Category B tank system.

\subsubsection{Standards for Pipe Assessment of Tank Systems}

\subsubsection{Tank System Piping Description and Design Standards}

\section{Transfer Lines Piping System Description}

The Transfer Lines Piping System connects the Melton Valley Waste Storage Tanks to the Bethel Valley Evaporator Service Tanks and is routed from the Control House Pump Pit through Pipe Tunnel 2 where it penetrates outside underground and continues to the Valve Box at Tank W-6, the South Parking Lot Valve Box, and ICPL Valve Box No. 1. The piping then proceeds outside underground to the Waste Storage Tanks Pipe Tunnel and Pump Pit and further to Tank Vaults W-24 through W-27 and W-28 through W-31. The piping system is used and managed by the Waste Management and Remedial Actions Division.

The Transfer Lines System core piping is constructed of 2", 4", and 6"; schedule 40S; type 304L SS with maximum design pressures of 150 and $300 \mathrm{psig}$ at a temperature of $150^{\circ} \mathrm{F}$. The Transfer Lines System jacket piping is $3^{\prime \prime}$, schedule 10S, type 304L SS with a design pressure and temperature of $300 \mathrm{psig}$ and $60^{\circ} \mathrm{F}$. The Transfer Lines Piping System has the capacity to contain a maximum volume of 1611 gal.

\section{$\underline{\text { Design Standards }}$}

The applicable codes and standards used for the Transfer Lines Piping System and its associated secondary containment systems are identified herein. The codes and standards listed are those identified on either the design drawings or the construction specifications. 
Air Moving and Air Conditioning Association (AMCA) Standards Handbook—Publications 99 , 201, and 261;

American Concrete Institute Standards;

American Conference of Government Industrial Hygienists, Industrial Ventilation;

American National Standards Institute;

American Society for Testing and Materials Standards A31, A444, A449, A563, A615, C31, C33, C94, C150, C260, D256, D1190, D1751, and D2729;

American Society of Heating, Refrigerating and Air Conditioning Engineers (ASHRAE) Handbook of Fundamentals;

American Society of Mechanical Engineers (ASME) Boiler and Pressure Vessel Code, Section II (SA-240);

American Standards Association;

ASHRAE Guide and Data Book-Applications;

ASHRAE Guide and Data Book-Equipment;

ASHRAE Handbook-Systems;

Duct Construction Standards;

Energy Research and Development Administration General Design Criteria, Appendix 6301;

Factory Mutual Engineering Corporation;

Federal Materials Specifications ES-XEM-2023 452, 454, 456, 459, and 460;

Federal Test Method Standard No. 141;

Filtration Systems for Nuclear Applications;

National Electrical Code;

National Electrical Manufacturers' Association.

National Fire Protection Association (NFPA) No. 90A-Air Conditioning and Ventilation Systems; 
NFPA No. 91-Blower and Exhaust Systems;

Nuclear Safety Information Center 65-Design, Construction, and Testing of High Efficiency Air Occupational Safety and Health Administration Safety Regulations;

Sheet Metal and Air Conditioning Contractors National Association (SMACNA) High Velocity SMACNA Ducted Electric Heat Guide for Air Handling Systems;

SMACNA Low Velocity Duct Construction Standards;

Tennessee Department of Highways Specification, Sections 303, 307, 402, 403, 411, 607, 801, and 910;

UCC-ND Engineering Standards Specifications;

UCC-ND Nondestructive Examinations Procedures NDE-21, NDE-30, and NDE-41;

UCC-ND Technical Specifications A-3.1, A-7.1, CV-1.3, CV-2.1, and CV-2.3;

UCC-ND Welding Procedure Specifications;

Underwriters Laboratories Inc.; and

Union Carbide Corporation Nuclear Division (UCC-ND) Engineering Standard Y-ES-4.11-12.

\subsubsection{Generic Description of Piping Contents}

The Transfer Lines Piping System was designed to transport high-level waste generated at the Oak Ridge National Laboratory (ORNL). However, because no significant quantities of highlevel waste were ever generated, this system was repiped to serve as a liquid low-level waste (LLLW) concentrate transfer system. LLLW is generated from a variety of facilities at ORNL including reactors, radioactive fuel processing areas, radioisotope processing areas, decontamination operations, hot cells, and radiochemical laboratories. The waste generators collect the waste, which is then transferred to LLLW Evaporator Feed Tank W-22. Any waste found to be acidic is adjusted to basic with sodium hydroxide in the generator collection tanks or in the evaporator feed tank which precipitates most of the transuranic waste components and heavy metals. The waste is then processed through the evaporator; and the concentrate is transferred to Tanks C-1, C-2, W-21, and W-23 before it is sent to the Melton Valley Waste Storage Tanks via the ICPL: a double-wall, type 304L SS pipeline connecting the two areas.

The Transfer Lines Piping System transfers LLLW between the Evaporator Service Tanks and the Melton Valley Waste Storage Tanks. The Transfer Lines Piping System contents have not been sampled; however, Tank W-23, including the Tank System W-23 piping, has been sampled. 
Design Demonstrations - Category B Tank Systems (Piping)

Because Tank System W-23 piping connects with the Transfer Lines Piping System, it is logical to assume that the characteristics of the waste stored in Tank W-23 should be similar to those of the waste transferred through the Transfer Lines Piping System (Figures 2.27-4 and 2.27-5).

The supernate liquid waste sampled in Tank W-23 ranges in color from pale to deep yellow with high $\mathrm{pH}(11-13)$ sodium/potassium nitrate salt solutions, which should be similar to the waste concentrate expected to be found in the Transfer Lines Piping System. Based on radiation levels found in Tank W-23, the Transfer Lines Piping System may contain radioactive materials.

\subsubsection{Pipe Corrosion Protection Measures}

Piping inside the Control House Pump Pit, Pipe Tunnel 2, the Valve Box at Tank W-6, the South Parking Lot Valve Box, ICPL Valve Box No. 1, the Waste Storage Tanks Pipe Tunnel and Pump Pit, Tank Vault W-24 through W-27, and Tank Vault W-28 through W-31 has no direct contact with the soil or water. Cathodic protection measures are not required for external corrosion.

The outside underground piping of the Transfer Lines System consists of three, doubly contained, cathodically protected systems of pipe.

The first system is between the South Parking Lot Valve Box and the Valve Box at Tank W-6, which is included in the Facility Manager's Cathodic Protection System No. 6A. The system consists of magnesium anodes, test stations, and connecting wire as shown on drawings C20013EA005, C20013EA006, and C20013EA007. The cathodic protection system was installed in May 1972 and modified in 1986. The installation drawings called for the use of electrical isolating devices at both ends of the piping run. The cathodic protection system design as shown on the drawings reviewed is considered to be adequate. However, the cathodic protection test report and survey performed in 1990 and 1991 indicate that extensive sections of the piping are not effectively receiving corrosion protection. This can be attributed to electrically shorted piping segments and depleted anode beds. In 1991, Harco completed the engineering design to upgrade the existing system. Energy Systems' upgrade is shown in Table 2.0-1.

The second system is between the Waste Storage Tanks Facility and the South Parking Lot Valve Box, which is included in the Facility Manager's Cathodic Protection System No. 14. The system consists of magnesium anodes, test station, and connecting wire as shown on drawings E20013ED003, E20013ED004, and E20013ED005. The cathodic protection system was installed in June 1976. The installation drawings called for the use of electrical isolating devices at both ends of the piping. The cathodic protection system design as shown on the drawings reviewed is considered to be adequate. However, the cathodic protection test report and survey performed in 1990 and 1991 indicate that two sections of this piping are not receiving effective cathodic protection. This can be attributed to an electrically shorted piping connection and inadequate anode placement. In 1991, Harco completed the engineering design to upgrade the existing system. Energy Systems' upgrade is shown in Table 2.0-1.

The third section is between the Valve Box at Tank W-6 and Pipe Tunnel 2, which is included in the Facility Manager's Cathodic Protection System No. 16. The impressed current system 
consists of a manually controlled, air-cooled rectifier in conjunction with graphite anodes and connecting wire as shown on drawing E20237ED008. The cathodic protection system was installed in May 1976. The installation drawings called for the use of electrical isolating devices at both ends of the piping. The cathodic protection system design as shown on the drawings reviewed is not considered to be adequate because test stations are not shown on the installation drawings. The cathodic protection test report and survey performed in 1990 and 1991 indicate that test stations were not installed during construction of the system and that sections of pipe may not be bonded together. In 1991, Harco completed the engineering design to upgrade the existing system. Energy Systems' upgrade is shown in Table 2.0-1.

\subsubsection{Documented Age of Tank System}

The initial Transfer Lines Piping System was installed in 1972. Additional portions of the piping were installed in 1976.

\subsubsection{Standards for Containment/Release Detection}

2.27.3.1 Constructed of or Lined with Materials That are Compatible with Stored Waste(s) or Substance(s) to Be Placed in the Tank System and Shall Have Sufficient Strength and Thickness to Prevent Failure

The Transfer Lines Piping System is constructed of single-wall, schedule 40S, type 304L SS that is routed from the Control House Pump Pit through Pipe Tunnel 2 where it penetrates outside underground in double-wall, schedule 40S (core pipe) and schedule 10S (jacket), type 304L SS. The double-wall pipe continues to the Valve Box at Tank W-6 and further outside underground through the South Parking Lot Valve Box and ICPL Valve Box No. 1 to the Waste Storage Tanks Pipe Tunnel and Pump Pit. The piping is single wall from the Pipe Tunnel and Pump Pit to Tank Vault W-24 through W-27 and Tank Vault W-28 through W-31. Each area is discussed below. The pipe penetration from Pipe Tunnel 2 to the Control House Pump Pit is a singly contained, 2", schedule 40S, type 304L SS pipe that is embedded in the concrete wall a length of $2^{\prime} 0^{\prime \prime}$. The pipe penetration from the outside underground piping into the Valve Box at Tank W- 6 is a singly contained, $2^{\prime \prime}$, schedule 40 S, type $304 \mathrm{~L}$ SS pipe that is embedded in the concrete wall to a length of $6^{\prime \prime}$. Pipe penetrations from the Waste Storage Tank Pipe Tunnel to the tank vaults consist of singly contained, $4^{\prime \prime}$ and $6^{\prime \prime}$, schedule 40S, type 304L SS pipes and are embedded in the concrete wall to a length of $3^{\prime} 0^{\prime \prime}$.

\section{Control House Pump Pit}

The bottom of the pump pit is lined with 16-gauge $\left(1 / 16^{\prime \prime}\right), 304 \mathrm{~L}$ SS, with sidewalls that project $3^{\prime} 0^{\prime \prime}$ up the pump pit. The pump pit walls above the SS liner are provided with a 30-mil-thick system of Amercoat 66 epoxy. The SS pump pit lining material, which is the same material as that used for the piping, is compatible with the waste and designed to prevent migration of waste into the concrete. According to manufacturer's specifications, the pump pit's epoxy coating is compatible with the waste and designed to prevent migration of waste into the concrete. 
Design Demonstrations - Category B Tank Systems (Piping)

\section{Pipe Tunnel 2}

The bottom of Pipe Tunnel 2 is lined with 16-gauge (1/16"), 304L SS, with sidewalls that project up to the pipe tunnel roof. This SS pipe tunnel lining material, which is the same material as that used for the piping, is compatible with the waste and designed to prevent migration of waste into the concrete.

\section{Outside Underground Piping}

The jacket of the double-wall pipe is $3^{\prime \prime}, 304 \mathrm{~L}$ SS. This secondary containment material is compatible with the waste.

\section{Valve Box at Tank W-6}

The bottom of the valve box is lined with 16-gauge (1/16"), 304L SS, which projects $3^{\prime \prime} 0^{\prime \prime}$ up the sidewalls of the valve box. The valve box walls above the SS liner are provided with a system of Amercoat 66 epoxy. The SS valve box lining material, which is the same material as that used for the piping, is compatible with the waste and designed to prevent migration of waste into the concrete. According to manufacturer's specifications, the valve box's epoxy coating is compatible with the waste and designed to prevent migration of waste into the concrete.

\section{South Parking Lot Valve Box}

The South Parking Lot Valve Box is not coated or lined with materials that are compatible with the waste and designed to prevent migration of waste into the concrete.

\section{$\underline{\text { ICPL Valve Box No. } 1}$}

The bottom of the valve box is lined with 16-gauge (1/16"), 304L SS, which projects $3^{\prime} 0^{\prime \prime}$ up the sidewalls of the valve box. The valve box walls above the SS liner are provided with a system of Carboline 193 epoxy. The SS valve box lining material, which is the same material as that used for the piping, is compatible with the waste and designed to prevent migration of waste into the concrete. According to manufacturer's specifications, the valve box's epoxy coating is compatible with the waste and designed to prevent migration of waste into the concrete.

\section{Waste Storage Tanks Pipe Tunnel and Pump Pit}

The bottom of the pipe tunnel and pump pit is lined with 16-gauge (1/16"), 304L SS, with sidewalls that project $3^{\prime} 0^{\prime \prime}$ up the walls. The walls above the SS liner are provided with a 30-mil-thick system of Amercoat 66 epoxy. The SS lining material, which is the same material as that used for the piping, is compatible with the waste and designed to prevent migration of waste into the concrete. According to manufacturer's specifications, the epoxy coating is compatible with the waste and designed to prevent migration of waste into the concrete. 


\section{Tank Vault W-24 Through W-27}

The assessments of the secondary containment system for Tank Vault W-24 through W-27 are presented in the Design Demonstrations for Tanks W-24 through W-27. Those assessments conclude that the vault is lined with materials that are compatible with the waste and designed to prevent migration of waste into the concrete.

\section{Tank Vault W-28 Through W-31}

The assessments of the secondary containment system for Tank Vault W-28 through W-31 are presented in the Design Demonstrations for Tanks W-28 through W-31. Those assessments conclude that the vault is lined with materials that are compatible with the waste and designed to prevent migration of waste into the concrete.

The assessment concludes that the Control House Pump Pit, Pipe Tunnel 2, the Valve Box at Tank W-6, ICPL Valve Box No. 1, the Pipe Tunnel and Pump Pit, and the Tank Vaults are coated or lined with materials that are compatible with the waste and designed to prevent migration of waste into the concrete. The assessment concludes that the jacket of the outside underground piping is compatible with the waste. The South Parking Lot Valve Box, however, is not coated or lined with materials that are compatible with the waste and designed to prevent migration of waste into the concrete.

\subsubsection{Placed on Foundation or Base Capable of Providing Support to the Secondary Containment System}

\section{Control House Pump Pit}

The pump pit foundation is a $21^{\prime} 0^{\prime \prime} \times 40^{\prime} 0^{\prime \prime} \times 2^{\prime} 0^{\prime \prime}$ thick, reinforced concrete base slab that rests on limestone.

\section{Pipe Tunnel 2}

The pipe tunnel foundation is a $9^{\prime} 6^{\prime \prime} \times 63^{\prime} 8^{\prime \prime} \times 1^{\prime} 0^{\prime \prime}$ thick, reinforced concrete base slab that rests on limestone.

\section{Valve Box at Tank W-6}

The valve box foundation is a $4^{\prime} 0^{\prime \prime} \times 6^{\prime} 0^{\prime \prime} \times 1^{\prime} 0^{\prime \prime}$ thick, reinforced concrete base slab.

\section{South Parking Lot Valve Box}

The valve box foundation is a $5^{\prime} 0^{\prime \prime} \times 5^{\prime} 0^{\prime \prime} \times 1^{\prime} 0^{\prime \prime}$ thick, reinforced concrete base slab. 


\section{ICPL Valve Box No. 1}

The valve box foundation is a $5^{\prime} 0^{\prime \prime} \times 5^{\prime} 0^{\prime \prime} \times 1^{\prime} 0^{\prime \prime}$ thick, reinforced concrete base slab.

\section{Waste Storage Tanks Pipe Tunnel and Pump Pit}

The pipe tunnel foundation is a $16^{\prime} 0^{\prime \prime} \times 133^{\prime} 6^{\prime \prime} \times 1^{\prime} 6^{\prime \prime}$ thick, reinforced concrete slab. The pump pit foundation is a $6^{\prime} 0^{\prime \prime} \times 66^{\prime} 6^{\prime \prime} \times 1^{\prime} 0^{\prime \prime}$ thick, reinforced concrete slab. The pipe tunnel and the pump pit are adjoined as one area and rest on a limestone base.

\section{Tank Vault W-24 Through W-27}

The assessments of the secondary containment system for Tank Vault W-24 through W-27 are presented in the Design Demonstrations for Tanks W-24 through W-27. Those assessments conclude that the vault foundation is properly designed to support the secondary containment system.

\section{Tank Vault W-28 Through W-31}

The assessments of the secondary containment system for Tank Vault W-28 through W-31 are presented in the Design Demonstrations for Tanks W-28 through W-31. Those assessments conclude that the vault foundation is properly designed to support the secondary containment system.

The assessment concludes that the Control House Pump Pit, Pipe Tunnel 2, the Valve Box at Tank W-6, the South Parking Lot Valve Box, ICPL Valve Box No. 1, the Pipe Tunnel and Pump Pit, and the Tank Vaults have properly designed foundations to support the secondary containment system.

2.27.3.3 Provided with a Leak Detection System That is Design and Operated to Detect Failure of Either Primary or Secondary Containment Structure or the Presence of Any Measurable Release of Hazardous or Radioactive Constituents

\section{Control House Pump Pit}

The pump pit floor is sloped to a 16-gauge (1/16"), 304L SS-lined sump where accumulation of liquid will be detected by a level sensor that will activate an alarm in the Waste Operations Control Center (Building 3130).

\section{Pipe Tunnel 2}

The Pipe Tunnel 2 floor is sloped to a 16-gauge (1/16"), 304L SS-lined sump. Liquid that flows to the Pipe Tunnel 2 sump will continue to flow to the Control House Pump Pit sump through a 4 ", schedule 40S, type $304 \mathrm{~L}$ SS sump drain pipe. The pump pit sump is lined with 16-gauge 
Design Demonstrations - Category B Tank Systems (Piping)

$\left(1 / 16^{\prime \prime}\right), 304 \mathrm{~L}$ SS; and accumulation of liquid will be detected by a level sensor that will activate an alarm in the Waste Operations Control Center (Building 3130).

\section{Outside Underground Piping}

The outside underground, double-wall piping is provided with a nitrogen-blanketed annulus leak detection system.

\section{Valve Box at Tank W-6}

The valve box floor is sloped to a 16-gauge $\left(1 / 16^{\prime \prime}\right), 304 \mathrm{~L}$ SS-lined sump where accumulation of liquid will be detected by a level sensor that will activate an alarm in the Waste Operations Control Center (Building 3130).

\section{South Parking Lot Valve Box}

A leak detection system for the South Parking Lot Valve Box could not be identified from the design drawings or construction specifications.

\section{ICPL Valve Box No. 1}

The valve box floor is sloped to a 16-gauge (1/16"), 304L SS-lined sump where accumulation of liquid will be detected by a level sensor that will activate an alarm in the Waste Operations Control Center (Building 3130).

\section{Waste Storage Tanks Pipe Tunnel and Pump Pit}

The pipe tunnel and pump pit floor is sloped to a 16-gauge (1/16"), 304L SS-lined sump. Liquid that flows from the pump pit will continue to flow by gravity to a 16-gauge, 304L SS-lined sump in the pipe tunnel. Accumulation of liquid will be detected by a level sensor that will activate an alarm in the Waste Operations Control Center (Building 3130).

\section{Tank Vault W-24 Through W-27}

The assessments of the secondary containment system for Tank Vault W-24 through W-27 are presented in the Design Demonstrations for Tanks W-24 through W-27. Those assessments conclude that the tank vault is provided with leak detection.

\section{Tank Vault W-28 Through W-31}

The assessments of the secondary containment system for Tank Vault W-28 through W-31 are presented in the Design Demonstrations for Tanks W-28 through W-31. Those assessments conclude that the tank vault is provided with leak detection. 
The assessment concludes that the Control House Pump Pit; Pipe Tunnel 2; the outside underground, double-wall piping; the Valve Box at Tank W-6; ICPL Valve Box No. 1; the Pipe Tunnel and Pump Pit; and the Tank Vaults are provided with leak detection. The South Parking Lot Valve Box, however, is not provided with a leak detection system.

\subsubsection{Sloped or Otherwise Designed or Operated to Drain and Remove Liquids Resulting from Leaks, Spills, or Precipitation}

\section{Control House Pump Pit}

The pump pit floor is sloped to a 304L SS-lined sump. The sump provides a low point within the pump pit to drain liquids to an instrumented location. A pumping system is provided to remove liquids that accumulate in the sump.

\section{Pipe Tunnel 2}

The pipe tunnel floor is sloped to a 304L SS-lined sump. Liquid that flows to the pipe tunnel sump will continue to flow to the pump pit sump through a sump drain pipe. The pump pit sump provides a low point to drain liquids to an instrumented location. A pumping system is provided to remove liquids that accumulate in the sump.

\section{Outside Underground Piping}

The outside underground, double-wall piping is sloped to low points and is provided with $1 / 2^{\prime \prime}$ drain test connections to remove liquids resulting from leaks.

\section{Valve Box at Tank W-6}

The valve box floor is sloped to a 304L SS-lined sump. The sump provides a low point to drain liquids to an instrumented location. A pumping system is not provided to remove liquids that accumulate in the sump. However, a portable system may be used to remove liquids upon detection from the alarmed level sensor located in the sump.

\section{South Parking Lot Valve Box}

The valve box floor is sloped to a sump. The sump provides a low point to drain liquids. A pumping system is not provided to remove liquids that accumulate in the sump.

\section{$\underline{\text { ICPL Valve Box No. } 1}$}

The valve box floor is sloped to a 304L SS-lined sump. The sump provides a low point to drain liquids to an instrumented location. A pumping system is not provided to remove liquids that accumulate in the sump. However, a portable system may be used to remove liquids upon detection from the alarmed level sensor located in the sump. 


\section{Waste Storage Tanks Pipe Tunnel and Pump Pit}

The pipe tunnel and pump pit floor is sloped to a 304L SS-lined sump. The sump provides a low point to drain liquids to an instrumented location. A pumping system is provided to remove liquids that accumulate in the sump.

\section{Tank Vault W-24 Through W-27}

The assessments of the secondary containment system for Tank Vault W-24 through W-27 are presented in the Design Demonstrations for Tanks W-24 through W-27. Those assessments conclude that the secondary containment is sloped and designed to drain and remove liquids resulting from leaks, spills, or precipitation.

\section{Tank Vault W-28 Through W-31}

The assessments of the secondary containment system for Tank Vault W-28 through W-31 are presented in the Design Demonstrations for Tanks W-28 through W-31. Those assessments conclude that the secondary containment is sloped and designed to drain and remove liquids resulting from leaks, spills, or precipitation.

The assessment concludes that the Control House Pump Pit; Pipe Tunnel 2; the outside underground, double-wall piping; the Pipe Tunnel and Pump Pit; and the Tank Vaults are sloped and designed to drain and remove liquids resulting from leaks, spills, or precipitation. The Valve Box at Tank W-6, the South Parking Lot Valve Box, and ICPL Valve Box No. 1 are sloped and designed to drain liquids. Pumping systems are not provided to remove liquids that accumulate in the sumps; however, portable systems may be used to remove liquids upon detection from the alarmed level sensors located in the sumps of the Valve Box at Tank W- 6 and ICPL Valve Box No. 1.

\subsubsection{Supplemental Information}

\subsubsection{Ancillary Equipment}

Tanks W-24 through W-31 are constructed of $304 \mathrm{~L}$ SS, which is the same material as that used in the piping system, and are located in tank vaults, which provide secondary containment. The pumps associated with the Transfer Lines Piping System are constructed of 304L SS, which is the same material as that used in the tanks and piping system, and are located in the pump pits, which provide secondary containment. The support equipment is exposed to the same liquids as other components of the piping system; therefore, 304L SS is an acceptable material for the support equipment. 


\subsubsection{Waste Acceptance Criteria}

Radioactively contaminated liquid wastes at ORNL are generated by various activities within the research and operating divisions. These activities include radiochemical processing, routine hot cell operations and decontaminations, and various waste treatment and environmental protection processes. The variations in composition of the waste streams are limited by the waste acceptance criteria that specify activity and concentration limits for waste discharged into the LLLW system. The Waste Acceptance Criteria for Liquid Waste Treatment Systems at the Oak Ridge National Laboratory (Oak Ridge National Laboratory, 1991), dated July 1991, is a guide for liquid waste generators to determine the proper means of disposal for LLLW. The criteria provide future discharge guidelines for the LLLW system, which includes the Transfer Lines Piping System. 


\subsubsection{References}

Binford, F. T., and S. D. Orfi. 1979. The Intermediate-Level Liquid Waste System at the Oak Ridge National Laboratory Description and Safety Analysis. ORNL/TM-6959. Oak Ridge National Laboratory.

Ebasco, and Main. July 20, 1992. Design Demonstrations-Category B Tank Systems, Revision 2. DOE Contract No. DE-AC05-91OR21928. Oak Ridge National Laboratory.

Energy Systems Drawing D-52563, 50,000-Gal High-Level Liquid Waste Tanks C-1 and C-2, Sheet 1, Revision 2.

Energy Systems Drawing E-S-52711, Cells Nos. 1 and 2, Stainless Steel Liners and Tank Vault Details, Revision 2.

Energy Systems Drawing D-5001, Control Flow Diagram C-1 and C-2 Tank Vault, Revision 1.

Energy Systems Drawing D-55003, Control Flow Diagram Cell, Revision 3.

Energy Systems Drawing D-55002, Control Flow Diagram Cell 2 and Valve Pit, Revision 5.

Energy Systems Drawing C-40307, Criteria Storage Tank Vault, Dated 1/30/62 (No Revision No.).

Energy Systems Drawing S3E-20237-B013, Extended Vault Plan Sections and Details, Revision 0.

Energy Systems Drawing P-20237-YE-079E, Evaporator Service Tanks Piping Flow Diagram, Process, Revision 3.

Energy Systems Drawing C-20237-YA-008E, Evaporator Service Tanks, Process, Service Piping Plan, Sheet 2, Revision 2.

Energy Systems Drawing E-F-52685, Footing Tunnel Drains and Sump Pit, Revision 1.

Energy Systems Drawing D-34551, High-Level Waste Facility Engineering Flowsheet No. 4, Dated 5/16/61 (No Revision No.).

Energy Systems Drawing D-52589, High-Level Waste Tank Cell Piping, Sheet 1, Revision 4.

Energy Systems Drawing D-52591, High-Level Waste Tank Cell Piping, Sheet 3, Revision 3.

Energy Systems Drawing P-20237-YE-073E, ILWMF Project Flow Sheet, Revision 2. 
Design Demonstrations - Category B Tank Systems (Piping)

Energy Systems Drawing S-20013-YB-002E, Interconnecting Pipeline Details and Sections, Revision 2.

Energy Systems Drawing P-20013-YA-006E, Interconnecting Pipeline Details, Revision 2.

Energy Systems Drawing S-20013-YB-001E, Interconnecting Pipeline New Valve Box Sections and Details, Revision 1.

Energy Systems Drawing P-20013-YC-001E, Interconnecting Pipeline Piping Details, Sheet 1, Revision 2.

Energy Systems Drawing P-20013-YC-002E, Interconnecting Pipeline Piping Details, Sheet 2, Revision 3.

Energy Systems Drawing P-20013-YC-003E, Interconnecting Pipeline Piping Details, Sheet 3 , Revision 2.

Energy Systems Drawing P-20013-YC-004E, Interconnecting Pipeline Piping Details, Sheet 4, Revision C.

Energy Systems Drawing P-20013-YE-001E, Interconnecting Pipeline Piping Flow Diagram, Revision 2.

Energy Systems Drawing P-20013-YA-002E, Interconnecting Pipeline Plan and Profile, Sheet 1 , Revision 2.

Energy Systems Drawing P-20013-YA-003E, Interconnecting Pipeline Plan and Profile, Sheet 2, Revision 1.

Energy Systems Drawing P-20013-YA-004E, Interconnecting Pipeline Plan and Profile, Sheet 3, Revision 1.

Energy Systems Drawing P-20013-YA-005E, Interconnecting Pipeline Plan and Profile, Sheet 4, Revision 1.

Energy Systems Drawing P-20013-YA-001E, Interconnecting Pipeline Site Plan, Revision 1.

Energy Systems Drawing D-52761, Off-Gas and Cell Ventilation Filter Pits, Revision 1.

Energy Systems Drawing P3E-20237-C021, Piping Details Evaporator Service Tank Area, Revision 0.

Energy Systems Drawing P3E-20237-C020, Piping Plan Building 2531 Area, Revision 0.

Energy Systems Drawing D-52608, Sample Flow Sheet, Revision 3. 
Energy Systems Drawing D-52750, Sampling Room Foundation Plan and Sections, Revision 1. Energy Systems Drawing E-S-52712, Tank Storage Vault and Retaining Wall Details, Revision 2. Energy Systems Drawing D-52757, Tank Vault Cover Plug Location Plan and Details, Revision 1.

Energy Systems Drawing E-M-52714, Wall Penetrations, Sheet 1, Revision 6.

Energy Systems Drawing D-52606, Waste Evaporator Building Cell 1 and 2 Process Flowsheet, Revision 4.

Energy Systems Drawing D-52604, Waste Evaporator Building Cell 1 and 2 Service Flowsheet, Revision 3.

Energy Systems Drawing P-21247-YE-026E, Waste Storage Tanks Piping Flow Diagram, Process, Sheet 1, Revision G.

Energy Systems Drawing P-21247-YE-027E, Waste Storage Tanks Piping Flow Diagram, Process, Sheet 2, Revision C.

Energy Systems Drawing P-21247-YC-001E, Waste Storage Tanks, Tanks, Pump Room and Tunnel Piping Plan, Revision E.

Energy Systems Drawing P-21247-YC-003E, Waste Storage Tanks, Pump Room, Piping Plan, Revision G.

Energy Systems Drawing P-21247-YC-004E, Waste Storage Tanks, Tank Piping Sections, Sheet 1 , Revision C.

Energy Systems Drawing P-21247-YC-006E, Waste Storage Tanks, Pump Room Piping Sections, Sheet 1 , Revision C.

Energy Systems Drawing P-21247-YC-011E, Waste Storage Tanks, Pump Room Piping Sections, Sheet 2, Revision D.

Energy Systems Drawing P-21247-YC-013E, Waste Storage Tanks, Pipe Support Details, Revision C.

Energy Systems Drawing C-20237-YA-009E, Evaporator Annex, Process, Service Piping Plan, Sheet 3, Revision 2.

Energy Systems Drawing C-20013-EA-011D, Enlarged Plan Sta. 0+00 to Sta. 0+25 and Valve Box Modifications, Revision 2. 
Design Demonstrations - Category B Tank Systems (Piping)

Energy Systems Drawing P-20237-YA-019E, Evaporator Annex, Process, Service Piping Profile, Sheet 13, Revision 2.

Energy Systems Drawing P-20237-YC-019E, Evaporator Annex, Process Pipe Tunnel Plan and Sections, Revision 3.

Energy Systems Drawing P-20237-YC-028E, Evaporator Service Tanks, Plan Piping Tanks Nos. 21, 22 and 23, Revision 3.

Energy Systems Drawing P-20237-YC-029E, Evaporator Service Tanks, Tanks Piping Sections and Details, Tanks Nos. 21, 22 and 23, Revision 3.

Energy Systems Drawing P-20237-YC-030E, Evaporator Service Tanks, Tank Piping Sections and Details, Sheet 1, Tanks Nos. 21, 22 and 23, Revision 3.

Energy Systems Drawing P-20237-YC-032E, Evaporator Service Tanks, Tank Piping Sections and Details, Sheet 3, Tanks Nos. 21, 22 and 23, Revision 2.

Energy Systems Drawing P-20237-YC-033E, Evaporator Service Tanks, Tank Piping Plan and Details, Revision 3.

Energy Systems Drawing P-20237-YC-037E, Evaporator Service Tanks, W-6 Valve Pit and Miscellaneous Details, Revision 4.

Energy Systems Drawing S-20237-YB-010-E, Evaporator Annex Plan Sections and Details Stainless Steel Liner, Revision 2.

Energy Systems Drawing C-20013-EA-005, Plan and Profile, Sheet 1, As-Built, Revision 2.

Energy Systems Drawing C-20013-EA-006, Plan and Profile, Sheet 2, As-Built, Revision 3.

Energy Systems Drawing C-20013-EA-007, Plan and Profile, Sheet 3, As-Built, Revision 4.

Energy Systems Drawing E-20013-ED-003, Interconnecting Pipeline Cathodic Protection System, Sheet 1, Revision B.

Energy Systems Drawing E-20013-ED-004, Interconnecting Pipeline Cathodic Protection System, Sheet 2, Revision 3.

Energy Systems Drawing E-20013-ED-005, Interconnecting Pipeline Cathodic Protection System, Sheet 3, Revision 4.

Energy Systems Drawing E-20013-ED-008, Evaporator Annex and Service Tanks Cathodic Protection, Revision 0. 
Harco Technologies Corporation. June 1990. Resurvey of the Cathodic Protection Systems, Oak Ridge National Laboratories, United States Department of Energy, Oak Ridge, Tennessee. Martin Marietta Energy Systems, Inc.

Harco Technologies Corporation. July 1991. Cathodic Protection System Upgrade Design Underground ILW Line 7567 to 3507, System No. 6. Oak Ridge National Laboratories, United States Department of Energy, Oak Ridge, Tennessee. Martin Marietta Energy Systems, Inc.

Harco Technologies Corporation. July 1991. Cathodic Protection System Upgrade Design Underground ILW Line VLV Box 1 to 2531 and 2537, System No. 16. Oak Ridge National Laboratories, United States Department of Energy, Oak Ridge, Tennessee. Martin Marietta Energy Systems, Inc.

Harco Technologies Corporation. August 1991. Cathodic Protection System Upgrade Design Underground ILW Line ILW VLV Box to 7830, System No. 14. Oak Ridge National Laboratories, United States Department of Energy, Oak Ridge, Tennessee. Martin Marietta Energy Systems, Inc.

Hertel, J. P. 1964. Procedure for Mass Spec. Leak Test. Job 3-127.

Oak Ridge National Laboratory. 1991. Waste Acceptance Criteria for Liquid Waste Treatment Systems at the Oak Ridge National Laboratory. WM-WMCO-201. Department of Waste Minimization Planning and Certification.

Peretz, F. J., et al." 1986. Characterization of Low-Level Liquid Wastes at the Oak Ridge National Laboratory. ORNL/TM-10218. Oak Ridge National Laboratory.

Procurement Specifications. 1963. High Level Liquid Waste Tanks $C-1$ and C-2. XSP-68A.

Risk Evaluation of Embedded, Single-Walled Liquid Low-Level Waste Piping at Oak Ridge National Laboratory.

Robinson, S. M., S. M. DePaoli, and A. B. Walker. 1991. Federal Facility Agreement Contingency, Upgrade, and Replacement Plans for the ORNL Active Low-Level Radioactive Waste Tank System. ORNL/TM-11795. Oak Ridge National Laboratory.

Specifications for Construction of Intermediate Level Waste Facilities for the Energy Research and Development Administration. Invitation No. EY-77-B-05-5350.

Technical Specifications for the Construction of Improvements to Radioactive Liquid Waste System, Phase I, Building 2531. 


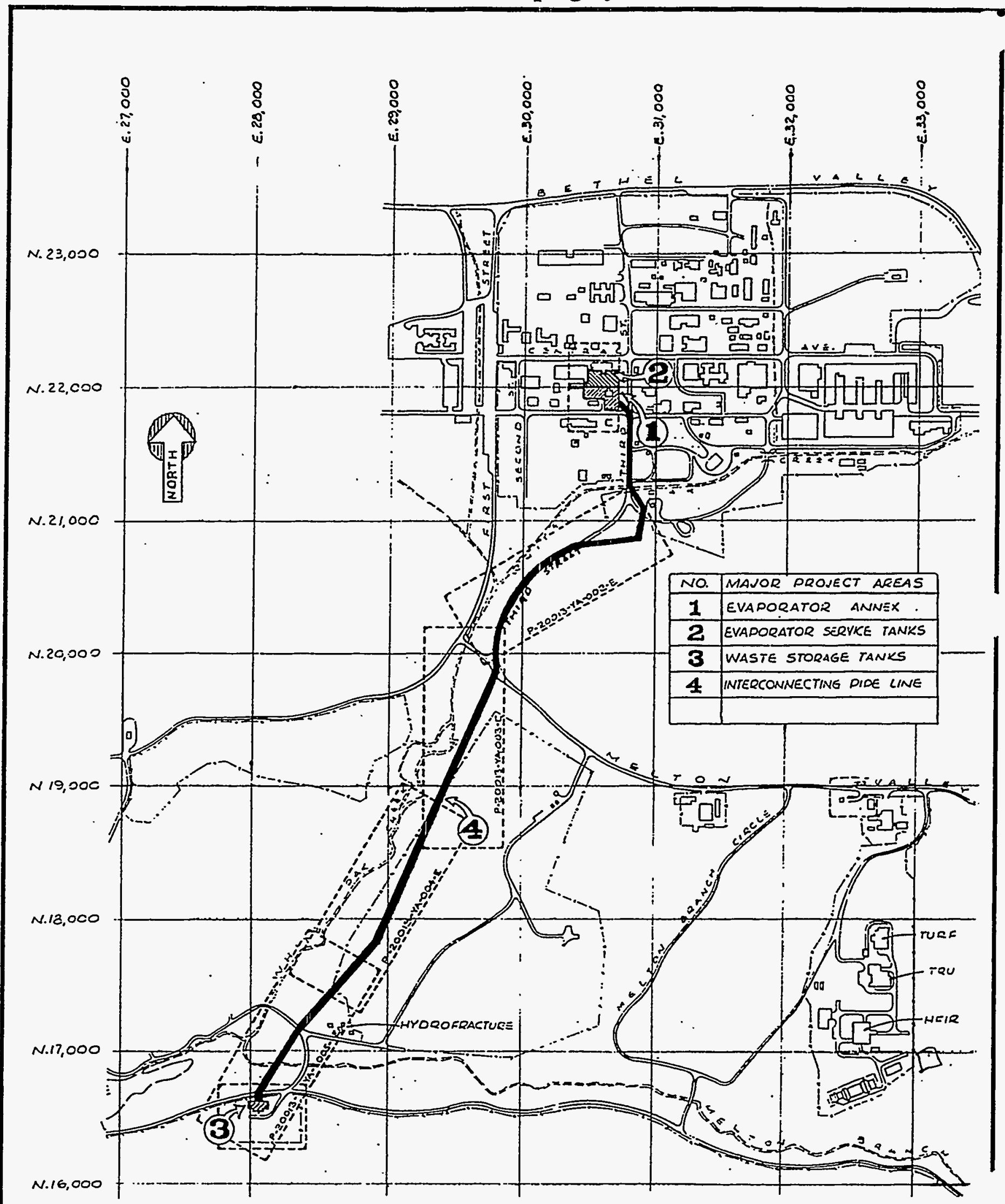




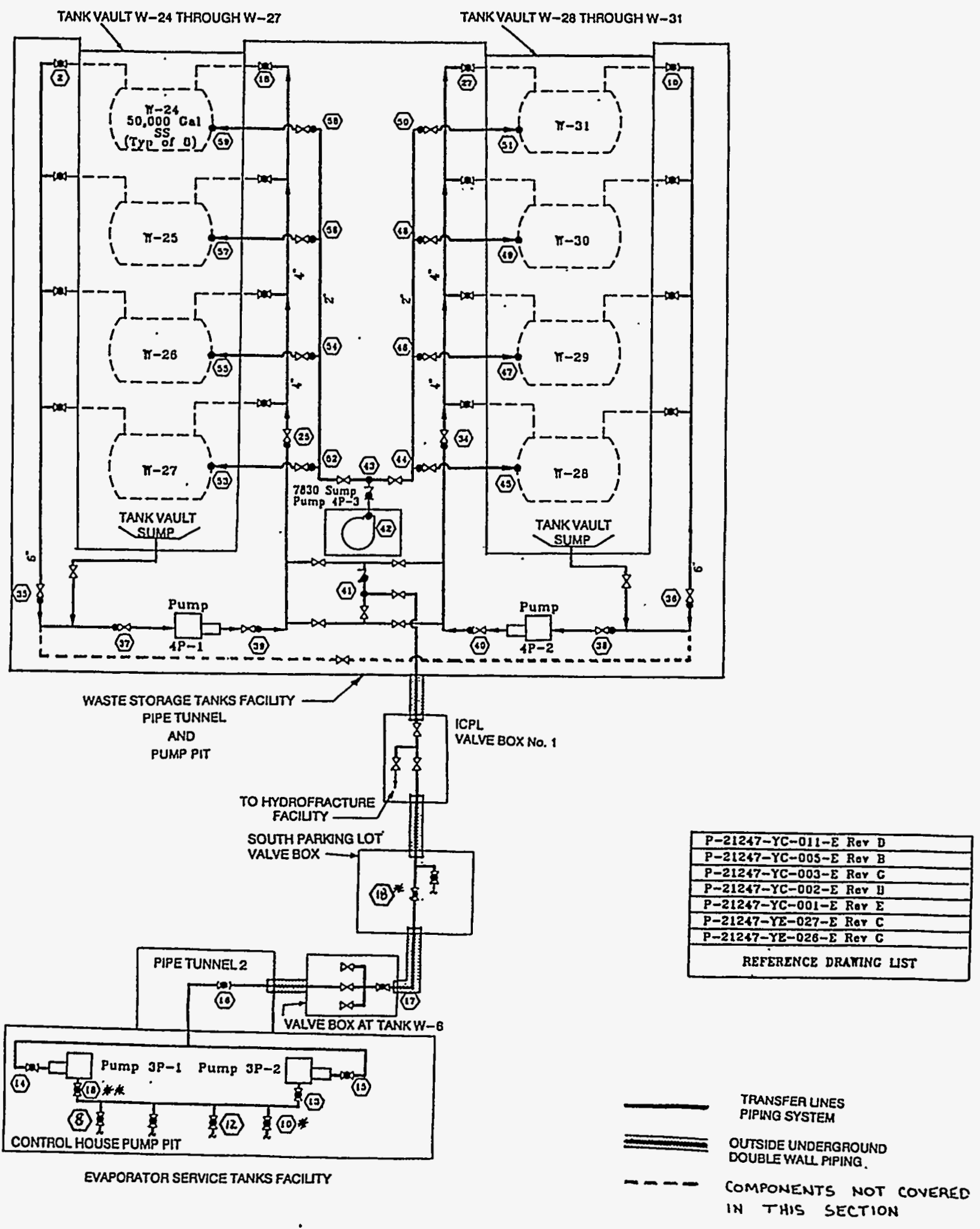


Figure 2.27-3 Transfer Lines Piping System Diagram (Sheet 2)

\begin{tabular}{|c|c|c|c|c|c|c|c|c|c|}
\hline LINE SEGMENT & (2) $-(35)$ & (39) $-(37)$ & (39) - (23) & (23) - (10) & (10) - (36) & (30) - (30) & (40)-(34) & (34) - (27) & (11) - (10) \\
\hline SIZE IN-DIA & 6 & 6 & 4 & 4 & 6 & 6 & 4 & 4 & 2 \\
\hline SCHEDULE & $40 \mathrm{~S}$ & $40 \mathrm{~S}$ & $40 \mathrm{~S}$ & $40 \mathrm{~S}$ & $40 \mathrm{~S}$ & $40 \mathrm{~S}$ & $40 \mathrm{~S}$ & 105 & 405 \\
\hline MATERIAL & SS & SS & SS & SS & SS & SS & SS & SS & ss \\
\hline LENGTH (FT) & 50 & 36 & 25 & 60 & 50 & 36 & 25 & 60 & 4724 \\
\hline VOLUME (GAL) & 75 & 54 & 17 & 40 & 75 & 54 & 17 & 40 & 824 \\
\hline
\end{tabular}

\begin{tabular}{|c|c|c|c|c|c|c|}
\hline LINE SEGMENT & $-(10 * *$ & $-(17)$ & -18) & -18 & - (10)**. & -12 \\
\hline SIZE IN-DIA & 2 & 2 & 2 & 2 & 4 & 4 \\
\hline SCHEDULE & $40 \mathrm{~S}$ & $40 \mathrm{~S}$ & $40 \mathrm{~S}$ & $10 \mathrm{~S}$ & $40 S$ & $40 \mathrm{~S}$ \\
\hline MATERLAL & SS & ss & SS & SS & SS & ss \\
\hline LENGTH (FT) & 1214 & 343 & 4 & 4 & 14 & 17 \\
\hline VOLUME (GAL) & 211 & 60 & 1 & 1 & 9 & 11 \\
\hline
\end{tabular}

\begin{tabular}{|c|c|c|c|c|c|c|}
\hline LINE SEGMENT & (10)* - 12 & (10)* $*$-13 & (12) - (43) & (19) - (50) & (19) $-(56$ & (Note 1) \\
\hline SIZE IN-DIA & 4 & 4 & 2 & 2 & 2 & 2 \\
\hline SCHEDULE & $40 \mathrm{~S}$ & $40 \mathrm{~S}$ & $40 \mathrm{~S}$ & $40 S$ & $40 S$ & $40 S$ \\
\hline MATERIAL & SS & SS & Ss & SS & SS & SS \\
\hline LENGTH (FT) & 5 & 12 & 8 & 63 & 63 & 64 \\
\hline VOLUME (GAL) & 3 & 8 & 1 & 11 & 11 & 11 \\
\hline
\end{tabular}

Notes:

(1) Typical for segments delined by Nodes $11-45$,

$46-47,48-49,50-51,52-53,54-55$,

$56-57$ and $58-59$. 
Figure 2.27-4 Radiochemical Analyses in the Evaporator Service Tanks

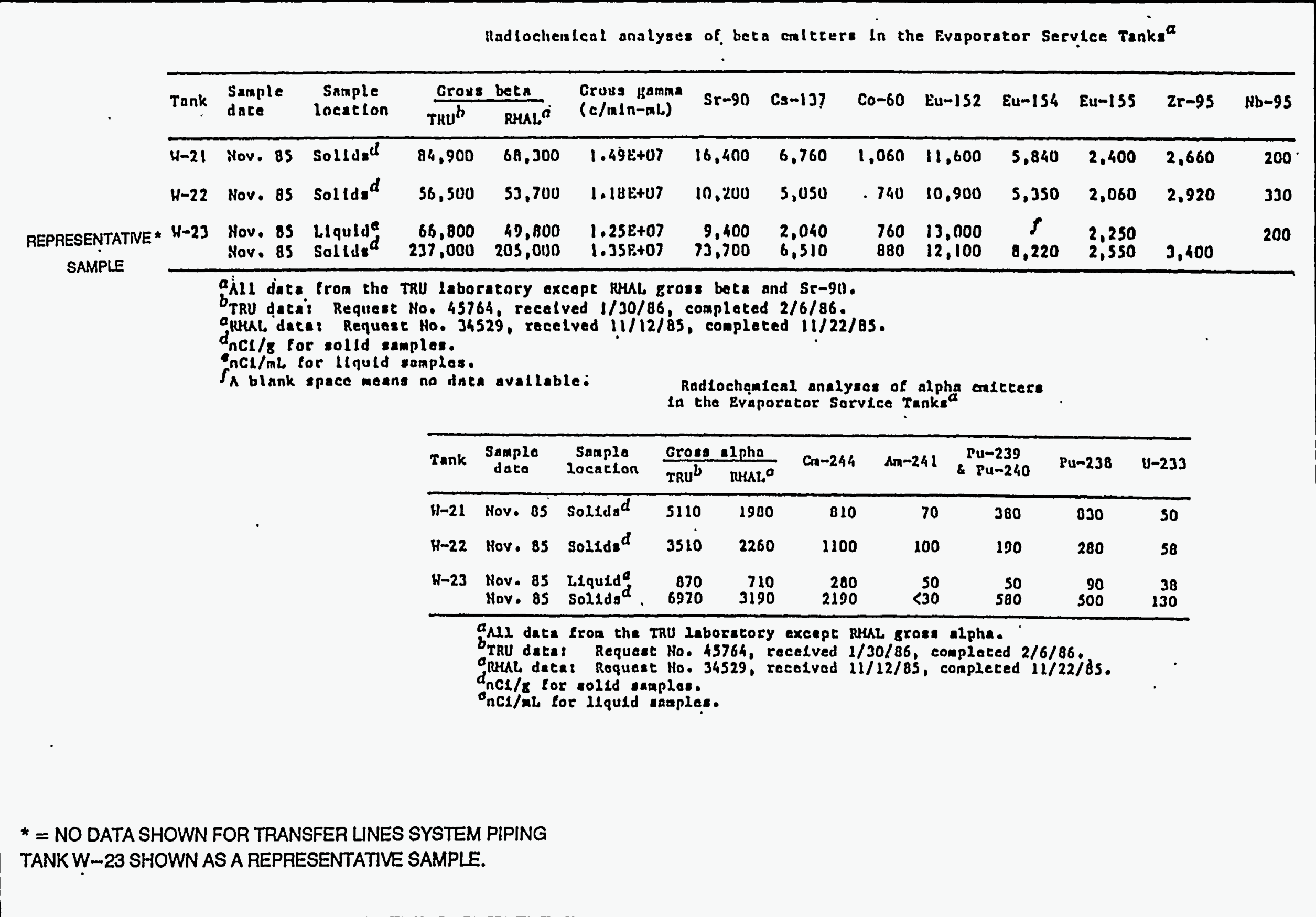


Figure 2.27-5

Analytical Data For Liquid and Sludge Samples (Evaporator Service Tanks)

\section{ANALYTICAL DATA FOR LIQUID SAMPLE}

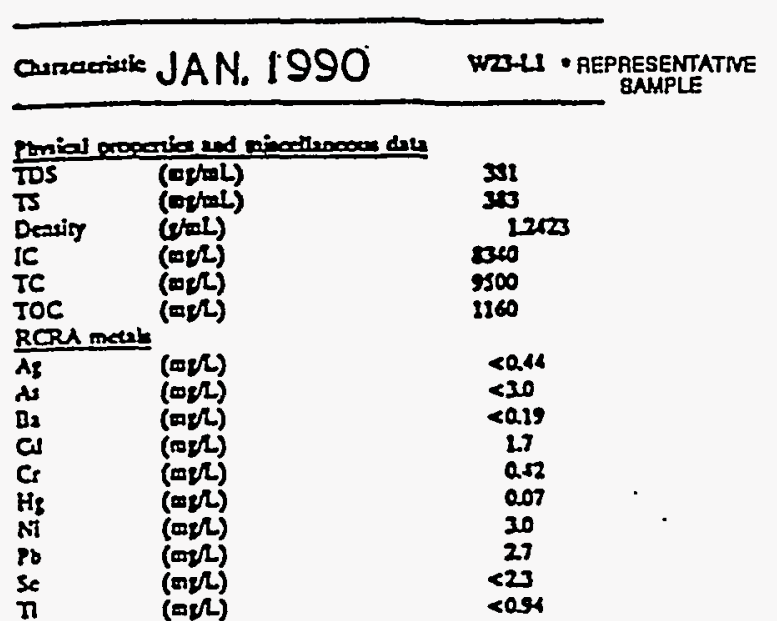

tom oxtst

0
0
$C_{2}$
$C_{0}$
$F_{c}$
$K$
$S_{6}$
$S_{2}$
$5 i$
58
$T R$
$U$
$U$

$(a \Omega)$

(ㅁㄴ)

( $( \pm 2)$

(me)

(mel)

(mel)

(mel)

(met)

(me)

Ciloride en

Averide (M)

Nitrite (M)

Prosphase $(M)$

Sulbite $(M)$

Altulinir

pH

H $\quad \dot{M}$

$\mathrm{OH}_{\mathrm{CO}}^{2} \quad \mathrm{CM}$

$\mathrm{HCO}_{3}-\mathrm{MO}$

Bextragras conittos

Gross alphar (Bg/nill)

Grous bela (Bofol)

"C (Batol)

"Ce (Bghl)

"Co (Bigl)

"Ba (B)

(Bqtal

HEv (Boml

$\omega_{E \square}$ (BqmL

HH (Bqtall

MNO (Bqtal)

${ }_{10}{ }_{R u}$ (Bqtal)

ist (Bqtat)

Nloha cmillars

IU (BqmL)

(Bqtal)

"Tor"so (BetmL

"PW"

गNCD (Befol)

18
10
18
20000
34
2000
$<1$
0.010
158

Q.10

$<0.053$

$<0053$

cosi

128

0.15

0.70

$20 x+01$
$402 x+05$

$43 t+01$

$<1<e+\infty$

$021 e+02$

$403 x+03$

$436 x+05$

$<2.1 e+02$

$<1<x+02$

C2S +02

$1.1 r+02$

$<1.0 x+02$

$378+03$

$4.12 x+02$

$<10 x+13$

$100 x+\infty$

$(c \infty)+\infty$

$290 x+01$
ANALYTICAL DATA FOR SLUDGE SAMPLE

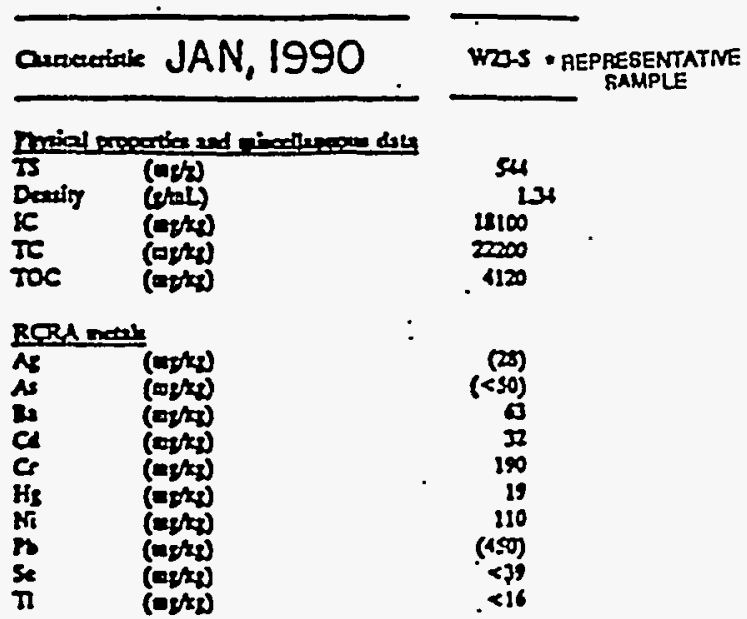

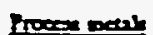

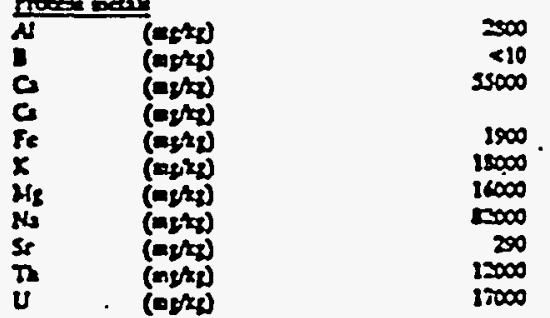

Revioniminos

Groen alghe (Degh)

Groes bets (ber)

"c (Bop)

wa (Bat)

"co (Ber

wa (B\%

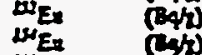

WE

on (Cy)

(Em

क्य.

Nphr minios

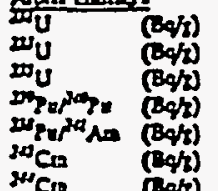

$<2 x+$ or

2.iketor

$3210+$ or

$<2(x+0)$
i.67etos

LEGEND:

TSD - TOTAL DISSOLVED SOLIDS

IC - INORGANIC CARBON

TC - TOTAL CARBON

TOC - TOTAL ORGANIC

CARBON

- = NO DATA SHOWN FOR TRANSFER LINES SYSTEM PIPING

TANK W-23 SHOWN AS A REPRESENTATIVE SAMPLE. 


\subsubsection{Tank System Summary}

Tank System S-223 is located near the Fission Product Development Laboratory (Building 3517) at the main Bethel Valley Complex (Figures 2.28-1 and 2.28-2). The tank system piping is schedule 40S, ASME SA-240, type 304L and type 347 stainless steel (SS) and is routed from Tank Vault S-223 (Cell 23) to the Cell 25 Pipe Tunnel and then outside underground through Valve Box 2A to Valve Box No. 2. Tank System S-223 piping is used to transfer liquid lowlevel waste (LLLW) from Building 3517 and waste from tank-farm cell sumps to Tank S-223 and is classified as Federal Facility Agreement (FFA) Category B tank system.

\subsubsection{Standards for Pipe Assessment of Tank Systems}

\section{-2.28.2.1 Tank System Piping Description and Design Standards}

\section{$\underline{\text { Tank System Piping Description }}$}

Tank System S-223 piping is located near Building 3517 and is routed from Tank Vault S-223 to Cell 25 Pipe Tunnel and then outside underground through Valve Box 2A to Valve Box No. 2. The piping system is used and managed by the Chemical Technology Division.

Tank System S-223 piping is constructed of $1-1 / 2^{\prime \prime}$ and $2^{\prime \prime}$, schedule 40S, type 304L and 347 SS with a maximum design pressure and temperature of $150 \mathrm{psig}$ and $125^{\circ} \mathrm{F}$. The outside underground jacket is constructed of $3 "$ ", schedule 10S, type 304L SS with a maximum design pressure and temperature of 150 psig and $32^{\circ} \mathrm{F}$. Tank System S-223 piping has the capacity to contain a maximum volume of approximately 82 gal.

\section{$\underline{\text { Design Standards }}$}

The applicable codes and standards used for Tank System S-223 piping and its associated secondary containment systems are identified herein. The codes and standards listed are those identified on either the design drawings or the construction specifications.

American Society for Testing and Materials A15-52T, A160-52T, A16-52T, A305-53T, A185-37, C39-49, C192-52T, C31-49, C33-52T, C39-49, C40-48, C42-49, C94-48, C150-53, and D544-52T;

American Society of Heating, Refrigeration, and Air Conditioning Engineers (ASHRAE) Handbook of Fundamentals;

American Society of Mechanical Engineers (ASME) Boiler and Pressure Vessel Code, Section II (SA-240);

American Standards Association; 
American Welding Society;

ASHRAE Guide and Data Book-Applications;

ASHRAE Guide and Data Book-Equipment;

Atomic Energy Commission Safety Code;

Federal Specifications LLL-F-321, Class A LLLF321;

National Electric Code; and

Underwriters Laboratories Inc.

\subsubsection{Generic Description of Piping Contents}

Tank System S-223 piping is designed to transfer LLLW from a variety of operations such as supernate from cesium and strontium precipitation, raffinates from a cesium-144 extraction process, and general decontamination solutions. Tank System S-223 piping may contain radioactive materials.

The analytical data (Figure 2.28-3) of waste stream contaminants from the generators are representative of the waste transferred through Tank System S-223 piping.

\subsubsection{Pipe Corrosion Protection Measures}

Piping inside Tank Vault S-223, the Cell 25 Pipe Tunnel, Valve Box 2A, and Valve Box No. 2 has no direct contact with the soil or water. Cathodic protection measures are not required for external corrosion.

The pipe routed outside underground from the Cell 25 Pipe Tunnel to Valve Box 2A and from Valve Box $2 \mathrm{~A}$ to Valve Box 2 is approximately $440^{\prime}$ in length and is double-wall piping with cathodic protection (with the exception of a segment of singly contained piping approximately $10^{\prime}$ in length located just outside the Cell 25 Pipe Tunnel). The cathodic protection for the outside underground piping is included in the Facility Manager's Cathodic Protection System No. 21. The cathodic protection system consists of magnesium anodes, test stations, and connection wire as shown on drawing E3E20013D031. The piping and cathodic protection system were designed and installed in 1985. The use of electrical isolation devices could not be identified on the design drawings. The cathodic protection system design as shown on the drawings reviewed is not considered to be adequate. The cathodic protection survey and test report performed in 1990 and 1991 yielded data that demonstrate a lack of effective overall cathodic protection on this piping system. This is due mainly to the lack of electrical isolation of the outside underground portion of the piping. In 1991, Harco completed the engineering design to upgrade the existing system. 


\subsubsection{Documented Age of Tank System}

A portion of Tank System S-223 piping was installed in 1955. The underground, double-wall piping was installed in 1985.

\subsubsection{Standards for Containment/Release Detection}

Tank System S-223 piping incorporates approximately $10^{\prime}$ of outside underground piping at the Cell 25 Pipe Tunnel that is singly contained. The singly contained areas are omitted from discussion in the following sections that address secondary containment.

2.28.3.1 Constructed of or Lined with Materials That are Compatible with Stored Waste(s) or Substance(s) to Be Placed in the Tank System and Shall Have Sufficient Strength and Thickness to Prevent Failure

Tank System S-223 piping is 1-1/2" and 2", schedule 40S, type 304L and type 347 SS piping that is routed from Tank Vault S-223 (Cell 23) to the Cell 25 Pipe Tunnel and then outside underground through Valve Box $2 \mathrm{~A}$ to Valve Box No. 2. The areas of secondary containment are discussed below. The piping penetrations from Tank Vault S-223 to Cell 25 and from Cell 25 to outside underground are singly contained, 1-1/2", schedule 40S, type 304L SS pipes that are embedded in the concrete wall to a length of $2^{\prime} 0^{\prime \prime}$ and $1^{\prime} 0^{\prime \prime}$, respectively.

The piping routed from the Cell 25 Pipe Tunnel to Valve Box $2 \mathrm{~A}$ is double wall with a 1-1/2", schedule 40S, type 304L SS core pipe and 3", schedule 10S, type 304L SS jacket. The piping routed from Valve Box $2 \mathrm{~A}$ to Valve Box No. 2 is double wall with a 2", schedule 40S, type 304L SS core pipe and a 3", schedule 10S, type 304L SS jacket.

\section{$\underline{\text { Tank Vault S-223 }}$}

The assessment of the secondary containment system for Tank Vault S-223 is presented in the Design Demonstrations for Tank S-223. That assessment concludes that Tank Vault S-223 is coated with materials that are compatible with the waste and designed to prevent migration of waste into the concrete.

\section{Cell 25 Pipe Tunnel}

The interior surfaces of Cell 25 are provided with a system of Amercoat 23 and 33 epoxy coating. According to manufacturer's specifications, the cell's epoxy coating is compatible with the waste and designed to prevent migration of waste into the concrete. 


\section{Valve Box 2A}

The bottom of Valve Box $2 \mathrm{~A}$ is lined with 16-gauge (1/16"), 304L SS, with sidewalls that project $2^{\prime} 0^{\prime \prime}$ up the valve box. The SS valve box lining material, which is the same material as that used for the piping, is compatible with the waste and designed to prevent migration of waste into the concrete.

\section{Valve Box No. 2}

The bottom of Valve Box No. 2 is lined with 16-gauge (1/16"), 304L SS, which is the same material as that used for the piping, and projects $2^{\prime} 0^{\prime \prime}$ up the sidewalls of the valve box. The SS valve box lining material is compatible with the waste and designed to prevent migration of waste into the concrete.

\section{Outside Underground Piping}

The jacket of the outside underground, double-wall pipe is 304L SS. The secondary containment material is compatible with the waste.

The assessment concludes that Tank Vault S-223, Cell 25, Valve Box 2A, and Valve Box No. 2 are coated or lined with materials that are compatible with the waste and designed to prevent migration of waste into the concrete. The assessment concludes that the jacket of the underground piping is compatible with the waste.

\subsubsection{Placed on Foundation or Base Capable of Providing Support to the Secondary Containment System}

\section{Tank Vault S-223}

The assessment of the secondary containment system for Tank Vault S-223 is presented in the Design Demonstrations for Tank S-223. That assessment concludes that the vault foundation is properly designed to support the secondary containment system.

\section{Cell 25 Pipe Tunnel}

The Cell 25 foundation is a $6^{\prime} 6^{\prime \prime} \times 63^{\prime} 8^{\prime \prime} \times 1^{\prime} 3^{\prime \prime}$ thick, reinforced concrete base slab that rests on limestone.

\section{Valve Box 2A}

The valve box foundation is an $8^{\prime} 0^{\prime \prime} \times 12^{\prime} 0^{\prime \prime} \times 1^{\prime} 0^{\prime \prime}$ thick, reinforced concrete base slab that rests on crushed stone. 


\section{Valve Box No. 2}

The valve box foundation is a $6^{\prime} 8^{\prime \prime} \times 14^{\prime} 4^{\prime \prime} \times 10^{\prime \prime}$ thick, reinforced concrete base slab that rests on limestone.

The assessment concludes that Tank Vault S-223, Cell 25, Valve Box 2A, and Valve Box No. 2 are properly designed to support the secondary containment systems.

2.28.3.3 Provided with a Leak Detection System That is Designed and Operated to Detect Failure of Either Primary or Secondary Containment Structure or the Presence of Any Measurable Release of Hazardous or Radioactive Constituents

\section{$\underline{\text { Tank Vault S-223 }}$}

The assessment of the secondary containment system for Tank Vault S-223 is presented in the Design Demonstrations for Tank S-223. That assessment concludes that the vault is provided with a leak detection system.

\section{Cell 25 Pipe Tunnel}

The Cell 25 floor is sloped to an epoxy-coated sump where accumulation of liquid will be detected by a level sensor that will activate an alarm in the operating area of Building 3517.

\section{Valve Box 2A}

The Valve Box 2A floor is sloped to a 16-gauge (1/16"), 304L SS-lined sump where accumulation of liquid will be detected by a level sensor that will activate an alarm in the Waste Operations Control Center (Building 3130).

\section{Valve Box No. 2}

The Valve Box No. 2 floor is sloped to a 16-gauge (1/16"), 304L SS-lined sump where accumulation of liquid will be detected by a level sensor that will activate an alarm in the Waste Operations Control Center (Building 3130).

\section{Outside Underground Piping}

The outside underground, double-wall piping is provided with a nitrogen-blanketed leak detection system.

The assessment concludes that Tank Vault S-223, Cell 25, Valve Box 2A, Valve Box No. 2, and the outside underground piping are provided with leak detection. 
Design Demonstrations - Category B Tank Systems (Piping)

\subsubsection{Sloped or Otherwise Designed or Operated to Drain and Remove Liquids Resulting from Leaks, Spills, or Precipitation}

\section{Tank Vault S-223}

The assessment of the secondary containment system for Tank Vault S-223 is presented in the Design Demonstrations for Tank S-223. That assessment concludes that the secondary containment is sloped and designed to drain and remove liquids resulting from leaks, spills, or precipitation.

\section{Cell 25 Pipe Tunnel}

The Cell 25 floor is sloped to an epoxy-coated sump. The sump provides a low point within Cell 25 to drain liquids to an instrumented location. A pumping system is provided to remove liquids that accumulate in the sump.

\section{Valve Box 2A}

The Valve Box 2A floor is sloped to a 304L SS-lined sump. The sump provides a low point within the valve box to drain liquids to an instrumented location. A pumping system is provided to remove liquids that accumulate in the sump.

\section{Valve Box No. 2}

The Valve Box No. 2 floor is sloped to a 304L SS-lined sump. The sump provides a low point within the valve box to drain liquids to an instrumented location. A pumping system is provided to remove liquids that accumulate in the sump.

\section{Outside Underground Piping}

The outside underground, double-wall piping is provided with $1 / 2$ " drain test connections to remove liquids resulting from leaks.

The assessment concludes that Tank Vault S-223, Cell 25, Valve Box 2A, Valve Box No. 2, and the outside underground piping are sloped and designed to drain and remove liquids resulting from leaks, spills, or precipitation.

\subsubsection{Supplemental Information}

\subsubsection{Ancillary Equipment}

Tank S-223 is constructed of $304 \mathrm{~L}$ SS, which is the same material as that used in the piping system, and is located in Tank Vault S-223, which provides secondary containment. The support equipment is exposed to the same liquids as other components of the tank system; therefore, $304 \mathrm{~L}$ SS is an acceptable material for the support equipment. 


\subsubsection{Waste Acceptance Criteria}

Radioactively contaminated liquid wastes at ORNL are generated by various activities within the research and operating divisions. These activities include radiochemical processing, routine hot cell operations and decontaminations, and various waste treatment and environmental protection processes. The variations in composition of the waste streams are limited by the waste acceptance criteria that specify activity and concentration limits for waste discharged into the LLLW system. The Waste Acceptance Criteria for Liquid Waste Treatment Systems at the Oak Ridge National Laboratory (Oak Ridge National Laboratory, 1991), dated July 1991, is a guide for liquid waste generators to determine the proper means of disposal for LLLW. The criteria provide future discharge guidelines for the LLLW system, which includes Tank System S-223. 
Design Demonstrations - Category B Tank Systems (Piping)

\subsubsection{References}

Construction Specification, Multicurie Fission Products Pilot Plant in Building 3517. Invitation No. 401-55-8A.

Ebasco, and Main. May 14, 1993. Design Demonstrations-Category B Tank Systems, Revision 2. DOE Contract No. DE-AC05-91OR21928. Oak Ridge National Laboratory

Energy Systems Drawing P3E-20013-C020, Building 3517 Low-Level Waste Collection Double Contained Pipe Detail, Revision 0.

Energy Systems Drawing P3E-20013-C019, Building 3517 Low-Level Waste Collection Partial Plan, Section and Details, Revision 0.

Energy Systems Drawing P3E-20013-C018, Building 3517 Low-Level Waste Collection Profile Double Contained Pipe, Revision 0.

Energy Systems Drawing P3E-20013-C017, Building 3517 Low-Level Waste Collection Underground Piping and Pit Location, Revision 0.

Energy Systems Drawing E3E-20013-D027, Building 3517 Low-Level Waste Collection, ORNL Signal System Sections and Details, Revision 0.

Energy Systems Drawing P3E-20013-C021, Building 3517 Low-Level Waste Collection, Piping Details, Revision 0.

Energy Systems Drawing E3E-20013-D031, Building 3517 Low-Level Waste Collection, Cathodic Protection, Revision 0.

Energy Systems Drawing S3E-20013-B002, Building 3517 Low-Level Waste Collection, Valve Pit 2A Section and Detail, Revision 0.

Energy Systems Drawing D22807, Building 3517, Elevations, Foundation Plan Tank Farm, Revision 2.

Energy Systems Drawing D22806, Building 3517, Elevations, Foundation Walls, Revision 4.

Energy Systems Drawing D22805, Building 3517, Foundation Plan and Details, Revision 3.

Energy Systems Drawing E31394, Building 3517, Phase II, Jet and Piping Schedule, Dated 4/10/58 (No Revision No.).

Energy Systems Drawing D24327, Building 3517, Phase II, Piping Schedule, Process Line, Revision 3. 
Energy Systems Drawing D24341, Building 3517, Phase II, Piping Schedule, Service Line, Revision 3.

Energy Systems Drawing D24398, Building 3517, Phase II, Piping Plan Cell 23, Revision 3.

Energy Systems Drawing D26832, Building 3517, Phase II, Piping Cell 25 Plan 1, Revision 4. Energy Systems Drawing D26833, Building 3517, Phase II, Piping Cell 25 Plan 2, Revision 3. Energy Systems Drawing D26834, Building 3517, Phase II, Piping Cell 25 Plan 3, Revision 3. Energy Systems Drawing D26835, Building 3517, Phase II, Piping Cell 25 Section A-A, Revision 3.

Energy Systems Drawing D26836, Building 3517, Phase II, Piping Cell 25 Section C-C, Revision 6.

Energy Systems Drawing D26837, Building 3517, Phase II, Piping Cell 25 Section D-D, Revision 5.

Energy Systems Drawing D26838, Building 3517, Phase II, Piping Plan Cell 26, Revision 2.

Energy Systems Drawing D22811, Building 3517, Plan, Tank Farm Sleeves, Revision 5.

Energy Systems Drawing D22812, Building 3517, Sections and Details, Tank Farm Sleeves, Revision 6.

Energy Systems Drawing D22808, Building 3517, Tank Farm, Sections and Details, Revision 2.

Energy Systems Drawing D22809, Building 3517, Tank Farm, Sections and Details, Revision 1.

Energy Systems Drawing D22810, Building 3517, Tank Farm, Sections and Details, Revision 2.

Harco Technologies Corporation. June 1990. Resurvey of the Cathodic Protection Systems, Oak Ridge National Laboratories, United States Department of Energy, Oak Ridge, Tennessee. Martin Marietta Energy Systems, Inc.

Harco Technologies Corporation. August 1991. Cathodic Protection System Upgrade Design

LLLW Generator Survey 1990 for Building 3517

Oak Ridge National Laboratory. 1991. Waste Acceptance Criteria for Liquid Waste Treatment Systems at the Oak Ridge National Laboratory. WM-WMCO-201. Department of Waste Minimization Planning and Certification. 
Risk Evaluation of Embedded, Single-Walled Liquid Low-Level Waste Piping at Oak Ridge National Laboratory.

Robinson, S. M., S. M. DePaoli, and A. B. Walker. 1991. Federal Facility Agreement Contingency, Upgrade, and Replacement Plans for the ORNL Active Low-Level Radioactive Waste Tank System. ORNL/TM-11795. Oak Ridge National Laboratory.

Underground ILW Lines, Building 3517 to VLV Box 2, System No. 21, Oak Ridge National Laboratories, United States Department of Energy, Oak Ridge, Tennessee. Martin Marietta Energy Systems, Inc. 


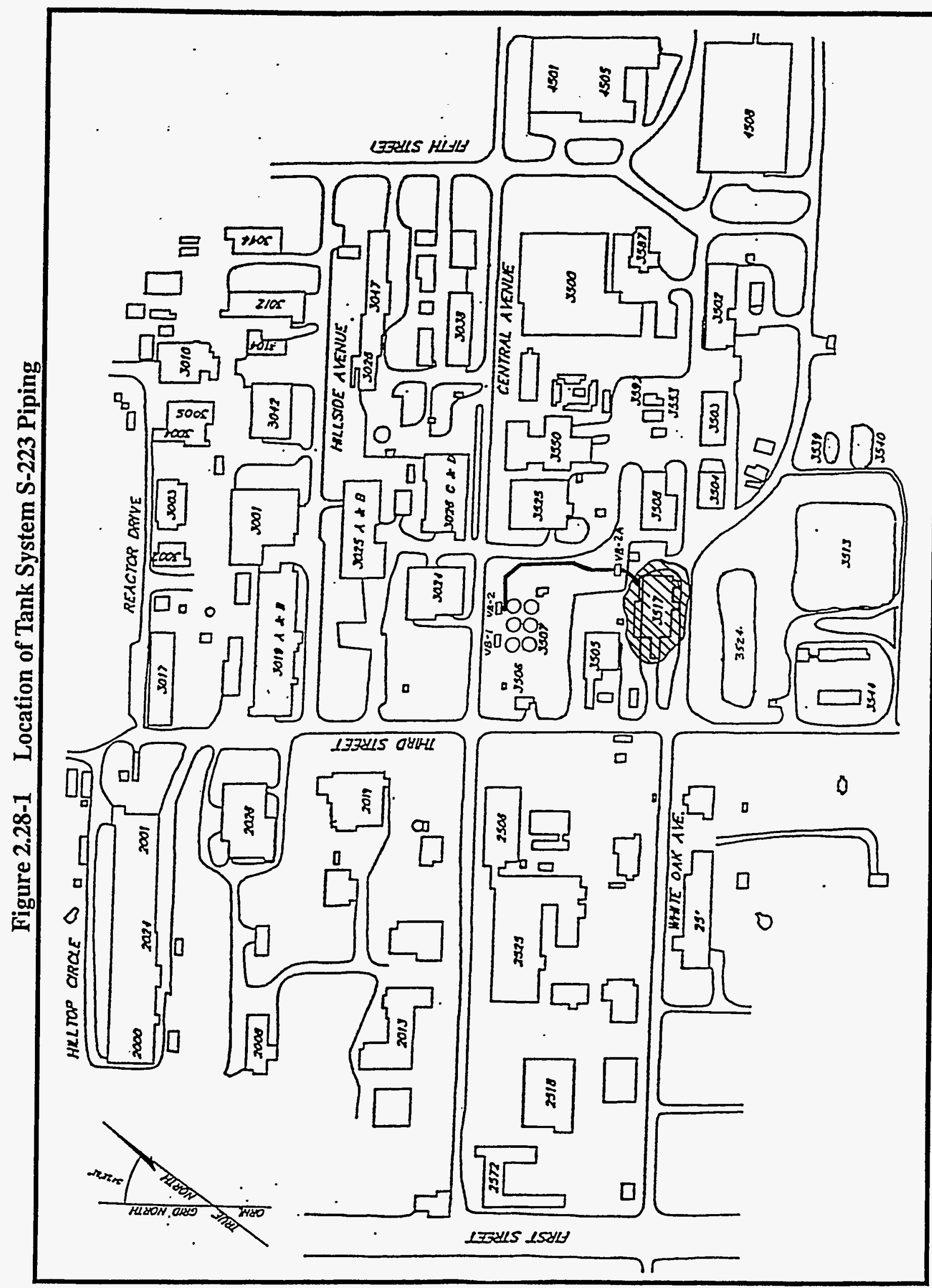


NOIDJJS SIHI NI

OJY3NOJ LON SINZNOSWOJ - - -

azNivero) s78no

Id'd ONnOZ943ON

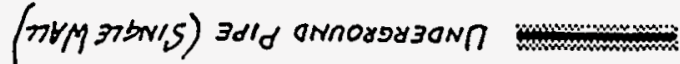

DNIdId ELZ-S WJLSAS XNEI

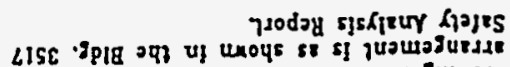

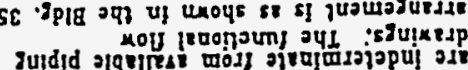

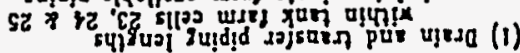

\begin{tabular}{|c|c|c|c|}
\hline$\varepsilon 9$ & $\angle$ & 1 & 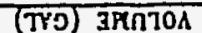 \\
\hline $09 \varepsilon$ & $\overline{O L}$ & of & (Id) HLON37 \\
\hline 55 & 5S & SS & TVIQSIVI \\
\hline 500 & SOt & $50 \mathrm{H}$ & 37กaรHวS \\
\hline .2 & $.7 / 11$ & $-2 / 1$ & VIa-NI azis \\
\hline (7) $-\sqrt{\varepsilon}$ & (ह) - (2) & (2) - (1) & JNaIYOJS INIT \\
\hline
\end{tabular}
:s?ion
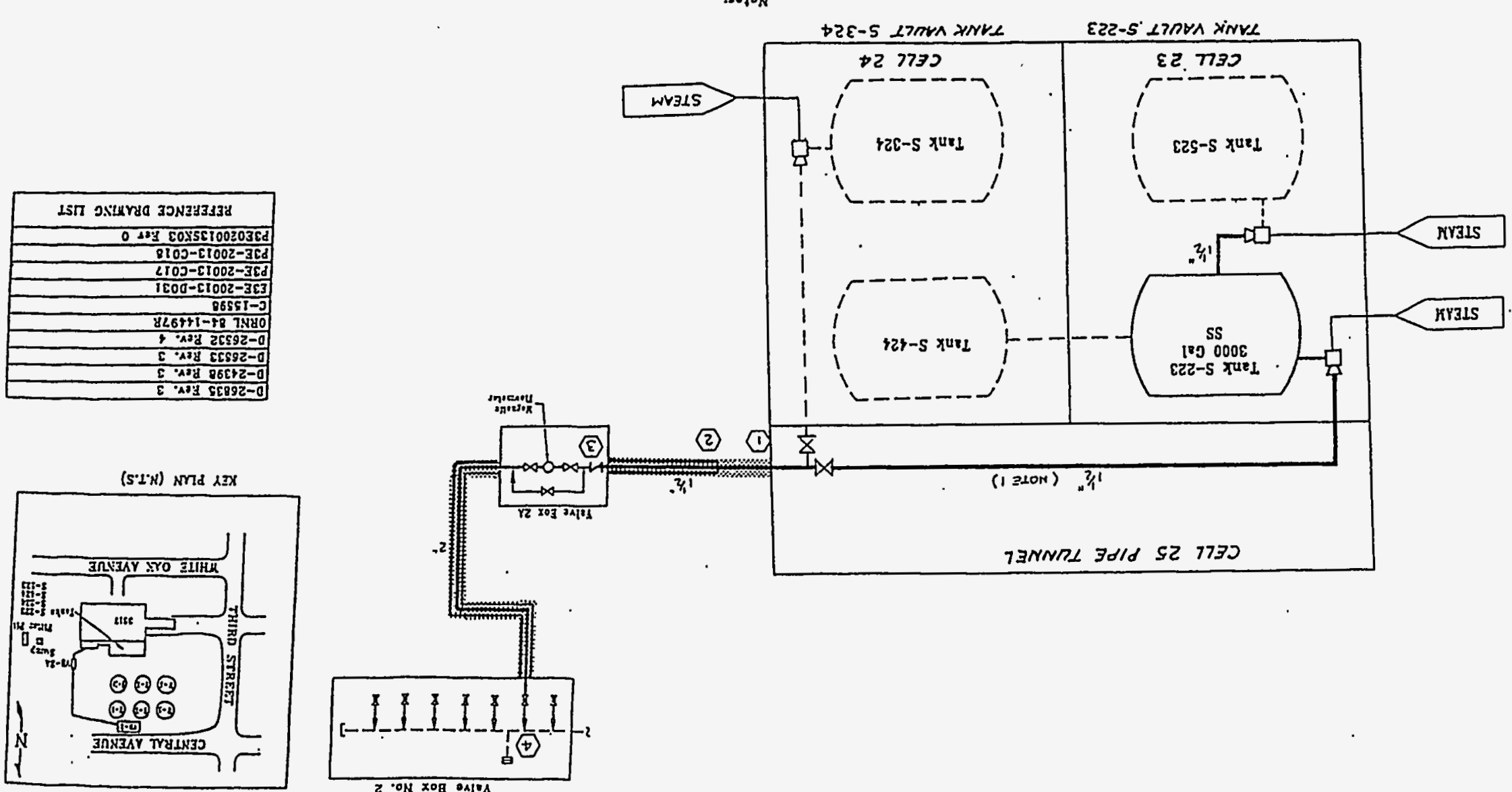

$z$ or $\times 08$ oxid 


\section{LLLW Generator SURVEY-1990}

$\begin{aligned} & \text { Isotopes: } \text { Cs }-137 \\ & \text { Sr }-90\end{aligned}$

Others (i.e. acids, bases, organics, cleaners, etc.)
Quantities: $500.00 \mathrm{Ci} /$ year

$500.00 \mathrm{Ci} /$ year

$25.0 \mathrm{Ibs} /$ year

Unknown

Unknown

Unknown 


\subsubsection{Tank System Summary}

Tank System S-324 is located near the Fission Product Development Laboratory (Building 3517) at the main Bethel Valley Complex (Figures 2.29-1 and 2.29-2). The tank system piping is schedule 40S, ASME SA-240, type 347 stainless steel (SS) and is routed from the Electro Polisher and Offgas Scrubber System floor drains through the Cells 1 through 9 Pipe Trench, the Building 3517 Pipe Trench, and the Cell 25 Pipe Tunnel to Tank Vault S-324. Tank System S-324 piping is used to transfer liquid low-level waste (LLLW) from the Electro Polisher and Offgas Scrubber System floor drains to Tank S-324 and further to the Evaporator and is classified as a Federal Facility Agreement (FFA) Category B tank system.

\subsubsection{Standards for Pipe Assessment of Tank Systems}

\subsubsection{Tank System Piping Description and Design Standards}

\section{Tank System Piping Description}

Tank System S-324 piping is located near Building 3517 and is routed from the Electro Polisher and Offgas Scrubber System floor drains through the Cells 1 through 9 Pipe Trench, the Building 3517 Pipe Trench and the Cell 25 Pipe Tunnel to Tank Vault S-324. The piping system is used and managed by the Chemical Technology Division.

Tank System S-324 piping is constructed of 1-1/2" and $2^{\prime \prime}$, schedule 40S, type 347 SS with a maximum design pressure and temperature of 150 psig and $125^{\circ} \mathrm{F}$. Tank System S-324 piping has the capacity to contain a maximum volume of approximately $50 \mathrm{gal}$.

\section{$\underline{\text { Design Standards }}$}

The applicable codes and standards used for Tank System S-324 piping and its associated secondary containment systems are identified herein. The codes and standards listed are those identified on either the design drawings or the construction specifications.

American Society for Testing and Materials A15-52T, A160-52T, A16-52T, A305-53T, A-185-37, C39-49, C192-52T, C31-49, C33-52T, C39-49, C40-48, C42-49, C94-48, C150-53, and D544-2T;

American Society of Heating, Refrigeration, and Air Conditioning Engineers (ASHRAE) Handbook of Fundamentals;

American Society of Mechanical Engineers (ASME) Boiler and Pressure Vessel Code, Section II (SA-240);

American Welding Society; 
ASHRAE Guide and Data Book-Applications;

ASHRAE Guide and Data Book-Equipment;

Atomic Energy Commission Safety Code;

Federal Specifications LLL-F-321, Class A LLLF321;

National Electric Code; and

Underwriters Laboratories Inc.

\subsubsection{Generic Description of Piping Contents}

Tank System S-324 piping is designed to transfer LLLW from a variety of operations, such as supernate from cesium and strontium precipitation, raffinates from a cesium-144 extraction process, and general decontamination solutions. Tank System S-324 piping may contain radioactive materials.

The analytical data (Figure 2.29-3) of waste stream contaminants from the generators are representative of the waste transferred through Tank System S-324 piping.

\subsubsection{Pipe Corrosion Protection Measures}

Piping inside the Cells 1 through 9 Pipe Trench, the Building 3517 Pipe Trench, the Cell 25 Pipe Tunnel, and Tank Vault S-324 has no direct contact with the soil or water. Cathodic protection measures are not required for external corrosion.

\subsubsection{Documented Age of Tank System}

Tank System S-324 piping was installed in 1955.

\subsubsection{Standards for Containment/Release Detection}

Tank System S-324 piping incorporates approximately $24^{\prime}$ of embedded floor drain and wall penetration piping that is singly contained. The singly contained areas are omitted from discussion in the following sections that address secondary containment.

2.29.3.1 Constructed of or Lined with Materials That are Compatible with Stored Waste(s) or Substance(s) to Be Placed in the Tank System and Shall Have Sufficient Strength and Thickness to Prevent Failure

Tank System S-324 piping is single-wall, schedule 40S, type 347 SS that is routed from the Electro Polisher and Offgas Scrubber floor drains in Building 3517 through the Cells 1 through 9 
Pipe Trench, the Building 3517 Pipe Trench, and the Cell 25 Pipe Tunnel to Tank Vault S-324. Each area is discussed below.

\section{Cells 1 Through 9 Pipe Trench}

The bottom of the pipe trench is lined with $1 / 4^{\prime \prime}$, 304L SS, with 11-gauge (1/8"), 304L SS sidewalls that project up to the cell's roof. The SS cell lining material, which is a similar material as that used for the piping, is compatible with the waste and designed to prevent migration of waste into the concrete.

\section{Building 3517 Pipe Trench}

The interior surfaces of the pipe trench are provided with a system of Amercoat 23 and 33 epoxy coating. According to manufacturer's specifications, the pipe trench's epoxy coating is compatible with the waste and designed to prevent migration of waste into the concrete.

\section{Cell 25 Pipe Tunnel}

The interior surfaces of the cell are provided with a system of Amercoat 23 and 33 epoxy coating. According to manufacturer's specifications, the cell's epoxy coating is compatible with the waste and designed to prevent migration of waste into the concrete.

\section{$\underline{\text { Tank Vault S-324 }}$}

The assessment of the secondary containment system for Tank Vault S-324 is presented in the Design Demonstrations for Tank S-324. That assessment concludes that Tank Vault S-324 is coated with materials that are compatible with the waste and designed to prevent migration of waste into the concrete.

The assessment concludes that the pipe trenches, cell, and tank vault are coated or lined with materials that are compatible with the waste and designed to prevent migration of waste into the concrete.

\subsubsection{Placed on Foundation or Base Capable of Providing Support to the Secondary Containment System}

\section{Cells 1 Through 9 Pipe Trench}

The pipe trench foundation is a $29^{\prime} 6^{\prime \prime} \times 89^{\prime} 0^{\prime \prime} \times 2^{\prime} 0^{\prime \prime}$ thick, reinforced concrete base slab that rests on limestone. 


\section{Building 3517 Pipe Trench}

The pipe trench foundation is a $7^{\prime} 6^{\prime \prime} \times 40^{\prime} 0^{\prime \prime} \times 11^{\prime \prime}$ thick, reinforced concrete base slab that rests on limestone.

\section{Cell 25 Pipe Tunnel}

The cell foundation is a $6^{\prime} 6^{\prime \prime} \times 63^{\prime} 8^{\prime \prime} \times 1^{\prime} 3^{\prime \prime}$ thick, reinforced concrete base slab that rests on limestone.

\section{Tank Vault S-324}

The assessment of the secondary containment system for Tank Vault S-324 is presented in the Design Demonstrations for Tank S-324. That assessment concludes that the vault foundation is properly designed to support the secondary containment system.

The assessment concludes that the pipe trenches, cell, and tank vault foundations are properly designed to support the secondary containment systems.

2.29.3.3 Provided with a Leak Detection System That is Designed and Operated to Detect Failure of Either Primary or Secondary Containment Structure or the Presence of Any Measurable Release of Hazardous or Radioactive Constituents

\section{Cells 1 Through 9 Pipe Trench}

The pipe trench floor is sloped to the epoxy-coated Building 3517 Pipe Trench, which is sloped to the epoxy-coated Cell 25 Pipe Tunnel. Accumulation of liquid will flow from the pipe trenches to the Cell 25 sump and will be detected by a level sensor that will activate an alarm in the operating area of Building 3517.

\section{Building 3517 Pipe Trench}

The pipe trench floor is sloped to the epoxy-coated Cell 25 Pipe Tunnel. Accumulation of liquid will flow by gravity from the pipe trench to the Cell $25 \mathrm{sump}$ and will be detected by a level sensor that will activate an alarm in the operating area of Building 3517.

\section{Cell 25 Pipe Tunnel}

The cell floor is sloped to an epoxy-coated sump where accumulation of liquid will be detected by a level sensor that will activate an alarm in the operating area of Building 3517. 


\section{Tank Vault S-324}

The assessment of the secondary containment system for Tank Vault S-324 is presented in the Design Demonstrations for Tank S-324. That assessment concludes that the vault is provided with a leak detection system.

The assessment concludes that the pipe trenches, cell, and tank vault are provided with leak detection.

\subsubsection{Sloped or Otherwise Designed or Operated to Drain and Remove Liquids} Resulting from Leaks, Spills, or Precipitation

\section{Cells 1 Through 9 Pipe Trench}

The pipe trench floor is sloped to the Building 3517 Pipe Trench, which slopes into the epoxycoated Cell 25 sump. The cell sump provides a low point to drain liquids to an instrumented location. A pumping system is provided to remove liquids that accumulate in the sump.

\section{Building 3517 Pipe Trench}

The pipe trench floor is sloped to the epoxy-coated Cell 25 sump. The cell sump provides a low point to drain liquids to an instrumented location. A pumping system is provided to remove liquids that accumulate in the sump.

\section{Cell 25 Pipe Tunnel}

The cell floor is sloped to an epoxy-coated sump. The sump provides a low point within the cell to drain liquids to an instrumented location. A pumping system is provided to remove liquids that accumulate in the sump.

\section{$\underline{\text { Tank Vault S-324 }}$}

The assessment of the secondary containment system for Tank Vault S-324 is presented in the Design Demonstrations for Tank S-324. That assessment concludes that the secondary containment is sloped and designed to drain and remove liquids resulting from leaks, spills, or precipitation.

The assessment concludes that the secondary containments for the pipe trenches, cell, and tank vault are sloped and designed to drain and remove liquids resulting from leaks, spills, or precipitation. 


\subsubsection{Supplemental Information}

\subsubsection{Ancillary Equipment}

Tank S-324 is constructed of $304 \mathrm{~L}$ SS, which is a similar material as that used for the piping system, and is located in Tank Vault S-324, which provides secondary containment. The support equipment is exposed to the same liquids as other components of the tank system; therefore, $304 \mathrm{~L}$ SS is an acceptable material for the support equipment.

\subsubsection{Waste Acceptance Criteria}

Radioactively contaminated liquid wastes at the Oak Ridge National Laboratory (ORNL) are generated by various activities within the research and operating divisions. These activities include radiochemical processing, routine hot cell operations and decontaminations, and various waste treatment and environmental protection processes. The variations in composition of the waste streams are limited by the waste acceptance criteria that specify activity and concentration limits for waste discharged into the LLLW system. The Waste Acceptance Criteria for Liquid Waste Treatment Systems at the Oak Ridge National Laboratory (Oak Ridge National Laboratory, 1991), dated July 1991, is a guide for liquid waste generators to determine the proper means of disposal for LLLW. The criteria provide future discharge guidelines for the LLLW system, which includes Tank System S-324. 


\subsubsection{References}

Construction Specification, Multicurie Fission Products Pilot Plant in Building 3517. Invitation No. 401-55-8A.

Ebasco, and Main. May 14, 1993. Design Demonstrations-Category B Tank Systems, Revision 2. DOE Contract No. DE-AC05-91OR21928. Oak Ridge National Laboratory

Energy Systems Drawing D20836, Multicurie Fission Product Pilot Plant, Cell Bank Building 3517, Hot Drain Line, Isometric Detail, Revision 2.

Energy Systems Drawing D20850, Multicurie Fission Product Pilot Plant, Cell Bank Building 3517, Plan of Hot Drain and Condensate Drain, Revision 1.

Energy Systems Drawing D20862, Multicurie Fission Product Pilot Plant, Cell Bank Building 3517, Ventilation, Revision 1.

Energy Systems Drawing D20863, Multicurie Fission Product Pilot Plant, Cell Bank Building 3517, Ventilation Sections, Revision 1.

Energy Systems Drawing E31394, Building 3517, Phase II, Jet and Piping Schedule, Dated 4/10/58 (No Revision No.).

Energy Systems Drawing D24327, Building 3517, Phase II, Piping Schedule, Process Line, Revision 3.

Energy Systems Drawing D24341, Building 3517, Phase II, Piping Schedule, Service Line, Revision 3.

Energy Systems Drawing D24407, Building 3517, Phase II, Piping Plan Cell 24, Revision 2.

Energy Systems Drawing D24408, Building 3517, Phase II, Piping Elevation Cell 24, Revision 2. Energy Systems Drawing D26832, Building 3517, Phase II, Piping Cell 25 Plan 1, Revision 4. Energy Systems Drawing D26833, Building 3517, Phase II, Piping Cell 25 Plan 2, Revision 3. Energy Systems Drawing D26834, Building 3517, Phase II, Piping Cell 25 Plan 3, Revision 3.

Energy Systems Drawing D26835, Building 3517, Phase II, Piping Cell 25 Section A-A, Revision 3.

Energy Systems Drawing D26836, Building 3517, Phase II, Piping Cell 25 Section C-C, Revision 6. 
Energy Systems Drawing D26837, Building 3517, Phase II, Piping Cell 25 Section D-D, Revision 5.

Energy Systems Drawing D26838, Building 3517, Phase II, Piping Plan Cell 26, Revision 2.

Energy Systems Drawing D22805, Building 3517, Foundation Plan and Detail, Revision 3.

Energy Systems Drawing D22806, Building 3517, Elevations, Foundation Walls, Revision 4.

Energy Systems Drawing D22807, Building 3517, Elevations, Foundation Plan Tank Farm, Revision 2.

Energy Systems Drawing D22808, Building 3517, Tank Farm, Sections and Details, Revision 2. Energy Systems Drawing D22809, Building 3517, Tank Farm, Sections and Details, Revision 1. Energy Systems Drawing D22810, Building 3517, Tank Farm, Sections and Details, Revision 2. Energy Systems Drawing D22811, Building 3517, Plan Tank Farm Sleeves, Revision 5.

Energy Systems Drawing D22812, Building 3517, Sections and Details, Tank Farm Sleeves, Revision 6.

LLLW Generator Survey 1990 for Building 3517.

Oak Ridge National Laboratory. 1991. Waste Acceptance Criteria for Liquid Waste Treatment Systems at the Oak Ridge National Laboratory. WM-WMCO-201. Department of Waste Minimization Planning and Certification.

Risk Evaluation of Embedded, Single-Walled Liquid Low-Level Waste Piping at Oak Ridge National Laboratory.

Robinson, S. M., S. M. DePaoli, and A. B. Walker. 1991. Federal Facility Agreement Contingency, Upgrade, and Replacement Plans for the ORNL Active Low-Level Radioactive Waste Tank System. ORNL/TM-11795. Oak Ridge National Laboratory. 


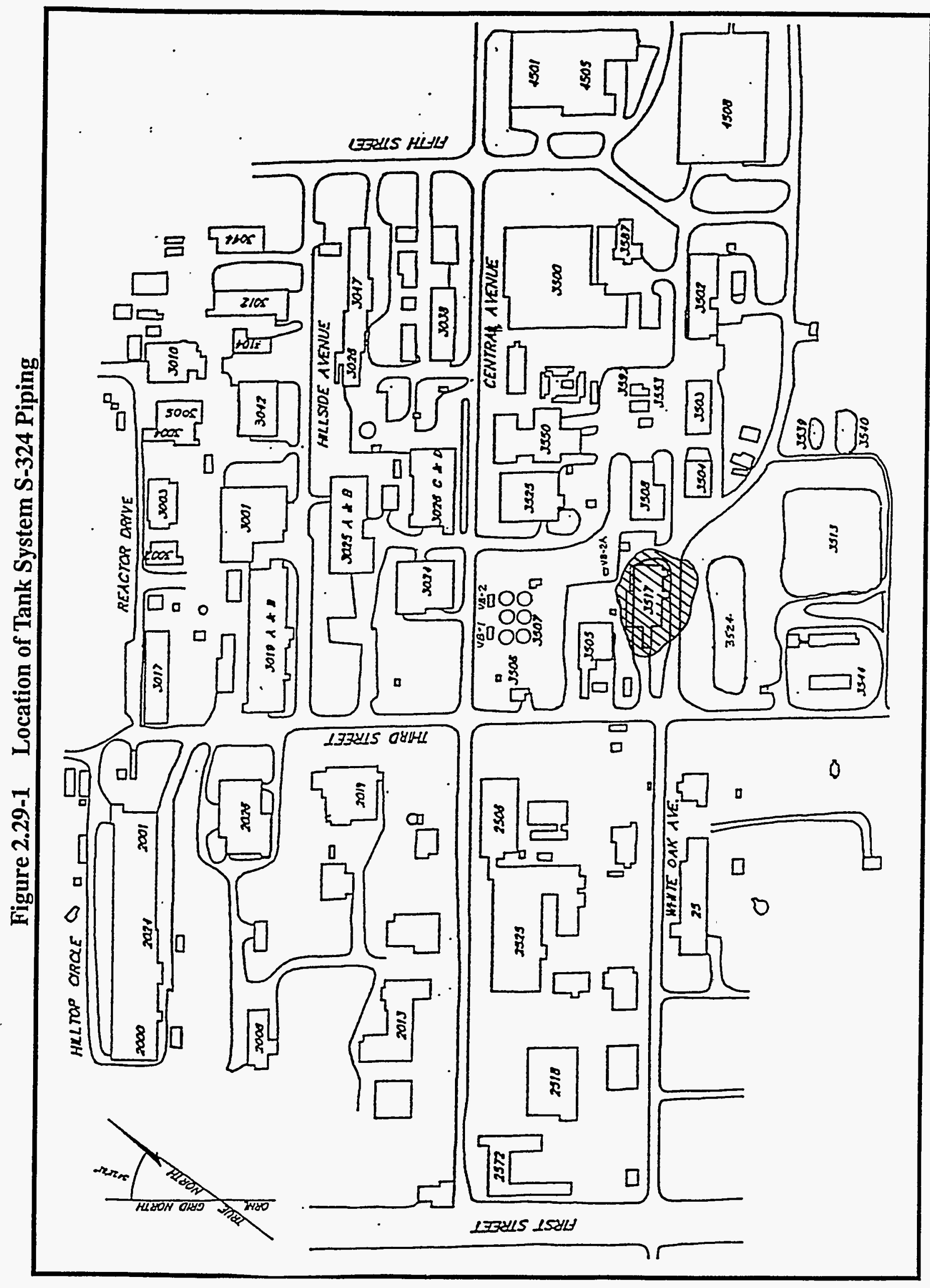




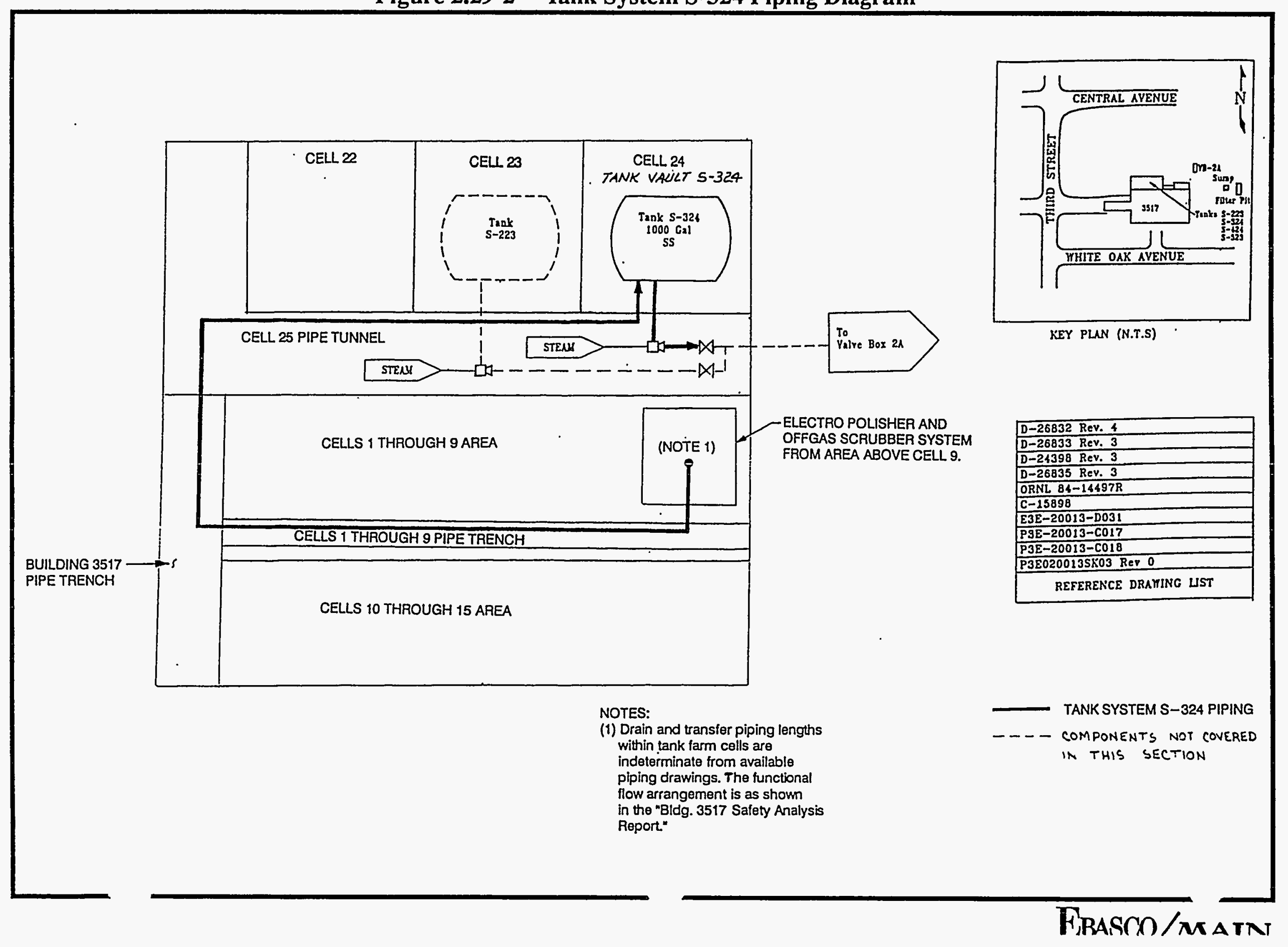


Figure 2.29-3

\section{LLLW Generator SURVEy - 1990}

$\begin{aligned} & \text { Isotopes: } \text { Cs-137 } \\ & \text { Sr-90 } \\ & \text { Others (i.e. acids, bases, or } \\ & \text { nitric acid } \\ & \frac{\text { turco decon } 4502}{\text { oxalic acid }} \\ & \frac{\text { sodium hydroxide }}{\text { Mr. Clean }} \\ & \text { Ajax Iiguid } \\ & \text { Planisol }\end{aligned}$

Quantities: $500.00 \mathrm{Ci} /$ year

$500.00 \mathrm{Ci} /$ year

$25.0 \mathrm{gal} /$ year

$25.0 \mathrm{lbs} /$ year

$25.0 \mathrm{lbs} /$ year

$25.0 \mathrm{lbs} /$ year

Unknown

Unknown

Unknown 


\subsection{Tank System S-523 Piping}

\subsubsection{Tank System Summary}

Tank System S-523 is located at the Fission Product Development Laboratory (Building 3517) at the main Bethel Valley Complex (Figures 2.30-1 and 2.30-2). The tank system piping is schedule 40 and 80, ASME SA-240, type 304L and type 347 stainless steel (SS) and is routed from the embedded Hot Cell floor drains in Building 3517 through the Building 3517 Pipe Trench and the Cell 25 Pipe Tunnel to Tank Vault S-523. Tank System S-523 piping is used to transfer liquid low-level waste (LLLW) from Building 3517 and waste from tank-farm cell drains and is classified as a Federal Facility Agreement (FFA) Category B tank system.

\subsubsection{Standards for Pipe Assessment of Tank Systems}

\subsubsection{Tank System Piping Description and Design Standards}

\section{Tank System Piping Description}

Tank System S-523 piping is located at Building 3517 and is routed from the embedded Hot Cell floor drains in Building 3517 through the Building 3517 Pipe Trench and the Cell 25 Pipe Tunnel to Tank Vault S-523. The piping system is used and managed by the Chemical Technology Division.

Tank System S-523 piping is constructed of 1-1/2", 2", and 4"; schedule 40 and 80; type 304L and type $347 \mathrm{SS}$ with a maximum design pressure and temperature of $150 \mathrm{psig}$ and $125^{\circ} \mathrm{F}$. Tank System S-523 piping has the capacity to contain a volume of approximately 100 gal.

\section{$\underline{\text { Design Standards }}$}

The applicable codes and standards used for Tank System S-523 piping and its associated secondary containment systems are identified herein. The codes and standards listed are those identified on either the design drawings or the construction specifications.

American Society for Testing and Materials A15-52T, A160-52T, A16-52T, A305-53T, A185-37, C39-49, C192-52T, C31-49, C33-52T, C39-49, C40-48, C42-49, C94-48, C150-53, and D544-52T;

American Society of Heating, Refrigeration, and Air Conditioning Engineers (ASHRAE) Handbook of Fundamentals;

American Society of Mechanical Engineers (ASME) Boiler and Pressure Vessel Code, Section II (SA-240);

American Welding Society; 
ASHRAE Guide and Data Book-Applications;

ASHRAE Guide and Data Book-Equipment;

Atomic Energy Commission Safety Code;

Federal Specifications LLL-F-321, Class A LLLF321;

National Electric Code; and

Underwriters Laboratories Inc.

\subsubsection{Generic Description of Piping Contents}

Tank System S-523 piping is designed to transfer LLLW from a variety of operations such as supernate from cesium and strontium precipitation, raffinates from a cesium-144 extraction process, and general decontamination solutions. Tank System S-523 piping may contain radioactive materials.

The analytical data (Figure 2.30-3) of waste stream contaminants from the generators are representative of the waste transferred through Tank System S-523 piping.

\subsubsection{Pipe Corrosion Protection Measures}

Piping inside the Building 3517 Pipe Trench, the Cell 25 Pipe Tunnel, and Tank Vault S-523 has no direct contact with the soil or water. Cathodic protection measures are not required for external corrosion.

The piping routed from the Hot Cell floor drains to the Building 3517 Pipe Trench is singly contained and embedded in the concrete floor.

\subsubsection{Documented Age of Tank System}

Tank System S-523 piping was installed in 1955.

\subsubsection{Standards for Containment and Release Detection}

Tank System S-523 piping incorporates approximately $185^{\prime}$ of embedded floor drain and wall penetration piping that is singly contained. The singly contained areas are omitted from discussion in the following sections that address secondary containment. 
2.30.3.1 Constructed of or Lined with Materials That are Compatible with Stored Waste(s) or Substance(s) to Be Placed in the Tank System and Shall Have Sufficient Strength and Thickness to Prevent Failure

Tank System S-523 piping is single-wall, schedule 40 and 80, type 304L and type 347 SS and is routed from the embedded Hot Cell floor drains in Building 3517 through the Building 3517 Pipe Trench and the Cell 25 Pipe Tunnel to Tank Vault S-523. The areas of secondary containment are discussed below.

\section{Tank Vault S-523}

The assessment of the secondary containment system for Tank Vault S-523 is presented in the Design Demonstrations for Tank S-523. That assessment concludes that Tank Vault S-523 is coated with materials that are compatible with the waste and designed to prevent migration of waste into the concrete.

\section{Cell 25 Pipe Tunnel}

The interior surfaces of Cell 25 are provided with a system of Amercoat 23 and 33 epoxy coating. According to manufacturer's specifications, the cell's epoxy coating is compatible with the waste and designed to prevent migration of waste into the concrete.

\section{Building 3517 Pipe Trench}

The interior surfaces of the pipe trench are provided with a system of Amercoat 23 and 33 epoxy coating. According to manufacturer's specifications, the pipe trench's epoxy coating is compatible with the waste and designed to prevent migration of waste into the concrete.

The assessment concludes that Tank Vault S-523, Cell 25, and the Building 3517 Pipe Trench are coated with materials that are compatible with the waste and designed to prevent migration of waste into the concrete.

\subsubsection{Placed on Foundation or Base Capable of Providing Support to the Secondary Containment System}

\section{Tank Vault S-523}

The assessment of the secondary containment system for Tank Vault S-523 is presented in the Design Demonstrations for Tank S-523. That assessment concludes that the vault foundation is properly designed to support the secondary containment system. 


\section{Cell 25 Pipe Tunnel}

The Cell 25 foundation is a $6^{\prime} 6^{\prime \prime} \times 63^{\prime} 8^{\prime \prime} \times 1^{\prime} 3^{\prime \prime}$ thick, reinforced concrete base slab that rests on limestone.

\section{Building 3517 Pipe Trench}

The pipe trench foundation is a $7^{\prime} 6^{\prime \prime} \times 40^{\prime} 0^{\prime \prime} \times 11^{\prime \prime}$ thick, reinforced concrete base slab that rests on limestone.

The assessment concludes that Tank Vault S-523, Cell 25, and the Building 3517 Pipe Trench foundations are properly designed to support the secondary containment systems.

2.30.3.3 Provided with a Leak Detection System That is Designed and Operated to Detect Failure of Either Primary or Secondary Containment Structure or the Presence of Any Measurable Release of Hazardous or Radioactive Constituents

\section{$\underline{\text { Tank Vault S-523 }}$}

The assessment of the secondary containment system for Tank Vault S-523 is presented in the Design Demonstrations for Tank S-523. That assessment concludes that Tank Vault S-523 is provided with a leak detection system.

\section{Cell 25 Pipe Tunnel}

The Cell 25 floor is sloped to an epoxy-coated sump where accumulation of liquid will be detected by a level sensor that will activate an alarm in the operating area of Building 3517.

\section{Building 3517 Pipe Trench}

The pipe trench floor is sloped to the epoxy-coated Cell 25 Pipe Tunnel. Accumulation of liquid will flow from the pipe trench to the Cell 25 sump and will be detected by a level sensor that will activate an alarm in the operating area of Building 3517.

The assessment concludes that Tank Vault S-523, Cell 25, and the Building 3517 Pipe Trench are provided with leak detection. 
Design Demonstrations - Category B Tank Systems (Piping)

2.30.3.4 Sloped or Otherwise Designed or Operated to Drain and Remove Liquids Resulting from Leaks, Spills, or Precipitation

\section{$\underline{\text { Tank Vault S-523 }}$}

The assessment of the secondary containment system for Tank Vault S-523 is presented in the Design Demonstrations for Tank S-523. That assessment concludes that the secondary containment is sloped and designed to drain and remove liquids resulting from leaks, spills, or precipitation.

\section{Cell 25 Pipe Tunnel}

The Cell 25 floor is sloped to an epoxy-coated sump. The sump provides a low point within Cell 25 to drain liquids to an instrumented location. A pumping system is provided to remove liquids that accumulate in the sump.

\section{Building 3517 Pipe Trench}

The pipe trench floor is sloped to the epoxy-coated Cell 25 sump. The cell sump provides a low point to drain liquids to an instrumented location. A pumping system is provided to remove liquids that accumulate in the sump.

The assessment concludes that Tank Vault S-523, Cell 25, and the Building 3517 Pipe Trench are sloped and designed to drain and remove liquids resulting from leaks, spills, or precipitation.

\subsubsection{Supplemental Information}

\subsubsection{Ancillary Equipment}

Tank S-523 is constructed of 304L SS, which is the same material as that used for the piping system, and is located in Tank Vault S-523, which provides secondary containment. The support equipment is exposed to the same liquids as other components of the tank system; therefore, $304 \mathrm{~L}$ SS is an acceptable material for the support equipment.

\subsubsection{Waste Acceptance Criteria}

Radioactively contaminated liquid wastes at the Oak Ridge National Laboratory (ORNL) are generated by various activities within the research and operating divisions. These activities include radiochemical processing, routine hot cell operations and decontaminations, and various waste treatment and environmental protection processes. The variations in composition of the waste streams are limited by the waste acceptance criteria that specify activity and concentration limits for waste discharged into the LLLW system. The Waste Acceptance Criteria for Liquid Waste Treatment Systems at the Oak Ridge National Laboratory (Oak Ridge National Laboratory, 1991), dated July 1991, is a guide for liquid waste generators to determine the proper 
means of disposal for LLLW. The criteria provide future discharge guidelines for the LLLW system, which includes Tank System S-523. 


\subsubsection{References}

Construction Specification, Multicurie Fission Products Pilot Plant in Building 3517. Invitation No. 401-55-8A.

Ebasco, and Main. May 14, 1993. Design Demonstrations-Category B Tank Systems, Revision 2. DOE Contract No. DE-AC05-91OR21928. Oak Ridge National Laboratory

Energy Systems Drawing D20836, Multicurie Fission Product Pilot Plant, Cell Bank Building 3517, Hot Drain Line, Isometric Detail, Revision 2.

Energy Systems Drawing D20850, Multicurie Fission Product Pilot Plant, Cell Bank Building 3517, Plan of Hot Drain and Condensate Drain, Revision 1.

Energy Systems Drawing D20862, Multicurie Fission Product Pilot Plant, Cell Bank Building 3517, Cell Ventilation, Revision 1.

Energy Systems Drawing D20863, Multicurie Fission Product Pilot Plant, Cell Bank Building 3517, Cell Ventilation Section, Revision 1.

Energy Systems Drawing E31394, Building 3517, Phase II, Jet and Piping Schedule, Dated 4/10/58 (No Revision No.).

Energy Systems Drawing D24327, Building 3517, Phase II, Piping Schedule, Process Line, Revision 3.

Energy Systems Drawing D24341, Building 3517, Phase II, Piping Schedule, Service Line, Revision 3.

Energy Systems Drawing D24398, Building 3517, Phase II, Piping Plan Cell 23, Revision 3.

Energy Systems Drawing D26832, Building 3517, Phase II, Piping Cell 25 Plan 1, Revision 4.

Energy Systems Drawing D26833, Building 3517, Phase II, Piping Cell 25 Plan 2, Revision 3.

Energy Systems Drawing D26834, Building 3517, Phase II, Piping Cell 25 Plan 3, Revision 3.

Energy Systems Drawing D26835, Building 3517, Phase II, Piping Cell 25 Section A-A, Revision 3.

Energy Systems Drawing D26836, Building 3517, Phase II, Piping Cell 25 Section C-C, Revision 6.

Energy Systems Drawing D26837, Building 3517, Phase II, Piping Cell 25 Section D-D, Revision 5. 
Energy Systems Drawing D26838, Building 3517, Phase II, Piping Plan Cell 26, Revision 2.

Energy Systems Drawing D22805, Building 3517, Foundation Plan and Detail, Revision 3.

Energy Systems Drawing D22806, Building 3517, Elevations, Foundation Walls, Revision 4.

Energy Systems Drawing D22807, Building 3517, Elevations, Foundation Plan Tank Farm, Revision 2.

Energy Systems Drawing D22808, Building 3517, Tank Farm, Sections and Details, Revision 2.

Energy Systems Drawing D22809, Building 3517, Tank Farm, Sections and Details, Revision 1.

Energy Systems Drawing D22810, Building 3517, Tank Farm, Sections and Details, Revision 2.

Energy Systems Drawing D22811, Building 3517, Plan Tank Farm Sleeves, Revision 5.

Energy Systems Drawing D22812, Building 3517, Sections and Details, Tank Farm Sleeves, Revision 6.

LLLW Generator Survey 1990 for Building 3517.

Oak Ridge National Laboratory. 1991. Waste Acceptance Criteria for Liquid Waste Treatment Systems at the Oak Ridge National Laboratory. WM-WMCO-201. Department of Waste Minimization Planning and Certification.

Risk Evaluation of Embedded, Single-Walled Liquid Low-Level Waste Piping at Oak Ridge National Laboratory.

Robinson, S. M., S. M. DePaoli, and A. B. Walker. 1991. Federal Facility Agreement Contingency, Upgrade, and Replacement Plans for the ORNL Active Low-Level Radioactive Waste Tank System. ORNL/TM-11795. Oak Ridge National Laboratory. 


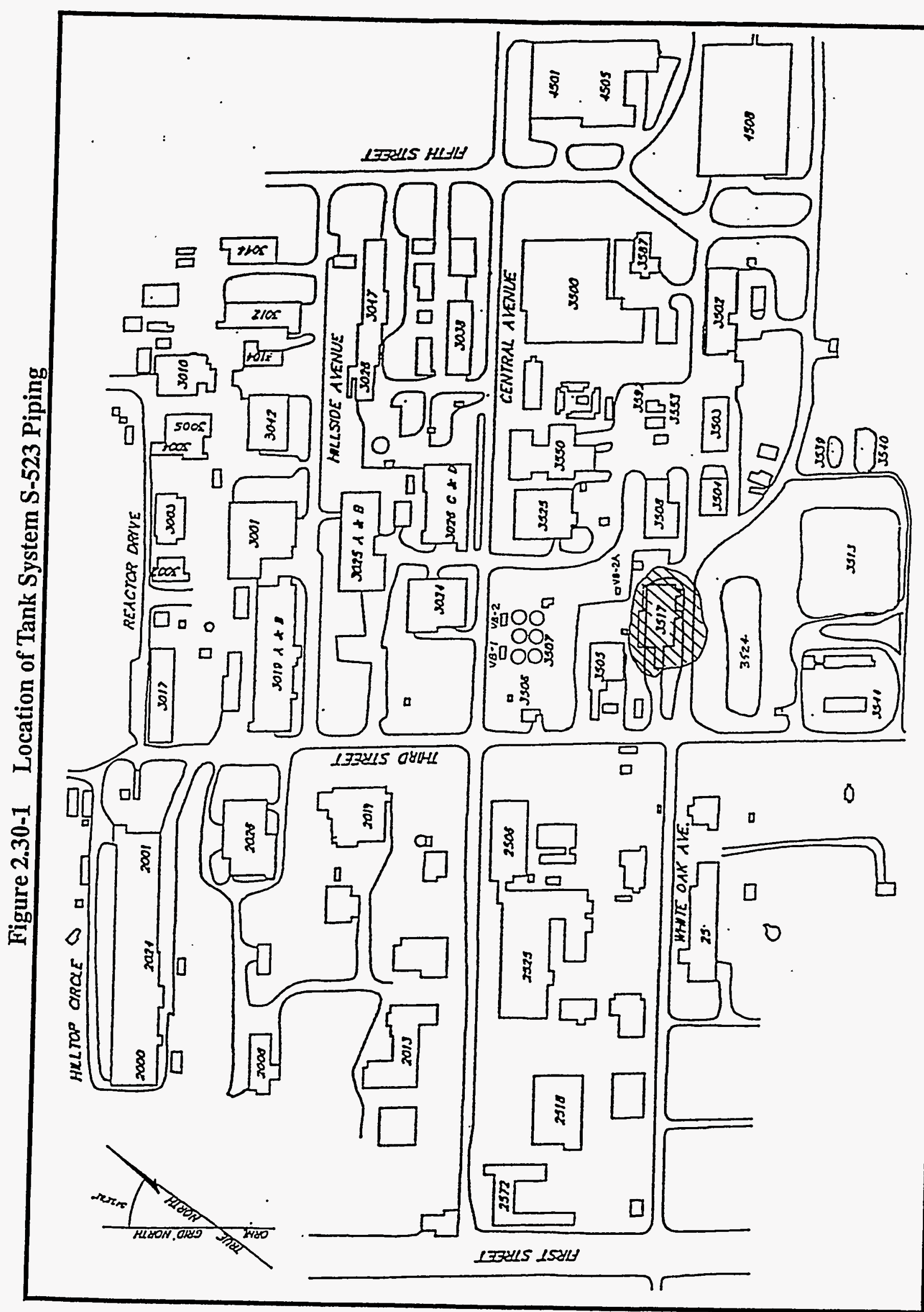


Figure 2.30-2 Tank System S-523 Piping Diagram
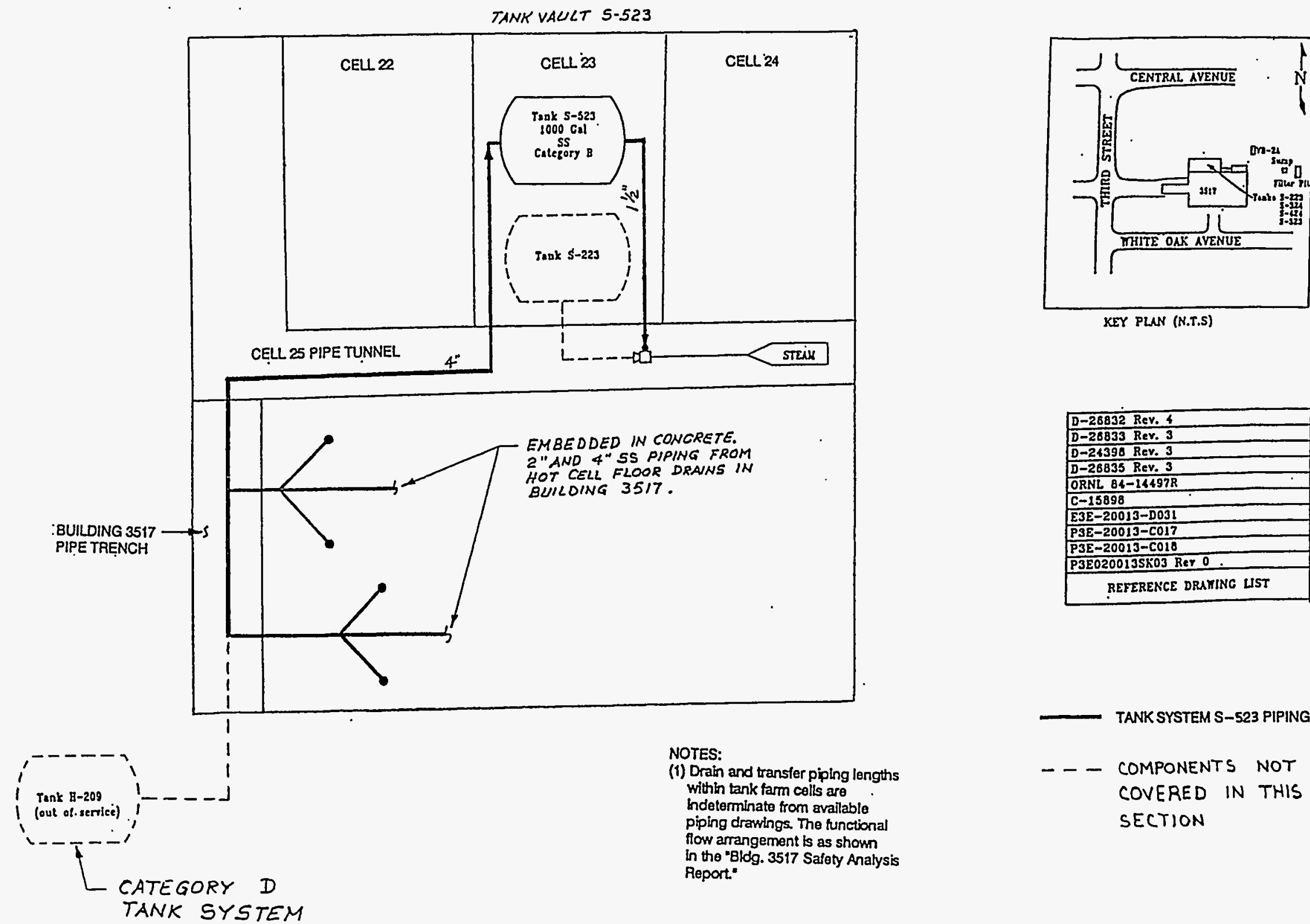

KEY PLAN (N.T.S)

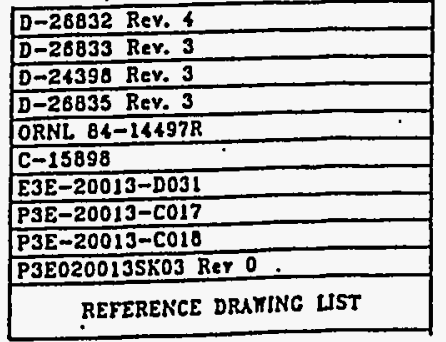

TANK SYSTEM S-523 PIPING

- - COMPONENTS NOT COVERED IN THIS SECTION 


\section{LLLW Generator SURVEY - 1990}

Isotopes: $\mathrm{Cs}-137$

Sr -90
Quantities: $500.00 \mathrm{Ci} /$ year

$500.00 \mathrm{Ci} /$ year

cleaners, etc.)

\begin{tabular}{l}
$\frac{25.0 \mathrm{gal} / \text { year }}{25.0 \mathrm{lbs} / \text { year }}$ \\
\hline $25.0 \mathrm{Ibs} /$ year \\
$25.0 \mathrm{lbs} /$ year \\
Unknown \\
Unknown \\
Unknown
\end{tabular}

nitric acid

turco decon 4502

oxalic acid

organics

sodium hydroxide

Mr. Clean

Ajax Iiquid

Planisol
Unknown 